\title{
Regres : een onderzoek naar het regresrecht van particuliere en sociale schadedragers
}

Citation for published version (APA):

Engelhard, E. F. D. (2003). Regres : een onderzoek naar het regresrecht van particuliere en sociale schadedragers. [Doctoral Thesis, Maastricht University]. Kluwer. https://doi.org/10.26481/dis.20031003ee

Document status and date:

Published: 01/01/2003

DOI:

10.26481/dis.20031003ee

Document Version:

Publisher's PDF, also known as Version of record

\section{Please check the document version of this publication:}

- A submitted manuscript is the version of the article upon submission and before peer-review. There can be important differences between the submitted version and the official published version of record.

People interested in the research are advised to contact the author for the final version of the publication, or visit the DOI to the publisher's website.

- The final author version and the galley proof are versions of the publication after peer review.

- The final published version features the final layout of the paper including the volume, issue and page numbers.

Link to publication

\footnotetext{
General rights rights.

- You may freely distribute the URL identifying the publication in the public portal. please follow below link for the End User Agreement:

www.umlib.nl/taverne-license

Take down policy

If you believe that this document breaches copyright please contact us at:

repository@maastrichtuniversity.nl

providing details and we will investigate your claim.
}

Copyright and moral rights for the publications made accessible in the public portal are retained by the authors and/or other copyright owners and it is a condition of accessing publications that users recognise and abide by the legal requirements associated with these

- Users may download and print one copy of any publication from the public portal for the purpose of private study or research.

- You may not further distribute the material or use it for any profit-making activity or commercial gain

If the publication is distributed under the terms of Article $25 \mathrm{fa}$ of the Dutch Copyright Act, indicated by the "Taverne" license above, 



\section{Regres}

Een onderzoek naar het regresrecht van particuliere en sociale schadedragers

\section{PROEFSCHRIFT}

ter verkrijging van de graad van doctor aan de Universiteit Maastricht,

op gezag van de Rector Magnificus, Prof.dr. A.C. Nieuwenhuijzen Kruseman volgens het besluit van het College van Decanen, in het openbaar te verdedigen

op vrijdag 3 oktober 2003 om 14.00 uur

door

Esther Frédérique Désiree Engelhard 



\section{Inhoudsopgave}

VOORWOORD

AFKORTINGEN

I VERANTWOORDING

$1.1 \quad$ Inleiding

1.2 Beperking tot personenschade

1.3 De onderhavige gevallen

1.3.1 Het regres bij letselschade

1.3.2 Het regres bij overlijdensschade

1.4 Begrippenapparaat

1.4.1 Terminologische opmerkingen

1.4.2 Aanduiding van de partijen

1.5 Tot slot

$2.1 \quad$ Het gecompenseerde deel van de schade 9

$\begin{array}{lll}2.2 & \text { De centrale situatie } & 10\end{array}$

2.3 Een omstreden onderwerp van studie 11

2.3.1 Een heldere gedachte... 11

2.3.2 Maatschappelijke meerwaarde? 12

$\begin{array}{lll}2.3 .3 & \text { Een duidelijke beleidskeuze } & 15\end{array}$

2.4 Probleemstelling en opzet 16

2.5 Doel van deze studie 18

III VERHOUDING SCHADEVEROORZAKER-BENADEELDE: SCHADEVEROORZAKER BEVRIJD

$3.1 \quad$ Eén schadevoorval, twee aanspraken 19

3.1.1 Aanspraak op de schadeveroorzaker $\quad 19$ 
$\begin{array}{ll}3.1,2 & \text { Aanspraak op derden } \\ 3.1 .3 & 20\end{array}$

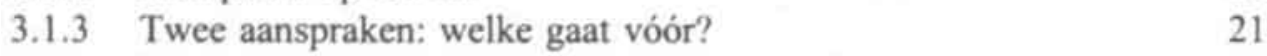

3.2 Samenloopregeling van het aansprakelijkheidsrecht 23

3.2.1 Drie standaardmodellen 23

3.2.2 Vestigings- en omvangfase 25

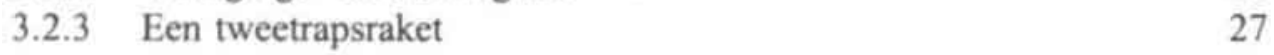

$\begin{array}{ll}3.3 & \text { Schadeveroorzaker bevrijd door betalingen van derden }\end{array}$

$\begin{array}{ll}3.3 .1 & \text { Twee technische gronden } \\ 3.3 .2 & 27\end{array}$

3.3.2 Intermezzo: wat is schade? 29

$\begin{array}{lll}3.3 .3 & \text { Concrete toepassing } & 30\end{array}$

3.3.4 Betalingen met schadekarakter (I): geen schade 31

3.3.4.1 Hulp in natura (medische zorg, vervoer, telefoonkosten) 31

3.3.4.2 Loondoorbetaling $\quad 32$

3.3.4.3 Voorziening in levensonderhoud bij overlijden 33

3.3.4.4 Tot slot 36

3.3.5 Betalingen naast schade: voordeelstoerekening $\quad 37$

$\begin{array}{ll}3.3 .5 .1 \text { Inleiding } & 37\end{array}$

3.3.5.2 Betalingen ter compensatie (II): 'verplichte' voordeelstoerekening 38

* Uitkeringen uit schadeverzekering 40

* Uitkeringen uit sociale verzekering 43

* Overige (sociale voorzieningen, onkostenvergoeding, giften) 46

3.3.5.3 Vrije toepassing van art. 6:100 BW 49

*Vrijblijvende giften en andere 'windfalls' 49

* Uitkeringen uit sommenverzekering 49

3.3.6 Aperçu: de bevrijdende werking van betalingen van derden 55

$\begin{array}{ll}\text { 3.3.7 Ratio en rechtspolitieke betekenis } & 57\end{array}$

3.4 Bijzondere perikelen in verband met het regres 60

3.4.1 Het risico van dubbele betaling 60

3.4.2 Hoe absoluut is 'verplichte voordeelstoerekening'? 62

3.4.3 Informatiegebrek 65

3.4.4 Onderling wisselende schadeposten 66

3.4.5 Postenstelsel bij voordeelstoerekening 67

$\begin{array}{lll}3.5 & \text { Conclusie } & 69\end{array}$

IV WETTELIJKE REGRESREGELINGEN

$\begin{array}{lll}4.1 & \text { Inleiding } & 73\end{array}$

4.2 Regres bij medische herstelkosten $\quad 74$

$\begin{array}{lll}4.2 .1 & \text { Art. } 83 b \text { ZFW } & 74\end{array}$

4.2.2 Art. 65b AWBZ $\quad 77$

$\begin{array}{lll}4.2 .3 & \text { Art. } 2 \text { lid } 1 \text { VOA } & 79\end{array}$

4.2.4 Art. $284 \mathrm{WvK} / \mathrm{art}$. 7.17.2.25 BW 82 
4.3 Regres bij inkomensschade $\quad 89$

$\begin{array}{lll}4.3 .1 & \text { Algemeen } & 89\end{array}$

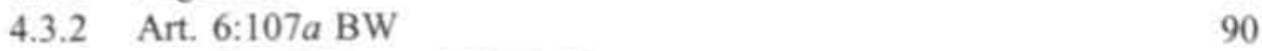

4.3.3 Art. 52a ZW, art. 8 WAMIL 93

4.3.4 Art. 90 WAO, art. 8 WAMIL, art. 76 WPA 94

4.3.5 Art. $69 \mathrm{WAZ}$, art. 61 WAJONG, art. 8 WAMIL 100

4.3.6 Art. 2 lid 2 VOA, art. 75 WPA, art. X4 AMP 101

4.3.7 Art. $284 \mathrm{WvK} / \mathrm{art}$. 7.17.2.25 BW 103

$\begin{array}{lll}\text { 4.3.8 Art. 49 REA } & 105\end{array}$

4.3.9 Art. 6 lid 3 WSG 106

$\begin{array}{lll}4.4 & \text { Regres bij immateriële schade } & 107\end{array}$

4.5 Regres bij overlijdensschade 111

4.5.1 Algemeen 111

4.5.2 Art. $61 \mathrm{ANW} \quad 111$

4.5.3 Art. 2 lid 3 VOA, art. 75 WPA, art. X4 AMP 112

$\begin{array}{lll}\text { 4.5.4 Art. } 6 \text { lid } 3 \text { WSG } & 114\end{array}$

4.5.5 Art. $284 \mathrm{WvK} /$ art. 7.17.2.25 BW 115

4.6 Schadedragers zonder regresrecht 115

4.6.1 Dè uitzondering: sociale voorzieningen 115

$\begin{array}{ll}\text { 4.6.2 Wet voorzieningen gehandicapten } & 116\end{array}$

$\begin{array}{lll}4.6 .3 & \text { Toeslagenwet } & 118\end{array}$

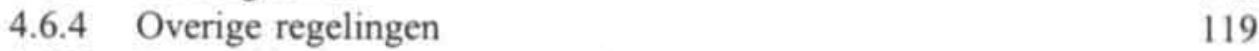

4.6.5 De positie van sommenverzekeraars 121

4.6.6 Naar komend recht (titel 7.17 BW) 122

$\begin{array}{lll}4.6 .7 & \text { Systematisch uitgangspunt ... } & 123\end{array}$

$\begin{array}{lll}\text { 4.6.8 Kwalificatie als schade- of sommenverzekering } & 124\end{array}$

$\begin{array}{ll}\text { 4.6.9 Specifieke ongevallenverzekeringen } & 130\end{array}$

4.6.10 Regresrecht voor levensverzekeringen? 131

4.7 Naar een uniforme regeling? 133

$\begin{array}{ll}\text { 4.7.1 Kritiek op de huidige regeling } & 133\end{array}$

4.7.2 Het tekstvoorstel van Van Boom 135

4.8 Gemeenschappelijke kenmerken van de regresbepalingen 137

$\begin{array}{ll}\text { 4.8.1 Een gemeenschappelijke prestatie } & 137\end{array}$

$\begin{array}{lll}\text { 4.8.2 Toevallige samenloop van prestaties } & 138\end{array}$

$\begin{array}{lll}4.8 .3 \text { Regresplafond } & 140\end{array}$

$\begin{array}{lll}\text { 4.8.4 Afgeleid karakter } & 141\end{array}$

4.9 Systematiek van wettelijke verhaalsrechten 142

4.9.1 Verhaalsrechten van art. 6:107 en 108 BW 142

4.9.2 Wettelijk systeem van ansprakelijkheid 143

$\begin{array}{lll}4.9 .3 & \text { Summa summarum } & 146\end{array}$

4.9.4 Andere afgeleide rechten: medeschuldenaren $\quad 147$

4.9.5 Cessie en contractueel regres 153 
4.9.6 Vorderingen tot schadevergoeding 154

$\begin{array}{lll}4.10 & \text { Conclusie } & 156\end{array}$

V WORDINGSGESCHIEDENIS

5.1 Regresrecht van particuliere schadeverzekeraars $\quad 159$

5.1.1 Achtergrond in vogelvlucht 159

$\begin{array}{ll}5.1 .2 & \text { Huidige rechtsopvatting } \\ 5.2\end{array}$

5.2 Eerste invoering van zelfstandige regresrechten 163

5.2.1 De (oude) Ongevallenwet $1901 \quad 163$

5.2.2 Uitbreiding naar andere sociale wetgeving 164

$\begin{array}{lll}5.2 .3 & \text { Kritiek } & 165\end{array}$

5.2.4 Rechtspositionele ambtenarenaanspraken $\quad 166$

$\begin{array}{lll}\text { 5.3 De huidige sociale wetgeving } & 167\end{array}$

5.3.1 Regres in de sociale werknemersverzekeringen 167

$\begin{array}{ll}\text { 5.3.2 Verhaalswet ongevallen ambtenaren } & 169\end{array}$

$\begin{array}{lll}5.4 & 171\end{array}$

$\begin{array}{lll}5.4 .1 & \text { Afstand van regres door schadeverzekeraars } & 171\end{array}$

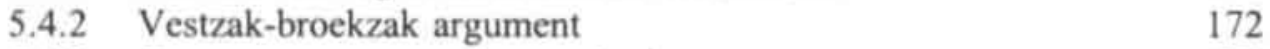

$\begin{array}{lll}5.4 .3 & \text { Geen regres voor volksverzekeringen } & 174\end{array}$

$\begin{array}{ll}\text { 5.4.4 Toenemende druk op het aansprakelijkheidsrecht } & 175\end{array}$

$\begin{array}{lll}\text { 5.4.5 De Studiegroep Verkeersaansprakelijkheid } & 177\end{array}$

$\begin{array}{lll}5.5 & \text { Budgettaire belangen } & 179\end{array}$

$\begin{array}{ll}\text { 5.5.1 Toenemende druk op het sociale zekerheidsstelsel } & 179\end{array}$

$\begin{array}{ll}\text { 5.5.2 Een duidelijke missie } & 181\end{array}$

$\begin{array}{ll}\text { 5.5.3 Adviezen SER en Sociale Verzekeringsraad } & 183\end{array}$

$\begin{array}{ll}\text { 5.5.4 Emstige kritiek } & 185\end{array}$

$\begin{array}{lll}\text { 5.5.5 De nieuwe koers } & 186\end{array}$

5.5.6 Onwenselijke ontwikkeling 193

$\begin{array}{ll}\text { 5.5.7 Regresopbrengsten van sociale verzekeraars } & 194\end{array}$

$\begin{array}{lll}5.6 & \text { Conclusie } & 197\end{array}$

VI DOELSTELLING EN FUNCTIE 199

$\begin{array}{lll}6.1 & \text { Inleiding } & 199\end{array}$

$\begin{array}{lll}\text { 6.2 Rechtsherstel } & 200\end{array}$

6.2.1 Het principe dat de schuldige betaalt 200

6.2.2 Individueel rechtsherstel? 200

6.2.3 Correctieve rechtvaardigheid 202

6.2.4 Geen (directe) correctieve rechtvaardigheid bij regres 204

6.2.5 Indirect rechtsherstel. Premieargument 205 
6.3 Collectief belang voorop 207

6.3.1 Distributieve rechtvaardigheid. Profijttheorie 207

$\begin{array}{ll}\text { 6.3.2 Utilistische benadering } & 209\end{array}$

6.3.3 Zuivere kostenallocatie 211

$\begin{array}{ll}\text { 6.3.4 Economische benadering } & 212\end{array}$

$\begin{array}{ll}\text { 6.3.5 Het belang van preventie } & 213\end{array}$

$\begin{array}{ll}\text { 6.3.6 Preventie langs twee wegen } & 216\end{array}$

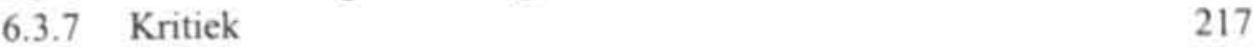

$\begin{array}{lll}6.3 .8 & \text { Belangrijke bezwaren } & 219\end{array}$

$\begin{array}{lll}6.3 .9 & \text { Tussenstand } & 221\end{array}$

6.4 Regres als reactie van de rechtsorde 222

$\begin{array}{ll}6.5 .1 & \text { Inleiding } \\ 6.5 .2 & 224\end{array}$

$\begin{array}{ll}\text { 6.5.2 De invloed van verzekeringen } & 224\end{array}$

$\begin{array}{ll}\text { 6.5.3 Aansprakelijkheid op risicogrondslag } & 224\end{array}$

$\begin{array}{ll}\text { 6.5.4 Ongelijke behandeling van gevallen } & 227\end{array}$

$\begin{array}{lll}6.6 & \text { Conclusie } & 228\end{array}$

VII AANSPRAKELIJKSHEIDSNORMEN BIJ REGRES

7.1 Inleiding

7.2 Regresconstructies: subrogatie en civiel plafond 230

$\begin{array}{ll}7.2 .1 & \text { Afgeleid karakter bij subrogatie } \\ 7.2 .230\end{array}$

$\begin{array}{ll}\text { 7.2.2 Afgeleid karakter bij zelfstandig regres } & 232\end{array}$

$\begin{array}{lll}7.2 .3 & \text { Het civiele plafond } & 233\end{array}$

$\begin{array}{lll}7.2 .4 & \text { Ratio van civiel plafond ... } & 236\end{array}$

$\begin{array}{lll}7.2 .5 & \text { Perikelen } & 237\end{array}$

7.2.6 'Civiel plafond' bij subrogatie 240

7.3 Toepasselijkheid van de gronden voor aansprakelijkheid 243

$\begin{array}{lll}7.3 .1 & \text { Hoofdregel } & 243\end{array}$

7.3.2 De Tijdelijke regeling verhaalsrechten (TRV) 244

$\begin{array}{lll}7.3 .3 & \text { Inhoud en wetstechniek } & 247\end{array}$

7.3.4 Kritiek op TRV 251

7.3.5 Functies van het regres 254

7.3.5.1 Het principe dat de schadeveroorzaker betaalt 254

7.3.5.2 Afschaffing omwille van zuivere kostenallocatie? 256

7.3.5.3 Afschaffing vanuit (algemeen) economisch gezichtspunt 257

$\begin{array}{lll}\text { 7.3.6 Conclusie } & 259\end{array}$

7.3.7 Differentiatie bij verkeersaansprakelijkheid 259

7.3.8 Uitsluiting van $50 \%$ en $100 \%$ regels juist? 266

$\begin{array}{lll}7.4 & \text { Omvang van aansprakelijkheid } & 268\end{array}$

$\begin{array}{lll}7.4 .1 & \text { Postenstelsel } & 268\end{array}$

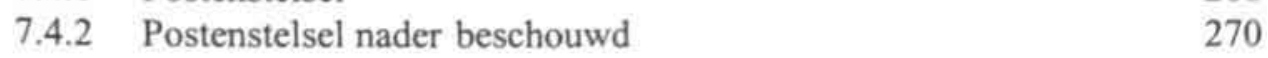


$\begin{array}{ll}\text { 7.4.3 Differentiatie in de omvangfase } & 272\end{array}$

$\begin{array}{ll}\text { 7.4.3.1 Inleiding } & 272\end{array}$

7.4.3.2 Causaliteitsperikelen (art. 6:98 BW) 273

7.4.3.3 Eigen schuld van de benadeelde (art. 6:101 BW) 274

7.4.3.4 Aan de benadeelde opkomend voordeel (art. 6:100 BW) 275

$\begin{array}{ll}\text { 7.4.3.5 Immateriële schade (art. 6:106 BW) } & 279\end{array}$

$\begin{array}{lll}7.5 & \text { Conclusie } & 281\end{array}$

VIII RECHTSKARAKTER VAN REGRESVORDERINGEN

8.1 Rechtskarakter van regresvorderingen 283

8.1.1. Inleiding 283

$\begin{array}{ll}\text { 8.1.2 Geen schade vereist } & 284\end{array}$

$\begin{array}{ll}\text { 8.2 Bruto-netto kwestie } & 287\end{array}$

$\begin{array}{lll}8.2 .1 & \text { Inleiding } & 287\end{array}$

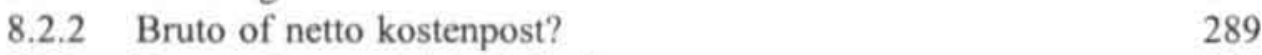

8.2.3 Bruto of netto civiel plafond $\quad 290$

8.2.4. Efficiency vóór dogmatiek? 294

8.2.5 Ook netto regres bij tijdelijke arbeidsongeschiktheid? Kritiek 294

8.3 Buitengerechtelijke kosten van regresnemers 296

$\begin{array}{lll}8.3 .1 & \text { Inleiding } & 296\end{array}$

8.3.2 Rechtsbijstandverzekeraars en de NORA-regeling 297

$\begin{array}{ll}\text { 8.3.3 Zelfstandig beroep op art. 6:96 lid 2 BW } & 298\end{array}$

8.3.4 Alleen de kosten van niet (tijdige) nakoming 301

$\begin{array}{ll}\text { 8.3.5 Is sprake van een algemene regel? } & 302\end{array}$

8.4 Verrekening of matiging van de regressom 304

8.4.1 Aan de regresnemer opgekomen voordeel (art. 6:100 BW) 304

$\begin{array}{ll}\text { 8.4.2 Matiging (art. 6:109 BW) } & 305\end{array}$

8.5 'Eigen schuld' van regresnemers en schadebeperkingsplicht 306

8.5.1 Aanknopingspunten binnen de regresregeling 306

$\begin{array}{ll}\text { 8.5.2 Aanlogie met art. 6:101 BW } & 309\end{array}$

8.5.3 Beoordelingsvrijheid in civilibus 311

8.6 Aanverwante regels 314

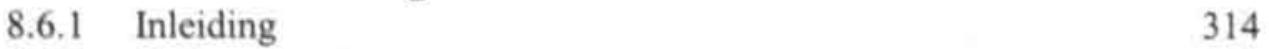

$\begin{array}{ll}\text { 8.6.2 Action directe } & 314\end{array}$

$\begin{array}{ll}\text { 8.6.2.1 Het WAM-regime (art. } 6 \text { WAM) } & 314\end{array}$

8.6.2.2 Algemene action directe (titel 7.17 BW) 317

$\begin{array}{lll}\text { 8.6.3 Voorrecht art. 3:287 BW } & 318\end{array}$

$\begin{array}{ll}8.6 .4 & \text { Voeging in strafproces } \\ 8.6 .5 & 320\end{array}$

$\begin{array}{ll}\text { 8.6.5 Bevrijdende verjaring } & 320\end{array}$

8.6.5.1 Inleiding $\quad 320$

8.6.5.2 Geldend recht: onduidelijkheid is er troef 322 
8.6.5.4 Naar een uniform verjaringsregime voor regresnemers? $\quad 326$

$\begin{array}{ll}\text { 8.6.5.5 Derogerende werking van de billijkheid } & 329\end{array}$

8.7 Conclusie 331

IX FUNCTIES OP UITVOERINGSNIVEAU 335

9.1 De afwikkeling van regresvorderingen $\quad 335$

9.1.1 Inleiding 335

9.1.2 Het regres van sociale verzekeraars 336

9.1.2.1 Convenant Verhaalsrecht 336

$\begin{array}{ll}\text { 9.1.2.2 ANW-convenant } & 338\end{array}$

9.1.2.3 AWBZ-convenant $\quad 340$

9.1.3 Kritiek en verdere ontwikkeling $\quad 340$

9.1.4 Andere kostenbesparende maatregelen dan standaardisering 343

$\begin{array}{ll}\text { 9.1.5 Het regres van particuliere verzekeraars } & 346\end{array}$

9.1.5.1 Algemeen 346

$\begin{array}{ll}\text { 9.1.5.2 NORA-regeling } & 347\end{array}$

9.1.5.3 Bedrijfsregeling Regres 347

9.2 Uitgesloten categorieën schadeveroorzakers 350

9.2.1 Regres op gezinsleden van de benadeelde 350

9.2.2 Regres van sociale verzekeraars op gezinsleden 351

9.2.3 Regres van schadeverzekeraars op gezinsleden 355

9.2.4 Aansluiting bij afdeling 7.17.2 BW? 358

9.2.5 Naar een verbeterde bescherming van de benadeelde 359

9.2.6 Het werkgeversverweer bij het regres van sociale verzekeraars 359

$\begin{array}{lll}\text { 9.2.7 Rationes } & 361\end{array}$

9.2.8 Het werkgeversverweer van afdeling 7.17.2 BW 365

9.2.9 Bijzonderheden van het werkgeversregres 367

$\begin{array}{lll}9.3 & \text { Concurrende vorderingen } & 370\end{array}$

9.3.1 Drie standaardregelingen $\quad 370$

9.3.2 Afdeling 7.17.2 BW, art. 2 VOA, art. 90 WAO 371

$\begin{array}{lll}\text { 9.3.3 Onduidelijkheid } & 372\end{array}$

$\begin{array}{lll}\text { 9.3.4 Voorstel algemene regel } & 374\end{array}$

9.4 Andere verhaalsacties 377

9.4.1 Normale onrechtmatige daadsactie $\quad 377$

$\begin{array}{ll}\text { 9.4.2 Een 'super' beperkende uitleg } & 378\end{array}$

$\begin{array}{ll}\text { 9.4.3 Bijzondere perikelen } & 381\end{array}$

9.4.4 Cessie 383

9.4.5 Afspraken tussen (potentiële) regresnemers en benadeelde $\quad 386$

$\begin{array}{lll}9.5 & \text { Conclusie } & 388\end{array}$ 
$\begin{array}{lll}10.1 & \text { Inleiding } & 389\end{array}$

$\begin{array}{lll}10.2 & \text { Wettelijk kader } & 390\end{array}$

10.3 Functies van het regres 394

$\mathbf{1 0 . 4}$ Het aansprakelijkheidsregime bij regres 396

$\begin{array}{lll}10.5 & \text { Uitvoering } & 398\end{array}$

SUMMARY 401

VERKORT AANGEHAALDE LITERATUUR 411

GERAADPLEEGDE RECHTSPRAAK 430

TREFWOORDENREGISTER 435

CURRICULUM VITAE 441 


\section{Afkortingen}

AAF

AAV

AAW

aant.

ABP

ABW

$A c P$

afd.

A-G

AMP

ANW

$A P B$

ARAR

adv

ARP

art.

$A \& V$

$A V \& S$

AWB

AWBZ

BBR

BGH

$B G H Z$

BV

BW

CAO

C.Ass.

Cass.mix.

Cass.civ.

Cass.soc.

CBS

CC
Arbeidsongeschiktheidsfonds voor ambtenaren

Nederlandse Vereniging van Algemene Aansprakelijkheidsverzekeraars

Algemene arbeidsongeschiktheidswet aantekening

Algemeen Burgerlijk: Pensioenfonds (Stichting Pensioenfonds $\mathrm{ABP}$ )

Algemene bijstandswet

Archiv für die civilistische Praxis

afdeling

Advocaat-Generaal

Algemene militaire pensioenwet

Algemene nabestaandenwet

Algemeen Politieblad

Algemeen rijksambtenarenreglement

arbeidsduurverkorting

Anti-Revolutionaire Partij

artikel

Aansprakelijkheid \& Verzekering

Aansprakelijkheid, Verzekering en Schade (voorheen A\&V)

Algemene Wet Bestuursrecht

Algemene Wet Bijzondere Ziektekosten

Bindend Besluit Regres

Bundesgerichtshof

Entscheidungen des Bundesgerichtshofs in Zivilsachen

Besloten Vennootschap

Burgerlijk Wetboek

collectieve arbeidsovereenkomst

Code des assurances

Cour de Cassation, Chambre mixte

Cour de Cassation, Chambre civile

Cour de Cassation, Chambre sociale

Centraal Bureau voor de Statistiek

Code civil 


$\begin{array}{ll}\text { CDA } & \text { Christen Democratisch Appèl } \\ \text { CHU } & \text { Christelijk Historische Unie } \\ \text { CJIB } & \text { Centraal Justitieel Incassobureau } \\ \text { c.q. } & \text { respectievelijk } \\ \text { CRvB } & \text { Centrale Raad van Beroep } \\ \text { CSS } & \text { Code de la Sécurité Sociale } \\ \text { CVZ } & \text { College voor Zorgverzekeringen } \\ D & \text { Recueil-Dalloz-Sirey } \\ \text { D66 } & \text { Democraten } 66 \\ \text { d.d. } & \text { de dato } \\ \text { diss. } & \text { dissertatie } \\ \text { e.a. } & \text { en anderen } \\ \text { enz. } & \text { enzovoort } \\ \text { EU } & \text { Europese Unie } \\ \text { e.v. } & \text { en volgende }\end{array}$

FAOP Fonds arbeidsongeschiktheidsverzekering overheidspersoneel GAK Gemeenschappelijk Administratiekantoor

Gaz.Pal. Gazette du Palais

HR Hoge Raad

i.e. id est

Inv. 6 W.H.M. Reehuis \& E.E. Slob, Parlementaire geschiedenis van het nieuwe burgerlijk wetboek, invoering Boek 6, Deventer 1990

JCP Jurisclasseur périodique. La semaine juridique

$J O$ Journal Officiel

KVP Katholieke Volkspartij

LB Loi Badinter

LISV Landelijk instituut sociale verzekeringen

losbl. losbladige editie

max. maximaal

m.n. met name

MvA

Memorie van Antwoord

MvT

Memorie van Toelichting

NCW

Nederlands Christelijk Werkgeversverbond

$N J$

Nederlandse Jurisprudentie

NJB Nederlands Juristenblad

NJV

NLG

Nederlandse Juristenvereniging

$\operatorname{nr}(\mathrm{s})$.

nt.

NTBR

o.a.

Nederlandse gulden

nummer(s)

noot

o.m.

Nederlands Tijdschrift voor Burgerlijk Recht

onder andere

OOW Overheidspersoneel onder werknemerverzekeringen 
OR

p.

par.

$P G 6$

P-G

PIV

PvdA

REA

$\mathrm{Rb}$.

RM Themis

r.o.

Rv.

$s$.

SER

SGB

$S M A$

Sr.

Stb.

Sv.

SVR

TICA

TK

ToV

TRV

TVP

TVP

TW

USZO

uvi('s)

UWV

$V A$

$V B$

VersR

vgl.

VNG

VNO

VOA

$V R$

$V r b$

VVD

$V V P$

W
Obligationenrecht

pagina

paragraaf

C.J. van Zeben e.a., Parlementaire geschiedenis van het nieuwe Burgerlijk Wetboek, Boek 6, Deventer 1981

Procureur-Generaal

Stichting Personenschade Instituut van Verzekeraars

Partij van de Arbeid

Wet op de (re)integratie arbeidsgehandicapten

rechtbank

Rechtsgeleerd Magazijn Themis

rechtsoverweging

Wetboek van Burgerlijke Rechtsvordering

section

Sociaal-Economische Raad

Sozialgesetzbuch

Sociaal Maandblad Arbeid

Wetboek van Strafrecht

Staatsblad

Wetboek van Strafvordering

Sociale Verzekeringsraad

Tijdelijk instituut voor coördinatie en afstemming

Kamerstukken Tweede Kamer

Tijdschrift voor Overheidsadministratie

Tijdelijke regeling verhaalsrechten

Tijdschrift voor Privaatrecht

Tijdschrift voor Personenschade

Toeslagenwet

Uitvoeringsinstituut Sociale Zekerheid Overheid en Onderwijs

uitvoeringsinstelling(en)

Uitvoeringsinstituut werknemersverzekeringen

Verzekerings-Archief

Verbondsbesluit

Versicherungsrecht

vergelijk

Vereniging van Nederlandse Gemeenten

Verbond van Nederlandse Ondernemingen

Verhaalswet ongevallen ambtenaren

Verkeersrecht

Verzekeringsrechtelijke berichten

Volkspartij voor Vrijheid en Democratie

Vereenigde Verzekeringspers

Weekblad van het Recht 


$\begin{array}{ll}\text { Afkortingen } & \\ \text { WA } & \text { wettelijke aansprakelijkheid } \\ \text { WAJONG } & \text { Wet arbeidsongeschiktheidsverzekering jong gehandicapten } \\ \text { WAM } & \text { Wet aansprakelijkheidsverzekering motorrijtuigen } \\ \text { WAMIL } & \text { Wet arbeidsongeschiktheidsverzekering militairen } \\ \text { WAO } & \text { Wet op de Arbeidsongeschiktheidsverzekering } \\ \text { WAZ } & \text { Wet arbeidsongeschiktheidsverzekering zelfstandigen } \\ \text { WBGA } & \text { Weekblad voor de Nederlandse Bond van Gemeenteambtenaren } \\ \text { WPA } & \text { Wet privatisering ABP } \\ \text { WPNR } & \text { Weekblad voor privaatrecht, notariaat en registratie } \\ \text { WSG } & \text { Wet schadefonds geweldsmisdrijven } \\ \text { WTV 1993 } & \text { Wet toezicht verzekeringsbedrijf 1993 } \\ \text { WTZ } & \text { Wet toegang ziektekostenverzekeringen 1998 } \\ \text { WULBZ } & \text { Wet uitbreiding loondoorbetalingsplicht bij ziekte } \\ \text { WVG } & \text { Wet gemeentelijke voorzieningen gehandicapten } \\ \text { WvK } & \text { Wetboek van Koophandel } \\ \text { WVW } & \text { Wegenverkeerswet } \\ \text { ZFW } & \text { Ziekenfondswet } \\ \text { ZW } & \text { Ziektewet }\end{array}$


Dit boek gaat over de wettelijke regresrechten van particuliere en sociale verzekeraars en andere schadedragers bij letsel of overlijden. Regres stelt hen in staat om de bedragen die ze moeten uitkeren te verhalen op degene die daarvoor aansprakelijk is. Die is meestal WA-verzekerd waardoor het regres (uiteindelijk) een zaak is tussen verzekeraars onderling. Is dat zinvol? De regering vindt dat wel, en heeft het aantal regresbepalingen in een tijdsbestek van vijf jaar meer dan verdubbeld. Zelfs zijn aanvullende regelingen ingevoerd die regresnemers extra financiële prikkels moeten geven tot het nemen van regres. Wenselijk of niet, het regres is 'alive and kicking'. De hoogste tijd dus voor een analyse: wat is het doel van deze regresrechten en in hoeverre vormt de huidige wettelijke regeling daarvoor het juiste kader?

\subsection{Inleiding}

Waarschijnlijk zullen velen zich nog de woelige regeerperiode herinneren van het christelijk-sociale kabinet Lubbers III. Daarin vond een trendbreuk plaats met betrekking tot de strijd tegen de stijgende kosten van sociale verzekeringen, met name de WAO. Niet langer wilde men zich 'blindstaren' op kostenbestrijding, de centrale peilers van het beleid werden gericht op het bevorderen van individuele verantwoordelijkheid en preventie. Met name op werkgevers werd tijdens Kok I en II in het sociale recht een vergaande verantwoordelijkheid gelegd voor de kosten van arbeidsongeschiktheid van eigen werknemers. ${ }^{2}$ Zo werden werkgevers verplicht tot doorbetaling van het loon in het eerste ziektejaar (inmiddels zijn er voorstellen tot uitbreiding naar de eerste $t w e e$ jaar waarin de werknemer niet tot werken in staat is) en werd het WAO-risico nauwer afgestemd op het risico per bedrijf. De gedachte hierachter is niet nieuw: de kosten moeten worden gedragen door de veroorzaker (en naar sociaal-economische maatstaven zijn dat primair werkgevers en uitkeringsgerechtigden). ${ }^{3}$ Door de kostenconfrontatie, of de dreiging daarvan, krijgt die een direct belang bij het nemen van kostenbeperkende maatre- 
gelen, hetgeen tot terugdringing van de sociale lasten zou moeten leiden. Dat is voor het huidige sociale beleid de centrale gedachte. ${ }^{4}$

Minder bekend is, dat in de nadagen van die periode, begin 1993, óók een beleid in gang is gezet met repercussies voor de civiel aansprakelijke. Bij het nieuwe sociaal-economische beleid paste volgens de regering namelijk tevens een uitbreiding van de verhaalsmogelijkheden voor werkgevers en sociale verzekeraars. ${ }^{5}$ Die zouden, als de arbeidsongeschiktheid of het letsel of overlijden is veroorzaakt door derden, in staat moeten zijn de uitkeringenlast op de bewuste derde te verhalen. Dat heeft geresulteerd in een aantal nieuwe 'regresrechten': rechten op basis waarvan sociale verzekeraars en werkgevers de uitkeringen die ze moeten doen kunnen verhalen op de civiele schadeveroorzaker. Het resultaat van die ontwikkeling is niet gering: vrijwel alle sociale verzekeringsinstellingen en werkgevers kunnen thans voor vrijwel alle uitkeringen en andere betalingen die ze bij ziekte, letsel of overlijden verschuldigd zijn een regresrecht inroepen jegens derden daarvoor aansprakelijk zijn. 'De veroorzaker betaalt' is het credo, óók in het aansprakelijkheidsrecht.

Het principe is best eenvoudig. Jansen loopt letsel op van een aanrijding in het wegverkeer en raakt arbeidsongeschikt. Voor de inkomensschade die daarvan het gevolg is heeft hij in beginsel een vordering tot schadevergoeding jegens de aanrijdende automobilist. Zonder het regres wordt die schade echter grotendeels door werkgevers en sociale verzekeraars vergoed, en ontspringt de automobilist dus spreekwoordelijk de dans. Maar omdat de sociale verzekeraar of werkgever in plaats van Jansen verhaal (regres) kan nemen wordt de civiele schadeveroorzaker (de aansprakelijke) toch nog met de kosten van het ongeval geconfronteerd.

\subsection{Beperking tot personenschade}

In dit boek volgt een bespreking van de wettelijke regresrechten van (met name) sociale verzekeraars en werkgevers. Het staat helemaal in het licht van de hiervoor beschreven ontwikkeling, en zal dan ook beperkt blijven tot het regres in de sfeer van personenschade: de schade door letsel of overlijden. Het personenschaderecht is een dermate specialistisch en op zichzelf staand gebied van aansprakelijkheid, ${ }^{6}$ dat een gescheiden behandeling ook op zijn plaats is. Het leek zinvol, zeker met het oog op de voortschrijdende privatisering, om ook het regresrecht van particuliere schadeverzekeraars erbij te betrekken. Eigenlijk geldt dàt voor alle soorten

\footnotetext{
Jaspers e.a. (2001), p. 39 (Jaspers) en p. 121 (Fluit \& Wilthagen).

Zie over de verhouding tussen die maatregelen en het aansprakelijkheidsrecht m. Klosse (2003), p. 25 e.v. Ook in praktisch opzicht, bij de schaderegeling, is het vergaand gespecialiseend, vgl. ook Studiegroep Verkeers. aansprakelijkheid (1978), p. 6. Cane (1996), p. 11 en $15-16$ wijst op constitutionele verschillen tussen personenrespectievelijk zaak- en zuivere vermogensschade.
} 
schade waarvoor de verzekering dekking biedt, dus ook cascoschade, brand of andere zaakschaden. Hier zal de regresregeling van particuliere schadeverzekeraars (art. $284 \mathrm{WvK} /$ art. 7.17.2.25 BW) dus wat beperkter worden bezien.?

In de sfeer van personenschade hebben alleen bepaalde categorieěn slachtoffers voor alleen bepaalde schade in het aansprakelijkheidsrecht recht op schadevergoeding. De consequentie daarvan is dat alleen de verzekeraars en werkgevers die aan die categorieën juist die schade vergoeden een regresrecht hebben.

\subsection{De onderhavige gevallen}

\subsubsection{Het regres bij letselschade}

Om welke gevallen het feitelijk gezien gaat, hangt af van de kring slachtoffers die aanvankelijk, zou de schade niet al door de regresnemer zijn vergoed, van de civiel aansprakelijke schadevergoeding had kunnen vorderen. Wie dàt zijn, is voor gevallen van letsel en overlijden vrij simpel vast te stellen: in het aansprakelijkheidsrecht geldt het uitgangspunt dat alleen aan degene die rechtstreeks van de schadeveroorzakende gebeurtenis letsel heeft opgelopen, een vordering tot schadevergoeding toekomt (de 'primair benadeelde'). Denk aan verkeersslachtoffers, asbestslachtoffers, of door het ongeval getraumatiseerde om- en bijstanders. ${ }^{8}$ Daarnaast hebben nog wat derden zoals familieleden, voorbijgangers en de werkgever van het primaire slachtoffer recht op schadevergoeding voor de kosten die ze moeten maken voor zijn herstel, bijvoorbeeld bezoekkosten of behandelingskosten (art. 6:107 BW). ${ }^{9}$ En als het recente wetsvoorstel 'affectieschade' van kracht wordt, dan zal bij ernstig letsel en overlijden ook nog een bepaalde kring van dierbaren recht hebben op smartengeld voor het verdriet en leed (immateriële schade) dat ze ondervinden van de kwetsing van het primaire slachtoffer. ${ }^{10}$ Het lijkt goed om in het navolgende ook met die toekomstige groep slachtoffers rekening te houden. Om wie het precies gaat, en op welk bedrag men recht zal krijgen, is nog onduidelijk.

Voor deze drie categorieën (het primaire slachtoffer, derden die kosten voor hem moeten maken voor zijn herstel en naasten met 'affectieschade'), kortom voor

Het regres bij brandschade is door brandverzekeraars zelf vergaand beperkt, hiemaar zal - ondanks dat dit veelal zaakschade is - wel enige aandacht uitgaan.

8. Mits hun trauma niet (uitsluitend) het gevolg is van het letsel of overlijden van andere slachtoffers, zie HR 22 februari 2002, NJ 2002, 240 nt. JBMV (Taxibus).

9 Denk ook aan veorbijgangers die een taxi regelen en betalen voor het vervoer van de benadeelde naar het ziekenhuis. De rechtspositie van 'good Samaritans' is, ook meer in zijn aigemeenheid, in de Engelse en Amerikaanse rechtsliteratuur vaker onderwerp van studie dan bij ons, zie Smits (2000), nt. 6 . 
al degenen met recht op schadevergoeding voor letselschade, zal in het navolgende de term benadeelde worden gebruikt. Van hun particuliere en sociale verzekeraars of werkgever komen de wettelijke regresrechten die hier centraal staan.

\subsubsection{Het regres bij overlijdensschade}

Sommige verzekeraars hebben (ook) een regresrecht voor uitkeringen die ze doen aan slachtoffers met aan overlijden gerelateerde schade. Naast het regres bij letselschade zullen daarom ook gevallen van overlijdensschade aan de orde komen. Voor het (definitief) ontnemen van het eigen leven heeft de overledene zelf jegens de aansprakelijke geen (te vererven) vordering, " maar wèl geeft het aansprakelijkheidsrecht bepaalde nabestaanden een vordering voor de schade die zij daarvan ondervinden. Art. 6:108 BW geeft onder meer de echtgenoot of geregistreerd partner en minderjarige kinderen, gezinsleden en bloed- en aanverwanten recht op vergoeding van de begrafeniskosten, indien die voor hun rekening komen, en de gederfde voorziening in het levensonderhoud (indien de overledene de kostwinner was). In de toekomst zal wellicht, als het genoemde wetsvoorstel 'affectieschade' van kracht wordt, ook een kring van dierbaren recht hebben op smartengeld voor het verdriet en leed (immateriële schade) dat ze ondervinden van het overlijden van het primaire slachtoffer. ${ }^{12} \mathrm{Bij}$ het gebruik van de term benadeelde in het navolgende moet dus óók worden gedacht aan al deze slachtoffers (nabestaanden met vermogensschade in de zin van art. 6:108 $\mathrm{BW}$ of, naar komend recht, affectieschade).

Voor het regres in de sfeer van overlijdensschade is alleen plaats in de genoemde gevallen. De regresnemers op dat gebied zijn hoofdzakelijk (bepaalde) uitvaartverzekeraars van de overledene en/of van de nabestaanden, het ABP, de Sociale Verzekeringsbank, en het Schadefonds Geweldsmisdrijven. ${ }^{13}$

\subsection{Begrippenapparaat}

\subsubsection{Terminologische opmerkingen}

Hiermee werden globaal de gevallen aangegeven waarop het regres voor personenschade betrekking heeft. Ook met betrekking tot het gekozen begrippenapparaat is verduidelijking vooraf op zijn plaats. Met de term aansprakelijkheidsrecht zal

Wel, onder omstandigheden, voor het ontnemen van de tijd om te (kunnen) leven, aldus HR 20 september 2002 , RviW 2002, 142 (Comapatiênt) 
het geheel van wettelijke regels worden bedoeld die personen of rechtspersonen aan wie de oorzaak van schade civielrechtelijk kan worden toegerekend tot schadevergoeding verplichten. Denk met name aan de regels van het onrechtmatige daadsrecht, zowel schuld- als risicoaansprakelijkheid en de regels bij de toerekenbare tekortkoming in de nakoming van een contractuele verplichting (art. 6:74 e.v. BW). De term aansprakelijkheid zal dus uitsluitend worden gebruikt in de zin van juridische verwijtbaarheid (en de daarop gebaseerde verplichting tot schadevergoeding). Dat is van belang op te merken, omdat tot het aansprakelijkheidsrecht soms alle wettelijke regels worden gerekend die tot schadevergoeding verplichten, ongeacht de grondslag daarvan. De term wordt zelfs nog weer anders gebruikt, namelijk in de zin van verhaalsaansprakelijkheid (het met het eigen vermogen moeten instaan voor de uitwinbaarheid bij wanbetaling). ${ }^{14} \mathrm{Ik}$ gebruik hem alleen in eerdergenoemde zin.

Ook de term regres verdient toelichting. In wettelijke regelingen wordt ook wel de term verhaal (en/of verhaalsrecht) gebruikt. ${ }^{\text {is }}$ Van Dale maakt geen onderscheid, ${ }^{16}$ maar strikt juridisch heeft de term verhaalsrecht de neutrale betekenis van: recht op betaling van een geldsom, ongeacht jegens wie en waarom. ${ }^{17}$ Daaronder valt dus óók het recht op schadevergoeding van de benadeelde zelf. Om de verhaalsrechten van verzekeraars en werkgevers van het recht op schadevergoeding te kunnen onderscheiden is de term regresrechten duidelijker. Regres betekent in juridisch jargon specifiek dat indien A (schuldenaar) een prestatie betaalt aan $Z$ (zijn schuldeiser), A daarvoor recht heeft op terugbetaling van B (een andere schuldenaar) omdat B diezelfde prestatie verschuldigd was aan Z. Dat is precies de situatie waarover het hier zal gaan. De term regres zal daarom worden aangehouden.

Het regresrecht van particuliere verzekeraars komt anders tot stand dan dat van sociale verzekeraars. Particuliere schadeverzekeraars worden gesubrogeerd, een vorm van rechtsovergang onder bijzondere titel. ${ }^{18}$ Gesproken wordt daarom ook wel van 'subrogatoire' regresrechten. Sociale verzekeraars verkrijgen niet de vordering van de benadeelde, maar beschikken los daarvan over een eigen regresrecht. Daarvoor zal ook wel de term 'zelfstandige' regresrechten worden gebruikt. Die term moet niet worden verward met normale, rechtstreekse onrechtmatige daadsac-

Zie daarover Asser-Hartkamp 4-I, nr. 33.

$\mathrm{VgL}$. De Bosch Kemper (1995), p. 80. In de sociale verzekeringswetgeving (maar ook in de TRV) wordt gesproken van 'verhaslsrechten', vgl. art. 90 WAO. Die term omvat ook de plicht tot terugbetaling die op de uitkeringsgerechtigde nust, bijvoorbeeld als blijkt dat hij zijn schade zèlf heeft veroorzaakt.

16 De term regres wordt er geduid als 'schadevergoeding', en de term verhal eigenlijk als hetzelfde ('schadeloosstelling').

Dat geldt zowel in als buiten het aansprakelijkheidsrecht, zo bijvoorbeeld voor de terugvordering van bijstand ingevolge de Algemene bijstandswet en de Wet terugvordering en verhaal; TK 1987-88, 20 598, nr. 3 (MvT), p. 1.

Zie art. 3:80 BW. Het recht ontstaat dan doordat bij betaling van de verzekeringsuitkering het recht op schadevergoeding van de benadeelde krachtens ant. $284 \mathrm{WvKJ}$ ant 7.17.2.25 BW op de verzekeraar overgaat. 
ties. Het zelfstandige karakter betekent slechts dat het regresrecht niet afhankelijk is van de vordering van de benadeelde.

\subsubsection{Aanduiding van de partijen}

Op het gebied van personenschade verdient de aanduiding van de partijen bijzondere aandacht. Uitgangspunt is dat bij de aan het regres ten grondslag liggende situatie drie partijen betrokken zijn:

de verzekeraar, werkgever of andere schadedrager (regresnemer) de aansprakelijke of diens WA-verzekeraar (schadeveroorzaker) het slachtoffer (benadeelde)

De onderhavige regresrechten zijn beperkt tot verzekeraars, werkgevers en anderen die de schade van de benadeelde anders dan uit of omwille van (wettelijke) aansprakelijkheid voor hun rekening nemen. Het gaat om de regresvorderingen van zulke schadedragers (en dus niet ook om het regres van mededaders of van WAverzekeraars die schade voor hun rekening nemen). Op het gebied van personenschade valt zoals ik al aangaf met name te denken aan particuliere schadeverzekeraars, socialezekerheidsinstanties, werkgevers en het Schadefonds Geweldsmisdrijven. Verder maken de regresregelingen geen onderscheid tussen schadedragers wier betrokkenheid al dan niet commerciële of zakelijke doeleinden dient. Zulke terminologische beperkingen lijken dan ook op voorhand onnodig complicerend. De term schadedragers is wat ruimer dan 'verzekeraars' en ziet op particuliere en sociale verzekeraars en andere risicodragers die rechtstreeks schade van de benadeelde voor hun rekening nemen. ${ }^{19}$ Met verzekeringen worden veelal die verzekeringen bedoeld, waarbij de benadeelde verzekerd is, zogenaamde first-party verzekeringen, niet ook aansprakelijkheids- ofwel WA(M)-verzekeringen. ${ }^{20}$

De term sociale zekerheid wordt in de rechtsliteratuur verschillend gebruikt. Hier zal ermee worden bedoeld: het geheel van aanspraken die de benadeelde ontleent aan sociale verzekeringen, sociale voorzieningen en/of verwante regelingen. ${ }^{21}$ In dat verband zullen met name het Uitvoeringsinstituut werknemersverzekeringen (het UWV), het College van Toezicht op de Zorgverzekeringen (het CTZ), en

Zie voor een overzicht van de branche-indeling van de schadeverzekeringsmarkt Oosenbrug e.a. (1996), p. 24. M. van Dam (2001), p. 237. De term first-party is nogal ambigu, soms wordt hij gebruikt als alternatief voor de term verkeersverzekering, zie TK 1995-96, 21 528, nr. 6, p. 7. Ik zal de term alleen gebnuiken voor particuliere verzekeringen in de zoěven in de hoofdtekst vermelde zin, niet ook voor sociale verzekeringen. Strikt genomen betaalt de verzekende immers alleen dan premie voor zijn eigen - geindividualiseerde - schaderisico. Het kwalificeren van sociale wetten als volks- of werknemersverzekering dan wel als sociale voorziening veronderstelt wellicht een scherper onderscheid dan er werkelijk is, maar dit kan hier blijven rusten. Bij verwante regelingen wordt gedacht aan ambtelijke en arbeidsrechtelijke aanspraken en voorzieningen, met name krachtens het ARAR en het BW. 
de Sociale Verzekeringsbank ter sprake komen. Dat zijn de uitvoerders van de meeste sociale regelingen waarvoor een regresrecht geldt.

De Sociale Verzekeringsbank is wel bekend, maar het UWV bestaat formeel pas sinds I januari 2002 en verdient dus een korte toelichting. Dit instituut is publiekrechtelijk van aard en verenigt de vijf uitvoeringsinstellingen en het LISV (dat sinds 1997 de taken heef overgenomen van de daar toen van ontheven bedrijfsverenigingen). Het CTZ ziet toe op de uitvoering van de Ziekenfondswet en de Algemene wet bijzondere ziektekosten. De uitvoering van de sociale verzekeringen blijt (vooralsnog) een publieke taak. Aanvankelijke plannen om de uitvoeringsinstellingen onderling te laten concurreren lijken (voorlopig) van de baan.

In plaats van 'civiel aansprakelijke' zal ik bij voorkeur de term schadeveroorzaker gebruiken. Daarmee wordt degene bedoeld die naar civielrechtelijke maatstaven (de normen van het aansprakelijkheidsrecht) als veroorzaker wordt aangemerkt. De term aansprakelijke is hier wat verwarrend. Bij het regres heeft die aansprakelijkheid namelijk steeds betrekking op de rechtsverhouding tussen de aansprakelijke en het slachtoffer (de primair benadeelde). Om dan toch van aansprakelijke te blijven spreken wekt gemakkelijk de indruk dat de schadeveroorzaker tevens aansprakelijk is (en dus tot schadevergoeding gehouden) jegens de regresnemer zelf. Het is een wat technisch punt, dat ik hier vast wilde aanstippen. Ik zal er nog uitvoerig op terugkomen.

Ten slotte verdient nog opmerking, dat onder 'benadeelde' degene zal worden verstaan, wiens schade de regresnemer voor zijn rekening heeft genomen en jegens wie aan alle voorwaarden voor aansprakelijkheid van de schadeveroorzaker is voldaan. Zoals hiervóór al kort werd aangegeven, moeten daaronder op het gebied van personenschade worden verstaan:

a. Het primaire slachtoffer (zoals verkeersslachtoffers, maar ook getraumatiseerde om- en bijstanders).2.

b. Derden die kosten maken voor het herstel van het primaire slachtoffer (voorzover art. 6:107 BW hen recht geeft op schadevergoeding).

c. Naasten van het primaire slachtoffer met affectieschade, voor wanneer ze daarvoor naar komend recht aanspraak maken op schadevergoeding.

d. Nabestaanden van het primaire slachtoffer met vermogens- of naar komend recht affectieschade (voorzover art. 6:108 BW hen daarvoor recht geeft op schadevergoeding). ${ }^{23}$

22 Mits an de voorwaarden is voldaan die de Hoge Raad daarvoor formuleerde, HR 22 februari 2002, NJ2002. $240 \mathrm{nt}$. JBMV (Taxibus).

23 En overigens andere derden die recht hebben op vergoeding van de kosten van lijkbezorging, op de voet van art. 6:108 lid 2 BW (of een eventuele lex specialis) 
Voor al deze categorieën wordt de term benadeelde gebruikt; de term gekwetste of 'slachtoffer' leek minder passend voor degenen die kosten maken voor het herstel van het primaire slachtoffer, categorie $b$. De genoemde vier categorieën benadeelden vragen om een korte toelichting. Onder 'primair slachtoffer' wordt degene verstaan die rechtstreeks schade opliep van het schadeveroorzakende gedrag. Daarin zit het verschil met de andere categorieën benadeelden (wier schade immers het gevolg is van het letsel of overlijden van anderen). Het uitgangspunt naar geldend recht ${ }^{24}$ is zoals gezegd dat alleen het primaire slachtoffer een integraal recht op schadevergoeding toekomt. Daarnaast hebben de categorieën benadeelden van sub $b-d$, voor de daar genoemde schadeposten, een beperkt recht op schadevergoeding. ${ }^{25}$ Voor hùn verzekeraars geldt mutatis mutandis hetzelfde als voor verzekeraars van het primaire slachtoffer (sub $a$ ).

De benadeelde is zèlf overigens geen regrespartij, hij is alleen betrokken in zijn hoedanigheid van oorspronkelijke schuldeiser van de regresnemende verzekeraar en van de aansprakelijke.

\subsection{Tot slot}

Het navolgende zal in hoofdzaak beperkt blijven tot het Nederlandse recht. De reden daarvan is dat een integrale studie naar de wettelijke regresrechten van particuliere en sociale verzekeraars en werkgevers nog ontbrak en juist die, gelet op de uitbreiding die het aantal regresrechten de laatste jaren heeft ondergaan, het hardst nodig leek. Rechtsvergelijkende overzichten zijn er al wel. ${ }^{26}$ Verder is het zo, dat de regresregelingen een sterk nationaal karakter hebben (denk aan de verhouding tussen sociale verzekeraars en WA-verzekeraars, het beleid inzake de sociaal zekerheid, de Tijdelijke regeling verhaalsrechten, het verkeersaansprakelijkheidsrecht, de positie van sociale verzekeraars, het werkgeversregres, enzovoort). Een studie met een rechtsvergelijkende opzet zou zich moeten uitstrekken over delen van het sociale zekerheidsrecht, het aansprakelijkheidsrecht en de positie van regresnemers in het buitenland. Binnen het beschikbare tijdsbestek leek dat in het licht van het voorgaande niet wenselijk, het Nederlandse recht riep daarvoor op zichzelf al teveel vragen op. Ook aspecten van internationaal privaatrecht en verdragenrecht bleven om die reden buiten beschouwing.

Dit uitgangspunt is volgens (thans demissionair) minister Donner aan heroverweging toe, TK 2002-03,28781. nr. 3. par. 7.

25 Ook de grondslag van het recht op schadevergoeding is in de gevallen sub $b-d$ anders, het gaat er niet om directe aansprakelijkheid. Dit aspect kan hier voorlopig blijven rusten; in paragraaf 4.9 zal het uitvoeriger aan de orde komen.

Voor uitvoerige overzichten van Duits, Frans, Zwitsers en ftaliaans recht en de uitvoeringspraktijk in die landen zij verwezen naar De Haas \& Hantief (1996), p. 46 e.v., zie voorts korte overzichten bij De Haas \& Hartlief (1998) en daarover Engelhard (1999), p. 180. Zie specifiek over de Franse regrespraktijk ook Barendrecht \& Weterings (2000), p. 16 e.v. en over het regres van schadeverzekeraars naar Frans en Duits recht Mulder (1988), p. 12 e.v.
} 


\section{Inleiding}

Wie door een persoonlijke fout of door risicoverhogende activiteiten schade veroorzaakt aan een ander moet de gevolgen daarvan dragen: op deze rechtsopvatting berust het aansprakelijkheidsrecht. Voor een deel van de schade gebeurt dat in de vorm van schadevergoeding. Voor schade die al door particuliere en sociale verzekeraars is vergoed vindt regres plaats, dat is terugbetaling van de uitkeringen die deze verzekeraars aan de benadeelde hebben moeten doen. Hoofdzakelijk om budgettaire redenen heeft de regering het aantal regresrechten de laatste jaren sterk uitgebreid. Maar in hoeverre zijn die regelingen ook juridisch-dogmatisch verantwoord? In dit hoofdstuk volgt een kennismaking en wordt de probleemstelling nader toegelicht.

\subsection{Het gecompenseerde deel van de schade}

Marcel D. heeft iemand van de nachtdienst wiens gedrag hem niet beviel, tijdens een uit de hand gelopen ruzie een dusdanige trap gegeven dat de man bijna negen maanden lang arbeidsongeschikt is geweest. De (toenmalige) bedrijfsvereniging heeft voor ruim 10000 Euro ziekengeld aan de man moeten uitkeren. ${ }^{27}$ Het is maar een greep uit de vele gevallen van letsel of overlijden dat door anderen dan het slachtoffer wordt veroorzaakt. In het kleine deel van de gevallen waarin de schadeveroorzaker daarvan een verwijt kan worden gemaakt in de zin van het aansprakelijkheidsrecht, ${ }^{28}$ kan de schade in beginsel voor zijn rekening worden

Feiten zoals weergegeven in de Conclusie van A-G Koopmans bij HR 23 december 1994, NJ 1996, 349 (Douma/Bedrijfsvereniging)

28 Naar mijn inschatting ligt de verhouding voor overlijdensschade zo, dat bij een - reeel geschat - totaal aantal overledenen van 135000 Nederianders, niet meer dan 3000 gevallen te wijten zijn aan anderen (men vergelijke de CBS-cijfers over het aantal overledenen naar doodsoorzaak, Statistisch Jaarboek 2000, p. 97 en 98 , tabel 23 en 24). Dat zal dan vermoedelijk in minder dan de helft van die gevallen (1 500 ), een percentage dus van maximaal $1 \%$, tot aansprakelijkheid leiden. Bij de Studiegroep Verkeersaansprakelijkheid (1978), p. 102 werd het percentage van verkeersslachtoffers met een vordering destijds geschat op $25 \%$. Het feitelijke aantal gevallen van overlijden (of letsel) dat tot aansprakelijkheid leidt is naar mijn weten onbekend. 
gebracht. Dat gebeurt grotendeels in de vorm van regres, dat wil zeggen door verhaalsacties van verzekeraars van de benadeelde. ${ }^{29}$

De benadeelde kan ook wel zelf de schadeveroorzaker aansprakelijk stellen voor zijn schade, maar financieel en emotioneel gezien ligt het voor de hand dat hij dat als een moeizame weg zal ervaren. Als er dan andere mogelijkheden zijn tot vergoeding lijkt zijn keuze gauw gemaakt. ${ }^{30}$ Vermoed wordt dat het grootste deel van zijn schade buiten het aansprakelijkheidsrecht om vergoed. ${ }^{31}$ Denk aan particuliere en sociale verzekeraars en andere schadedragers, zoals werkgevers die door loondoorbetaling een deel van de inkomensschade voor hun rekening nemen. De wet kent voor zulke gevallen afzonderlijk regelingen, waarin de schadedrager een regresrecht wordt gegeven jegens de schadeveroorzaker.

\subsection{De centrale situatie}

Het navolgende gaat over het regres van particuliere en sociale verzekeraars, werkgevers en anderen die de schade voor hun rekening nemen. Door de betalingen die zij doen aan de benadeelde is de schadeveroorzaker van zijn eigen vergoedingsplicht jegens de benadeelde bevrijd. De wettelijke regresbepalingen geven de schadedrager zoals gezegd recht op terugbetaling, regres. Het is dan toch nog, hoewel de schade van de benadeelde al is vergoed, de aansprakelijke, de schadeveroorzaker, die de schade draagt. Een voorbeeld kan illustreren hoe dit werkt.

Kees de Vries ontvangt naar aanleiding van het letsel dat hij opliep van een aanrijding met een beschonken chauffeur een ziekenhuisrekening van 5000 Euro. Zijn ziektekostenverzekeraar en het Uitvoeringsinstituut werknemersverzekeringen (UWV) dekken elk de helft van de kosten, zonder direct premienadeel of eigen risico voor De Vries. Daarmee verliest De Vries zijn vordering op de schadeveroorzaker. Zijn ziektekostenverzekeraar en het UWV kunnen de schadeveroorzaker echter wèl, op hun beurt, aanspreken tot regres, elk voor de helft van de schade.

Blijkens het bekende GRAS-rapport uit 1977 kwam ongeveer $56 \%$ van de totale schadelast bij personenschade ten goede aan regresnemende particuliere en sociale verzekeraars en de overheid, TK 1989-90, 21 528, nr. 1. p. 10. In 1986 werd geschat dat ongeveer tweederde van de procedures over personenschade alleen al kwam van sociale verzekeraars, zie Inv 6, p. 1410. Volgens cijfers van het Centrum voor Verzekeringsstatistiek van het Verbond van Verzekeraars zou de schadelast voor letselschade in het jaar 1997 'slechts' voor $40 \%$ uit regresschade bestaan en voor $60 \%$ uit vergoedingen aan de benadeelde zelf (respectievelijk 600 en 900 miljoen gulden); TK 1996-97, 21528, nr. 7, p. 2. Sinds toen is het aantal regresrechten echter fors uitgebreid en wordt bovendien het ten gelde maken daarvan gestimuleerd.

30 Uiteraard kan dat ook andere redenen hebben dan dat slachtoffers zich de gang van het aansprakelijkheidsrecht willen besparen, dat kan hier verder in het midden blijven.

31 Voor verkeersslachtoffers wordt gesproken van "het overgrote deel' van de schade, aldus TK 1995-96, 21528. nr. 6 (beantwoording Kamervragen), met de toevoeging dat data ontbreken. Bloembergen \& Van Wersch (1973), p. 144 noemden destijds voor verkeersongevallen een (macro)percentage van $90 \%$ van de personenschade. Het lijken inderdaad met name de 'top' van het inkomen en immateriele schade, die buiten het aansprakelijkheidsrecht onvergoed blijven. In vergelijkbare zin Bloembergen (1978), p. 704; Hartlief (1997), p. 29; Van Dam (1989), p. 206; Van Maanen (1998), p. I16; Hartlief (1998), p. 257; in die zin ook Markesinis (1994), p. 919 en Atiyah (1997), p. 96 en 98. 
De onderhavige regresrechten berusten alle op de wet. De wijze waarop particuliere en sociale verzekeraars hun regresrecht verkrijgen is wel enigszins verschillend geregeld. Bij particuliere verzekeraars gaat dat via een wettelijke vorm van rechtsovergang (subrogatie), zij verkrijgen de vordering die de benadeelde oorspronkelijk zelf tegen de schadeveroorzaker kon instellen. Hun regresactie staat of valt dan met die vordering, de benadeelde zelf is haar in zoverre als gevolg van de rechtsovergang verloren. ${ }^{32}$ Sociale verzekeraars die uitkeringen moeten doen hebben daarvoor zelfstandige regresrechten, los van de vordering van de benadeelde. ${ }^{33}$

\subsection{Een omstreden onderwerp van studie}

\subsubsection{Een heldere gedachte...}

De gedachte achter dit - ingewikkelde - systeem van aansprakelijkheid en regres is helder. Particuliere en sociale verzekeringen en andere laagdrempelige vergoedingssystemen voorkomen dat 19e eeuwse scenario's ontstaan, waarin de benadeelde voor het meest elementaire deel van zijn schade, ${ }^{34}$ afhankelijk is van het aansprakelijkheidsrecht (dat traag is en duur, en relatief weinig zekerheid biedt dat het ook daadwerkelijk tot vergoeding komt). ${ }^{35}$ Deze vergoedingssystemen bieden de snelle en ongecompliceerde opvang die nodig is, hetgeen ook verdere schade kan voorkomen. Er kunnen ook principiële motieven aan ten grondslag liggen, zoals bij uitstek het geval is bij de schadeopvang die de overheid financiert in de vorm van het Schadefonds Geweldsmisdrijven. Het fonds is bedoeld als blijk van empathie met de benadeelde.

Het Schadefonds Geweldsmisdrijven doet uitkeringen voor vermogens- en ook voor immateriële schade van slachtoffers van opzettelijke geweldsmisdrijven. Voorwaarde is wèl dat redelijkerwijs niet kan worden gevergd dat de benadeelde de betreffende schade reeds zelf langs andere weg kan verhalen. Indien derden voor de schade aansprakelijk (kunnen) zijn is bijvoorbeeld nodig dat de politie de benadeelde vanwege het risico van represailles heeft afgeraden om zèlf een vordering tegen de dader in te stellen. Hij krijgt zijn vergoeding dan van het fonds, dat op haar beurt door een regresactie de dader aanspreekt.

Het vooruitzicht van dubbele vergoeding van de benadeelde wordt vermeden door de regeling dat de benadeelde de schade die verzekeraars en fondsen vergoeden

Momenteel geldt daarvoor nog art. 284 WvK. Bij de incorporatie van het verzekeringsrecht in het Burgerlijk Wetboek zal deze bepaling worden vervangen door het vrijwel gelijkluidende art. 7.17.2.25 BW.

33. Zie onder meer ant. 90 WAO.

34 Cane (1996), p. 11 e.v.

35 'Duur' in die zin dat kosten van incasso, reiskosten, vrije dagen, correspondentie en dergelijke slechts zelden worden vergoed, omdat het zo zelden tot een gerechtelijke procedure komt, zo stelt Van Wersch (1971), p. 78 (en, voeg ik toe, bij schikking de bereidheid daartoe kennelijk ontbreekt). Wel valt het risico van sommige van deze kosten tegenwoordig veelal onder rechtsbijstandsverzekeringen. 
niet ook nog eens op de schadeveroorzaker kan verhalen. De regresrechten van deze schadedragers zorgen ervoor dat de schadeveroorzaker toch wordt geconfronteerd met de gevolgen van zijn verwijtbare gedrag. Regres voorkòmt met andere woorden dat hij 'de dans ontspringt' ${ }^{36}$ Dat het uiteindelijk toch nog de schadeveroorzaker is, die de schade draagt, bevredigt het rechtsgevoel. ${ }^{37}$

\subsubsection{Maatschappelijke meerwaarde?}

De bedragen die verzekeraars op de schadeveroorzaker kunnen verhalen zijn voor hen natuurlijk extra opbrengsten, geschat wordt dat jaarlijks op het gebied van personenschade in guldens een 'slordige' 1.5 miljard als regresopbrengsten wordt behaald. Maar de meer algemene, maatschappelijke betekenis hiervan houdt de meningen verdeeld. In hoeverre die opbrengsten eraan kunnen bijdragen dat de hoogte van de verzekeringspremies voor het collectief verzekerden waarvan de benadeelde deel uitmaakt beperkt blijft, is bijvoorbeeld moeilijk te zeggen ${ }^{38}$ Voor sociale verzekeraars zijn de regresopbrengsten zeer gering in verhouding tot het totaal van de sociale uitgaven. ${ }^{39}$ Voor schadeverzekeraars zal dat niet anders zijn. Meer intrinsieke voordelen van regres, zoals dat het bijdraagt aan een goede rechtsorde omdat de schadeveroorzaker moet betalen, klinken 'soft' en hebben geen directe geldwaarde. Vaker gehoorde rechtspolitieke argumenten zijn dat regres de schadeveroorzaker laat betalen en daarmee de 'juiste' prijs van schadeveroorzakende activiteiten beter zichtbaar maakt. Dat zou dan tevens preventief werken (nieuwe schadevoorvallen voorkomen). Specifieke studies hierover zijn echter zeldzaam en de 'harde' gegevens die beschikbaar zijn stemmen bovendien weinig optimistisch. ${ }^{40}$ Maar er zijn ook nadelen die het regres ronduit bezwaarlijk kunnen maken. Hèt bezwaar zijn de uitvoeringskosten, omdat die in verhouding tot de opbrengsten van regresacties redelijk hoog zijn. Daarbij moet vooral worden gedacht aan de kosten voor de direct bij het regres betrokkenen; die worden door regresnemers bij een normale afwikkeling van individuele regresvorderingen geschat op tien à vijftien procent van de regresopbrengsten. Aan de kant van WA-verzeke-

Bolt (1989a), p. 34

Vgl. TK 1995-96, 21 528, nr. 6, p. 19; Dorhout Mees (1935), p. 320 en Drion (1955), p. 6. Anders Bloembergen (1965), nr. 252, die stelt te betwijfelen 'of het wel onredelijk is de aansprakelijkheid te beperken in gevallen waarin het slachtoffer zelf al beschermd is'.

Zie paragraaf 6.2 .5 .

TK 1995-96, 21 528, nr. 6, p. 19: 'Een regresopbrengst van een paar honderd miljoen gulden op een totaal van $f 100$ miljard aan sociale uitkeringen en van ongeveer 4.5 miljard aan personensehade in het verkeer, is niet veel.' Zie ook Bloembergen (1994), p. 117 e.v. Veegens weet in zijn NJ-noot bij HR 17 oktober 1986, $N J 1987,317 \mathrm{nt}$.JBMV (Schotamus/Bedriffsvereniging) te vermelden dat niet meer dan $0.5 \%$ van de uitkeringen krachtens Ziektewet en WAO wortt verhaald. Voor het deel van de volksverzekeringen (oude AAW-deel. AWBZ en ANW) werd door de SER (1993), p. 6 uitgegaan van een percentage tussen de $0.57 \%$ en $1.14 \%$ van de totale uitgaven. Over het regres van de ZFW concludeert de Algemene Rekenkamer (1996), p. 9 dat in de jaren 19901994 gemiddeld ongeveer $5.81 \%$ per verzekerde aan regresopbrengsten werd behaald.

Zie hoofdstuk 6. 
raars wordt een percentage geschat van vijf à tien procent, ${ }^{41}$ waarbij voor de WA-verzekeraars alleen een totaalbedrag wordt genoemd van vijftig miljoen gulden per jaar, ${ }^{42}$ Andere kosten, met name wegens de extra belasting van het rechterlijk apparaat, acht de regering niet prohibitief. ${ }^{43}$

In 1989 werd ervan uitgegaan dat de rechterlijke macht ongeveer 1 tot $0.75 \%$ van haar totale werktijd besteedt aan vorderingen uit onrechtmatige daad en ongeveer $0.5 \%$ aan regreszaken." Inmiddels is wel ook het werkgeversregres ingevoerd ( $a r t .6: 107 a \mathrm{BW}$ ). Daar staat tegenover dat sociale verzekeraars door het maken van afspraken vooraf met WA-verzekeraars in aanmerkelijk meer gevallen dan in 1989 het risico van procedures weten te vermijiden.

Dat de afwikkelingskosten voor de bij het regres betrokkenen in verhouding tot de opbrengsten vrij hoog zijn is moeilijk met algemene cijfers te staven, ${ }^{45}$ maar het ligt ook eigenlijk wel voor de hand. Elk schadegeval moet in beginsel afzonderlijk worden afgehandeld. Daardoor ontstaat een administratieve omhaal van het aanhouden van dossiers, waarbij voor elk concreet geval moet worden nagegaan of er voldoende aanknopingspunten zijn voor het nemen van regres. Het moeten vaststellen van de toedracht van het ongeval en het inschatten van de aard en omvang van aansprakelijkheid zijn bewerkelijk, soms meer nog dan bij vorderingen van de benadeelde zelf. ${ }^{46}$ Sommige regresnemende verzekeraars zullen de kosten die dit meebrengt kunnen doorberekenen in de premies en dan is het dus in feite het hele collectief verzekerden dat ervoor betaalt. Weinig efficiënt is het bovendien als regresnemers, indien onverhoopt blijkt dat aan de benadeelde meer dan één uitkering moet worden verstrekt, bij elke betaling weer een nieuwe regresvordering moeten opstarten.

Afspraken tussen verzekeraars de laatste jaren hebben in dit opzicht een enorme verbetering gebracht. ${ }^{47} \mathrm{Zo}$ kan het UWV alle loonsvervangende uitkeringen bij arbeidsongeschiktheid die betrekking hebben op één individuele zaak 'bundelen',

41 Het verschit laat zich aldus verklaren, dat het regres voor WA-verzekeraars tezamen met de schadeclaims van verzekerden door de afdeling Personenschade kan worden afgewikkeld terwijl het regres voor regresnemers een aparte (personele) investering vergt; zie Barendrecht \& Weterings (2000), nt. 14.

Aldus Kremer (2000), p. 425 (directeur Stichting Personenschade Instituut voor Verzekeraars (PIV). Met vergelijkbare cijfers en percentages komen Barendrecht \& Weterings (2000), p. 9-10 in hun rapport, in opdracht van het PIV.

In de Notitie Verkeersaansprakelijkheid TK 1989-90, 21 528, nr. 1, p. 15 worden de kosten van extra belasting van de rechterijke macht die regreszaken veroorzaken althans 'niet groot' genoemd. TK 1989-90, 21 528, nr. 1 met nog verdere gegevens in dit verband.

45 Tien tot vijftien jaar geleden schatten de (toenmalige) bedrijfsverenigingen dat hun eigen kosten van het regres ongeveer $15 \%$ besloegen van de opbrengsten die het hen opleverde, TK 1995-96, 21 528, nr. 6, p. 19. Voor de schadeverzekeraars was het moeilijker cijfers te geven omdat de schadeafdeling het regres niet separaat van haar reguliere taken afhandelt, TK 1989-90, 21 528, nr. 1, p. 15.

$\mathrm{Vgl}$. Van Wersch (1971), p. 83. Dat is ook wel zo bij inning door de benadeelde zelf, maar met name verzekeraars kampen met in verhouding tot de opbrengsten substantiele administratickosten.

47 O.a. TK 1998-99, 26 238, Sib. 1999, 239 (Wet invoering en versterking regresrecht in AWBZ en ZFW). Wel lijkt de uitvoering van de regresrechten van verzekeraars en andere professionele schadedragers tevens te zijn bemoeilijkt door de invoering van art. 6:197 BW en de 'reflexwerking' darvan op het gebied van verkecrsaansprakelijkheid. 
in één keer afwikkelen. ${ }^{48}$ Het hoeft dus niet bij elke periodieke uitkering die naar aanleiding van hetzelfde schadevoorval wordt verstrekt weer een nieuwe regresactie in te stellen. Ook zijn in dit verband belangrijke afspraken gemaakt met het Verbond van Verzekeraars, die erop neerkomen dat men bij het WAOregres over bepaalde kwesties (te weten vrijwel alles wat betrekking heeft op het civiele plafond, zoals de bruto netto kwestie) niet meer procedeert, en bepaalde procedures en termijnen naleeft. ${ }^{49}$ Opmerkelijk is het regres van de Sociale Verzekeringsbank voor de uitkeringen aan nabestaanden en van het College voor Zorgverzekeringen voor de uitkeringen ingevolge de AWBZ. In beide gevallen vindt het regres plaats in de vorm van één jaarlijks vast te stellen afkoopsom die alle te verwachten schadevoorvallen dekt die tot regres kunnen leiden. Voor ANW- en AWBZ-uitkeringen worden dan ook vrijwel geen afzonderlijke regresvorderingen meer ingesteld. ${ }^{50}$ Dit voorkomt dat aansprakelijkheid, causaliteit en de omvang van het regresrecht in elk individueel geval afzonderlijk moeten worden vastgesteld. ${ }^{51}$ Het grote voordeel daarvan is dat dit de afwikkeling voor beide partijen (regresnemer en WA-verzekeraar) eenvoudiger maakt, wat dan weer tot een aanmerkelijke kostenreductie blijkt te kunnen leiden. ${ }^{52}$ Een collectieve afwikkeling relativeert bovendien het bezwaar, dat in regressituaties twee of meer procedures kunnen worden gevoerd waar dat er anders maar één zou zijn (hetgeen extra belastend zou zijn voor de rechterlijke macht). De regering hoopt intussen dat ook andere regresnemers dan de Sociale Verzekeringsbank en de AWBZ-organen zover kunnen komen. Bijzondere wetsbepalingen in onder meer de Ziekenfondswet en bijzondere arbeidsongeschiktheidswetten (WAZ en WAJONG) moeten bevorderen dat ook de regresvorderingen van die wetten collectief, in de vorm van één algehele som, worden afgewikkeld. ${ }^{53}$ Dit heeft nog niet geleid tot het maken van concrete afspraken. Want hoewel een collectieve afwikkeling van regresvorderingen 'in het veld'

Zie ant. 90 lid 2 WAO: 'Overeenkomstig door Onze Minister te stellen regelen kan het Uifvoeringsinstituut werknemersverzekeringen in plaats van het bedrag der periodieke verstrekkingen de contante waarde daarvan vorderen.

Voot alle lopende vorderingen met betrekking tot schadevoorvallen die vóór I januari 2001 hebben plaatsgevonden geldt het Convenant Verhaalsrecht WAO d.d. 27 november 1998. Bij schadevoorvallen na die datum geldt het Convenant Verhaalsrecht 2001 (voor Ziektewet, WAO, WAZ en WAJONG).

Zie paragraaf 4.2 .2 en 4.5 .2 .

De band met individuele vorderingen ontbreekt dan namelijk volledig. Barendrecht (1996), p. 138. Zie daarover verder o.m. Bloembergen 1987, p. 18; Hartief \& Van Maanen (1991), p. 302; Bloembergen (1994), p. 123; Faure (1996), p. 60; Barendrecht \& Weterings (2000), p. 11.

Barendrecht \& Weterings (2000), p. 12. Zelf plaats ik hierbij twijfels, zie paragraaf 6.5 .2 .

Ant. 61 lid 2 ANW: 'De Bank kan in plaats van het bedrag der periodieke verstrekkingen de contante waarde daarvan vorderen in de vorm van een jaarlijks vast te stellen afkoopsom die aan de Bank wordt vergoed voor de totale schadelast ten gevolge van het veroorzaken van overlijden.' Mutatis mutandis hetzelfde staat in ant. 69 lid 2 WAZ, ant 61 lid 2 WANONG, ant $65 b$ lid 3 AWBZ en an $83 b$ lid 3 ZFW. 
als een belangrijke verbetering lijkt te worden ervaren, ${ }^{54}$ is er ook scepsis, met name over het eigen rendement bij de overeen te komen regressom.

Een ander bezwaar bij het regres heeft vooral betrekking op het regres van sociale verzekeraars op WA-verzekeraars. In feite komt dat neer, zo gaat het, op een heenen-weer geschuif van betalingen tussen onderling sterk overlappende collectiviteiten van premiebetalers. Is immers niet het grootste deel van de Nederlandse ingezetenen zowel sociaal verzekerd als verzekerd voor het risico van wettelijke aansprakelijkheid? Het collectief sociaal verzekerden dat in de vorm van een premieverlaging van het regres kan profiteren is dan vrijwel gelijk aan het collectief dat de premies daarvoor opbrengt (de WA-verzekerden). Dit maakt regresacties omstreden, zeker waar het gaat om 'gemeenschapsgeld'.

\subsubsection{Een duidelijke beleidskeuze}

Het kabinet, of beter: het Ministerie van Sociale Zaken (de initiator van de recente uitbreiding van het regres), maakte een duidelijke keuze: de budgettaire voordelen van wettelijke regresrechten voor sociale verzekeraars prevaleren wat haar betreft boven de genoemde bezwaren. Tijdens de regeerperiode van kabinet Lubbers III en onder het sociaal-liberale bewind van kabinet Kok I en II is uitdrukkelijk gekozen voor een beleid waarin degene die aansprakelijk is voor het ontstaan van bepaalde kosten (schade) zoveel mogelijk met die kosten moet worden geconfronteerd. ${ }^{55}$ Dat dit principe niet langer beperkt moest blijven tot de civiele één-op-één verhouding tussen slachtoffer en schadeveroorzaker (of WA-verzekeraar) maar nu óók zou moeten gelden voor het deel van de schade dat door sociale verzekeraars en werkgevers wordt vergoed, had hoofdzakelijk te maken met het directe budgettaire belang van de regresopbrengsten. ${ }^{56}$ De opbrengsten zijn door het kabinet bij de invoering van de regresbepalingen voor sociale verzekeraars dan ook als het doel aangemerkt van die bepalingen. ${ }^{57}$ Daarnaast zou het regres (potentiële) schadeveroorzakers sterker dan voorheen moeten wijzen op hun individuele verantwoordelijkheid.

34 In die zin Kremer (1997), p. 45; Jansen (1999), p. 80; Frenk (1999), p. 42; Sinninghe Damsté (1999), p. 72; Kremer (2000), p. 427. Vgl, ook het rapport van Barendrecht \& Weterings (2000), p. 13, waarin een collectieve afwikkeling in vraaggesprekken als 'in principe de mooiste oplossing' wordt beschouwd en TK 1999-2000, $26238, \mathrm{nr} .13$ (ministeriele brief over de collectivering van het regres krachtens de AWBZ): 'Zowel bij de schadeverzekeraars als bij de uitvoeringsorganen $A$ WBZ bleek het draagvlak voor collectivering van regres groot:

55 Zie SER-rapport (1993), p. 22; daarover o.a. Bloembergen (1994), p. 117 e.v.; Hartief \& Van Maanen (1994), p. 75 e.v.; Van Maanen (1994), p. 94 e.v.; Janssen (1997), p. 156; diverse bijdragen in: De Haas en Hartief (1996), p. 26 e.v.; Kremer (2000), p. 424; Van Boom (2000a), p. 102 e.v.

s6. SER-rapport (1993), p. 21.

57 O.a. TK 1995-96, 24760 , nr. 3, p. 25, TK 1995-96, 24758 , nr. 3, p. 48, en TK 1998-99, 26 238, nr. 3, p 8. 
Gesproken werd zeer uitdrukkelijk van 'een tweeledig doel': regres moest extra opbrengsten genereren èn schadeveroorzakers wijzen op hun eigen verantwoordelijkheid voor het schadeveroorzakende gedrag. ${ }^{58}$ Met deze tweede peiler, het bevorderen dat de schadeveroorzaker de schade draagt, wilde het kabinet de kosten van schadeveroorzakend gedrag beter zichtbaar maken. Wat het daarvan precies verwachtte is onduidelijk, het benadrukt soms het belang van het verantwoordelijkheidsbesef (als einddoel) dan weer het belang van preventie. Waarschijnlijk paste het principe gewoon goed bij het (noodzakelijke) streven naar het terugdringen van de kosten van sociale zekerheid en de overheveling van risico's van de sociale naar de particuliere sector.

Maar in het ontbreken van een duidelijke visie op dit, voor de fundering van de geschetste ontwikkeling zo vitale punt, schuilt een moeilijkheid: waar ligt de grens? Men kan bij de uitbreiding en toepassing van de regresrechten moeilijk eenzijdig het belang van de regresopbrengsten laten prevaleren. Het geld zal toch ergens vandaan moeten komen. Het credo 'de schadeveroorzaker betaalt' wordt bovendien gemakkelijk een dekmantel voor een willekeurige uitbreiding van diens draagplicht. Dit laatste is, naar zal worden gezien, niet denkbeeldig; in de bruto-netto discussie bijvoorbeeld pleegt dat beginsel te worden aangevoerd als argument voor een uitbreiding van het regres die haaks staat op het gekozen wettelijke kader.

\subsection{Probleemstelling en opzet}

Ondanks het gebrek aan een duidelijke visie heeft dit beleid in de 'paarse' regeringsperiode in snel tempo geleid tot een uitbreiding van de wettelijke regresrechten. Dat roept materieelrechtelijke vragen op naar de rol die het aansprakelijkheidsrecht daarbij speelt en kàn spelen. In de eerstvolgende hoofdstukken zal na een korte introductie worden ingegaan op de juridische consequenties van het gekozen beleid: hoe ver kan en mag de wetgever gaan bij het aanwenden van het aansprakelijkheidsrecht voor het gekozen beleid? Opmerking verdient daarbij dat deze studie niet empirisch was. De bedoeling is ook niet om tot een definitieve eindwaardering van het regres te komen, zo dat al mogelijk en haalbaar zou zijn, maar om uitgaande van de beleidskeuze van het kabinet (het bevorderen van regres) de consequenties daarvan te beoordelen voor het materiële recht.

Hoe dit aan te pakken? In hoofdstuk 3 volgt een bespreking van de situatie die aan alle regresrechten ten grondslag ligt: de samenloop van verschillende vergoedingssystemen. Indien de schade van de benadeelde al door verzekeraars of werkgevers wordt vergoed, is de schadeveroorzaker (of diens WA-verzekeraar) in zoverre van zijn vergoedingsplicht bevrijd. Het regres zorgt ervoor dat de uiteindelijke draagplicht met betrekking tot de schade dan toch weer bij hem komt te liggen. 
In hoofdstuk 4 wordt nagegaan voor welke van die gevallen wettelijke regresbepalingen gelden. Dat gebeurt in de vorm van korte besprekingen van de regresbepalingen afzonderlijk en van de situaties waarin het regres (nog) ontbreekt. In het tweede deel van het hoofdstuk zal een algemeen juridisch kader voor deze regelingen worden geschetst: wat zijn de gemeenschappelijke kenmerken en voorwaarden? In hoofdstuk 5 wordt de hiervoor genoemde ontwikkeling van de regresregelingen in kaart gebracht, en de discussie over de functies van het regres die dit teweeg bracht. Die discussie betreft hoofdzakelijk aspecten zoals de regresopbrengsten, kosten en het effect daarvan op de premies, kortom: ze 'dekt' alleen de financiële en praktische kant van (uitbreiding van) het regres. Haar meer intrinsieke functie, haar doelstelling, krijgt nog onvoldoende aandacht. Daarover gaat hoofdstuk 6 .

Met deze theoretische en rechtspolitieke 'bagage' gaan we het tweede deel van het boek in. Een aantal bijzondere factoren bemoeilijkt de rechtspositie van de regresnemer in het algemeen vergeleken met die van de benadeelde. De wetgever heeft daaraan bij zijn keuze voor het regres vrijwel geen aandacht besteed. Hier kan alvast een impressie worden gegeven van hetgeen waaraan dan moet worden gedacht. Er zijn:

\section{Materieelrechtelijke complicaties}

Op grond van de Tijdelijke regeling verhaalsrechten (art. 6:197 BW) en jurisprudentie van de Hoge Raad geldt een deel van het aansprakelijkheidsrecht niet voor regresnemers. De commentaren in de literatuur zijn over deze differentiatie tussen regresnemer en benadeelde overwegend kritisch. In hoofdstuk 7 volgt hiervan een bespreking, en wordt tevens gewezen op rechtsregels waarvoor differentiatie juist wel (of: beter) op zijn plaats is.

\section{Technische complicaties}

Ook voor het bepalen van de omvang van het regres moet aansluiting worden gezocht bij het aansprakelijkheidsrecht; dit komt eveneens in hoofdstuk 7 en voorts in hoofdstuk 8 aan de orde. Met name het zogenaamde civiele plafond vraagt in dit verband aandacht, onduidelijkheid daarover maakt de grenzen van het regresrecht onzeker, hetgeen onwenselijk lijkt voor de praktijk en met het oog op een goede rechtsontwikkeling. In hoofdstuk $9 \mathrm{zal}$ worden nagegaan hoe $d$ wingend de grenzen zijn van de wettelijke regresbepalingen. Kunnen die grenzen door onderlinge partijafspraken of onrechtmatige daadsacties opzij worden gezet?

\section{Complicaties bij de uitvoering}

Hoewel het centrale punt van aandacht ligt bij de consequenties van de genoemde ontwikkeling voor het materiële recht, het aansprakelijkheidsrecht, kan dit moeilijk zonder aandacht te besteden aan de uitvoering 
van het regres. Dat gebeurt dan ook in de eerste plaats geïntegreerd, bij de bespreking van de genoemde deelonderwerpen. Een algemene bespreking volgt in hoofdstuk 9 . Nagegaan wordt in hoeverre de benadeelde nadeel kan en mag ondervinden van het regres, hoe de uitvoering in.de praktijk plaatsvindt en of er - buiten de grenzen van de wettelijke regresrechten - ruimte is voor andere acties tegen de schadeveroorzaker (op basis van diens aansprakelijkheid voor het schadevoorval).

Naast de genoemde punten zijn er uiteraard (zuiver) feitelijke verschillen tussen regresacties en de actie van de benadeelde. Wellicht zijn regresnemers beter in staat tot het voeren van langdurige procedures, maar ook eerder dan de benadeelde bereid tot schikken. Hun belang bij het inroepen van de aansprakelijkheid van de schadeveroorzaker is (in beginsel) zuiver financieel en dat zal bepalend zijn voor hun beleid bij het voeren van procedures.

\subsection{Doel van deze studie}

Deze studie gaat, zo is na het voorgaande duidelijk, over de gevolgen van de uitbreiding van het regres, die het kabinet met het credo 'de schadeveroorzaker betaalt' " propageert, voor het aansprakelijkheidsrecht. De centrale probleemstelling heeft betrekking op de mate waarin particuliere en sociale verzekeraars, werkgevers en andere regresnemers het aansprakelijkheidsrecht kunnen aanwenden, en behoren te kunnen aanwenden voor het 'terugvorderen' van door hen verschuldigde bedragen. $\mathrm{Zij}$ laat zich als volgt samenvatten:

In hoeverre bieden de regels en systematiek van het aansprakelijkheidsrecht (en de daaraan ten grondslag liggende dogmatiek) ruimte voor de toepassing ervan door regresnemers? 


\section{Verhouding schadeveroorzaker - benadeelde: schadeveroorzaker bevrijd}

De onderhavige regresrechten zijn bedoeld voor gevallen van aansprakelijkheid, waarin de benadeelde naast zijn vordering jegens de schadeveroorzaker schadeuit. keringen ontvangt van derden. Volgens de regels van het aansprakelijkheidsrecht verliest de benadeelde dan zijn recht op schadevergoeding, en gaat de schadeveroorzaker dus 'vrijuit'. De betalende derde heeft, op zijn beurt, regres voor de door hem betaalde bedragen en als gevolg daarvan komt de draagplicht met betrekking tot de schade uiteindelijk toch weer bij de schadeveroorzakerte rusten. Dit hoofdstuk gaat over dit vertrekpunt voor de wettelijke regresrechten: nagegaan wordt voor welke betalingen (en op welke grond) de benadeelde zijn recht op schadevergoeding verliest. In het volgende hoofdstuk wordt in kaart gebracht voor welke van die gevallen regresregelingen gelden.

\subsection{Eén schadevoorval, twee aanspraken}

\subsubsection{Aanspraak op de schadeveroorzaker}

Aan de onderhavige regresrechten ligt de situatie ten grondslag dat de benadeelde in het aansprakelijkheidsrecht een vordering tot schadevergoeding heeft, maar zijn schade al door derden wordt vergoed. Met de term aansprakelijkheidsrecht wordt het geheel van wettelijke regels bedoeld, die degene aan wie de oorzaak van de schade rechtens wordt toegerekend tot schadevergoeding verplichten. ${ }^{59}$ Denk aan het onrechtmatige daadsrecht, het wettelijke deel van het contractenrecht (met name art. 6:74 BW) en titel 6.4 BW (zaakwaarneming, onverschuldigde betaling en ongerechtvaardigde verrijking). Daarnaast zijn er bijzondere wetsbepalingen die tot het aansprakelijkheidsrecht kunnen worden gerekend, zoals art. $185 \mathrm{WVW}$. Al deze gronden voor aansprakelijkheid hebben gemeen dat de aansprakelijke een verwijt treft met betrekking tot de oorzaak van de schade. Hij is schadeveroorzaker, dat wil zeggen veroorzaker volgens de normen van het aansprakelijkheidsrecht (normen van verwijtbaarheid), en op die grond schadevergoeding verschuldigd. 


\subsubsection{Aanspraak op derden}

De centrale situatie is deze, dat de benadeelde voor zijn schade al vergoeding heeft ontvangen van derden, buiten het aansprakelijkheidsrecht om. Met name valt daarbij te denken aan uitkeringen uit particuliere of sociale verzekering. Verzekeringen moeten de zekerheid bieden dat bij een onzeker schadevoorval een uitkering of voorziening plaatsvindt. ${ }^{60} \mathrm{Ze}$ doen dat, vergeleken met het aansprakelijkheidsrecht, onder relatief eenvoudige randvoorwaarden. ${ }^{61} \mathrm{Zo}$ is de precieze toedracht van de schadeveroorzakende gebeurtenis voor het recht op de uitkering veelal niet van belang, ${ }^{62}$ en zijn er, mede daardoor, betere mogelijkheden om alvast een voorschot te krijgen als de schade nog niet precies vaststaat. ${ }^{63}$ Snelle en relatief eenvoudige schadeopvang (of het vooruitzicht daarop) kan de benadeelde wellicht ook verdere psychische of financiële schade besparen. Denk aan het recht op loondoorbetaling, de voorziening in revalidatietherapie door de werkgever, uitvaarten nabestaandenverzekeringen enzovoort. Met een beroep op zijn verzekeraar kan de benadeelde zich de kosten, tijd en energie en de emoties en onzekerheid van een beroep op het aansprakelijkheidsrecht besparen.

Dat de benadeelde met betrekking tot zijn schade tevens een beroep kan doen op het aansprakelijkheidsrecht staat dan ook veelal niet aan het ontstaan en geldend maken van zijn aanspraken op derden in de weg. Zonder uitdrukkelijk polisbeding kunnen particuliere verzekeraars zich niet ineens aan hun uitkeringsplicht onttrekken als blijkt dat óók de schadeveroorzaker voor de schade tot vergoeding is gehouden. ${ }^{64}$ Dat geldt ook voor anderen die wettelijk of contractueel jegens de benadeelde gehouden zijn tot het doen van een uitkering. Voor de Staat in zijn hoedanigheid als ambtenarenwerkgever bijvoorbeeld èn voor sociale verzekeraars en 'gewone' werkgevers (die verplicht loon doorbetalen bij arbeidsongeschiktheid) zijn bedingen tot vrijwaring zelfs nietig. ${ }^{65}$ De aanspraken daarop gaan dus niet ineens verloren

Vgl. de algemene definitie van Levenbach bij Köster (1971), p. 101.

Hartlief (1997), p. 28 e.v. De bescherming die verzekeringen bieden is veelal beperkt, en ook kan het geidend maken ervan voor de benadeelde onder omstandigheden weinig aantrekkelijk zijn, bijvoorbeeld omdat hij daarvan premienadeel ondervindt.

Vgl. Van Dam (1993), p. 162; Atiyah (1997), p. 120 en 151. Het is dan pas bij de weigering tot betaling dat de precieze toedracht relevant is. Stel- en bewijsplicht rusten op de verzekeraar, HR 22 september 2000, NTBR (2001), p. 47 (Engelhard).

Dat neemt niet weg, dat ook het inroepen van deze eigen particuliere en sociale verzekeringen voor de benadeelde nadelen kent. Schadeverzekeraars werden meer recent aangezet tot het verbeteren van de uitvoering als gevolg van de commotie over het vermeende traineren van de uitkering. NRC Handelsblad 5 oktober 2001 en TK 200102, nr. 134 (Antwoord op kamervagen). Voor de sociale verzekeringen probeen de regering al jaren om de uitvoering efficiênter te maken, zie o.a. de 'Notitie inzake schadevergoedingsmogelijkheden bij overschrijding van beslistermijnen op grond van de sociale verzekeringswetten', EK 2000-01, 27248 , nr. 123e, p. 3. Ledeboer (1927), p. 11 (met verwijzingen naar jurisprudentie); Köster (1971), p. 116; Mulder (1988), p. Se.v.; Van Boom \& Storm (1995), p. 149; en Van Boom (2000a), p. 18. Meer algemeen ook Bloembergen (1965), nr. 100.

HR 15 februari 1935, NJ 1935, 417 nt. EMM (RVB/Tolenaars). Voor bevrijding is alleen plaats voorzover de wet dat bepaalt, vgl. Köster (1971), p. 105. Hage (1935), p. 135 spreekt van de regel 'dat de aanspraken uit sociale verzekeringswetten nooit vermindering ondergaan'? 
door het enkele gegeven dat de benadeelde ook jegens de schadeveroorzaker aanspraak heeft op schadevergoeding.

Ook in het aansprakelijkheidsrecht is het uitgangspunt dat de benadeelde niet a priori zijn recht op schadevergoeding verliest als blijkt dat hij andere mogelijkheden heeft tot vergoeding. Het vorderingsrecht jegens de schadeveroorzaker heeft geen subsidiair karakter. Dat laat zich verklaren door de essentievan wettelijke aansprakelijkheid: de nadelige consequenties van het ongeval moeten binnen het kader dat de wet daarvoor biedt voor rekening komen van degene die daarvan een verwijt treft. ${ }^{66}$ Daarbij past dat de schadeveroorzaker zich jegens de benadeelde niet automatisch kan bevrijden door hem naar andere schuldenaren te verwijzen. ${ }^{67}$

Rechtens ontstaat dan een samenloop van aanspraken: de benadeelde heeft naar aanleiding van het schadevoorval een aanspraak op de schadeveroorzaker èn een aanspraak op derden. Dat vraagt zowel voor het aansprakelijkheidsrecht als voor de samenlopende vergoedingssystemen om een bijzondere regeling: beslist moet worden of hij beide aanspraken mag cumuleren.

\subsubsection{Twee aanspraken: welke gaat vóór?}

Hoe regelt het aansprakelijkheidsrecht de situatie waarin het schadevoorval de benadeelde ook al aanspraak geeft op prestaties (betalingen, verstrekkingen) van derden, zoals particuliere of sociale verzekeraars of zijn werkgever (denk voorts bijvoorbeeld aan betalingen die hij ontvangt van naasten of van fondsen)? Het uitgangspunt is dat de benadeelde vrij is om zelf te bepalen wie hij aanspreekt tot betaling. ${ }^{68}$ Dat lijkt ook redelijk. Hij moet financiële steun uit andere vergoedingssystemen niet opgedrongen krijgen en moet in staat zijn de door hem gewenste (en betaalde) mate van bescherming zelf te bepalen. Kiest hij voor schadevergoeding langs de weg van het aansprakelijkheidsrecht, en komt hem die keuze inderdaad toe, dan is daarmee voor dit boek 'de kous af'. De schadeveroorzaker moet de schade dan voor zijn rekening nemen. Hij kan de schade, of zelfs maar een deel van de schade, niet op zijn beurt afwentelen op de genoemde derden. De draagplicht berust in het wettelijke systeem dan uiteindelijk bij de schadeveroorzaker, degene die het verwijt treft van het ontstaan van de schade. De gedragsnormen van het aansprakelijkheidsrecht hebben kortom ook bij samenloop met andere vergoedingssystemen het laatste woord. Die normen, en niet de samenlopende

66 In hoofdstuk 6 zal ik verder hierop ingaan.

67 HR 23 april 1976, NJ 1976, 451 nt. GJS (Franciscaner pater); Schadevergoeding, ant. 107 (Bolt), aant. 10; Bloembergen (1965), nr. 100; Kóster (1971), p. 96; en Frick (1985), p. 1; Mulder (1988), p. II; Bolt (1989a), p. 37 ,

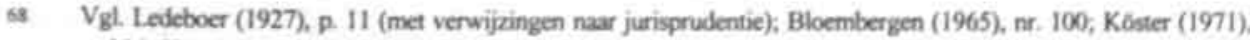
p. 116; Kottenhagen-Edzes (1993), p. 305; Van Boom \& Storm (1995), p. 149 en Van Boom (2000a), p. 18. 
vergoedingssystemen, bepalen bij wie de draagplicht met betrekking tot de schade uiteindelijk behoort te rusten. ${ }^{69}$

In het particuliere en het sociale verzekeringsrecht en het arbeidsrecht gelden echter bijzondere regelingen voor samenloop met het aansprakelijkheidsrecht, waarvan sommige de benadeelde wèl kunnen beperken in zijn keuze. Het gaat om contractuele of wettelijke (civielrechtelijke) regels waarin bepaald wordt of al dan niet aan degene die een beroep kan doen op het aansprakelijkheidsrecht aanspraak op een uitkering wordt geboden. Die regels lijken in het algemeen het uitgangspunt te delen dat dubbele schadevergoeding bij de benadeelde moet worden voorkomen. Schade kan en moet, zo lijkt het, slechts eenmaal worden vergoed. In het schadeverzekeringsrecht geldt daartoe het zogenaamde indemniteitsbeginsel: het schadevergoedingskarakter van de verzekering staat eraan in de weg dat wordt uitgekeerd voor schade die bijvoorbeeld al via het aansprakelijkheidsrecht is vergoed. De benadeelde mag door de verzekeringsuitkering niet in een duidelijk voordeligere positie geraken. ${ }^{70}$ Dubbele vergoeding van de benadeelde zou niet sporen met de wijze waarop art. $246 \mathrm{WvK} / \mathrm{art}$. 7.17.2.1 BW worden uitgelegd. ${ }^{71}$ Ook in het sociale recht heerst de visie dat dubbele vergoeding, eerst via het aansprakelijkheidsrecht en dan via de sociale verzekering of omgekeerd, onwenselijk is. In de Memorie van Toelichting bij de WAO merkt minister Veldkamp daarover op:

'Intussen dient de getroffene uiteraard niet langs tweeërlei weg, te weten via de regelen van het burgerlijk recht en via de voorgestelde arbeidsongeschiktheidsverzekering schadevergoeding te ontvangen. $\mathrm{Nu}$ is het niet uitgesloten, dat de rechter in het algemeen bij de vaststelling van de schadevergoeding, warop de verzekerde naar burgerlijk recht aanspraak kan maken ter zake van zijn arbeidsongeschiktheid, ook zonder nadere voorziening, rekening zal houden met de aanspraken die de betrokkene krachtens de voorgestelde wet heeft. Zeker is dit evenwel niet. Daarom is dit in het wetsontwerp [van de WAO, EE] neergelegd in artikel $89 .^{n}$

De gedachte bij de minister is dat indien de benadeelde een aanspraak heeft op een WAO-uitkering, daarbij niet ook nog eens plaats kan zijn voor schadevergoeding via het aansprakelijkheidsrecht. Voor alle 'verplichte' aanspraken uit sociale verzekering en het arbeidsrecht gelden daarom bijzondere voorrangsregelingen: ${ }^{73}$ het bedrag van de aanspraak komt in mindering op de door de schadeveroorzaker verschuldigde schadevergoeding, ongeacht of de aanspraak feitelijk al tot betaling

Asser-Hartkamp 4-1, nr. 446; Bloembergen (1965), nr. 101; Bolt (1989a), p. 37. Binnen het aansprakelijkheidsrecht zelf zijn er vervolgens nog verdere, meer verfijnde mogelijkheden van reallocatie van de schade, via het interne regres tussen medeaansprakelijken (art. 6:102 BW juncto art. 6:7 e.v. BW)

Dat laatste luidt: 'Schadeverzekering is de verzekering strekkende tot vergoeding van vermogensschade die de verzekerde zou kunnen lijden'. Uit het schadevergoedingskarakter wordt afgeleid dat voor het vergoeden van uit andere hoofde gecompenseerde schade geen plaats is. Vgl. Kremer (1988), p. 20.

7 Zie naast art. 89 WAO, onder meer ant 52 Ziektewet, ant. 83a Ziekenfondswet, ant. $13 \mathrm{AWBZ}$ en art. $60 \mathrm{ANW}$ Voor de uitkeringen krachtens de ambtenarenreglementen ontbreckt een uitdrukkelijke bepaling van verplichte voordeelstoerekening, maar is de regeling niet anders. 
is gekomen (zie onder meer art. $89 \mathrm{WAO}$ ). Vanuit het gekozen uitgangspunt dat dubbele vergoeding onwenselijk is ligt dat het meest voor de hand. Sociale verzekeringen bieden relatief meer zekerheid dat het ook daadwerkelijk tot vergoeding zal komen, de randvoorwaarden zijn er minder streng dan in het aansprakelijkheidsrecht. ${ }^{74}$ Het zou ook tot relatief meer administratieve omhaal leiden als de benadeelde de vrije keuze zou hebben, Van Boom wijst daarop: ${ }^{75}$ voor het ontstaan van het recht op een sociale uitkering of op loondoorbetaling zou dan in alle gevallen eerst moeten worden nagegaan of er daarnaast ruimte is voor aansprakelijkheid (hetgeen tot rechtsonzekerheid zou leiden en het proces van vergoeding voor uitkeringsgerechtigden zou kunnen vertragen). De consequentie van de voorrangsregelingen is dat benadeelde als het ware wordt genoodzaakt tot het geldend maken van de aanspraken op loon en een sociale uitkering.

Alleen voor fondsen geldt vaak het omgekeerde: die zijn dan pas tot vergoeding gehouden indien andere wegen zoals het aansprakelijkheidsrecht zijn afgesloten. Ze hebben cen subsidiair karakter. ${ }^{7}$ De invulling daarvan loopt uiteen. Het Schadefonds Geweldsmisdrijven komt al tot betaling als van de benadeelde redelijkerwijs niet kan worden gevergd dat hij de schadeveroorzaker aanspreekt tot vergoeding. Als men naar inschatting van het fonds een rečle aanspraak heeft op de schadeveroorzaker, wordt ook wel gewerkt met voorschotconstructies. Het fonds heeft dan recht op terugvordering. Ook vrijwillige betalers, zoals familieleden van de benadeelde, zijn uiteraard vrij om te bepalen of ze nog willen betalen als blijkt dat de benadeelde ook een beroep kan doen op het aansprakelijkheidsrecht.

Maar wat zijn de consequenties van het geldend maken van de aanspraken op deze derden voor de vergoedingsplicht van de schadeveroorzaker? Hoe is de samenloopregeling als de benadeelde een beroep doet op het aansprakelijkheidsrecht voor schade waarvoor hij al betalingen van derden heeft (of: nog gaat) ontvangen?

\subsection{Samenloopregeling van het aansprakelijkheidsrecht}

\subsubsection{Drie standaardmodellen}

Wat is rechtens indien de benadeelde zijn recht op schadevergoeding van het aansprakelijkheidsrecht inroept naar aanleiding van een schadevoorval waarvoor hij tevens betalingen ontvangt buiten het aansprakelijkheidsrecht om, zoals uit particuliere of sociale verzekering of van de werkgever? De samenloopregeling is één van de meest complexe onderdelen van het aansprakelijkheidsrecht. Een

\footnotetext{
Vgl. Hantief (1997), p. 28-29.

Van Boom (2000a), p. 25.

Het Waarborgfonds Motorverkeer heeft zelfs een speciale afdeling Fraude ter bestrijding van het risico van het opzettelijk ondermijnen van het subsidiaire karakter van het fonds
} 
dogmatisch kader kan helpen om daarbij het overzicht te houden. Er zijn globaal drie mogelijkheden om deze gevallen van samenloop in het recht te regelen. ${ }^{77}$ In het eerste model (cumulatie) heeft de benadeelde de vrijheid om zijn recht op schadevergoeding van de schadeveroorzaker onverminderd met zijn aanspraken jegens derden te cumuleren, ook al hebben die betrekking op hetzelfde schadevoorval. Een voorbeeld hiervan is de regel dat de benadeelde bij letselschade in beginsel zijn recht op schadevergoeding behoudt naast uitkeringen uit zogenaamde particuliere sommenverzekeringen. Het tweede model (bevrijding) houdt in dat de betalingen in mindering komen op de schadevergoeding en de schadeveroorzaker daardoor definitief is bevrijd van zijn aansprakelijkheid met betrekking tot de schade. Eén van de weinige voorbeelden daarvan is het geval waarin samenloop ontstaat tussen het aansprakelijkheidsrecht en de voorzieningen ingevolge de Wet voorzieningen gehandicapten. De gehandicapte verliest zijn recht op schadevergoeding jegens de schadeveroorzaker, voorzover de gemeente al betaalt voor de aanpassing van zijn woning. Door deze gemeentelijke voorzieningen is de schadeveroorzaker dus definitief van zijn aansprakelijkheid voor de schade bevrijd. ${ }^{78}$ Het derde model (interne draagplicht) verschilt in zoverre van het tweede, dat de derden die naar aanleiding van het schadevoorval gehouden waren tot betaling, daarvoor verhaal kunnen zoeken bij de schadeveroorzaker. De uiteindelijke draagplicht met betrekking tot de schade rust dan toch weer bij hem, op grond van zijn aansprakelijkheid voor de schade. Dat resultaat zou men kunnen bereiken door deze derden een normale, rechtstreekse vordering tot schadevergoeding toe te staan jegens de schadeveroorzaker, ${ }^{79}$ maar dat heeft zoals nog zal worden gezien nadelen. ${ }^{80}$ Een meer voorkomende manier waarop de uiteindelijke draagplicht toch weer bij de schadeveroorzaker kan worden gelegd zijn de wettelijke regresrechten, die in dit boek centraal staan.

Ook in andere rechtsstelsels worden dit de standaardregelingen genoemd voor de samenloop tussen de vordering tot schadevergoeding en betalingen uit andere vergoedingssystemen. Frick wijst tevens op de rechtspolitieke dimensie die in elk van die regelingen besloten ligt:

Zie Koster (1971). p. 105; vgl. ook Hartief (1997), p. 30 waar nog een vierde model wordt genoemd, namelijk dat waarin het ansprakelijkheidsecht is uitgeschakeld en vergoeding dus plantsvindt via concurrente vergoedingssystemen. Nu het mij gaat het om modellen voor samenloop van de aanspraken van het aansprakelijkheidsrecht zelf met aanspraken daarbuiten kan dit vierde model blijven rusten.

De WGV is éen van de weinige relevante sociale zekerheidswetten die vooralsnog geen wettelijk regresrecht kent.

Buiten het aansprakelijkheidsrecht kunnen enigszins vergelijkbare maatregelen worden getroffen. Van Bloembergen (1970), p. 74 ev. komt de suggestie van een toeslag op de accijnzen ten laste van het collectief schadeveroorzakers waarvan de aansprakelijke deel uitmaakt. De opbrengsten zouden volgens dit voorstel ten goede kunnen komen aan de verzekeringskas. 
'Das Zusammentreffen von Versicherungs- und Ersatzanspruch in der Person des Versicherungsnehmers begruindet aber dennoch Rechtsbeziehungen zwischen den beteiligten Personen. Es stellt sich nämlich bei funktionaler Betrachtungsweise das problem der gerechten Verteilung der Lasten unter Versicherungsnehmer, Versicherer und dritthaftendem Schädiger. Eine Lösung bietet sieh in dreifacher Hinsicht an. Man kann beide Ansprïche dem geschädigten Versicherungsnehmer belassen, sie in seiner Person hăufen und kommt so zum Kumulationsprinzip. Der Ersatzanspruch kann aber auch im Wege der Regresslösung dem Versicherer zugewesen werden. Ferner ist denkbar, die Leistung aus dem Versicherungsvertrag auf den schaden im Wege der Vorteilsausgleichung zugunsten des Schädigers anzurechnen."

In het navolgende zal worden gezien welke regels de samenloopregeling van het Nederlandse aansprakelijkheidsrecht biedt voor het maken van die keuze. Eerst zal het wettelijke kader daarvoor globaal in kaart worden gebracht (paragraaf 3.2.2 en 3.2.3), daarna volgt een bespreking van de samenloopregeling voor verschillende soorten betalingen afzonderlijk (paragraaf 3.3). De rationes en rechtspolitieke doeleinden die hieraan ten grondslag liggen vragen daarbij nog afzonderlijk aandacht (paragraaf 3.3.7).

\subsubsection{Vestiging-en omvangfase}

De vraag naar de invloed van vergoedingen of andere betalingen die de benadeelde al van derden heeft of gaat ontvangen komt pas aan de orde, nadat de aansprakelijkheid eenmaal vaststaat. In het Burgerlijk Wetboek wordt onderscheiden tussen de fase waarin wordt nagegaan of aan de voorwaarden voor aansprakelijkheid is voldaan (vestigingsfase) en die waarin het bedrag van de schadevergoeding die de schadeveroorzaker verschuldigd is wordt vastgesteld (omvangfase). ${ }^{82}$ Pas in de omvangfase ontstaat de vraag of de benadeelde ook reeds vergoedingen of verstrekkingen heeft ontvangen of nog zal ontvangen van derden.

De omvangfase wordt beheerst door de regels van afdeling 6.1.10 BW (Wettelijke verplichting tot schadevergoeding). Het uitgangspunt van afdeling $6.1 .10 \mathrm{BW}$ is, dat de schadeveroorzaker of diens WA-verzekeraar de benadeelde zoveel mogelijk in de toestand moet brengen waarin de benadeelde zonder het schadevoorval zou hebben verkeerd. ${ }^{83}$ Daarvoor moet een vergelijking worden gemaakt tussen de

Frick (1985), p. 2 (cursief toegevoegd, EE); zo ook Fredericq (1971), p. 5 -6 en Fleming (1970), p. 3 en Fleming (1985), p. 129: 'There are three possibilities: one is to permit the plaintiff to 'double recover', the second is to reduce his award, the third is to compel the tortfeasor to reimburse the other source.'

82 PG 6, p. 331; Asser-Hartkamp 4-I, nr. 404 ev.; Spier e.a (2000), nr. 197 (Hartlief); Bloembergen \& Lindenbergh (2001), p. 30. Bekend is dat dit onderscheid in de praktijk en soms ook bij de rechtsregels zelf zo scherp niet is, denk aan causaliteitskwesties, de regeling voor de vergoeding van shockschade en de $100 \%$-regel op het gebied van verkeersaansprakelijkheid. Ook afdeling 6,1.10 BW is niet steeds consequent: zo heeft ant. 6:99 BW (alternatieve causaliteit) betrekking op causaliteitsproblematick van de vestigingsfase.

83. In de Toelichting Meijers wordt niet uitgesloten dat afdeling 6.1.10 BW een ruimer bereik wordt gegeven, dus voor verbintenissen tot schadevergoeding die op een andere grond benust dan (eivielrechtelijke) wettelijke aanspra: kelijkheid. Voor de contractueie schadevergoeding geidt zij echter niet van rechtswege, PG 6, p. 331. Ook past terughoudendheid bij de vraag naar de toepasselijkheid ervan bij verplichtingen tot schadevergoeding die hun grondslag vinden in het bestuursrecht, Inv. 6, p. 1262. 
werkelijke toestand van de benadeelde en de (hypothetische) toestand zonder het schadevoorval. ${ }^{84}$ Indien blijkt dat de benadeelde van het letsel of overlijden schade ondervindt, dan dient vervolgens te worden nagegaan in hoeverre die volgens de regels van afdeling 6.1.10 BW verhaalbaar is. Als de vergelijking uitwijst dat het schadevoorval daarnaast ook voordeel voor de benadeelde heeft opgeleverd, dan kan dit voordeel onder omstandigheden in mindering worden gebracht op de door de schadeveroorzaker verschuldigde schadevergoeding. Dat geldt zowel voor reeds genoten voordeel als voor toekomstige aanspraken. ${ }^{85}$ Dat voordeel hoeft overigens niet noodzakelijk te bestaan uit betalingen of verstrekkingen die de benadeelde ontvangt van derden, zoals verzekeringsuitkeringen. Ook ander voordeel kan op het bedrag van de schadevergoeding in mindering worden gebracht, denk aan bespaarde kosten of fiscaal voordeel.

In de gevallen waarin de schade door de betalingen of verstrekkingen van derden geacht kan worden te zijn vergoed, is de schadeveroorzaker jegens de benadeelde bevrijd. In zoverre is de schade van de benadeelde 'goedgemaakt', zo is de gedachte, en voor een dubbel goedmaken van de schade is (ook) in het aansprakelijkheidsrecht geen plaats. De kosten van het ongeval zijn hiermee (uiteraard) niet minder geworden, ze zijn alleen overgegaan op de betalende derden (particuliere of sociale verzekeraars, werkgevers, naasten, fondsen) ${ }^{86}$ Zonder nadere regeling bepaalt het toeval dan:

"to what extent, if at all, "risk communities" other than that represented by the tortfeasor are to participate in bearing the loss. If, for example, the tortfeasor's liability were to be reduced by the amount of Social Security benefits accruing to the victim (...) its effect is that the general community shoulders part of the loss, relieving pro tanto the specific risk-creating activity (motoring, manufacturing, etc.). ${ }^{n}$

Regresbepalingen zorgen ervoor dat de uiteindelijke draagplicht met betrekking tot de schade alsnog bij de schadeveroorzaker (diens WA-verzekeraar) komt te rusten. Diezelfde functie vervult ook het vorderingsrecht van art. 6:107 BW. Dit laatste is strikt genomen geen regresrecht, maar het lijkt daar wel op. Het regelt dat niet alleen de primair benadeelde (de gekwetste), maar óók degene die kosten maakt ten behoeve van het herstel van de benadeelde recht heeft op schadevergoeding van de schadeveroorzaker. Denk aan familieleden die de verpleging en verzorging van de primair benadeelde op zich nemen en die daarvan schade ondervinden. ${ }^{88}$ Het vorderingsrecht van art. 6:107 BW heeft echter maar een beperkt geldingsbereik. Zo vallen werkgevers die bij arbeidsongeschiktheid loon doorbetalen

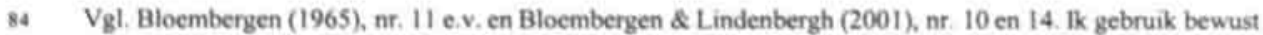
niet de term vermogenstoestand omdat de vergelijking bij vorderingen tot vergoeding van immateriele schade niet wezenlijk anders lijkt, zij het dat de waadering dan natuurlijk slechts bij (ruwe) benadering kan plaatsvinden. Vgl. Inv. 6, p. 1289 en Van Boom (2000a), p. 24.

Vgl. Atiyah (1997), p. 69 en Posner (1986), p. 186.

Fleming (1966a), p. 167.

Art. 6:107 BW juncto art. 6:162 BW, Vgl, naar oud recht HR 28 mei 1999, NJ 1999, 564 nt. ARB (Gemeente Lasser $/$ De V Vries).
} 
erbuiten, alsmede alle betalingen van particuliere en sociale verzekeraars. Daarvoor gelden wettelijke regresregelingen.

\subsubsection{Een tweetrapsraket}

Hiermee is de wettelijke systematiek van de samenloopregeling kort in kaart gebracht. Schematisch laat de regeling zich als volgt weergeven:

- De benadeelde verliest door betalingen van derden jegens de schadeveroorzaker het recht op schadevergoeding, waarbij

- deze derden in een aantal van die gevallen jegens de schadeveroorzaker recht hebben op regres (of op schadevergoeding ingevolge art. 6:107 $\mathrm{BW})$.

In de navolgende paragrafen zal dit samenspel van regels uitvoeriger worden besproken en geanalyseerd. Nu eerst zal worden nagegaan onder welke omstandigheden de schadeveroorzaker door betalingen van derden van zijn vergoedingsplicht jegens de benadeelde is bevrijd. ${ }^{89}$

\subsection{Schadeveroorzaker bevrijd door betalingen van derden}

\subsection{Twee technische gronden}

Het vertrekpunt voor het regres ligt bij betalingen van derden die tot gevolg hebben dat de schadeveroorzaker jegens de benadeelde van zijn verplichting tot schadevergoeding is bevrijd. Maar wanneer is hiervan nu precies sprake? Hoe moet worden beoordeeld of betalingen van derden aan het recht op schadevergoeding van de benadeelde in de weg staan?

Afdeling 6.1.10 BW geeft daarvoor twee algemene gronden. Betalingen van derden die tot gevolg hebben dat de benadeelde de nadelige consequenties van het letsel of het overlijden niet of minder voelt in zijn eigen vermogen worden, al dan niet expliciet, verdisconteerd in het schadeoordeel (zie art. 6:97 BW). Bij zulke betalingen, denk aan loondoorbetaling, is de schade verplaatst naar derden (verplaatste schade) en heeft de (primair) benadeelde reeds om die reden geen recht op schadevergoeding. Als de benadeelde wèl zelf schade heeft (zoals schulden, denk aan doktersrekeningen die op zijn naam staan), maar die schade óók aanleiding geeft tot betalingen van derden of ander voordeel, dan geldt de regeling van voordeelstoerekening (art. 6:100 BW). Het voordeel, bijvoorbeeld de verzekeringsuitkering, 
komt dan voorzover dat redelijk is in mindering op het bedrag van de schadevergoeding. ${ }^{90}$ Kortom: kosten die derden rechtstreeks maken ten behoeve van de benadeelde moeten worden meegenomen in het proces van schadebegroting, ze staan a priori aan het aannemen van schade bij de benadeelde in de weg. Bij betalingen die eenmaal ontstane schade 'goedmaken' dient de regeling van voordeelstoerekening te worden toegepast.

De verleiding moet worden weerstaan om te redeneren dat voorzover voordeel rechtens de schade 'opheft' reeds het vestigen van de aansprakelijkheid vastloopt. Het hebben van 'schade' is weliswaar constitutief voor het vestigen van aansprakelijkheid, ${ }^{91}$ maar voor die fase van het proces van aansprakelijkstelling is niet méér vereist dan enig feitelijk nadeel, bijvoorbeeld letsel of zaaksbeschadiging. ${ }^{92}$ Dat sprake is van vermogensnadeel of nadeel met een concrete geldwaarde is dààrvoor niet vereist. Dat laat zich zo verklaren, dat de beoordeling of sprake is van aansprakelijkheid, verwijtbaarheid, niet behoort af te hangen van de - tamelijk willekeurige - vermogensrechtelijke gevolgen die de benadeelde daarvan ondervindt. Pas bij het vaststellen en begroten van de vergoedingsplicht van de schadeveroorzaker moet de schade in geld worden vertaald en wordt het letsel of overlijden gewaardeerd in de vorm van geldbedragen voor de concrete nadelige (materiële en immateriële) gevolgen, zoals het bedrag van de ziekenhuisrekening of op geld gewaardeerd leed. Bij dit systeem past dat het al vergoed zijn van de schade door derden geen afbreuk doet aan de op de schadeveroorzaker rustende aansprakelijkheid, maar alleen aan diens daaruit voortvloeiende vergoedingsplicht jegens de benadeelde. Aansprakelijkheid ziet als rechtsoordeel primair op de verwijtbaarheid van het gedrag; de gevolgen die het heeft in geldwaarde moeten nog zoveel mogelijk daarbuiten blijven.

Ook om formele wetstechnische redenen is het beter om het oordeel dat sprake is van aansprakelijkheid niet te laten staan of vallen met de precieze financièle consequenties die het letsel of ander feitelijk nadeel voor de eiser heeft. Met name bij subrogatie is het regresrecht afhankelijk van het recht op schadevergoeding van de benadeelde, een recht dat dan, bij het ontbreken van aansprakelijkheid, strikt genomen niet zou bestaan. ${ }^{93}$ Ook in dit opzicht is het dus beter om de invloed van betalingen van

Onder 'voordeel' in deze zin moeten zowel besparingen als de toename van vernogensbestanddelen of gevoelens van welbevinden worden verstaan, vgl. anders Bolt (1989a), p. 5 e.v. die haar definitie beperkt tot materieel voordeel. Immateriele schade kan, alle (rechts)filosofische of psychologische nuances daargelaten, niet bestaan in de vorm van verplaatste schade in bovengenoemde zin. Als derden die schade willen 'goedmaken' (bijvoorbeeld door er immaterieel voordeel tegenover te stellen of door de betaling van een geldsom), dan kan dat slechts - onder omstandigheden - aanleiding zijn voor vragen van voordeelstoerckening. Vgl. HR 21 februari 1997. NJ 1999, 145 nt. CJHB (Wrongful birth). Schut (1997), p. 30. Het onderscheid tussen de vestigings- en de omvangfase werd hiervoor al uiteengezet, paragraaf 3.2 .2 . Maar vgl. Luntz (1998), nt. 16, die dat probleem 'weg' schrijt door te stellen dat de regresvordering 'is predicated on liability on the part of the third party to the employee [= the victim] but for the particular bar, i.e. there must be someone who would be a torteasor vis-a-vis the employee if the employee had sued instead of accepting the benefits. 
derden pas in de omvangfase mee te wegen, nadat de aansprakelijkheid van de schadeveroorzaker eenmaal vaststaat.

Het hier gezegde raakt een belangrijk punt dat ook in de navolgende hoofdstukken nog zal terugkomen, namelijk de betekenis van het schadebegrip. Het is daarom goed hierover iets nadrukkelijker te zijn.

\subsubsection{Intermezzo: wat is schade?}

Schade is de discrepantie tussen de feitelijke toestand en de toestand zoals die zonder het schadevoorval zou zijn geweest. ${ }^{94}$ Voor het schadebegrip in de vestigingsfase van aansprakelijkheid moet worden aangesloten bij de betekenis van de term in het spraakgebruik: letsel, overlijden, of buiten personenschade: zaaksbeschadiging, leed of ander nadeel. Pas in de omvangfase, voor de toepasselijkheid van afdeling 6.1.10 BW, betekent schade: de verhaalbare financiële of niet-financiële (maar wel steeds op geld waardeerbare) nadelige consequenties van het letsel of overlijden, zoals inkomensschade, herstelkosten, smartengeld, kosten van lijkbezorging, derving van de voorziening in het levensonderhoud en buitengerechtelijke kosten. ${ }^{95}$ Het is in deze laatste zin (het schadebegrip in de omvangfase) dat ik de term hier veelal zal gebruiken. Omstreden is overigens nog wel of de term schade normatief is (dan wel feitelijk), ${ }^{96}$ maar de betekenis van die discussie wordt terecht gerelativeerd. In elk geval is de term in die zin normatief, dat de invulling ervan, ook bij het schadebegrip in de vestigingsfase, berust op concrete beleidskeuzes.

Of sprake is van schade in de omvangfase (de verhaalbare nadelige consequenties van het letsel of overlijden) hangt direct samen met de vraag hoe de schade wordt vastgesteld of gewaardeerd. Bij letsel-en overlijdensschade is sprake van concrete schadebegroting: bij vermogensschade betekent dit dat de vermogenssituatie van de benadeelde zoals die zonder het schadevoorval zou zijn geweest zo goed mogelijk moet worden benaderd. Daarvoor moet rekening worden gehouden met alle omstandigheden die van invloed kunnen zijn op de schade. ${ }^{97}$ Voor sommige schadeposten in de sfeer van letsel en overlijden is deze wijze van schadebegroting zo concreet mogelijk - lastiger dan voor andere. Met name de vraag naar de verhaalbaarheid van (de vermogenswaarde van) verloren vrije tijd kan indien dit verlies geen concrete geldwaarde heeft problematisch zijn. Of dan plaats is voor dingmoet worden vergoed bestaat uit vermogensschade en ander nadeel. Slechts enkele specifieke schadeposten zijn wettelijk geregeld, zie art. 6:96 BW en ant. 6:106 BW. Lindenbergh (2001), nr. 32 (met verdere verwijzingen).

97 Zie 0.3. Barendrecht \& Storm (1995), p. 31; Bouman \& Tilanus-Van Wassenaer (1998), nr. 20 (p. 33); Spier e.a. (2000), nr. 207 (Hartlief); Bloembergen \& Lindenbergh (2001), nf. 36 (p. 51). 
schadevergoeding is onduidelijk, ${ }^{98}$ maar àls dat het geval is, geldt het voorgaande ook hier onverminderd.

In het arrest inzake Gemeente Losser/De Vries achtte de Hoge Raad schadevergoeding mogelijk voor het verlies van vrije tijd die door ouders werd opgeofferd ten behoeve van hun kind, ${ }^{97}$ dat ernstig letsel had opgelopen en daardoor intensieve en langdurige verpleging vergde. Aangenomen werd dat onder die omstandigheden ruimte is voor schadevergoeding indien het aannemelijk is dat zonder deze mantelzorg professionele hulp zou zijn ingeschakeld. Bij de schadebegroting kan dan worden geabstraheerd van het feit dat in werkelijkheid geen professionele hulp werd ingeschakeld, en de schade (verloren tijd) lijkt te worden gesteld op de gemiddelde kosten van professionele hulp. ${ }^{100}$ In zoverre is dan sprake van abstracte schadebegroting. Concreet is de schadebegroting echter ook dan nog in die zin dat van feitelijke schade sprake moet zijn, en dat daarvan géén sprake is voorzover eventuele betalingen van derden ertoe strekken de verloren vrije tijd te compenseren (zoals extra vakantiedagen die de werkgever van de ouder(s) in de plaats stelt van de verloren vakantiedagen).

Met het voorgaande is duidelijk dat de vraag naar de invloed van betalingen van derden op de vordering tot schadevergoeding van de benadeelde pas ter sprake komt, en behoort te komen, in de omvangfase van het proces van aansprakelijkstelling. Verder werd gezien dat afdeling 6.1.10 BW daarvoor twee gronden geeft: het deel van de schade dat rechtstreeks voor rekening komt van anderen dan de benadeelde $7 a l$ al gelijk worden verdisconteerd in het schadeoordeel (art. 6:97 $\mathrm{BW}$ ), met vergoedingen dient rekening te worden gehouden in het kader van voordeelstoerekening (art. 6:100 BW). Het resultaat blijft min of meer gelijk: de schadeveroorzaker is in zoverre van zijn vergoedingsplicht jegens de benadeelde bevrijd.

\subsubsection{Concrete toepassing}

In het navolgende zal de betekenis en toepassing van beide gronden in kaart worden gebracht voor de concrete betalingen die de benadeelde ontvangt van derden (naasten, de werkgever, verzekeraars, enzovoort). Welke betalingen bevrijden de schadeveroorzaker in diens verhouding tot de benadeelde? Vooraf past de opmerking dat de meningen over de keuze voor de precieze technische gronden (schadebegroting of voordeelstoerekening) voor bepaalde gevallen uiteenlopen. Van een serieuze discussie lijkt niet echt sprake, de praktische betekenis ervan is gering. Op die punten zal ik daarom het systeem weergeven zoals het me, in aansluiting op de regels van geldend recht, het meest wenselijk lijkt. ${ }^{101}$

O.a. Spier c.a. (2000), nr. 253 (Hartlief); Bloembergen \& Lindenbergh (2001), p. 62; Spier (2002); specifiek over smartengeld in verband met verlies van vrije tijd Barenrecht \& Storm (1995), p. 298.

Daarvoor is tevens van belang dat de vrije tijd is opgeofferd ten behoeve van de verzorging envof verpleging. Voor de aan het bezoek gerelateerde vakantiedagen was in Gemeente Losser geen schadevergoeding mogeijik. Dat lijkt ook zo voor de vergoeding van de verzorgingskosten zelf. in HR 6 juni 2003, C02/062 HR (Kriuter-Van de Pol/Holding $B$ V) laat de Hoge Raad de afwijzing van schadevergoeding voor de verzorgingskosten in stand, voorzover die berust op het cordeel dat het inschakelen van professionele hulp in concreto (thuisverzorging van mesothelioomslachtoffer door echtgenoot) niet normaal en gebruikelijk is. 


\subsubsection{Betalingen met schadekarakter (I): geen schade}

Sommige betalingen van derden - met of zonder regresrecht - leiden rechtens tot het oordeel dat de benadeelde geen verhaalbare schade (meer) heeft. Ze worden in aanmerking genomen bij de schadebegroting. Art. 6:97 BW bepaalt dat de rechter de schade begroot op de wijze die het meest met de aard van de schade in overeenstemming is. Kan de omvang van de schade niet nauwkeurig worden vastgesteld, dan wordt deze geschat. Bouman en Tilanus wijzen erop, dat de term begroting eigenlijk te beperkt is: voordat men aan de berekening van de schade toekomt is een waardering nodig van alle omstandigheden die daarop van invloed zijn. ${ }^{102}$ Dat is een normatief proces: in hoeverre houdt men bij de vraag naar het vermogensnadeel rekening met omstandigheden die daarop van invloed kunnen zijn? Bij letsel-en overlijdensschade is zoals gezegd sprake van een concrete schadebegroting: de feitelijke situatie van de benadeelde zoals die zonder het schadevoorval zou zijn geweest moet zo goed mogelijk worden benaderd. ${ }^{103}$ Daarbij moet rekening worden gehouden met alle relevante omstandigheden, óók met de vraag naar de invloed van betalingen die derden doen aan of ten behoeve van de benadeelde en die aan het aannemen van schade in de weg staan. Het gaat dan om al die betalingen, waardoor specifiek getroffen vermogensbestanddelen van de benadeelde (alsnog) feitelijk onaangetast blijven. Kort maar goed: het moet gaan om betalingen of verstrekkingen die (a priori) voorkomen dat concrete schade ontstaat. Het gevolg daarvan is dat de schadeveroorzaker in zoverre van zijn vergoedingsplicht jegens de benadeelde is bevrijd. Voorzover de werkgever bij arbeidsongeschiktheid het loon 'normaal' doorbetaalt heeft de werknemer geen inkomensschade. Die is verplaatst naar de werkgever (die daarvoor een regresrecht heeft, art. 6:107a BW). Ontvangt de werknemer in dat geval echter geen loon maar andere betalingen van derden zoals extra adv-dagen, extra rendement uit beleggingen of verzekeringsuitkeringen, dan is in zoverre nog wèl sprake van inkomensschade (wel kan dan voordeelstoerekening plaatsvinden, zie paragraaf 3.3.5).

Om welke betalingen gaat het zoal? Genoemd werd al kort het doorbetaalde loon bij dreigende inkomensschade. Hierna zullen tevens andere categorieën van betalingen die aan het aannemen van schade in de weg kunnen staan worden besproken.

\subsubsection{HULP IN NATURA (MEDISCHE ZORG, VERVOER, TELEFOONKOSTEN)}

Om te beginnen valt te denken aan kosten die derden in natura maken ten behoeve van de benadeelde en die tot gevolg hebben dat de benadeelde die kosten niet voelt in zijn eigen vermogen, zoals eerste hulp aan de benadeelde. Andere voorbeel-

\footnotetext{
102 Bouman \& Tilanus-Van Wassenaer (1998), nr. 20 (p. 33).

103 Zie 0.2. Barendrecht \& Storm (1995), p. 31; Bouman \& Tilanus-Van Wassenaer (1998), nr. 20 (p. 33); Spier e.a. (2000), nr. 207 (Hartlief); Bloembergen \& Lindenbergh (2001), nr. 36 (p. 51).
} 
den van zulke verplaatste schade zijn de door voorbijgangers gemaakte kosten voor het vervoer naar het ziekenhuis en therapeutische zorg die rechtstreeks door de werkgever wordt geregeld en betaald. ${ }^{104}$ Verder valt te denken aan de uitgaven die partners doen voor elkaar en aan de kosten van verzorging en verpleging van naasten (bijvoorbeeld van partners of van kinderen door hun ouders of omgekeerd). ${ }^{105}$ Met zulke betalingen dient bij de schadebegroting rekening te worden gehouden: de daarmee corresponderende schade is 'verplaatst' naar de derde. In al deze gevallen heeft de (primair) benadeelde zelf geen juridische schade. ${ }^{106}$ Wel heeft degene naar wie de schade is verplaatst een regresrecht dan wel de vordering van art. 6:107 BW (en wordt hij ingeval van art. 6:107 BW op zijn beurt als benadeelde aangemerkt). ${ }^{107}$

Wanneer is hiervan sprake? Het moet zoals gezegd gaan om betalingen die aan het ontstaan van schade in het vermogen van de eiser in de weg staan. De betalingen moeten corresponderen met de schadepost waarvoor de eiser schadevergoeding vordert: voorzover de benadeelde door zijn partner wordt verpleegd, heeft hij zèlf geen verpleegkosten, verdere schade laat dit onverlet. Alle betalingen die concreet verhinderen dat specifieke vermogensbestanddelen van de benadeelde wijziging ondergaan moeten in aanmerking worden genomen. Of ze al dan niet naar aanleiding van het schadevoorval zijn voldaan is niet relevant. In de praktijk zal de vraag of daarvan sprake is niet gauw tot problemen leiden. Procedureel gezien is het aan de eiser om te stellen en zo nodig te bewijzen dat hij schade heeft en daarvan is a priori geen sprake bij schade die in het vermogen valt van een derde. Voorzover de vervoerskosten door de derde zijn gemaakt of de telefoonrekening op naam staat van een derde heeft de benadeelde zelf geen schade in de zin van art. 6:95 BW.

\subsubsection{LOONDOORBETALING}

Een ander typisch voorbeeld van verplaatste schade is loondoorbetaling: voorzover het loon bij arbeidsongeschiktheid 'gewoon' wordt doorbetaald is er geen sprake van inkomensschade. Daarvoor geldt een aanvullende regeling, art. 6:107a BW. Het eerste artikellid bepaalt dat reeds het bedrag van de wettelijke en/of contractuele aanspraak op loon in aanmerking moet worden genomen, los van de vraag of

104 Zie Inv 6, p. 1282

105 Vgl. HR 28 mei 1999, NJ 1999, $564 \mathrm{nt}$. ARB (Gemeente Losser/De Vries), waar zulke kosten voor het oude recht, omdat daarin een regeling zoals ant. 6:107 BW ontbrak, werden aangemerkt als schade van de primair benadeelde, degene in wiens belang ze waren gemaakt (gesteld op de kosten van professionele hulp). Dat stelde de ouders in staat om darvoor schadevergoeding te vorderen in hun hoedanigheid van wettelijk vertegenwoordiger van het kind.

107 Als 'derde' in de zin van art. 6:107 BW. Voor de vordering tot schadevergoeding van deze derden gelden dan dezelfde regels als die hier wenden en worden besproken. 
die feitelijk ook al tot betaling is gekomen. ${ }^{108}$ Daarvoor wordt ook wel de term verplichte voordeelstoerekening gebruikt, maar van 'echte' voordeelstoerekening is geen sprake. Het loon wordt al in aanmerking genomen bij het begroten van de schade: ${ }^{109}$ ten belope van het bedrag van de aanspraak op het loon wordt de benadeelde geacht geen inkomensschade te hebben in de zin van art. 6:95 BW. De term verplichte voordeelstoerekening ziet op het verplichtende karakter van deze regeling, in aanvulling op art. 6:97 BW: doordat het bedrag van de aanspraak op het loon in aanmerking wordt genomen, ongeacht of die al tot betaling is gekomen, heeft de benadeelde geen vrije keuze voor het aansprakelijkheidsrecht.

Ook bij loonaanspraken die nog niet tot betaling zijn gekomen kan door deze bepaling reeds bij voorbaat geen sprake zijn van toekomstige inkomensschade. Voorzichtigheid past derhalve bij de cessie van vorderingen die betrekking hebben op toekomstige inkomensschade: ten belope van de bedragen waarvoor de werkgever van de benadeelde wettelijk of contractueel belast is met de verplichting tot loondoorbetaling kan van schade geen sprake zijn (en in zoverre dus evenmin van een vordering tot schadevergoeding).

\subsubsection{VOORZIENING IN LEVENSONDERHOUD BIJ OVERLIJDEN}

Bij overlijden gelden bijzondere 'samenloop'-regels voor de verhouding tussen de schadeveroorzaker en de nabestaanden met een vordering voor de derving van levensonderhoud (art. 6:108 lid 1 BW). Met de schade waarvoor dan vergoeding wordt gevorderd wordt het bedrag bedoeld dat de benadeelde (nabestaande) als gevolg van het overlijden minder te besteden heeft teneinde in het eigen levensonderhoud te kunnen voorzien. Om de schade te kunnen vaststellen dient zijn bestedingsniveau dan op het moment dat hij de vordering instelt te worden vergeleken met hoe dit zonder het overlijden zou zijn geweest. ${ }^{110}$ Volgens de Hoge Raad moet bij de vaststelling daarvan rekening worden gehouden met in beginsel alle inkomsten en uitgaven van de nabestaanden die van invloed kunnen zijn op het deel van het levensonderhoud waarin de overledene, de kostwinner, zou zijn blijven voorzien (het behoeftigheidsvereiste). Hierdoor is ook de vraag naar de invloed van betalingen van derden zoals levensverzekeraars een kwestie van schadebegroting. ${ }^{\text {"II }}$

Typische voorbeelden van betalingen van derden die van invloed zijn op de vraag naar de schade zijn de erfenis, uitkeringen uit levensverzekeringen en uitkeringen uit de Algemene nabestaandenwet. Daarnaast worden (in beginsel) alle overige

108 Lid 2 geeft de werkgever een regresrecht voor het verplicht krachtens de wet of een collectieve of individuele arbeidsovereenkomst betaalde loon.

109 Vgl. Bolt (1992), p. 215.

110 Zie HR 29 april 1994, NJ 1995, 609 nt. CJHB (Nationale Nederlanden/ABP), waar bij de berekening van het civiele plafond voor het regres van pensioen-en overlijdensuitkeringen rekening werd gehouden met de mogelijkheid van de 'VUT' voor de kostwinner en de hertrouwkansen van de weduwe.

11 Zie HR 4 februari 2000, NJ 2000, $600 \mathrm{nt}$. MMM (Kwidama/Raphael Richandson) en darover Engelhard (2000). p. 254 c.v. 
actieve vermogensbestanddelen in aanmerking genomen. Levensverzekeringen zijn veelal bedoeld als voorziening voor nabestaanden van de overledene. De verzekering kan door de overledene zijn afgesloten of door de nabestaanden zelf indien ze bij zijn leven belang hebben (omdat ze financieel afhankelijk van hem zijn). ${ }^{112}$ Overigens kunnen ook schuldeisers die belang hebben bij het leven van hun schuldenaar diens leven verzekeren. ${ }^{113}$ De hypothecaire levensverzekering is een bekende nabestaandenverzekering: bij voortijdig overlijden wordt de openstaande schuld voldaan uit de opbrengst van de levensverzekering (om te verhinderen dat het huis van de overledene moet worden verkocht en de nabestaanden zouden moeten verhuizen).

Voor de uitkeringen waarop de nabestaanden van art. 6:108 BW aanspraak maken ingevolge de Algemene nabestaandenwet geldt, net als bij de aanspraak op verplicht doorbetaald loon, een aanvullende bepaling van verplichte 'voordeelstoerekening' (art. 60 ANW): reeds het bedrag van de wettelijke aanspraak, ongeacht of deze feitelijk al tot betaling is gekomen, staat aan het aannemen van schade in de weg, en in zoverre is de schadeveroorzaker van zijn vergoedingsplicht jegens de benadeelde bevrijd (maar gehouden tot regres, art. 61 ANW).

Na het eerder gezegde zou het voor de hand liggen te denken dat dit regime berust op hetzelfde principe als bij letselschade. De gedachte zou dan deze zijn, dat de benadeelde, ook bij overlijden, geen recht heeft op schadevergoeding voor schade die naar derden is verplaatst (die dan op hun beurt recht hebben op schadevergoeding of regres): ten belope van de som die de levensverzekeraar uitkeert derft de nabestaande geen onderhoudsvoorziening. Maar aan het behoeftigheidsvereiste ligt een ander principe ten grondslag. Volgens het regime van de Hoge Raad dient rekening te worden gehouden met elk actief vermogensbestanddeel van de benadeelde (nabestaande). Daaronder vallen alle betalingen van derden, ongeacht de strekking ervan, en dus óók betalingen die zonder het overlijden naast het besteedbare inkomen voor het levensonderhoud zouden zijn genoten.

Dit laatste punt makt het behoeftigheidsvereiste in mijn visie omstreden. ${ }^{114}$ Het gevolg hiervan kan immers zijn dat de benadeelde in een nadeligere vermogenstoestand wordt gebracht dan waarin hij zonder het overlijden van de kostwinner zou verkeren. Een duidelijk voorbeeld is het geval waarin de weduwe (of weduwnaar) een prijs wint uit een loterij. Zelfs die zou naar geldend recht als inkomensbron worden aangemerkt voor de voorziening in het levensonderhoud, en daarmee in de weg staan aan het aannemen van schade (derving van voorziening in het levensonderhoud). Maar als de lottoprijs zonder het overlijden van de kostwinner

114 Zie PG 6. p. 404 en o.m. HR 19 juni 1970, NJ 1970, 380 nt. GJS (NBM/Eagle Star) en HR 4 februari 2000, NJ2000, $600 \mathrm{nt}$. MMM (Kwidama/Raphael Richardson). De bestaansgrond van het vereiste zelf is nochtans omstreden. Zie uitvoerig Bolt (1989a), p. 60 (met verdere verwijzingen): "Nergens in het schadevergoedingsrecht wordt de eis gesteld dat de vorderende partij behoefte heeft aan schadevergoeding' (en daarmee instemmend a.w. p. 220) en de inzichtelijke Conclusie van A-G Spier (m.n. par. 3) inzake Kwidama/Raphael Richandson. 
naast de voor het levensonderhoud ontvangen voorziening tot het vermogen van de weduwe zou hebben behoord, dan gaat zij er netto op achteruit. Dat lijkt bezwaarlijk. Zo ook kan zich naar geldend recht het geval voordoen, dat de uitkering uit een hypothecaire levensverzekering, dan wel de som van de daarmee bespaarde hypothecaire rente, aan de nabestaande worden toegerekend ${ }^{115}$, terwijl diens vordering ingevolge art. 6:108 lid $1 \mathrm{BW}$ slechts betrekking heeft op het deel van het inkomen van de kostwinner dat bestemd was als huishoudgeld, en niet ook voor het deel dat voor de maandelijkse aflossing van de hypotheek werd aangewend. Het bedrag van de schadevergoeding lijkt daarbij als geheel in aanmerking te worden genomen, zonder differentiatie naar het deel van de onderhoudskosten waarvoor schadevergoeding wordt gevorderd.

De Hoge Raad laat wel enige beoordelingsvrijheid om zulke resultaten te voorkomen. ${ }^{116}$ Voor de vordering tot schadevergoeding van minderjarige kinderen lijkt het behoeftigheidsvereiste bovendien beperkt of zelfs niet te worden toegepast. Onder het oude recht besliste de Hoge Raad dat noch de wijze waarop de nieuwe kostwinner en verzorger na het overlijden van de verzorgende ouder in het levensonderhoud van de kinderen voorziet noch bepaalde, voor hun levensonderhoud bedoelde sociale uitkeringen van invloed waren op hun vordering tot schadevergoeding. ${ }^{117}$ Aangenomen wordt dat dit naar geldend recht hierop kan worden gebaseerd, dat het kind ten minste recht heeft op schadevergoeding voor het bedrag dat hem volgens de regels van het alimentatierecht verschuldigd zou zijn (art. 6:108 lid 1 sub $a$ BW) en volgens die regels geldt het behoeftigheidscriterium niet (art. 1:392 lid 2 BW). ${ }^{118}$ Voor de overige categorieën nabestaanden van art. 6:108 lid $1 \mathrm{BW}$ blijft het uitgangspunt echter dat àlle betalingen die kunnen bijdragen aan de voorziening in het levensonderhoúd van de eiser, aan een vordering in de weg staan. Het feit dat bij strikte toepassing van de wijze waarop het behoeftigheidsvereiste wordt uitgelegd resultaten kunnen ontstaan als de genoemde blijft dan ook onbevredigend. Zo al niet in dogmatisch opzicht (wat is de legitimatie van het in mindering brengen van een uitkering die strekt tot vergoeding van kostenpost $x$ op de vordering strekkende tot vergoeding van kostenpost $y$ ?), dan

$\mathrm{VgL}$. 0.a. Schadevergoeding, art. 108 (Bolt), aant. 41 (aangenomen wordt dan dat de uitkering weliswaar niet rechtstreeks de behoeft aan levensonderhoud van de nabestaanden verminder, 'maar wel indirect doordat de periodieke betaling van hypotheekrente wordt bespaard. De uitkering komt dan ook in zoverne in mindering op de schadevergoeding') en voorts HR 4 februari 2000, NJ 2000, 600 nt. MMM (Kwidama/Raphad Richartson). Doch vermoedelijk anders Inv. 6. p. 1291 en terecht genuanceerder p. 1302 (punt 1), waar de hypothecaire levensverzekering, gelijk ik ook zou menen, genoemd wordt als voorbeeld van een sommenverzekering die niet met vorderingen voor àndere schade dan de lasten van het woonhuis zou behoren te worden verrekend. Bij de terugverwijzing van de zaak door de Hoge Raad inzake HR 4 februari 2000, NJ 2000, $600 \mathrm{nt}$. MMM (Kwidama/Raphael Richandson) stelt de raad dat (onder meer) nader onderzocht zal dienen te worden of het in mindering brengen van de verzekeringsuitkering billijk is. Zie daarover Engeihard (2000), p. 259. 
toch vanuit het perspectief van rechtsgelijkheid en de compensatiefunctie van het aansprakelijkheidsrecht voor nabestaanden.

Wèl kan het uitgangspunt van toerekening van de uitkeringen uit sommenverzekering bij de vordering van art. 6:108 lid $1 \mathrm{BW}$ worden onderschreven, maar dan niet op de enkele grond dat die de behoefte aan schadevergoeding wegnemen (hetgeen immers ook kan worden gezegd van vermogensvoordeel dat niet het gevolg is van het overlijden van de kostwinner, zoals een prijs uit de lotto). Beslissend moet zijn of de uitkering geacht kan worden te zijn bedoeld voor (onder andere) juist de kostenposten voor het levensonderhoud, waarvoor de benadeelde in het kader van art. 6:108 lid 1 BW schadevergoeding vordert. Indien de sommenverzekering (mede) ertoe strekt om voor de betreffende posten van het levensonderhoud te worden aangewend (zoals de hypothecaire levensverzekering de woonlasten vermindert), heeft zij hier, vanwege het bijzondere karakter van de schade, wèl een schadevergoedingskarakter. Wat 'schade' is wordt in het kader van art. 6:108 lid $1 \mathrm{BW}$ immers bepaald door alle - ook toevallige - vermogensbestanddelen die geacht kunnen worden bij te dragen aan de voorziening in het levensonderhoud. Vanuit dit perspectief, dat dezelfde schade niet tweemaal moet worden vergoed, zou tevens het verschil met het regime bij letselschade zijn te funderen. Bij letselschade geldt dat sommenverzekeringen in beginsel geen nadelige invloed hebben op het bedrag van de schadevergoeding dat op die schadeposten betrekking heeft. Zou echter blijken dat de uitkering op de omvang en duur van de inkomensschade is afgestemd, dan zou de benadeelde - vaste som of niet - in zoverre zijn recht op schadevergoeding moeten verliezen. Zo ook zou bij overlijden dan, nogmaals, alleen voor de betalingen die strekken tot voorziening in juist het levensonderhoud waarvoor ingevolge art. 6:108 lid $1 \mathrm{BW}$ schadevergoeding wordt gevorderd het behoeftigheidsvereiste moeten gelden. Betalingen die zijn bedoeld voor kosten van het levensonderhoud die door de benadeelde (nabestaande) niet zijn opgevoerd zouden zijn vordering onverlet moeten laten.

\subsubsection{TOT SLOT}

Resumerend kan in elk geval worden gesteld dat de benadeelde, zowel bij letselals bij overlijdensschade, geen vordering tot schadevergoeding toekomt voor rechtstreeks naar derden verplaatste schade (doorbetaald loon, de kosten van verzorging, telefoonkosten, voorziening in het levensonderhoud). Zulke betalingen moeten worden meegewogen in het schadeoordeel. Bij vorderingen wegens een gederfde voorziening in het levensonderhoud gaat het regime echter wat verder en worden alle betalingen van derden in aanmerking genomen bij het vaststellen van de schade, ongeacht of ze strekken tot het voorkomen van schade (het derven van de voorziening in het levensonderhoud) dan wel daarvan volkomen losstaan. Dat verdient naar ik stelde heroverweging, ik zal hierop terugkomen (paragraaf 3.3.5.3). In de navolgende paragrafen zal worden gezien dat een vergelijkbaar 'harde' regel geldt voor betalingen van derden die de strekking hebben dat ze reeds ingetreden 
schade (achteraf) 'goedmaken'. Die komen door voordeelstoerekening in mindering op de schadevergoeding waarop de benadeelde recht heeft.

\subsubsection{Betalingen naast schade: voordeelstoerekening}

\subsubsection{INLEIDING}

Voor de vraag naar voordeelstoerekening geldt de algemene regeling van art. 6:100 BW (ongeschreven gold zij ook al onder het oude recht): als eenzelfde gebeurtenis voor de benadeelde naast schade ook voordeel oplevert, dan komt dit 'voorzover dat redelijk is' in mindering op het bedrag van de schadevergoeding. Onder voordeel in de zin van art. 6:100 BW moet al het (feitelijke) materiële en ook wel het immateriële voordeel worden verstaan dat het gevolg is van het schadevoorval, en in een geldwaarde kan worden uitgedrukt. Voor de afzonderlijke schadeposten moet beoordeeld worden of het voordeel in mindering dient te komen op het bedrag van de schadevergoeding. De regeling van voordeelstoerekening zorgt ervoor dat niet alleen wordt gerekend met de nadelige gevolgen die het schadevoorval voor de benadeelde heeft, de schade, maar ook met voordeel dat hij ervan ondervindt. Voorkomen moet worden dat de benadeelde door het inroepen van het aansprakelijkheidsrecht in een betere (vermogens)toestand raakt dan waarin hij zonder het schadevoorval zou hebben verkeerd. ${ }^{119}$ Voor nabestaanden met de vordering van art. 6:108 lid $1 \mathrm{BW}$ (gederfde onderhoudsvoorziening) is voor voordeelstoerekening geen plaats. Alle actieve vermogensbestanddelen worden dan, zoals gezegd, al in aanmerking genomen bij het vaststellen van de schade. ${ }^{120}$

Bij de totstandkoming van art. 6:100 BW bestond nog onvoldoende duidelijkheid over de vraag wanneer voordeelstoerekening moet plaatsvinden. De wetgever heeft daarom de redelijkheidsmaatstaf tot de beslissende factor gemaakt. Met de woorden 'voorzover dat redelijk is' is beoogd om de rechter een ruime marge van beoordelingsvrijheid te laten bij de concrete toepassing van deze regeling. ${ }^{121}$ De rechtspraak en literatuur bieden wel concrete handvaten voor de vraag welk voordeel op de vordering van de benadeelde in rekening moet komen (en bij welke schadeposten). ${ }^{122}$ Bolt heeft algemene deelregels geformuleerd. ${ }^{123}$ Zo wordt aangenomen dat de bespaarde kosten van levensonderhoud door een verblijf in het ziekenhuis en de verbeteringen nieuw voor oud, die een reparatie oplevert, in beginsel

Bolt (1989a), p. 9 merkt in dit verband op dat de 'rechtvaardiging' van voordeelstoerekening ligt bij de redelijkheid en billijkheid. Waarom het redelijk en billijk is, blijft in het midden.

Er zijn ook auteurs die beweren dat er voor het leerstuk van voordeelstoerekening nog plaats zou zijn indien de uitkering niet van invloed is op de behoeftigheid, zie (dit terecht afwijzend) Barenrecht \& Storm (1995). p. 245 e.v., met verwijzingen.

$121 \quad P G$ 6, p. 348.

122 O.a. Asser-Hartkamp 4-1, nr. 443 e.v; Kottenhagen-Edzes (1993), p. 301; Bouman \& Tilanus-Van Wassenaer (1998), p. 68 e.v.; Spier e.a. (2000), nr. 225 (Hartlief?

Bolt (1989a), p. 205 e.v. 
in mindering komen op de door de schadeveroorzaker verschuldigde schadevergoeding. ${ }^{124} \mathrm{Bij}$ belastingvoordeel dat het gevolg is van het schadevoorval is meer discussie mogelijk. ${ }^{125}$ Uiteindelijk is dan toch weer de redelijkheidsmaatstaf van art. 6:100 BW beslissend. ${ }^{126}$

Deze bijzondere vragen van voordeelstoerekening kunnen hier blijven rusten. Voor het regres is voordeelstoerekening alleen interessant voorzover die betrekking heeft op de gevallen waarin een samenloop ontstaat met de vergoeding van derden. Bij ander voordeel is voor regres geen plaats. ${ }^{127}$ Het navolgende blijft dan ook beperkt tot de regels die gelden bij voordeel dat bestaat uit concrete betalingen van derden die al dan niet als schadevergoeding kunnen worden aangemerkt (en waarvoor dus eventueel regres mogelijk is): in hoeverre komen die door voordeelstoerekening in mindering op het bedrag van de schadevergoeding die de schadeveroorzaker zelf verschuldigd is aan de benadeelde?

\subsubsection{BETALINGEN TER COMPENSATIE (II): 'VERPLICHTE' VOORDEELSTOEREKE- NING}

Als derden de schade van de benadeelde vergoeden, dan wordt aangenomen dat dir bedragerroprde doorde schadeveroorzaker, verschuldigde schadevergoeding in mindering dienen te komen. Daarin kan een algemene regel worden ontwaard: voor alle betalingen die door hun schadevergoedingskarakter sterke gelijkenis hebben met de prestatie waarvoor de benadeelde de schadeveroorzaker aanspreekt geldt dat die tevens bevrijdend zijn voor de schadeveroorzaker (en diens WAverzekeraar). Beslissend is of de betaling van de derde strekt tot vergoeding van schade waarvoor ook de schadeveroorzaker tot schadevergoeding gehouden is. Als dat zo is, heeft zij een schadevergoedingskarakter en juist dàt is beslissend voor de vraag of zij voor de schadeveroorzaker bevrijdend is: zijn beide prestaties naar hun strekking gelijk (strekken ze tot vergoeding van dezelfde schade)? Dat principe van samenloop is vanzelfsprekend als de benadeelde door de WAverzekeraar van de schadeveroorzaker wordt vergoed, ter kwijting van diens schuld (art. 6:30 BW). Er is dan immers maar één schuld. Ook lijdt het bevrijd zijn van de schadeveroorzaker geen twijfel indien de benadeelde wordt vergoed door derden die medeaansprakelijk zijn voor dezelfde schade. Ook dan is de schadeveroorzaker door de betaling van de derde van zijn eigen vergoedingsplicht jegens de benadeelde bevrijd. De technische reden is dan dat sprake is van hoofdelijkheid (art. 6:102,

124 Barendrecht \& Storm (1995), p. 176; Spier e.a. (2000), nr. 225 (Hartief). Als besparingen samenvallen met het ontstaan van schade kan ook worden gesteld dat in zoverre geen schade is geleden, aldus Bolt (1989a). p. 22. Dat is anders bij verbeteringen 'nieuw voor oud': die ontstaan pas door het herstel, nadat de schade is ingetreden, Bolt $(1989 a)$, p. 28 Zie uitvoerig Bolt $(1989 a)$, p. 24 e.v. In die zin: Bolt (1989a), p. 15; Bouman \& Tilanus-Van Wassenaer (1998), p. 70; Bloembergen \& Lindenbergh (2001), p. 19; Kottenhagen-Edzes (1993), p. 316. Zie paragraaf 4.8 .2 . 
tezamen met art. 6:7 lid 2). ${ }^{128}$ Die bevrijdende werking gold echter reeds onder het oude recht, ook als geen sprake was van hoofdelijkheid. Zij werd niet gehinderd door de omstandigheid dat beide vergoedingsplichten niet door enige rechtsband met elkaar verbonden waren, zoals het geval waarin de schadeverzekeraar en de aansprakelijke beiden tot vergoeding van dezelfde schade gehouden zijn. In navolging van Van Goudoever werd voor die gevallen onder het oude recht (en wordt ook thans nog wel) gesproken van een 'toevallig samenlopende verbintenissen'. ${ }^{129}$ Betaling door de één behoorde dan tevens de ander in diens verhouding tot de benadeelde te bevrijden. De ratio lijkt deze, dat onwenselijk is dat de benadeelde met betrekking tot dezelfde schade twee of meerdere malen wordt vergoed. Dat op elk van beide schuldenaren een zelfstandige verbintenis rust jegens de benadeelde, doet daaraan geen afbreuk. Het principe dat vergoedingen van derden tot gevolg hebben dat de schadeveroorzaker jegens de benadeelde is bevrijd geldt, dunkt mij, behoudens bijzondere omstandigheden voor alle gevallen waarin de benadeelde schadevergoeding vordert via het aansprakelijkheidsrecht voor schade die al buiten het aansprakelijkheidsrecht om werd vergoed (niet noodzakelijk door schadeverzekeraars, maar ook door sociale verzekeraars of werkgevers). Voorwaarde is slechts dat de genoemde derden (particuliere of sociale verzekeraar, werkgever, enzovoart, aav de henadeelde dezelfde, nrestatie betalen, schadevergoeding. als waartoe de schadeveroorzaker jegens hem verplicht is. Zoals gezegd werd de figuur van toevallige samenloop van verbintenissen onder het oude recht gebruikt voor de situatie waarin een schadeverzekeraar, uit hoofde van zijn verzekeringsovereenkomst met de benadeelde, net als de schadeveroorzaker jegens de benadeelde gehouden is tot schadevergoeding. ${ }^{130}$ Maar niet valt in te zien wat ertegen zou zijn om ook vergoedingsplichten van sociale verzekeraars en andere derden eronder te laten vallen. Aan de andere kant is de term wat te beperkt nu de samenloopregeling die geldt voor gevallen waarin schadeverzekeraars verplicht uitkering doen (op grond van hun verbintenis jegens de benadeelde) óók geldt indien zij dat onverplicht doen. ${ }^{131}$ Beter is het daarom wellicht te spreken van een toevallige samenloop van prestaties. In de onderhavige gevallen is geen sprake van hoofdelijkheid, ${ }^{132}$ het bevrijd zijn van de schadeveroorzaker berust, uitzonderingen daargelaten, ${ }^{133}$ op voordeelstoerekening. ${ }^{134}$

128 Van Boom (1999), p. 29.

129 Van Boom (1999), p. 14 e.v.

130 Zo o.a. Bolt (1989), p. 35 en Van Boom (1999), p. 39 e.v

131 HR 7 januari 2000. NJ 2000, 212 nt. MMM (Nationale Nederlanden/Woudsend II).

132 Het punt is dat de verplichting van de particuliere of sociale verzekeraat niet op wettelijke aansprakelijkheid berust in de zin van art. 6:102 BW. Anders: Bloembergen (1965), nr. 99; Bolı (1989a), p. 35 en 217 e.v.; Van Boom (1999), p. 41 e.v. Zie nader over de toevallige samenloop, paragnaaf 4.8 .2 .

133 Indien de betalende derde recht heeft op subrogatie (zoals veelal geldt voor schadeverzekerars en het Schadefonds Geweldsmisdrijven) verliest de benadeelde reeds daardoor zijn vordering tot schadevergoeding (zie hiema). Ook in de gevalien van verplatste schade, die in paragraf 3.3 .4 werden besproken, is van voordoelstoerekening geen sprake.

134 In die zin ook Asser-Hartkamp 4-1, nr. 446 en zie ook nr. 491. 
Dit laatste lijkt echter omstreden. ${ }^{135}$ Volgens sommige auteurs vallen gevallen waarin sprake is van een samenloop van vergoedingsplichten buiten de problematiek van de voordeelstoerekening. Daarvoor worden uiteenlopende redenen aangevoerd. Bolt stelt dat het bevrijd zijn van de schadeveroorzaker hieruit volgt, dat na betaling door de schadeverzekeraar geen sprake meer is van schade. ${ }^{176}$ Zowel Bloembergen als De Kok stellen dat dan sprake is of behoort te zijn van hoofdelijkheid. ${ }^{137} \mathrm{Naar}$ nog zal worden gezien is het evenwel noodzakelijk en ook zinvol om het bevrijd zijn van de schadeveroorzaker technisch te doen berusten op voordeelstoerekening of subrogatie (en niet te laten volgen uit het blote feit van de samenloop of de opvatting dat van schade geen sprake meer is).

Voor betalingen van particuliere en sociale schadedragers die door hun schadevergoedingskarakter sterke gelijkenis hebben met de prestatie waarvoor de benadeelde de schadeveroorzaker aanspreekt geldt een absoluut regime van voordeelstoerekening of subrogatie. Dat wil zeggen dat reeds vanwege het schadevergoedingskarakter van de betaling aan de benadeelde (en de toevallige samenloop van prestaties die daardoor ontstaat met de vergoedingsplicht van de schadeveroorzaker) voordeelstoerekening of subrogatie plaatsvindt. Dat er ook verschillen zijn tussen de vergoeding(splicht) van de particuliere of sociale verzekeraar en de vergoeding waartoe het aansprakelijkheidsrecht de schadeveroorzaker verplicht, doet hieraan geen afbreuk. Dat is tot op zekere hoogte onvermijdelijk: ${ }^{138}$ particuliere of sociale verzekeraars of andere risicodragers zijn immers, voor betalingen die ze buiten het aansprakelijkheidsrecht om doen aan de benadeelde, niet gebonden aan de regels van afdeling 6.1.10 BW (tenzij ze voor hun uitkeringsbeleid aansluiting zoeken bij die regels). Het schadevergoedingskarakter is bovendien bij sommige betalingen sterker dan bij andere.

Hierna zullen afzonderlijke categorieën van betalingen waarbij de toevallige samenloop ontstaat, en dus een absoluut regime van subrogatie of voordeelstoerekening geldt, aan de orde komen. Daarbij zal tevens worden gewezen op omstreden gevallen, waarvoor dit regime ook wel verdedigbaar lijkt, maar dit naar geldend recht twijfelachtig of omstreden is.

\section{* Uitkeringen uit schadeverzekering}

In de eerste plaats geldt dat voor uitkeringen uit schadeverzekering, mits ze de strekking hebben juist die schade te vergoeden waarvoor de benadeelde schadevergoeding vordert. In hoeverre de schadeverzekeraar uitkering doet hangt af van

\footnotetext{
135 Zie daarover Bolt (1989), p. 33 e.v. en Zwalve (1993), p. 151 (met rechtshistorische beschouwingen).

136 Mulder (1988), p. 11 en Bolt (1989), p. 35.

137 Bloembergen (1965), nt. 99 e.v. en De Kok (1965), p. 89 e.v. Ook Van Boom (1999), p. 41 gaat voor dat geval uit van hoofdelijkheid.

138. Vgl. Bolt (1989a), p. 35: Kottenhagen-Edzes (1993), p. 303 en Dommering-Van Rongen (1993), p. 239. Opmerkelijk is dat Dommering stelt dat de wyre waarop de schade moet worden berekend in beginsel in het verzckeringsrecht dezelfde is als in het schadevergoedingsrecht (p. 240).
} 
de vraag of en hoeveel vermogensschade de verzekerde heeft. ${ }^{139}$ De verzekerde zal moeten stellen en kunnen aantonen dàt, en hoeveel schade hij heeft en de verzekeringsuitkering zal in beginsel niet méér bedragen dan dat bedrag. Dit maakt de gelijkenis met de op de schadeveroorzaker rustende vergoedingsplicht bijzonder sterk. De redelijkheid van het in mindering brengen van uitkeringen uit schadeverzekering is dan ook onomstreden. ${ }^{140}$

De technische grond daarvoor is veelal geen voordeelstoerekening, maar subrogatie. Schadeverzekeraars worden op het moment dat ze uitkering doen gesubrogeerd in de vordering tot schadevergoeding van de benadeelde. Door de rechtsovergang bij subrogatie verliest de benadeelde in zoverre zijn vordering jegens de schadeveroorzaker. ${ }^{\mid 14}$ Voor voordeelstoerekening is dan geen plaats. De vraag naar voordeelstoerekening komt aan de orde voorzover geen subrogatie plaatsvindt. Een bekend voorbeeld is de situatie waarin de benadeelde (ook) in de toekomst nog uitkeringen uit schadeverzekering zal ontvangen in verband met schade waarvoor ook de schadeveroorzaker in beginsel tot schadevergoeding is gehouden. Ook het moment van de subrogatie ligt dan nog in de toekomst; schadeverzekeraars worden telkens pas gesubrogeerd op het moment dat ze nieuwe uitkeringen doen aan de benadeelde. ${ }^{142} \mathrm{Om}$ in dat geval dubbele vergoeding van de benadeelde in de toekomst te vermijden is voordeelstoerekening noodzakelijk. ${ }^{143}$ Het eindresultaat is kortom hetzelfde als in gevallen waarin de benadeelde door subrogatie zijn vordering op de schadeveroorzaker verliest: de toekomstige schadeuitkeringen worden zonder meer verrekend met het bedrag van de schadevergoeding.

Dit absolute regime van subrogatie en voordeelstoerekening geldt alleen voor verzekeringsuitkeringen die bedoeld zijn voor schade die correspondeert met de concrete schadeposten waarvoor de benadeelde de schadeveroorzaker aanspreekt, èn die daadwerkelijk door de benadeelde zijn of zullen worden genoten. Is aan deze voorwaarden voldaan, dan verliest de benadeelde in zoverre zonder meer, als regel, jegens de schadeveroorzaker zijn recht op schadevergoeding. Deze regel kan rechtens niet door (polis)afspraken tussen de benadeelde en de uitkerende

In art. 7.17.2. I BW wordt zij omschreven als de verzekering strekkende tot vergoeding van vermogensschade die de verzekerde zou kunnen lijden; zie over de schadeverzekering voorts Kremer (1987), p. 17 en 30; Mulder (1988), p. 37 e.v.; Bolt (1989a), p. 38; Mok (1998), p. 57 die erop wijst dat de definitic van het ontwerp nalaat de hoofdverbintenis te noemen, te weten de bescherming tegen het risico van een onzeker voorval.

$140 \mathrm{Vgl}$ Kottenhagen-Edzes (1993), p. 316. Aangenomen wordt overigens dat daaraan ook geen afbreuk doet dat de benadeelde voor de verzekering zelf de premies heeft opgebracht.

14) Asser-Hartkamp 4-I, nr. 446, anders Bolt (1989a), p. 117 waar er vanuit wordt gegaan dat reeds het feit van de samenloop van de vergoedingsplichten en het gegeven dat schade slechts eenmaal kan worden vergoed ertoe leidt dat de schadeveroorzaker jegens de benadeelde is bevrijd. Zie voor een belangwekkende bespreking van beide visies vanuit rechtshistorisch perspectief Zwalve (1993), p. IS1 e.v.

142 Van Boom (2000a), p. 54.

143 Zie Asser-Hartkarnp 4-1, nr. 446; Bolt (1989a), p. 34; Kottenhagen-Edres (1993), nt. I1. Andere gevallen waanin geen subrogatie kan plaatsvinden zjin onder meer die waarin de schadeveroorzaker behoon tot een categorie van personen op wie geen subrogatie mogelijk is en die warrin de verzekeraar afstand deed van zijn recht. 
verzekeraar worden omzeild. ${ }^{144}$ Het gaat om een bijzondere invulling van de redelijkheidsmaatstaf van art. 6:100 $\mathrm{BW}$ : bij uitkeringen uit schadeverzekering is voordeelstoerekening zonder meer redelijk. ${ }^{145}$ Verdere ruimte voor beoordelingsvrijheid ontbreekt in zoverre. ${ }^{146}$

Enige discussie bestaat nog over de vraag of dit regime dogmatisch gezien de juiste basis is om aanspraken van de benadeelde uit schadeverzekering in aanmerking te nemen, ik stipte dat al kort aan. Anders dan de ontwerpers bij de invoering van afdeling 6.1.10 BW voor ogen heeft gestaan, ${ }^{147}$ wordt ook wel gesteld dat schadeuitkeringen niet op grond van voordeelstoerekening, maar technisch gezien al eerder in het proces van aansprakelijkheid in aanmerking moeten worden genomen. Bolt stelt het zo, dat voorzover de schade wordt vergoed deze rechtens verdwijnt. Een uitkering uit een particuliere schadeverzekering kan in haar visie niet worden aangemerkt als een voordeel dat al dan niet in mindering kan worden gebracht op de schade. De uitkering is niet anders dan een schadevergoeding, die tot gevolg heeft dat schade verdwijnt. ${ }^{148} \mathrm{Het}$ wettelijk systeem van afdeling 6.1 .10 $\mathrm{BW}$ is dunkt me anders; het schadebegrip ziet alleen op de nadelige gevolgen van het schadevoorval. ${ }^{149}$ Het proces van schadebegroting behoort dus beperkt te blijven tot het begroten van vermogensnadeel (ziekenhuisnota's en dergelijke). Pas voor de daarop volgende vraag of de schade volledig aan de benadeelde moet worden vergoed dient rekening te worden gehouden met voordeel dat hij van het schadevoorval ondervindt. De vraag naar voordeelstoerekening maakt die afweging expliciet: voordeelstoerekening leidt dogmatisch gezien ertoe dat de benadeelde op minder schadevergoeding recht heeft dan het bedrag waarvoor hij rechtens schade heeft, en vraagt in zoverre om een goede onderbouwing. ${ }^{150}$ Voordeelstoerekening bevordert een methodische schadeafwikkeling en kan wellicht zelfs bijdragen aan een meer afgewogen eindoordeel. Ook omwille van de eenvoud heeft het huidige systeem voor schadeverzekeringen (subrogatie en bij het ontbreken daarvan voordeelstoerekening) mijn voorkeur. Ook bij andere betalingen die tot vergoeding strekken wordt daarvan uitgegaan, zoals bij uitkeringen van het Schade-

Dat zou immers de vergoedingsplicht van de schadeveroorzaker (de aansprakelijke) uitbreiden buiten de grenzen van de algemene regels van het schadevergoedingsrecht, zie Köster (1971), p. 103. Mogelijk is dat de benadeelde voor dezelfde schade eerst zijn aanspraken op de schadeverzekeraar en toen die op de schadeveroorzaker ten gelde heefl gemaakt. Betaalde dexe taatste onwetend, dan kan hij hiervan op later moment terugbetaling vorderen. bijvoorbeeld krachtens art. 6:203 BW (onverschuldigde betaling).

O.a. Inv. 6, p. 1294; Asser-Hartkamp 4-I, nt. 446; Tekst \& Commentaar, art. 6:100 (Oosterveen), p. 1653; Kottenhagen-Edzes (1993), p. 302.

146 Wel schuilt er een zekere marge van beoordelingsvrijheid bij het bepalen of een verzekering als schadeverzekering moet worden gekwalificeerd en of de verzekeringsuitkering betrekking heeft op juist die schade waarvoor de benadeelde schadevergoeding vordert. Inv. 6. p. 1292 en 1294.

148 Bloembergen (1965), nr. 99; Bolt (1989a), p. 35.

149 In die zin trouwens ook Bolt (1989a), p. 8.

$150 \mathrm{Vgl}$. Kottenhagen-Edzes (1993), nt. 3, waur erop wordt geweren dat volgens de ganghare opvatting het voordeel in mindering komt op de schadevergoeding, niet op de schade. Bolt (1989a). p. 7 ev. vermeldt ook anders luidende opvattingen. 
fonds Geweldsmisdrijven. Het fonds zoekt voor haar uitkeringsbeleid aansluiting bij de regels van het schadevergoedingsrecht van afdeling 6.1.10 BW. Haar betalingen vertonen in zoverre nog een sterkere gelijkenis met de vergoedingsplicht van de schadeveroorzaker (aansprakelijke) dan uitkeringen uit schadeverzekering. Het Schadefonds keert echter anders dan schadeverzekeraars óók, naar analogie met art. 6:106 lid $1 \mathrm{BW}$, smartengeld uit. ${ }^{\mid ⿰ 1}$ Mocht de benadeelde dan nadat hij een uitkering van het fonds heeft ontvangen (alsnog) trachten om voor deze immateriële schade de schadeveroorzaker aan te spreken, dan kan deze laatste de subrogatie van het fonds dan wel voordeelstoerekening tegenwerpen (de schade is al 'goedgemaakt' door het fonds). Bij Bolt's benadering dat er geen schade meer is zou voor dat geval het oordeel moeten zijn dat het leed van de benadeelde door de betalingen van het Schadefonds rechtens minder is geworden.

Natuurlijk zou men, uitgaande van Bolt's benadering, voor deze laatste gevallen ook gewoon een uitzondering kunnen maken en het regime van voordeelstoerekening (alleen) dan laten gelden. Maar uit oogpunt van de wenselijkheid van een uniforme schadepraktijk en hanteerbaarheid van het recht is er, mede in het licht van de eerdergenoemde argumenten, veel voor te zeggen om dezelfde technische gronden en systematick te laten gelden bij het in aanmerking nemen van de overige uitkeringen van het fonds, schadeverzekeraars of andere derden. Alle betalingen van derden die tot schadevergoeding strekken kunnen dan, behoudens ingeval van subrogatie, probleemloos op dezelfde grond (voordeclstoerekening) in aanmerking worden genomen.

Als technische grond zijn subrogatie en, buiten de gevallen waarin subrogatie plaatsvindt, voordeelstoerekening kortom het meest passend. Dat sluit ook het meest aan bij het door de wetgever bij de invoering van afdeling 6.1.10 BW beoogde systeem. ${ }^{152}$ Tot principieel andere resultaten leidt dit wat semantische punt intussen niet. Ten belope van de uitkering uit schadeverzekering verliest de benadeelde, ook bij de door Bolt gekozen benadering, zijn recht op schadevergoeding, en is de schadeveroorzaker in zoverre jegens hem bevrijd.

\section{* Uitkeringen uit sociale verzekering}

Het tweede type betalingen van derden waarbij een toevallige samenloop ontstaat met de door de schadeveroorzaker verschuldigde schadevergoeding, en waarvoor dus een absoluut regime van voordeelstoerekening geldt, zijn sociale verzekeringsuitkeringen. Ook die strekken tot vergoeding van specifieke schadeposten (inkomensschade, ziektekosten, enzovoort). Voorzover daarvan sprake is en de schadeveroorzaker in beginsel voor dezelfde schade aansprakelijk is, geldt eveneens een

Vgl. HR 21 februari 1997, NJ 1999, 145 nt. CJHB (Wrongful birth) waar de ruimte wordt gelaten om ook voordeei van de benadeelde dat betrekking heeft op de immateriele schade waarvoor hij schadevergoeding vorden door voordeelstoerekening in aanmerking te nemen. Ook de smartengelduitkeringen van het Schadefonds komen darvoer in aanmerking dunkt me, voorsover het fonds niet al in de vordering van de benadeelde wordt gesubrogeend. 
absoluut regime van voordeelstoerekening. Om discussie daarover te voorkomen stellen bijzondere bepalingen in de sociale verzekeringswetten zeker dat de uitkering in die gevallen in mindering komt op de door de schadeveroorzaker verschuldigde schadevergoeding. ${ }^{153}$ Dit worden wel bepalingen van 'verplichte voordeelstoerekening' genoemd, maar zelf laten ze de technische grond voor het in aanmerking nemen van de uitkering in het midden. Bepaald wordt slechts dat met de uitkering rekening behoort te worden gehouden bij het 'vaststellen van de schadevergoeding'. De technische grond daarvoor is (in beginsel) voordeelstoerekening. ${ }^{154}$ Deze bepalingen stellen buiten twijfel dat de uitkering in mindering moet komen op de schadevergoeding en geven daarmee een absolute invulling van de redelijkheidsmaatstaf van art. 6:100 BW: de rechter mist dus ook hier, net als bij de vraag naar de invloed van uitkeringen uit schadeverzekering, beoordelingsvrijheid. Of de uitkerende sociale verzekeraar succesvol is in zijn regresvordering is daarvoor niet relevant. ${ }^{155}$

Deze bepalingen berusten uitdrukkelijk op de (beleids)visie dat (ook) sociale uitkeringen voor de benadeelde een vorm van schadevergoeding zijn, en schade slechts eenmaal kan worden vergoed. ${ }^{156} \mathrm{Net}$ als bij particuliere schadeverzekeringen is dan sprake van een toevallige samenloop met de verplichting tot schadevergoeding die rust op de schadeveroorzaker. Van subrogatie is evenwel geen sprake; niet zozeer omdat de sociale verzekering voldoende schadevergoedingskarakter mist, maar om de - formele - reden dat daarbij niet wordt uitgekeerd op basis van een particuliere verzekeringsovereenkomst. In het arrest Koopmans/Bedrijfsvereniging gaf de Hoge Raad echter voor de niet-toepasselijkheid van subrogatie voor sociale verzekeraars (ziekenfondsen) nog het argument dat de verbintenis tot betaling van de sociale verzekeraar krachtens de Ziektewet inhoudelijk onvoldoende gelijk was te schakelen met de vergoedingsplicht die op schadeverzekeraars rust: 'De verzekeraar, zijne verplichting tot uitkering van ziekengeld volgens de Ziektewet nakomende, betaalt niet de schade aan een verzekerd voorwerp in den zin van art. $284 \mathrm{WvK} .{ }^{157}$ Kritisch daarover was Meijers in zijn NJ-noot bij het arrest: ook de schadeverzekering heeft volgens Meijers een zeker sommenkarakter aangezien ook dan uitgekeerd wordt conform de normen die men vooraf overeenkwam, zij het dat die uitkering veelal meer de feitelijke schade benadert. Bovendien is

Zie onder meer art. 89 WAO, art. 52 Ziektewet, art. $83 a$ Ziekenfondswet, art. 13 Algemene wet bijzondere ziektekosten en art. 60 Algemene nabestaandenwet. Voor de uitkeringen krachtens de ambtenarenregiementen ontbreekt een uitdrukkelijke bepaling van verplichte voordeelstoerekening, maar is de regeling niet anders. Alleen de sociale verzekeringsuitkeringen die aan het ontstaan van schade in het vermogen van de benadeelde in de weg staan, zoals de uitkeringen van de Sociale Verzekeringsbank aan nabestaanden die tevens een beroep kunnen doen op ant. 6:108 lid I BW, worden al meegenomen bij de begroting van de schade (art. 60 tesamen met ant. 6:97 BW).

HR 3 januari 1936, NJ 1936, 78 nt. EMM (Koopmans/Bedrijfsvereeniging) 
ook de vergoedingsplicht van het aansprakelijkheidsrecht soms gefixeerd (vgl. thans art. 6:119 BW).

Die kritiek lijkt me overtuigend. Weliswaar worden uitkeringen uit sociale verzekering meer dan die uit schadeverzekering vastgesteld zonder dat de precieze, concrete omvang van de schade van de benadeelde vaststaat. Maar dat doet aan de aard van de uitkering, het schadevergoedingskarakter, geen afbreuk; het is gewoon een kwestie van doelmatigheid. ${ }^{158}$ Het schadevergoedingskarakter (en dus ook de gelijkenis met de vergoedingsplicht van de schadeveroorzaker) is bij de ene verzekering sterker aanwezig dan bij andere, maar wat alle sociale verzekeringen in de eerste plaats gemeen hebben is dat ze ertoe strekken concrete schadeposten op te vangen (inkomensschade, gederfd levensonderhoud, ziektekosten), die tevens schadeposten zijn waarvoor de benadeelde een beroep zou kunnen doen op het aansprakelijkheidsrecht. Voorts is het zo, dat de omvang van de vergoeding in meerdere of minder mate afhangt van de schade in concreto of van daarvoor beslissende factoren (graad van arbeidsongeschiktheid, periode waarover inkomen wordt gederfd, hoogte van het inkomen, van de ziekenhuisnota, behoeftigheid bij de nabestaanden enzovoort). Zo bezien lijkt het, ervan uitgaande dat schade slechts eenmaal wordt vergoed, consequent om ook voor deze uitkeringen het samenloopregime te laten gelden (dat wil zeggen dat ze zijn aan te merken als een alternatief voor schadevergoeding en het WAO-orgaan daarom bevrijdend betaalt voor de schadeveroorzaker en in zoverre regres op hem heeft).

Het hier gezegde vindt steun in de wordingsgeschiedenis van de WAO. De bepaling van verplichte voordeelstoerekening (art. 89 WAO) werd door de verantwoordelijke bewindsman onderbouwd met de stelling dat de WAO-verzekering strekte tot vergoeding van inkomensschade, en dat de verplichte voordeelstoerekening dubbele schadevergoeding moest voorkomen. ${ }^{159}$ Daaraan deed (kennelijk) geen afbreuk dat het juist in het kader van de WAO vóórkomt dat de benadeelde meer of minder uitkering ontvangt dan het precieze bedrag van zijn schade. Uitgekeerd wordt terwijl de precieze, concrete omvang van de schade van de benadeelde (niet te verwarren met diens mate van arbeidsongeschiktheid) niet noodzakelijk vaststaat. Als arbeidsongeschikten immers ieder afzonderlijk gerechtigd zouden zijn tot een uitkering die exact hun graad van arbeidsongeschiktheid en de daarmee corresponderende inkomensschade zou moeten weerspiegelen, dan zou dat de uitvoering vertragen en tot hogere uitvoeringskosten leiden. Door de bepalingen van verplichte voordeelsstoerekening mist de kwestie overigens concrete praktische relevantie: de

\footnotetext{
158 Anders voor de vraag of de bedrijfsvereniging voor utkeringen krachtens de Ziektewet kon worden gesubrogeerd: P-G Besier inzake HR 3 januari 1936, NJ 1936, $78 \mathrm{nt}$. EMM (Koopmans/Bedrijfsvereeniging); het doel van de Ziektewet is weliswaar blijkens de Memorie van Toelichting de geldelijke gevolgen van arbeidsongeschiktheid te vergoeden, maar de P-G acht het voor subrogatie bezwaarlijk dat dit gebeurt in de vorm van een gefixeerde som, onafhankelijk van de geleden schade.

159 Aldus expliciet TK 1962-63, 7171, nr. 3 (MvT), p. 21.
} 
voordeelstoerekening moet dubbele vergoeding voorkomen, ongeacht de mate waarin de uitkering is afgestemd op de schade.

Het bijzondere van de bepalingen van verplichte voordeelstoerekening is verder dat het bedrag van de wettelijke aanspraak op de uitkering in aanmerking moet worden genomen. Niet nodig is dus dat de uitkering ook al daadwerkelijk aan de benadeelde werd verstrekt. ${ }^{160}$ Dat lijkt me bij het uitgangspunt dat dubbele vergoeding moet worden voorkomen niet onredelijk. In verreweg de meeste gevallen zal de aanspraak op een sociale uitkering ook daadwerkelijk tot betaling komen. Dat legitimeert de keuze om uit efficiency oogpunt reeds het bedrag van de aanspraak aan de benadeelde toe te rekenen (zonder dat die tot betaling is gekomen). De redelijkheid hiervan ontbreekt evenwel als vaststaat dat de uitkering ondanks de aanspraak daarop feitelijk niet door de benadeelde zal (kunnen) worden genoten. Dan is voor voordeelstoerekening geen plaats, dit zal hierna nog aan de orde komen.

\section{* Overige (sociale voorzieningen, onkostenvergoeding, giften)}

Al wat geldt voor vergoedingen die de benadeelde ontvangt uit particuliere en sociale verzekering, namelijk dat hij in zoverre jegens de schadeveroorzaker zijn recht op schadevergoeding verliest, geldt dunkt me in beginsel ook voor vergoedingen uit andere hoofde. Specifiek voor voordeelstoerekening valt te denken aan de uitkeringen van het Schadefonds Geweldsmisdrijven, gemeentelijke betalingen ingevolge de Wet voorzieningen gehandicapten en compensatieregelingen van de werkgever. Als zulke betalingen naar hun aard en omvang strekken tot schadevergoeding, dan is de schadeveroorzaker ook in zoverre jegens de benadeelde van zijn vergoedingsplicht bevrijd. Ook hier is sprake van een toevallige samenloop met de door de schadeveroorzaker (aansprakelijke) verschuldigde prestatie: de betaling strekt ertoe schade te vergoeden waarvoor de benadeelde vervolgens ook de schadeveroorzaker aanspreekt.

Overigens biedt de wet evenzeer ruimte om rekening te houden met uitkeringen zonder schadevergoedingskarakter. Ondanks de bewoordingen van art. 6:100 BW past dan terughoudendheid: slechts indien dat op grond van bijzondere omstandigheden redelijk lijkt, kunnen de betalingen aan de benadeelde geheel of gedeeltelijk in mindering worden gebracht op zijn recht op schadevergoeding van de schadeveroorzaker. ${ }^{161}$ Er kan zelfs ook buiten de sfeer van voordeelstoerekening rekening mee worden gehouden, bij toepassing van het rechterlijke matigingsrecht (art. 6:109 BW). Aan de motiveringsplicht moeten dan dunkt me hoge eisen worden gesteld.

TK 1995-96, 24 758, nr. 3 (MvT), p. 81 en TK 1996-97, 25478 , nr. 3 (MvT), p. 95.

Bolt (1989), p. 194 e.v. acht ook dan weer de strekking van het voordeel van belang. PG 6, p. 348 is hierover summier; Asser-Hartkamp 4-I, nr, 445 merkt op dat de redelijkheid eigenlijk een negatief criterium is (zo ook de bewoordingen van art. 6:100 BW): de redelijkheid kan aan voordeelstoerekening in de weg staan. Het is overigens de vraag of het criterium ook zo restrictief wordt toegepast. De Hoge Raad lijkt terughoudender. zie HR I februari 2002, NJ 2002, 122 (Van Siraaten/Brandts) en daarover Engelhard (2002), p. 165. 
Van een absoluut regime is al zeker geen sprake; de redelijkheid is de enige maatstaf. ${ }^{162}$ Ook van regres van de verstrekker van zulke uitkeringen op de schadeveroorzaker kan geen sprake zijn, daarvoor is nodig dat hij aan de benadeelde dezelfde prestatie betaalde als waartoe de schadeveroorzaker jegens de benadeelde gehouden was. ${ }^{103}$

Voor uitkeringen die naasten doen uit vrijgevigheid wordt aangenomen dat voordeelstoerekening in beginsel moet uitblijven. Die komen niet in mindering op het bedrag dat de schadeveroorzaker aan de benadeelde verschuldigd is, tenzij daarvoor aanvullende gronden gelden. De schadeveroorzaker zou daarvan niet moeten kunnen profiteren. Men heeft dan veelal het oog op giften die als extraatje dienen voor de benadeelde. Maar hoe is het regime van voordeelstoerekening bij giften waarvan de strekking is dat ze concrete schade van de benadeelde 'goedmaken'? Vanuit de gedachte dat het schadevergoedingskarakter (de gelijkenis met de prestatie waartoe de schadeveroorzaker op basis van diens aansprakelijkheid jegens de benadeelde gehouden is) beslissendmoet zijn, ligt voordeelstoerekening wèl voor de hand. ${ }^{164}$ Dat is tevens het meest in overeenstemming met het regime dat geldt voor de - sterk gelijkende - situatie waarin naasten rechtstreeks (en om niet) kosten maken ten behoeve van de eiser. Deze naasten hebben daarvoor jegens de schadeveroorzaker op grond van art. 6:107 BW recht op schadevergoeding en de eiser wordt geacht in zoverre geen vermogensschade te ondervinden. Hetzelfde zou dan moeten gelden als de betaling/gift niet kan voorkomen dat de eiser schade ondervindt in zijn vermogen, maar wèl diens schade (achteraf) 'goedmaakt' of vergoed. Art. 6:107 BW geldt dan niet, dàt is naar de letter bedoeld voor derden die rechtstreeks kosten voor hun rekening nemen. Maar de positie van de benadeelde behoort achteraf niet gunstiger te zijn dan bij betalingen die zijn schade rechtstreeks wegnemen. Dat zou de benadeelde slechts ertoe aansporen om - om voordeelstoerekening te vermijden - de kosten eerst zelf te maken en de naasten daarna pas aan hemzelf te laten betalen (hetgeen niet in alle gevallen mogelijk zal zijn, waardoor de facto rechtsongelijkheid zou ontstaan).

Er is nog een argument vóór een absoluut regime van voordeelstoerekening bij giften met een compensatoir karakter: het past bij de gedachte die besloten ligt in het arrest Nationale Nederlanden/Woudsend II. In dat arrest besliste de Hoge Raad dat schadeverzekeraars ook voor onverplichte schadeuitkeringen ('uit coulan$c e$ ') worden gesubrogeerd in de vordering tot schadevergoeding van de benadeelde. De raad overweegt daartoe dat de schadeveroorzaker anders definitief van zijn

\footnotetext{
162 Vgl. Bouman \& Tilanus-Van Wassenaer (1998), p. 70 ('Redelijkheid is maatstaf'); Bloembergen \& Lindenbergh (2001), p. 19 ('een kwestie van redelijkheid').

163 Zie paragraf 4.8 .1 .

164 In die zin ook Bloembergen (1965), $\mathrm{nr}$. 241, die daartoe stelt dat giften in de meeste gevallen die strekking zullen hebben (en dus bedoeld zijn als financiele steun ter beperking van de schade), doch anders Bolt (1989a), p. 243 die met enige aarzeling het persoonlijke karakter ook dan beslissend acht.
} 
vergoedingsplicht zou zijn bevrijd. ${ }^{165}$ Hiermee veronderstelt de raad dat die uitkeringen zonder subrogatie in mindering zouden komen op de door de schadeveroorzaker verschuldigde schadevergoeding. Het ligt dan voor de hand om voor uitkeringen van naasten hetzelfde te laten gelden. Voordeelstoerekening sluit kortom het beste aan bij het regime voor onverplicht betaalde verzekeringsuitkeringen alsook bij het eerdergenoemde geval waarin naasten rechtstreeks schade op zich nemen (art. 6:107 BW). Giften hebben in het algemeen wel vergeleken met vrijwillige uitkeringen uit schadeverzekering een wat persoonlijker karakter. Ze zijn bedoeld voor de benadeelde persoonlijk. Bolt acht dat persoonlijke element doorslaggevend om geen voordeelstoerekening te laten plaatsvinden. ${ }^{166}$ Ook daar valt wat voor te zeggen, maar een scherp criterium is dat niet. Oók uitkeringen uit schadeverzekering kunnen een zeker persoonlijk element hebben, indien de benadeelde daarvoor zelf heeft gekozen en (eventueel) er ook de premies voor heeft betaald. Toch weegt dan het schadevergoedingskarakter bij de vraag naar voordeelstoerekening (of subrogatie) zwaarder. Men zou daartegen kunnen inbrengen dat de vergelijking met schadeverzekeringen mank gaat omdat daar een zakelijke verhouding aan ten grondslag ligt. ${ }^{167}$ Het motief van schadeverzekeraars bij coulance-uitkeringen is hovendien meestal commercieel: beoogd zal veelal worden de verzekerde of de tussenpersoon tevreden te houden of kostbare procedures te vermijden. ${ }^{100}$ Bij giften is het gebaar van de schenker persoonlijk, zulke 'echt' altruïstische motieven zouden meer beschermingswaardig zijn. Maar ook het motief achter de gift lijkt me in dit verband een wat wankel en weinig transparant criterium. Het enkele feit dat de verstrekker van de gift behoort tot de persoonlijke sfeer van de benadeelde betekent immers nog niet dat zijn motieven vrijblijvend waren (en hoe stelt men dat in concreto vast). Twijfelachtig is bovendien of voordeelstoerekening bij giften die als schadevergoeding zijn bedoeld, juist die bedoeling van de schenker frustreert. Zulke giften kunnen wel persoonlijk zijn bedoeld, maar ze worden niet helemaal vrij gegeven: ze hebben een bestemming, één die de benadeelde bij het behoud van zijn recht op (andermaal) schadevergoeding via het aansprakelijkheidsrecht zou frustreren.

Kortom, voorzover de gift strekt tot vergoeding van specifieke, met de vordering van de benadeelde corresponderende schade ontstaat een samenloop en behoort de benadeelde voor de betreffende schade zijn vordering op de schadeveroorzaker te verliezen. Als niet aannemelijk is dat de gift die strekking heeft, pleegt ze

HR 7 januari 2000, N/2000, $212 \mathrm{nt}$. MMM (Nationale Nederlanden/Woudsend II). Dit sluit aan bij het wetsontwerp van subrogatie voor komend recht. Volgens art. 7.17.2.25 BW is niet relevant of de verzekeringsuitkering in het kader waarvan subrogatie plaatsvindt verplicht dan wel onverplicht is betaald. Bolt $(1989 a)$, p. 243.

167 Bij coulance-betalingen in het verzekeringsbedrijf kan worden gedacht aan kwijtschelding van (een deel van) de premie, zie Mok (1998), p. 100 e.v., maar ook - en zo versta ik de term hier - aan schadeuitkeringen, die dan veelal zijn bedoeld om een geschil op te lossen of te voorkomen (bij wijze van een vaststellingsovereenkomst. art. $7: 900 \mathrm{BW}$ ) 
- terecht - niet te worden verrekend, dit komt nu nader aan de orde.

\subsubsection{VRIJE TOEPASSING VAN ART, 6:100 BW}

\section{* Vrijblijvende giften en andere 'windfalls'}

Bij betalingen van derden die niet strekken tot vergoeding van de concrete schade waarvoor de benadeelde de schadeveroorzaker aansprakelijk stelt, is er in beginsel geen plaats voor het verrekenen daarvan door voordeelstoerekening. Te denken valt dan aan de bedoelde 'vrije' giften. Als die als vermogenswinst voor de benadeelde zijn bedoeld, dan dienen ze in beginsel niet in mindering te komen op het bedrag van de schadevergoeding die de schadeveroorzaker verschuldigd is. De redelijkheidsmaatstaf van art. 6:100 BW laat de rechter een zekere mate van beoordelingsvrijheid om bij uitzondering - indien daarvoor bijzondere, aanvullende redenen zijn aan te voeren - toch met zulke giften rekening te houden. Afdeling 6.1.10 BW biedt daarvoor ook andere gronden, zoals het matigingsrecht (art. 6:109 $\mathrm{BW}$, doch zie lid 2). De regeling van art. 6:100 BW biedt de rechter verder de mogelijkheid om - bij de vaststelling van het smartengeld - rekening te houden met immaterieel voordeel. Een geval waarin daarvoor vermoedelijk ruimte bestaat is bij vorderingen tot smartengeld wegens ongewenste zwangerschap. De vreugde van het ouderschap kan het dan redelijk maken om daarmee rekening te houden bij de vaststelling van de omvang van het smartengeld. ${ }^{169}$

\section{* Uitkeringen uit sommenverzekering}

Ook uitkeringen uit particuliere sommenverzekering plegen niet te worden verrekend, maar ook hier heeft de rechter een zekere mate van beoordelingsvrijheid met betrekking tot de vraag naar voordeelstoerekening. Sommenverzekeringen zijn verzekeringen waarbij wordt uitgekeerd los van de vraag of en hoeveel financiële schade is geleden. ${ }^{170}$ De hoogte van de uitkering is reeds bij het sluiten van de verzekeringsovereenkomst vastgesteld, uitgekeerd wordt ook als de benadeelde geen schade heeft, en de uitkering kan minder of méér bedragen dan de eventuele schade. Bekende voorbeelden zijn arbeidsongeschiktheidsverzekeringen, ongevallen- en levensverzekeringen. ${ }^{171}$ Zulke uitkeringen plegen niet te worden verre-

169. HR 21 februari 1997, NJ 1999, $145 \mathrm{nt}$. CJHB (Wrongful birth).

170 Ant. 7.17.3.1 BW luidt: 'Sommenverzekering is de verzekering waarbij het onverschillig is of en in hoeverre met de uitkering schade wordt vergoed. Zij is slechts toegelaten bij persoonsverzekering en bij verzekeringen welke dartoe bij algemene maatregel van bestuur, zo nodig binnen daarbij vast te stellen grenzen, zijn aangewezen.

171 Zie a.2. HR 28 november 1969, NJ1970, $172 \mathrm{nt}$. GJS (IBCD erka), en in die zin o.a. Rb. Amsterdam 30 december 1998, VR 1999, 81 (S/Centraal Beheer Schadeverzekering): geen voordeelstoerekening van cen uitkering uit collectieve ongevallenverzekering, nude WA-verzekeraar geen concrete feiten of omstandigheden heeft gesteld (noch zijn die gebleken), om af te wijken van even genoemd arrest. Zie voorts de rechtspraak vermeld bij Schade. 
kend, maar de kwestie is omstreden. ${ }^{172}$ Het belang van de vraag naar voordeelstoerekening is groot, aangezien geen subrogatie plaatsvindt (zie paragraaf 4.6). Dit laatste zal bij de inwerkingtreding van het wetsontwerp voor het verzekeringsrecht naar komend recht worden verankerd in titel $7.17 \mathrm{BW} .{ }^{173}$

Naar geldend recht wordt de kwestie in de eerste plaats beheerst door de rechtspraak. Sinds het arrest inzake IBC/Derkx wordt bij letselschade aangenomen dat uitkeringen uit particuliere sommenverzekering in beginsel niet in mindering behoren te komen op het bedrag van de schadevergoeding van de benadeelde. De Hoge Raad noemt de uitkering uit sommenverzekering in dat arrest een omstandigheid die de schadeveroorzaker 'niet aangaat', ${ }^{174}$ De benadeelde heeft zich door het afsluiten van de ongevallenverzekering voor onzekere tijden willen verzekeren van een vermogensaanwas of welstand (en daarmee van een zekere gemoedsrust). Het aansprakelijkheidsrecht mag daar niet tussenkomen. Dit standpunt van de Hoge Raad sluit aan bij jurisprudentie van vroegere datum waarin de raad besliste dat sommenverzekeraars niet worden gesubrogeerd (omdat de benadeelde zijn vordering tot schadevergoeding behoort te behouden). ${ }^{175}$ Een uitzondering geldt bij vorderingen wegens derving van de voorziening in het levensonderhoud (art. 6:108 lid $1 \mathrm{BW}$ ). Dan wordt wegens de aard van de schade wèl, maar al bij de schadebegroting, rekening gehouden met in beginsel alle inkomsten en uitgaven van de benadeelde, ook met uitkeringen uit verzekering. Te denken valt aan ongevallen- en aan levensverzekeringen. Dat levensverzekeringen typische sommenverzekeringen zijn, het zijn tot op zekere hoogte vormen van sparen of vermogensbeheer, doet daaraan niet af. Zoals ik eerder aangaf worden in beginsel alle uitkeringen in aanmerking genomen bij het vaststellen van de schade (het behoeftigheidsvereiste). Voor voordeelstoerekening lijkt de Hoge Raad bij vorderingen ingevolge art. 6:108 lid $1 \mathrm{BW}$ geen plaats te zien. ${ }^{176}$

De commentaren op het arrest inzake IBC/Derkx (en latere jurisprudentie) waarin de Hoge Raad de koers van geen voordeelstoerekening bij sommenverzekeringen volgt, zijn verschillend. Bij de invoering van Boek $6 \mathrm{BW}$ is over de kwestie een

vergoeding, art. 107 (Bolt), aant. 31, en over sommenverzekeringen in het algemeen Mulder (1988), p. 39 ev.; Van der Burg (1990), p. 172 e.v.; Mok (1998), p. 14 e.v.

Het zou te ver voeren hier een volledige beschrijving te geven van rechtspraak en vele literatuur op dit punt. Verwezen zij naar gedegen en nog steeds actuele besprekingen elders. Zie met name Asser-Hartkamp 4-1, nr. 477; Van den Heuvel (1960), p. 1-44; Bolt (1989a), p. 48 e.v.; Kottenhagen-Edzes (1993), vanaf p. 308 (tot p. 317) en de Conclusie van A-G Spier bij HR 4 februari 2000, NJ 2000,600 nt. MMM (Kwidama/Raphael Richandson).

173 Maar het geldt reeds sinds HR 31 december 1931, NJ 1932, $419 \mathrm{nt}$. EMM (Spoorwegongeval De Vink). De nieuwe subrogatieregeling, ant. 7.17.2.25 BW staat in afdeling 7.17.2 BW ('Schadeverzekering'), en geldt niet ook voor afdeling 7.17.3 BW ('Sommenverzekering'), zoals laatstelijk gewijzigd bij EK 2002-03, 19 529, nr. 206 (Gewijzigd voorstel van wet, d.d. 24 april 2003).

176 Aldus HR 19 juni 1970, NJ1970,380 nt. GJS (NBM/Eagle Star); HR 4 februari 2000, NJ2000, 600 nt. MMM (Kwidama/Raphael Richandson). 
principiēle discussie op gang gekomen. De vaste kamercommissie vond in meerderheid dat voor ongevallenverzekeringen dezelfde regeling zou moeten gelden als voor schadeverzekeringen. ${ }^{17}$ (Oud-)minister Van Agt wees dat aanvankelijk van de hand. Art. 6:100 BW zou niets moeten veranderen aan de rechtspraak van de Hoge Raad. De minister wees op het belang van de persoonlijke vrijheid: potentiële slachtoffers zouden zich moeten kunnen beschermen tegen onvolkomenheden van het aansprakelijkheidsrecht en een onzekere toekomst, met betrekking tot het inkomen. ${ }^{178}$ Toch werd bij de Invoeringswet, in 1982, alsnog een (ontwerp)regeling voorgesteld die ertoe strekte dat voor elke verzekeringsuitkering die geacht moest worden de schade te verminderen voordeelstoerekening zou moeten plaatsvinden. Een belangrijke taak werd gelegd bij de rechter: die zou met name bij invaliditeits- en ongevallenuitkeringen moeten onderzoeken of die, hoewel ze naar de letter van de verzekeringspolis niet gerelateerd waren aan de schade, feitelijk daarvan niet los konden worden gezien en konden dienen als aanvullend inkomen uit vermogen. ${ }^{179}$ Dit stuitte op grote bezwaren in de Tweede Kamer. De CDAfractie amendeerde met de stelling 'dat juist het verzekeren tegen cen onzeker voorval, waarvoor soms jarenlang premie is betaald, niet als voordeel in de schoot mag vallen van de pleger van een onrechtmatige daad. ${ }^{180}$ Ter ondersteuning beriep men zich op een enquête in een NOS-programma onder de titel Rechtsgevoel (november 1986) waarin het CDA-standpunt, zij het bij een nogal ambigu vraagstelling, ${ }^{181}$ kon rekenen op brede steun $(92 \%$ van de ondervraagden was het ermee eens). Besloten werd toen de ontwerp-regeling te laten vervallen en de zaak over te laten aan de rechter. Een mager resultaat van een uitvoerige discussie, maar niet geheel zonder betekenis (met name omdat het standpunt van de regering in de discussie zo nadrukkelijk steun gaf aan de wenselijkheid van voordeelstoerekening bij invaliditeitsuitkeringen die als vergoeding van inkomensschade of uit belegging verkregen vruchten kunnen worden aangemerkt). ${ }^{182}$

178 PG 6. p. 349 met verwijzing naar HR 28 november 1969, NJ 1970, 172 nt. GJS (IBCCDerkx). Vermoedelijk speelde mee dat de subrogatieregeling voor Boek $7 \mathrm{BW}$ gereed was en die uitsluitend werd gereserveerd voor schadeverzekeraars. Wel wees de minister op de mogelijkheid van matiging van de schadevergoeding van de benadeelde met een niet-verrekenbare sommenuitkering Art. 6.1.9.11a, vierde lid van het ontwerp voor de Invoeringswet van Boeken 3-6 van het BW, zie $\ln v$. 6, p. 1278 e.v. en over de genoemde sommenuitkeringen expliciet Inv. 6, p. 1290-1291.

$180 \operatorname{lnv}, 6$, p. 1295.

I81 Zie Inv. 6, p. 1305. Men heeft de vraag naar de wenselijkheid van voordecistoerekening beperkt tot gevallen van schuldaansprakelijkheid. De mening van de meerderheid van de ondervraagden dat voordeelstoerekening onwenselijk was kan daardoor uiteraard zijn beinvloed.

Is2 Inv. 6, p. 1309. Ook de Hoge Raad wijst in zijn arrest inzake HR 4 februari 2000, NJ 2000, 600 nt. MMM (Kwidama/Raphael Richardson) in navolging van A-G Spier op het belang van deze discussie (r.o. 3.6). De rad stelt dat het belang daarvan vooral ligt bij de discussie over de vraag nar voordeelstoerckening bij letselschade en bij de mogelijkheid die dit biedt om sommenuitkeringen anders dan in het arrest inzake IBC/Derkx toch an de benadeelde toe te rekenen. Dit duidt mogelijk op een koerswijziging in 's raads jurisprudentie bij toekomstige gevallen in de richting van voordeelstoerekening bij letselschade. 
Het belangrijkste argument voor het (ingetrokken) wetsontwerp was het verschil met overlijdensschade: anders dan bij letselschade worden sommenuitkeringen in het kader van het behoeftigheidsvereiste zoals gezegd wèl in aanmerking genomen. De minister wenste een einde maken aan dat verschil, het zou tot een uiteenlopende positie van benadeelden leiden. ${ }^{18}$ Ook werd gewezen op het verschil met uitkeringen uit sociale verzekering, die net als particuliere sommenverzekeringen geen volkomen schadevergoedingskarakter hebben terwijl toch voordeelstoerekening plaatsvindt. ${ }^{14}$ Later in de discussie heeft de minister nog benadrukt dat voordeelstoerekening bij sommenverzekeringen eigenlijk vooral bedoeld was om het oplopen van de WA-schadelast tegen te gaan. ${ }^{175}$ Vanuit die gedachte, het effect op de WA-premies, wordt momenteel ook een argument gezien om de huidige koers bij overlijdensschade (waarbij sommenverzekeringen wèl in aanmerking worden genomen) te handhaven. ${ }^{156}$

Het verschil met gevallen van overlijdensschade is (ook) momenteel het belangrijkste argument in de discussie. ${ }^{187}$ Kottenhagen-Edzes wijst op de uiteenlopende positie die benadeelde en schadeveroorzaker door het min of meer toevallige feitelijke verloop van de schade innemen. Het huidige systeem leidt er toe dat een minder hoge schadevergoeding betaald hoeft te worden wanneer men iemand doodt, zo stelt zij, dan wanneer men iemand kwetst. ${ }^{188} \mathrm{Er}$ is los van starre dogmatiek, zo stelt A-G Spier het, geen overtuigende reden waarom gevallen van dood en letselschade zo fundamenteel verschillend zouden moeten worden behandeld. ${ }^{189}$ Omwille van de helderheid is het goed om voorop te stellen dat aan de uiteenlopende regeling voor sommenverzekeringen geen principieel onderscheid tussen letsel-en overlijdensschade ten grondslag ligt. Het verschil speelt tussen enerzijds de vorderingen tot schadevergoeding bij letsel- en overlijdensschade en, anderzijds, vorderingen tot schadevergoeding in de zin van art. 6:108 lid $1 \mathrm{BW}$ (gederfde voorziening in het levensonderhoud). De contouren van dit huidige systeem lijken me in beginsel goed verdedigbaar, indien in beide gevallen het schadevergoedingskarakter van de verzekering beslissend wordt gemaakt. Als uitkeringen uit sommenverzekering niet strekken tot vergoeding van de schadepost waarvoor schadevergoeding wordt gevorderd, dan behoren ze niet daarop in mindering te komen. Dat is bij overlijdensschade niet anders dan bij letselschade. Ze moeten in het kader van art. 6:108 lid $1 \mathrm{BW}$ wel in aanmerking worden genomen als ze dienen als (extra) voorziening voor het bestedingsbudget (dat zal bij uitkering uit levensverze-

Inv. 6, p. 1309 en 1287 waar het onderscheid 'systematisch weinig fraai' heet. Dit laatste zie ik niet direct nu de grond voor toerekening van uitkeringen uit sommenverzekering bij vorderingen ingevolge art. 6:108 lid $1 \mathrm{BW}$ het behoeftigheidsvereiste is en niet voordeelstoerekening. 
kering die voor de nabestaanden zijn afgesloten veelal ook het geval zijn). Uit de aard van de schade van art. 6:108 lid $1 \mathrm{BW}$ volgt dat elk vermogensvoordeel dat zonder het overlijden voor het levensonderhoud zou zijn aangewend, in aanmerking moet worden genomen. Ongevallen-, levens- en andere verzekeringen kunnen bij de vordering van art. 6:108 lid $1 \mathrm{BW}$ (derving van voorziening in het levensonderhoud) veelal worden geacht te strekken als alternatief voor de weggevallen voorziening voor de behoefte aan levensonderhoud. Bij letselschade behoeft met sommenuitkeringen naar de aard van de schade veelal geen rekening te worden gehouden. Dat daarmee in het kader van het behoeftigheidsvereiste van art. 6:108 lid $1 \mathrm{BW}$ wèl rekening moet worden gehouden botst dan ook geenszins. Wel past voorzichtigheid bij de kwalificatie van een verzekering als schade- dan wel sommenverzekering. Dit komt nog uitvoerig aan de orde, ${ }^{190}$ maar vraagt hier kort aandacht. Particuliere ongevallenverzekeringen die ertoe strekken om bij letsel een vaste som uit te keren die bedoeld is als compensatie voor schade waarvoor de benadeelde vervolgens de schadeveroorzaker aansprakelijk stelt hebben, dunkt mij, voldoende schadevergoedingskarakter om ze te verrekenen door subrogatie of voordeelstoerekening. Denk aan arbeidsongeschiktheids- en/of ongevallenverzekeringen waarbij met standaardtarieven of getarifieerde percentages wordt gewerkt. ${ }^{191}$ Dat met schalen van arbeidsongeschiktheid (Gliedertaxe) wordt gewerkt of een vaste som vooraf wordt afgesproken zou daaraan geen afbreuk moeten doen als die zijn vastgesteld aan de hand van concrete schadegegevens van de benadeelde: hoogte van het inkomen, mate van arbeidsongeschiktheid (èn die op het moment van de uitkering nog representatief zijn voor diens werkelijke omstandigheden. Daarvan kan immers moeilijk worden volğehouden dat ze de feitelijke schade onverlet laten, en dàt was het uitgangspunt voor voordeelstoerekening of subrogatie. Als prima facie onduidelijk is voor welke schadepost de verzekeringsuitkering precies bedoeld is, dan zal moeten worden afgegaan op de brochure, de verzekeringspolis en voorwaarden voor declaratie enzovoort. Van sommenverzekeringen lijkt dan slechts sprake indien de verzekering in het geheel niet geacht kan worden te zijn bedoeld voor de vergoeding van de betreffende schadeposten.

Ook bij de uitleg van het behoeftigheidsvereiste zou het schadevergoedingskarakter voorop moeten staan. Thans wordt het regime zoals gezegd ook wel zo uitgelegd, dat het erom gaat in hoeverre de nabestaande voor de voorziening in zijn levensonderhoud schadevergoeding behoeft (en dus niet zozeer om de vraag in hoeverre de nabestaande geacht kan worden levensonderhoud te derven). Terwijl dus voor het regime van voordeelstoerekening bij letselschade de strekking van de uitkering die de benadeelde ontvangt van derden beslissend is, geldt voor het behoeftigheids-

\footnotetext{
190 Met name in paragraaf 4.6 .

191 In de literatuur gaan daarvoor meer stemmen op, zie daarover Bolt (1989b), p. 42 en Bloembergen (1965). nr. 257 e.v. en in de door mij bedoelde zin ook 0.2. Van Boeschoten (1950), p. 614, De Kok (1965), p. 94, Mulder (1988), p. 43, en Bouman \& Tilanus-Van Wassenaer (1998), p. 17; anders Bolt (1989a), p. 224. Zoals werd gezien biedt ook de parlementaire discussie steun voor voordeelstoerekening.
} 
vereiste dat in beginsel alle betalingen in mindering komen op de vordering van de benadeelde (nabestaanden). De vraag of het voordeel strekt tot vergoeding van het gederfde levensonderhoud is dan volstrekt niet relevant. Zoals ik eerder aangaf, kan dit tot onredelijke resultaten leiden: ${ }^{192}$ de weduwe die schadevergoeding vordert voor het deel van het levensonderhoud dat betrekking heeft op huishoudelijke uitgaven zoals voeding, kleding en verzekeringspremies (conform de levensstandaard zoals die zonder het overlijden zou zijn geweest) zou die vordering kunnen verliezen vanwege haar uitkering uit hypothecaire levensverzekering (hoewel die eigenlijk bedoeld is als voorziening voor de niet door haar opgevoerde hypothecaire lasten). Dit moeilijk te billijken verschil met het regime van voordeelstoerekening bij letselschade kan worden voorkomen.

Beter zou zijn om, zoals ik aangaf, bij de uitleg van het behoeftigheidsvereiste van art. 6:108 lid $1 \mathrm{BW}$, net als bij letselschade, het schadekarakter beslissend te laten zijn. Ook dan zullen wellicht in beginsel alle uitkeringen uit sommenverzekering de behoeftigheid van de nabestaanden verminderen voorzover daarmee in hun levensonderhoud wordt voorzien. Immers zullen de betalingen van derden (en andere vermogensvoordeel voor de nabestaande) extra activa opleveren vergeleken met de situatie zoals die zonder het overlijden zou zjin geweest.Daarbij past wel een tweetal restricties. In eerste plaats dient dat alleen te gelden voor uitkeringen uit sommenverzekering die in plaats komen van het weggevallen aandeel van de kostwinner. Het winnen van een prijs in de loterij moet dus buiten beschouwing blijven. Niet omdat de betreffende bedragen niet voor het levensonderhoud kunnen worden aangewend, maar omdat ze zonder het overlijden in beginsel naast het aandeel van de kostwinner in het huishoudbudget zouden zijn genoten. Nabestaanden dienen hun recht op schadevergoeding ingevolge art. 6:108 lid $1 \mathrm{BW}$ niet te verliezen wegens vermogensvoordeel dat zonder het overlijden sowieso - naast het weggevallen aandeel van de overledene in hun levensonderhoud - deel zou uitmaken van hun vermogen. Ten tweede brengt een redelijke invulling van het behoeftigheidsvereiste mee dat alleen die inkomsten moeten worden verrekend die strekken tot voorziening in juist de onderhoudskosten waarvoor schadevergoeding wordt gevorderd. Een uitkering uit hypothecaire levensverzekering (althans de daarmee bespaarde hypothecaire rente) dient dan niet te worden verrekend met de vordering van art. 6:108 lid $1 \mathrm{BW}$ indien die vordering betrekking heeft op andere kosten van levensonderhoud dan woonlasten (de kosten van voeding, kleding, verzekering), zoals het geval was in het arrest inzake Kwidama/Raphael Richardson.$^{193}$ Dat geldt óók, dunkt mij, indien de benadeelde al op andere wijze dan door de betreffende verzekeringsuitkering in staat is om de hypothecaire schuld reeds uit andere middelen te voldoen. Ook in het ultieme geval waarin de weduwe twee uitkeringen uit hypothecaire levensverzekering ontvangt, en haar vordering

193 Zie Engelhard (2000), p. 254-259, noot bij HR 4 februari 2000, NJ 2000, $600 \mathrm{nt}$. MMM (Kwidama/Raphael Richantson). 
tot schadevergoeding geen betrekking heeft op de woonlasten, dienen deze verzekeringsuitkeringen haar vordering onverlet te laten.

Een voor de hand liggende consequentie van het hier voorgestane regime zal zijn dat nabestaanden hun vordering anders zullen gaan inkleden. Illustratief is het al genoemde arrest Kwidama/Raphael Richardson: in lagere instanties was schadevergoeding gevorderd voor het deel van de voorziening dat betrekking had op de hypothecaire lasten, maar dit deel van de vordering werd nadien ingetrokken en daarbij werden de overige kostenposten van het levensonderhoud aanmerkelijk hoger gewaardeerd. Wellicht hoopte de raadsman van de weduwe te voorkomen dat dàt deel van de gevorderde som zou worden afgewezen. Bezwaarlijk lijkt dit risico van strategische procesvoering echter niet, de nabestaanden zullen de opgevoerde schadeposten immers moeten kunnen waarmaken.

\subsubsection{Aperçu: de bevrijdende werking van betalingen van derden}

Resumerend kunnen de regels voor de invloed van betalingen van derden op de schadevergoeding naar geldend recht (met of zonder mijn suggesties voor een redelijke uitleg daarvan) in drie regimes worden onderverdeeld:

In de eerste plaats zijn er de rechtstreekse betalingen van derden die a priori aan het ontstaan van schade in het vermogen van de benadeelde in de weg staan (paragraaf 3.3.4). Indien juist de schade(post) waarvoor de benadeelde de schadeveroorzaker tot schadevergoeding aanspreekt, feitelijk werd gedragen door derden, dan loopt de vordering daarop stuk, zie art. 6:97 $\mathrm{BW},{ }^{194} \mathrm{Zij}$ zijn dan op hun beurt als benadeelde aan te merken. Ik noemde als voorbeelden de rechtstreeks door naasten gemaakte herstelkosten, bijvoorbeeld voor medische behandeling of bij eerste hulp, loondoorbetaling door de werkgever en voorts de diverse uitkeringen aan nabestaanden met een vordering ingevolge art. 6:108 lid $1 \mathrm{BW}$ : ten belope van betalingen uit dienstbetrekking, bijstand in geld of natura en levensverzekeringen worden de nabestaanden geacht van het wegvallen van de voorziening voor het levensonderhoud geen schade te ondervinden. Daarbij stelde ik dat in mijn visie wèl noodzakelijk is dat de betaling is bedoeld als voorziening voor juist dàt deel van het levensonderhoud waarin door de kostwinner werd voorzien. $\mathrm{Bij}$ een vordering wegens het verlies van de bijdrage van de kostwinner die betrekking had op het huishoudbudget en niet de woonlasten mag het in beginsel geen rol spelen dat de nabestaande een uitkering uit hypothecaire levensverzekering geniet. De schadeveroorzaker is dan in zoverre nog wèl jegens de nabestaanden tot schadevergoeding gehouden.

In de tweede plaats zijn er betalingen van derden die ertoe strekken dat eenmaal ingetreden schade van de benadeelde wordt vergoed (paragraaf 3.3.5.2). Zulke betalingen dienen door voordeelstoerekening in mindering te komen op de vergoeding voor de desbetreffende schadeposten (art. 6:100 BW). Het ontbreekt de rechter in deze gevallen aan enige mate van beoordelingsvrijheid. Genoemd werden uitke-

194 Wel hebben indien het gaat om medische herstelkosten van de benadeelde, de betrokken derden in zijn plaats recht op schadevergoeding, zie art. 6:107 BW. 
ringen van particuliere ziektekostenverzekeraars, sociale verzekeraars, het Schadefonds Geweldsmisdrijven, de gemeente ingevolge de Wet voorzieningen gehandicapten en compensatieregelingen voor het loon of verlofuren die de werkgever de benadeelde biedt. Daarbij stelde ik dat dit regime (van absolute voordeelstoerekening) in mijn visie ook dient te gelden voor gefixeerde particuliere sommenuitkeringen mits ze strekken tot vergoeding van bepaalde schade, zoals arbeidsongeschiktheidsverzekeringen. Van uitkeringen uit vrijgevigheid, zoals giften van naasten, wordt aangenomen dat ze niet in mindering komen. Daarbij stelde ik dat voordeelstoerekening in mijn visie wèl in de rede ligt indien aannemelijk is dat de gift is bedoeld als vergoeding voor de schade (waarvoor de benadeelde schadevergoeding vordert), ${ }^{195}$ en niet als extraatje, los van de schade.

In de derde plaats zijn er betalingen van derden die in het geheel geen schadevergoedingskarakter hebben, zij het dat ze wel feitelijk ter beperking van de schade kunnen worden aangewend. Behoudens de vordering van art. 6:108 lid $1 \mathrm{BW}$ komen die in beginsel niet in mindering op de vordering tot schadevergoeding; de benadeelde mag ze daarmee cumuleren. Illustratief zijn de prijs uit de lotto, vrijblijvende giften, uitkeringen uit particuliere sommenverzekering die uitsluitend bedoeld zijn als 'spaarpotje' en extra door de werkgever betaalde verlofuren. Hetzelfde zou meen ik moeten gelden voor betalingen van derden die wèl een schadevergoedingskarakter hebben, maar die niet strekken tot vergoeding van juist de concrete schadepost waarvoor de benadeelde schadevergoeding vordert. In zoverre dienen ook die in beginsel niet in mindering te komen op het bedrag van de schadevergoeding. Dit wordt vrij algemeen aangenomen en zal hierna aan de orde komen. ${ }^{196}$ Ook voor subrogatie is in deze gevallen geen plaats. ${ }^{197}$ Slechts bij bijzondere omstandigheden kan onder verwijzing naar de redelijkheidsmaatstaf van art. 6:100 BW toch voordeelstoerekening plaatsvinden, ${ }^{198}$ of kan de schadevergoeding worden gematigd (art. 6:109 BW). Sprake moet dan zijn van aanvullende omstandigheden, het enkele gegeven van de uitkering is niet voldoende (bijvoorbeeld de omstandigheid dat de betaling het bedrag van de schade aanmerkelijk overtreft).

De drie genoemde regimes kunnen worden geduid als 'hard and fast rules', waarvan behoudens bijzondere omstandigheden geen afwijking mogelijk is. Met name voor de eerste twee genoemde categorieën van deelregels kan over de wenselijkheid daarvan ook anders worden gedacht: in de literatuur klinkt ook de opvatting dat juist op het terrein van voordeelstoerekening de redelijkheid bepalend dient te

In die zin ook Bloembergen (1965), nr. 240 en 241 . Anders Bolt (1989a), p. 243 waar (uiteindelijk) vanwege de sterk persoonlijke sfeer anders wordt geconcludeerd (geen voordeelstoerekening, ook niet bij giften die als schadevergoeding zijn bedoeld).

198 Vgl. HR 16 september. NJ 1996, 329 nt. CJHB (Nationale Nederianden/Woudsend I) en HR 1 februari 2002, NJ 2002, 122 (Van Straaren/Brandts), en daarover Engelhard (2002), p. 164 e.v. 
zijn. Voor een automatisme zou geen plaats zijn. ${ }^{199}$ Daar staat tegenover dat de praktijk om duidelijkheid vraagt. ${ }^{200}$ Harde deelregels kunnen bijdragen aan rechtszekerheid en efficiëntie. De genoemde regels kunnen dan worden geduid als gestandaardiseerde uitwerkingen van de redelijkheid: van absolute voordeelstoerekening is alleen sprake indien de te verrekenen betaling als 'schadevergoeding' kan worden aangemerkt, daarbuiten zijn voor voordeelstoerekening bijzondere omstandigheden vereist. Alleen dan kunnen derden geacht worden de vergoedingsfunctie van het aansprakelijkheidsrecht voor de benadeelde voldoende te ondervangen. Zo werd het bij de invoering van de WAO ook verwoord door toenmalig minister Veldkamp:

'Voor een deel wordt de schadevergoeding, waarop de verzekerde bij het ontbreken van aanspraken krachtens de sociale verzekeringswetgeving ex de artikelen 1406 en 1407 BW aanspraak zou hebben, venvangen door een vordering van de gedupeerde werknemer op het uitvoeringsorgaan van de sociale verzekering. 201

\subsubsection{Ratio en rechtspolitieke betekenis}

Maar waarom is dit eigenlijk zo, waarom moet de benadeelde kiezen? Waarom behoudt hij niet gewoon zijn recht op schadevergoeding naast de vergoeding van zijn verzekeraar? De rechtsliteratuur biedt op dit punt weinig duidelijkheid. Het lijkt vanzelfsprekend dat de benadeelde voor uitkeringen uit ziektekostenverzekering of Ziekenfondswet zijn recht op schadevergoeding verliest. ${ }^{202}$ De juridisch verhaalbare schade van de benadeelde wordt in zoverre rechtens geacht te zijn 'goedgemaakt' en de schadeveroorzaker is daarvoor dan jegens hem bevrijd. Vermogensnadeel waar concreet vermogensvoordeel tegenover staat moet niet (tevens) tot schadevergoeding kunnen leiden. De regel is dan tevens de verklaring; schade kàn feitelijk immers slechts eenmaal worden vergoed. ${ }^{203}$

Ook de Hoge Raad oordeelde meer recent dat de strekking van de regeling van voordeelstoerekening is, 'dat aan de benadeelde het feitelijke nadeel dat voor hem uit een tot schadevergoeding verplichtende gebeurtenis voortvloeit, wordt ver-

199 De woorden van Van Wassenaer van Catwijck, instemmend aangehaald bij Kottenhagen-Edzes (1993), p. 316. In gelijke zin Bouman \& Tilanus-Van Wassenaer (1998).

200 Bolt $(1989 a)$, p. 3.

201 TK 1962-63, 7171, nr. 3 (MvT), p. 21 (cursief toegevoegd, EE)

202 Zo Sinninghe Damsté (1999), p. 11: 'De benadeelde heeft recht op vergoeding van zijn schade. Maar een dubbele vergoeding is natuurlijk niet aan de orde.' Hartlief \& Van Maanen (1991), p. 293 ('bet slachtoffer heeft natuurlijk slechts...') en Van Boeschoten (1950), p. 614: 'Het behoeft nauwelijks betoog dat het doel van art. 284 (WvK) niet is bevoordeling van de verzekerde te voorkomen - deze zou ook zonder deze wetsbepaling van de aansprakelijke niet vergoeding van hem reeds door zlin assuradeur vengoede schade kunnen vorderen' (cursief toegevoegd. EE).

203 Hoezeer zij aan het redelijkheidsgevoel appelleert illustreert dunkt mij het Amerikaanse recht, waar het bewijs van vergoedingen naast de gevorderde schadevergoeding als prejudicial wordt aangemerkt omdat die voor de benadeelde een nadelige invloed zouden (kunnen) hebben op de jury, zie daarover Bolt (1992), p. 211. 
goed. ${ }^{204}$ Vanzelfsprekend is dat echter niet. De visie dat de ziektekostenverzekeraar schade wegneemt of goedmaakt sluit aan bij de concrete vermogenstoestand van de benadeelde. Maar dat geldt óók als de verzekeraar de benadeelde in de vorm van een vaste som uitkeert, los van de vraag naar de precieze schade. Toch laten uitkeringen uit sommenverzekering het schadeoordeel en het recht op schadevergoeding van de benadeelde onverlet. De reden voor het maken van het onderscheid is dat met de ongevallenverzekering niet wordt beoogd om schade te vergoeden; dat is een zuiver normatief criterium. De strekking van de betaling van de derde is beslissend. Dat lijkt me een belangrijk verschil met het indemniteitsbeginsel van het schadeverzekeringsrecht. De verzekerde mag volgens dat beginsel door de verzekeringsuitkering niet in een duidelijk voordeliger positie geraken dan die waarin hij zonder het schadevoorval zou hebben verkeerd. ${ }^{205}$ Veelal wordt op de parallel tussen beide regels gewezen, ${ }^{206}$ maar een belangrijk verschil is dat de strekking van de betaling voor het indemniteitsbeginsel niet noodzakelijk van belang is. Sprake is van een overwegend feitelijk of economisch criterium. Het beginsel van het aansprakelijkheidsrecht is normatief. Toch stelt Dorhout Mees:

'Meent men nu werkelijk dat de verzekerde die beide vorderingen (één uit onrechtmatige daad en én tegen zijn schadeverzekeraar, EE) geldend zou kunnen maken zonder dat hem tegen geworpen zou kunnen worden dat één schade hem niet meer dan éénmaal vergoed kan worden? ${ }^{207}$

De retoriek van die vraag, de veronderstelde vanzelfsprekendheid van de regel dat de benadeelde één van zijn vorderingen moet inleveren, zal nauw verweven zijn met onze rechtscultuur, met de heersende opvattingen over de plaats en functie van het aansprakelijkheidsrecht als vergoedingssysteem en de schadepraktijk. ${ }^{208}$ Daarnaast is er een 'harde', rechtseconomische component. Het inroepen van het aansprakelijkheidsrecht moet niet het vooruitzicht bieden van vermogensvermeerdering. ${ }^{209}$ Dat zou een aanzuigende werking hebben en het fingeren van schade bevorderen, een bekend probleem van rechtsstelsels waarin het aansprakelijkheids-

HR I februari 2002, NJ 2002, 122 (Van Straaten/Brandts); daarover Engelhard (2002), p. 164.

En overigens het criterium ook anders, namelijk dar de verzekerde door het schadevoorval niet in een 'duidelijk voordeliger vermogenspositie' mag geraken (art. 7.17.2.24, eerste volzin BW). Zie over dat beginsel Kremer (1988), p. 17 e.v.

Die parallel is getrokken door Van Wassenaer van Catwijck, zie instemmend Kottenhagen-Edzes (1993), p. 313; Dommering-Van Rongen (1993), p. 244; Barendrecht \& Storme (1995), p. 20. Allen wijzen wel op een ànder verschil met het indemniteitsbeginsel: betalingen van derden worden alleen in aanmerking genomen als de verzekerde anders in een 'duidelijk voordeliger positie' komt te verkeren, zie HR 3 maart 1972, NJ 1972, $339 \mathrm{nt}$. HB (La Confiance resp. L'Union/Maring) en art. 7.17.2.24 BW.

Dorhout Mees (1935), p. 319.

Vgl. bijvoorbeeld Bolt (1992), p. 219, die op basis van haar onderzoek naar het Amerikaanse recht concludeen dat dit met betrekking tot de regeling voor samenlopende vergoedingen (op het moment van schrijven) 'fundamenteel anders is'. Zij zoekt de verklaring van die verschillen tevens in factoren buiten het materièle recht. zoals de jury-rechtspraak en 'contingent fees'

Dorhout Mees (1935), p. 319: 'In het bijzonder gaat deze regel (dat de schade in het aansprakelijkheidsrecht niet meer dan eenmaal mag worden vergoed, EE) op wanneer een der gronden voor vergoeding verzekering is, waarvan immers uit en te na betoogd is ( $m$ ) dat zij nooit tot bevoordeeling van den verzekerde mag leiden." 
recht wèl mede tot vergoeding kan leiden van gecompenseerde schade. Zo is de benadeelde volgens de Amerikaanse collateral source rule in staat om bepaalde benefits tot op zekere hoogte met zijn schadevordering te cumuleren. De schadeveroorzaker blijft dan desondanks volledig aansprakelijk. ${ }^{210}$ De gedachte is deze, dat de schadeveroorzaker de nadelige consequenties van het schadevoorval behoort te dragen. ${ }^{21 t}$ Daarvoor is het regres dan niet nodig. Maar:

'Its sting lies in the corollary that the plaintiff may ordinarily keep both the damages as well as the collateral benefit and thus tum his plight into a bonanza. ${ }^{212}$

Om die reden is voor een aantal gevallen in het Amerikaanse recht een regresrecht ingevoerd op basis van subrogatie. De verzekeraar van de benadeelde wordt dan gesubrogeerd in diens vordering jegens de schadeveroorzaker. Door de rechtsovergang kan dubbele schadevergoeding bij de benadeelde worden voorkomen zonder dat de schadeveroorzaker de dans ontspringt. ${ }^{213}$

Ook in het Nederlandse recht is regres het sequeel van het bevrijd zijn van de schadeveroorzaker in diens verhouding tot de benadeelde. Maar zoals werd gezien is het juridische vertrekpunt anders: het risico van dubbele schadevergoeding van de benadeelde wordt ook zonder het regres al tegengegaan, door de regels van voordeelstoerekening. Die zorgen ervoor dat de schadeveroorzaker door schadeuitkeringen van derden - met of zonder subrogatie - van zijn vergoedingsplicht jegens de benadeelde is bevrijd. Anders dan in het Amerikaanse recht is het regres (ook het recht van subrogatie) dus niet nodig om dubbele vergoeding van de benadeelde te voorkomen. Het is in het huidige wettelijke kader eigenlijk alleen nodig voor het rechtsgevolg in de verhouding tussen regresnemer en schadeveroorzaker (of diens WA-verzekeraar). ${ }^{214}$ Het regres moet, volgens de heersende opvatting, ${ }^{215}$ voorkomen dat de schadeveroorzaker definitief van zijn draagplicht met betrekking tot de schade is bevrijd.

Fleming (1966b), p. 1478; Bolt (1992), p. 201 e.v:; bij M. van Dam (2001), p. 394-395 wordt vermeld dat Amerikaanse (verkeers?)slachtoffers gemiddeld voor $18 \%$ van het bedrag van de schadevergoeding die ze van de schadeveroorzaker of diens WA-verzekeraar ontvangen tevens een vergoeding uit andere hoofde tot hun beschikking hebben.

211 En overigens dat de verzekeringsuitkeringen, hoewel ze daarvoor niet zijn bedoeld, compensatie bieden voor het (substantiéle) deel van de toegewezen schadevergoeding dat de benadeelde verliest aan het honorarium van zijn raadsman, aldus Schwartz (1990), p. 351 en Bolt (1992), p. 204.

212 Fleming $(1966 b)$, p. 1478.

213 Fleming (1970), p. 18 noemt het dan ook de belangrijkste functie van regres dat wordt voorkornen dat de benadeelde meer ontvangt dan zijn werkelijke schade en een 'byproduct' dat daarbij de schade wordt verplaatst naar de schadeveroorzaker. M. van Dam (2001), p. 395 vermeldt dat regesnerners in het Amerikaanse recht vanwege de hoge transactiekosten zelfs 'nauwelijks' van het regrestecht gebruikmaken.

214 In die zin ook Inv. 6, p. 1294, vgl. anders voor Belgisch recht Fredericq (1971), p. 20: 'Telkens moet worden uitgemaakt of het slachtoffer de verzekeringsvergoeding mocht cumuleren met de vergoeding uit het gemeen recht, met andere woorden of de verzekeraar al dan niet in de rechten van zijn verzekerde was gesubrogeerd'. Zie paragraf 6.3.1. 


\subsection{Bijzondere perikelen in verband met het regres}

\subsection{Het risico van dubbele betaling}

De onderhavige regresrechten zijn, zoals gezegd, het sequeel van regels van het schadevergoedingsrecht die de schadeveroorzaker bij een toevallige samenloop van prestaties van zijn vergoedingsplicht jegens de benadeelde bevrijden. Het bevrijd zijn van de schadeveroorzaker is de aanleiding voor de wettelijke regresrechten. Die leggen de draagplicht met betrekking tot de schade alsnog bij hem. De vraag naar de wenselijkheid van voordeelstoerekening gaat dan ook vooraf aan de vraag naar het regres, het werkt niet omgekeerd. ${ }^{216}$ Als eenmaal wordt gekozen voor een systeem van regres, dan ontstaat daarmee een noodzakelijke cirkel die, wil het regresrecht niet tot onredelijke resultaten leiden, niet mag worden doorbroken: noodzakelijk is dat in al die gevallen waarin regresrechten gelden de schadeveroorzaker van zijn verplichting tot schadevergoeding jegens de benadeelde wordt bevrijd. Zonder voordeelstoerekening is de schadeveroorzaker immers dubbel betaling verschuldigd.

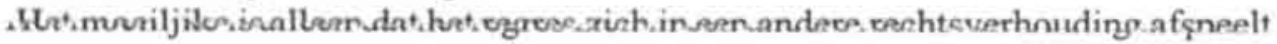
dan de verhouding waarbinnen de schadeveroorzaker van zijn vergoedingsplicht moet worden bevrijd. Bij subrogatie is dat uiteraard het minst problematisch. ${ }^{217}$ Het reeds aan de benadeelde betaalde kan hij dan aan de gesubrogeerde tegenwerpen en vice versa. Daarbij kunnen echter problemen ontstaan, met name indien het moment van subrogatie nog in de toekomst ligt of als over het schade- of sommenkarakter van de verzekering onduidelijkheid bestaat. Als bijvoorbeeld de arbeidsongeschiktheidsverzekeraar na het betalen van de verzekeringsuitkering regres zoekt en de verzekering in die procedure als een schadeverzekering wordt aangemerkt, dan bestaat het risico dat de benadeelde mogelijk zonder medeweten zijn vordering verliest. Reëler is het risico van dubbele betaling in het algemeen bij de zelfstandige regresrechten (sociale verzekeraars, de ambtenareninstanties of particuliere werkgevers in het kader van art. 6:107a BW). De schadeveroorzaker of diens WA-verzekeraar kan zich geconfronteerd zien met een regresvordering terwijl hij aan de benadeelde voor diezelfde schade al schadevergoeding betaalde, zonder dat hij deze onverschuldigde betaling aan de regresnemer kan tegenwerpen. Als gevolg van het zelfstandige karakter van het regresrecht laten betalingen in de verhouding tussen de schadeveroorzaker (of diens WA-verzekeraar) en de benadeelde zelf, het regres onverlet. Om dubbele betaling te voorkomen stellen de bepalingen van verplichte voordeelstoerekening in de aanspraakverlenende wet

Niet uitgesloten is echter dat de Hoge Raad bij zijn afwijzing van voordeelstoerckening voor uitkeringen uit sommenverzekering, inzake HR 28 november 1969, NJ 1970, 172 nt. GJS (IBC/Denkx), de omgekeerde benadering heeft gevolgd. Dat is de stelling van Bolt (1989a), p. 41, en in aansluiting daarop noemt ook zij de vraag naar regres juist prealabel voor kwesties van voordeelstoerckening.

Asser-Hartkamp 4-I. nr. 446. 
zeker, dat de rechter bij het vaststellen van de schadevergoeding rekening moet houden met de aanspraak van de benadeelde op een uitkering (of loon). ${ }^{218}$ Maar als ten onrechte geen voordeelstoerekening plaatsvindt, dan doet dit geen afbreuk aan het regresrecht. Het vorderingsrecht van de regresnemer staat, dat is het zelfstandige karakter, los van het vorderingsrecht van de benadeelde.

Het kan zijn dat de benadeelde, bewust of uit onwetendheid, zijn aanspraken op de schadeveroorzaker geldend maakt terwijl hij zonder medeweten van de schadeveroorzaker tevens, door hetzelfde schadevoorval, een niet verrekende aanspraak heeft op een sociale verzekeringsuitkering. In dat geval kan de schadeveroorzaker (of diens WA-verzekeraar) van de benadeelde ten belope van het onverschuldigd betaalde bedrag terugbetaling vorderen krachtens art. 6:203 BW. Wat de schadeveroorzaker niet kan is in een daarop volgende regresprocedure van de uitkerende sociale verzekeraar betaling weigeren op de grond dat reeds betaald is. ${ }^{219}$

De bepalingen van verplichte voordeelstoerekening bevorderen dat onnodige of dubbele betaling wordt voorkomen. Dat het bedrag van de aanspraak wordt verrekend, en niet pas het uiteindelijk betaalde bedrag, maakt de bij het regres betrokkenen bovendien minder afhankelijk van traagheid van de betrokken uitkeringsinstantie. Wèl loopt de benadeelde hierdoor het risico tijdelijk te zijn overgeleverd aan de administratie en de betrouwbaarheid van uitkeringsorgaan en/of werkgever. Zo lijkt niet ondenkbaar dat reeds vaststaat dat de benadeelde aanspraak maakt op loon of een uitkering, maar dat de verstrekker daarvan feitelijk nog niet tot betaling daarvan is overgegaan en onzeker is dat dit binnen onafzienbare tijd ook zal gebeuren. In dat geval kan de benadeelde proberen om de schadeveroorzaker (of diens WA-verzekeraar) bereid te vinden het bedrag van de schadevergoeding onverminderd te betalen, eventueel bij wijze van voorschot. Dat zal echter gelet op diens onverminderde blootstelling aan regres niet gemakkelijk lukken. Zou de werkgever of het uitkeringsorgaan dan immers op later moment alsnog tot betaling overgaan, dan loopt de schadeveroorzaker het risico om bij een regresactie voor dezelfde schade opnieuw te worden aangesproken. In theorie kan met cessieconstructies worden gewerkt (de benadeelde cedeert zijn loonaanspraak), ${ }^{220}$ maar die zullen alleen uitkomst bieden als voldoende zeker is dat het ook tot betaling zal komen.

\subsubsection{Hoe absoluut is 'verplichte voordeelstoerekening'?}

Voordeelstoerekening van de enkele aanspraak op een sociale verzekeringsuitkering of loon roept ook in ander opzicht vragen op. Wat geldt indien definitief vaststaat

Zie onder meer art. 89 WAO, art. 52 Ziektewet, art. 83 a Ziekenfondswet, ant. 13 Algemene wet bijzondere ziektekosten en art. 60 Algemene nabestaandenwet; en daarover voorts Schadevergoeding, art. 107a (Bolt). aant. 4. Voor rechtspositionele uitkeringen aan ambtenaren geldt, naar ik aanneem hetzelfde, maar geeft de Verhaalswet ongevallen ambtenaren hiervoor geen bijzondere regeling.

Köster (1971), p. 108. 
dat de aanspraak op loondoorbetaling of uit sociale verzekering niet daadwerkelijk tot betaling zal komen? Of de benadeelde zijn wettelijke aanspraak ook daadwerkelijk zal benutten bepaalt hij immers veelal zelf. ${ }^{22 !}$ WAO-uitkeringen zullen (tijdig) bij het Uitvoeringsinstituut Werknemersverzekeringen moeten worden aangevraagd, en voor het geldend maken van de aanspraken krachtens de Ziekenfondswet is aanmelding nodig en een verklaring van de werkgever. Veelal zal de benadeelde zich wel melden, aangezien hij daar zelf belang bij heeft. Die weg lijkt goedkoper en sneller dan een vordering tegen de schadeveroorzaker. ${ }^{222}$ Maar wat geldt als hij dit nalaat (en zich dus ondanks de wettelijke aanspraken op een uitkering tot de schadeveroorzaker wendt en schadevergoeding vordert)?

In het arrest Nationale Nederlanden/Woudsend I werd de Hoge Raad in dit verband om een oordeel gevraagd. ${ }^{223}$ Een vakantiewerker op Texel had schade opgelopen van een aanrijding waarvoor zijn werkgever jegens hem aansprakelijk was. De ziektekostenverzekeraar van zijn vader nam de schade voor zijn rekening. In de daarop volgende regresprocedure van de (gesubrogeerde) verzekeraar weigerde de WAM-verzekeraar van de werkgever betaling: de jongen had als vakantiewerker ook een aanspraak krachtens de Ziekenfondswet, en dus zou verplichte voordeelstoerekening moeten plaatsvinden ( $a r t .83 a \mathrm{ZFW}$, tezamen gelezen met art. 6:100 BW). De ziekenfondsaanspraak zou dan dus in mindering komen op de vordering waarin de ziektekostenverzekeraar was gesubrogeerd. ${ }^{224}$ Dat de jongen van die aanspraak helemaal niet op de hoogte was geweest, zich in elk geval niet bij het fonds had aangemeld om die aanspraak geldend te maken en het ziekenfonds in werkelijkheid niets had uitgekeerd was volgens de WAM-verzekeraar geen beletsel. Naar het oordeel van de Hoge Raad echter strekte de regeling van verplichte voordeelstoerekening ertoe:

'(...) dat de voordelen die de verzekerde aan zijn aanspraken krachtens de in die wet bedoelde verzekering ontleent, in rekening worden gebracht bij de vaststelling van de schadevergoeding waarvoor naar burgerlijk recht jegens de verzekerde aansprakelijkheid bestaat. Het strookt niet met deze strekking dat mede aanspraken in rekening zouden worden gebracht, die niet tot verstrekkingen of vergoedingen ingevolge de verplichte verzekering hebben geleid, behoudens voor zover dit in rekening brengen - in de bewoordingen van art. 6:100 BW - niettemin redelijk is. ${ }^{225}$

221 Al lijkt best verdedigbaar dat het weigeren van loonbetalingen bij arbeidsongeschiktheid, die aan de daarvoor geldende voorwaarden voldoen (vgl. art. 7:621 BW), crediteursverzuim of zelfs wanprestatie oplever (aangezien de loondoorbetaling een wezenlijk element is van de arbeidsovereenkomst).

$222 \mathrm{Vgl}$. de Conclusie van A-G Koopmans (nr. 10) bij HR I6 september 1994, NJ 1996. $329 \mathrm{nt}$. CJHB (Nationale Nederlanden/Woudsend $n$ ).

Zie HR 16 september 1994, NJ1996, $329 \mathrm{nt}$. CJHB (Nationale Nederianden/Woudsend $/$ ). Als a priori vaststaat dat definitief niets uitgekeerd zal worden, vindt geen toerekening plaats, aldus Köster preadvies (1971), p. 108. Hoewel het fonds feitelijk niets had uitgekeerd, de benadeelde feitelijk niets had ontvangen en de (niettemin in zijn vorderingsrecht beperkte) gesubrogeerde ziektekostenverzekeraar op het moment dat zij de uitkering deed van niets wist. HR 16 september 1994, NJ 1996, 329 nt. CJHB (Nationale Nederlanden/Woudsend I). 
Anders gezegd, de verplichte voordeelstoerekening moet geen 'blinde' voordeelstoerekening worden. Het uitgangspunt is dat niet genoten uitkeringen niet voor voordeelstoerekening in aanmerking komen. Dat is anders indien de omstandigheden van het geval voordeelstoerekening 'niettemin redelijk' maken, in de zin van art. 6:100 BW. In het meer recente arrest inzake Van Straaten/Brandts kwam de Hoge Raad tot een vergelijkbaar oordeel. Aanspraken die niet daadwerkelijk tot verstrekkingen hebben geleid dienen volgens de raad niet te worden toegerekend. Ook nu met de restrictie 'behoudens voorzover dat niettemin redelijk is'. ${ }^{226}$ Dat sluit aan bij de genoemde ratio van de voordeelstoerekening: het voorkomen dat de benadeelde door het inroepen van het aansprakelijkheidsrecht in een financieel gunstiger positie komt te verkeren dan waarin hij zonder schadevoorval zou hebben verkeerd. ${ }^{227}$

De Hoge Raad laat echter de mogelijkheid open om het bedrag van de - niet genoten - aanspraken op het recht op schadevergoeding van de benadeelde in mindering te laten komen. Kàn dat redelijk zijn? Brunner wijst in zijn NJ-noot inzake Nationale Nederlanden/Woudsend I op het geval waarin de benadeelde 'zonder goede reden' nalaat zich bij het ziekenfonds aan te melden. In de procedure zelf was die reden er overigens wèl: de werkgever had ten opzichte van de benadeelde ontkend dat sprake was van een dienstbetrekking, hetgeen impliceerde dat de benadeelde geen aanspraak maakte op een uitkering krachtens de sociale werknemersverzekeringen. De zaak laat goed zien welke consequenties die simpele nalatigheid kan hebben: de WAM-verzekeraar zag zich daardoor geconfronteerd met een regresvordering van de ziektekostenverzekeraar in plaats van met een regresvordering van het ziekenfonds. Dat was nadelig, omdat alleen het regres van het ziekenfonds beperkt werd door het zogenaamde werkgeversverweer (art. 83c ZFW) terwijl de ziektekostenverzekeraar onbeperkt verhaal kon nemen. Verder noemt Brunner het geval waarin de benadeelde zich wel aanmeldt, maar zijn kosten vervolgens feitelijk niet declareert. Ook Van Boom wijst op het geval dat het eigenlijk voor de benadeelde niet geoorloofd was om de sociale uitkering onbenut te laten. ${ }^{228}$ Daarvan kan volgens hem ook sprake zijn als de benadeelde de aanvraagtermijnen heeft veronachtzaamd of anderszins is tekortgeschoten in formaliteiten die de aanspraakverlenende wet oplegt. ${ }^{229}$

Een zekere medewerking aan een vlotte afhandeling en inachtneming van de belangen van schadeveroorzaker en regresnemer mogen uiteraard, analoog aan de schadebeperkingsplicht van de benadeelde (art. 6:2 BW), wel verlangd worden. Bij het toekennen van rechtsgevolg daaraan in de vorm van voordeelstoerekening past in mijn visie echter terughoudendheid, mede gelet op het 'uitzondering-op-uitzonde-

HR I februari 2002, NJ 2002, 122 (Van Straaten/Brandts), zie daarover Engelhard (2002), p. 164.

Zie paragraaf 3.3.7.

Als de benadeelde bij de administratie bekend was zal het uitkeringsorgaan, ondanks zijn uitdrukkelijke wens om zijn aanspraken onbenut te laten, toch tot uitkering (moeten) overgaan.

Van Boom (2000a), p. 28 
ring' karakter (zonder dat het feitelijk tot betaling komt, toch voordeelstoerekening). Vergissingen en een zekere nalatigheid bij het invullen van papieren en declareren moeten in dit verband, ook als ze verwijtbaar zijn (apathisch of frauduleus gedrag van de benadeelde), niet kunnen leiden tot het verlies van de vordering. Het lijkt erop dat ze gereserveerd wordt voor ernstige gevallen, waarbij wel wordt gedacht aan het door opgave van valse voorwendselen verloren hebben van een aanvankelijke aanspraak op uitkering. Maar zelfs dan betwijfel ik of voordeelstoerekening op zijn plaats is. Waar het om gaat is, welke betekenis moet - en: mag - worden toegekend aan de schending daarvan. De normale ratio voor voordeelstoerekening ontbreekt in deze gevallen, nu er geen risico is van dubbele vergoeding bij de benadeelde. Toerekening zou overigens in een geval als in de zaak Nationale Nederlanden/Woudsend I aan de orde was, slechts de gesubrogeerde ziektekostenverzekeraar treffen (zij het dat die eventueel sancties zou kunnen stellen jegens de benadeelde).

Zelf zou ik daarom eigenlijk meer zien in een andere oplossing: nimmer voordeelstoerekening bij niet genoten uitkeringen. De benadeelde dient van zulke risico's niet de kosten te dragen; hij heeft 'zijn portie' al gekregen in de zin dat hij geen uitkering meer ontvangt (of meer gelijkend op het onderhavige geval, hij uit andere hoofde een schadeuitkering geniet en om die reden - in casu werd de ziektekostenverzekeraar in zijn vordering tot schadevergoeding gesubrogeerd - zijn recht op schadevergoeding verliest). Om hem dan in verwijtbare gevallen ook nog via de redelijkheidsmaatstaf van art. 6:100 BW (bij wijze van uitzondering-op-uitzondering) zijn recht op schadevergoeding te laten verliezen lijkt een stap teveel: de benadeelde zou door zijn eigen schuld tussen wal en schip vallen. Sterker nog, het aansprakelijkheidsrecht behoort in mijn visie met zijn schuld geen enkele bemoeienis te hebben; de vermogenstoestand van de benadeelde kan alleen van invloed zijn op zijn vordering tot schadevergoeding jegens de schadeveroorzaker indien hij daardoor dubbel zou worden vergoed. Dit sluit bovendien beter aan bij het regime van art. $284 \mathrm{WvK} / \mathrm{art}$. 7.17.2.25 BW: ook dan verliest de benadeelde zijn recht op schadevergoeding slechts voorzover de uitkering feitelijk werd genoten (alleen in zoverre is subrogatie mogelijk). ${ }^{230} \mathrm{Om}$ te voorkomen dat ook de regresnemer recht heeft op verhaal en de schadeveroorzaker dus meer dan eens gehouden is tot vergoeding van dezelfde schade, zal in de (eventuele) regresprocedure toch moeten worden nagegaan of de uitkering daadwerkelijk is of zal worden verstrekt. Afwijzing van de regresvordering past, indien blijkt dat de betrokken uitkering niet daadwerkelijk aan de benadeelde zal en behoeft te worden verstrekt. De schadeveroorzaker doet er dan wel goed aan niet tè snel te schikken indien er twijfel mogelijk is over de vraag of de uitkering feitelijk wel zal worden verstrekt. De regresnemende uitkeringsinstantie kan daartoe dunkt me om een afschrift van het toekenningsbesluit worden gevraagd of om een voorlopig besluit tot toekenning. 
Kan zij dit niet overleggen (terwijl men kennelijk wèl over voldoende informatie beschikt voor een regresprocedure), dan zal ofwel de regresvordering moeten worden afgewezen (indien uit de omstandigheden blijkt dat men definitief geen uitkering verschuldigd is) of zal een voorlopige of een voorwaardelijke toewijzing (vgl. art. 6:105 BW) kunnen volgen. Hetzelfde heeft te gelden als zonder de onheuse informatie van de benadeelde nooit aanspraak op een uitkering zou hebben bestaan (het ontbreken van het Nederlanderschap indien dat een voorwaarde is voor het recht op de bewuste uitkering). Dan zal eveneens sprake zijn van voordeelstoerekening tenzij de aanspraak wegens de fraude uiteindelijk niet tot betaling komt, en zal de regresvordering al dan niet onder de voorwaarde dat de uitkering ook daadwerkelijk (zij het ten onrechte) wordt verstrekt, moeten worden toegewezen. $^{231}$

\subsubsection{Informatiegebrek}

Ook kan het gebeuren dat voordeelstoerekening ten onrechte niet plaatsvindt omdat de schadeveroorzaker niet precies weet in hoeverre de benadeelde tevens aanspraak maakt op andere vergoedingen. Dat vereist immers kennis van de persoonlijke omstandigheden van de benadeelde zoals diens precieze werkzaamheden, nationaliteit of graad van arbeidsongeschiktheid. De benadeelde kan de schadeveroorzaker daarin ook manipuleren. ${ }^{232}$ Als de schadeveroorzaker dan onverschuldigd aan de benadeelde betaalt, kan hij dit - door het zelfstandige karakter van het regresrecht - niet ook tegenwerpen aan de regresnemer

Dit geval had zich voorgedaan in de zaak Rijksverzekeringsbank/Tolenaars uit $1935 .{ }^{233}$ De benadeelde had dubbele vergoeding ontvangen door zich eerst tot de schadeveroorzaker te wenden en daarna pas tot de sociale verzekeraar (risicodrager in de zin van de Ongevallenwet 1921). De sociale verzekeraar sprak daarop eveneens de schadeveroorzaker aan. Dat was volgens de Hoge Raad terecht, gelet op het zelfstandige karakter van het regresrecht. Het gegeven dat de schadeveroorzaker voor dezelfde schadeposten al schadevergoeding aan de benadeelde zelf had betaald deed daaraan geen afbreuk. Dat sloot aan bij Meijers' eerdere $N J$-noot bij het arrest inzake Fatum/Ruhaak. ${ }^{234}$ De annotator had enig verband tussen de vordering van de benadeelde en de daarop betrekking hebbende voordeelstoerekening en (anderzijds) het slagen van de regresvordering nadrukkelijk van de hand gewezen.

231 Zie over dit laatste nader, paragraf 8.5 .

232 Van Boom (1995), p. 864 wijst op het geval dat de benadeelde zich als zelfstandige voordoet en de schadeveroorzaker of diens WA-verzekeraar daardoor voorbij ziet aan zijn aanspraken uit sociale verzekering. p. 26-27.

234 HR 5 december 1929, NU 1930, $1055 \mathrm{nt}$. EMM (Ruhaak/Fatum). 
De schadeveroorzaker rest dan in beginsel slechts een vordering uit onverschuldigde betaling jegens de benadeelde (voorzover dat althans in het licht van hun eerdere schikking nog mogelijk is). Van Boom wijst erop dat de schadeveroorzaker in uitzonderlijke gevallen jegens de regresnemer een beroep zal kunnen doen op art. 6:34 BW. Hij werpt daartoe het geval op dat de schadeveroorzaker op redelijke grond meende dat de benadeelde zelfstandige was en niet een werknemer in de zin van art. 6:107a BW. ${ }^{235}$ Verder noemt hij het geval van een onverwachte wending in de (sociaalrechtelijke) rechtspraak die tot gevolg heeft dat de benadeelde alsnog aanspraak krijgt op een sociale verzekeringsuitkering. ${ }^{236}$ Ook de WA-verzekeraar zal daarop aanspraak kunnen maken.

\subsubsection{Onderling wisselende schadeposten}

De afstemming tussen de vraag naar voordeelstoerekening en het regres kan ten slotte nog in ander opzicht problematisch zijn. Lange tijd was het zo dat aanspraken uit sociale verzekering volgens de Hoge Raad in mindering moesten komen op de vergoeding voor de som van de schadeposten, het volle bedrag van de schadevergoeding dus. Dit hetekende dat ze zo.nodig nok in mindering mnesten.knmen op andere schadeposten van de benadeelde, zoals immateriële schade. ${ }^{237}$ De laatste jaren gaan stemmen op voor een 'postenstelsel' bij voordeelstoerekening: ${ }^{238}$ inkomensvoordeel komt dan uitsluitend in mindering op de vergoeding voor de inkomensschade en niet óók op smartengeld, immaterieel voordeel uitsluitend op smartengeld enzovoort. Die ontwikkeling kan op steun rekenen in de rechtspraak. In 1976 oordeelde de Hoge Raad uitdrukkelijk dat het ten aanzien van alle schadeposten ter beoordeling van de rechter staat in hoeverre het redelijk is het voordeel daarop in mindering te laten komen. ${ }^{239}$ Maar de rechter is vrij om de verzekeringsuitkering ook in mindering te laten komen op de vordering die de benadeelde heeft met betrekking tot andere schadepost(en) dan die waarvoor de uitkering is bedoeld. De Hoge Raad wijst op de grote vrijheid die de rechter in het kader van art. 6:100 BW heeft.

Voor de eerdergenoemde gevallen waarin een absoluut regime van voordeelstoerekening geldt lijkt het postenstelsel zelfs het enige juiste. Dat de uitkering uit particuliere schadeverzekering of sociale verzekering bijvoorbeeld zonder meer op het bedrag van de schadevergoeding in mindering dienen te komen berusten op de

Van Boom (1995), p. 864 en dezelfde (2000a), p. 32.

Van Boom (2000a), p. 32.

Reeds in die zin HR 23 juli 1946, NJ 1946, 545 nt. DJV (Centrale Werkgevers/Fenverda). Ook Bloembergen wijst daarop in zijn $N J$-noot bij HR 17 december 1976, NJ 1977, 351 (Van den Endt/Bongaerts); zie voorts Bolt (1989a), nt. 62.

Bouman \& Tilanus-Van Wassenaer (1998), p. 68 e.v. gaan er vanuit dat dit al geldend recht is, maar baseren dit op een in mijn optiek te ruime uitleg van de relevante overwegingen van de Hoge Raad in HR 17 december 1976, NJ 1977, 351 nt. ARB (Van den Endt/Bongaerts). 
gedachte dat de benadeelde slechts eenmaal vergoeding behoort te ontvangen voor zijn schade. Dat veronderstelt een zekere gelijkenis tussen de vergoedingsplicht van de verzekeraar en die van de schadeveroorzaker, een toevallige samenloop van prestaties. Daarvan kan geen sprake zijn bij vergoedingsplichten die elk afzonderlijk betrekking hebben op uiteenlopende schadeposten.

\subsubsection{Postenstelsel bij voordeelstoerekening}

Het is vanuit diezelfde gedachte van samenloop dat de wettelijke regresregelingen de ene prestant een regresrecht geven jegens de andere. Toch heerst onduidelijkheid over de vraag of (ook) bij het regres een sommen- of een postenstelsel behoort te gelden. Specifiek voor uitkeringen uit schadeverzekeringen lijkt een postenstelsel bij voordeelstoerekening zonder meer beter aan te sluiten bij het regresregime. Schadeverzekeraars worden alleen gesubrogeerd in de vordering van de benadeelde met betrekking tot de schadeposten waarvoor uitkeringen zijn verstrekt. De benadeelde verliest dan ook alleen voor die schadeposten zijn vordering. ${ }^{240}$ Dat kan ook wel worden ingelezen in de woorden van art. $284 \mathrm{WvK} / \mathrm{art}$. 7.17.2.25 BW: de verzekeraar wordt gesubrogeerd in vorderingen die de verzekerde heeft ter zake van zijn schade voorzover de verzekeraar 'die' schade heeft vergoed. Daaronder dient dan schade te worden verstaan in de zin van art. 6:95 BW (concrete schadeposten zoals inkomensschade, herstelkosten en kosten van lijkbezorging). Hiervan uitgaande ligt het voor de hand om dan hetzelfde te laten gelden voor die gevallen waarin subrogatie (tijdelijk) niet mogelijk is en voordeelstoerekening plaatsvindt. Toekomstige uitkeringen uit ziektekostenverzekering dienen dus uitsluitend op de schadepost ziektekosten in mindering te komen, en niet te worden meegewogen bij de vaststelling van het smartengeld.

Het regresrecht van het Schadefonds Geweldsmisdrijven heeft betrekking op zowel de materièle als de immateriële schade van het fonds. Voorzover het materiële deel bestaat uit ziektekosten en inkomensschade wordt het fonds, net als particuliere verzekeraars, uitsluitend gesubrogeerd in de vordering die de benadeelde heeft voor die schadeposten (en naar rato van de omvang van de aansprakelijkheid voor die schadeposten). Voor het immateriele deel van de schade treedt het fonds in de vordering tot smartengeid, en heeft daarmee jegens de schadeveroorzaker een regresrecht voor niet méér dan de maximale omvang van diens aansprakelijkheid voor de immateriêle schade.

Het verschil tussen een sommen- en een postenstelsel bij voordeelstoerekening heeft belangrijke consequenties indien de te verrekenen uitkering groter is dan de schadepost waarop zij betrekking heeft, ${ }^{241}$ bijvoorbeeld bij eigen schuld. Eigen schuld leidt immers veelal niet tot vermindering van de aanspraken op een verzekeringsuitkering, en wèl tot vermindering van het recht op schadevergoeding van

Van Boom (2000a), p. 53, waar wordt gesproken van het congruentievereiste; zie ook Van Boom (1996), p. 99.

241 Bolt (1989a), p. 20. 
het aansprakelijkheidsrecht. In een postenstelsel kan de uitkering dan dus maar gedeeltelijk worden verrekend. De benadeelde komt meer schadevergoeding toe dan bij een sommenstelsel, aangezien het surplus van de uitkering niet ook in mindering kan worden gebracht op andere schadeposten waarvoor de schadeveroorzaker aansprakelijk is. Het lijkt dan onredelijk (en niet in overeenstemming met de vergoedingsfunctie van het aansprakelijkheidsrecht) uitkeringen óók in mindering te laten komen op de vergoeding voor schadeposten die niet corresponderen met de schade in het kader waarvan de betrokken sociale uitkering wordt gedaan, zoals smartengeld. ${ }^{242}$ Ook de bepalingen van verplichte voordeelstoerekening staan daaraan niet in de weg. Die zorgen er alleen voor dat reeds het bedrag van de aanspraak op de uitkering aan de benadeelde wordt toegerekend en niet, zoals bij de normale toepassing van art. $6: 100 \mathrm{BW}$, de feitelijk verstrekte bedragen. De rechter mist dus alleen beoordelingsvrijheid met betrekking tot de vraag of het verrekenen van de betreffende uitkering als zodanig redelijk is. ${ }^{243}$ Over de vraag of het bedrag van de aanspraak die (verplicht) moet worden toegerekend in mindering moet komen op het volledige bedrag van de schadevergoeding of alleen op de daarmee corresponderende schadeposten, zwijgen de bepalingen van

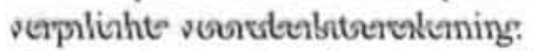

Uitgaande van de ratio van voordeelstoerekening in dit verband, het voorkomen dat de benadeelde dubbel wordt vergoed lijkt een postenstelsel het meest zuiver. ${ }^{244}$ Is het immers niet onredelijk om de benadeelde het recht op schadevergoeding te ontzeggen op de grond dat zijn schade (juridisch) al vergoed is door een verzekering die voor de betreffende schadeposten helemaal niet bedoeld was? Dat kan naar geldend recht bijvoorbeeld gebeuren indien de ziektekosten van de benadeelde volledig worden vergoed krachtens de Ziekenfondswet en de benadeelde de schadeveroorzaker daarom uitsluitend aanspreekt tot schadevergoeding voor de overige schade. Bij een sommenstelsel bestaat dan de mogelijkheid om de ziekenfondsgelden daarop in mindering te laten komen.

Janssen werd slachtoffer van een aanrijding waarvoor de firma Huys BV aansprakelijk is. Hij vordert van Huys BV schadevergoeding voor zijn ziektekosten, die echter door Janssens eigen nalatigheid (niet-naleving van schadebeperkingsplicht, een vorm van eigen schuld, art. 6:101 BW) aanmerkelijk hoger zijn dan ze hadden hoeven zijn. Los daarvan, maar naar aanleiding van hetzelfde schadevoorval, heeft hij ook recht op smartengeld van Huys BV. Als de ziektekosten in dit voorbeeld volledig worden vergoed ingevolge de Ziekenfondswet dient dat Janssens recht op smartengeld onverlet te laten.

In gelijke zin Bloembergen (1965), nr. 246 en Bolt (1989a), p. 183 e.v. (en zie haar verdere literatuurverwijzingen in nt. 62 op p. 20). Doch zie Hof Den Bosch 24 december 1974, NJ 1977, 214 (Derkx/IBC), waar het hof de WAO-uitkeringen zonder veel omhaal ook in mindering laat komen op het smartengeld. aangaf, op te maken dat de rechter nog wèl enige beoordelingsvrijheid heeft indien het risico van dubbele betaling door de schadeveroorzaker of dubbele vergoeding van de benadeelde, niet aan de orde is. sel wordt gepleit en daarover kritisch Asser-Hartkamp 4-I, nr. 445. 
Uiteraard is het van belang het regime van voordeelstoerekening parallel te laten lopen met het regresregime voor de zelfstandige regresrechten. Of dàn een sommenof postenstelselgeldt isniet helemaal duidelijk; volgenseen uitspraak van de Hoge Raad kan de regresnemer zich op de schadeveroorzaker verhalen tot ten hoogste de som van diens aansprakelijkheid voor alle schadeposten. ${ }^{245}$ Zo is voor het regresrecht van de WAO alleen nodig dat de regresnemer krachtens die wet kosten heeft gemaakt. Niet nodig is dat de benadeelde voor het bedrag van de WAOuitkering ook verhaalbare inkomensschade heeft (waarvoor de schadeveroorzaker volgens de regels van het aansprakelijkheidsrecht aansprakelijk is). Bepaald wordt slechts dat de schadeveroorzaker niet méér verschuldigd is dan hij aan de benadeelde verschuldigd zou zijn geweest (het civiele plafond). Vanuit mijn eerdere standpunt dat het regres het regime van voordeelstoerekening moet volgen, en niet omgekeerd, ligt naar huidige maatstaven een postenstelsel het meest voor de hand. Maar er zijn ook zelfstandige redenen om tevens voor het regres, zoals Van Boom meerdere malen heeft bepleit, ${ }^{246}$ een postenstelsel te laten gelden. In hoofdstuk $7 \mathrm{zal}$ hiernaar uitvoeriger aandacht uitgaan.

\subsection{Conclusie}

In dit hoofdstuk lag de nadruk op de achtergrond en directe aanleiding voor de onderhavige regresrechten: de toevallige samenloop van prestaties. De betalingen van particuliere of sociale verzekeraars of andere derden moeten strekken tot vergoeding van dezelfde schade als waarvoor de schadeveroorzaker aan hem schadevergoeding verschuldigd is. Als daarvan sprake is, dan werken die betalingen bevrijdend voor de schadeveroorzaker (of diens WA-verzekeraar). Dat volgt uit regels van het schadevergoedingsrecht die erop neerkomen dat de benadeelde voor (het deel van) de schade dat door anderen wordt vergoed zijn recht op schadevergoeding verliest. Schade kan en behoeft slechts eenmaal te worden vergoed. Het al gecompenseerd zijn van de schade doet geen afbreuk aan de aansprakelijkheid als zodanig. Het speelt pas een rol in de zogenaamde omvangfase (de fase van het vaststellen van de schadevergoeding): voor het deel van de schade van de benadeelde dat al door derden wordt vergoed is de schadeveroorzaker jegens hem bevrijd.

De technische gronden die afdeling 6.1.10 BW hiervoor geeft zijn verschillend. Voor rechtstreekse kosten die derden maken ten behoeve van de benadeelde, ${ }^{247}$ 
heeft de benadeelde geen schade in zijn eigen vermogen (en dus evenmin recht heeft op schadevergoeding) ${ }^{248}$ Voorbeelden daarvan zijn de loondoorbetaling door de werkgever bij arbeidsongeschiktheid, verstrekkingen in natura zoals het vervoer naar het ziekenhuis, rechtstreekse voorzieningen op de werkplek zoals therapeutische zorg, of extra vrije dagen (voorzover zonder deze betalingen schade zou zijn ontstaan waarvoor de schadeveroorzaker aansprakelijk zou zijn geweest). Betalingen daarentegen nadat rechtens eenmaal schade is ontstaan in het vermogen van de benadeelde (zoals verzekeringsuitkeringen aan de benadeelde of aan zijn schuldeisers, bijvoorbeeld het ziekenhuis) komen in mindering door subrogatie dan wel voordeelstoerekening (art. 6:100 BW). Alle betalingen dienen uitsluitend van invloed te zijn (in mindering te komen) op de schadeposten waarop ze betrekking hebben.

Voor betalingen waarbij sprake is van de genoemde samenloop geldt, als regel, een absoluut regime van subrogatie dan wel voordeelstoerekening. Dat houdt in dat de benadeelde ten belope van die uitkeringen ongeacht de verdere omstandigheden van het geval zijn recht op schadevergoeding verliest. ${ }^{249}$ De titel van betaling, in geld of in natura, verplicht of onverplicht, en de vraag of de regresactie van de verstrekker slaagt, staan daaraan niet in de weg. Een zo absoluut regime geldt voor betalingen die strekken tot vergoeding van schade, die tevens schade is in de zin van afdeling 6.1.10 BW (en waarvoor de benadeelde schadevergoeding vordert). Met name valt daarbij te denken aan uitkeringen uit particuliere schadeverzekering, onkostenvergoedingen, sociale verzekeringsuitkeringen, betalingen van de werkgever, giften die zijn bedoeld ter vergoeding van de schade, en aanvullende ambtenarenvoorzieningen. Ook verzekeringsuitkeringen waarbij tot op zekere hoogte met gefixeerde bedragen of berekeningstabellen wordt gewerkt kunnen die strekking hebben (zoals invaliditeitsuitkeringen op basis van zogenaamde Gliedertaxe, schalen van arbeidsongeschiktheid waarbij de hoogte van de uitkering tussen de schalen varieert). Daarvoor dient in mijn visie dan ook eveneens subrogatie dan wel voordeelstoerekening te gelden, mits aan twee voorwaarden is voldaan. De schadebepalende factoren moeten zijn vastgesteld aan de hand van concrete schadegegevens van de benadeelde (hoogte van het inkomen, mate van arbeidsongeschiktheid) èn die moeten op het moment van de uitkering nog representatief zijn geweest voor diens feitelijke vermogenstoestand. ${ }^{250}$

het regime zoals het hier wordt besproken.

Van een echte samenloop van prestaties is dan strikt genomen geen sprake: de werkgever moet het loon doorbetalen (en daarmee schade voorkomen), de schadeveroorzaker moet inkomensschade vergoeden.

Ook ander voordeel van de benadeelde kan op grond van voordeelstoerekening in mindering komen op zijn recht op schadevergoeding; daarvoor gelden andere vuistregels, zie Spier e.a. (2000), nr. 225 (Hartlief) en de redelijkheidsmaatstaf van art. 6:100 BW. Zie voorts Asser-Hartkamp 4-I, nr. 442 e.v. en vgl. Bolt (1989a), p. 183 e.v.

Dit komt uitvoeriger aan de orde in paragraaf 4.6 . 
Bij de zelfstandige regresrechten gelden aanvullende bepalingen in de aanspraakverlenende wet. Die bepalen dat reeds het bedrag van de aanspraak in aanmerking behoort te worden genomen, ongeacht of de aanspraak daadwerkelijk al tot betaling heeft geleid. Dat heeft uitsluitend te maken met het verplichte karakter van de aanspraakverlenende wet of arbeidsovereenkomst: deze bepalingen ontnemen de benadeelde de keuze om zich door een beroep op het aansprakelijkheidsrecht aan de desbetreffende aanspraken te onttrekken. Uitkeringen die feitelijk niet worden genoten behoren in beginsel niet op de vordering van de benadeelde in mindering te komen, tenzij de benadeelde te kwader trouw heeft gehandeld. De Hoge Raad laat daarvoor ruimte in de arresten Nationale Nederlanden/Woudsend I en Brandts/ Van Straaten. ${ }^{251}$ Aangenomen wordt wel dat voor deze exceptie (voordeelstoerekening bij feitelijk niet genoten betalingen) alleen plaats is in gevallen van boze opzet. Dat houdt dunkt me de marge van de beoordelingsvrijheid van de rechter in dit verband beperkt, hetgeen op zich wenselijk is. In mijn visie ontbreekt voor voordeelstoerekening echter elke goede grond, zelfs als de benadeelde zijn uitkering door eigen toedoen misliep. De reactie op het verwijtbare gedrag moet in dit verband niet komen van het aansprakelijkheidsrecht; dàt heeft zich alleen te richten op de feitelijke vermogenstoestand van de benadeelde (en de vraag in hoeverre de schade kan worden geacht te zijn opgeheven door de betalingen van derden of ander voordeel). Slechts zal in de daarop volgende regreszaak, ervan uitgaande dat de aanspraken van de benadeelde niet tot betaling zullen komen, de regresvordering moeten worden afgewezen. Voor het geval dat het nog onzeker is of de betalingen door de benadeelde zullen worden genoten, opperde ik om de regresnemer een (voorlopig) toekenningsbesluit van de uitkering te laten overleggen of, als dat onder omstandigheden nog niet mogelijk is, zijn vordering voorwaardelijk toe te wijzen, analoog aan art. 6:105 BW.

Bij betalingen ten slotte, die niet strekken tot schadevergoeding of tot vergoeding van de schade waarvoor schadevergoeding wordt gevorderd (vrijblijvende giften, uitkeringen uit 'echte' sommenverzekering) ontstaat er geen samenloop met de vergoedingsplicht van de schadeveroorzaker. Voor een absoluut regime van voordeelstoerekening en regres is dan ook geen plaats. Wel kan de betaling om andere, aanvullende redenen dan het (ontbrekende) schadevergoedingskarakter in mindering komen op het bedrag van de schadevergoeding. Ook kan er rekening mee worden gehouden door rechterlijke matiging (art. 6:109 BW). De consequentie is dan echter dat de schadeveroorzaker definitief van zijn vergoedingsplicht is bevrijd; voor het regres is in deze gevallen immers, wegens het ontbreken van samenloop, geen plaats. Het zou goed zijn om die omstandigheid bij de vraag naar voordeelstoerekening te betrekken.

251 HR 16 september 1994, NJ 1996, 329 nt. CJHB (Nationale Nederlanden/Woudsend I); HR I februari 2002. NJ 2002, 122 (Van Siraaten/Brandts). 
De aanleiding voor de wettelijke regresrechten ligt bij de omstandigheid dat de schadeveroorzaker in diens verhouding tot de benadeelde is bevrijd. ${ }^{252}$ De ratio van het regres is om ervoor te zorgen dat het aansprakelijkheidsrecht dan normale doorgang vindt opdat de uiteindelijke draagplicht met betrekking tot de schade toch weer bij de schadeveroorzaker ligt. In de navolgende hoofdstukken volgt een verdieping in de achtergrond en functies van het regres. Maar eerst vragen het rechtskarakter en de inhoud van de regresregelingen meer aandacht. 


\section{Wettelijke regresregelingen}

In dit hoofdstuk volgt een bespreking van de wettelijke regresregelingen en van gevallen van samenloop waarvoor (vooralsnog) geen regresrechten gelden. In de literatuur klinken voorstellen om te komen tot een algemene, uniforme regresregeling. Mede met het oog daarop zal een drietal gemeenschappelijke kenmerken worden geformuleerd die de regresrechten onderscheiden van andere verhaalsrechten. Voor een goed begrip daarvan zullen de regresrechten aan een korte interne vergelijking worden onderworpen: wat zijn de verschillen met andere afgeleide rechten (zoals het regresrecht van medeaansprakelijken of cessie) en met schadeclaims? Tot slot volgt een definitie en een suggestie voor de formulering van een uniform regresrecht.

\subsection{Inleiding}

In het vorige hoofdstuk werd gezien dat voor de gevallen waarin derden a priori of achteraf schade van de benadeelde voor hun rekening nemen, deze laatste als regel, zijn recht op schadevergoeding verliest. In de komende paragrafen zal worden gezien in welke van die gevallen de betalende derden daarvoor een beroep kunnen doen op de onderhavige regresrechten. Daartoe zal eerst kennis worden gemaakt met alle wettelijke regresregelingen afzonderlijk. Daarna zullen ze als zelfstandige categorie van verhaalsrechten worden besproken. Natuurlijk geeft niet elke schade waarvoor de benadeelde een uitkering uit hoofde van sociale zekerheid ontvangt, aanleiding tot regres. Uitkeringen ingevolge de Algemene ouderdomswet bijvoorbeeld zijn gerelateerd aan het bereiken van de leeftijd van vijfenzestig jaar, niet aan het schadevoorval, en behoren dus niet te kunnen leiden tot regres. De Algemene Ouderdomswet kent dan ook terecht geen regeling voor samenloop met het aansprakelijkheidsrecht. De wèl relevante gevallen, verstrekkers van uitkeringen die wèl gerelateerd kunnen worden aan een concreet schadevoorval zijn gerangschikt naar gelang de aard van de schade: het regres met betrekking tot medische herstelkosten, inkomensschade, overlijdensschade (gederfd levensonderhoud en begrafeniskosten), en de immateriële schade bij letsel of overlijden. In paragraaf 4.6 komt een aantal schadedragers aan de orde voor wie een regresrecht ontbreekt. 


\subsection{Regres bij medische herstelkosten}

De meest voorkomende schadepost in de sfeer van letsel en overlijden zijn de medische herstelkosten. Daartoe behoren ziekenhuisrekeningen, de kosten van medicatie en medische hulpmiddelen, consulten, therapie, en alle overige kosten die in redelijkheid nodig zijn om het lichaam zoveel mogelijk in de toestand te brengen van vóór het ongeval. ${ }^{256}$ Voor vrijwel alle gevallen waarin derden buiten het aansprakelijkheidsrecht om ten behoeve van de benadeelde zulke kosten moeten maken of voor hun rekening nemen, gelden één of meerdere van de onderhavige regresrechten dan wel het vorderingsrecht van art. 6:107 BW. Dit laatste komt in paragraaf 4.9 uitvoeriger aan de orde en zal in het navolgende overzicht daarom buiten beschouwing blijven. Om welke regelingen gaat het daarnaast precies?

\subsection{Art. $83 b \mathrm{ZFW}$}

Een belangrijk deel van de medische herstelkosten wordt vergoed door sociale verzekeraars. De meest in het oog springende sociale verzekeringswet is in dit verband de Ziekenfondswet. De Ziekenfondswet biedt dekking voor eenvoudige ziektekosten, zoals de kosten van huisarts, specialist, fysiotherapeut, tandheelkundige hulp en farmaceutische hulp. Maar ook de kosten van onderzoek, behandeling en verpleging in een ziekenhuis vallen eronder, en (thans) voorts onder meer kosten van orgaantransplantatie, medischehulpmiddelen (prothesen, bril), ziekenvervoer en bepaalde kosten van revalidatie. De benadeelde moet met de hoogte van zijn inkomen onder een bepaalde loongrens verkeren, ${ }^{257}$ of meeverzekerd zijn als partner of kind in dezelfde huishouding. De vergoedingen vinden plaats in natura, dat wil zeggen dat de door de benadeelde gemaakte kosten door het ziekenfonds aan bijvoorbeeld huisarts, apotheek of ziekenhuis worden vergoed.

Het bedrag waarvoor de Ziekenfondswet de benadeelde aanspraak geeft op zulke verstrekkingen of voorzieningen komt in mindering op zijn recht op schadevergoeding voor de desbetreffende schade. De grondslag daarvan is in beginsel voordeelstoerekening, rechtstreekse betalingen en verstrekkingen zullen al bij het proces van schadebegroting zijn verdisconteerd. ${ }^{258}$ Voorzover de geldwaarde van de verstrekkingen niet kan worden vastgesteld, wordt deze bepaald op een geschat

De kosten moeten vanuit medisch oogpunt wenselijk zijn en in aard en omvang redelijk zijn, zie o.a. Asser-Harkamp 4-I, nr. 471: Barendrecht \& Storm (1995), p. 169 c.v.: Bouman \& Tilanus-Van Wassenaer (1998), nr. 25 (p. 46).

De Ziekenfondswet geldt niet alleen voor werknemers, maar ook voor zelfstandige ondernemers en voor uitkeringsof pensioengerechtigden. Voor het jaar 2002 bedraagt de loongrens voor werknemers 30700 Euro.

Art. $83 a$ ZFW: ' $B$ ij de vaststelling van de schadevergoeding, waarop de verzekerde naar burgerlijk recht aanspraak kan maken ter zake van een feit, dat aanleiding geeft tot het verlenen van verstrekkingen of vergoedingen ingevolge de verzekering, houdt de rechter rekening met de aanspraken, die de verzekerde krachtens deze wet heeft." 
bedrag. ${ }^{259}$ De benadeelde verliest zijn recht op schadevergoeding slechts met betrekking tot de betreffende herstelkosten (de ziekenhuisrekening, de kosten van medicatie, enzovoort). De ziekenfondsaanspraken dienen het overige deel van de vordering van de benadeelde (andere ziektekosten, inkomensschade of smartengeld) ongemoeid te laten. ${ }^{260}$ Voor niet verzekerde schade zoals verpleging 'hoogste klasse' of bijbetalingen die de benadeelde het ziekenfonds verschuldigd is, kan de benadeelde dan nog wèl een beroep doen op het aansprakelijkheidsrecht. Voor het deel van de schade dat voor rekening komt van het ziekenfonds, heeft het fonds een zelfstandige regresvordering op de schadeveroorzaker, los van de vordering van de benadeelde. Art. $83 b \mathrm{ZFW}$ luidt:

$\because$ 1. Behoudens toepassing van het derde lid, eerste volzin, heeft een ziekenfonds voor de krachtens de verzekering gemaakte kosten verhaal op degene, die in verband met het veroorzaken van het /schadevoorval] jegens de verzekerde naar burgerlijk recht tot schadevergoeding is verplicht, doch ten hoogste tot het bedrag, waarvoor deze bij het ontbreken van de aanspraken krachtens de verzekering naar burgerlijk recht aansprakelijk zou zijn, verminderd met een bedrag, gelijk aan dat van de schadevergoeding tot betaling waarvan de aansprakelijke persoon jegens de verzekerde naar burgerlijk recht is gehouden' (mijn cursief, EE).

De regeling kent een drietal componenten, die mutatis mutandis in dezelfde bewoordingen terugkomen in alle overige regresregelingen, zij het dat de uitleg en invulling die eraan gegeven wordt nogal eens uiteenloopt. In de eerste plaats geldt het regresrecht van het fonds alleen voor de krachtens de verzekering gemaakte kosten; voorzover verstrekkingen in natura zijn gedaan, kunnen die krachtens het tweede lid worden bepaald op een geschat bedrag. Om welke kostenposten het dan gaat, en in hoeverre die kunnen worden verhaald, komt in de navolgende hoofdstukken uitvoeriger aan de orde. In de tweede plaats kan het regresrecht alleen worden ingeroepen jegens de schadeveroorzaker (de civiel aansprakelijke). In art. $83 c$ ZFW wordt het regres op de werkgever of collega's van de benadeelde echter beperkt tot gevallen waarin de schade door hun opzet of bewuste roekeloosheid is ontstaan. Ook het regres op gezinsleden is slechts beperkt mogelijk. Van deze kwestie, de van het regres gevrijwaarde personen en instanties, volgt een bespreking in hoofdstuk 9 . In de derde plaats is het regresrecht beperkt tot het bedrag dat de schadeveroorzaker zou hebben moeten betalen in de - fictieve - situatie dat de betalingen van de Ziekenfondswet (en ook andere voorzieningen) zouden ontbreken en hij rechtstreeks door de benadeelde zèlf zou zijn aangesproken (het civiele plafond). Ook hiervan volgt in het navolgende, in het bijzonder in hoofdstuk 7, nog uitvoerig bespreking.

Hier zal ik me beperken tot bijzondere onderdelen van de regeling van art. $83 c$ ZFW. Het meest in het oog springt dan het derde lid van die regeling. De laatste

Art. $83 b$ lid 2 ZFW bepaalt zulks voor het regressecht zelf, hetzelfde zal dan gelden bij de vrag naar voordeelstoerekening.

250 De argumenten voor dit zogenaamde postenstelsel kwamen hiervoor al aan de orde, in paragraa 3.4 .5 
jaren is actief gewerkt aan verbetering van de uitvoering van het ziekenfondsregres. Het regresbeleid van de fondsen bleek nogal inefficiënt: dat hield de regresopbrengsten naar het oordeel van de regering onnodig laag. De Algemene Rekenkamer werd gevraagd een onderzoek in te stellen naar de uitvoering van het regres van de fondsen. Haar belangrijkste conclusie was dat het regres de fondsen onvoldoende financiële prikkels bood. Het regresrecht van art. $83 \mathrm{~b}$ ZFW strekt zich weliswaar uit over de krachtens de wet 'gemaakte kosten', maar de regresopbrengsten gingen naar de centrale ziekenfondskas. Alleen de uit deze kas aan de uitkeringsgerechtigde zelf verschuldigde bedragen voor recepten, verpleging en behandeling zijn namelijk verhaalbaar. De fondsen hebben geen regresrecht voor de vaste bedragen die ze aan huisartsen en apotheken betalen. ${ }^{261}$ Het regres stelde ziekenfondsen aanvankelijk dan ook voor procedure- en administratiekosten, terwijl ze van de opbrengsten ervan niet (rechtstreeks) konden profiteren. Dat zou, naast andere factoren (zoals de moeilijke toegang tot politiedossiers), een negatieve invloed hebben op de organisatie van de uitvoering van het regres en de beoordelingsvrijheid bij de beslissing tot het instellen van een regresactie. ${ }^{262}$ Dit heeft de betrokken instanties alerter gemaakt op de noodzaak van een efficiënte uitvoering. Zo heeft de Ziekenfondsraad naar aanleiding daarvan de financiële verantwoording van de regresopbrengsten aangepast. De Commissie Toezicht Uitvoeringsorganisatie heeft laten weten scherper toezicht te houden op onnodig gemaakte uitgaven ten behoeve van het verhaal. De regering zelf ten slotte heeft toegezegd met nieuwe regelgeving te komen. Als gevolg daarvan geldt sinds 1 januari 1998 dat de ziekenfondsen, om ze toch een financiële prikkel te geven tot het nemen van regres, bij een succesvolle regresvordering één-derde van de opbrengst zelf mogen houden. De rest gaat dan naar de ziekenfondskas. ${ }^{263}$ Hoewel dit het regres voor de fondsen aantrekkelijker maakt, helpt het niet bij het terugdringen van de relatief hoge kosten van de afwikkeling van de individuele regresvorderingen van elk fonds. Ter beperking van die kosten is in 2001 nog een derde lid ingevoerd: ${ }^{264}$

\footnotetext{
$\because$ 3. Het College [voor Zorgverzekeringen, EE] kan met verzekeraars een overeenkomst sluiten inhoudende een door die verzekeraars aan het College te betalen afkoopsom voor de voor de komende periode te verwachten schadelast tengevolge van de schadeplichtigheid van diens verzekerden ingevolge het eerste lid. De overeenkomst heeft geen betrekking op de schadelast van een ziekenfonds dat voor de aanvang van de onderhandelingen over de bedoelde overeenkomst aan het College te kennen heeft gegeven van zijn bevoegdheid in het eerste lid gebruik te maken. Het College stelt voor aanvang van de periode waarvoor een afkoopsom is overeengekomen, ziekenfondsen op de hoogte van de totstandkoming van bedoelde overeenkomst.'
}

Van Barneveld (1984), p. 101

De conclusies van het rapport van de Algemene Rekenkamer (1996), p. 5 berusten op een onderzoek naar de wijze waarop de ziekenfondsen in de jaren 1990-1994 het regres uitvocrden en hoe de Ziekenfondsraad daarop toezicht hield.

Circulaire ZFW/5/98, richtlijn Ziekenfondsraad uitgebracht op 21 januari 1998.

Frenk (1999), p. 42. 
Dit derde lid voorziet in de mogelijkheid van een totale afkoop van alle regresvorderingen ineens (waarbij de genoemde financięle prikkel voor individuele fondsen dan moet worden afgeschaft). ${ }^{265}$ Het College voor Zorgverzekeringen kan met aansprakelijkheidsverzekeraars een vaststellingsovereenkomst sluiten waarin één periodieke afkoopsom wordt overeengekomen voor alle vorderingen van de fondsen. De bedoeling daarvan is dat over individuele zaken gedurende die periode niet meer kan en behoeft te worden geprocedeerd. De regering achtte het opnemen van deze regeling wenselijk, omdat de partij die collectiveert niet dezelfde is als de rechthebbende van het regresrecht en onduidelijkheid over de juiste bevoegdheidsverdeling moest worden tegengegaan. Daarnaast dient de regeling als een stimulans voor partijen om tot een andere vorm van schaderegeling te komen. ${ }^{260}$ Daargelaten dat de wenselijkheid van zulke regelingen wat mij betreft moet worden betwijfeld, ${ }^{267}$ hebben ze tot dusverre nog niet het beoogde resultaat bereikt. Zo hebben de ziekenfondsen aangegeven zelf van hun regresrecht gebruik te willen blijven maken, en daarin lijkt vooralsnog - zolang de fondsen de genoemde financiële prikkel van een deel van de regresopbrengsten blijven behouden - geen verandering te verwachten.

\subsubsection{Art. 65b AWBZ}

Benadeelden die als gevolg van het schadevoorval langdurige verpleging of behandeling behoeven kunnen daarvoor als Nederlands ingezetene in beginsel aanspraak maken op een uitkering of verstrekking krachtens de Algemene Wet Bijzondere Ziektekosten (AWBZ). Deze wet voorziet in een vergoeding voor omvangrijke geneeskundige kosten zoals de juistgenoemde, maar ook in extramurale geneeskundige verzorging. De aanspraken die de benadeelde aan deze wet kan ontlenen komen door voordeelstoerekening (of het proces van schadebegroting) in mindering op het bedrag waarvoor de schadeveroorzaker jegens hem aansprakelijk is. ${ }^{268}$ Het verlies van het recht op schadevergoeding moet beperkt blijven tot alleen die schadeposten waarvoor de AWBZ-uitkering bedoeld is te gelden (dat zijn de betreffende ziektekosten: revalidatiekosten en/of medicatie, enzovoort). ${ }^{269}$ Voor de uitgekeerde bedragen heeft het AWBZ-orgaan een zelfstandig regresrecht, los van de benadeelde. Art. $65 b$ AWBZ bepaalt:

TK 1998-99, 26239 , nr. 5, p. 5. Deze bepaling is tevens ingevoerd in de AWBZ en al eerder, en naar tevredenheid, in de ANW.

266 TK 1998-99, 26236 , nr. 5, p. 4.

257 Zie paragraaf 6.5 .2 en paragraaf 9.1 .

268 Art. 6:100 BW juncto art. 65a AWBZ: 'Bij de vaststelling van de schadevergoeding, waarop de verzekerde naar burgerlijk recht aanspraak kan maken ter zake van een feit, dat aanleiding geeft tot het verlenen van zorg. bedoeld in artikel 6 , houdt de rechter rekening met de aanspraken, die de verzekerde krachtens deze wet heef.: De argumenten voor dit zogenaamde postenstelsel kwamen hiervoor al aan de orde, in paragraaf 3.4.5. 
-1. Behoudens toepassing van het derde lid, eerste volzin, heeft een ziekenfonds, ziektekostenverzekeraar of uitvoerend orgaan voor de krachtens deze wet gemaakte kosten verhaal op degene, die in verband met het [schadevoorval, EE] jegens de verzekerde naar burgerlijk recht tot schadevergoeding is verplicht, doch ten hoogste tot het bedrag, waarvoor deze bij het ontbreken van de aanspraken krachtens deze wet (...) aansprakelijk zou zijn, verminderd met een bedrag, gelijk aan dat van de schadevergoeding tot betaling waarvan de aansprakelijke persoon jegens de verzekerde naar burgerlijk recht is gehouden.'

Net als art. $83 b$ ZFW kent de regeling het al genoemde drietal componenten, die mutatis mutandis in dezelfde bewoordingen terugkomen in de zelfstandige regrestegelingen van andere sociale verzekeraars. In de eerste plaats geldt het regresrecht van het AWBZ-orgaan alleen voor de krachtens de verzekering gemaakte kosten. Voorzover de geldwaarde van de verleende zorg niet kan worden vastgesteld, wordt deze bepaald op een bij AMvB geschat bedrag. In de tweede plaats kan het regresrecht alleen worden ingeroepen jegens de schadeveroorzaker (de civiel aansprakelijke). In art. 65c AWBZ wordt het regres op de werkgever of collega's van de benadeelde echter beperkt tot gevallen waarin de schade door hun opzet of bewuste roekeloosheid is ontstaan. De voor de ZFW geldende beperking van het regres op gezinsleden geldt hier vermoedelijk niet. ${ }^{270}$ In de derde plaats is het regresrecht beperkt tot het bedrag dat de schadeveroorzaker zou hebben moeten betalen in de - fictieve - situatie dat de betalingen van de AWBZ (en ook overigens elke mogelijke andere voorziening) zouden ontbreken en hij rechtstreeks door de benadeelde zèlf zou zijn aangesproken, het civiele plafond. ${ }^{271}$

Net als in het kader van de Ziekenfondswet bestaat ook voor de regresvorderingen krachtens de AWBZ de mogelijkheid van een collectieve afkoop. Daartoe is bij de invoering van art. $65 \mathrm{~b}$ AWBZ in 2001, gelijktijdig met de afkoopregeling van de Ziekenfondswet, een derde lid toegevoegd. Dat luidt:

'- 3. Het College kan met verzekeraars een overeenkomst sluiten inhoudende een door die verzekeraars aan het College te betalen afkoopsom voor de voor de komende periode te verwachten schadelast tengevolge van de schadeplichtigheid van diens verzekerden ingevolge het eerste lid. De overeenkomst heeft geen betrekking op de schadelast van een ziekenfonds, ziektekostenverzekeraar of uitvoerend orgaan dat voor de aanvang van de onderhandelingen over de bedoelde overeenkomst aan het College te kennen heeft gegeven van zijn bevoegdheid in het eerste lid gebruik te maken. Het College stelt voor aanvang van de periode waarvoor een afkoopsom is overeengekomen, ziekenfondsen, ziektekostenverzekeraars en uitvoerende organen op de hoogte van de totstandkoming van bedoelde overeenkomst.'

Op 24 november 2001 hebben het College voor Zorgverzekeringen en WA-verzekeraars verenigd in het Verbond van Verzekeraars een convenant ondertekend, waarbij alle regresvorderingen van de AWBZ zijn afgekocht voor de periode van 1 juli 1999 tot en met het jaar 2002 (inmiddels is dit verlengd). Daarbij zijn de bedragen 
overeengekomen die het kabinet bij de invoering van het regresrecht heeft beoogd, respectievelijk 15 en 30 miljoen gulden. Voor de navolgende jaren werden bedragen overeengekomen die gebaseerd zijn op nieuwe reële schadegegevens. ${ }^{272}$ Het bijzondere daarvan is dat het $\mathrm{CvZ}$ haar achterban kennelijk voldoende wist te mobiliseren tot het maken van afspraken. Geen van de uitvoeringsorganen van deAWBZ (ziekenfondsen, zorgkantoren en particuliere ziektekostenverzekeraars) heeft aangegeven gebruik te willen maken van de in lid 3 geboden mogelijkheid om van deelname aan een collectieve afkoopregeling in dat verband af te zien, 'opting out'. ${ }^{273}$ Naar verluidt heeft $95 \%$ van de WA-verzekeraars op het convenant 'ingetekend. ${ }^{274}$

\subsubsection{Art. 2 lid I VOA}

Ambtenaren vallen sinds enkele jaren óók onder de dekking van de sociale werknemersverzekeringen, hun positie is in zoverre gelijkgesteld aan die van gewone werknemers, waardoor ook daarvoor de regresregelingen van die wetten gelden. Maar daarnaast blijven ambtenaren bij ziekte en bij arbeidsongeschiktheid krachtens bijzondere rechtspositieregelingen recht op aanvullende uitkeringen en verstrekkingen houden. ${ }^{275}$ Voor de bovenwettelijke uitkeringen die overheidslichamen moeten doen hebben ze een regresrecht krachtens de Verhaalswet ongevallen ambtenaren (VOA). De reden dat de regresregeling niet gewoon in de Ambtenarenwet werd opgenomen is, dat zij ook geldt voor ander personeel dat volledig uit de openbare middelen wordt betaald (zoals militairen). De VOA beslaat een zevental artikelen, waarvan het laatste de citeertitel geeft. Vragen omtrent de interpretatie en uitleg daarvan hebben echter aanleiding gegeven tot een groot aantal arresten. Bij de uitleg van zelfstandige regresregelingen voor sociale verzekeraars en werkgevers pleegt bij deze rechtspraak te worden aangesloten.

Hoewel de VOA dit niet uitdrukkelijk bepaalt verliest de benadeelde voor het deel van de schade dat aanspraak geeft op de betreffende uitkeringen of verstrekkingen het recht op schadevergoeding van de schadeveroorzaker. ${ }^{276}$ Dat moet, uitgaande van het postenstelsel, beperkt blijven tot de schadevordering voor de ziektekosten, en andere kosten (en schadeposten) ongemoeid te laten. Het uitkerende overheidslichaam heeft, op haar beurt, voor de bovenwettelijke uitkeringen een zelfstandig regresrecht, los van de vordering van de benadeelde. Art. 2 VOA bepaalt voor aan ziektekosten gerelateerde uitkeringen:

\footnotetext{
272 De opbrengsten worden vermeid in de Zorgnota 2000, TK 2000-01, nr. 1-2, p. 165.

27 Janssen (1999), p. 80; Kremer (2000), p. 427.

274 Voor WA-versekeraars geldt dat elke versekerar afzonderlijk uitdrukkelijk darop moet intekenen om gebonden te zijn. Het Verbond van Verzekeraars kan haar leden niet door een besluit binden.

27s Uit de CBS-cijfers over de jaren 1995-1998 (hetp:/huswecbs nl/cijfers/kencijfers) valt af te leiden dat het zickteverzuim onder ambtenaren aanmerkelijk groter is dan bij particuliere bedrijven. 
-1. Het lichaam dat aan of ten behoeve van een ambtenaar krachtens diens rechtspositieregeling uitkeringen of verstrekkingen verleent ter zake van een aan deze overkomen ongeval, heeft voor de kosten van deze voorzieningen verhaal op degene die, bij het ontbreken van die voorzieningen, in verband met het veroorzaken van het ongeval jegens de ambtenaar naar burgerlijk recht aansprakelijk zou zijn voor de alsdan door deze geleden schade. Het verhaal kan niet ten nadele van de ambtenaar worden uitgeoefend.

(..)

-4. Voor zover het eerste lid niet rechtstreeks van toepassing is, is het van overeenkomstige toepassing op de uitkeringen, door het lichaam, dat belast is met de uitvoering van een publiekrechtelijke ziektekostenregeling voor ambtenaren, aan een deelnemer in die regeling verleend ter zake van een aan deze of aan zijn gezinsleden overkomen ongeval.'

Net als werd gesteld voor de zelfstandige regresrechten van sociale verzekeraars kent ook deze regeling de genoemde drie componenten. In de eerste plaats geldt het regresrecht van het overheidslichaam alleen voor de krachtens de rechtspositieregeling gemaakte kosten. De 'uitkeringen en verstrekkingen' in de zin van lid 1 kunnen naast medische herstelkosten betrekking hebben op de aanvullende ziektekostenregelingen, maar óók de bovenwettelijke uitkeringen bij arbeidsongevallen vallen eronder, ${ }^{277}$ alsmede invaliditeits- en weduwe en wezenpensioenen. ${ }^{278}$ Het gaat in feite om alle rechtspositionele uitkeringen of verstrekkingen, óók de betalingen die niet ten laste zijn gekomen van de openbare middelen mar van het $\mathrm{ABP} .{ }^{279}$ In de tweede plaats kan het regresrecht alleen worden ingeroepen jegens de schadeveroorzaker (de civiel aansprakelijke). De hiervoor, in het kader van de ZFW en AWBZ besproken beperking van het regres op collega's van de benadeelde, geldt hier niet. Wèl is het nemen van regres op zijn levenspartner slechts beperkt mogelijk. Van deze bijzondere kwestie volgt een bespreking in paragraaf 9.2 .

In de derde plaats geldt weer, net als bij ZFW en AWBZ, de beperking van het civiele plafond. Volgens art. $3 \mathrm{VOA}$ is het regresrecht beperkt tot het bedrag dat de schadeveroorzaker zou hebben moeten betalen in de - fictieve - situatie dat de betalingen van de Ziekenfondswet zouden ontbreken en hij rechtstreeks door de benadeelde zèlf zou zijn aangesproken. Met de VOA is dan ook volgens de Memorie van Toelichting geen ruimer verhaalsrecht beoogt dan de oude cessieconstructies, waarvoor het in de plaats komt, zouden toelaten. ${ }^{280}$ Ten onrechte wordt dit in de literatuur soms zo uitgelegd, dat de VOA alleen zou gelden voor die

Met name art. $37 \mathrm{en} 38$ ARAR. De betrokken ambtenaar heeft hierop alleen recht indien het ongeval in overwegende mate door het werk is veroorzaakt en niet het gevolg is van zijn eigen onvoorzichtigheid (zie art. 35 sub $c$ en $d$ ARAR). Het derde lid verklaart het cerste lid van overeenkomstige toepassing op de ter zake van het ongeval verleende uitkeringen of verstrekkingen na zijn ontslag.

Zie HR 4 juni 1976, NJ 1977, $4 \mathrm{nt}$. ARB (invaliditeitspensioenen ingevolge art. E4 AMP); HR 4 maart 1977. NJ 1978. $144 \mathrm{nt}$. ARB (invaliditeitspensioen ingevolge art. F9 ABPW); HR I5 februari 1985, NJ 1986, 687 (weduwepensioen van ABP). Mok (1977), p. 182 oppen dat de kamercommissies is ontgaan dat de VOA ook betrekking zou hebben op weduwen- en invaliditeitspensioenen, overigens zonder daarvoor concrete gronden aan te voeren.

TK 1964-65, 7812, nr. 3 (MvT), p. 3. 
ambtenarenuitkeringen en verstrekkingen waarvoor voorafgaand aan de inwerkingtreding van deze wet cessie plaatsvond. ${ }^{281}$ Eén van de redenen voor invoering van de VOA is juist geweest dat een uitbreiding van de verhaalsmogelijkheden wenselijk was. ${ }^{282}$ Met de betreffende passage uit de toelichting wordt niet méér bedoeld dan dat de beperkingen die voortvloeien uit het afgeleide karakter bij cessie (de verzekeraar verkrijgt de vordering van de benadeelde), eveneens gelden voor het zelfstandige verhaalsrecht. De VOA geldt derhalve voor een onbeperkt aantal gevallen, zij het beperkt tot ten hoogste de omvang van aansprakelijkheid van de schadeveroorzaker jegens de benadeelde.

Dit laatste vindt ook steun in de rechtspraak van de Hoge Raad. Op de evenbedoelde plaatsen in de literatuur wordt nog gesteld dat de raad aanvankelijk, in het arrest inzake Gemeente Sneek/Oosterhof, wèl steun gaf voor de opvatting dat het VOA-regres beperkt zou moeten blijven tot uitsluitend de ambtenarenuitkeringen waarvoor voorheen cessie gold, en pas in latere arresten van koers is veranderd. ${ }^{283}$ Maar dat berust op een onjuiste lezing van de betreffende arresten. Het arrest inzake Gemeente Sneek/Oosterhof heeft in cassatie nog betrekking op een regresvordering van de gemeente voor het deel van de sociale premies waarvoor de gemeente zèlf als werkgeefster van de benadeelde stelt schade te hebben. Het hof heeft die vordering toegewezen en daarmee aan het regres krachtens de VOA een wijder bereik gegeven dan (het derivatieve karakter van) de cessieconstructie zou toelaten. Terecht ziet de Hoge Raad daarvoor onder verwijzing naar de eerdergenoemde passage geen plaats omdat ook cessie voor zulke bedragen, voorafgaand aan de VOA, niet mogelijk was. ${ }^{284}$ Daarmee schetst de raad slechts de contouren van het regresrecht als zelfstandig recht: dat is technisch qua omvang net zó begrensd als bij cessie. Niets staat (kennelijk) eraan in de weg om de VOA ook te laten gelden voor ambtenarenvoorzieningen waarvoor voor haar inwerkingtreding geen cessie mogelijk was.

De uitspraak inzake Gemeente Sneek/Oosterhof is dogmatisch wel wat misleidend omdat de raad het zo stelt, dat het regresrecht zich niet uitstrekt over het betreffende geval (het werkgeversdeel van de sociale premies) omdat daarvoor onder het oude regime, voorafgaand aan de VOA, ook geen cessie mogelijk zou zijn geweest. Beter ware het art. 2 VOA wèl gewoon voor het gevorderde te laten gelden, maar dit deel van de vordering onder verwijzing naar het civiele plafond af te wijzen (art. 3 VOA). Anders dan zijn A-G bewandelt de Hoge Raad deze weg niet omdat toepassing van het civiele plafond in dit verband zou leiden tot 'ernstige complicaties'. Dan zou immers, zo stelt de raad het, de ingewikkelde vraag moeten worden beantwoord voor welk deel van de sociale premies de benadeelde zonder de premieafdracht zèlf schade zou lijden en een vordering tot schadevergoeding zou toekomen.

\footnotetext{
28 Zie Mok (1977), p. 170.

282 Zie paragraaf 5.3 .2 .

283 Mok (1977), p. 170 en Mac Lean (1986), p. 284 en 285.

24. HR 5 december 1969, NJ 1970, 140 (Gemeente Sneek/Oosterhof)
} 
In latere arresten, waarin Mok en Mac Lean een koerswijziging lezen, ${ }^{285}$ wordt de raad pas voor het eerst uitdrukkelijk de vraag voorgelegd of uit de genoemde passage uit de vergelijking met cessie moet worden afgeleid dat de VOA geen uitbreiding van het regres toestaat naar nieuwe ambtenarenuitkeringen (in casu invaliditeitspensioenen aan militairen). De Hoge Raad verwerpt die stelling en beslist dat de VOA ook geldt voor uitkeringen waarvoor vóór haar inwerkingtreding geen cessie mogelijk was. De raad verandert hiermee dus niet van koers, maar oordeelt over een ander punt dan in het arrest inzake Gemeente Sneek/Oosterhof. De stelling dat bij invoering van de VOA is gestreefd naar handhaving van het verhaalsvolume, en dat daarvoor steun te vinden is of was in de jurisprudentie, is kortom in alle opzichten onjuist. Naar nog zal worden gezien, is met deze wet juist gestreefd naar uitbreiding van (potentiële) regressituaties.

Tot slot past nog een opmerking over de uitvoering van het VOA-regres. Die is sinds 1 december 1997 in handen van BSA Schaderegeling BV. Deze uitvoering is tot op zekere hoogte genormeerd. In 1994 heeft de Hoge Raad, aansluitend bij de in de praktijk geldende gedragslijn voor het regres van de VOA, geoordeeld dat men voor individuele dossiers ook de contante waarde van in de toekomst nog verschuldigde uitkeringen kan vorderen. ${ }^{286}$ Dat heeft het voordeel dat regresprocedures nief roor elke botaling opnieuw behoeven te worden heropond. $D$ t uitvoering van het regres van de AWBZ is zoals gezegd verdergaand vereenvoudigd; daar wordt het zelfs niet meer afgehandeld op basis van individuele dossiers.

\subsubsection{Art. 284 WvK/art. 7.17.2.25 BW}

Ook bij ziektekostenverzekeraars en andere particuliere verzekeraars wordt een deel van (het risico van) de medische herstelkosten ondergebracht. Voor bepaalde categorieën van verzekerden biedt de Wet op de toegang tot ziektekostenverzekeringen 1998 de mogelijkheid van een standaardverzekering. Bij de totstandkoming van die wet heeft de regering afgezien van het opnemen van een aparte regeling van het regresrecht voor deze gevallen. ${ }^{287}$ Daarvoor geldt een algemene wettelijke regeling, die bedoeld is voor alle uitkeringen die schadeverzekeraars op grond van de verzekeringsovereenkomst voor hun rekening nemen. ${ }^{288}$ Thans is dat nog art. 284 WvK:

HR 4 juni 1976, NJ 1977, $4 \mathrm{nt}$. ARB (Van Geffen/Staat) en HR 4 maart 1977, NJ 1978, $144 \mathrm{nt}$. ARB (Providen$(i a / A B P)$.

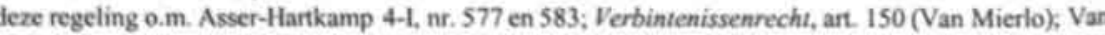
Achterberg (1999), nr. 25 met verdere verwijzingen; en Bolt (1989b), p. 42. Voor het oude recht stelt Ledeboer (1927), p. 44 onder verwijzing naar andere auteurs dat de wet niet ertoe dwingt an. 284 WvK te beschouwen als specialis van art. 1436 e.v. BW (oud). Het daar geregelde regresrecht, met name dat ingevolge art. 1438 sub 3 BW (oud) geldt echter volgens vaste jurisprudentie niet voor schadeverzekeraars in de situatie van art. 284 WvK. 
'Indien de verzekerde ter zake van door hem geleden schade vorderingen tot schadevergoeding op derden heeft, anders dan uit verzekering, gaan die bij wijze van subrogatie over op de verzekeraar voor zover deze die schade vergoedt.'

In verband met de overheveling van het verzekeringsrecht naar het Burgerlijk Wetboek, die naar ik vermoed medio 2004 of 2005 eindelijk zal plaatsvinden, zal art. 284 WvK worden vervangen door art. 7.17.2.25 BW. Op 16 mei 1986 werd bij de Tweede Kamer het wetsvoorstel ingediend tot vaststelling van titel 7.17 BW (Verzekering) en titel 7.18 BW (Lijfrente). De parlementaire behandeling werd toen uitgesteld tot na de behandeling van het wetsvoorstel van het erfrecht. $\mathrm{Na}$ de inwerkingtreding dààrvan, is met 'horten en stoten', het gerucht gaat in de wandelgangen dat het wetsvoorstel meer recent zelfs enige maanden 'zoek' was bij het ministerie, ook de parlementaire behandeling van het verzekeringsrecht weer op gang gebracht. Een gewijzigd voorstel van wet is inmiddels naar de Eerste Kamer verzonden. ${ }^{289}$ De subrogatieregeling geldt voor schadeverzekeraars en is daarom ondergebracht bij afdeling 7.17.2 BW. Het eerste lid van art. 7.17.2.25 BW is vrijwel gelijk aan art. $284 \mathrm{WvK}$ :

$\because$ 1. Indien de verzekerde ter zake van de door hem geleden schade anders dan uit verzekering vorderingen tot schadevergoeding op derden heeft, gaan die vorderingen bij wijze van subrogatie op de verzekeraar over voor zover deze, al dan niet verplicht, die schade vergoedt. De verzekerde moet zich, nadat het risico zich heeft verwezenlijkt, onthouden van elke gedraging welke aan het recht van de verzekeraar tegen die derden afbreuk doet.'

De verzekeraar wordt in de vordering tot schadevergoeding van de benadeelde gesubrogeerd, een vorm van rechtsovergang onder bijzondere titel. ${ }^{290}$ Wilsinstemming van de benadeelde (als verzekerde) is dus, anders dan bij cessie, ${ }^{291}$ niet vereist. De rechtsovergang vindt plaats van rechtswege, uit hoofde van wettelijke bepalingen ('cessio legis'). Daarmee verliest de benadeelde dan zijn vordering. De vordering gaat slechts over met betrekking tot dàt deel van de ziektekosten dat daadwerkelijk door de verzekeraar is vergoed. Voor het deel van de schade dat niet door de verzekeraar wordt vergoed behoudt de benadeelde zijn vordering. ${ }^{292}$ Het regresrecht van de verzekeraar bestaat uit de door subrogatie verkregen vordering tot schadevergoeding van de benadeelde (en is beginsel dan ook naar aard en omvang daaraan gelijk). Voor toekomstige schade waarvoor de benadeelde nog verzekeringsuitkeringen zal ontvangen en niettemin schadevergoeding

EK 2002-03, 19 529, nr. 206 (Gewijzigd voorstel van wet d.d. 24 april 2003). Uitgegaan wordt van deze tekst. de gewijzigde tekst zoals die volgens dit voorstel door de minister aan de Eerste Kamer is voorgelegd.

Zie ant. 3:80 BW. Het recht op betaling ontstaat dan doordat bij betaling van de verzekeringsuitkering het recht op schadevergoeding van de benadeelde overgat op de schadeverzekeraar krachtens ant. 284 WvKJ art. 7.17.2.25 BW.

Het wezenlijke verschil met cessie is echter, 20 stelt Ledeboer (1927), p. 22 en 49, dat voor subrogatie betaling van de rechtsverkrijger (de schadeverzekeraar) noodzakelijk is.

De Kok (1965), p. 91; Van Boom (2000a), p. 19. 
vordert van de schadeveroorzaker (art. 6:105 BW), ligt óók het moment van subrogatie nog in de toekomst. De verzekeraar heeft immers nog niets uitgekeerd. In die gevallen vindt bij de benadeelde voordeelstoerekening plaats, en kan de verzekeraar slechts eerder over de vordering trachten te beschikken door cessie (uiteraard mits de vordering voldoende bestaanbaar en bepaalbaar is). Voor wat betreft de verkrijging van het regresrecht levert het derivatieve karakter (en de evengenoemde invulling daarvan) kortom daadwerkelijk van belang zijnde verschillen op met de zelfstandige regresrechten: pas op het moment dat de verzekeraar de verzekeringsuitkering daadwerkelijk heeft verstrekt - en de schade van de benadeelde dus feitelijk is vergoed, verliest de benadeelde zijn vordering en krijgt de verzekeraar daarmee recht op regres.

Nodig is daarvoor wèl dat de verzekering strekt tot het vergoeden van concrete schade van de benadeelde. Sommenverzekeringen, dat zijn verzekeringen waarbij de verzekeraar gehouden is tot uitkering van een vaste vooraf vastgestelde som die losstaat van de concrete schade (vgl. art. 7.17.3.1 BW), vallen erbuiten. Of sprake is van een schade- of sommenverzekering hangt onder meer af van de premieen de uitkeringsvoorwaarden. Geen ruimte voor subrogatie bestaat bijvoorbeeld indien blijkens de polis vaste uitkeringen of uitkeringstarieven overeengekomen zijn die losstaan van de schade. Bij verzekeringen die betrekking hebhen op de medische herstelkosten moet dan met name worden gedacht aan ongevallenverzekeringen. Omstreden is of ongevallenverzekeringen waarbij met arbeidsongeschiktheidspercentages en/of getarifieerde bedragen wordt gewerkt óók als sommenverzekering moeten worden aangemerkt. De discussie is met name van belang in de sfeer van inkomensschade door arbeidsongeschiktheid, ${ }^{293}$ maar ook bij medische herstelkosten lijken tussenvormen mogelijk (bijvoorbeeld standaardpercentages of -bedragen voor de kosten van therapeutische behandeling of tandheelkundige zorg). Zoals ik eerder aangaf, dient de definitie van de sommenverzekering naar komend recht (art. 7.17.3.1 BW) wat mij betreft restrictief te worden uitgelegd en dient primair de strekking van de verzekering in het concrete geval beslissend te zijn. Indien de strekking is om de herstelkosten te vergoeden, dan doet daaraan geen afbreuk dat uit oogpunt van doelmatigheid met getarifieerde percentages of bedragen wordt gewerkt. Van sommenverzekeringen is alleen sprake indien de verzekering daadwèrkelijk losstaat van de concrete schade. Zie nog nader paragraaf 4.6.

Noodzakelijk is dat de verzekeringsuitkering ook daadwerkelijk aan de benadeelde werd verstrekt; niet nodig is echter dat de uitkering door de verhaalzoekende verzekeraar uiteindelijk volledig zelf wordt gefinancierd. Ook bij uitkeringen aan benadeelden waarvoor de al genoemde Wet op de toegang tot de ziektekostenverzekeringen een contracteerplicht voorschrijft gelden art. $284 \mathrm{WvK} / \mathrm{art}$. 7.17.2.25 BW onverminderd. In die gevallen geldt in beginsel dat de schade kan worden omgesla- 
gen over alle particulier verzekerden jonger dan vijfenzestig jaar (behalve voor het deel waarvoor de benadeelde premie verschuldigd is). Onder de schade die de verzekeraar in die gevallen ten laste van de omslagregeling kan brengen behoort echter niet het deel dat hij op de derden kan verhalen. ${ }^{294}$ Zonder nadere regeling zouden verzekeraars bij het regres dan weinig belang hebben (en eigenlijk vooral kosten). Speciaal met het oog hierop is bepaald dat verzekeraars die overgaan tot het nemen van regres $25 \%$ van de regresopbrengsten zelf mogen houden. ${ }^{295}$ Dit kan tegengaan, dat zal ook zijn beoogd, dat in gevallen waarin derden voor het ongeval aansprakelijk zijn, de kosten daarvan over alle verzekerden moeten worden omgeslagen. Overigens valt te betwijfelen of het vooruitzicht van $25 \%$ wel effectief is, en niet te gering. Dit percentage wordt in de Memorie van Toelichting evenmin toegelicht als de regeling zelf. ${ }^{296}$

Afgezien van deze wijze van verkrijging (en de daarmee verband houdende beperkingen) zijn de contouren van het recht dat door subrogatie verkregen wordt, wèl sterk gelijk aan de zelfstandige regresregelingen. Het kent dezelfde drie algemene componenten als die centraal stonden bij de bespreking van het regresrecht van ZFW, AWBZ en VOA (zij het dat er ook hier verschillen zijn bij de uitleg en invulling daarvan). In de eerste plaats geldt het recht van subrogatie alleen voor de krachtens de particuliere schadeverzekering gemaakte kosten; dat de kosten verplicht zijn gemaakt is niet vereist. ${ }^{297}$ In het kader van art. 284 WvK en art. 7.17.2.25 BW moet het gaan om een (privaatrechtelijke) verzekeringsovereenkomst, met de benadeelde als verzekeringsnemer of als beoogd begunstigde (verzekerde). Op uitkeringen uit sociale verzekering zijn beide regelingen niet van toepassing. ${ }^{298}$ De uitkeringen aan benadeelden waarvoor de Wet op de toegang tot de ziektekostenverzekeringen een contracteerplicht voorschrijft vallen er wel onder ${ }^{299}$ De regeling van art. $284 \mathrm{WvK}$ gold aanvankelijk alleen voor verplicht uit hoofde van de verzekeringsovereenkomst verstrekte uitkeringen. In het arrest KPM/Liverpool oordeelde de Hoge Raad dat voor subrogatie krachtens art. 284 WvK geen plaats is voor verzekeraars die meer uitkeren dan ze volgens de polis verplicht zijn te

Art. 8 WTZ 1998; de Memorie van Toelichting is hierover uiterst summier, over het regres wordt helemaal niets vermeld, TK 1997-98, 25859 , p. 34.

Dat volgt uit de lastig geformuleerde tweede volzin van art. 8 lid I WTZ: 'Onder (de te verrekenen, EE) schade wordt verstaan de som van de (aan de verzekerde, EE) te verstrekken vergoedingen, onder aftrek van 75\% van de opbrengst van verhaal van kosten van die vergoedingen op derden.'

Bij de regeling voor ziekenfondsen die vrijwel dezelfde strekking heeft (maar in ander verband geldt) is bepaald dat fondsen een derde deel van de regresopbrengsten mogen behouden, zie darover paragraaf 4.2.1. Ook bepaalde werkgevers ontvangen voor hun regresinspanningen een compensatic, zie paragraf 4.3.2 en 4.3.4.

HR 7 januari 2000, N 2000, 212 nt MMM (Nationale Nederlanden/Woudsend II); zie ook uitvoeriger paragraaf 8.5 .

HR 3 januari 1936, NJ 1936, 78 nt, EMM (Koopmans/Bedrijfsvereeniging); HR 13 maan 1959, NJ 1962, 338 (Ziekenfonds/Hogestijn I); HR 24 januari 1964, NJ 1964, 465 nt. GIS (Bedriffsereniging/Hendriksen).

TK 1997-98, 25 859, nr. 6, p. 5. 
voldoen. ${ }^{300}$ De reden daarvan was volgens annotator Meijers dat ze dit meerdere niet als verzekeraar uitkeren. In het meer recente arrest Nationale Nederlanden/ Woudsend II, beslist de Hoge Raad echter dat verzekeraars ook bij onverplichte schadeuitkeringen worden gesubrogeerd ingevolge art. $284 \mathrm{WvK}^{301} \mathrm{De}$ raad overweegt daartoe dat het vooruitzicht van subrogatie schadeverzekeraars coulanter kan maken in hun uitkeringsbeleid en ook acht hij vrijwaring van de schadeveroorzaker onwenselijk. De commentaren op het arrest lijken overwegend positief. ${ }^{302}$ Het arrest loopt in feite vooruit op het wetsontwerp van subrogatie voor komend recht. Ook voor art. 7.17.2.25 BW is niet relevant of de uitkering ter zake waarvan subrogatie plaatsvindt verplicht of onverplicht is betaald. De ratio daarvan is eveneens dat de schadeveroorzaker (de WA-verzekeraar) de verschuldigdheid van de uitkering zou kunnen betwisten en dit verzekeraars terughoudender zou kunnen maken in hun uitkeringsbeleid.

De als tweede te noemen component van het regresrecht bij subrogatie is, dat het net als de zelfstandige regresrechten alleen kan worden ingeroepen jegens de schadeveroorzaker (de civiel aansprakelijke). Art. $284 \mathrm{WvK} / \mathrm{art}$. 7.17.2.25 BW bepalen daarover zelf echter slechts dat op de schadeverzekeraar de vorderingen 'tot schadevergoeding, anders dan uit verzekering' overgaan. Aangenomen moet worden dat

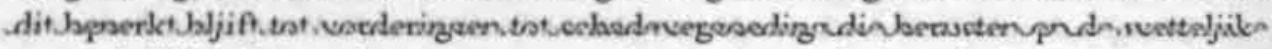
aansprakelijkheid voor het ontstaan van de schade van de benadeelde. Mulder wijst echter op wat uitspraken waarbij de subrogatie ook is toegelaten voor andere vorderingen; ik zal hierop terugkomen. ${ }^{303}$ Buiten de sfeer van personenschade valt te denken aan kredietverzekeraars en ook met betrekking tot zakelijke vorderingen van de benadeelde vindt geen subrogatie plaats. ${ }^{304}$ Als schadeverzekeraars bij diefstal de waarde van de gestolen zaak vergoeden, dan behoudt de verzekerde zijn vordering tot revindicatie. Van subrogatie kan dan geen sprake zijn, niet alleen omdat de vordering op de schuldenaar geen betrekking had op de verzekerde schade, ${ }^{305}$ maar veelal ook omdat de vordering niet berust op wettelijke aansprakelijkheid. Dit laatste is vereist (èn ook dat de schade dezelfde is als waarvoor de verzekeraar uitkering deed). Wel bepaalt art. 7.17.2.25 BW, als gevolg van de Nota van Wijziging van 21 juni 2000 en zoals het ontwerp onlangs naar de Eerste Kamer ging, net als art. $83 \mathrm{c}$ ZFW en art. $65 \mathrm{c} \mathrm{AWBZ}$ dat (in beginsel) ${ }^{306}$ geen regres

HR 10 januari 1941, NJ 1941, $824 \mathrm{nt}$. EMM (KPM/Liverpool); en vgl. HR 24 januari 1964, NJ 1964, 465 nt. GJS (Bedriffsvereniging/Hendriksen).

302 Rinkes (2000), p. 206; Van Boom (2000a), p. 63 ('Het is goed dat de Hoge Raad is omgegaan'); Tollenaar (2001), p. 66.

303 Mulder (1988), p. 52; zie daarover ook infra, paragraaf 7.2.1.

304 Koster (1971), p. 119; Mulder (1988), p. 48; Van Dam (1995), p. 103.

305 In die zin Köster (1971), p. 119.

306 Art. 7.17.2.25 BW, derde lid, zoals gewijzigd bij Nota van Wijziging, TK 1999-2000, 19 529, nr. 5 en overgenomen bij het Gewijzigd voorstel van wet d.d. 24 april 2003 (EK 2002-03, 19 529, nr. 206). Volgens de tweede volzin van lid 3 geldt deze beperking niet 'voor zover zulk een persoon jegens de verzekerde aansprakelijk is wegens een omstandigheid die afbreuk zou hebben gedaan aan de uitkering, indien die omstandigheid aan 
mogelijk is op onder meer de schadeveroorzakende werkgever of collega's van de benadeelde. Van deze kwestie volgt een bespreking in paragraaf 9.2. In de derde plaats is het regresrecht in feite ook bij subrogatie beperkt tot het bedrag dat de schadeveroorzaker zou hebben moeten betalen in de fictieve situatie dat de verzekering of andere voorziening zou hebben ontbroken en hij rechtstreeks door de benadeelde zèlf zou zijn aangesproken (het civiele plafond). Verwezen zij naar paragraaf 7.2 .

\subsubsection{Art. 6 lid 3 WSG}

Indien de medische kosten onverzekerd zijn en het gevolg zijn van een opzettelijk geweldsmisdrijf dan kan de benadeelde ook, bij wijze van ultimum remedium, in aanmerking komen voor een uitkering van het Schadefonds Geweldsmisdrijven. ${ }^{307}$ Daarvoor moet in beginsel binnen drie jaar na het schadevoorval een (vormvrij) verzoek tot uitkering bij het fonds worden ingediend. Het fonds is een overheidsinstelling die onder de verantwoordelijkheid valt van het Ministerie van Justitie. Op het verzoek wordt beslist door de Commissie die met het beheer van het fonds is belast, de Commissie Schadefonds Gewveldsmisdrijven. Het fonds keert alleen uit bij ernstig lichamelijk of geestelijk letsel en/of overlijden. ${ }^{308}$ Het uitkeringsbeleid van het fonds is sterk gelijk aan de regels voor het vaststellen van de omvang van aansprakelijkheid (afdeling 6.1.10 BW). Voor het recht op een uitkering van het fonds moet voldoende aannemelijk zijn dat de schade niet elders verhaalbaar is en dat de financiële omstandigheden van de benadeelde zodanig zijn dat deze de schade niet 'zonder bezwaar' zelf kan dragen. Om te verifiëren of aan dit zogenaamde subsidiariteitsvereiste is voldaan, kan door de Commissie aanvullende informatie worden opgevraagd bij verzekeringsmaatschappijen. Art. 6 lid 1 WSG bepaalt dat geen uitkering wordt toegekend voor schade die langs burgerrechtelijke weg kan worden verhaald (sub 1). Daaraan worden niet al te hoge eisen gesteld. De benadeelde moet doen wat redelijkerwijs van hem kan worden verwacht; aangenomen wordt wel dat hij zich kan beperken tot de vordering als beledigde partij (art. $51 a \mathrm{~Sv}$.). ${ }^{309}$ Ook dan kan zijn verzoek tot een uitkering van het fonds tussentijds worden ingewilligd indien wordt verwacht dat het proces lang gaat duren (art. 6 lid 2 WSG). Het bedrag van de uitkering van het fonds

de verzekerde zou zijn toe te rekenen.'

307 Bij culpose delicten gat het valk om verkecrsmisdrijven. De financiele consequenties darvan worden opgevangen door het systeem van WA-verzekering en het Waarborgfonds Motorverkeer.

30s Onder zwaar lichamelijk of geestelijk letsel wordt letsel verstaan dat met levensgevaar gepaard is gegaan, dat blijvende gevolgen heeft of waarvan het herstel lang duurt (doorgaans betekent dit: langer dan zes weken arbeidsongeschikt), Syllabus Schadefonds Geweldsmisdrijuen, Den Haag januari 2002, p. 15, idem Willems (1996), p. 16.

309 De vordering kan alle soorten van schade omvatten, maar moet van eenvoudige aard zijn, art. 51 la lid $3 \mathrm{~Sv}$. Voor toewijzing is vereist dat de schadeveroorzaker strafrechtelijk wordt veroordeeld (art. 361 lid 2 onder $a$ Sv.). Bij vrijspraak of ontslag van rechtsvervolging kan de benadeelde in beginsel alsnog een civiele procedure starten. 
moet dan worden terugbetaald nadat en in zoverre schadevergoeding van de schadeveroorzaker (eventueel diens WA-verzekeraar) is ontvangen.

Hoewel het een ervaringsfeit is bij het fonds dat slachtoffers sowieso ook zelf al wel een gedeeltelijke betaling door de dader prefereren boven volledige uitkering van het fonds alleen, ${ }^{310}$ worden ze met de terugbetalingsplicht ook in zekere zin onder druk gezet om dat ook daadwerkelijk te doen: ze moeten, als belanghebbende, de confrontatie met het strafproces aangaan. Dat is voor de benadeelde echter lang niet altijd een (reẻle) optie, bijvoorbeeld als geen strafzaak tegen de schadeveroorzaker wordt ingesteld. Het fonds heeft dan de mogelijkheid om zelf de schadeveroorzaker aansprakelijk te stellen voor de aan de benadeelde uitgekeerde bedragen. Voor het bedrag van de uitkering kan het fonds worden gesubrogeerd in de vordering tot schadevergoeding van de benadeelde. ${ }^{311}$ Art. 6 lid 3 WSG bepaalt:

'Het fonds treedt voor het aan de benadeelde uitgekeerde bedrag in de rechten die deze ter zake van de door hem geleden schade tegenover derden heeft. Het oefent deze rechten niet uit dan met toestemming van Onze Minister.'

Het aantal gevallen waarin het Schadefonds Geweldsmisdrijven van haar regresrecht geóruik maaḱt is niet zo groot. ${ }^{32}$ De feitelijke betekenis ervan ligt met name bij gevallen waarin een strafprocedure heeft plaatsgevonden en schadevergoeding is toegewezen (dan wel op vordering van het Openbaar Ministerie een schadevergoedingsmaatregel is opgelegd, art. $36 f \mathrm{Sr}$.). Het regresrecht van art. 6 lid 3 WSG stelt het fonds dan rechtens in staat de door de schadeveroorzaker betaalde bedragen van de benadeelde of het Centraal Justitieel Incasso Bureau te kunnen terugvorderen.

Sinds de oprichting van het Schadefonds Geweldsmisdrijven is slechts enkele malen rechtstreeksvan dit verhaalsrecht tegen de dader gebruik gemaakt. Voor het instellen van een regresprocedure is namelijk toestemming nodig van de minister van Justitie. De reden daarvan is dat het fonds alleen uitkeert indien de dader het schadevoorval opzettelijk heeft gepleegd en juist die gevallen veelal niet door WAverzekering gedekt zijn. De dader biedt dan mogelijk onvoldoende verhaal, met het risico dat de regresopbrengsten niet opwegen tegen de voorbereidings- en procedurekosten van het fonds (waarbij te bedenken valt dat de inschakeling van de landsadvocaat vereist is). ${ }^{313}$ De ministeriële toestemming is bedoeld om terug-

310 De Beer (1991). p. 7

31 Voorzover het beleid van het fonds plaats laat voor een uitkering terwijl volgens de regels van afdeling 6.1.10 BW geen ruimte is voor aansprakelijkheid past voorzichtigheid. Van regres kan in zoverre immers geen sprake zijn.

$312 \mathrm{Al}$ is het wel stijgende, ongeveer 4000 tot 5000 mensen doen jaarlijks een beroep op het fonds terwij! bij de oprichting aan een aantal van viervoudige werd gedacht. De regering is voomemens meer bekendheid te geven aan het fonds: zie TK 2000-01, 274000 VI, nr. 54, p. 6 en nr. 59, p. 1-3. 
houdendheid te betrachten en onnodige risico's te vermijden. Toch klinken vanuit het fonds zelf geluiden die (formele) restrictie af te schaffen. Volgens De Beer zou het handzamer en goedkoper zijn als de Commissie van het fonds zelf de bevoegdheid zou toekomen de haalbaarheid en zin van een regresactie te beoordelen. ${ }^{314}$ In de praktijk werkt het fonds veelal met voorschotconstructies, op basis waarvan het de uitkeringen kan terugvorderen indien de benadeelde zich in de strafprocedure heeft gevoegd of een schadevergoedingsmaatregel wordt toegewezen. Dat vindt maar plaats in een beperkt aantal van de gevallen waarin het fonds uitkering doet, immers alleen indien het strafbare feit door de strafrechter bewezen is verklaard.

\subsection{Regres bij inkomensschade}

\subsubsection{Algemeen}

In het voorgaande werden de voor medische kosten relevante regresregelingen besproken. Hierna staat het regres voor uitkeringen en betalingen met betrekking tot inkomensschade bij tijdelijke of blijvende arbeidsongeschiktheid centraal. Vergelijkende cijfers ontbreken, maar zeker is wel dat bij de navolgende regresregelingen voor uitkeringen voor (korte en langdurige) inkomensschade, de meeste betekenis ligt voor regresnemers. ${ }^{315}$ De regresregelingen zullen worden besproken aan de hand van het uitkeringstraject zoals dat bij arbeidsongeschiktheid wordt doorlopen. Hoe ziet dat traject eruit? Tijdens de eerste pericde van arbeidsongeschiktheid is de werkgever gehouden tot doorbetaling van het loon. Thans is dat éen jaar (tweeënvijftig weken, zie art. 7:629 BW). Overwogen wordt overigens wel om die termijn te verlengen tot twee jaar. ${ }^{316}$ Werkgevers hebben voor het in die periode verplicht doorbetaalde loon een wettelijk regresrecht, art. 6:107a $\mathrm{BW}$. In bijzondere gevallen heeft de benadeelde in dat stadium recht op een uitkering krachtens de Ziektewet; ook daarvoor geldt een regresbepaling (art. 52a ZW). In de navolgende bespreking komen het ('normale') werkgeversregres en het regres ingevolge de Ziektewet daarom als eerste aan de orde. Indien de arbeidsongeschiktheid na die periode voortduurt (langdurige inkomensschade) kan de benadeelde een beroep doen op het stelsel van sociale zekerheid, met name de WAO. De desbetreffende regresbepalingen worden besproken in paragraaf 4.3.4 en 4.3.5. Bijzondere aandacht vragen nog het regres voor aanvullende rechtspositionele

\footnotetext{
314 De Beer (1991), p. 8.

315 Exacte cijfers zijn niet bekend, zie Kremer (2000), p. 425 war tevens wordt gesteld dat het regres met betrekking tot de sociale ziektekostenverzekeringen, de arbeidsongeschiktheidswetten en de loonplicht van werkgevers $90 \%$ van het huidige regresvolume beslaat.

316 Klosse (2003), p. 25 e.v.
} 
uitkeringen aan ambtenaren (paragraaf 4.3.6) en de positie van particuliere verzekeraars (paragraaf 4.3.7).

\subsubsection{Art. 6:107a BW}

Op werkgevers rust sinds 1 maart 1996 de wettelijke verplichting om indien hun werknemers tijdelijk of blijvend arbeidsongeschikt raken, gedurende de eerste tweeenvijftig weken ten minste $70 \%$ van het dagloon te blijven doorbetalen (art. 7:629 BW). ${ }^{317}$ Daarnaast kan sprake zijn van aanvullende verplichtingen tot loondoorbetaling, door CAO of individuele arbeidsovereenkomst. De werkgever heeft voor al deze loonverplichtingen sinds de genoemde datum een zelfstandig regresrecht jegens de schadeveroorzaker (art. 6:107a BW) ${ }^{318}$ Het wettelijke regresrecht geldt alleen voor ongevallen die op of na 1 maart 1996 hebben plaatsgevonden. Onder het oude regime was het vrij gebruikelijk om een zogenaamde voorschotconstructie deel te laten uitmaken van de individuele of collectieve arbeidsovereenkomst. De voorschotconstructie kwam erop neer dat de werkgever gedurende de arbeidsongeschiktheid slechtseen voorschot betaalde op het salaris van de benadeelde/werknemer. Eén van de moeilijkheden was (en is) bijvoorbeeld dat de gecedeerde vorde-

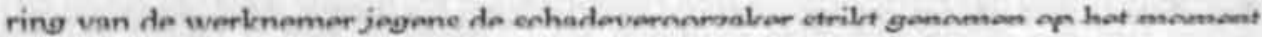
van de doorbetaling niet (meer) bestaat. De onzekerheid over de geldigheid van zulke constructies maakte een wettelijk regresrecht van belang. Voor ongevallen van eerdere datum zullen werkgevers zich echter nog met cessieconstructies moeten behelpen. Ook blijven die van belang voor de (eventuele) onverplichte loondoorbetaling.

Dit laatste sluit aan bij de samenloopgedachte en het principe dat de schadeveroorzaker de schade behoort te dragen. Voorzover het loon wordt doorbetaald heeft de betrokken werknemer zoals gezegd immers, verplicht of niet, geen schade (vgl. art. 6:97 BW). Art. 6:107a BW geeft daarvoor slechts een aanvullende regeling, die net als het regresrecht van het tweede lid alleen geldt voor het verplicht doorbetaalde loon. Krachtens het eerste artikellid moet reeds de aanspraak op de loondoorbetaling in aanmerking worden genomen, ongeacht of deze feitelijk al tot betaling heeft geleid. ${ }^{319}$ Hoewel daarover voor de zelfstandige regresrechten wisselend kan worden gedacht, behoort dit dunkt mij alleen te gelden voor het deel van de vordering van de benadeelde dat betrekking heeft op de inkomensscha-

317 Zoals gezegd wordt thans voorgesteld die periode te verlengen tot twee jaar.

318 TK 1994-95, 24 326, nr. 3 (MvT), p.9. Hem komt dunkt me geen beroep toe op art. 6: 107 BW (voor ongevallen die op of na I januari 1992 plaatsvonden) aangezien die regeling beperkt lijkt te zijn tot medische herstelkosten (kosten die rechtstreeks bijdragen aan het herstel van de benadeelde). Zou men het anders zien, dan zal in beginsel ook een beroep daarop ook moeten toekomen aan de pensioenfondsen voorzover die uitkering doen voor verhaltbre schade.

319 Lid 1: 'Indien iemand ten gevolge van een gebeurtenis waarvoor een ander aansprakelijk is, lichamelijk of geestelijk letsel oploopt, houdt de rechter bij de vaststelling van de schadevergoeding waarop de gekwetste aanspraak kan maken rekening met de aanspraak op loon die de gekwetste heeft krachtens art. 629 lid 1, van Bock 7 of krachtens individuele of collectieve arbeidsovereenkomst.' 
de gerelateerd aan het eerste ziektejaar. ${ }^{320}$ In aansluiting daarop regelt het tweede lid een regresrecht voor de werkgever:

$\because 2$ Indien een werkgever krachtens art. 629, lid 1, van Boek 7 of krachtens individuele of collectieve arbeidsovereenkomst verplicht is tijdens ziekte of arbeidsongeschiktheid van de benadeelde het loon door te betalen, heeft hij, indien de ongeschiktheid tot werken van de benadeelde het gevolg is van een gebeurtenis waarvoor een ander aansprakelijk is, jegens deze ander recht op schadevergoeding ten bedrage van het door hem betaalde loon, doch ten hoogste tot het bedrag, waarvoor de aansprakelijke persoon, bij het ontbreken van de loondoorbetalingsverplichting aansprakelijk zou zijn, verminderd met een bedrag, gelijk aan dat van de schadevergoeding tot betaling waarvan de aansprakelijke persoon jegens de benadeelde is gehouden.'

De regeling van art. 6:107a $\mathrm{BW}$ geldt voor de op de werkgever rustende verplichtingen tot loondoorbetaling aan de benadeelde. De bedragen hoeven niet al feitelijk door de werkgever te zijn betaald. Voor 'eigen' bedrijfsschade (zoals extra kosten van vervanging en productieverlies) is aanvankelijk bij de invoering van art. 6:107a BW de mogelijkheid opengelaten van een normaal, rechtstreeks beroep op het aansprakelijkheidsrecht. ${ }^{321}$ Vermoedelijk heeft men zich daarbij niet gerealiseerd dat dit voor schade die samenhangt met letsel of overlijden van de getroffen werknemer in beginsel uitgesloten is. Werkgevers kunnen bij letsel (niet bij overlijden) van hun werknemers, enkel schadevergoeding vorderen voor de medische kosten die ze ten behoeve van de betrokken werknemer voor hun rekening nemen. ${ }^{322}$ Het regresrecht is verder op gelijke wijze als in de andere zelfstandige regresregelingen beperkt tot het civiele plafond, het bedrag waarvoor de schadeveroorzaker bij het ontbreken van de desbetreffende verplichting tot loondoorbetaling jegens de benadeelde tot schadevergoeding gehouden is.

Voor welke loongerelateerde betalingen geldt het regresrecht van art. 6:107a BW? Zelf bepaalt het dat daaronder alleen het verplicht, wettelijk dan wel krachtens individuele of collectieve arbeidsovereenkomst, doorbetaalde loon valt, met inbegrip van het vakantiegeld en de pensioenpremies. Dat is een niet goed uit te leggen verschil met het regresrecht dat de Staat toekomt in zijn hoedanigheid als ambtenarenwerkgever. ${ }^{323}$ Van Boom wijst in dit verband nog op de moeilijkheid dat de schadeveroorzaker niet steeds bekend zal zijn met gegevens over het dienstverband en (de geldigheid van) contractuele afspraken over loonbetaling en aanvulling van het loon door de werkgever. Dat kan ertoe leiden dat de schadeveroorzaker onverplicht aan de werkgever betaalt of, indien de vordering komt van de benadeel-

Zie paragraaf 3.4 .5 voor een bespreking van de argumenten die pleiten vóór dit zogenaamde postenstelsel. EK 1995-96, 24326 , nr. 1196 , p. 3.

In Hof Den Bosch 26 juni 1996, NJ 1997, 252 (Bartels BVIMammoet-Stoof BV) werd een vordering van de werkgever voor doorbetaling van het loon aan de levenspartner van de overleden werknemer dan ook afgewezen. Voor de kosten van geneeskundige verzorging en behandelingen andere letselschade die werkgevers voor hun rekening nemen kan de werkgever een beroep doen op het algemene verhaalsrecht van art. $6: 107 \mathrm{BW}$, zie Schadevergoeding, art. 107 (Bolt), aant. 44.

323 Zie Storm (1996), p. 119 e.v. en infra, paragraf 4.3.6.
} 
de, geen of te weinig voordeelstoerekening plaatsvindt. ${ }^{324}$ Onder de verplichting tot loondoorbetaling vallen volgens het eerste lid echter ook contractuele verplichtingen tot loondoorbetaling (krachtens individuele arbeidsovereenkomst of CAO) en niets belet de werkgever dan natuurlijk om als daarover niets is afgesproken aanvullende uitkeringen te doen. Onduidelijk is of moet worden uitgegaan van het netto dan wel het bruto loon. De aanvankelijke regeling voor werkgevers, art. 6.1.9.11 $a \mathrm{BW}$, voorzag werkgevers van een verhaalsrecht voor het 'loon, met inbegrip van ingehouden belasting en ingehouden of te zijnen laste komende premies', kortom het volledige brutoloon. Maar die bepaling is nooit wet geworden en ondanks dringende verzoeken om bruto-regres vanuit de praktijk, ${ }^{325}$ is door de minister uiteindelijk toch gekozen voor het nettoloon. In een later stadium van de wordingsgeschiedenis is twijfel ontstaan over wat daaronder precies moet worden verstaan. ${ }^{326}$ Onduidelijkheid heerst verder over de vraag of het regresrecht ook geldt voor de door de werkgever afgedragen sociale premies. Het lijkt wenselijk om op deze beide punten aansluiting te zoeken bij de bruto-netto jurisprudentie voor de regresrechten van sociale verzekeraars en de ambtenarenwerkgever. ${ }^{327}$ Opmerking verdient nog dat het werkgeversregres (vooralsnog) een zaak is van individuele werkgevers met individuele regresvorderingen, hoewel niets eraan in de weg staat dat werkgevers met WA-verzekeraars afşoraken maken voor de-afivikkeling van meerdere vorderingen ineens. ${ }^{328}$ Het wordt wèl gestimuleerd door een recente maatregel die werkgevers die voor schadevoorvallen van op of na 1 januari 2002 de doorbetaalde lonen weten te verhalen, op hun eigen verzoek een daarop afgestemde premiecorrectie biedt voor het gedifferentieerde deel van de WAO-premie. ${ }^{329}$ Die maatregel is voor een aantal werkgevers echter langs een omweg, dunkt me, komen te vervallen. Het betreft de werkgevers waarvoor meer recent het omstreden 'Koninklijk Besluit d.d. 6 september 2002 tot afschaffing van de Regeling Premiedifferentiatie WAO (Pemba) voor kleine werkgevers' is gaan gelden. Krachtens dat besluit is met ingang van 1 januari 2003 voor bedrijven met een loonsom beneden een bepaald bedrag (het premieloon) de WAO-in-

Van Boom (1995), p. 864.

De Raad van de Centrale Ondernemingsorganisaties richte ten tijde van de Veegwet een adres aan de kamerfracties, zie TK 24 326, nr. 6, p. 5. Voor bruto regres zijn ook Van der Veen (1993), p. 757; Hammerstein (1994). p. 1 e.v.; Beekman (1995), p. 1236; Dennekamp (2000), p. 889.

926. TK 1995-96, 24 326, nr. 7 en TK 1995-96, 24 326, nr. 119 b, p. 2; PG 6, p. 608 en Inv. 6, p. 1281 e.v. en daarover Hammerstein (1994), p. 2. Janssen (1997), p. 158 gaat uit van het netto-loon, doch anders Dennekamp (2000), p. 889.

In die zin ook Hartlief \& Van Maanen (1996), p. 127 die regres op bruto-basis niet voor de hand vinden liggen, omdat dat verschil zou opleveren met het regresrecht krachtens de WAO en de VOA. Zie paragraaf 8.2.

Een georganiseerd, collectief regres is moeilijk te realiseren, aangezien werkgevers daarvoor veelal een te incidenteel belang hebben bij het regres en bovendien de werkgeversbonden niet bevoegd zijn tot het maken van bindende afspraken; zie TK 1995-96, 24326 , nr. 7, p. 6. Kremer (2000), p. 425 vermeldt dat er over het werkgeversregres 'wel eens' contact is geweest tussen VNO en NCW en het Verbond van Verzekeraars, zij het zonder bindende afspraken voor de leden.

Zie infra, paragraaf 4.3 .4 . 
stroom gestandaardiseerd: voor deze werkgevers geldt sindsdien een vast percentage, los van het precieze aantal WAO-ers van het bedrijf. ${ }^{330} \mathrm{Nu}$ de gedifferentieerde WAO-premie voor deze werkgevers is vervallen, is vanzelfsprekend ook voor een individuele compensatie voor dat premiedeel geen plaats. Daarmee is dus wellicht tevens hun stimulans voor het regres van art. 6:107a BW komen te ontbreken.

\subsubsection{Art. 52a ZW, art. 8 WAMIL}

De Ziektewet beoogt een voorziening te treffen voor loonderving gedurende de eerste tweeënvijftig weken van arbeidsongeschiktheid. De wet wordt uitgevoerd door het UWV, maar door de privatisering van grote delen van de Ziektewet is het in verreweg de meeste gevallen de werkgever die het loon doorbetaald. ${ }^{331}$ Wat overblijft is hoofdzakelijk nog haar 'vangnetfunctie' voor werknemers die geen recht hebben op loondoorbetaling van hun werkgever of wier dienstbetrekking tijdens ziekte wordt beëindigd en voor werkeloze werknemers. Zwangerschap en bevalling (in het kader waarvan ook aansprakelijkheid kan bestaan) zijn gelijkgesteld met ziekte. Niet-werknemers zoals zelfstandige ondernemers en jonggehandicapten vallen niet onder de Ziektewet en zullen het risico van inkomensschade tijdens het eerste ziektejaar zelf moeten verzekeren. ${ }^{332}$

Het bedrag waarvoor de Ziektewet aanspraak geeft op een uitkering komt door voordeelstoerekening in mindering op de door de schadeveroorzaker aan de benadeelde verschuldigde schadevergoeding. ${ }^{333}$ Hoewel daarover naar geldend recht onduidelijkheid heerst, behoort dit beperkt te blijven tot het deel van het aansprakelijkheidsrecht dat betrekking heeft op de inkomensschade van de benadeelde uit het eerste ziektejaar, en dus de vordering van de benadeelde met betrekking tot zijn overige schadeposten (latere inkomensschade, ziektekosten, smartengeld, buitengerechtelijke kosten, enzovoort) ongemoeid te laten. Volgens constante jurisprudentie gaat het ook daarbij om het 'netto' ontvangen bedrag. Daarop volgend heeft het uitvoeringsinstituut recht op regres. Art. $52 a \mathrm{ZW}$ luidt:

'Het Uitvoeringsinstituut werknemersverzekeringen heeft voor de krachtens deze wet gemaakte kosten verhaal op degene, die in verband met het veroorzaken van ongeschiktheid tot werken jegens de verze-

Het UWV schat dat ongeveer 36000 werkgevers tegen dit besluit bezwaar hebben aangetekend, omdat ze door het vaste percentage thans een hogere premie zouden betalen dan vootheen bij het gedifferentieerde percentage het geval was (UWV Nieuws, jaargang 2, nr. 2, juni 2003).

331 Dit laatste geldt volgens Noordam (2000), p. 24 voor wel $90 \%$ van de werknemers. Art. $29 \mathrm{ZW}$ bepaalt dat in beginsel geen ziekengeid wordt uitgekeerd als de werknemer recht heeft op loondoorbetaling ingevolge ant. 7:629 BW of het Bezoldigingsbesluit Burgerlijke Rijksambtenaren 1984.

332 Omstreden is of de arbeidsongeschiktheidsverzekerar wordt gesubrogeerd in hun vordering tot schadevergoeding. zie paragraaf 4.3.7.

333 Art. 6:100 BW juncto art. $52 \mathrm{ZW}$ : 'Bij de vaststelling van de schadevergoeding, waarop de verzekerde naar burgerlijk recht aanspraak kan maken ter zake van zjn ongeschiktheid tot werken wegens ziekte, houdt de rechter rekening met de aanspraken, die hij krachtens deze wet heeft.' 
kerde naar burgerlijk recht tot schadevergoeding is verplicht, doch ten hoogste tot het bedrag, waarvoor deze bij het ontbreken van de aanspraken krachtens deze wet naar burgerlijk recht aansprakelijk zou zijn, verminderd met een bedrag. gelijk aan dat van de schadevergoeding tot betaling waarvan de aansprakelijke persoon jegens de verzekerde naar burgerlijk recht is gehouden.'

De praktische betekenis van het regresrecht van art. $52 a \mathrm{ZW}$ lijkt, gelet op de beperkte betekenis die de ZW nog heeft, niet groot. Een voorbeeld daarvan lijkt me het geval waarin een uitzendkrachten door de fout van een ander arbeidsongeschikt raakt terwijl zijn dienstverband tijdens deze periode van ziekte afloopt. Ook valt te denken aan door de fout van een ander (verdergaand) arbeidsongeschikt geraakte werklozen en aan zwanger geraakte werknemers ('wrongful birth'-zaken). ${ }^{334}$ Sinds 1 januari 2001 vallen ook ambtenaren en andere overheidswerknemers (onderwijzend personeel en militairen), ${ }^{335}$ onder de Ziektewet die op of na die datum ziek worden of arbeidsongeschikt. De loondoorbetalingsplicht van de overheid als ambtenarenwerkgever blijft echter bestaan en ook ambtenaren hebben pas recht op ziekengeld als het loon niet of niet langer wordt doorbetaald. Het regresrecht komt toe aan het Uitvoeringsinstituut werknemersverzekeringen, dat belast is met de verantwoordelijkheid voor en coördinatie van de uitvoering van de Ziektewet, en dus niet bij individuele uitvoeringsinstellingen zoals het GAK en de USZO. Voomheer was het Landelijk instrtưt socrale verzekeringen daarmee belast en nog weer vroeger, vóór 1997, was dat het Tijdelijk instituut voor coördinatie en afstemming. Dit heeft in 1996 met het Verbond van Verzekeraars een overeenkomst (convenant) afgesloten voor de afwikkeling van het regres van de Ziektewet. Daarmee werd beoogd vertraging door onenigheid over de omvang van de regresvordering zoveel mogelijk te vermijden. Zo werd overeengekomen dat indien aan de regresvordering geen geschilpunten over schuld en causaliteit (meer) in de weg stonden, de regressom werd vastgesteld door de regresvordering te verminderen met een forfaitaire korting. ${ }^{336} \mathrm{Na}$ de inwerkingtreding van de WULBZ werd een apart convenant voor het (teruggelopen) regres ingevolge de Ziektewet niet nodig geacht. Sinds 1 januari 2001 geldt voor alle regresvorderingen die op of na die datum zijn ontstaan een nieuw convenant van vergelijkbare strekking, voor alle arbeidsongeschiktheidswetten (het Convenant Verhaalsrecht, zie hierna).

\subsubsection{Art. 90 WAO, art. 8 WAMIL, art. 76 WPA}

Gedurende de eerste tweeënvijftig weken van arbeidsongeschiktheid ontvangen werknemers, ook ambtenaren, zoals werd gezien loon van hun werkgever of een

Vgl. HR 21 februari 1997, NJ 1999, 145 nt. CJHB (Wrongful birth).

En enkele specificke categorieěn overheidswerknemers.

Die bedroeg aanvankelijk 24\%. Het Convenant tussen het Verbond van Verzekeraars en het Tica inzake het verhaalsrecht van de Ziektewet d.d. 18 januari 1996 is opgenomen als Bijlage 2 bij Sinninghe Damstè (1999). p. $84-86$. 
uitkering krachtens de Ziektewet. Als het in die periode niet lukt de betrokken werknemer naar de arbeidsmarkt terug te leiden, dan treedt een nieuw traject in van loonvervangende uitkeringen, met name ingevolge de Wet op de arbeidsongeschiktheidsverzekering (WAO). Dat heeft betrekking op de inkomensvoorziening voor vrijwel alle werknemers die langdurig arbeidsongeschiktheid raken (langer dan tweeënvijftig weken). Het regres in dit verband lijkt dan ook het belangrijkste aandeel voor het totale regresvolume op te leveren. ${ }^{337}$ De WAO geldt sinds 1 januari 1998 ook voor ambtenaren, bijzonder onderwijzend overheidspersoneel en militairen.

De regresregeling lijkt sterk op de andere zelfstandige regresregelingen. Het bedrag van de WAO-uitkeringen komt door voordeelstoerekening in mindering op het bedrag waarvoor de schadeveroorzaker jegens de benadeelde aansprakelijk is (art. 6:100 BW juncto art. 89 WAO). Het behoort slechts in mindering te (kunnen) komen op de inkomensschade die zonder de uitkeringen na afloop van het eerste ziektejaar zijn ontstaan, niet ook op andere schadeposten. Net als bij de overige sociale verzekeringen heeft de benadeelde geen keuze om voor de schade waarvoor hij WAO-aanspraken heeft een vordering tot schadevergoeding in te stellen jegens de schadeveroorzaker. Reeds het bedrag van de aanspraak ingevolge de WAO komt in mindering op zijn vordering, ongeacht of die al tot feitelijke betaling is gekomen. ${ }^{338}$ Voor het overige deel van de schade (inkomens- en andere schade waarvoor geen WAO-aanspraken bestaan) behoudt de benadeelde zijn recht op schadevergoeding. Te bedenken valt dat de WAO-uitkering slechts een getarifieerd percentage van het krachtens de Coördinatiewet sociale verzekering vastgestelde dagloon bedraagt. Voorzover het dagloon van de werknemer hoger is dan het dagloon krachtens de Coördinatiewet komt het niet voor een WAO-uitkering in aanmerking. ${ }^{339}$

Volgens art. 90 WAO heeft het UWV een regresrecht jegens de schadeveroorzaker:

$\because$ 1. Het Uitvoeringsinstituut werknemersverzekeringen heeft voor de krachtens deze wet gemaakte kosten verhaal op degene, die in verband met het veroorzaken van arbeidsongeschiktheid jegens de verzekerde naar burgerlijk recht tot schadevergoeding is verplicht, doch ten hoogste tot het bedrag, waarvoor deze bij het ontbreken van de aanspraken krachtens deze wet naar burgerlijk recht aansprakelijk zou zijn, verminderd met een bedrag, gelijk aan dat van de schadevergoeding tot betaling waarvan de aansprakelijke persoon jegens de verzekerde naar burgerlijk recht is gehouden.

-2. Overeenkomstig door Onze Minister te stellen regelen kan het Uitvoeringsinstituut werknemersverzekeringen in plaats van het bedrag der periodieke verstrekkingen de contante waarde daarvan vorderen.'

In het jaar 1999 waren er naar schatting maar liefst 900000 langdurig arbeidsongeschikten, 20 stelt Noordam $(2000)$, p. 28. Interessant zou zijn te weten welk percentage darvan tevens een beroep toekwam op het aansprakelijkheidsrecht.

Art. 89 WAO: 'Bij de vaststelling van de schadevergoeding, waarop de verzekerde naar burgerlijk recht anspraik kan maken ter zake van zijn arbeidsongeschiktheid, houdt de rechter rekening met de aanspraken, die hij krachtens deze wet heeft.'

De 'hoog' betalde werknemers zullen dus relatief meer schade zeif lijden, aldus Schoordijk (1967), p. 348. 
Het eerste lid geeft het Uitvoeringsinstituut werknemersverzekeringen recht op regres voor de 'krachtens deze wet gemaakte kosten'. Dit betekent niet dat de WAO-uitkeringen ook volledig door de regresnemende instantie moeten zijn gefinancierd. ${ }^{340}$ Onduidelijk is of het regresrecht van het eerste lid óók geldt voor WAO-uitkeringen die uit hoofde van de vrijwillig bij het Uitvoeringsinstituut werknemersverzekeringen afgesloten verzekering worden gedaan. ${ }^{341}$ Het sociale karakter van de verzekering lijkt dan te overwegen; het meest voor de hand ligt dan dat niet art. $284 \mathrm{WvK}$ geldt, maar art. 90 WAO van toepassing blijft. Het regres van de WAO-uitkeringen voor ambtenaren verloopt langs een ander traject, dat thans (onder meer) in handen is van het Fonds arbeidsongeschiktheidsverzekering overheidspersoneel. ${ }^{342}$ Voorzover het Fonds WAO-uitkeringen verstrekt aan arbeidsongeschikt geraakte ambtenaren is de regresregeling van de WAO van overeenkomstige toepassing. ${ }^{343}$

Net als bij de andere zelfstandige regresregelingen is het regresrecht beperkt tot het bedrag dat de schadeveroorzaker bij het ontbreken van de WAO-uitkering in zijn verhouding tot de benadeelde verschuldigd zou zijn geweest. Aangenomen wordt wel dat het civiele plafond het bedrag is dat de schadeveroorzaker bij het ontbreken van de uitkering over de gehele duur van arbeidsongeschiktheid verschuldigd zou zijn. In dit verband moet worden gewezen op het Convenant Verhaalsrecht 2001 , waarin afspraken zijn neergelegd tussen (thans) het UWV en WA-verzekeraars ter vereenvoudiging van het regres voor de arbeidsongeschiktheidswetten. Volgens dit convenant worden de regresvorderingen van het UWV die betrekking hebben op inkomensschade geacht beneden het civiele plafond te blijven (art. 3). Voorts bepaalt het dat partijen die deelnemen aan dit convenant (meer dan $95 \%$ van de aansprakelijkheidsverzekeraars doet mee), ${ }^{344}$ voor de duur van het convenant jegens elkaar geen beroep doen op rechterlijke uitspraken over het civiele plafond in procedures waarbij niet-deelnemers betrokken zijn (art. 4). Daaronder is tevens de bruto netto problematiek begrepen, die vraagt om een afzonderlijke bespreking. ${ }^{345}$ In zoverre zijn van het civiele plafond, een van de belangrijkste bronnen voor geschillen bij het WAO-regres, dus weinig moeilijkheden meer te verwachten. De langdurige arbeidsongeschiktheid zorgt wel nog voor bijzondere complicaties. De WAO heeft betrekking op een vervolgtraject, hetgeen tot gevolg

$340 \mathrm{Vgl}$. voor de oude Ongevallenwet: HR 23 juni 1961, NJ 1961, 397 (Eerste Rottendamsche/Visser), met scherpe kritick van Van der Veen (1961), p. 931.

341 Van Boom (2000a), p. 17 wijst hierop, zie art. 81 e.v. WAO.

342 Voor alle voorafgaand aan de privatisering ingestelde vorderingen treedt het fonds in alle rechten van het $A B P$. Art. 76 WPABP bepaalt: 'Voor de uitoefening van het verhaalsrecht (van art. 76 lid 1 WPABP juncto art. 90 WAO, EE) treedt het FAOP wat betreft de door hem verrichte en te verrichten uitkeringen, onder algemene titel in de rechten en verplichtingen van het ABP."

Art. 76 lid I WPABP: 'Ten aanzien van verhaal van kosten die het FAOP mankt bij de overeenkomstige toepassing van de WAO, zijn de artikelen 90 en 91 van die wet van overeenkomstige tocpassing.'

Zie paragraaf 8.2 . 
heeft dat sprake is van een 'opeenstapeling van regresrechten': naast de WAOvordering staan de vorderingen ingevolge art. 6:107a BW dan wel de Ziektewet. Om dubbele betaling of miscalculaties te voorkomen zal de aansprakelijkheid bij samenlopende regresrechten beperkt moeten worden naar de hoogte en duur van de inkomensschade waarop de uitkering is gebaseerd. Bij regres krachtens de Ziektewet kan dan alleen de inkomensschade van het eerste ziektejaar in aanmerking worden genomen en bij regres in het kader van de WAO alleen de schade over de periode van de WAO-uitkering. ${ }^{346}$ Een ander typisch WAO-probleem voor de berekening van het civiele plafond (maar dat ook voorkomt in gevallen van kortdurende arbeidsongeschiktheid), is dat de einddatum voor het vaststellen van de aansprakelijkheid in het schadevergoedingsrecht vaak lastig bepaalbaar is. Bij uitstek geldt dat als het vooruitzicht van herstel door revalidatie en de mogelijkheid van deelneming door de benadeelde aan het arbeidsproces nog onzeker zijn. $^{347}$

Over de omvang van de regresvordering zijn ook afgezien van het civiele plafond (en de bruto netto problematiek in dat verband) afspraken neergelegd in het Convenant Verhaalsrecht 2001. Art. 2, de kernbepaling van het convenant, bepaalt dat voor de regresvorderingen waarvoor dit geldt (ingevolge de ZW, WAO, WAZ, en WAJONG) wordt uitgegaan van de bruto-uitkering op grond van deze wetten. De regresvordering wordt vervolgens verminderd met een forfaitaire korting van $22 \%$. ${ }^{348}$ Ondanks de werking van dit convenant zou een totale afkoopregeling, zuiver wetssystematisch gezien voor art. 90 WAO niet misstaan. Het tweede artikellid voorziet momenteel slechts in de mogelijkheid van afkoop van de zogenaamde 'contante waarde' van alle periodieke vorderingen die betrekking hebben op één individuele verzekerde. ${ }^{349}$ Voor andere arbeidsongeschiktheidswetten bij langdurige arbeidsongeschiktheid (WAZ en WAJONG, zie hierna) geldt een regeling voor de afkoop van de collectieve regresvorderingen van alle verzekerden tezamen (generale collectieve afkoop). ${ }^{350}$

Het regres ingevolge art. 90 lid 1 WAO geldt alleen voor de WAO-uitkeringen die het UWV doet. In die gevallen zijn werkgevers 'normaal' WAO-verzekerd en betalen voor het WAO-risico van de eerste vijf jaar van arbeidsongeschiktheid

346 Giltay Veth (1969), p. 213. Niet nodig is dat de betrokken verzekering of voorziening al tot betaling is gekomen, HR 18 juni 1982, NJ 1983, 369 (Peters/Bedriffsvereniging).

34) Zie HR 8 december 1938, NJ 1939.545 nt. EMM (Rijksverzekeringsbank/Schônberger) en Giltay Veth (1969), p. 238.

348 Voor de regresvorderingen die nog vallen onder het WAO-Convenant van 27 november 1998 geldt een korting van $24 \%$.

349 Dat kan pas als de Gemeenschappelijke Medische Dienst de eindtoestand had vastgesteld, zie Schadevergoeding. art. 108 (Bolt), aant. 70.

350 VgL. TK 1998-99, 26239 , nr. 3 (MvT), p. 20, waar gelijkschakeling wenselijk wordt geacht, zij het in die zin dat daar nog wordt voorgesteld om 'in de artikelen 69, tweede lid van de WAZ en 61, tweede lid van de WASONG de formulering van art. 90 , tweede lid WAO over te nemen.' Nu dit laatste niet is gebeurd mag worden verwacht dat het de WAO is, die zal worden aangepast. 
naast het basisdeel van de premies een gedifferentieerd bedrag. De hoogte daarvan hangt af van het arbeidsongeschiktheidsrisico, het aantal arbeidsongeschikten dat op het moment van meting nog geen vijf jaar in de WAO zit, binnen hun bedrijf. 'Grotere' werkgevers echter kunnen het vijfjarige risico van inkomensschade van hun werknemers zelf dragen, en dus als 'eigen-risicodrager' optreden. De werkgever draagt het risico van inkomensschade van zijn werknemers dan zelf, particulier, maar slechts voor de genoemde vijf jaar. Dat betekent dat hij geen WAO-premies hoeft af te dragen, en kan proberen de kosten laag te houden door het treffen van preventieve maatregelen die de uitkeringenlast beperkt houden. Het arbeidsongeschiktheidsrisico na de genoemde vijf jaar wordt wèl weer gedragen door het UWV. ${ }^{351}$ Eigen-risicodragers hebben ingevolge het derde lid van art. 90 WAO recht op regres en verkeren daardoor in de mogelijkheid om hun WAO-gerelateerde kosten te laten dragen door de schadeveroorzaker (uit hoofde van diens aansprakelijkheid jegens de benadeelde). Het derde lid van art. 90 WAO luidt:

- 3. De eigen risicodrager treedt voor de toepassing van het eerste en het tweede lid in de plaats van het Uitvoeringsinstituut werknemersverzekeringen voorzover hij het risico van de betaling van de arbeidsongeschiktheidsuitkering draagt.'

Deze bepaling geldt alleen voor de 'eigen-risicodragende' werkgever, die in staat is om het risico van de inkomensschade gedurende de eerste vijf jaar van arbeidsongeschiktheid niet te laten dragen door het WAO-orgaan, maar het zelfstandig te dragen of het particulier te verzekeren. ${ }^{352}$ Als de werkgever het risico van loondoorbetaling bij een particuliere arbeidsongeschiktheidsverzekeraar heeft ondergebracht, dan kan deze onder omstandigheden in de vordering van de benadeelde worden gesubrogeerd. ${ }^{353}$

Op deze regeling voor eigen-risicodragers was aanvankelijk kritiek: zij zou werkgevers die eigen risicodrager zijn in een aanmerkelijk voordeligere positie brengen dan werkgevers die het WAO-risico gewoon door het UWV laten dragen. Deze 'normaal' WAO-verzekerde werkgevers zijn voor wat betreft de hoogte van de WAO-premies, of beter, het genoemde gedifferentieerde deel daarvan, afhankelijk van het arbeidsongeschiktheidspercentage in hun eigen bedrijf. Indien de arbeidsongeschiktheid te wijten is aan externe schadeveroorzakers, dan betekent dat voor deze werkgevers extra lasten (in de vorm van hogere premies) zonder dat ze daarvoor regres hebben. Weliswaar heeft het UWV ingevolge art. 90 lid 1 WAO een regresrecht voor de WAO-uitkeringen in deze (normale) gevallen, maar de opbreng-

De reden dat het eigen-risicodragen slechts mogelijk is gedurende de eerste vijf jaar van arbeidsongeschiktheid en niet ook voor de periode nadien (indien de arbeidsongeschiktheid voortduurt) schijnt te zijn dat particuliere verzekeraars dan de eerste jaren (te) hoge premies zouden moeten rekenen (in verband met het verplichte kapitaaldekkingsstelsel), hetgeen herverzekeren kostbaar - en dus voor werkgevers onaantrekkelijk - zou maken. Door de Wet premiedifferentiatic en marktwerking bij arbeidsongeschiktheidsverzekeringen, TK 1995-96, 24 698.

353 Zie nader paragraaf 4.3 .7 
sten daarvan werden niet doorberekend naar het gedifferentieerde premiedeel van de (betreffende) werkgever. Dit werd als onbillijk ervaren. ${ }^{354}$ Waarom zou men, ervan uitgaande dat deze differentiatie slechts bedoeld is om werkgevers te confronteren met de risico's binnen hun bedrijf, óók een hogere premie moeten betalen als de arbeidsongeschiktheid de schuld was van derden (buiten het bedrijf)?

Meer recent heeft de regering daarom de mogelijkheid geopend om ook de 'normaal' WAO-verzekerde werkgevers te laten delen in de regresopbrengsten. ${ }^{355}$ Volgens een nieuwe maatregel ontvangen deze werkgevers in regressituaties voor het gedifferentieerde deel van de WAO-premies een compensatie (in de vorm van een premiecorrectie). Deze compensatie is afhankelijk gesteld van de vraag of $z e$ in het concrete geval tevens zelf regres hebben ingesteld in het kader van art. 6:107a BW (dan wel of hun particuliere verzekeraar dat heeft gedaan) en daaruit regresopbrengsten hebben ontvangen. ${ }^{356}$ In WAO-gevallen waarin plaats is voor regres kan de werkgever of diens verzekeraar immers, ook voor de loonkosten van het eerste ziektejaar regres zoeken. Alleen als ook de regresactie ingevolge art. 6:107a BW (c.q. art. $284 \mathrm{WvK} / \mathrm{art}$. 7.17.2.25 BW) succesvol was, kan de werkgever bij het UWV een verzoek indienen tot het verkrijgen van een (aan de regresopbrengsten gerelateerde) compensatie. De 'kleine' werkgever waarvoor onlangs bij het Besluit tot afschaffing van de Pemba voor kleine ondernemers is gaan gelden heeft daar, dunkt me, niets aan. De aan de WAO-instroom gerelateerde opslag of korting op de WAO-premie is voor hen bij dat besluit immers op een vast percentage gesteld.

Met de nieuwe compensatiemaatregel is beoogd de onbillijkheid weg te nemen van de premiedifferentiatie voor de werkgever in regressituaties: hij ondervindt dan immers door toedoen van de schadeveroorzaker premienadeel, zonder dat hij dààrvoor verhaal heeft, terwijl eigen risicodragers voor de door hen gemaakte kosten wèl een regresrecht hebben. Het is technisch een ingenieuze oplossing, die met name de grote werkgevers (tevens) kan aansporen tot het voeren van een actiever regresbeleid. Dat lijkt gelet op de doelstellingen van het regres toe te juichen. ${ }^{357} \mathrm{Bij}$ de wijze waarop dat gebeurt heb ik twijfels. Vanuit civielrechtelijk oogpunt geldt ook voor anderen zonder regresrecht dat hun schade (premienadeel of andere schade), die ze van het schadevoorval vinden, civielrechtelijk niet kan worden verhaald. Bovendien is zeer de vraag of de compensatie die het kabinet de werkgever hiermee in het vooruitzicht stelt (en waarvan hij overigens de facto pas voor een toekomstig premiejaar, twee jaar na het indienen van het verzoek, de vruchten plukt) kan opwegen tegen de matige opbrengsten (het brutodeel van

155 Besluit van 4 maat 2002 tot wijziging van het Besluit Premiedifferentiatie WAO (Regres en premievermindering WAO), Stb. 2002, 138. Het besluit is met terugwerkende kracht vanaf I januari 2002 ingegaan. Plannen in deze richting worden al zjjelings genoemd bij lanssen (1997), p. 159 en Pardaan (2001), p. 15.

356 Voordat de werkgever het verzoek tot compensatie bij het UWV kan aanvragen, moet hij de regresopbrengsten met betrekking tot het eerste ziektejaar heiemaal en definitief (geen voorschot) hebben ontvangen.

In paragraaf 6.4 wordt uiteengezet welke dat (primair) zijn. 
het doorbetaalde loon kan niet volledig worden verhaald, zie paragraaf 7.2) en veelal de hoge kosten van het werkgeversregres van art. 6:107a BW. De onderhavige premiemaatregel dient als stimulans voor het regres (en de daaraan verbonden doelstellingen), maar is dunkt me voor werkgevers te weinig aantrekkelijk om effectief te kunnen zijn. Beter ware het regresrecht zelf op enkele punten wat aantrekkelijker te maken voor de werkgever door een einde te maken aan enkele moeilijk te funderen beperkingen: het netto regres als absolute regel en de beperking van art. 6:107a BW tot verplicht doorbetaald loon. Om een einde te maken aan de genoemde ongelijkheid met eigen-risicodragers lijkt het dan beter gewoon ten behoeve van deze werkgevers een vast (sociaalrechtelijk) percentage te verdisconteren bij de berekening van de premie.

\subsubsection{Art. 69 WAZ en art. 6I WAJONG, art. 8 WAMIL}

Naast de WAO gelden voor de inkomensschade bij langdurige arbeidsongeschiktheid twee nieuwe regelingen: de Wet arbeidsongeschiktheidsverzekering zelfstandigen (WAZ) en de Wet arbeidsongeschiktheidsvoorziening jonggehandicapten (WAJONG). De eerstgenoemde van de twee wetten geldt specifiek voor zelfstandigen en vrije beroepsbeoefenaren (zoals advocaten, notarissen of artsen), ${ }^{358}$ hun meewerkende echtgenoten en voorts directeuren en grootaandeelhouders. De krachtens deze wet verschuldigde uitkeringen komen, net als bij de WAO, in mindering op de door de schadeveroorzaker aan de benadeelde verschuldigde schadevergoeding voor het betreffende deel van de inkomensschade. ${ }^{359}$ Art. 69 WAZ regelt dat het UWV een regresrecht toekomt:

'- 1. Het Uitvoeringsinstituut werknemersverzekeringen heeft voor de op grond van deze wet gemaakte kosten verhaal op de persoon (op degene?, EE) die in verband met het veroorzaken van arbeidsongeschiktheid jegens de verzekerde naar burgerlijk recht tot schadevergoeding is verplicht, doch ten hoogste tot het bedrag, waarvoor deze bij het ontbreken van de aanspraken krachtens deze wet naar burgerlijk recht aansprakelijk zou zijn, verminderd met een bedrag, gelijk aan dat van de schadevergoeding tot betaling waarvan de aansprakelijke persoon jegens de verzekerde naar burgerlijk recht is gehouden.

- 2. Het Uitvoeringsinstituut werknemersverzekeringen kan in plaats van het bedrag van de periodieke verstrekkingen de contante waarde daarvan vorderen in de vorm van een jaarlijks vast te stellen afkoopsom die aan het Uitvoeringsinstituut werknemersverzekeringen wordt vergoed voor de totale schadelast ten gevolge van het veroorzaken van arbeidsongeschiktheid.'

De WAJONG geeft een inkomensvoorziening aan, kort gezegd, gehandicapten met nog geen of weinig werkervaring en gehandicapt geraakte studenten. Deze en winst uit ondememing geniet. Noordam (2000), p. 29 en Pardaan (2001), p. 24. 
wordt niet uit sociale premies maar uit de algemene middelen gefinancierd. Het is dus strikt genomen geen sociale verzekering, maar een sociale voorziening en daarmee de eerste sociale voorziening die in een regresregeling voorziet. Voorop staat ook hier dat de krachtens de wet aan de benadeelde verschuldigde bedragen in mindering komen op het recht op schadevergoeding dat de benadeelde heeft met betrekking tot zijn inkomensschade gedurende die periode. ${ }^{360}$ Vervolgens geeft art. 61 het regresrecht voor het UWV:

$\div$ 1. Het Uitvoeringsinstituut werknemersverzekeringen heeft voor de op grond van deze wet gemaakte kosten verhaal op degene, die in verband met het veroorzaken van arbeidsongeschiktheid jegens de jonggehandicapte naar burgerlijk recht tot schadevergoeding is verplicht, doch ten hoogste tot het bedrag, waarvoor deze bij het ontbreken van de aanspraken krachtens deze wet naar burgerlijk recht aansprakelijk zou zijn, verminderd met een bedrag, gelijk aan dat van de schadevergoeding tot betaling waarvan de aansprakelijke persoon jegens de jonggehandicapte naar burgerlijk recht is gehouden.

-2. Het Uitvoeringsinstituut werknemersverzekeringen kan in plaats van het bedrag van de periodicke verstrekkingen de contante waarde daarvan vorderen in de vorm van een jaarlijks vast te stellen afkoopsom die aan het Uitvoeringsinstituut werknemersverzekeringen wordt vergoed voor de totale schadelast ten gevolge van het veroorzaken van arbeidsongeschiktheid."

De regresregelingen van de WAZ en de WAJONG voorzien beide in een generale afkoopregeling, dat wil zeggen een regeling die erop neerkomt dat UWV en WAverzekeraars één bedrag overeenkomen waarmee alle regresvorderingen ineens worden afgekocht. De band met individuele vorderingen wordt dan dus volledig doorgesneden. Daarvan is thans nog geen sprake, het regres vindt nog plaats voor individuele gevallen afzonderlijk en dus niet in de vorm van een algehele afkoopsom. Wèl geldt het genoemde WAO-convenant ook voor de regresvorderingen ingevolge de WAZ en de WAJONG. Wellicht kunnen de drie arbeidsongeschiktheidsregelingen in de toekomst tezamen worden afgekocht. ${ }^{361}$

\subsubsection{Art. 2 lid 2 VOA, art. 75 WPA, art. X4 AMP}

Tot 1998 waren er op het gebied van inkomensschade rechtspositioneel gezien vrij grote verschillen tussen de positie van ambtenaren (en arbeidscontractanten bij de overheid) en gewone werknemers (in de zin van titel 7.10 BW). De bijzondere positie van ambtenaren was met name eraan te wijten dat de werknemersverzekeringen voor hen niet golden. Ook het regresregime was daardoor anders. Inmiddels is daarin enige verandering gekomen; de inhoudelijke verschillen tussen ambtenaren en werknemers zijn grotendeels verdwenen. De verschillen die er nog

\footnotetext{
360 Art. 60 WANONG: 'Bij de vaststelling van de schadevergoeding, waarop de jonggehandicapte naar burgerlijk recht aanspraak kan maken ter zake van zijn arbeidsongeschiktheid, houdt de rechter rekening met de aanspraken, die hij op grond van deze wet heeft.'

46) Dat cen wettelijke grondslag darvoor ontbroekt in art. 90 WAO lijkt me voor het maken van onderlinge afspraken in die richting geen beletsel. Zelf zou ik van collectivering overigens geen voorstander zijn, zie paragraaf 6.5 .2$.
} 
wèl zijn werken wel nog door naar het regres, en vragen daarom nog afzonderlijk aandacht.

Ambtenaren hebben krachtens bijzondere rechtspositieregelingen net als andere werknemers recht op loondoorbetaling gedurende het eerste jaar van ziekte of arbeidsongeschiktheid en voorts recht op een pensioen. ${ }^{362}$ Ook de ambtenaar die slachtoffer werd van een ongeval heeft gedurende tweeënvijftig weken, te rekenen vanaf de eerste ziektedag, recht op doorbetaling van zijn bezoldiging. Daarna kunnen ambtenaren in beginsel op grond van hun dienstbetrekking in aanmerking komen voor een WAO-uitkering met een bovenwettelijke uitkering. ${ }^{363}$ De bovenwettelijke uitkering vult tijdens de eerste zesentwintig weken de WAOuitkering aan tot $100 \%{ }^{364}$ De WAO-uitkeringen worden verstrekt door het UWV, dat de feitelijke uitvoering (voorlopig) heeft uitbesteed aan het USZO. Daarvoor geldt het (normale) regime van art. 90 WAO. Het FAOP is als rechtsopvolger onder algemene titel van het $\mathrm{ABP}$ belast met de toepassing van bepaalde onderdelen van de WAO op overheidspersoneel en het kan daarvoor ook een beroep doen op het regresrecht van art. 90 WAO (zie art. 76 lid 2 Wet privatisering ABP). De bovenwettelijke voorzieningen worden verstrekt door de betrokken overheidslichamen. De Verhaalswet ongevallen ambtenaren (VOA) geeft hen daarvoor een zelfstandig regresrecht jegens de schadeveroorzaker (uit hoofde van diens aansprakelijkheid jegens de benadeelde), ${ }^{365}$ mits de uitkeringen niet het karakter hebben van ouderdomspensioen. ${ }^{366}$ Voor de voormalige dienstplichtige militairen, die bij of na het eindigen van de dienstplicht arbeidsongeschikt waren of werden geldt niet het regime van de VOA, maar zijn de regresregelingen van de Ziektewet en de WAO van overeenkomstige toepassing. Wel wordt de VOA van overeenkomstige toepassing verklaard door de Algemene Burgerlijke Pensioenwet, en voor uitkeringen aan beroepsmilitairen. ${ }^{367}$ De regresregeling van de VOA kwam al aan de orde; het daar gezegde geldt mutatis mutandis ook hier. Voor het doorbetaalde loon bepaalt art. 2 VOA in het tweede lid:

- 2. Is de ambtenaar ten gevolge van het ongeval geheel of voor een deel van zijn normale diensttijd verhinderd zijn dienst te verrichten, dan worden de krachtens zijn rechtspositieregeling over de periode van die gehele of gedeeltelijke verhindering uitbetaalde bezoldiging of beloning en hiermede verband houdende uitkeringen - met inbegrip van de ingehouden loonbelasting en van de premie voor sociale

Als 'ambtenaar' worden in dit verband aangemerkt degenen die uit hoofde van een dienstbetrekking loon ontvangen dat rechtstreeks of krachtens subsidieregelingen ten laste komt van de openbare geldmiddelen.

363 Wel maakt verschil of de ambtenaar deelnemer is in het pensioenreglement van de Stichting Pensioenfonds ABP, zie art. 37 en 38 ARAR.

Bij ongevallen die 'in overwegende mate hun oorzaak vinden in het werk' ook nog nadien, art. 37 lid 4 ARAR. Mok (1977), p. 164 spreekt in dit verband van een privaatrechtelijk verhaalsrecht en noemt de regresbepaling van lid I van publiekrechtelijke aard.

366 In die zin oordeelde de Hoge Raad in HR 22 juni 1990, NJ 1991, 760 nt. CJHB (ABP/Baasw) voor het op de voet van art, F12 Algemene Bungerlijke Pensioenwet herberckende pensioen. Dat sluit aan bij de gedachte van een postenstelsel voor het regres, zie paragraaf 7.4.2. 
voorzieningen geheel of voor een met de mate van de verhindering overeenkomend deel onder de in het eerste lid bedoelde uitkeringen begrepen (cursief toegevoegd, EE).

Het VOA-regres geldt voor het doorbetaalde salaris, het tweede lid spreekt met zoveel woorden van het bruto betaalde bedrag, èn de loongerelateerde betalingen ('met het loon verband houdende betalingen'). Onder dit laatste worden in de woorden van de Memorie van Toelichting 'onder meer verstaan de kinderbijslag en de vakantieuitkering (niet de premies voor eventuele premiespaarregelingen van de benadeelde). ${ }^{.368}$ In het arrest Gemeente Sneek/Oosterhof beperkt de Hoge Raad dit bruto-deel tot de loonbelasting en sociale premies die ten laste van de ambtenaar zijn ingehouden, dus slechts tot het werknemersdeel van de belasting en de premies. Ook voor de pensioenbijdrage is het regres volgens de raad beperkt tot het bedrag waarvoor die ten laste komt van de ambtenaar zelf. ${ }^{369}$ Bedragen die uit het AAF-fonds zijn ontvangen plegen op de regresvordering van Staat of $\mathrm{ABP}$ in mindering te worden gebracht. ${ }^{30}$

Anders dan bij 'normale', particuliere werkgevers lijkt het regresrecht van de VOA de facto ook mogelijk voor onverschuldigd gedane uitkeringen. Volgens de Hoge Raad geeft de VOA immers, zoals gezegd, een regresrecht voor de kosten van de aldaar bedoelde voorzieningen 'op grond van het enkele feit dat het lichaam aan de ambtenaar krachtens diens rechtspositieregeling uitkeringen of verstrekkingen heeft verleend'. ${ }^{371}$ Dat levert een niet goed uit te leggen verschil op met de regresregeling voor particuliere werkgevers voor het doorbetaalde loon (art. 6:107a $\mathrm{BW}$ ): die geldt niet ook voor de loondoorbetaling die onverplicht plaatsvond (ongeacht of dat in het kader van de arbeidsovereenkomst gebeurde).

\subsubsection{Art. 284 WvK/art. 7.17.2.25 BW}

Hoe is de regresregeling voor particuliere verzekeraars die het risico van inkomensschade dragen? Onderscheid moet worden gemaakt tussen particuliere verzekeraars van de werkgever dan wel van de werknemer. Om met de laatste te beginnen, de benadeelde kan zèlf het risico van inkomensschade hebben verzekerd (of meeverzekerd zijn), opdat aanvullende bescherming wordt verkregen naast de bescherming van de sociale verzekeringen. Te denken valt aan zelfstandige ondernemers en aan jonggehandicapten (voorzover men niet onder het regime van de Algemene bijstandswet valt). Zoals gezegd, ${ }^{372}$ is er discussie over de vraag of arbeidsonge-

TK 1964-65, 7812, nr. 3 (MvT), p. 4 (1.kolom).

HR 5 december 1969, NJ 1970, 140 (Gemeente Sneek/Oosterhof.

$\mathrm{Vgl}$. Hof Den Boseh 26 september 1995, NJ 1997, 460 (Thijssen/ABP), waar bleek dat de Staat en het ABP die bedragen zelf al op hun regresvordering in mindering pleegden te brengen. wijst erop dat het regres voor uitkeringen of verstrekkingen die zelfs buiten de rechtspositieregeling om gaan. strikt genomen, well uitgesioten behoort te zijn.

Paragraf 3.3.5.3.
} 
schiktheidsverzekeringen en ongevallenverzekeringen als schade dan wel sommenverzekeringen moeten worden aangemerkt. In het voorgaande werd de voorkeur uitgesproken om slechts verzekeringen die volledig losstaan van de concrete schade van de benadeelde als sommenverzekering te kwalificeren. Het gaat dan om verzekeringen die niet strekken tot het vergoeden van schade die tevens kan worden aangemerkt als schade in de zin van art. 6:95 BW (de materiële of immateriële gevolgen van het letsel of overlijden, concrete schadeposten). Ongevallenverzekeringen en/of arbeidsongeschiktheidsverzekeringen waarbij wordt uitgekeerd aan de hand van standaardpercentages en/of getarifieerde bedragen die zijn afgestemd op of bedoeld voor de concrete inkomenspositie van de benadeelde althans strekken tot vergoeding van zijn concrete inkomensschade, hebben in beginsel voldoende schadevergoedingskarakter om ze als schadeverzekering aan te merken. Indien uit hoofde daarvan wordt uitgekeerd aan de benadeelde, dan wordt de verzekeraar gesubrogeerd in diens vordering tot schadevergoeding (art. $284 \mathrm{WvK} /$ art. 7.17.2.25 BW) ${ }^{373}$ Verwezen zij naar paragraaf 4.6.

Anders ligt het bij de vraag naar subrogatie voor herverzekeraars waarbij het risico van de werkgever is ondergebracht. Werkgevers kunnen het risico van loondoorbetaling gedurende het eerste ziektejaar zelf dragen of zich daarvoor particulier verzekeren (veelal geldt dan overigens een eigen risico voor de loondaarhetaling gedu. rende de eerste weken, en komt dan dus nog steeds een belangrijk deel van het ziekteverzuim voor rekening van de werkgever). Ook de werkgevers die ingevolge de WAO als eigen-risicodrager optreden voor het risico van inkomensschade gedurende de eerste vijf jaar van de langdurige arbeidsongeschiktheid, kunnen (of: moeten) dat risico (her)verzekeren. Dit lijkt vooralsnog met name interessant voor kleine ondernemingen: slechts enkele zieke werknemers kunnen dan immers een relatief hoog ziekteverzuim opleveren. Dat maakt dat de financiële last voor kleine ondernemers - waarbij dan vervanging nodig is of aan productiviteit moet worden ingeleverd - relatief zwaar weegt. Hoe dit zij, door de belasting van werkgevers met het risico van inkomensschade wordt het van toenemend belang om te weten of zulke verzekeraars zich voor de betreffende loongerelateerde uitkeringen kunnen verhalen. Belang daarbij heeft niet in de laatste plaats ook de bij hen verzekerde werkgever zèlf: de regresopbrengsten die door subrogatie zijn verkregen komen veelal in mindering op de schadelast waarover de werkgever de premies betaalt, maar óók kan de werkgever - indien hij geen eigen-risicodrager is - voor de opbrengsten die de verzekeraar daarbij behaalt een compensatie krijgen voor (het gedifferentieerde deel van) de WAO-premies. Een technisch probleem is intussen wèl dat art. $284 \mathrm{WvK}$ en art. 7.17.2.25 BW slechts kunnen leiden tot de rechtsovergang van een vordering tot schadevergoeding, en dus niet van regresvorderingen. Om zich toch van de mogelijkheid van subrogatie te verzekeren ligt een daarop gericht polisbeding in de rede, waarin onder verzekerde ook de werknemer van 
de verzekeringsnemer wordt begrepen. Veelal is het echter zo geregeld, dat als de verzekering tot uitkering komt, de verzekeringsmaatschappij aan de werkgever uitbetaalt, en dat de werkgever het loon doorbetaald. De uitkering van de verzekeringsmaatschappij is kortom voor de werkgever; het is zijn verzekering. De benadeelde/werknemer heeft recht op doorbetaling van het loon, hetgeen los staat van de verzekering. Indien de verzekeraar echter desondanks ook als verzekeraar van de benadeelde (de werknemer) kan worden aangemerkt, dan kan hij in diens vordering worden gesubrogeerd (de vordering tot schadevergoeding die de benadeelde zonder loondoorbetaling jegens de schadeveroorzaker hebben gehad). Voor de strekking van polisbedingen die de werkgever op grond van het regres premievoordeel toestaan alsmede voor de stimuleringsmaatregel voor premiecompensatie in het kader van de WAO, is dat een zuiver dogmatisch verschil, voor het belang van de regresopbrengsten zal het immers weinig uitmaken op welke vordering de subrogatie precies berust. Aangenomen moet echter worden dat die regelingen alleen betrekking kunnen hebben op de subrogatie in de vordering van de benadeelde, en niet op de (niet geldige) subrogatie in de regresvordering ingevolge art. 6:107a BW van de werkgever. Als de 'her'verzekeraar niet tevens als verzekeraar van de werknemers van het betrokken bedrijf kan worden aangemerkt, dan is cessie de (enige) aangewezen weg tot verhaal.

\subsubsection{Art. 49 REA}

In de sfeer van inkomensschadeen arbeidsongeschiktheid vraagt de regresregeling van de Wet op de (re)integratie arbeidsgehandicapter (REA) nog aandacht. Deze is zonder veel omhaal of discussie in 1998 ingevoerd. De strekking van de REA is blijkens de considerans 'een krachtige impuls' te geven aan de integratie en reïntegratie van arbeidsgehandicapten. Daartoe belast de REA de werkgever en het UWV met een aantal nieuwe rechten, bevoegdheden en verplichtingen die herintreding moeten bevorderen en institutionele belemmeringen moeten wegnemen. Net als de andere zelfstandige regresregelingen schrijft de REA voor dat het bedrag van de aanspraken die de benadeelde aan deze wet kan ontlenen in mindering komt op zijn recht op schadevergoeding. ${ }^{374}$ Art. 49 REA regelt geeft het UWV een regresrecht jegens de schadeveroorzaker:

$\{1$. Het Uitvoeringsinstituut werknemersverzekeringen heeft voor de op grond van deze wet gemaakte kosten verhaal op de persoon (op degene?, EE), die in verband met het veroorzaken van de arbeidshandicap, jegens de arbeidsgehandicapte, bedoeld in artikel 10, naar burgerlijk recht tot schadevergoeding verplicht is, doch ten hoogste tot het bedrag, waarover [waarvoor? EE] deze bij het ontbreken van de aanspraken op grond van deze wet naar burgerlijk recht verplicht zou zijn, verminderd met een

Art. 48 REA: 'Bij de vaststelling van de schadevergoeding, waarop de arbeidsgehandicapte, bedoeld in ant. 10, naar burgerlijk recht aanspraak kan maken terzake van zijn arbeidshandicap houdt de rechter rekening met de aanspraken die de arbeidsgehandicapte op grond van deze wet heef.. 
bedrag gelijk aan dat van de schadevergoeding tot betaling waarvan de aansprakelijke persoon jegens de arbeidsgehandicapte naar burgerlijk recht gehouden is.

- 2. Het Uitvoeringsinstituut werknemersverzekeringen kan indien een aanspraak als bedoeld in het eerste lid, wordt toegekend in de vorm van periodieke verstrekkingen, de contante waarde daarvan vorderen in de vorm van een jaarlijks vast te stellen afkoopsom die aan het Uitvoeringsinstituut werknemersverzekeringen wordt vergoed voor de totale schadelast ten gevolge van het veroorzaken van de arbeidshandicap."

Het eerste lid is nogal ruim geformuleerd. Het geeft het Uitvoeringsinstituut werknemersverzekeringen een regresrecht voor 'de op grond van deze wet gemaakte kosten' ten behoeve van de arbeidsgehandicapte in de zin van art. 10 REA. ${ }^{375}$ Art. 10 belast het UWV met de bevordering van de inschakeling van de arbeidsgehandicapte in het arbeidsproces indien bij diens eigen werkgever geen passende arbeid voorhanden is of hij voorafgaand aan het ongeval een uitkering genoot. Niet wordt in de regresregeling bepaald dat de kosten betrekking moeten hebben op uitkeringen die aan de benadeelde zelf worden verstrekt. Strikt genomen lijkt het dus ook te kunnen gaan om subsidies die aan de werkgever worden verstrekt voor zijn kosten voor het in dienst nemen van de benadeelde. Het regresrecht zou dan (potentieel) verder strekken dan de schade waarvoor de schadeveroorzaker bij het uitblijven van de regresbepaling aansprakelijkheid zou hebben geriskeerd. De regeling van het civiele plafond beperkt de betalingsplicht van de schadeveroorzaker echter tot het bedrag waarvoor hij ten hoogste aansprakelijk zou zijn geweest jegens de benadeelde, zie art. 49 lid 1 REA. Naar nog zal worden gezien geeft die regeling intussen geen absolute waarborgen dat niet toch teveel verschuldigd is. ${ }^{376}$ Het te ruime bereik zou eenvoudig kunnen worden aangepast door in het eerste lid van art. 49 na 'de krachtens deze wet gemaakte kosten' toe te voegen: 'ter vermindering van de door de arbeidsgehandicapte geleden schade'.

\subsubsection{Art. 6 lid 3 WSG}

Slachtoffers van opzettelijke geweldsmisdrijven kunnen voor de resterende (gederfde en toekomstige) inkomensschade in aanmerking komen voor een uitkering van het Schadefonds Geweldsmisdrijven. Het fonds wordt bij het doen van de uitkering gesubrogeerd in de vordering tot schadevergoeding van de benadeelde, en kan dan - met toestemming van de minister van Justitie - een regresactie instellen tegen de schadeveroorzaker. Verwezen zij naar het eerder gezegde (paragraaf 4.2.5). Zoals daar werd opgemerkt werkt het fonds veelal met voorschotconstructies, het Centraal Justitieel Incasso Bureau zorgt dan ervoor dat de bij een schadevergoedingsmaatregel ten behoeve van de benadeelde toegewezen bedragen bij wijze van terugbetaling toekomen aan het fonds. Op die wijze zal het fonds indien de

Dat is een arbeidsgehandieapte voor wie bij de eigen werkgever geen passende arbeid meer voorhanden is dan wel een uitkeringsgerechtigde in de zin van sub $a-d$ van die bepaling.

In die zin ook Asser-Hartkamp 4-1, nr. 491 en Van Boom (2000a), p. 36; zie infra, paragraaf 7.2. 
schadeveroorzaker onvoldoende verhaal biedt (en de WA-verzekeraar bij opzet geen dekking biedt) de facto voorrang hebben boven de (eventuele) regresvorderingen van de werkgever en het UWV. Die zullen immers pas in het geding komen als het strafproces gaande of zelfs voorbij is (en kunnen zich ook zelf niet in het strafproces voegen als benadeelde).

\subsection{Regres bij immateriële schade}

Het voorgaande bleef beperkt tot het regres voor zuiver materiële ofwel vermogensschade. Particuliere en sociale verzekeraars met een regresrecht doen geen uitkering voor immateriële schade. ${ }^{377}$ Hun uitkeringen aan de benadeelde hebben (primair) betrekking op vermogensschade (doktersrekening, inkomensschade) en dienen het deel van de aansprakelijkheid van de schadeveroorzaker dat betrekking heeft op de immateriële schade van de benadeelde onverlet te laten. Dat volgt voor een aantal gevallen al uit de regeling van art. 6:106 BW. Het tweede lid bepaalt dat het recht op vergoeding van immateriële schade niet vatbaar is voor overgang en beslag, tenzij het bij overeenkomst is vastgelegd of ter zake een vordering in rechte is ingesteld. Het recht op smartengeld is dus in die zin hoogstpersoonlijk dat de benadeelde zelf moet hebben laten blijken te voelen voor het geldend maken van die vordering. Dit komt uitvoeriger aan de orde in paragraaf 7.4.3.5.

Toch kan indien het ziekenfonds uitkering doet en daarvoor regres zoekt (art. 83b ZFW) naar geldend recht in het kader van het civiele plafond de vraag rijzen of het regresrecht zich mede kan uitstrekken over het dẹel van de aansprakelijkheid dat betrekking heeft op de immateriële schade van de benadeelde. Hèt nadeel daarvan is dat indien het deel van de aansprakelijkheid dat betrekking heeft op de ziektekosten ontoereikend blijkt te zijn (bijvoorbeeld wegens rechterlijke matiging indien de benadeelde tevens een uitkering geniet uit sommenverzekering, art. 6:109 $\mathrm{BW}$ ) de regresvordering zou concurreren met de resterende vordering van de benadeelde zelf (vordering tot smartengeld). Als regresnemers als eerste de schadeveroorzaker of diens WA-verzekeraar aanspreken, dan zou dit zich tevens kunnen uitstrekken tot de aansprakelijkheid van de schadeveroorzaker voor het smartengeld. De benadeelde zou daardoor de facto het risico kunnen lopen zijn vordering tot smartengeld te verliezen. Het principe kan het beste worden geîllustreerd met een voorbeeld:

Van sommenverzekeringen zou men nog kunnen stellen dat ze de facto mede gelden als vergoeding voor leed. mar alleen schadeverzekeraars worden gesubrogeerd (HR 31 december 1931, NJ 1932, 419 nt. EMM (Spoanveg. ongeval De Vink), en die keren nimmer smartengeld uit (vgl. art. 7.17.2.1 BW; schadeverzekeringen zijn 'de verzekering strekkende tot vergoeding van vermogensschade die de verzekerde zou kunnen lijden', cursief toegevoegd, EE). 
A raakt emstig gewond door onrechtmatig gedrag van $\mathrm{X}$ en heeft recht op vergoeding van de ziektekosten (5.000 Euro) alsmede recht op smartengeld (10.000 Euro). De totale omvang van aansprakelijkheid van X zou kortom IS.000 Euro bedragen, ware het niet dat A eigen schuld toekomt. Ik zal ervan uitgaan dat het door de schadeveroorzaker verschuldigde bedrag om die reden wordt gehalveend: $(2.500$ $+5.000 \Rightarrow$ ) 7.500 Euro (zie art. 6:101 lid $1 \mathrm{BW}$ ). Als nu de ziektekosten volledig door het ziekenfonds zijn vergoed, dan gaat het met die schadepost corresponderende recht op schadevergoeding over op deze verzekeraar. Maar het zou A benadelen als het ziekenfonds de volle 5.000 Euro, en niet slechts 2.500 Euro, op X zou kunnen verhalen door óók (gedeeltelijk) het recht op smartengeld ten gelde te maken. Over het bedrag dat als smartengeld is bedoeld behoort het regres zich niet te kunnen uitstrekken.

Benadeling van de benadeelde door het regres van zijn particuliere of sociale verzekeraar kan niet de bedoeling zijn. Dit bezwaar van benadeling kan ook wel worden ondervangen als men ervan uitgaat dat de vordering van de benadeelde ten alle tijde vóór gaat op de vordering van de regresnemer, zie paragraaf 9.3. Maar juister zou in dit verband zijn, de regresvordering (het civiele plafond), nog los van art. 6:106 lid 2 BW, a priori te beperken tot het deel van de aansprakelijkheid dat betrekking heeft op de ziektekosten (en niet óók het smartengeld. Dat is niet alleen minder risicovol voor de benadeelde, maar houdt ook de regrespraktijk overzichtelijk en lijkt principieel juister. Indien sociale verzekeraars of werkgevers inkomensschade voor hun rekening nemen behoort dat niet de schadeveroorzaker van zijn verplichting tot het betalen van smartengeld te kunnen bevrijden. In aansluiting daarop behoort ook hun regresvordering zich - daargelaten de beperkingen die art. 6:106 lid 2 BW oplegt - niet over dat deel van de aansprakelijkheid van de schadeveroorzaker te kunnen uitstrekken (indien de aansprakelijkheid van de schadeveroorzaker ontoereikend is). Alleen met betrekking tot de ziektekosten is er een 'toevallige samenloop van prestaties', zie daarover nader paragraaf 4.8.2. Voor particuliere schadeverzekeraars en het Schadefonds Geweldsmisdrijven die uitkering doen in verband met inkomensschade geldt dit zogenaamde postenstelsel al. Die worden bij uitkeringen voor vermogensschade van de benadeelde alleen gesubrogeerd in diens vordering tot schadevergoeding met betrekking tot die vermogensschade, zoals ziektekosten, en niet (ook) in de vordering tot smartengeld. Ook het regres van sociale verzekeraars en werkgevers dient de aansprakelijkheid voor immateriële schade (en andere schadeposten waarvoor ze geen uitkering doen) dan ongemoeid te laten.

Dat wil uiteraard niet zeggen dat bij slachtoffers met immateriële schade geen plaats zou zijn voor regres. Wat het wel betekent is dat daarvan slechts sprake kan zijn in de (uitzonderlijke) gevallen waarin de door de regresnemer verstrekte uitkeringen specifiek bedoeld waren als schadevergoeding voor de immateriële schade van de benadeelde. Eén van de weinige gevallen waarin daarvan sprake is, komt voor bij het Schadefonds Geweldsmisdrijven. Het fonds verstrekt namelijk óḱk uitkeringen voor immateriële schade van het slachtoffer van een opzettelijk geweldsmisdrijf en, indien het al genoemde wetsvoorstel 'affectieschade' kracht 
van wet krijgt, ${ }^{378}$ van nabestaanden. Het fonds keert uit naar analogie met de regels van het schadevergoedingsrecht, in het bijzonder art. 6:106 BW. De immateriẻle schade betreft het geleden verdriet, de pijn en de gederfde levensvreugde van de benadeelde en wordt, bij ernstig letsel, eigenlijk altijd door de Commissie verondersteld aanwezig te zijn. ${ }^{379}$ Het fonds geeft voor de immateriële schade recht op een gestandaardiseerde uitkering, in het jaar 2002 was dat maximaal 9100 gulden. $^{380}$

Voorzover het fonds dit smartengeld uitkeert kan het worden gesubrogeerd in de vordering tot smartengeld van de benadeelde jegens de schadeveroorzaker. Door de rechtsovergang verliest de benadeelde in zoverre zijn vordering. De subrogatie is echter aan bijzondere beperkingen onderhevig. Het recht op smartengeld is immers maar beperkt vatbaar voor overgang (en beslag): zoals gezegd is volgens art. 6:106 lid 2 BW nodig dat het bij (vaststellings)overeenkomst is vastgelegd of door de benadeelde een vordering in rechte is ingesteld. ${ }^{381}$ Art. 6:106 lid 2 $\mathrm{BW}$ laat voor overgang onder algemene titel (erfopvolging) intussen een minder restrictief regime gelden. Dan is in beginsel ten minste nodig dat de benadeelde aan de wederpartij heeft medegedeeld op het smartengeld aanspraak te maken. ${ }^{382}$ Volgens de Toelichting Meijers is er

'geen reden waarom uit het door het slachtoffer ondergane leed nog kapitaal geslagen kan worden als de vergoeding niet meer kan dienen om zijn leed te verzachten of hem genoegdoening te verschaffen. De aanspraak moet daarom niet overgaan op de erfgenamen van het slachtoffer. Voorts brengt het persoonlijke karakter mee, dat zij niet in de huwelijksgemeenschap moet vallen en niet overdraagbaar en voor beslag vatbaar moet zijn. ${ }^{363}$

Dat een uitzondering geldt indien de aansprakelijkheid bij overeenkomst is vastgelegd of de benadeelde ter zake een vordering heeft ingesteld wordt niet afzonderlijk gemotiveerd. In de literatuur is kritiek op dit onderdeel van de regeling. ${ }^{384} \mathrm{Lin}-$ denbergh wijst erop dat met de genoemde uitzonderingen de principiële bezwaren bij de overdraagbaarheid van de vordering niet komen te vervallen. ${ }^{385}$ Bovendien zouden de gestelde voorwaarden (met name de bij erfopvolging vereiste medede-

TK 2002-03, 28 781, nr. 1-2; zie daarover Verheij (2002), p. 210 c.v.

Jalink (1989), p. 114 en in die zin ook Willems (1996), p. 16.

Syllabus Schadefonds Geweldsmisdrijven, Den Haag 2002, p. 22.

38: Asser-Hartkamp 4-1, nr. 468; Spier e.a. (2000), nr. 250 (Hartlief); Bouman \& Tilanus-Van Wassenaer (1998), nr. 43F; Lindenbergh (1999), p. 58; Bloembergen \& Lindenbergh (2001), p. 73; Verheij (2003), p. 537 e.v. waar er tevens op wordt gewezen dat de onderhavige beperkingen ook gelden indien het recht op smartengeld op andere bepalingen dan art. 6:106 BW berust.

In HR 20 september 2002, C00/328HR (Comapatiēnt) oordeelde de Hoge Raad dat ook comateuze slachtoffers onder omstandigheden ondanks dat ze enige tijd in staat van bewusteloosheid hebben verkeerd, recht dienen te hebben op smartengeld. Het recht op smartengeld kan dan dus ook aan derden worden toegekend (in dit geval op grond van zaakwaameming). Aangenomen werd dat aan de voorwaarden van ant. 6:106 lid 2 BW was voldaan.

Van Dam (199I), p. 87 e.v.; Lindenbergh (1999), p. 63; zie voor een bespreking Verheij (2003), p. 240 e.v.

Lindenbergh (1999), p. 63.
} 
ling) onnodig belastend zijn voor de benadeelde en tot praktische complicaties kunnen leiden (bij een onbereikbare debiteur). ${ }^{386}$ In het Duitse recht zou een vergelijkbare regeling zijn geschrapt omdat zij tot een 'Wettlauf gegen dem Tode' zou leiden. ${ }^{387}$ Het bijzondere, hoogstpersoonlijke karakter ligt, zo stelt Lindenbergh het, bij de overgang van immateriële schade; niet zozeer in de aanspraak zelf, maar vooral in de aard van de schade. Het gaat dan ook om de vraag in hoeverre het hoogstpersoonlijke karakter van de schade het recht op vergoeding in vermogensrechtelijk opzicht kleurt. Zo bezien lijkt hem onbeperkte overdraagbaarheid niet bezwaarlijk: slaagt de benadeelde erin om zijn vordering op deze wijze te verzilveren, dan bestaat daartegen geen bezwaar. ${ }^{388}$

Dat veronderstelt dat de benadeelde de vordering zèlf overdraagt, bij subrogatie zou de benadeelde echter zonder daarop gerichte wil zijn vordering kunnen verliezen. Zo bezien wordt het argument van het hoogstpersoonlijke karakter dunkt mij van meer gewicht. Heeft de verzekeraar van de benadeelde het smartengeld voor zijn rekening genomen, dan kan subrogatie - in het licht van het in hoofdstuk 3 genoemde uitgangspunt dat voor dubbele schadevergoeding voor de benadeelde geen plaats is - nog het rechtsgevoel goeddoen. De subrogatie herstelt in zekere zin de genoegdoeningsfunctie van de verplichting tot het betalen van het smartengeld (het is toch nog de schadeveroorzaker of diens WA-verzekeraar die voor het leed betaalt). Deed de tot subrogatie gerechtigde zelf geen uitkering voor de immateriële schade, dan weegt het hoogstpersoonlijke karakter zwaarder, óók dunkt me als wèl aan de voorwaarden voor art. 6:106 lid 2 BW is voldaan. Het persoonlijke karakter wordt in feite ook gewaarborgd door het postenstelsel: met betrekking tot het smartengeld is geen sprake van samenloop met de verbintenis tot schadevergoeding die op de schadeveroorzaker rust, en de verzekeraar behoort dan niet te kunnen profiteren van de aansprakelijkheid van de schadeveroorzaker voor dat deel van de schade, te meer niet door het hoogst persoonlijke karakter ervan.

Enige steun kan daarvoor worden gevonden bij het Echtscheiding-arrest uit 1997. De Hoge Raad laat in dat arrest het oordeel van het hof in stand, dat erop neerkomt dat bij de ontbinding van een huwelijkse gemeenschap door echtscheiding de bijzondere verknochtheid van het smartengeld meebrengt dat de aanspraak daarop buiten de verdeling moet vallen, en dus niet in de gemeenschap. Dat geldt ook als aan de voorwaarde van art. 106 lid $2 \mathrm{BW}$ is voldaan ${ }^{189}$ Meer recent, inzake Leonardus/Linssen lijkt de raad in andere zin te oordelen voor een faillissement: ${ }^{390}$ indien aan de voorwaarden van art. 6:106 lid $2 \mathrm{BW}$ is voldaan, dan vallen de smartengelduitkeringen gewoon in het faillissement. Ook de schuldeisers kunnen zich daarop dus verhalen. Aangezien de wettelijke restricties dan in acht zijn genomen, staat het hoogstpersoonlijke karakter volgens de raad dàaraan dan niet in de weg. Dat de gefailleerde met zijn hele vermogen moet instaan voor zijn schulden weegt dan zwaarder.

386 Lindenbergh (1999), p. 64; in die zin ook Van Dam (1991), p. 91.

387 In het kader van $\$ 847$ BGB, zie Lindenbergh (1999), p. 65.

388 Lindenbergh (1999), p. 66.

389 Zie art. 1:94 lid 3 BW; HR 24 oktober 1997. NJ 1998, 693 nt. WMK (H/K) en daarover ook Verheij (2002). p. 539.

390 HR 22 november 2002, NJ 2003, $32 \mathrm{nt}$. PvS (Leonardus/Linssen). 


\subsection{Regres bij overlijdensschade}

\subsubsection{Algemeen}

Als het primaire slachtoffer door de schadeveroorzakende gebeurtenis komt te overlijden, dan kunnen bepaalde categorieên nabestaanden de schadeveroorzaker aansprakelijk stellen voor de schade die ze daarvan ondervinden. Art. 6:108 lid $1 \mathrm{BW}$ geeft zijn echtgenoot, geregistreerd partner, minderjarige kinderen, andere bloed- en aanverwanten en in- of samenwonenden in beginsel recht op schadevergoeding voor het derven van de voorziening voor hun levensonderhoud. Voorts moeten de kosten van lijkbezorging worden vergoed (lid 2). Indien het wetsvoorstel 'affectieschade' van kracht wordt, dan zullen sommige nabestaanden (echtgenoten, ouders) voorts recht krijgen op smartengeld voor hun leed en verdriet als gevolg van het overlijden.

Hierna volgt een bespreking van de regresregelingen die gelden indien de twee eerstgenoemde schadeposten (gederfde voorziening in het levensonderhoud en voorts de kosten van lijkbezorging) door particuliere of sociale verzekeraars worden vergoed. Het regres bij immateriële schade, waaronder affectieschade, kwam hiervoor aan de orde (paragraaf 4.4).

\subsubsection{Art. 61 ANW}

Bij overlijden heeft slechts een beperkte groep nabestaanden voorzover ze 'behoeftig' zijn, recht op een inkomensvervangende uitkering krachtens de Algemene nabestaandenwet. ${ }^{391}$ Voor het financiële risico dat buiten het kader van deze wet valt wordt men geacht een overlijdensverzekering te hebben afgesloten en door deelname aan het arbeidsproces in de eigen levensbehoeften te kunnen voorzien. Maar hebben de nabestaanden aanspraak op een ANW-uitkering, dan komt die volgens art. $60 \mathrm{ANW}$ in mindering op de schadevergoeding ingevolge art. 6:108 lid $1 \mathrm{BW}$, waartoe ze zonder die aanspraak gerechtigd zouden zijn. ${ }^{392}$ Art. $60 \mathrm{ANW}$ geeft daarmee een dwingende invulling van het behoeftigheidsvereiste: voor het bedrag van de aanspraken hebben de nabestaanden geen recht op schadevergoeding, ongeacht in hoeverre die ook daadwerkelijk kunnen worden geacht bij te dragen aan de voorziening in het levensonderhoud. Uitgaande van

391 Namelijk uitsluitend (behoeftige) nabestaanden met kinderen onder de leeftijd van achttien jaar, gehandicapte nabestaanden en nabestaanden zonder kinderen en geboren vóór 1945 (dit laatste vanwege hun moeilijke positie op de arbeidsmarkt). Volgens de regering is het risico van gederfd levensonderhoud door overtijden goed particulier verzekerbaar, TK 1994-95, 24 169, nr. 3 (MvT), p. 4.

392 Art. 60 ANW: 'Bij de vaststelling van de schadevergoeding. waarop de nabestaande en ouderloos geworden kinderen van de verzekerde naar burgerfijk recht aanspraak kunnen maken ter zake van het overlijden van de verzekende, houdt de rechter rekening met de aanspraken op uitkeringen, die de nabestaande en het ouderloos geworden kind op grond van deze wet heeft. 
een postenstelsel, behoren de ANW-aanspraken alleen in mindering te komen op het bedrag van de schadevergoeding voor de gederfde voorziening in het levensonderhoud (art. 6:108, eerste lid BW). Niet behoren ze, geheel of gedeeltelijk, in mindering te komen op het deel van de schadevergoeding dat betrekking heeft op de begrafeniskosten (art. 6:108 lid 2 BW). De Sociale Verzekeringsbank heeft voor de verschuldigde ANW-uitkering een zelfstandig regresrecht (art. $61 \mathrm{ANW}$ ):

- 1. De Bank heeft voor de krachtens deze wet gemaakte kosten verhaal op degene, die in verband met het veroorzaken van het overlijden van de verzekerde, jegens diens nabestaande en ouderloos geworden kinderen naar burgerlijk recht tot schadevergoeding is verplicht, doch ten hoogste tot het bedrag, waarvoor deze bij het ontbreken van de aanspraken op grond van deze wet naar burgerlijk recht aansprakelijk zou zijn, verminderd met een bedrag. gelijk aan dat van de schadevergoeding tot betaling waarvan de aansprakelijke persoon jegens de nabestaande en ouderloos geworden kinderen naar burgerlijk recht is gehouden.

- 2. De Bank kan in plaats van het bedrag der periodieke verstrekkingen de contante waarde daarvan vorderen in de vorm van een jaarlijks vast te stellen afkoopsom die aan de Bank wordt vergoed voor de totale schadelast ten gevolge van het veroorzaken van overlijden.'

Het regresrecht zèlf (lid 1) lijkt sterk op de andere zelfstandige regresrechten: het is beperkt tot het civiele plafond en geldt bij regres op de werkgever en collega's van de overledene slechts als sprake is van opzet of bewuste roekeloosheid (art. $62 \mathrm{ANW}) .{ }^{393}$ Het tweede lid voorziet, net als de WAZ, WAJONG, REA en AWBZ, in de mogelijkheid van een generale afkoop van regresvorderingen, teneinde de afwikkelingskosten van het regres te beperken. De afkoopsom bestaat niet alleen uit het geschatte aantal regresvorderingen met betrekking tot één schadegeval, zoals bij de WAO, maar uit het totale aantal schadegevallen in het tijdsbestek van één jaar. De Sociale Verzekeringsbank heeft in 1996, net als nadien is gebeurd in het kader van de AWBZ, een convenant gesloten met het Verbond van Verzekeraars. Dit wordt jaarlijks verlengd, met aanpassing van het overeengekomen bedrag. ${ }^{394}$

\subsubsection{Art. 2 lid 3 VOA, art. 75 WPA, art. X4 AMP}

De Verhaalswet ongevallen ambtenaren (VOA), die in paragraaf 4.2 en 4.3 al vrij uitvoerig ter sprake kwam, geldt ook bij uitkeringen aan nabestaanden van overheidswerknemers. Daartoe is aan art. 2 VOA nog een derde lid toegevoegd:

$\because 1$. Het lichaam dat aan of ten behoeve van een ambtenaar krachtens diens rechtspositieregeling uitkeringen of verstrekkingen verleent ter zake van een aan deze overkomen ongeval, heeft voor de kosten van deze voorzieningen verhaal op degene die, bij het ontbreken van die voorzieningen, in

393 Maar kan slechts netto worden verhaald; zie daarover paragraaf 8.2 .

394 Het Convenant inzake collectivering regres Algemene nabestaandenwet d.d. 9 juli 1996 is volledig opgenomen als Bijlage 3 bij Sinninghe Damste (1999), p. 87-91; zie voorts 0.a. Faure (1996), p. 61 e.v. en Kremer (2000), p. 427. 
verband met het veroorzaken van het ongeval jegens de ambtenaar naar burgerlijk recht aansprakelijk zou zijn voor de alsdan door deze geleden schade. Het verhaal kan niet ten nadele van de ambtenaar worden uitgeoefend.

$(\ldots)$

- 3. Het eerste lid is van overeenkomstige toepassing op de uitkeringen of verstrekkingen, krachtens de voor de ambtenaar geldende rechtspositieregeling ter zake van het ongeval $(. .$.$) aan of ten behoeve$ van zijn nagelaten betrekkingen na zijn overlijden ten gevolge van het ongeval.'

Deze regeling gold aanvankelijk óók voor de Stichting Pensioenfonds ABP. In art. 75 van de Wet privatisering $A B P$ is zij tijdelijk van toepassing verklaard op pensioenen aan overheidswerknemers die als zodanig niet vallen onder het regime van de VOA (ambtenaren in dienst van privaatrechtelijke lichamen). Dat geldt aiet alleen voor de vóór de privatisering al lopende pensioenen, ${ }^{395}$ en voor herplaatsingstoelagen aan overheidswerknemers en hun nabestaanden, ${ }^{396}$ maar ook voor alle pensioenen die op later tijdstip zijn of worden toegekend ${ }^{397}$ (en uitkeringen aan nabestaanden van militairen). ${ }^{398}$

De (oude) ABP-regresregeling heeft geleid tot een reeks arresten, die mede van betekenis zijn voor het regime van de VOA. In het bekende arrest inzake $A B P /$ Baauw oordeelde de Hoge Raad dat het invaliditeitspensioen van een benadeelde ambtenaar nadat deze de leeftijd van vijfenzestig jaar heeft bereikt, zodanig van karakter verandert dat vanaf die datum in feite van een ouderdomspensioen moet worden gesproken. ${ }^{399}$ De desbetreffende uitkeringen zijn dan, naar 's raads oordeel, niet meer te beschouwen als uitkeringen 'ter zake van het ongeval', in de zin van art. 2 VOA. Daarvoor is derhalve geen regres mogelijk. ${ }^{400}$ Dat is anders voor weduwepensioenen na het overlijden die (thans) onder de reikwijdte van deze wet vallen. Het regresrecht voor die pensioenen strekt zich wèl mede uit over de uitkeringsperiode die intreedt nadat de overleden ambtenaar de leeftijd van vijfenzestig jaar zou hebben bereikt. ${ }^{401}$ Het civiele plafond vormt dan geen belemmering, omdat ook pensioen tot het inkomen wordt gerekend op grond waarvan de ambtenaar in het levensonderhoud van zijn nagelaten partner zou hebben voorzien, zoals vereist door art. $1406 \mathrm{BW}$ oud (thans art. $6: 108 \mathrm{BW}) .^{402}$

395 Preciezer gezegd gaat het om kosten van de op 31 december 1995 reeds ingegane pensioenen.

396 Het regresrecht van art. 75 lid 1 en lid 5 juncto art. 2 VOA.

397 Althans de tussen 31 december 1995 en I januari 2001 verstrekte uitkeringen. Lid 3 van art. 75 WPABP verklaart het regresrecht van art. 75 lid I en 5 WPABP juncto art. 2 VOA van overeenkomstige toepassing.

398 Lid 2 respectievelijk lid 4 verklaren het regresrecht van art. 75 lid I respectievelijk lid 3 WPABP juncto art. 2 VOA van overeenkomstige toepassing.

399 HR 22 juni 1990, NJ 1991, $760 \mathrm{nt}$. CJHB (ABP/Baauw).

400 In zijn $N J$-noot bij het arrest acht Brunner het wèl redelijk om regres mogelijk te laten zijn voor dat gedeelte van het ouderdomspensioen dat tijdens de jaren van arbeidsongeschiktheid is opgebouwd.

401 HR 15 februan 1985, NJ 1986, 687 nt. FHJM (Siad Rotterdam/ABP).

-02 HR 15 februani 1985, NJ 1986, 687 nt. FHJM (Siad Rotterdam/ABP). Van Leeuwen \& Bouma (1991), p. 236 leiden hieruit af dat het regresrecht voor het weduwepensioen zich uitstrekt over de gehele looptijd daarvan, tot aan de statistische eindleeftijd. 


\subsubsection{Art. 6 lid 3 WSG}

Het Schadefonds Geweldsmisdrijven geeft bij overlijden ook bepaalde nabestaanden een beperkt recht op uitkering voor de door hen geleden vermogensschade. Het begrip nabestaande komt sterk overeen met de categorieën nabestaanden van art. 6:108 BW (lid 1). ${ }^{403}$ De betekenis is dus vrijwel gelijk aan de term in het (civiele) schadevergoedingsrecht. Te denken valt onder meer aan: ouders, kinderen en echtgenoten of samenwonende partners, voorzover ze voor hun levensonderhoud van het primaire slachtoffer (de overledene) afhankelijk waren. Het fonds kan bij doodslag uitkeringen doen voor hun materiële schade bestaande uit gederfd levensonderhoud en begrafeniskosten en, indien het wetsvoorstel 'affectieschade' van kracht wordt, óók een som verstrekken voor het leed van de nabestaanden. ${ }^{404}$ De uitkering aan nabestaanden bedroeg in het jaar 2002, inclusief (eventueel) toe te kennen bedragen voor de schade van het primaire slachtoffer voorafgaand aan het overlijden, 22700 Euro. Voor de aanspraak van deze nabestaanden op het fonds gelden dezelfde voorwaarden als de voorwaarden die zouden gelden bij een verzoek om een uitkering van het primaire slachtoffer zelf: het moet gaan om een opzettelijk (en in Nederland gepleegd) geweldsmisdrijf waardoor het overlijden is ontstaan en de schade van de nabestaanden kan niet zonder bezwaar door henzelf worden gedragen of langs andere weg worden vergoed. De Commissie kan uitkering weigeren, en doet dit ook regelmatig, ${ }^{405}$ wegens eigen schuld van het primaire slachtoffer. ${ }^{406}$

Het regresrecht van art. 6 lid 3 WSG strekt zich ook uit over deze vorderingen van nabestaanden. Met toestemming van de minister van Justitie zou het fonds dan, voor de uitkeringen voor gederfd levensonderhoud en/of de begrafeniskosten verhaal kunnen zoeken bij de dader, de schadeveroorzaker (of diens WA-verzekeraar). Het uitkeringsbeleid van het fonds loopt niet helemaal gelijk met de regels van afdeling 6.1.10 BW (art. 6:108 BW). Het fonds is namelijk terughoudender dan de regeling van art. 6:108 BW: het kent zoals gezegd niet het minimum-niveau van het wettelijk verschuldigde levensonderhoud en bovendien is het fonds eerder dan in het kader van art. 6:108 lid 1 BW het geval is, geneigd om voordeel in het kader van het behoeftigheidsvereiste in aanmerking te nemen. ${ }^{407}$ Het wordt dan slechts in zoverre gesubrogeerd. Gebruikelijker is zoals gezegd dat het fonds de uitkering bij wijze van voorschot betaalt, waarvan terugbetaling kan worden gevorderd indien de actie van de nabestaanden jegens de dader slaagt.

Art. 3 lid 2 WSG is wat restrictiever geformuleerd. Art. $6: 108$ sub $a$ BW biedt echtgenoten en minderjarige kinderen tenminste recht op schadevergoeding ten belope van het hen bij analoge toepassing van het familierecht verschuldigde deel (art. 1:392 BW). Die mogelijkheid ontbreekt bij het fonds.

TK 2002-03, 28 781, nr. 1-2; zie paragraf 1.3.1.

Syllabus Schadefonds Geweldsmisdrijven, Den Haag januari 2002, p. 19.

Eventuele medeschuld van de nabestaande zelf wordt ook betrokken bij de beslissing over het toekennen van een uitkering.

In die zin Syllabus Schadefonds Geweldsmisdriven, Den Haag (2002), p. 25. 
Ook uitkeringen uit particuliere levensverzekering strekken typisch tot uitkering bij de dood van een persoon, ze kwamen hiervoor al ter sprake. Indien de voorziening geen betrekking heeft op bijzondere vermogensbestanddelen (zoals bij de hypothecaire levensverzekering wèl het geval is), dan komt deze - bijzonderheden daargelaten - volledig in mindering op de vordering van art. 6:108 lid $1 \mathrm{BW}$. Indien er bijzondere vermogensbestanddelen mee beoogd zijn dan dient zij alleen in mindering te komen voorzover schadevergoeding wordt gevorderd met betrekking tot de voorziening in dàt deel van de kosten van levensonderhoud. Aangenomen wordt dat subrogatie dan uitgesloten is: levensverzekeringen moeten worden aangemerkt als sommenverzekering (vgl. art. 7.17.3.1 BW). Het risico van kosten van lijkbezorging (grafsteen, vervoer, crematie, enzovoort) kan ook particulier worden verzekerd, door het afsluiten van een begrafenis- of uitvaartverzekering. Voorzover ook die als levensverzekering moet worden aangemerkt ontbreekt ook dan de mogelijkheid van subrogatie. Uitgaande van het schadeverzekeringskarakter zou het voor de hand liggen om uitvaartverzekeringen aan te merken als schadeverzekering. Art. 7.17.3.9 $a$ BW bepaalt echter dat sommige bepalingen uit afdeling 7.17.3 BW ('Sommenverzekering') niet gelden voor 'verzekeringen strekkende tot voorziening in de kosten van lijkbezorging'. Daaruit kan wellicht à contrario worden afgeleid dat deze verzekeringen óók als sommenverzekering worden aangemerkt. Dat zou impliceren dat de aparte regeling voor schadeverzekeringen (afdeling 7.17.2 BW), en daarmee ook het recht van subrogatie (art. 7.17.2.25 BW) voor uitvaartverzekeraars niet geldt. Dit zou overigens wel in de pas lopen met het regime voor andere regresnemers, met name werkgevers; die hebben immers evenmin een regresrecht voor de begrafeniskosten die ze voor hun rekening nemen. ${ }^{408}$

\subsection{Schadedragers zonder regresrecht}

\subsubsection{Dè uitzondering: sociale voorzieningen}

De invoering van een aantal nieuwe regresbepalingen, beschreven in de voorgaande paragrafen, heeft eraan bijgedragen dat inmiddels alle sociale verzekeraars die medische kosten vergoeden bij samenloop met het aansprakelijkheidsrecht recht hebben op regres. ${ }^{409}$ Anders is dat voor de sociale voorzieningen. Voor sociale

\footnotetext{
4 as $V_{g l}$. Hof Den Bosch 26 juni 1996, NJ 1997, 252 (Bartels BV/Mammoel-Stoof BV), dat de vordering van de werkgever voor de door hem betaalde begrafeniskosten (alsmede doorbetaling van het loon aan de levenspartner van de omgekomen werknemer), afwees onder verwijzing naar het gesioten systeem van art. 1406 BW (oud).

De voorzieningen uit de Wet arbeidsongeschiktheidsvoorziening jonggehandicapten worden uit de algemene middelen betaald en plegen darom niet tot de sociale verzekeringen te worden gerekend, maar tot de sociale voorzieningen.
} 
voorzieningen geeft de wet, met uitzondering van de Wet arbeidsongeschiktheidsvoorziening jonggehandicapten, geen regeling voor samenloop met het aansprakelijkheidsrecht. Qua doelstelling verschillen sociale voorzieningen echter niet fundamenteel van sociale verzekeringen, ${ }^{410}$ ze vormen een aanvulling voor wie niet (of niet meer) in aanmerking komt voor een uitkering op grond van een sociale verzekering of een uitkering krijgt die onder een sociaal minimum valt. De voorzieningen vullen het inkomen dan in zoverre aan. Anders dan bij sociale verzekeringen worden voorzieningen uit de algemene middelen gefinancierd en meestal verstrekt door de gemeente (dat wil zeggen de gemeentelijke sociale diensten of afdelingen sociale zaken op het gemeentehuis). Voor de meeste sociale voorzieningen is van samenloop met het aansprakelijkheidsrecht zelden sprake, maar er zijn voorzieningen waarvoor een regeling van voordeelstoerekening en regres wèl betekenis heeft, en niettemin ontbreekt. Dat geldt met name voor de Wet voorzieningen gehandicapten.

\subsubsection{Wet voorzieningen gehandicapten}

De in 1994 ingevoerde Wet voorzieningen gehandicapten belast de gemeente met de zorg voor het verstrekken van woon- en vervoersvoorzieningen voor langdurig gehandicapten opdat die zo zelfstandig mogelijk kunnen blijven functioneren. Gemeenten verstrekken in het kader van deze taak zowel voorzieningen in natura als financiële tegemoetkomingen voor voorzieningen. De nadere invulling ervan en van de aard en omvang van de te verstrekken voorzieningen zijn, uit oogpunt van doelmatigheid en kostenbeheersing, in zeer vergaande mate overgelaten aan de gemeenten afzonderlijk. Bijzondere gemeentelijke verordeningen geven bijvoorbeeld recht op aanpassing of verbouwing van hun woning, ${ }^{411}$ rolstoelverstrekkingen, een eigen gehandicaptenauto en vergoedingen voor het gebruik van een (rolstoel)taxi. De WVG is in zoverre vergelijkbaar met de Wet op de reïntegratie arbeidsgehandicapten (REA), met dit verschil dat REA de hervatting van het arbeidsproces moet bevorderen van zieke of gehandicapte werknemers. Maar ook REA geeft recht op voorzieningen (vervoersmiddelen, scholing, hulpmiddelen enzovoort) waarvoor anders wellicht de schadeveroorzaker tot schadevergoeding gehouden zou zijn. ${ }^{412}$ Zoals gezegd voorziet REA het UWV van een regresrecht jegens de schadeveroorzaker voor de kosten van de benodigde aanpassingen en voorzieningen voor de arbeidsgehandicapte. Voor de bedragen die met de WVG-

410 Het recht op bestaanszekerheid; vgl. Pardaan (2001), p. 13.

411 Sinds 1 april 2000 zijn ook woningaanpassingen die 45000 NLG of meer kosten gedecentraliseerd met als gevolg dat de zorgplicht van de gemeenten inmiddels betrekking heeft op alle woningaanpassingen; Sib. 1999. 598 .

412 Zie supra, paragraaf 4.3.8. 
verstrekkingen gemoeid zijn ontbreekt het de gemeente daarentegen aan een regresrecht jegens de schadeveroorzaker. ${ }^{413}$

Er zijn aanwijzingen dat de bij de gemeente beschikbare capaciteit om te verhalen een rol heeft gespeeld. Tijdens de evaluatie van de WVG in 1996 is naar verluidt namelijk om deze reden, na een kosten-baten analyse in overleg met de betrokken partijen (gemeenten en verzekeraars), besloten af te zien van invoering van een regresrecht voor de door de gemeente krachtens die wet gemaakte kosten. ${ }^{414}$ Wel schijnt de ontoereikendheid van de overheidsbijdragen aan het Gemeentefonds ter financiering van de WVG-voorzieningen in 1998 aanleiding te zijn geweest tot heroverweging van het regres. Hoewel de WVG namelijk primair niet gefinancierd wordt door de gemeenten maar door stortingen van de rijksoverheid in het Gemeentefonds, zal de gemeente voorzover die bijdragen onvoldoende blijken moeten putten uit andere middelen (waarbij overigens primair te denken valt aan het vaststellen van een eigen bijdrage of betaling). Gemeenten bleken genoodzaakt tot het aanwenden van andere financiële middelen om aan hun verplichtingen in het kader van de WVG te kunnen blijven voldoen. De overheidsbijdragen zijn daarop weliswaar verhoogd, maar daarbij heeft de VNG, de belangenorganisatie voor Nederlandse gemeenten, het ministerie van Sociale Zaken en Werkgelegenheid naar verluidt verzocht om te onderzoeken of men de tekorten niet mede door de invoering van een regresrecht zou kunnen terugdringen. De Directie Bijstandszaken van het ministerie heeft naar aanleiding daarvan een nota uitgebracht waarvan maar één onderdeel, een opsomming van de voor- en nadelen van de invoering van het WVG-regres, openbaar is gemaakt. Als het meest zwaarwegende voordeel worden de regresopbrengsten genoemd, als bijkomende yoordelen worden genoemd dat het rechtvaardigheidsgevoel wordt bevredigd doordat de nadelige gevolgen van een onrechtmatige daad niet via de WVG op gemeenschapsgelden worden afgewenteld en dat, in bestuurlijke zin, wordt tegemoet gekomen aan de wens van de VNG. Het belangrijkste nadeel dat wordt genoemd heeft betrekking op de hoge uitvoeringskosten; betwijfeld wordt of gemeenten wel voldoende toegerust zijn voor de uitvoering van het regres en dat, waar dat niet het geval is, externe deskundigen zullen moet worden ingeschakeld. Daarnaast wordt gevreesd voor een moeizaam wetgevingsproces en voor een remmende voorsprong van de WVG als eerste en voorlopig enige gemeentelijke sociale voorziening in het kader waarvan de regrespraktijk zich dan zal ontwikkelen. Gemeenten hebben weliswaar ook een verhaalsrecht voor in het kader van de Algemene bijstandswet verleende bij-

413. De SER maakt bij zijn - zo nauw door de wetgever gevolgde - positieve advies voor uitbreiding van het regres naar de volksverzekeringen uitdrukkelijk een voorbehoud voor juist de AAW-voorzieningen die kort nadien. In 1994, naar de nieuw in te voeren WVG zullen worden overgeheveld. Het SER-rapport (1993), p. 24 stelt voor die voorzieningen dat 'niet duidelijk is of bij invoering van een regresmogelijkheid in de AAW de kosten van deze voorzieningen ook verhaalbaar worden.' 
stand (art. $93 \mathrm{ABW}$ ), maar dat voorziet alleen in regres op bepaalde onderhoudsplichtigen, zoals gewezen echtgenoten (zonder aansprakelijkstelling).

Ook bij de gemeenten zelf blijkt om die reden weinig interesse te bestaan voor het regres. Men zou niet over de capaciteit beschikken om hiervan op een efficiënte wijze gebruik te maken. Zo zou men bij onvoldoende juridische kennis en middelen voor het geldend maken van regresvorderingen aangewezen zijn op externe deskundigheid. Daar staat tegenover dat het percentage van gehandicapten die onder de Wet voorzieningen gehandicapten vallen en wier handicap is veroorzaakt door een schadevoorval dat is veroorzaakt door derden die daarvoor aansprakelijk zijn, naar verluidt zeer gering is (geschat wordt ongeveer $1 \%$ van het totale aantal aanvragen voor verstrekkingen in de zin van die wet). Men heeft wellicht willen voorkomen dat het regresrecht meer zou kosten dan opleveren, vergelijkbaar met het risico dat in 1996 ook door de Algemene Rekenkamer naar aanleiding van haar onderzoek naar het regres van de Ziekenfondswet werd onderkend. ${ }^{415}$ Dit gezegd zijnde lijkt er dan, zonder bijzondere omstandigheden in de rechtsverhouding tussen gemeente en schadeveroorzaker, ook geen ruimte voor verhaal op de schadeveroorzaker op andere, rechtstreekse gronden voor aansprakelijkheid, ${ }^{416}$ zoals door cessie of het vorderingsrecht van art. 6:107 BW (dat uitvoeriger aan de orde komt in paragraaf 4.8).

Wellicht loont regres in het kader van de WVG wèl voldoende als het gecollectiveerd kan worden afgewikkeld. De gezamenlijke regresbelangen - gecollectiveerd zouden dan kunnen worden behartigd door de VNG (waarbij alle Nederlandse gemeenten verplicht aangesloten zijn). Een technische moeilijkheid voor een gecollectiveerd regres zou dan kunnen zijn dat de VNG geen rechtspersoonlijkheid bezit, en geen afdeling voor verhaalszaken heeft. De situatie is in zoverre te vergelijken met het regresrecht van werkgevers (art. 6:107a BW), dat evenmin centraal kan worden afgehandeld omdat de werkgeversbond rechtspersoonlijkheid mist. Maar dat is wellicht niet onoverkomelijk. Zelf neig ik echter te denken dat de 'prijs' die bij de afwikkeling van het regres in de vorm van één collectieve afkoopsom wordt betaald (geen vaststelling van aansprakelijkheid in individuele gevallen) te hoog is, in de zin dat dit het regres grotendeels 'uitkleedt', ontdoet van haar meerwaarde (die in mijn visie juist verband houdt met de toepassing van de aansprakelijkheidsnormen in concrete gevallen). ${ }^{417}$

\subsubsection{Toeslagenwet}

Opmerkelijk is dat ook voor de uitkeringen die het UWV doet krachtens de Toeslagenwet een regresregeling voor samenloop met het aansprakelijkheidsrecht ontbreekt. De TW vult een aantal sociale uitkeringen aan, tot het relevante sociaal

\footnotetext{
415 Zie supra, paragraaf 4.2.1.

416 Vgl. Van Boom (2000a), p. 13.

417 Zie infra, paragraaf 6.4 .
} 
minimum in de gevallen waarin de betrokkene (de benadeelde) daar met zijn gezinsinkomen onder blijft. Tot die wetten behoren met name de arbeidsongeschiktheidsuitkeringen, terwijl daarvoor zoals werd gezien wèl wettelijke regresrechten gelden (WAO, WAZ, WAJONG, WAMIL). Het bijzondere van de toeslag is dat die niet wordt betaald uit premies maar uit de algemene middelen, en dus net als de WVG een sociale voorziening (geen verzekering) is. ${ }^{418}$

Noch uit de toelichting noch uit de in de kamerstukken gepubliceerde verslagen van de driejaarlijkse evaluatie van de wet blijkt precies waarom het UWV geen regresrecht toekomt voor verstrekkingen in het kader van de TW. Is het punt geweest dat de TW een sociale voorziening is en men voorzag dat de introductie van een regresrecht dan een - ongewenste - discussie in gang zou zetten naar de nvoering van regresrechten voor andere sociale voorzieningen? De gedachte zou ook meer principieel kunnen zijn, en erop kunnen neerkomen dat sociale voorziesingen een staatstaak zijn van de staat, uit de algemene middelen worden gefinancierd en niet op individuele burgers mogen worden afgewenteld. Waarschijnlijker s dat voor de afweging van het kabinet een budgettaire afweging het zwaarst weegt. Uitgaande van het beginsel dat de schadeveroorzaker de totale schade moet dragen zou de invoering van een regresrecht echter voor de hand liggen.

\subsubsection{Overige regelingen}

Uitzonderlijk maar niet denkbeeldig zijn de gevallen waarin de benadeelde als gevolg van het schadevoorval uitkeringen behoeft krachtens de Algemene bijstandswet of aanverwante regelingen, denk aan de Wet inkomensvoorziening oudere en gedeeltelijk arbeidsongeschikte werkloze werknemers en de Wet inkomensvoorziening oudere en gedeeltelijk arbeidsongeschikte gewezen zelfstandigen. Samenloop met het aansprakelijkheidsrecht is dan vrijwel uitgesloten. Te denken valt wellicht aan gevallen waarin de benadeelde door toedoen van de schadeveroorzaker zijn beroep of bedrijf heeft verloren. Binnen de sfeer van letselschade valt wellicht te denken aan gevallen waarin bijstand wordt verstrekt naar aanleiding van een verkeersfout van derden, waardoor de benadeelde in een inrichting moet worden opgenomen en/of abrupt zijn studie moet afbreken. Bij 'echte' werkloosheidsvoorzieningen is dat meer uitzonderlijk; die beschermen immers tegen het risico van onvrijwillige werkloosheid. Te denken valt dan onder meer aan de situatie dat degene die door de fout van een ander zijn eenmansbedrijf of zijn dienstbetrekking heeft verioren of arbeidsongeschikt is geraakt waarop nadien een (rechtsgeldig) ontslag is gevolgd. Van 'echte' samenloop tussen de onderhavige regelingen en het aansprakelijkheidsrecht is in zulke gevallen in beginsel echter geen sprake. Ze hebben een vangnetfunctie en komen dus in beginsel alleen tot betaling indien 
de benadeelde geen andere middelen heeft om in zijn bestaan te voorzien. ${ }^{419}$ Inkomsten van de benadeelde of diens partner uit (of: in verband met) arbeid zoals loon, pensioenen, VUT, maar ook schadevergoeding wegens inkomensschade komen volledig op de uitkering in mindering. De schadeveroorzaker blijft in zoverre dus gewoon betaling verschuldigd aan de benadeelde zelf, en voor het regres is daarbij geen plaats.

In dit verband verdient wèl de Algemene Kinderbijslagwet nog kort aandacht. Dat is nog één van de weinige sociale verzekeringen (geen sociale voorziening), waarin het regresrecht ontbreekt. De gevallen waarop die wet betrekking heeft zullen veelal geen aanleiding geven tot samenloop met het aansprakelijkheidsrecht, maar er zijn gevallen waarvoor dat anders is. Zo valt te denken aan de situatie waarin kinderbijslag wordt verstrekt naar aanleiding van een mislukte sterilisatie, ondeugdelijk anticonceptiemiddel of aanranding waarvoor derden aansprakelijk zijn. ${ }^{420}$ Gelet op het leidende beginsel dat dubbele vergoeding bij de benadeelde moet worden voorkomen (zie paragraaf 3.3), ligt het dan voor de hand om ook de aanspraken uit de kinderbijslagwet 'verplicht' in mindering te brengen op hun recht op vergoeding voor de kosten van levensonderhoud van het kind, al dan niet naar analogie met de regelingen van verplichte voordeelstoerekening in andere

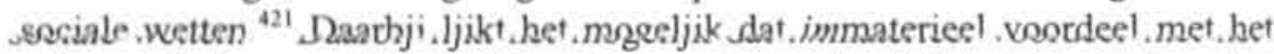
recht op schadevergoeding van de ouders wordt verrekend. In het arrest Wrongful birth besliste de Hoge Raad, dat immateriële voordelen (waartoe onder omstandigheden zelfs het verhoogde levensgeluk voortkomend uit de geboorte van het kind lijkt te worden gerekend) uitsluitend in mindering kunnen komen op de immateriële schadevergoeding. ${ }^{422}$ Hoewel het kabinet het beginsel vooropstelt dat de schadeveroorzaker de schade behoort te dragen, ontbreekt het de Sociale Verzekeringsbank als verstrekker van de Kinderbijslag aan een wettelijk regresrecht. Enkele jaren geleden zijn daarover door enkele kleine christelijke kamerfracties vragen gesteld aan (toenmalig) minister Borst. In haar wel zeer beknopte antwoord is de minister echter pragmatisch: 'gelet op de algemene aard van de wetten (inzake ouderdomspensioen en kinderbijslag), wordt de invoering van een algemeen regresrecht voor deze volksverzekeringswetten niet opportuun geacht. Terughoudendheid bij regelgeving is hier op zijn plaats. ${ }^{, 423}$ De praktische relevantie van een wettelijk regresrecht is in dit verband zo incidenteel, dat zelfs voor de wel relevante gevallen geen actief regresbeleid te verwachten valt.

Bolt (1989a), p. 69.

Zulke aanspraken zullen krachtens art. 6:100 BW in mindering moeten komen op het recht op schadevergoeding van de benadeelde, zie paragraaf 3.3 .5 .

Art. 6:100 BW en PG 6. p. 348; Bloembergen (1965), nr. 222; Bolt (1989a), p. 12.

HR 21 februari 1997, NJ 1999, 145 nt. CJHB (Wrongful birth); vgl. reeds HR 17 december 1976, NJ 1977 , $351 \mathrm{nt}$. ARB (Van den End/Bongaerts); Bolt (1989a), par. 1.4.5 en Sinninghe Damsté (1999), p. 23. In Engeland is in oktober 1997 (de Social Security Administration Act 1992) het postenstelsel ingevoerd. Op grond van de Social Security (Recovery of Benefits) Act 1997 kan voordeel nu nog slechts in mindering worden gebracht op daarmee corresponderende schadeposten van het slachtoffer, zie Law Commission Paper (1997), p. 32. Nota naar aanleiding van het verslag, d.d. 11 december 1998, TK 1998-99, 26 238, nr. 5, p. 2. 


\subsubsection{De positie van sommenverzekeraars}

Uitdrukkelijk uitgesloten van het regres zijn particuliere sommenverzekeraars. Deze regel komt uit het bekende arrest Spoorwegongeval De Vink. ${ }^{424}$ Een vrouw is omgekomen bij een ongeval waarvoor op de Spoorwegmaatschappij aansprakelijkheid rust. Haar ongevallenverzekeraar keert aan haar twee zonen de verzekerde som uit, en stelt daardoor te zijn gesubrogeerd in de vordering tot schadevergoeding van de jongste zoon (art. 1406 BW oud/art. 6:108 BW). Zelf lijkt deze, blijkens de feitelijke weergave van de procedure in het arrest, te hebben bestreden dat hij zijn vordering door subrogatie van de ongevallenverzekeraar zou zijn verloren; hij heeft ook zelf de Spoorwegmaatschappij tot schadevergoeding aangesproken. De Hoge Raad stelt voorop dat de verzekeraar het verzekerde bedrag volgens de polis verschuldigd was onverschillig of en hoeveel schade de zonen hadden. Onder die omstandigheden was volgens de raad voor subrogatie geen plaats. Daargelaten dat de gekozen systematiek van het Wetboek van Koophandel (WvK) de toepasseijkheid ervan voor sommenverzekeringen best zou hebben toegelaten, ${ }^{425}$ lijkt Jat de Hoge Raad niet te verenigen met de bewoordingen en de strekking van Irt. $284 \mathrm{WvK} .^{426}$ De raad baseert zijn oordeel op het inmiddels verlaten standpunt dat de subrogatie op grond van die regeling dubbele vergoeding van de benadeelde moet voorkomen. Art. $284 \mathrm{WvK}$ laat immers vorderingen overgaan op de schadeverzekeraar die de verzekerde heeft 'ter zake van zijn schade'. Zij zou daarom niet ook behoren te gelden voor verzekeringen waarbij de verzekeraar niet tot vergoeding van schade gehouden is maar tot 'een vaste som onafhankelijk van geleden schade'. In het arrest inzake Koopmans/Bedrijfsvereeniging oordeelde de raad in vergelijkbare zin voor de uitkeringen krachtens de Ziektewet (later is men gaan aannemen dat de niet-toepasselijkheid van art. $284 \mathrm{WvK}$ bij de sociale verzekeringen hieruit volgt, dat deze niet berusten op een particuliere verzekeringsovereenkomst). ${ }^{427}$

HR 31 december 1931, NJ 1932, 419 nt. EMM (Spoorwegongeval De Vink). Voorafgaand aan dit arrest werd de uitsluiting van sommenverzekeraars ook in de lagere rechtspraak al aanvaard, zoals bij de rechtbank in de procedure die heeft geleid tot HR 3 april 1930, NJ 1930, $1407 \mathrm{nt}$. EMM (Eerste Onderlinge/PGEM). Hof en Hoge Raad komen aan een oordeel daarover niet toe.

Van Boeschoten (1950), p. 615 en ook Bolt (1989b), p. 41 wijzen erop dat hoewel de regeling van art. 246 e.v. WvK bedoeld is voor schadeverzekeringen, de regeling van art. 248 WvK al het navolgende (waartoe ook nog art. 284 WvK behoort) van overeenkomstige toepassing verklaart op alle verzekeringen.

Bij de invoering van het WvK in 1838 zullen onder verzekeringen ook wel alleen de contracten zijn verstaan die ertoe strekten concrete schade te vergoeden. Daarvbor waren er wel schaderegelingen, zoals voor kistenmakersknechten begin 17e eeuw. Schuurmans Stekhoven (1938), p. 25: 'Zo enig geselle zo crank wiende ofte enig Acsident hadde - door Godes hand ontfangen, - dat hij een docter ofter chirurgijn moste hebben, die zal hem door de olderman en hovelingen (...) uit het screen worden betaalt". Zie over de ontwikkeling van de verzekeringspraktijk in die tijd o.a. Fredericq (1971), p. II: Van Bameveld (1984), p. 51 en Oosenbrug e.a. (1996), p. 51.

427 HR 3 januari 1936, NJ1936, 78 nt. EMM (Koopmans/Bedriffsereeniging), zie ook HR 28 april 1989, NJ 1990, $703 \mathrm{nt}$. JCS (Tollenaar/Bundesversicherungsanstalt). 
Op het arrest Spoorwegongeval De Vink en de sindsdien geldende regel dat sommenverzekeraars niet worden gesubrogeerd is veel kritiek. ${ }^{428}$ Twee meer fundamentele punten vragen hier aandacht. Het eerste punt heeft betrekking op 's raads argument dat de strekking van art. $284 \mathrm{WvK}$ is om dubbele vergoeding van de benadeelde te voorkomen. Dàt volgt naar de huidige rechtsopvatting al uit de regels van het schadevergoedingsrecht. Dubbele vergoeding wordt al voorkomen door regels van het schadevergoedingsrecht, die bepalen dat de verzekerde ter hoogte van de schadeuitkering geen schade meer heeft en op die grond geen recht heeft op vergoeding van de schadeveroorzaker. Dààrvoor is art. $284 \mathrm{WvK}$ dus niet nodig. ${ }^{429}$ Ook de Hoge Raad heeft inmiddels op dat punt zijn koers gewijzigd. ${ }^{430}$ In het arrest Nationale Nederlanden/Woudsend II hecht de raad er voor de vraag naar subrogatie bij schadeverzekeringen aan dat art. $284 \mathrm{WvK}$ voorkomt dat de schadeveroorzaker van zijn vergoedingsplicht wordt bevrijd. ${ }^{431}$ Dit veronderstelt dat dubbele vergoeding van de benadeelde al op andere grond wordt voorkomen. Het tweede, meer gehoorde punt van kritiek op de regel dat sommenverzekeraars zijn uitgesloten van subrogatie is dat het onderscheid tussen schade- en sommenverzekeringen weinig scherp is. ${ }^{432}$ Dat sommenverzekeraars gehouden zijn tot uitkering van een vaste som, onafhankelijk van de vraag of en hoeveel schade geleden wordt, zegt immers nog weinig over de strekking van de betreffende verzekering. Dat met vaste taxaties of vaste uitkeringsbedragen wordt gewerkt kan doelmatigheidsredenen hebben die niet noodzakelijk afbreuk doen aan de strekking van de verzekering.

\subsubsection{Naar komend recht (titel $7.17 \mathrm{BW}$ )}

Twee gefundeerde bezwaren, zo lijkt het, maar welke betekenis moet eraan worden toegekend? Terecht handhaaft het nieuwe verzekeringsrecht (zie paragraaf 4.2.4) het onderscheid tussen schade- en sommenverzekeringen voor het recht op subrogatie. Afdeling 7.17.2 BW is gewijd aan schadeverzekeringen. Die worden gedefinieerd als verzekeringen strekkende tot vergoeding van vermogensschade die de verzekerde kan lijden. ${ }^{433}$ In deze afdeling is ook art. 7.17.2.25 BW opgenomen. $\mathrm{Bij}$ uitkeringen uit ziektekosten- of tandartsverzekering wordt dus gesubrogeerd. ${ }^{434}$

Zie o.a. Dorhout Mees (1935) p. 318; Van Boeschoten (1950), p. 614; Van den Heuvel (1960), p. 4 e.v; Slachter (1963), p. 147; Bloembergen (1965), nr. 257; De Kok (1965), p. 93 e.v; Bolt (1989b), p. 40; Schadevergoeding. art. 107 (Bolt), aant, 52 met verder verwijzingen.

In die zin reeds Van Boeschoten (1950), p. 614 en meer recent Bolt (1989b), p. 42 en Van Boom (2000a), p. 8.

Zie paragraaf 6.3.1.

HR 7 januari 2000, NJ 2000, 212 nt. MMM (Nationale Nederlanden/Woudsend II).

Zie o.a. Asser-Clausing-Wansink (1998), nr, 318; Dorhout Mees (1935), p. 319; De Kok (1965), p. 93; Van Boeschoten (1950), p. 614; Bolt (1989b), p. 42 en in constaterende zin Schadevergoedingsnecht, art. 107 (Bolt). aant. 53 en Van Dam (1995), p. 104.

Art. 7.17.2.1 BW.

TK 1985-86, 19.529 , nr. 3 (MvT), p. 34. 
Afdeling 7.17.3 BW geeft een regeling voor sommenverzekeringen. Uit de gekozen wetstechniek volgt dat de regeling van subrogatie daarop niet van overeenkomstige toepassing is. Om welke verzekeringen gaat het? Sommenverzekeringen worden in art. 7.17.3.1 BW gedefinieerd als verzekeringen waarbij het onverschillig is of en in hoeverre met de uitkering schade wordt vergoed. Ze zijn slechts toegelaten bij persoonsverzekering en bij verzekeringen die bij algemene maatregel van bestuur zijn aangewezen. ${ }^{435}$ Bekende vormen van persoonsverzekeringen in dit verband zijn de ongevallenverzekering, de arbeidsongeschiktheidsverzekering, de levensverzekering, de lijfrenteverzekering en de pensioenverzekering. ${ }^{436}$ Voor uitvaartof begrafenisverzekeraars gelden enkele bijzonderheden, ze kwamen al ter sprake. ${ }^{437}$ Waarom is de voortzetting van dit regime in het nieuwe verzekeringsrecht inderdaad wenselijk?

\subsubsection{Systematisch uitgangspunt}

Voorop staat dat de strekking van het regres is, daarover lijken de meningen onverdeeld, dat de draagplicht met betrekking tot de schade weer bij de schadeveroorzaker moet worden gelegd (het is pas bij de vraag welke functies dit heeft, dat de meningen fundamenteel uiteenlopen, zie paragraaf 6.1 ). Dit betekent dat het regres in beginsel begerkt moet blijven tot die gevallen waarin de schadeveroorzaker van zijn vergsedingsplicht jegens de benadeelde is bevrijd. De keerzijde van de medaille is dat het regres daarbuiten niets te zoeken heeft. Dat nu is een belangrijk uitgangsoun, want het betekent dat de vraag naar voordeelstoerekening dogmatisch gezien een 'vorrstation' is dat moet worden gepasseerd om aan de vraag naar subrogatie toe te kunnen komen: als de uitkering aan de benadeelde wordt toegerekend is regres nodig om te voorkomen dat de schadeveroorzaker 'de dans ontspringt:

Als het overigens senmaal regel is ditde verzekeringsuitkering aan de benadeeldemoet worden toegerekend en ment de veruekenar dasop in de vordering jegens de schadeveroorzaker laat subrogeren opdat de laatale niet wordi hevrijd, dan zal de subrogatie fechnisch gezien de grond zijn waarop de benadeelde ziji vordering verliesi (en komi men systematisch gezien immens aan de regeling van voordeelstoerekening nie med toe).

Voordeelsoerckening is zonder meer redelijk in die gevallen, waarin de benadeelde een vergoeding ontvangt buiten het aansprakelijkheidsrecht om die daaraan qua strekking eigenilik gelijk is, ${ }^{49}$ In zulke gevallen, waarin de vergoedingsplicht van de schadeveroorzaker samenloopt met een daaraan gelijk te stellen vergoeding

\footnotetext{
48 Zie an. 7.17.3.1 IWW, tweede volzin. Voonteelden daarvan zijn regen- en hagelverzekeringen, gevallen waarin de thas naar aansprakelijkheid niet direct an de orde is, TK 1985-86, $19529, \mathrm{nr} .3$ (MvT), p. 35.

44. Mak (1995), a. 13

49 Zie panyas 4.5 .5 .

4i Zie paragnaf 3.3 .5
} 
van derden, is sprake van een toevallige samenloop van prestaties. ${ }^{439}$ Indien de benadeelde dan vergoed wordt door die derden, dan verliest hij daarmee zijn aanspraak jegens de schadeveroorzaker, en is deze laatste bevrijd. Volgens de geldende rechtsopvatting is hij dan niet door een beroep op het aansprakelijkheidsrecht nogmaals tot vergoeding gehouden. Dit berust op het principe dat schade slechts eenmaal kan en behoort te worden vergoed, en heeft ook een instrumentele functie: het aansprakelijkheidsrecht moet niet aanzetten tot chicaneuze praktijken, door het vooruitzicht te bieden van vergoeding van schade waarvoor al vergoed werd. ${ }^{440}$ Het regres kan dan ervoor zorgen dat de draagplicht met betrekking tot de schade alsnog bij hem komt te liggen. ${ }^{441}$ Dit wil uiteraard nog niet zeggen dat in alle gevallen waarin voordeelstoerekening plaatsvindt inhoudelijk gezien ook regres moet plaatsvinden. Wèl biedt het een helder systematisch vertrekpunt voor de discussie: indien regels van het schadevergoedingsrecht de benadeelde bij een uitkering uit sommenverzekering dubbele vergoeding toestaan zou de toepasselijkheid van art. $284 \mathrm{WvK}$ niet alleen dat resultaat ondergraven, maar ook geen goede zin hebben.

Voor de vraag naar voordeelstoerekening geldt dat uitkeringen uit sommenverzekering als uitgangspunt niet door voordeelstoerekening met het recht op schadevergoeding worden verrekend. ${ }^{42}$ De rechter is wel vrij om op grond van àndere (of: aanvullende) omstandigheden in afwijking van de jurisprudentie van de Hoge Raad op dit punt tot voordeelstoerekening te komen. ${ }^{443}$ Maar enkel uitgaande van het karakter van de sommenverzekering en de vergoedingsplicht van de schadeveroorzaker is er onvoldoende gelijkenis voor absolute voordeelstoerekening. Dat sommenverzekeringen uitgesloten zijn van subrogatie is daarmee in overeenstemming.

\subsubsection{Kwalificatie als schade- of sommenverzekering}

Het onderscheid tussen schade- en sommenverzekeringen is kortom niet onwenselijk, meer aandacht vraagt de kwalificatie van concrete verzekeringen als schadeof sommenverzekering. ${ }^{44}$ Met name van ongevallenverzekeringen wordt gesteld dat ze een schadevergoedingskarakter hebben. Daarbij past voorzichtigheid, het gegeven dat de verzekering recht geeft op een uitkering bij het verlies van een been is niet voldoende om haar als schadeverzekering te kwalificeren. Voor de

439

440

441

442

443

444

Paragraaf 4.8.2.

Supra, paragraaf 3.3.7.

In hoofdstuk $6 \mathrm{zal}$ worden ingegaan op de functies die dit heeft.

Bolt vermeldt dat uitkeringen uit sommenverzekering slechts incidenteel als voordeel in mindering worden gebracht op de schadevergoeding. Wel lijkt de verzekeringsuitkering aanleiding te kunnen zijn om het bedrag van de schadevergoeding te matigen, zie voor een uitvoerig overzicht Schadevergoeding, ant. 107 (Bolt), aant. 31. PG 6. p. 1309 en meer recent HR 4 februari 2000, NJ 2000, 600 nt. MMM (Kwidama/Raphael Richardson). Volgens Hartlief \& Tjittes (1991), nt. 7 laat de uitsluiting van particuliere sommenverzekeraars van subrogatic de mogelijkheid van een contractueel verhaalsrecht onverlet. 
vraag of sprake is van een toevallige samenloop van prestaties tussen de verzekeringsuitkering en de schadevergoeding van het aansprakelijkheidsrecht gaat het niet slechts om schade in de feitelijke, fysieke zin (verlies van een been of ander letsel of overlijden), maar om de materiële en immateriële gevolgen daarvan (doktersrekening, gederfd levensonderhoud). De verzekering moet tevens strekken tot vergoeding van schade in deze laatste zin, de schade(posten) van afdeling 6.1.10 BW. Als dàt zo is, is er niets op tegen dat wordt gewerkt met (voor)taxaties of standaardisering, mits die maar een benadering zijn van de werkelijke schade. Uiteindelijk zal de inhoud van de overeenkomst (zoals onder meer blijkt uit de verzekeringspolis) beslissendzijn. ${ }^{445}$ Voor een goede afstemming van de procedure van de benadeelde en die van de verzekeraar lijkt het dus wenselijk aansluiting te zoeken bij de normen van het schadevergoedingsrecht. ${ }^{446}$ Daarvoor zal tevens nodig zijn dat de uitkeringsvoorwaarden of tarieven op het risico van juist de gevorderde schade werden afgestemd. Werden de uitkeringstarieven gerelateerd aan het inkomen van de verzekerde en is dàt de basis van de uitkering? Voor verzekeringen waarbij (alleen) dit laatste het geval is, geldt dan eveneens dat sprake is van een schadeverzekering voorzover de uitkering naar aard en omvang met die schade correspondeert. Dan kan immers niet gezegd worden dat het 'onverschillig' is 'of en in hoeverre met de uitkering schade wordt vergoed' (in de woorden van art. 7.17.3.1 BW).

Deze benadering heeft de goedkeuring van de Hoge Raad, zo blijkt uit het arrest Koning/Nationale Nederlanden ${ }^{447}$ Koning wordt directeur-grootaandeelhouder bij een bedrijf, en op die basis wordt een arbeidsongeschiktheidsverzekering afgesloten bij Nationale Nederlanden. Het gaat echter niet goed met het bedrijf, en nadat Nationale Nederlanden duidelijk wordt dat Konings inkomen nog maar een procent is geworden van het opgegeven inkomen, besluit ze de verzekering wegens onvoldoende verzekerbaar belang te royeren. Bij het intreden van diens arbeidsongeschiktheid spreekt Koning Nationale Nederlanden tevergeefs aan tot betaling en betwist het royement omdat sprake zou zijn van een sommenverzekering. De Hoge Raad laat echter het oordeel van het hof in stand. Dat heeft de verzekering na uitvoerig onderzoek naar de polis, de jaarlijkse loonopgave en de wijze waarop Koning de polis tezamen met verklaringen over en weer gedurende de looptijd van de verzekering heeft kunnen en moeten opvatten, als schadeverzekering aangemerkt. Bij verzekeringen als deze overweegt duidelijk het schadevergoedingselement.

Of sprake is van een sommenverzekering hangt dus af, zoals ook uit het genoemde arrest Koning/Nationale Nederlanden lijkt te kunnen worden afgeleid, van de

\footnotetext{
$445 \mathrm{Vgl}$. in die zin ook HR 6 juni 2003, C01/356HR (Koning/Nationale Nederlanden).

44. Voor verzekeringen strekkende tot voorziening in de kosten van lijkbezorging (vgl. ant. 6: 108 lid 2 BW) bestaat meer reden tot twijfel. Art. 7.17.3.9a BW lijkt darvoot zonder meer te veronderstellen dat het gaat om sommenverzekeringen, daarop werd al gewezen (zie boven). 
feitelijke invulling van de verzekering. De Memorie van Toelichting bij het wetsontwerp voor de regeling van titel 7.17 BW is op dit punt wat terughoudender. ${ }^{448}$ Naar komend recht worden ongevallen-, arbeidsongeschiktheids- en invaliditeitsverzekeringen als sommenverzekering aangemerkt indien de uit te keren bedragen bij het afsluiten van de verzekering (definitief) zijn vastgelegd. Dat enkele gegeven is dan beslissend voor de kwalificatie als sommenverzekering. Zoals ik hiervoor aangaf lijkt me dat onwenselijk; voor regres (door subrogatie) is een feitelijke samenloop van onderling inwisselbare vergoedingsplichten voldoende. ${ }^{449}$ Ook kan men de kwalificatie van de verzekering voor afzonderlijke delen van de verzekering laten differentiëren. Een verzekering kan ten dele als schadeverzekering en ten dele als sommenverzekering worden aangemerkt. Alleen voor het schadedeel gelden dan de regels van afdeling 7.17.2 BW (en dan ook slechts voor dat deel het recht van subrogatie). ${ }^{450}$ Voor de hand ligt dan dat ook de betrokken uitkering een gemengd karakter kan hebben. Bolt wijst erop dat voor ongevallen-, arbeidsongeschiktheids- en invaliditeitsverzekeringen mogelijk een beletsel ligt in de hiervoor genoemde passage. ${ }^{451}$ Inderdaad lijkt die in de weg te staan aan gedeeltelijke subrogatie voor (het deel van de) uitkeringen op grond van vooraf vastgestelde bedragen. Die zou men niet voorzover ze geheel of gedeeltelijk feitelijk schade compenseren als schadeuitkering mogen aanmerken. Als de verzekering of de uitkering uit een vast en uit een variabel deel bestaat lijkt daarmee echter niet onverenigbaar om het variabele deel (het deel waarvoor vooraf geen vaste sommen zijn afgesproken) als schadeuitkering aan te merken. Bolt wijst nog op een belangrijker bezwaar, namelijk dat gedeeltelijke subrogatie leidt tot ingewikkelde toestanden. ${ }^{452}$ Dat argument heeft een extra dimensie: hoe ingewikkelder het wordt, hoe groter het risico wordt op een verschillend oordeel in gevallen waarin los van de verzekeraar ook de benadeelde procedeert. Zoals gezegd is het oordeel van de Hoge Raad in het arrest Spoorwegongeval de Vink niet zozeer een oordeel over de wenselijkheid van subrogatie of over de beoogde rechtspositie voor sommenverzekeraars, maar heeft de raad met zijn beslissing de rechtspositie van de benadeelde willen beschermen. De Hoge Raad stelt niet zonder reden voorop dat art. $284 \mathrm{WvK}$ dubbele vergoeding bij de benadeelde moet voorkomen. Subrogatie zou betekenen, zo lijkt de redenering, dat de benadeelde zijn vordering op de aansprakelijke verliest en dat zou ingaan tegen het met de verzekering beoogde resultaat. Het toeval wil dat de vordering van de benadeelde op de aansprakelijke in het arrest Spoorwegongeval De Vink strekte tot vergoeding van gederfd levenson-

TK 1985-86, 19925, nr. 3 (MvT), p. 6.

TK 1985-86, 19925 , nr. 3 (MvT), p. 6.

TK 1985-86, 19 529, nr. 3 (MvT), p. 6.

Bolt (1989b), p. 43.

Bolt (1989b), p. 45. Zij wijst tevens op het algemene bezwaar van Köster tegen subrogatie van sommenverzekeraars, namelijk dat dan juist vanwege de moeilijke taxeerbaarheid van de letselschade met vaste uitkeringen wordt gewerkt. Bolt relativeent dat bezwaar terecht, veelal zal ook voor het inschalen van de verzekerde al wel diens precieze schade moeten worden vastgesteld. 
derhoud (art. $1406 \mathrm{BW}$ oud, nu art. 6:108 lid $1 \mathrm{BW}$ ). Daarvoor geldt thans in elk geval het vereiste dat de benadeelde behoeftig is en wordt om die reden, ook zonder subrogatie, wèl rekening gehouden met de door hem uit verzekering te ontvangen bedragen uit (sommen)verzekering. Eigenlijk is het dus niet zo dat de strekking die de Hoge Raad in het arrest Spoorwegongeval De Vink aan art. 284 WvK toeschreef (het voorkomen van dubbele vergoeding bij de benadeelde), in dat geval onverenigbaar was met de positie van de benadeelde. De uitkering uit sommenverzekering zou immers sowieso, als gevolg van dit behoeftigheidsvereiste, in mindering komen op het recht op schadevergoeding van de benadeelde. Maar de rechter heeft bij het toepassen van het behoeftigheidsvereiste enige speelruimte om te beslissen in hoeverre hij van oordeel is dat de verzekeringsuitkering van invloed kan worden geacht op de behoeftigheid van de benadeelde. De redenering van de Hoge Raad in het arrest Spoorwegongeval De Vink moet mijns inziens dan ook zo worden verstaan, dat men de mogelijkheid heeft willen uitsluiten dat de benadeelde reeds zijn vordering tot schadevergoeding verliest omdat de vordering bij wijze van subrogatie overgaat op de sommenverzekeraar. Duidelijk is dat het, zoals ik het arrest lees, primair de rechtspositie van de benadeelde is die de Hoge Raad met zijn beslissing dat sommenverzekeraars niet worden gesubrogeerd, op het oog lijkt te hebben gehad.

De vraag moet dan, als men de rechtspositie van de benadeelde vooropstelt, zijn: of de uitkering van de schadeverzekering voldoende alternatief biedt voor de vordering tot schadevergoeding. ${ }^{453}$ Dat vereist dat de schade die onder de dekking valt van de verzekering naar haar aard dezelfde is als die waarvoor de aansprakelijke jegens de benadeelde tot schadevergoeding is gehouden. De kritiek in de literatuur is zoals gezegd dat het onderscheid tussen schade- en sommenverzekeringen in de praktijk helemaal niet scherp genoeg is om een zo uiteenlopende positie te kunnen dragen. ${ }^{454}$ Sommenverzekeringen onderscheiden zich weinig van verzekeringen met een getaxeerde polis. $\mathrm{Bij}$ de sommenverzekering wordt alleen, omdat de precieze omvang van de schade dikwijls moeilijk is te berekenen of niet zal zijn aan te tonen, ${ }^{455}$ geen bewijs van schade meer verlangd. Betwijfeld wordt of het belang daarvan bij het uitsluiten van sommenverzekeraars niet wordt overschat. Bij het afsluiten van de verzekering zal immers wèl, zij het impliciet, ervan zijn uitgegaan dat bij de verwezenlijking van het schadevoorval waarvoor de verzekering dekking verleent sprake is van schade. Van Boeschoten noemt gevallen waarin wordt uitgekeerd zonder dat sprake is van schade uitzonderlijk. Dat de verzekeraar anders dan bij schadeverzekeringen óók moet betalen als geen of minder schade geleden is, berust in zijn visie op doelmatigheidsredenen. ${ }^{456}$ Sommenverzekeringen hebben daarom, ook volgens hem, een gemengd karakter

\footnotetext{
453 Zie paragraaf 3.3 .5 .2$.

454 Zie 0.a. Wery (1984), p. 12; Van Bameveld (1984), p. 228; en Oosenbrug e.a. (1996), p. 63.

455 Vgl. Koster (1971), p. 107.

456 Van Boeschoten (1950), p. 616.
} 
en onderscheiden zich slechts in die zin dat de verzekeraar zich van zijn uitkeringsplicht aan de verzekerde kan bevrijden door het bewijs dat geen schade geleden is ${ }^{457}$ Deze behoort dan ook voorzover hij wèl schade heeft vergoed net als schadeverzekeraars te worden gesubrogeerd. ${ }^{458}$ Dit lijkt niet erg verhelderend: verstaat men schade in een zo ruime zin (schade in de zin van letsel of overlijden, of enig vermogensnadeel) dan kan elke verzekering inderdaad als een schadeverzekering worden aangemerkt. ${ }^{459}$

Het impliciete standpunt dat aan het arrest Spoorwegongeval De Vink ten grondslag ligt, en dat ook naar komend recht beslissend zou moeten zijn, is dat de benadeelde naast het geldend maken van zijn uitkering uit sommenverzekering zijn vordering op de aansprakelijke niet behoort te verliezen. Daarmee is echter niet gezegd wat dat verlies van de vordering door de benadeelde zo onwenselijk zou maken. De Hoge Raad wijst daartoe op het karakter van de verzekering in kwestie: de verzekeraar keert uit ongeacht schade. Maar de Hoge Raad legt niet uit waarom dat betekent dat de benadeelde naast de uit sommenverzekering ontvangen bedragen onverminderd recht houdt op schadevergoeding van de aansprakelijke. In het standaardarrest IBC/Derkx ${ }^{460}$ is de Hoge Raad daarover iets uitvoeriger. Het Hof heeft vastgesteld dat de door Derkx afgesloten verzekering een sommenverzekering is, welke aan Derkx in geval van tijdelijke of blijvende invaliditeit tengevolge van een ongeval recht gaf op bij de polis bepaalde uitkeringen, ongeacht of Derkx als gevolg van die invaliditeit enige schade zou hebben geleden. De raad komt voor zulke invaliditeitsverzekeringen tot het oordeel:

'dat in zodanig geval geen rechtsregel meebrengt, dat de verzekeringsuitkering, of de vordering te dier zake, als een aan de gelaedeerde opkomend voordeel op de aan hem te vergoeden schade in mindering moet worden gebracht;

dat het bestaan van een sommenverzekering een aangelegenheid is die de schuldige aan het ongeval niet aangaat, immers het afsluiten van een dergelijke verzekering in de huidige maatschappij een zuiver individuele en persoonlijke beslissing is, zowel wat betreft de vraag of men een zodanige verzekering zal afsluiten, als wat betreft de vraag voor welke bedragen men zich wenst te verzekeren en welke premie men in verband daarmee bereid is te betalen.'

Dat past bij de functie van voordeelstoerekening die in paragraaf 3.3 .7 werd genoemd, te weten het bevorderen dat wordt voorkomen dat de benadeelde financieel beter wordt van het inroepen van aansprakelijkheid dan hij zonder het schade-

Van Boeschoten (1950), p. 616.

Zo o.a. Meijers in zijn noten onder HR 31 december 1931, NJ 1932, 419 (Spoonwegongeval De Vink) en HR 3 januari 1936, NJ 1936, 78 (Koopmans/Bedrijfsvereeniging); Dorhout Mees (1935), p. 320; De Kok (1965). p. 94.

Van der Felitz (1973), p. 7 stelt, los van de vraag naar regres, dat in de definitie van art. 246 WvK teveel nadruk wordt gelegd op de verplichting van de verzekeraar om schade te vergoeden en te weinig aandacht besteed aan zijn hoofdverplichting het overeengekomen gevaar te lopen.

HR 28 november 1969, NJ 1970, 172 nt. GJS (IBCDerkx); vgl. HR 18 november 1937, NJ 1938, $269 \mathrm{nt}$. EMM (Van Rompu/Cleeves). 
voorval zou zijn geweest (omdat het vooruitzicht van financieel gewin zou kunnen aanzetten tot simulatie van schade). Daarvan is geen sprake als de uitkering weliswaar naar aanleiding van het schadevoorval is verstrekt, maar ertoe strekt de benadeelde van een bepaalde som te verzekeren onafhankelijk van zijn schade. Van belang zijn dan de aard van de verzekering en hetgeen verzekeraar en verzekerde met de verzekering voor ogen heeft gestaan. ${ }^{461}$ Verder is van belang in hoeverre door de uitgekeerde verzekeringssommen feitelijk schade wordt geacht te zijn vergoed. In de literatuur klinken ook andere opvattingen. Volgens Mok ligt het onderscheid tussen schade- en sommenverzekeringen bij het al dan niet aanwezig zijn van een verband tussen het onzekere voorval en de schade. ${ }^{462}$ Voor de sommenverzekering zou dat verband ontbreken, terwijl dit in de schadeverzekering juist een wezenlijk bestanddeel is. Dit verklaart volgens Mok waarom de ongevallenuitkering bij het verlies van een been als sommenverzekering wordt aangemerkt. Anders dan ik stelde ziet Mok reeds daarin een schadevergoedingselement, maar het punt is volgens hem dat het verband tussen het onzekere voorval (het ongeval) en de omvang en het bestaan van de schade ontbreekt. Het noodzakelijke oorzakelijk verband met de schade (invaliditeit) verklaart volgens Mok mede waarom de invaliditeitsverzekering ondanks de vaste invaliditeitsgraden een schadeverzekering is. Fredericq zoekt het verschil tussen schade- en sommenverzekeringen hierin, dat bij schadeverzekeringen de schuld van de verzekeraar van dezelfde aard is als de schuld van de aansprakelijke. Zij berust op de verplichting een geleden schade te vergoeden, die direct afhangt van het door de benadeelde werkelijk geleden verlies. ${ }^{463}$

Hoewel 's raads motivering voor het ontbreken van voordeelstoerekening ingeval van sommenverzekering wat vaag blijft, ${ }^{464}$ is zijn oordeel goed verenigbaar met het hiergezegde: voordeelstoerekening zou slechts de inhoud en bedoeling van een rechtsgeldige verzekeringsovereenkomst frustreren. De zuivere sommenuitkering is immers niet bedoeld als alternatief voor de schadevergoeding van het aansprakelijkheidsrecht, maar is bedoeld als spaargeld of financiële reserve, naast de aangetaste vermogensbestanddelen. Voorafgaande aan het schadevoorval heeft de benadeelde een (voorwaardelijke) verzekerde som in zijn vermogen, ${ }^{465}$ die onder bepaalde omstandigheden tot betaling komt. Het is de bedoeling van de overeenkomst, en de benadeelde heeft daar navenante premies voor betaald, dat de bena-

PG 6, p. 346 en $\operatorname{lnv}, 6$, p. 1291.

Mok (1998), p. 57.

Fredericq (1971), p. 10; in die zin ook Drion (1955), nt. 39.

In die zin de noot van Meijers onder HR 8 februari 1935, NJ 1935, p. 425 (op p. 427) en HR 18 december 1963, NJ 1964 nt. NJP waarin voordeelstoerekening wordt aangemerkt als een foepassing van het beginsel van volledige schadevergoeding; daarover Bloembergen (1965), nr. $85 \mathrm{en} \mathrm{nr} .100$ (en nt. 4 op p. 138); Bolt (1989a) en Sinninghe Damste (1999), p. 53: 'een dubbele vergoeding is natuurlijkniet aan de orde' (cursief toegevoegd, EE).

45s De som komt tot uitkering bij het intreden van het verzekende schadevoorval. 
deelde hoe dan ook, los van de omstandigheid of en hoeveel schade hij heeft, over een bepaald bedrag in zijn vermogen zal kunnen beschikken. De (toevallige) omstandigheid dat tevens sprake is van aansprakelijkheid mag deze bedoeling van de benadeelde en de verzekeraar niet frustreren. Kon Van Boeschoten in 1950 opmerken dat sommenverzekeringen gewoonlijk werden afgesloten omdat men beseft aan welke gevaren men in het moderne leven bloot staat 'en welke ontzaglijke financiële rampen daardoor veroorzaakt kunnen worden', ${ }^{466}$ inmiddels is dat toch wat anders. Het aanvullende risico dat men eventueel in gedachten heeft, is niet iets waarvoor aansprakelijkheid geldt, men dekt zich (ook) in voor de oude dag, een gering pensioen, een tegenvallende conjunctuur. ${ }^{467}$ De vermogenspositie van de benadeelde zou dan door het in mindering brengen van de uitkering uit sommenverzekering verslechteren ten opzichte van de situatie waarin na het schadevoorval geen beroep op het aansprakelijkheidsrecht zou zijn gedaan. Wèl toegerekend worden bijvoorbeeld periodieke verzekeringsuitkeringen of de uit belegging verkregen vruchten die feitelijk èn in overeenstemming met de polis, moeten worden geacht de inkomensschade op te heffen. ${ }^{468}$

Als de schadeveroorzaker niet als gevolg van voordeelstoerekening van zijn aansprakelijkheid is bevrijd, dan ligt dààrin dus geen directe reden voor het laten subrogeren van sommenverzekeraars. De regel in het arrest Spoorwegongeval De Vink biedt de benadeelde dan een aanvullende bescherming opdat hij zijn vordering op de aansprakelijke feitelijk niet toch verliest door subrogatie.

\subsubsection{Specifieke ongevallenverzekeringen}

Ongevallenverzekeringen worden over het algemeen aangemerkt als sommenverzekering; ${ }^{469}$ voor de kwalificatie in concreto zijn evenwel de inhoud en strekking beslissend. De mogelijkheid van voordeelstoerekening bestaat dan voorzover uit de concrete omstandigheden van het geval blijkt dat het cumuleren van de door de aansprakelijke verschuldigde schadevergoeding en de verzekeringsuitkeringen de benadeelde geheel of ten dele een vermogenswinst oplevert die daarmee niet is beoogd (of een winst is beoogd die in het verzekeringsrecht niet geoorloofd en dus niet rechtsgeldig is). Wanneer is daarvan nu sprake?

Globaal kan men zich verzekeren van een uitkering aan derden bij het eigen overlijden (rubriek A van de ongevallenverzekering), een uitkering bij blijvende arbeidsongeschiktheid (rubriek B), een daggeldvergoeding bij tijdelijke arbeidsongeschiktheid (rubriek C) en de vergoeding van medische kosten (rubriek D). Een ongevallenverzekering die recht geeft op vergoeding van de concrete medische kosten 
is een schadeverzekering, waarvoor de verzekeraar bij uitkering wordt gesubrogeerd. Terecht stelt Van Boeschoten dat het daarvoor niet behoort uit te maken dat de verzekeraar volgens de verzekeringspolis ook zou moeten vergoeden als het ongeval zonder schade zou zijn geschied. ${ }^{470}$ Ook ongevallenverzekeringen met vaste invaliditeitsgraden voor bepaalde letsels (Gliedertaxe) zijn veelal schade- en geen sommenverzekering. Door de vaste schadetaxatie wordt de 'eisch van het belang' weliswaar gerelativeerd, aldus Schuurmans Stekhoven, maar 'dat is evenzeer het geval bij de zuivere schadeverzekering, waarbij het stelsel van vaste taxaties evenzeer bestaat.' Juist in polissen met op deze wijze gefixeerde uitkeringen wordt vastgehouden aan de voorwaarde dat de uitkering evenredig behoort te zijn aan de mate van invaliditeit. Dikwijls gaat slechts op grond van praktische overwegingen de evenredigheid tussen schade en uitkering gedeeltelijk verloren. ${ }^{471}$

\subsubsection{Regresrecht voor levensverzekeringen?}

Een belangrijke, volgens Köster zelfs 'veruit de belangrijkste' categorie sommenverzekeraars zijn levensverzekeraars. Het gaat daarbij veelal om aanbieders van kapitaalverzekeringen, pensioenen of lijfrenten of andere spaarvormen, die eerder een beleggings- dan (schade)risicokarakter hebben. Ook uitkeringen uit levensverzekeringen worden bij samenloop met het aansprakelijkheidsrecht in het licht van het vorengezegde terecht als een voordeel beschouwd, waar de schadeveroorzaker in beginsel buiten staat. ${ }^{472}$ De ratio daarvan is slechts dat wordt voorkomen dat de benadeelde door het inroepen van aansprakelijkheid, voor wat betreft het vermogensbestanddeel waarvan hij vergoeding vraagt, in een financieel voordeliger situatie raakt dan die waarin hij zonder het schadevoorval zou hebben verkeerd. De uitkering uit levensverzekering is een voordeel van het sparen; naast de bescherming tegen het risico van financiële schade door plotseling overlijden, dienen levensverzekeringen als pensioen of rendement dat de vrucht is op zijn verdiensten en dus in feite niet te onderscheiden is van zijn andere spaargeld. De verzekerde is de verzekering aangegaan omdat hij zich van extra geld wil verzekeren ingeval van overlijden of arbeidsongeschiktheid. Hij heeft daarin geïnvesteerd door premiebetaling, maar die premies behoren in feite nog tot zijn vermogen als een investering die op een bepaald tijdstip, onzeker is alleen wanneer, tot uitkering komt. ${ }^{473}$ Door voordeelstoerekening zou hem dit vermogensbestanddeel worden ontnomen. De premies voor schadeverzekeringen dienen alleen ter verzekering van schaderisico

\footnotetext{
470 Van Boeschoten (1950), p. 616.

47 Schuurmans Stekhoven (1938), p. 27; Van Boeschoten (1950), p. 616; Van der Burg (1990), p. 214, Mok (1998), p. 15.

47. Art. I van de Wet op het levensverzekeringsbedrijf omschrijt de levensverzekering als een overeenkomst tot het doen van geldelijke uitkeringen tegen betaling van premie, in verband met het leven en de dood. Voor levensverzekeringen geldt een speciale wettelijke regeling, ant. 302-308 WvK.

473 Het bij Nederiandse levensverzekeraars verzekerde bedrag liep eind 1992 naar het schijnt in de honderden miljarden(t) guidens.
} 
waarvan het al dan niet intreden en de omvang van de schade die dan ontstaat onzeker is. ${ }^{474}$ Vanuit die gedachte willen ook zij, die pleiten voor subrogatie voor sommenverzekeraars, levensverzekeraars van subrogatie uitsluiten. ${ }^{475}$ Dat past ook bij de door mij gevolgde benadering: regres moet alleen betrekking hebben op die schade, waarvan de schadeveroorzaker een juridisch verwijt wordt gemaakt (en dat is niet de schade waarop het risico waarvoor de verzekering dekking biedt betrekking heeft).

Voor het hier gezegde lijkt het geen verschil te maken of te moeten maken of de levensverzekering al dan geen risico-element heeft. ${ }^{476}$ Levensverzekeringen zonder risico-element zijn spaarverzekeringen waarvoor geldt dat de levensverzekeraar op een overeengekomen tijdstip een bepaalde som zal betalen. Het meest gebruikelijke type levensverzekeringen bestaat uit een combinatie van het risicoen het spaarelement: men verzekert zich tegen het risico van vroegtijdig overlijden èn spaart voor de oude dag. ${ }^{47}$ Van een samenloop met de vergoedingsplicht die op de schadeveroorzaker rust, en dus van bevrijdende betaling door de levensverzekeraar, is ook dan geen sprake, en dus is ook voor subrogatie geen plaats. Dat is alleen anders indien de verzekering (tevens) de concrete financiële gevolgen waarvoor ook art. 6:108 BW geldt beoogt te vergoeden. Indien nabestaanden bij overliiden vergoeding vorderen wegens gederfd of nng te dervero levensonderhoud, dan komen de door hun genoten uitkeringen uit levensverzekering, naar geldend recht wèl in mindering op hun recht op schadevergoeding. ${ }^{478}$ De uitkering wordt dan geacht van invloed te zijn op de behoefte aan levensonderhoud. ${ }^{479}$ Dat lijkt terecht mits de verzekering precies die schade of zelfs kostenposten beoogt te dekken, waarvoor de benadeelde tevens tot schadevergoeding via het aansprakelijkheidsrecht gerechtigd is (althans: indien hij dit zonder de verzekering zou zijn geweest). Op de vergoeding voor die schade of kostenposten moet de uitkering uit levensverzekering dan in mindering worden gebracht, ik stelde dat hiervoor al. Aangenomen wordt echter wel, dat levensverzekeraars, aangezien dit typische sommenverzekeraars zijn, niet worden gesubrogeerd. Men gaat er dan aan voorbij dat ze als ze dienen als voorziening in het levensonderhoud van nabestaanden, voor de vordering van art. 6:108 BW wel degelijk een schadevergoedend karakter kunnen hebben. Het gevolg daarvan is dat de schadeveroorzaker, ten belope van de door de levensverzekeraar uitgekeerde bedragen, volledig van zijn vergoedingsplicht is bevrijd. Omwille van het belang van een consequente toepassing van het

\footnotetext{
474 In het Engelse schadevergoedingsrecht is het zelfs regel dat de uitkeringen uit particuliere schadeverzekeringen niet op het recht in schadevergoeding in mindering worden gebracht indien de gekwetste hiervoor premies heeft opgebracht; zie Law Commission Paper (1997), p. 10. Wel wordt de schadeverzekeraar gesubrogeerd in zijn vordering tot schadevergoeding.

475 In die zin bijvoorbeeld Van Boeschoten (1950), p. 616.

476 Van Bameveld (1984), p. 23.

47 Van Bameveld (1984), p. 233.

478 Zie nader paragraaf 3.3 .4 .3

479 Zie HR 19 juni 1970, NJ 1970, $380 \mathrm{nt}$. GJS (NBM/Eagle Star)
} 
principe dat de schadeveroorzaker de schade behoort te dragen lijkt dat onwenselijk. Een praktisch nadeel van het regres in dit verband is weliswaar dat levensverzekeringen typisch betrekking hebben op een (ook) in het schadevergoedingsrecht moeilijk te berekenen schade, ${ }^{480}$ maar er zijn ook andere regresrechten waarvoor dat dan zou moeten gelden. De kwestie lijkt echter van 'studeerkamer' belang. Zoals bekend immers tonen levensverzekeraars in het algemeen weinig interesse voor een regresrecht (of andere vormen van verhaal, zoals cessie) op de schadeveroorzaker; ze kunnen het door hen gedekte (spaar)risico al zo exact doorberekenen in de verzekeringspremies, dat ze niet lijken te talen naar voor het anderszins afwentelen van de schadelast. Mocht dat in de toekomst veranderen, dan behoren $z e$ in de evengenoemde gevallen van art. 6:108 BW gewoon in het recht op schadevergoeding te worden gesubrogeerd.

Overigens is het kabinet Kok I bij de invoering van het regres in de Algemene nabestaandenwet door één van de kamerfracties (D66) de vraag voorgelegd naar invoering van een regresrecht voor pensioenverzekeraars. Wat de pensioenfondsen met sommenverzekeraars gemeen hebben is dat premies worden bijeengebracht door hen die ter dekking van de risico's van invaliditeit en overlijden over bepaalde financiële middelen willen kunnen putten. Vooralsnog ontbreken ook voor hen, pensioenfondsen en pensioen- en lijfrenteverzekeraars, regresregelingen, en het lijkt erop dat ook van het regres in dat verband op korte termijn niet veel valt te verwachten. ${ }^{481}$ Ook het regresrecht voor de ABP-pensioenen lijkt, sinds de privatisering van het $\mathrm{ABP}$, voor de toekomst niet langer te worden gehandhaafd. ${ }^{482}$ Daarmee zal een belangrijk argument (het ongefundeerde verschil tussen de positie van het $\mathrm{ABP}$ en particuliere pensioenfondsen) komen te vervallen. Juist in deze onderling verschillende rechtspositie lag het argument van sommige auteurs om voor een uitbreiding van het regres op dit gebied te pleiten. ${ }^{483}$

\subsection{Naar een uniforme regeling?}

\subsection{Kritiek op de huidige regeling}

In het voorgaande werden alle relevante regresbepalingen geïntroduceerd en kort besproken, en werd tevens ingegaan op enkele gevallen waarvoor zulke regelingen (vooralsnog) lijken te ontbreken. Als men het geheel probeert te overzien, dan ziet men een kluwen van regelingen die door de wet verspreid zijn geregeld en

\footnotetext{
480 Dit is eén van de punten van kritiek van Mok (1977), p. 187 tegen de uitbreiding van het regres van de Verhalswet ongevallen ambtenaren naar weduwepensioenen.

481 TK 1994-95, 24 169, nr. 6, p. 32; de argumentatie van de wetgever voor het ontbreken van cen regresrecht voor pensioenverzekeraars is weinig helder: 'bij dit soort verzekeringen bestaat een veel geringere band tussen de onrechtmatige daad en de verzekeringsuitkering:

48: Zie paragraaf 4.5.3.

483 Mok (1977), p. 185
} 
een verscheidenheid van gevallen waarvoor min of meer dezelfde regels gelden. Gezien werd dat voor het regresrecht van particuliere verzekeraars een regeling gold in het verzekeringsrecht (art. $284 \mathrm{WvK} /$ art. 7.17.2.25 BW). Voor het Schadefonds Geweldsmisdrijven is een bepaling van dezelfde strekking opgenomen in de Wet Schadefonds Geweldsmisdrijven (art. 6 lid 3 WSG). De zelfstandige regresbepalingen van sociale verzekeraars staan in de desbetreffende sociale wetgeving: ze zijn er te vinden onder een speciaal titelhoofd 'De invloed van de verzekering op het burgerlijk recht'. Voor het regres dat betrekking heeft op rechtspositionele uitkeringen aan ambtenaren geldt een aparte wet, de Verhaalswet ongevallen ambtenaren. Het regres voor loonkosten bij arbeidsongeschiktheid in normaal dienstverband is afzonderlijk geregeld in het Burgerlijk Wetboek (art. 6:107a BW). Voor de kosten die werkgevers of andere niet-verzekeraars (familieleden, hulpverleners) rechtstreeks maken voor het herstel van anderen geldt het vorderingsrecht van art. 6:107 BW. ${ }^{444}$

Tevens werd gezien dat deze regelingen niet alleen verschillen kennen met betrekking tot hun constructie en wettelijke vindplaats, maar dat ook de inhoud en uitleg van de regresrechten uiteenlopen. Bij zo vele regresbepalingen, die over verschillende wetten verspreid geregeld zijn, ${ }^{485}$ en ook nog eens qua reikwijdte en (ingewikkelde) regresconstructie yan elkaar verschillen, kan het niet verhazen dat de regeling tot klachten heeft geleid, zowel vanuit de wetenschap als de praktijk. De bijzondere regresregelingen zouden niet goed op elkaar zijn afgestemd en daardoor de afwikkeling van het regres belemmeren. ${ }^{486}$ Het ingewikkelde samenspel van wettelijke regelingen vraagt bovendien om gedegen juridische kennis van de betrokkenen. Zelfs voor professionele schadedragers zoals sociale verzekeraars, particuliere verzekeraars die belast zijn met de uitvoering van uitkeringen uit sociale verzekering, de overheid als ambtenarenwerkgever (Staat, provincies en gemeenten), het $\mathrm{ABP}$ en werkgevers leidt een beroep op de zelfstandige regresbepalingen al gauw tot ingewikkelde vragen en juridisch-technische verweren. Dat kan belemmerend werken, waardoor de beoogde doelstellingen in de praktijk (onnodig) worden gefrustreerd.

Degenen die deze kosten maken zijn op hun beurt als benadeelde aan te merken en voor hun regresnemers geidt het normale regime zoals hiervoor al werd beschreven.

Ant. 2 VOA; art. 8 WAMIL; art. $\mathrm{N}_{11} \mathrm{ABP}$; art. 75 Wet privatisering ABP; art. $83 \mathrm{~b} \mathrm{ZFW}$, art. $65 \mathrm{~b}$ AWBZ; art. $284 \mathrm{WvK} / \mathrm{art}$ 7.17.2.25 BW; art. 6:107a BW; ant. 52a ZW; ant. 90 WAO; ant. 69 WAZ; art. 61 WAJONG; art. 76 Fonds arbeidsongeschiktheidsverzekering overheidspersoneel; art. $61 \mathrm{ANW} ;$ art. $65 \mathrm{~b}$ AWBZ; en art. 6:107 BW.

486 De samenhang met het regres in de verschillende sociale verzekeringswetten werd ook door het kabinet van groot belang geacht, aldus TK 1995-96, 24 326, nr. 7, p. 8. Zie voorts Koster (1971), preadvies p. 126 en met klem p. 143 (waar daaraan zelfs een argument wordt ontleend voor afschaffing van het regres) en vgl. ook Beekman (1995), p. 1235 en met name ook Van Boom (1996), p. 96 e.v. Het punt is vanuit de praktijk aan de orde gesteld in de lezing van Sinninghe Damsté op het congres voor de Nederlandse Vereniging van Letselschadeadvocaten in 1999. Klachten klonken opnieuw op de op 27 mei 1999 gehouden studiedag Regres, door het Personenschade Instituut van Verzekeraars en het Verbond van Verzekeraars. 
In de literatuur zijn dan ook voorstellen gedaan om te komen tot een algemene regeling. Ruim dertig jaar geleden pleitte Köster voor een regeling voor de samenloop tussen de aanspraak op schadevergoeding uit onrechtmatige daad en die uit (verzekerings)overeenkomst. Bij de samenloop van contractuele aanspraken op verschillende schuldenaren, zoals aanspraken uit schadeverzekering en uit vervoersovereenkomst deden zich, volgens hem, aanmerkelijk minder problemen voor omdat de vraag naar de uiteindelijke draaglast dan veelal moet worden vastgesteld door uitleg van de contractinhoud. ${ }^{487}$ In zijn dissertatie had ook Bloembergen een algemene samenloopregeling voorgesteld die erop neerkwam dat tussen de contractuele schuldenaar en die uit onrechtmatige daad, de onderlinge draagplicht bij de laatste moest rusten.

'Als iemand, die ingevolge art. 1401 [BW oud, art. 6:162 BW, EE] - dus op grond van schuld - voor de schade aansprakelijk is, staat tegenover iemand die contractueel tot vergoeding van schade gehouden is en aan wie geen verwijt omtrent de schade gemaakt kan worden, dan behoort de eerste de schade te dragen. ${ }^{\text {(4) }}$

De regeling zou ook moeten gelden voor particuliere verzekeraars, maar uiteraard alleen voorzover de schadeuitkering die ze aan de benadeelde hebben verstrekt de schadeveroorzaker van zijn vergoedingsplicht jegens de benadeelde bevrijdt. ${ }^{49}$ Sommenverzekeraars zou om die reden geen beroep toekomen op de onderhavige regresregeling. ${ }^{490}$ De moeilijkheid is echter dat de gekozen rangorde niet aansluit bij de voorwaarde van aansprakelijkheid in de onderhavige regresregelingen, zie nader paragraaf 4.9. Voor het regresrecht wordt immers geen onderscheid gemaakt tussen contractuele en buitencontractuele aansprakelijkheid.

\subsubsection{Het tekstvoorstel van Van Boom}

Interessanter is thans het voorstel van Van Boom om te komen tot een uniforme wettelijke regeling. Zijn voorstel heeft uitsluitend betrekking op regresnemers, ${ }^{491}$ en voorziet in één zelfstandig regresrecht voor alle particuliere en sociale verzekeraars en andere risicodragers voor de uitkeringen, vergoedingen en verstrekkingen die ze aan de benadeelde doen. Verder wordt bepaald dat de benadeelde in zoverre

489 Bloembergen heeft zich laten inspireren door de ten onzent zwaar bekritiseerde samenloopregeling van het Zwitserse recht (Riickgriff bei Kaskadenhaftung). Ant. 51 Obligationenrecht (OR): 'Haften mehrere Personen aus verschiedenen Rechtsgruinden, sei es aus unerlaubter Handlung, aus Vertrag oder aus Gesetzesvorschrift dem Verletzten für denselben Schaden, so wird die Bestimmung aber den Rockgriff unter Personen die einen Schaden gemeinsam verschuldet haben, entsprechend auf sie angewandt. Dabei trägt in der Regel derjenige in erster Linie den Schaden, der ihn durch unerlaubte Handlung verschuldet hat und in letzter Linie derjenige, der ohne eigene Schuld und ohne vertragliche Verpflichtung nach Gesetzesvorschrift haftbar ist.

Van Boom (1996), p. $116-118$.
} 
zijn recht op schadevergoeding verliest. Voorgesteld wordt om het voorstel in de plaats te laten komen van afdeling 6.3.5 BW, de Tijdelijke regeling verhaalsrechten. ${ }^{492}$ Opmerkelijk is dat het voorstel beperkt blijft tot het regres bij uitkeringen voor letselschade. De hoofdlijnen van het voorstel laat ik hier volgen: ${ }^{493}$

\section{Artikel 1}

In deze afdeling wordt verstaan onder:

a. gekwetste: degene die lichamelijk of geestelijk letsel heeft opgelopen ten gevolge van een gebeurtenis waarvoor een ander jegens hem tot schadevergoeding verplicht is,

b. risicodrager: overheidslichaam, verzekeraar of werkgever die krachtens wet of overeenkomst verplicht is tot het doen van vergoedingen, uitkeringen of verstrekkingen aan de gekwetste in verband met diens letsel.

Artikel 2

De gekwetste heeft geen recht op schadevergoeding jegens de aansprakelijke voor zover de risicodrager gehouden is de eerstgenoemde schadeloos te stellen.

\section{Artikel 3}

1. De risicodrager heeft verhaal op degene die in verband met het letsel jegens de gekwetste tot schadevergoeding verplicht is, doch ten hoogste tot het bedrag, waarvoor deze bij het ontbreken van deze afdeling aansprakelijk zou zijn jegens de gekwetste, verminderd met een bedrag, gelijk aan dat van de schadevergoeding tot betaling waarvan de aansprakelijke persoon, met inachtneming van deze afdeling, jegens de gekwetste is gehouden.

Hiermee is de kern van het voorstel weergegeven; daarnaast kent het tekstvoorstel bepalingen voor deelonderwerpen. Zo laat art. 3 lid 2 van het voorstel de schadeveroorzaker aan de regresnemer, ondanks het zelfstandige karakter van diens regresrecht, eerdere betalingen die de schadeveroorzaker te goeder trouw deed aan de benadeelde tegenwerpen. Ook wordt een informatieplicht van de benadeelde geregeld en wordt een beperkte kring van aansprakelijken (onder andere echtgenoten, huisgenoten en de werkgever van de benadeelde) opgesomd jegens wie geen regres mogelijk is. ${ }^{494}$

In het navolgende zal met dit tekstvoorstel in het achterhoofd worden nagegaan wat de gemeenschappelijke kenmerken zijn van de onderhavige regresrechten en waarin ze zich onderscheiden van andere verhaalsrechten. Aan de hand daarvan zal in paragraaf 4.10 - kort - worden teruggekomen op de mogelijkheden van een uniforme regeling.

\footnotetext{
492 Van Boom (1996), p. 116.

493 Van Boom (1996), p. 117.

494 Art. 4 en 5 lid 2; Van Boom (1996), p. 118.
} 


\subsection{Gemeenschappelijke kenmerken van de regresbepalingen}

\subsubsection{Een gemeenschappelijke prestatie}

Want is er voldoende gemeenschappelijkèn voldoende onderscheidend vermogen ten opzichte van andere vorderingsrechten in het aansprakelijkheidsrecht voor een geuniformeerde regeling? Dàt de onderhavige regresregelingen gemeenschappelijke kenmerken hebben is duidelijk, in het vorige hoofdstuk werd gezien dat het in feite telkens dezelfde situatie van samenloop is, die aan het regres ten grondslag ligt: de regresnemer heeft schade voor zijn rekening genomen die ook schade vormt in de zin van art. 6:95 BW (inkomensschade, herstelkosten, smartengeld, kosten van levensonderhoud, kosten van lijkbezorging enzovoort), en voldoet daarmee dezelfde prestatie als waartoe de schadeveroorzaker gehouden was. De schadeveroorzaker is als gevolg hiervan in zijn verhouding tot de benadeelde bevrijd. Dat kenmerkt het regres in het algemeen: de situatie is typisch deze, dat schuldeiser $\mathrm{X}$ (de benadeelde) jegens meer dan één schuldenaar recht heeft op dezelfde prestatie (schadevergoeding), en dat één van beide aan X betaalt. De regresregeling houdt in dat $\mathrm{X}$ dan, bij het geldend maken van zijn aanspraak op schuldenaar $\mathrm{A}$, zijn aanspraak op schuldenaar B verliest en dat schuldenaar A voor de door hem betaalde prestatie (of een deel daarvan) recht heeft op terugbetaling (regres) jegens B. Een eenvoudig voorbeeld van regres buiten het aansprakelijkheidsrecht geeft de Algemene bijstandswet. Gemeenten die bijstandsuitkeringen verstrekken bij onvermogendheid na echtscheiding kunnen de betreffende bedragen verhalen op de exechtgenoot. Daarvoor wordt aangeknoopt bij diens alimentatieplicht jegens de bijstandgerechtigde, en de regels van het familierecht. ${ }^{495}$ Ook valt te denken aan de eigenaar wiens stuk grond bezwaard is met een hypotheek ten behoeve van de schuld van een ander en die na executie regres heeft op de schuldenaar. ${ }^{496}$ De toepassingen van het leerstuk zijn zo uiteenlopend, dat algemene verhandelingen over 'het regres' weinig zinvol lijken; die zijn in de Nederlandse rechtsliteratuur ook vrij zeldzaam. ${ }^{497}$

Maar hebben de onderhavige regresregelingen (voor particuliere en sociale schadedragers) ook voldoende onderscheidend vermogen ten opzichte van andere regresrechten? In paragraaf 3.3.5 werd de aan deze regelingen ten grondslag liggende situatie getypeerd als een toevallige samenloop van prestaties. Hoewel die term met name viel bij de samenloop van het aansprakelijkheidsrecht met uitkeringen uit particuliere of sociale verzekering, geldt het daar gezegde ook voor de samen-

Zie ant. 93 Algemene bijstandswet.

496 Als niet al sprake is van cen 'normale', rechtstrecke contractucle gehoudenheid tot terugbetaling van de schuldenaar jegens de huiseigenaar zèl, dan geldt in dat geval de regeling van art. 6:150 sub $a$ BW.

47 De Engelse en Duitse literatuur kennen meer publicaties over regres in verschillende rechtssferen, zoals die van Selb (1963); Friedmann \& Cohen (1991b); Fleming (1970). Een breed terrein beslaan de dissertaties van Van Vrijberghe De Coningh (1943) en De Kok (1965), het beknopte overzichtswerk van Sinninghe Damsté (1999) en specifiek over de onderhavige reyesrechten Van Boom, Hartlief \& Spier (1996) en Van Boom (2000a).
} 
loop die aan de overige regresregelingen ten grondslag ligt. Dit vraagt nu meer aandacht.

\subsubsection{Toevallige samenloop van prestaties}

Regresnemende derden betalen dezelfde prestatie als de prestatie die de regresplichtige in zijn eigen verhouding tot de benadeelde verschuldigd was. Bij de onderhavige regresrechten bestaat die gemeenschappelijke prestatie uit het betalen van schadevergoeding. Gesproken kan worden van een toevallige samenloop van prestaties: de regresnemer nam in zijn verhouding tot de benadeelde juist die schade voor zijn rekening waarvoor ook de schadeveroorzaker tot schadevergoeding gehouden was. Die term wordt gebruikt voor de samenloop van vergoedingsplichten bij medeaansprakelijkheid, maar ook voor schadeverzekeraars die op basis van de verzekeringsovereenkomst schade voor hun rekening nemen waarvoor de schadeveroorzaker aansprakelijk is. Niet alleen de overeenkomst van schadeverzekering, maar ook andere overeenkomsten en de wet kunnen aanleiding geven tot een toevallige samenloop van de vergoedingen van derden met de vergoedingsplicht van de schadeveroorzaker. Zeker in de sfeer van letsel- en overlijdensschade valt daarbji te denken aan een betergoene oropen bedyivan an instantię_zoals soniale verzekeraars, werkgevers en het Schadefonds Geweldsmisdrijven.

Gesproken wordt ook wel van een 'toevallige samenloop van verbintenissen', hetgeen dan echter impliceert dat op beide schuldenaren de plicht rust tot betaling (terwijl dat voor de onderhavige regresnemers niet steeds het geval is). Van Boom wijst erop dat de achtergrond van deze figuur ligt bij het correale karakter van de regeling van hoofdelijkheid. ${ }^{49}$ De regeling dat elke schuldenaar aansprakelijk is voor het totaal werd aanvankelijk onder het oude reeht (art. $1316 \mathrm{e.v}$. BW oud) uitgelegd als lotsverbondenheid. Dàt vond men te ver gaan indien een rechtsband tussen de schuldenaren ontbrak, zoals bij samenloop tussen de vergoedingsplichten van schadeverzekeraar en schadeveroorzaker.

Wanneer is daarvan nu sprake? Van samenloop met het aansprakelijkheidsrecht is sprake indien zij betalingen doen ter vergoeding van dezelfde schade, dat is schade in de zin van afdeling 6.1.10 BW (art. 6:95 BW). Daarbij zijn twee aspecten van belang. Ten eerste moet de betaling van de regresnemer de strekking hebben schade van de benadeelde te vergoeden. Betalingen die slechts feitelijk door de benadeelde worden aangewend ter vermindering van zijn schade zonder dat ze daarvoor ook bedoeld zijn vallen buiten het bereik van de onderhavige regresregeling. Denk aan het (illusoire) geval waarin de organisator van een loterij de hoofdprijs uitkeert aan een winnaar die tevens slachtoffer werd van een verkeersongeval. Indien de prijs door de winnaar wordt aangewend ter voldoening van ziekenhuisrekeningen of bij overlijden door zijn nabestaanden voor de voorziening in hun levensonderhoud, dan hoort dit geen repercussies te hebben voor het recht op

Van Boom (1999), p. 17, nt. 67. 
schadevergoeding. Evenmin behoort de spelorganisatie (uiteraard) de mogelijkheid te hebben tot het nemen van regres. ${ }^{49}$ Het tweede punt is dat met de betaling van de regresnemer beoogd moet zijn om juist die schade te vergoeden waarvoor ook de schadeveroorzaker aansprakelijk is. Bij de bespreking van de afzonderlijke regresbepalingen bleek globaal om welke schade het typisch gaat bij letsel en overlijden: inkomensschade, medische herstelkosten, smart, derving van voorziening in levensonderhoud, kosten van lijkbezorging.

Indien derden tot vergoeding gehouden zijn van deze schade en ook op de schadeveroorzaker een vergoedingsplicht rust met betrekking tot die schade, dan wordt deze laatste door hen van zijn vergoedingsplicht bevrijd. Zoals in het vorige hoofdstuk werd gezien leidt de gelijkenis van de prestaties (meerdere vergoedingsplichten ter zake van dezelfde schade) immers, ook los van het regres, tot een absoluut regime van voordeelstoerekening. De benadeelde dient slechts eenmaal te worden vergoed. In die gevallen heeft de betalende een regresrecht op degene die door die betaling wordt bevrijd. Regresregelingen regelen de interne verdeling van de draagplicht tussen de regrespartijen; hoe de onderlinge draagplicht wordt verdeeld hangt af van de situatie.

Op dit punt moeten de gevallen van toevallige samenloop worden onderscheiden in deelcategorieën van regresnemers, afhankelijk van de grondslag van betaling aan de benadeelde. Voor gevallen van medeaansprakelijkheid geldt de regeling van hoofdelijkheid (en intern regres, art. 6:102 BW). Voor de onderhavige gevallen is daarvan zoals gezegd geen sprake, maar heeft de uitkerende derde een wettelijk regresrecht dan wel het vorderingsrecht van art. 6:107 BW. Anders dan bij de regeling voor medeaansprakelijken leggen de onderhavige regresrechten de interne draagplicht met betrekking tot de schade volledig bij de schadeveroorzaker, vanwege diens aansprakelijkheid voor het ontstaan van de schade. Het regres maakt in theorie een ronde cirkel: de schadeveroorzaker is jegens de benadeelde bevrijd, maar is voor hetzelfde bedrag uit hoofde van diens aansprakelijkheid jegens de benadeelde betaling verschuldigd aan de regresnemer.

De regresrechten behoeven dan ook een uitdrukkelijke wettelijke grondslag. Die ontbreekt (vooralsnog) voor uitkeringen in het kader van de Wet voorzieningen gehandicapten. Is de benadeelde, bijvoorbeeld, naar aanleiding van het schadevoorval gehandicapt geraakt en daardoor gerechtigd tot aanpassing van zijn huis door de gemeente, dan is de schadeveroorzaker voor dat deel van de schade van zijn schuld bevrijd zonder dat een nieuwe schuld ontstaat jegens de gemeente.

49 Nog afgezien van het feit dat hem geen wettelijk regresrecht toekomt en dit, gelet op het gesloten systeem van de regeling van het regres in dit verband, noodrakelijk is. 


\subsubsection{Regresplafond}

De onderhavige regresrechten hebben nog iets gemeen: voor méér dan de omvang van zijn aansprakelijkheid jegens de benadeelde is de schadeveroorzaker geen regres verschuldigd. Vermogensrechtelijk dient hij er vergeleken met de situatie waarin de schade voor rekening van de benadeelde zelf zou zijn gebleven, niet op vooruit of achteruit te gaan. ${ }^{500}$ Daarvoor wordt gebruik gemaakt van verschillende constructies:

\section{Regres door rechtsovergang}

De eerste constructie is subrogatie, een vorm van rechtsovergang onder bijzondere titel (vgl. art. 3:80 lid 3 BW). Op die constructie berust het regresrecht van particuliere schadeverzekeraars en van het Schadefonds Geweldsmisdrijven. Voorzover zij uit hoofde van de verzekeringspolis of de wet uitkering doen aan de benadeelde, gaat diens recht op schadevergoeding op hen over (art. $284 \mathrm{WvK} /$ art. 7.17.2.25 BW en art. 6 lid 3 Wet Schadefonds Geweldsmisdrijven). Dit regresrecht heeft kortom een derivatief karakter: het is naar de aard en omvang beperkt tot het vorderingsrecht van de benadeelde voorzover dit op de gesubrogeerde overgaat (en deze laatste verliest.zjin recht. in zoverrę).

\section{Zelfstandig regres}

De tweede constructie is van belang voor regresrechten die rechtstreeks worden verkregen, los van de vordering van de benadeelde. Door een wettelijke bepaling worden die begrensd tot de omvang van de aansprakelijkheid van de schadeveroorzaker jegens de benadeelde. Dat geldt voor het regres van sociale verzekeraars, overheidsheidsinstellingen die rechtspositioneleuitkeringen doen aan ambtenaren en gewone werkgevers (onder meer art. 90 WAO, art. 2 Verhaalswet ongevallen ambtenaren, en art. 6:107a BW).

Terwijl dus op particuliere verzekeraars het recht overgaat van de benadeelde, ze worden gesubrogeerd, is het regresrecht van sociale verzekeraars en werkgevers volstrekt zelfstandig. ${ }^{501}$ Dat kan zoals ik eerder aangaf, ${ }^{502}$ met name op formeelrechtelijke punten belangrijke consequenties hebben. Regresnemers met een zelfstandig regresrecht, met name sociale verzekeraars en werkgevers, zijn daardoor bijvoorbeeld niet gebonden aan een schikking tussen de benadeelde en de schadeveroorzaker of diens WA-verzekeraar. Voor de inhoud van het verkregen recht zijn de verschillen minder groot. In beide gevallen (óók voor de zelfstandige regres-

\footnotetext{
500 In de navolgende hoofdstukken zal blijken dat dit in de praktijk gemakkelijk anders uitpakt.

s01 Zo geeft art. $83 \mathrm{~b}$ van de Ziekenfondswet het fonds het recht om de krachtens deze wet uitgekeerde bedragen te verhalen op degene die naar burgerlijk recht voor de schade aansprakelijk is.

502 Zie paragraaf 4.2 .4 en infra, paragraaf 7.2 .
} 
rechten) moet worden aangeknoopt bij de aansprakelijkheid van de schadeveroorzaker jegens de benadeelde.

\subsubsection{Afgeleid karakter}

Hiermee is een volgend kenmerk van de onderhavige regresrechten gegeven: steeds zijn de onderhavige regresrechten gekoppeld aan de aansprakelijkheid van de schadeveroorzaker. Het zijn als het ware ervan afgeleide rechten. ${ }^{503}$ De aard van zijn aansprakelijkheid, contractueel of buitencontractueel, is daarvoor niet relevant. ${ }^{504}$ Voorwaarde is wèl dat de schadeveroorzaker aansprakelijk is voor het ontstaan van de schade, dat wil zeggen schadeveroorzaker volgens de normen van het aansprakelijkheidsrecht. Kenmerkend voor het regres is dat de regels van ansprakelijkheid worden toegepast als betrof het de verhouding tussen schadeveroorzaker en benadeelde.

Indien het ziekenfonds naar aanleiding van de aanrijding een zelfstandige regresactie instelt jegens Je aanrijdende automobilist, dan berust de grondslag van diens aansprakelijkheid niet op het verwijt Jat hij de (financiële) belangen van het fonds geschonden heeft. De automobilist moet betalen omdat iij ongemotoriseerden door het gevaar van zijn motorrijtuig blootstelt aan een extra schaderisico, en dit leidt tot dermate emstige gevallen van letsel en overlijden (ziekenhuisopname, revalidatie) dat het aansprakelijkheidsrecht de financiële consequenties daarvan behoudens tegenbewijs bij hem te legt (art. 185 Wegenverkeerswet 1994 juncto art. $83 \mathrm{~b}$ ZFW). De belangen van het fonds hebben daarmee niets te maken.

Het is vooral dit aspect, wat het regres in theorie zo ingewikkeld maakt: het vindt plaats op basis van het feitenrelaas zoals het zich tussen de schadeveroorzaker en de benadeelde heeft afgespeeld en de gedragsnormen van het aansprakelijkheidsrecht zoals ze binnen die verhouding gelden. De positie van de benadeelde is daarbij niet, althans niet direct, meer aan de orde. ${ }^{505}$ De wettelijke regresrechten kennen alsnog rechtsgevolg toe aan de jegens hem geschonden norm.

503 Ik zal deze term maar beperkt gebruiken omdat die in de rechtsliteratuur ook wel anders wordt gebruikt, namelijk afgeleid voor wat betreft de manier waarop het regresrecht wordt verkregen (door rechtsovergang). De term wordt dan alleen gebruikt voor subrogatie, zoals bij Robben (1993), p. 198. Ik bedoel ermee dat de inhoud van het recht afgeleid is, en dat geidt ook voor de zelfstandige regresrechten, ook in deze zin De Bosch Kemper (1995), p. 88.

so4 Wel staat de Tijdelijke regeling verhaalsrechten (art. 6:197 BW) aan het inroepen van bepaalde gronden van risicoaansprakelijkheid in de weg.

sos Vgl. Shavell (1984), p. 358. Wel ligt in het gegeven dat de benadeelde al uit andere hoofde dan aansprakelijkheid wordt vergoed, zoals gezegd, de aanleiding voor het aan regres ten grondslag liggende rechtssysteem. Voor het recht op regres is dan ook nodig dat de benadeelde is of wordt vergoed. Deze vergoeding bepalt naar geidend recht tevens de omvang van de betaling waarop de regresnemer recht heeft. 


\subsection{Systematiek van wettelijke verhaalsrechten}

\subsubsection{Verhaalsrechten van art. 6:107 en $108 \mathrm{BW}$}

Regresrechten zijn hierin niet uniek: ook bij het recht op schadevergoeding van de benadeelde zèlf komt deze constructie voor. De verhaalsrechten van art. 6:107 en 108 BW kwamen al verschillende keren ter sprake. Ze verbinden aan de aansprakelijkheid van de schadeveroorzaker jegens de primair benadeelde een beperkt recht op schadevergoeding voor andere benadeelden die van het letsel of overlijden schade ondervinden. Deze regelingen hebben volgens de Hoge Raad een gesloten karakter: buiten de grenzen van art. 6:107 en 108 BW heeft niemand recht op schadevergoeding voor aan het letsel of overlijden van een ander gerelateerde schade, ${ }^{506}$ De regeling van art. 6:107 BW berust op de gedachte dat bepaalde medische herstelkosten onder omstandigheden typisch terechtkomen bij derden, anderen dan het primaire slachtoffer. ${ }^{507}$ Het verhaalsrecht van deze derden ingevolge art. 6:107 BW moest een halt toeroepen aan de rechtspraktijk onder het oude BW, waarbij cessieconstructies en andere spitsvondigheden alternatieve wegen tot verhaal moesten bieden voor werkgevers en andere derden die voor de door hun gemaakte kosten geen 'normaal' beroep konden doen op de regels van het onrechtmatige daadsrecht. Het gaat om kosten die bijvoorbeeld naasten of voorbijgangers moeten maken ten behoeve van het herstel van het primaire slachtoffer, zoals de kosten van verpleging en verzorging, vervoers- en telefoonkosten. De schade is als het ware naar hen verplaatst ('verplaatste schade'). Deze naasten of voorbijgangers kunnen voor de gemaakte kosten dan zoveel schadevergoeding vorderen, als het primaire slachtoffer bij het maken van die kosten zonder hun financiële steun zèlf zou toekomen. Voorzover ten behoeve van de benadeelde 'redelijke kosten ter beperking of voorkoming van schade' worden gemaakt, die kunnen bijdragen aan zijn herstel, is de schadeveroorzaker in mijn visie ook daarvoor tot vergoeding gehouden. ${ }^{508}$ Art. 6:108 BW geeft nabestaanden bij overlijden een beperkt recht op schadevergoeding. Volgens een recent wetsvoorstel zullen art. 6:107 en $108 \mathrm{BW}$ bij ernstig letsel of overlijden voorts bepaalde dierbaren van de primair benadeelde een beperkt recht op smartengeld geven voor het verdriet dat ze als gevolg daarvan kunnen ondervinden. ${ }^{509}$

Zie meest recent HR 28 mei 1999, NJ 1999, 564 nt. ARB (Gemeente Losser/De Vries).

Dat eriterium wordt niet heel dogmatisch toegepast. $\mathrm{Vgl}$. Inv. 6, p. 1289: ook bezoekkosten vallen eronder. In HR 28 mei 1999, NJ 1999, 564 nt. ARB (Gemeente LosseriDe Vries) worden ook door ouders opgeofferde vrije dagen voor de verzorging van hun kind aangemerkt als schade van het kind. Vergoeding vindt plaats voot de kosten die het kind zelf zou kunnen vorderen indien hij een betaalde kracht had moeten inschakelen; vgl. ook HR 6 juni 2003, C02/062HR (Krïter-Van de Pol/Holding).

Mits ook die als verplaatste schade van het primaire slachtoffer kunnen worden aangemerkt. Zie art. 6:96 BW. TK 2002-03, 28 781, nr. 1-2. 
Voor de juridische constructie van deze regelingen is het principe hetzelfde als bij de wettelijke regresbepalingen: ook de verhaalsrechten van art. 6:107 en 108 $B W$ zijn gekoppeld aan het feitenrelaas zoals zich dat tussen de schadeveroorzaker en de primair benadeelde heeft afgespeeld en aan de gedragsnormen van het aansprakelijkheidsrecht zoals ze binnen die verhouding gelden. Niet relevant is of (tevens) rechtstreeks jegens de eiser zelf aan de voorwaarden voor aansprakelijkheid B voldaan. Anders dan bij de zelfstandige regresrechten wordt in art. 6:107 BW als 6:108 BW overigens uitdrukkelijk bepaald dat de schadeveroorzaker de benadeelde dezelfde verweermiddelen kan tegenwerpen als die hem zouden toekomen n een procedure tegen de primair benadeelde zelf. Voor verweren die betrekking hebben op het vestigen van de aansprakelijkheid (ontbreken van schuld, overmacht, causaliteit) volgt dat eigenlijk ook al wel uit het vereiste van aansprakelijkheid.

\subsubsection{Wettelijk systeem van aansprakelijkheid}

Dit afgeleide karakter van de onderhavige regresrechten en van het vorderingsrecht at. 6:107 en $108 \mathrm{BW}$ moet worden gezien in het licht van de systematiek van ret Nederlandse aansprakelijkheidsrecht. Bij een normaal, rechtstreeks beroep op het aansprakelijkheidsrecht zou de schadeveroorzaker niet steeds met de gevolgen van zijn normschendende gedrag kunnen worden geconfronteerd zonder het huidige regime op te rekken. Het uiteindelijke criterium voor aansprakelijkheid is immers of de schadeveroorzakende gedraging jegens de direct daarbij betrokkenen verwijtbaar was. Aansprakelijkheidsnormen beschermen in het contractenrecht, behoudens derdenbedingen of andere wettelijke uitzonderingen, toci eerst en vooral de wederpartij-contractant, en niet óók derden, zoals diens schadeverzekeraar. ${ }^{510}$ Evenmin eenvoudig is om ten behoeve van schadeverzekeraars of anderen met wier (financiële) belangen de schadeveroorzaker geen rekening behoefde te houden een onrechtmatige daad te construeren. In het relatieve systeem van onrechtmatigheid zijn verkeersfouten van een vrachtwagenchauffeur niet tevens onrechtmatig jegens verstekelingen wier belangen de bestuurder ten tijde van het veroorzaken van een ongeval niet behoefde te kennen. ${ }^{\text {sI }}$ Van 'onrechtmatigheid' (en dus van de mede daarop gebaseerde verplichting tot schadevergoeding van de schadeveroorzaker) is alleen sprake jegens degene wiens concrete, geïndividualiseerde belangen voor de schadeveroorzaker kenbaar en voorzienbaar zijn geweest. ${ }^{512}$ Een systeem waarin de veroorzaker van een verkeersovertreding de daaruit voortvloeiende schade van een in beginsel onbepaalde kring gerechtigden moet betalen, zoals geldt in

Vgl. HR 8 september 2000, N 2000, 734 nt. ARB (Baby Joost). Er zjin veel ingewikkeldere contractuele situaties waar de vraag ontstaat naar de aansprakelijkheid jegens niet-contractanten. Meestal gaat het dan om (nog weer meer) meerpartijensituaties, zoals de situatie waarin bij nakoming van de overeenkornst de belangen van derden zijn betrokken. Maar het uitgangspunt blijt ook dan dat de verplichting tot schadevergoeding slechts geldt tegenover degene jegens wie aan de voorwaarden voor aansprakelijkheid is voldaan.

511 HR 27 januari 1984, NJ 1984, $536 \mathrm{nt}$. G (Verstekeling).

$512 \mathrm{Vgl}$. Rb. Den Haag 5 december 2001 (H/Hannover International), NTBR 2002, p. 162 (Engelhard). 
het Franse (schuld)aansprakelijkheidsrecht, zou haaks staan op dit relatieve concept van onrechtmatigheid. De gedragsnormen hebben uitsluitend en specifiek betrekking op de verhouding tussen de schadeveroorzaker en degene met wiens belangen de schadeveroorzaker rekening heeft kunnen en moeten houden. Bij de invoering van Boek 6 van het Burgerlijk Wetboek in 1992 heeft de wetgever expressis verbis aan dit systeem vastgehouden en in dat verband gewezen op het belang van een duidelijke afbakening voor de beheersbaarheid van het aantal schadeclaims. ${ }^{513}$ Schadeverzekeraars en andere regresnemers zullen veelal ten tijde van het schadeveroorzakende gedrag niet ter plaatse zijn geweest, ze vallen niet onder de beschermende strekking van de geschonden norm. Een (rechtstreekse) vordering tot schadevergoeding van hen jegens de schadeveroorzaker zal dus - nogmaals - niet spoedig tot aansprakelijkheid leiden. Aangezien vorderingen in het verbintenissenrecht een relatief karakter hebben, en dus alleen door en tegen bepaalde personen kunnen worden uitgeoefend, ${ }^{514}$ zou dan bij het ontbreken van een wettelijk regresrecht veelal geen verhaal mogelijk zijn. Bij aansprakelijkheid voor letsel en overlijden komt daar nog de bijzondere beperking bij dat de kring van tot schadevergoeding gerechtigden limitatief is. ${ }^{515}$ In een lange reeks arresten oordeelt de Hoge Raad dat voor aansprakelijkheid wegens het veroorzaken van het letsel of overlijden van een ander buiten het wettelijke regime van art. 6:107 en 108 BW geen plaats is. ${ }^{516}$ Alleen de direct in het ongeval betrokken geraakte benadeelden, ${ }^{517}$ getraumatiseerde derden, ${ }^{518}$ en de in art. 6:107 en 108 BW bedoelde derden hebben recht op schadevergoeding. ${ }^{519}$ En alleen hun particuliere en sociale verzekeraars

513 Zie PG 6, p. 608 en 614 en 616 (over het relatieve en gesloten systeem van onrechtmatige daad); wel wordt bij de Invoeringswet ook gewezen op 'de weinig scherpe begrenzingen, gelegen in de eisen van causaal verband en van de relativiteit van de overtreden norm", Inv. 6, p. 1279. Daarom wordt (uiteindelijk) tevens gekozen, zie $\ln v, 6, p, 1287$, voor de beperking van de vergoeding bij letsel tot in beginsel alleen degene jegens wie aan de voorwaarden voor aansprakelijkheid is voldaan.

514 Vgl. Asser-Mijnssen-De Haan I (1992), nr. 350 en Van Achterberg (1999), nr. 1.

515 Maar volgens de Memorie van Toelichting bij het wetsvoorstel affectieschade is deze regel aan heroverweging toe, TK 2002-03, $28781, \mathrm{nr}, 3$ (slotzin van par. 7). Of daarvan wat te verwachten valt is de vraag. Al in de MvT bij de Invoeringswet in 1982 wordt opgemerkt dat de regel aanvankelijk niet was opgenomen in Boek 6 omdat zij blijkens literatuur en rechtspraak vrij algemeen als onredelijk werd gevoeld, Inv, 6, p. 1278. Met het wetsvoorstel en de verhalbarheid van shockschade is bovendien de praktische relevantie van de uitbreiding van het aansprakelijkheidsregime bij personenschade voor derden aanmerkelijk minder groot dan voorheen. $P G$ 6, p. 1278 en HR 22 februari 2002, NJ 2002, $240 \mathrm{nt}$. JBMV (Taxibus). In dezelfde zin reeds eerder HR 2 januari 1931, NJ 1931, $348 \mathrm{nt}$. EMM (Vollaand/Van der Jacht); HR 2 april 1936, NJ 1936, 752 nt. EMM (Cnasborn/Liverpool); HR 15 februari 1963, NJ 1964, $423 \mathrm{nt}$. DJV (Houtappel/Velthuyzen); HR 10 januari $1958, N J 1958,79 \mathrm{nt}$. LEHR (Van Hoof Van der Plas); HR 16 juni 1972, NJ 1972, 375 (Van Wetten/Cournois); HR 4 november 1983, NJ 1984, 786 nt. EAAL.; HR 8 april 1983, NJ1984, 717 nt. CJHB (Van der Heijden/Holland); HR 12 december 1986, NJ 1987, 958 nt. CJHB (Rockwool/Poly); en HR 28 mei 1999, NJ 1999, 564 nt. ARB (Gemeente Lossen De Vries).

517 Dat is ók degene wiens leed opzettelijk is veroorzaakt middels het ombrengen van een dierbare; HR 26 oktober 2001, NJ 2002, $216 \mathrm{nt}$. JBMV (RVan de $\boldsymbol{W}$ ).

518 Mits is voldaan aan de voorwaarden die de Hoge Raad daarvoor geeft. HR 22 februari 2002, NJ 2002, 240 nt. JBMV (Taxibus)

519 lets anders is dat op de erfgenamen de 'vererfde' vordering tot vergoeding van de letselschade van de primair benadeelde kan overgaan. 
of andere risicodragers hebben een regresrecht. Hierbuiten is voor aansprakelijkheid geen plaats, en daarmee is dan evenmin plaats voor regres.

De uitsluiting van anderen die van het letsel of overlijden schade ondervinden geldt zelfs indien het schadevoorval (toevallig) op andere gronden dan het veroorzaken van het letsel of overlijden óók jegens henzelf onrechtmatig was. Zo moest je vordering tot schadevergoeding van het bedrijf dat kon aantonen dat jegens zaar de hinderwetvergunning was overtreden door een concurrent op een aangrenzend perceel, maar dat schade leed door het juist als gevolg van die hinder ziek zeworden personeel, volgens de Hoge Raad worden afgewezen. ${ }^{520}$ Dat de geschonden norm strekte ter bescherming van het belang van het bedrijf (de eiser) zelf en aan de overige voorwaarden voor aansprakelijkheid was voldaan, is dan kennelijk) zonder betekenis. Ook voor de regreszoekende verzekeraar van het sedrijf is in zulke gevallen geen plaats. ${ }^{521}$

Dit staat haaks op het uitgangspunt dat het relatieve karakter van de aansprakelijkreidsnormen beslissend is voor de vraag wie hieraan bescherming kan ontlenen. Jf de schadeveroorzaker aansprakelijk is hangt volgens deze restrictieve uitleg ran de regeling van art. 6:107 en $108 \mathrm{BW}$ af van de vraag of de schade het rechtstreekse gevolg is geweest van het schadevoorval zèlf dan wel van het letsel of overlijden van een ander; ongeacht de reikwijdte van de geschonden norm. Dat houdt de kring van verhaalsgerechtigden voorspelbaar, hetgeen ook wenselijk is vanuit het oogpunt van rechtszekerheid en verzekerbaarheid. Maar de praktische betekenis hiervan wordt, vergeleken met een systeem waarin enkel de inhoud van de norm bepalend is, gemakkelijk overschat. Bij een beoordeling zuiver op grond van de inhoud van de geschonden norm zal nauwelijks vaker sprake zijn van aansprakelijkheid dan in het huidige regime van de Hoge Raad. De schadeveroorzaker is immers niet aansprakelijk voor de schending van belangen die hij niet heeft kunnen en behoeven te voorzien en vermijden, zoals die van particuliere en sociale verzekeraars. ${ }^{522}$ Het systeem van de Hoge Raad is eigenlijk alleen van betekenis voor een geval zoals in het arrest inzake Rockwool/Poly aan de orde was, ${ }^{523}$ waarin er aanvullende omstandigheden zijn die het voorval (ook) voor de eiser onrechtmatig maken. Een beroep hierop heeft onder het huidige regime geen zin

\footnotetext{
520 In die zin naar oud recht HR 12 december 1986, NJ 1987, $958 \mathrm{nt}$. CJHB (RockwoolPoly), en voorts Inv. 6. p. 1278.

521 Dit levert een verschil op met gevallen van zaakschade, waar verzekeraars van de direct getroffene, de eigenaar van de zaak, wèl een normaal beroep op het aansprakelijkheidsrecht toekomt. Een ongelukkige consequentie hiervan lijkt me dat aan de schending van dezelfde gedragsnorm, afhankelijk van de schadesoort, een ander rechtsgevolg wordt verbonden.

522 Vgl. HR 24 januari 1930, NJ 1930, 299 nt. EMM (Brandstichting).

523 HR 12 december 1986, NJ 1987, $958 \mathrm{nt}$. CJHB (RockwoolPoly). De schending van de Hinderwetvergunning die de oorzaak was van het letsel van het primaire slachtoffer (werknemers) was volgens de normale regels van het onrechtmatige daadsrecht tevens onrechtmatig jegens de eiser die van dat letsel schade ondervond (de werkgever).
} 
omdat men dan aannemelijk moet maken dat de schade geen verband houdt met het veroorzaakte letsel of overlijden. ${ }^{524}$

Met het vorengezegde is duidelijk wat de betekenis is van de onderhavige regresregelingen (en van de verhaalsrechten van art. 6:107 en 108 BW): die geven een zekere uitbreiding van de verhaalsmogelijkheden, zonder daarbij afbreuk te doen aan de beslotenheid (relativiteit) van de norm. Op de rechtspolitieke betekenis hiervan zal in de navolgende hoofdstukken worden ingegaan. Eerst is het goed de ingewikkelde structuur van de verhaalsrechten bij de aansprakelijkheid voor letsel of overlijden nog eens kort in schema zetten.

\subsubsection{Summa summarum}

Schematisch weergegeven komt het wettelijke regime van verhaalsrechten bij de aansprakelijkheid voor letsel of overlijden dan hierop neer:

a. Alleen de primair benadeelde ${ }^{525}$ en de benadeelden in de zin van art. 6:107 en 108 BW hebben recht op schadevergoeding. De benadeelden van art. 6:107 en I08 BW hebben een van de aansprakelijkheid jegens de primair benadeelde afgeleid recht op schadevergoeding. Daarvoor is niet méér nodig dan dat in de verhouding tussen de schadeveroorzaker en de primair benadeelde aan de voorwaarden voor aansprakelijkheid is voldaan.

b. Particuliere en sociale verzekeraars van de primair benadeelde hebben een van de aansprakelijkheid jegens de primair benadeelde afgeleid regresrecht.

c. Particuliere en sociale verzekeraars van de benadeelden in de zin van art. 6:107 BW en art. 6:108 BW hebben een van de aansprakelijkheid jegens hènzelf afgeleid regresrecht. Dat vraagt dus om een dubbele beoordeling: de schadeveroorzaker moet zowel in zijn verhouding tot de primair benadeelde alsook in de op art. 6:107 of 108 BW gebaseerde verhouding tot de daar bedoelde benadeelden aansprakelijk zijn geweest.

De ingewikkelde constructie van afgeleide rechten zorgt ervoor dat het relatieve karakter van de aansprakelijkheidsnormen volkomen in stand blijft. Die blijven immers betrekking hebben op hetgeen zich binnen de verhouding van de schade-

Vgl. Spier e.a. (2000), nr. 251 (Hartlief) en HR 22 februari 2002, NJ 2002, $240 \mathrm{nt}$. JBMV (Taxibus). Hieronder vallen ook getraumatiseerde omstanders en naasten mits ze voldoende zelf bij het ongeval betrokken zijn geraakt. Daarvoor geldende voorwaarden en criteria geformuleerd in het Texibus-arrest (HR 22 februari 2002, NJ 2002, $240 \mathrm{nt}$. JBMV). 
veroorzaker tot de primair benadeelde heeft afgespeeld. De afgeleide rechten geven alleen een uitbreiding van de vermogensrechtelijke consequenties daarvan. De facto leiden ze tot een resultaat dat afwijkt van de hoofdregel dat alleen de primair benadeelde wordt beschermd.

\subsubsection{Andere afgeleide rechten: medeschuldenaren}

In de voorgaande paragrafen lag weliswaar de nadruk op de aansprakelijkheid van de schadeveroorzaker jegens de benadeelde, maar ook op regresnemers zèlf kan in hun verhouding tot de benadeelde de verplichting rusten tot het vergoeden van schade. Voor alle onderhavige regresrechten geldt echter, dat zou men nog een kenmerk kunnen noemen naast de in paragraaf 4.9.2-4.9.4 genoemde kenmerken, dat de betaling die de regresnemer deed aan de benadeelde nimmer zijn oorsprong mag vinden in wettelijke aansprakelijkheid. De regresnemer moet de schade van de benadeelde anders dan uit wettelijke aansprakelijkheid voor zijn rekening hebben genomen. ${ }^{526}$ Werkgevers bijvoorbeeld die het loon moeten doorbetalen an de werknemer die als gevolg van een verkeersongeval arbeidsongeschikt is geraakt, kunnen geen beroep doen op art. 6:107a BW als ze daarvoor zèlf (mede)aansprakelijk zijn. Indien pas achteraf blijkt dat ze medeaansprakelijk zijn verliezen ze hun wettelijke aanspraak en is door de schadeveroorzaker in zijn verhouding tot de werkgever onverschuldigd, althans op een onjuiste wettelijke basis, betaald (art. 6:203 BW). De werkgever zou in het gegeven voorbeeld de schadeveroorzaker slechts kunnen aanspreken als medeaansprakelijke, voor het hem in hun onderlinge verhouding verschuldigde deel (art. 6:10 lid $1 \mathrm{BW}$ ). Dat vergt een verdeling, waarvoor de verdeelsleutel ligt in art. 6:102 juncto art. 6:101 BW, dan wel in bijzondere bepalingen zoals art. 6:170 lid $3 \mathrm{BW}$. Zulke -interne - regresacties zijn van de onderhavige te onderscheiden en vallen buiten het kader van dit bestek.

lets anders is dat ook schadeverzekeraars op later moment, door het verzaken van op hen rustende verplichtingen jegens de benadeelde, voor de daardoor ontstane schade aansprakelijkheid riskeren.

Reeds onder het oude recht gold, dat de algemene regeling voor medeschuldenaren (art. 1436 e.v. BW oud) niet van overeenkomstige toepassing was op de schadeverzekeraar van de benadeelde die regres zocht bij de schadeveroorzaker, ${ }^{527}$ Voor de meeste onderdelen van die regeling sprak dat voor zichzelf, omdat daarin heel specifieke gevallen werden geregeld. Het meest algemeen was de regeling van art. 1438 sub 3 van het oude $B W$, waarin een recht van subrogatie werd toegekend

\footnotetext{
526 Consequent lijkt dan ook de WA-verzekeraar van de schadeveroorzaker bij medeaansprakelijkheid uitte sluiten van bijvoorbeeld ant. 284 WvK/art. 7.17.2.25 BW, maar hierover wordt verschillend gedacht (zie hiema). 
aan 'dengenen die, met anderen, of voor anderen gehouden zijnde tot voldoening van eene schuld, belang had om dezelve te voldoen'. Volgens de rechtspraak van de Hoge Raad was daarvoor nodig, dat tussen de betalende en de andere schuldenaren 'van elders' een rechtsband bestond die meebracht dat de schuld door één of meerdere van de anderen of door alle schuldenaren gezamenlijk gedragen moest worden. ${ }^{528}$ Aangenomen werd dat daarvan bij samenloop van de vergoedingsplichten van de schadeverzekeraar en de schadeveroorzaker (aansprakelijke) geen sprake was omdat de verschuldigde prestaties, ook als de verschuldigde vergoedingen betrekking hadden op dezelfde schade, los van elkaar stonden. ${ }^{529}$ Deze gevallen werden 'toevallig samenlopende verbintenissen' genoemd of kortweg 'samenloop'. Als de benadeelde bijvoorbeeld kwijtschelding verleend had aan de schadeveroorzaker gold niet dat hij daarmee tevens zijn recht had verwerkt op vergoeding van de schadeverzekeraar. ${ }^{530}$ Wèl kon betaling door de één tevens de ander bevrijden, maar dat kwam door de gelijkenis van de verschuldigde prestaties, en stond dus los van de grondslag (schuld) waarop die berustten. Naar aard en inhoud van de prestatie (verplichting tot schadevergoeding) paste daarbij geen dubbele betaling. Met de inwerkingtreding van het huidige $\mathrm{BW}$ is de regeling van art. $1436 \mathrm{en}$ volgende $\mathrm{BW}$ (oud) vervangen door de regeling van afdeling 6.1.2 $\mathrm{BW}$, en geldt dat schuldenaren die gehouden zijn tot vergoeding van dezelîẩe schade hooráeilijk '. aansprakelijk zijn. ${ }^{531}$ Afdeling 6.1.2 BW geeft een regeling voor de pluraliteit van schuldenaren, zowel voor wat betreft ieders rechtsverhouding tot de gezamenlijke schuldeiser als voor de rechtsverhouding tussen de schuldenaren onderling. ${ }^{532}$ Volgens de hoofdregel is ieder van beide schuldenaren jegens de schuldeiser voor een gelijk deel verbonden, tenzij uit wet, gewoonte of rechtshandeling voortvloeit dat ze voor ongelijke delen of hoofdelijk verbonden zijn. Bij hoofdelijkheid heeft de schuldeiser tegenover ieder recht op nakoming van het geheel, met dien verstande dat betaling door de één (tevens) de anderen van hun schuld jegens de schuld-

HR 19 januari 1933, NJ 1933, $1757 \mathrm{nt}$. EMM (Roodhuyzen/Hartogh) en HR 3 januari 1936, NJ 1936, $78 \mathrm{nt}$. EMM (Koopmans/Bedriffsvereeniging). Art. 1438 BW (oud) komt oorspronkelijk uit de Franse Code civil en werd ook zo geinterpreteerd. Zie Ledeboer (1927), p. 21; Bloembergen (1965), nr. 102; Mijnssen (1970), p. 2; Sinninghe Damsté (1999), p. 52-53

Zie HR 3 januari 1936, NJ 1936, 78 nt. EMM (Koopmans/Bedriifsvereeniging); en o.a. Ledeboer (1927), p 21. Asser-Hartkamp 4-1, nr. 581/fe.v., Bloembergen (1965), nt. 6 op p. 142 (met verwijzingen), Köster (1971), p. II5, Bolt (1989b), p. 4I, en Sinninghe Damsté (1999), p. 51. Anders Knap (1925), p. 48 e.v. die zich eerder tegen de 'toch door niemand aangehangen' opvatting keerde dat subrogatie slechts mogelijk zou zijn bij verbintenissen uit dezelfde oorzaak.

Hetzelfde gold voor meerdere schuldenaren die onafhankelijk van elkaar onrechtmatig schade hadden veroorzaakt Ook op die gevallen was art. 1438 BW (oud) niet van toepassing, zie HR 30 oktober 1925, NJ 1926, 157 (Stoomvaarimaatschappij/Franse rederii); HR 17 december 1954, NJ 1955, 68 (Van der G/X, Y en Z); HR 4 november 1955, NJ 1956, I (London \& Lancashire Insurance/Haygen); Van Buchem-Spapens (1982), p. 9 Bloembergen (1965), nr. 104; Mijnssen (1970), p. 2 en Van Boom (1999), p. 42. Bij de samenloop van de vergoedingsplicht van de schadeveroorzaker en onverplichte betalingen van de schadedrager zouden de regels van afdeling 6.1 .2 BW dan wellicht analoog kunnen worden toegepast. 
iser bevrijdt. ${ }^{533}$ Daarvan is volgens het tweede lid van art. 6:6 BW sprake, indien le prestatie ondeelbaar is of als uit de wet, gewoonte of rechtshandeling voortvloeit lat - in de woorden van art. 6:6 lid 2 BW - de schuldenaren ten aanzien van eenrelfde schuld ieder voor het geheel aansprakelijk zijn. Ook voor de samenloop ran rechtsplichten die berusten op aansprakelijkheid en die de wettelijke verpliching behelzen tot het betalen van schadevergoeding bepaalt de wet anders dan onder let oude recht dat sprake is van hoofdelijke verbondenheid uit de wet. Art. 6:102 $3 \mathrm{~W}$ geeft een regeling voor schuldenaren die elk aansprakelijk zijn voor dezelfde chade en bepaalt, vanuit die (in beginsel) gelijkwaardigheid, dat de schade over le schuldenaren wordt verdeeld met overeenkomstige toepassing van art. 6:101 $3 \mathrm{~W}$, tenzij uit de wet of rechtshandeling een andere verdeling voortvloeit. Het leoogt te voorkomen dat de benadeelde ieder van de schuldenaren moet aanspreken oor een deel van zijn totale schade. ${ }^{534}$ Beide zijn daarom ieder aansprakelijk oor het geheel. De interne regresregeling is hiervan het gevolg. ${ }^{535}$

jeldt de regeling van hoofdelijkheid en intern regres van art. 6:102 BW ook voor ,evallen van de soort waarvoor art. 90 WAO, art. 284 WvK en de hiervoor besproien regresregelingen gelden? De regresrechten van particuliere en sociale schadedra;ers berusten op het principe dat degene die volgens de regels van het aansprakelijkheidsrecht een verwijt kan worden gemaakt van het ontstaan van de schade, deze schade - volledig - moet dragen. Zou men die niet gewoon moeten aanmerken als bijzondere uitwerkingen van de verdeelsleutel voor het interne regres van medeschuldenaren? Op zich lijkt daar weinig op tegen, met dien verstande dat schadeverzekeraars bijvoorbeeld, of de ambtenarenwerkgever, voor de toepasselijkheid van hun regresrecht niet steeds in die zin schuldenaar hoeven te zijn geweest van de benadeelde dat hun betaling aan hem rechtens afdwingbaar was. Voor sociale verzekeraars en de werkgevers van art. 6:107a BW geldt inderdaad dat als ze onverplicht (vrijwillig) aan de benadeelde hebben betaald, ze geen recht hebben op regres, maar schadeverzekeraars worden daarentegen óók gesubrogeerd voor schade die ze onverplicht (uit 'coulance') hebben vergoed. ${ }^{536}$

De regresregeling voor medeschuldenaren (art. 6:6 e.v. BW en art. 6:102 BW) veronderstelt echter dat beide schuldenaren in hun verhouding tot de benadeelde aansprakelijk zijn voor de schade. ${ }^{537}$ De grondslag van de gehoudenheid van ieder in zijn verhouding tot de benadeelde, en dus ook de gevolgen daarvan zijn er min of meer gelijk te stellen. Het regresrecht heeft dan ten doel om tot een verdeling te komen van de schade waarvoor beiden (hoofdelijk) aansprakelijk zijn. Aangezien de schuldenaren alle aansprakelijk zijn voor de schade kunnen zij voor

De term hoofdelijkheid is naar geidend recht een synoniem voor hoofdelijke verbondenheid, Buchem-Spapens (1982), p. 7.

PG 6, p. 354

PG 6, p. 354.

Mits de schadeuitkering plaatsvond op basis van de verzekeringsovereenkomst; zie HR 7 januari $2000, N / 2000$. 212 nt. MMM (Nationale Nederlanden/Woudsend II)

Vgl. Asser-Hartikamp 4-I, nr. 99. 
wat betreft hun draagplicht, ook in de verhouding van ieder tot de schuldeiser (de benadeelde) worden gelijkgesteld (zie bijvoorbeeld art. 6:9 BW). Ook als de aansprakelijkheid van A jegens X berust op art. 6:162 BW (schuldaansprakelijkheid) en die van B jegens X op art. 185 WVW (kwalitatieve aansprakelijkheid van de houder van het motorrijtuig), zijn beiden uiteindelijk draagplichtig en kan vervolgens op een meer verfijnd niveau (wie trof schuld en in hoeverre, hoe waren de onderlinge afspraken tussen A en B, wie is verzekerd, enzovoort) de draagplicht van ieder afzonderlijk worden vastgesteld. Maakt een werknemer een beroepsfout waarvoor ook zijn werkgever aansprakelijk is (art. 6:170 BW/art. 6:76 BW), dan geldt hetzelfde, zij het dat de verdeelsleutel voor hun interne draagplicht gefixeerd is in het voordeel van de werknemer (zie lid 3). Beide treft dan immers een verwijt van de schade. Aan de onderhavige regresrechten ligt een scherper onderscheid tussen de samenlopende vergoedingsplichten ten grondslag. Ze berusten op het principe dat slechts één van beide schuldenaren, de schadeveroorzaker, in diens verhouding tot de benadeelde een verwijt treft van het ontstaan van de schade. De ander (particuliere of sociale verzekeraar) nam slechts de gevolgen voor zijn rekening.

Hiermee is tevens gezegd dat in de onderhavige gevallen in beginsel geen sprake kan zijn van hoofdelijke verbondenheid. ${ }^{38}$ Buiten de regeling van art. 6:102 $\mathrm{BW}$ vereist art. 6:7 BW voor hoofdelijke verbondenheid dat de schuldenaren dezelfde prestatie verschuldigd zijn ten aanzien van eenzelfde schuld. ${ }^{539}$ Zoals gezegd is daarvan geen sprake; de verplichting tot uitkering van de onderhavige regresnemers is een geheel andere dan de op de schadeveroorzaker (aansprakelijke) rustende vergoedingsplicht. ${ }^{540}$ De benadeelde kan dan ook niet de particuliere of sociale verzekeraar dan wel de schadeveroorzaker aanspreken voor méér dan het deel van de schade dat hij in zijn verhouding tot de benadeelde verschuldigd was te vergoeden (waarbij betaling van de eerste bevrijdend werkt voor de laatste).

Van Boom verdedigt echter dat indien de benadeelde het keuzerecht toekomt om ofwel zijn schadeverzekeraar ofwel de schadeveroorzaker (aansprakelijke) tot schadeuitkering of schadevergoeding aan te spreken, sprake is van hoofdelijkheid tussen schadeverzekeraar en aansprakelijke in de zin van deze afdeling. De benadeelde kan dan immers twee personen tot dezelfde prestatie aanspreken en dat $\mathrm{nu}$, stelt Van Boom, volstaat reeds voor hoofdelijkheid in de zin van art. 6:6 lid

Art 6:7 ev. BW juncto ant 6:102 BW. Dat werd en wontt ook aanvaard voor de regeling van medeaansprakelijkheid onder het oude recht (art. 1438 BW oud), zie HR 19 januari 1933, NJ 1933, 1757 nt. EMM (Roodhuysen/Hartogh) en Mijnssen (1970), p. 2.

540 In die zin ook Rb. Zutphen 26 maart 1936, NJ 1938, 443 (NBO ea. Van den B) Dat is ook de heersende leet op dit punt, zie Asser-Hartkamp 4-I, nr. 99; doch zie Van Boom (1999), p. 41, die erop wijst dat dit argument door het zelfstandige karakter van elk van de verbintenissen bij hoofdelijkheid grotendeels aan betekenis heeft ingelevend. 
$2 \mathrm{BW} .{ }^{541} \mathrm{Bij}$ de zelfstandige regresbepalingen voor sociale verzekeraars, de overheid en werkgevers gaat dat niet op, nu de aansprakelijke ook reeds zonder dat je sociale verzekeraar tot uitkering is overgegaan, ter hoogte van de aanspraken sit sociale verzekering jegens de benadeelde is bevrijd. Dat volgens het tweede id de schuldenaren, net als onder het oude recht, aansprakelijk moeten zijn voor lezelfde schuld, acht Van Boom geen bezwaar. De speciale regeling van art. 6:102 3W stelt dat laatste vereiste niet; hoofdelijkheid geldt volgens die regeling óók ij volstrekt los van elkaar staande schulden. Het bijzondere van de regeling van irt. 6:102 BW is dat zelfs sprake is van deze hoofdelijkheid als de aansprakelijkheid wet voortkomt uit dezelfde schuld. ${ }^{542}$ Ook Bloembergen wijst reeds erop dat iet voor art. 6:102 BW niet relevant is dat op particuliere en sociale verzekeraars n de schadeveroorzaker elk een andere, zelfstandige schuld rust. Daarom zou ıet óók kunnen gelden voor deze gevallen van samenloop. ${ }^{543}$ Het punt is echter lat de (primaire) verbintenis van schadeverzekeraars voortvloeit uit het verzekeingscontract en niet - zoals art. 6:102 BW vraagt - uit wettelijke aansprakelijkheid. Art. 6:102 BW makt deel uit van afdeling 6.1.10 BW en voor de toepasselijkheid ran die afdeling moet de verplichting tot schadevergoeding van de verzekeraar en niet-beoogd rechtsgevolg zijn, dat rechtstreeks berust op een wettelijke bepaling. ${ }^{544}$

De regeling van art. 6:102 BW noch het meer algemene art. 6:6 lid 2 BW zijn kortom bedoeld te gelden voor de - ongelijkwaardige - interne verhouding tussen de regresnemer en de schadeveroorzaker. Art. 6:102 BW vraagt dat beide schuldenaren voor de schade aansprakelijk zijn en art. 6:6 lid 2 BW spreekt van 'dezelfde schuld'. Het is dus vooral een technisch (wettelijk), en niet zozeer dogmatisch, onderscheid dat maakt dat de regelingen niet toepasselijk zijn naast bepalingen zoals art. $90 \mathrm{WAO}$ en art. $284 \mathrm{WvK}$. Overeenkomstige toepassing van de regeling van afdeling 6.1.2 BW zou het regresrecht mogelijk ook alleen maar verder laten reiken dan de omvang van de aanvankelijke aansprakelijkheid van de schuldenaar jegens de benadeelde. Met name zouden krachtens art. 6:10 BW ook eventuele bijkomende kosten (administratiekosten, over de uitkering afgedragen sociale premies) kunnen worden verhaald. De regresnemer zou daarbij twee wegen kunnen bewandelen, bijvoorbeeld zich ter zake van de hoofdvordering beroepen op subrogatie en ter zake van de bijkomende kosten op het zelfstandige regresrecht van art. 6:10 derde lid BW. ${ }^{545}$ Het onverhaalbaar gebleken deel van een insolvente aansprakelijke zou, krachtens art. 6:13 BW, over de eventuele mede-aansprakelijke

\footnotetext{
4) Van Boom (1999), p. 42; en Van Boom (2000a), p. 4.

542 Zie $P G$ 6. p. 99; en o.a. Sinninge Darnsté (1999), p. 30.

s4 Bloembergen (1965), nr. 100; Van Boom (1999), p. 42.

544 Mijnssen (1970), p. 2-3; anders Bloembergen (1965), nt. 2 op p. 145 (beiden nog over de - gelijkluidende ontwerpregeling voor art 6:102 BW).

S45 Vgl. Sinninghe Damsté (1999), p. 20.
} 
schuldenaren kunnen worden omgeslagen. De niet-toepasselijkheid van deze regels laat overigens de mogelijkheid onverlet om ze analoog toe te passen.

De conclusie moet zijn, dat het voor het leggen van de draaglast bij de schadeveroorzaker naar geldend recht om goede redenen verschil maakt of men uit hoofde van een overeenkomst van schadeverzekering of uit medeaansprakelijkheid de schade die door een fout van een derde is veroorzaakt voor zijn rekening neemt. De wettelijke regresregelingen voor particuliere en sociale verzekeraars, de overheid, werkgevers en de derden bedoeld in art. 6:107 BW gaan uit van de situatie dat de regresnemer niet (mede) aansprakelijk is voor het ontstaan van de schade. $\mathrm{Hij}$ neemt uitsluitend de gevolgen voor zijn rekening. Daarin onderscheiden ze zich van de vraag in hoeverre mededaders, nadat één van hen de benadeelde heeft vergoed, recht hebben op betaling van de anderen (het verdelen van de schade naar rato van ieders bijdrage). Dit laatste is in het wettelijke systeem een verdelingsvraagstuk dat afhangt van ieders mate van bijdragen aan het ontstaan van de schade in concreto, geen kwestie van toebedeling in abstracto. ${ }^{546}$

Particuliere of sociale verzekeraars, de overheid of reguliere werkgevers kunnen in heel uitzonderlijke gevallen ook zelf verwijtbaar hebben bijgedragen aan het ontstaan van juist die schade waarvoor de schuldenaar aansprakelijk is. In dat geval is het dus niet zo, dat hun aandeel in het geheel alleen eruit bestaat dat ze uit hoofde van wettelijke of contractuele verplichtingen de schadelijke gevolgen van het ongeval voor hun rekening nemen maar kan hen tevens zèlf een verwijt kan worden gemaakt van de oorzaak van de schade. Die situatie kwam in het voorgaande al kort aan de orde. Als het verwijt zelfs voldoende grond oplevert voor eigen, rechtstreekse aansprakelijkheid voor de betreffende schade kan van regres krachtens de onderhavige regresbepalingen geen sprake zijn (zie hiervoor), en zullen de betreffende instanties aansprakelijkheid riskeren (met eventueel de mogelijkheid van intern regres op de medeaansprakelijke, krachtens art. 6:102 BW). Weer anders is de situatie dat op particuliere of sociale verzekeraars, overheidsinstanties, werkgevers enzovoort pas in tweede instantie, als gevolg van de niet-nakoming van hun verplichtingen jegens het slachtoffer, aansprakelijkheid komt te rusten en ze uit dien hoofde zelf tot schadevergoeding gehouden zijn. Voor de daardoor ontstane (vertragings- en/of gevolg)schade zou dan in theorie op henzelf regres mogelijk zijn door weer andere verzekeraars, bijvoorbeeld uit hoofde van art. 284 WvK of art. 90 WAO. Maar eerder zal het geval zich kunnen voordoen dat de uitkeringen waarvoor ze regres zoeken bij de schadeveroorzaker door hun eigen toedoen (administratieve vertraging, onjuiste inschaling van de benadeelde, enzovoort) hoger zijn dan zonder hun toedoen het geval zou zijn geweest. Slechts onder

946 Voor het regres van hoofdelijk verbonden schuldenaren is het regres in mijn visie met name het sequeel van de wens tot bescherming van de schuldeiser tegen insolventie van (éen van) de schuldenaren. Hij kan ieder voor de gehele schade aanspreken, betaling van de eén bevrijdt de anderen en de betalende schuldenaar kan de anderen aanspreken tot betaling van hun deel. 
bijzondere omstandigheden kan medeschuld van de regresnemer bij toepassing van de regresregelingen een grond opleveren voor een beroep op eigen schuld (door analoge toepassing van art. 6:101 BW). ${ }^{547}$

Verdedigd wordt soms wel, dat art. 284 WvK óók geldt ten behoeve van de WA-verzekeraar, ${ }^{\text {st }}$ dat is met het vorengezegde niet onverenigbaar, Ook zij betalen strikt genomen niet uit hoofde van sansprakelijkheid voor het ontstaan van de schade. Art. $284 \mathrm{WvK} / \mathrm{art}$. 7.17.2.25 BWblijven dan gewoon zelden. Dat lijkt me in elk geval anders te moeten zijn voor WAM-verzekeraars. Het eigen recht dat ut. 6 lid I WAM verkeersslachtoffers geeft jegens de WAM-verzekeraar, crebert een hoofdelijk debiteurschap voor de WAM-verzekeraar en de WAM-verzekerde. Als de WAM-verzekeraar in dat geval verhaal zoekt op een mededader, anders dan degene wiens schuld hij voldeed, dan geldt dunkt mij rechtstreeks) de regeling voor het interne regres van medeschuldenaren. ${ }^{500}$

\subsubsection{Cessie en contractueel regres}

De wettelijke regresrechten geven een uitbreiding van de gevolgen van aansprakelijkheid. ${ }^{550}$ Ze belasten de schadeveroorzaker met een schuld die er anders niet zou zijn geweest (zij het een schuld die niet groter is dan de aanspraak op schadevergoeding van de benadeelde zelf zou zijn geweest). ${ }^{551}$ Dat vraagt om een expliciete keuze van de wetgever. Tegen deze achtergrond lijkt voor een extensieve interpretatie of analoge toepassing van de wettelijke regresbepalingen (in beginsel) geen plaats. De wettelijke regresrechten worden beschouwd als regelingen met een gesloten karakter. Wel heerst onduidelijkheid over de precieze 'impact' hiervan. Omstreden is met name of regresnemers en niet-regresnemers buiten de wettelijke regresregeling om contractuele mogelijkheden tot verhaal toekomen. ${ }^{552}$

Van de daarvoor beschikbare verhaalsconstructies lijkt cessie voor de praktijk het meest relevant. Een overeenkomst tussen de benadeelde en de schadeverzekeraar (bijvoorbeeld) is dan de titel voor de overdracht van het vorderingsrecht van de eerste naar de laatste (zie art. 3:94 BW). Schadeverzekeraars maken hiervan wel gebruik met de bedoeling dat ze nog voordat ze tot uitkering aan de benadeelde zijn overgegaan, over diens vorderingsrecht kunnen beschikken. ${ }^{553}$ Naast cessie kan worden gedacht aan de situatie waarin derden het door de schadeveroorzaker aan de benadeelde verschuldigde bedrag voor of omwille van de schadeveroorzaker

Zie daarover paragraaf 8.5 .

Ook de 'behoudens'-regel van art. 6:197 BW lid 2 sub $a$ lijkt te veronderstellen dat art. 284 WvK wèl tevens geldt voor WA-verzekeraars. Deze regel namelijk laat de beperkingen die de Tijdelijke regeling verhaalsrechten aan regresnemers oplegt, vervolgens uitdrukkelijk niet geiden voor verzekeraars van mededaders.

Voor verhailsacties van de WAM-verzekeraar op eigen verzekeringsnemers, de aansprakelijke zelf als verzekerde (zoals bij schending van de polisvoorwaarden) geldt een apart verhaalsrecht (art. IS WAM).

Hartlief \& Tjittes (1999), p. 79; Van Boom (2000a), p. 14.

Dat geldt met name in de sfeer van personenschade omdat daar alleen de categorieên slachtoffers die in de inleiding als 'benadeelde' werden bestempeld recht hebben op schadevergoeding.

Zie hoofdstuk 9.

Wetelijke subrogatie kan namelijk pas platsvinden indien de betaling ook daadwerkelijk is verricht; zie Fredericq (1971), p. 9 en voorts Van Boom (2000a), p. 19 e.v. 
betalen. ${ }^{554}$ Indien de schadeveroorzaker daarmee instemt laat art. 6:150 sub $d$ BW hen onder bepaalde voorwaarden subrogeren in de vordering van de benadeelde. In dit laatste verband wordt ook wel gesproken van 'contractueel regres', maar dit kan wat verwarrend zijn. ${ }^{555}$ Voor een beroep op de wettelijke regresrechten voor particuliere en sociale verzekeraars en werkgevers is juist nodig dat die de schade uit eigen hoofde vergoeden, en niet uit hoofde van de aansprakelijkheid van de schadeveroorzaker (ter delging van diens schuld). De regeling van art. 6:150 BW gaat kortom uit van een principieel andere situatie en zal daarom verder blijven rusten.

\subsubsection{Vorderingen tot schadevergoeding}

De wettelijke regresregelingen, en regresrechten in het algemeen, hebben geen compensatiefunctie; regres is geen schadevergoeding. ${ }^{556}$ Mogelijk is wèl dat het schadevoorval tevens voldoende grond oplevert voor rechtstreekse aansprakelijkheid van de schadeveroorzaker jegens de (particuliere of sociale) verzekeraar zelf. Naar geldend recht is dat zoals gezegd nogal uitzonderlijk, schadeverzekeraars en andere derden worden in beginsel niet mede door de jegens de benadeelde geschonden norm b́eschermu'. ${ }^{-k}$ ' Weilìint zou een normaal, rechitstreek's (integraal) recht op schadevergoeding van, bijvoorbeeld, particuliere schade- en sommenverzekeraars, jegens de schadeveroorzaker op de enkele grond dat letsel is veroorzaakt aan degene die bij hen verzekerd is, maatschappelijk ook op weinig draagvlak kunnen rekenen. ${ }^{558}$ Particuliere en sociale verzekeraars hebben juist het risico van schadevoorvallen op zich genomen, óók het schaderisico bij onrechtmatige daad. Dat ligt anders bij opzettelijke benadeling van de particuliere of sociale verzekeraar. Integrale schadevergoeding van de betrokken verzekeraar lijkt dan op zijn plaats. Ook naar geldend recht is daarvoor ruimte. ${ }^{599}$

Mevrouw $\mathrm{X}$ leeft samen met haar broer, de heer $\mathrm{Y}$, die in financiële geldzorgen verkeert. Om die reden besluitzij, zo blijkt later uit de psychiatrische rapportage, door brandstichting de brandverzekeraar van $\mathrm{Y}$ te 'tillen'. De verzekeraar doet nietsvermoedend uitkering aan $\mathrm{Y}$. Zou de verzekeraar bevoegd en in staat zijn tot het instellen van een regresactie jegens $\mathrm{X}$ (zie paragraaf 9.1.5.3), dan zou nodig zijn dat $\mathrm{X}$ voor de brandstichting jegens $Y$ aansprakelijk is. Bij samenzwering tussen $\mathrm{X}$ en $\mathrm{Y}$ kan de verzekeraar jegens X (en Y) echter óók een normaal, rechtstreeks beroep doen op het aansprakelijkheids(1965), p. 51 en Van Achterberg (1999), p. 41. Men vindt deze figuur ook in andere rechtsstelsels terug. In het Belgische recht spreekt men van 'conventionele subrogatic' (subrogatie van schade- of sommenverzekeraars krachtens cen daartoe opgenomen clausule in de polisvoorwaarden), zie Fredericq (1971), p. 9. subrogation juist (hoofdzakelijk) gevallen van cessie worden bedoeld. 
echt. De verzekeraar moet dan stellen, en zonodig bewijzen, dat X 'willens en wetens' zijn bedrijf ieeft willen benadelen.

luist omdat een rechtstreekse aanspraak op schadevergoeding via het aansprakelijkjeidsrecht voor regresnemers veelal geen reële optie is, zo lijkt het, geldt de conitructie van het regres. ${ }^{561}$ Ook de beperkte mogelijkheid tot het instellen van ormale schadevorderingen voor verzekeraars en andere schadedragers roept vragen op omtrent de reikwijdte en de betekenis van de wettelijke regresbepalingen. ${ }^{562}$ Zo is in de regresbepalingen zoals gezegd limitatief geregeld wie voor welke vertrekkingen recht heeft op regres en dat, bijvoorbeeld, behoudens opzet geen verhaal nogelijk is op inwonende gezinsleden van de benadeelde. ${ }^{563}$ De wetgever zou deschadeveroorzaker natuurlijk ook uit hoofde van diens aansprakelijkheid jegens de benadeelde kunnen verplichten tot schadeloosstelling van particuliere en sociale rerzekeraars. Dat is de constructie van het al genoemde vorderingsrecht bij verplaatste schade, art. 6:107 BW. ${ }^{564}$ Dat geeft anderen dan het primaire slachtoffer ten zelfstandig verhaalsrecht jegens de veroorzaker, maar heeft - anders dan de wettelijke regresrechten - een compensatoir karakter. Van schade in de zin van urt. 6:107 $\mathrm{BW}$ is bijvoorbeeld sprake indien de rekeningen van therapeutische xehandelingen niet op.naam komen van de benadeelde, zoals bij schadeverzekeringen en het ziekenfonds veelal geldt, maar op naam van diens werkgever. De werkgever heeft dan ingevolge art. 6:107 BW recht op schadevergoeding, niet in zijn hoedanigheid van schadedrager (waarbij hetgeen de werkgever aan de benadeelde verschuldigd is terugbetaald moet worden), maar als benadeelde (waarbij zijn feitelijke schade vergoed moet worden). Dogmatisch gezien is dan van regres geen sprake. De betekenis van dit verschil tussen art. 6:107 BW en de wettelijke regresrechten is echter marginaal omdat het verhaalsrecht in beide gevallen beperkt is tot de schade die eigenlijk thuishoort bij de primair benadeelde.

Ondanks dit marginale verschil met de structuur van regresrechten heeft art. 6:107 BW een bijzondere status. Het is zoals nog zal worden gezien niet opgenomen in de Tijdelijke regeling verhaalsrechten (art. 6:197 BW) en kan ook gewoon worden ingeroepen tegen collega's en de werkgever van het primaire slachtoffer. Het uiteenlopende toepassingsbereik van deze regelingen kan de uiteenlopende

Vgl. HR 24 januari 1930, NJ 1930, 299 nt. EMM (Brandstichting).

561 Het verband tussen regresrechten en het beperkte en gesloten systeem van aansprakelijkheid pleegt als vanzelfsprekend te worden aangenomen, zie o.m. Giltay Veth (1969), p. 211; Haardt (1970), p. 253; Mok (1977), p. 164, Hammerstein (1994), p. 4; en Hartlief \& Van Maanen (1996), p. 125.

562 Defacto is het beroep op het aansprakelijkheidsrecht waarschijnlijk vooral van belang voor schade die losstaat van of voorafgaat aan de schadeuitkering aan de benadeelde en voor administratickosten.

563. De vrag of deze door een normaal beroep op het aansprakelijkheidsrecht opzij kunnen worden geschoven komt aan de orde in hoofdstuk 9. Dat gaat specifiek over de grenzen van de wettelijke regresbepalingen.

564 Art. 6:107 BW luidt: 'Indien iemand ten gevolge van een gebeurtenis waarvoor een ander aansprakelijk is, lichamelijk of geestelijk letsel oploopt, is die ander (...) ook verplicht tot vergoeding van de kosten die een derde anders dan krachtens cen verzekering ten behoeve van de gekwetste heeft gemaakt en die deze laatste, zo hij ze zelf zou hebben gemaakt, van die ander had kunnen vorderen'
} 
verhaalspositie beter funderen. Art. 6:107 BW geldt hoofdzakelijk voor niet-professionele schadedragers zoals voorbijgangers, ouders en kinderen die kosten voor het slachtoffer hebben gemaakt. Bij de regresrechten zijn het professionele 'deep pockets' die, veelal tegen premiebetaling, risico dragen. Dat het zogenaamde werkgeversverweer juist hen treft is zó nog wel uit te leggen: de schadedragers in de zin van art. 6:107 BW staan dichter bij het slachtoffer en zijn financieel kwetsbaarder.

\subsection{Conclusie}

In het voorgaande zijn alle relevante regresbepalingen geïntroduceerd en kort besproken. Zoals werd gezien vertonen ze niet alleen verschillen met betrekking tot hun constructie en wettelijke vindplaats, maar ook lopen de inhoud en uitleg van de regresrechten uiteen. De regresbepalingen hebben geleid tot klachten, zowel vanuit praktijk als wetenschap. De bijzondere regelingen zouden niet goed op elkaar zijn afgestemd en daardoor de afwikkeling van het regres belemmeren. In de literatuur zijn daarom pogingen gedaan om tot een algemene, uniforme regresregeling te komen. Met name het tekstvoorstel van Van Boom vraagt in dit verband aandacht, omdat daarin een algemene regeling worđt geformuleerd waarmee de onderhavige regelingen lijken te kunnen worden ondervangen zonder dat dit tot een substantiële uitbreiding van het regres zou hoeven te leiden.

$\mathrm{Na}$ een korte bespreking daarvan werd nagegaan wat deze regresbepalingen kenmerkt en waarin ze verschillen van het regresrecht van medeaansprakelijken, contractueel regres, cessie en het recht op schadevergoeding. Als eerste kenmerk werd genoemd dat sprake moet zijn van een gemeenschappelijke prestatie: de prestatie die de regresnemer in zijn verhouding tot de benadeelde heeft betaald en waarvoor hij regres zoekt is dezelfde als de prestatie die de schadeveroorzaker in zijn verhouding tot de benadeelde verschuldigd is en waarvan hij is bevrijd. Daarvan is sprake indien de betalingen van de regresnemer aan de benadeelde de strekking hadden om schade te vergoeden die (al dan niet toevallig) tevens een schadepost is in de zin van afdeling 6.1.10 BW. Betalingen die slechts feitelijk door de benadeelde worden aangewend ter vermindering van zijn schade zonder dat ze daarvoor ook bedoeld zijn vallen buiten het bereik van de onderhavige regresregeling.

Het tweede kenmerk van de wettelijke regresbepalingen dat werd besproken is dat het ontstaan en de omvang van het regresrecht afhankelijk is van de verhouding tussen de schadeveroorzaker en de benadeelde (en de regels en normen van het aansprakelijkheidsrecht die daarvoor gelden). Voor de onderhavige regresrechten betekent dit dat de aansprakelijkheidsnormen worden toegepast alsof het de rechtsverhouding van de schadeveroorzaker tot de benadeelde zelf betrof. $\mathrm{Ze}$ hebben kortom een afgeleid karakter. In dit opzicht verschillen de regresbepalingen echter niet van het verhaalsrecht krachtens cessie en niet wezenlijk van de verhaalsrechten van art. 6:107 en 108 BW; ook die hebben een afgeleid karakter. In een korte vergelijking werd gewezen op de onderlinge verhouding en verschillen met het 
regres. Ten derde kenmerkt de wettelijke regresbepalingen dat de schadeveroorzaker niet méér verschuldigd is dan de omvang van zijn aansprakelijkheid jegens de benadeelde zelf. Juist zijn aansprakelijkheid in die verhouding maakt dat binnen de regresverhouding de uiteindelijke draagplicht met betrekking tot de schade ten volledig op hem rust. Voor meer dan de omvang van zijn aansprakelijkheid is geen regres verschuldigd. Voor regres is geen plaats, dat is het vierde kenmerk, ndien de regresnemer, de loondoorbetalingsplichtige werkgever bijvoorbeeld, in zijn verhouding tot de benadeelde ook zelf aansprakelijk is voor het ontstaan van de schade (alsmede dat hij niet namens of ten behoeve van de schadeveroorzaker an de benadeelde heeft betaald). ${ }^{565}$

Gelet op deze vier kenmerken kan de term regresrecht worden gedefinieerd als:

de (wettelijke) verbintenis tot terugbetaling tussen de aansprakelijke (de schadeveroorzaker) en particuliere of sociale schadedragers die anders dan uit of omwille van aansprakelijkheid schade voor hun rekening hebben genomen.

In de definitie is in het midden gelaten of de regresnemer jegens de benadeelde verplicht was de schade voor zijn rekening te nemen. Naar werd gezien is dat niet in alle regresbepalingen een noodzakelijke voorwaarde voor het (kunnen) nemen van regres. Het werkgeversregres voor het aan de benadeelde doorbetaalde loon bijvoorbeeld (art. 6:107a BW) is beperkt tot de verplicht krachtens wet of $\mathrm{CAO}$ door hen doorbetaalde bedragen. $\mathrm{Bij}$ regresbepalingen voor particuliere verzekeraars geldt deze beperking sinds het arrest Nationale Nederlanden/Woudsend II niet langer. ${ }^{566}$ Voorts past de opmerking dat de uitdrukking 'anders dan uit of omwille van aansprakelijkheid' in de definitie alleen aangeeft dat de regresnemer niet ook zèlf aansprakelijk is voor het ontstaan van de schade, althans dat dit oorspronkelijk niet de grond is geweest voor zijn betalingen aan de benadeelde. Betaald kan onder meer zijn uit hoofde van een sociale of particuliere verzekering, loondoorbetalingsverplichting, $\mathrm{CAO}$ enzovoort. De grondslag van zijn betaling aan de benadeelde bepaalt welke regresregeling op hem van toepassing is. 
Gelet op het voorgaande zou een klein amendement passen op Van Boom's tekstvoorstel voor een uniforme regresbepaling. ${ }^{567}$ De regeling zou dan als volgt kunnen luiden:

Degene op wie de verplichting tot schadevergoeding rust in de zin van afdeling 6.1.10 BW, is jegens derden ten belope van de schade die ze daartoe bereid of verplicht, buiten het aansprakelijkheidsrechtom voor hun rekening nemen, gehouden tot terugbetaling.

667 De verdere finesses van het voorstel laat ik hier rusten; 20 gaan over (deel)onderdelen van de wettelijke regresregelingen die in de navolgende hoofdstukken verder aan de orde zullen komen. Waar relevant wordt daarbij tevens ingegaan op de mogelijkheden tot uniformering 


\section{Wordingsgeschiedenis}

De rechtspolitieke betekenis van het regres van particuliere en sociale verzekeraars is omstreden. Na de invoering van de eerste wettelijke regresrechten in ons land heeft lange tijd de opvatting geheerst, dat het regres moet voorkomen dat de schadeveroorzaker de dans ontspringt. Mede door het WA-verzekerd zijn van schadeveroorzakers is het aansprakelijkheidsrecht steeds meer een zaak geworden van collectiviteiten. Als gevolg daarvan is op de regresrechten van particuliere en sociale verzekeraars in toenemende mate kritiek gaan klinken. Maar toen in de loop van de jaren tachtig van de twintigste eeuw nieuwe inkomstenbronnen in de sociale zekerheid moesten worden aangeboord, werd het aantal regresrechten toch weer sterk uitgebreid. Daarvoor werd een nieuw argument aangevoerd: de kosten van schadeveroorzakend gedrag moeten zoveel mogelijk worden gelegd waar ze worden veroorzaakt.

\subsection{Regresrecht van particuliere schadeverzekeraars}

\subsubsection{Achtergrond in vogelvlucht}

Het systeem van aansprakelijkheid en regres, zoals dat in het vorige hoofdstuk werd beschreven, is sinds de vroegste invoering ervan in 1838 in essentie weinig veranderd. Uiteraard moeten de eigen middelen van de benadeelde om tot vergoeding te komen aanvankelijk veel beperkter zijn geweest. Na de opkomst van de stoommachine en de daaruit voortvloeiende industrialisering zijn particuliere ongevallenverzekeringen ontstaan; in meer uitzonderlijke gevallen was de benadeelde als werknemer verzekerd of had hij aanspraak op een uitkering van het bedrijf waarbij hij werkzaam was. ${ }^{568}$ Maar tot halverwege de jaren vijftig van de vorige eeuw, de naoorlogse periode, waren slachtoffers en hun nabestaanden toch hoofdzakelijk aangewezen op de steun binnen de eigen sociale kring of van charitatieve instellingen. ${ }^{569}$ Daarnaast bood het aansprakelijkheidsrecht degene die zich erop kon beroepen de mogelijkheid tot het verkrijgen van volledige schadevergoeding. Derden met schade, zoals verzekeraars en werkgevers, hadden voor de door hen 
betaalde bedragen vrijwel geen wettelijke gronden tot verhaal. ${ }^{570}$ Wel schijnt in bepaalde kringen een zekere usance van verhaalsacties jegens de schadeveroorzaker te zijn ontstaan..$^{571}$

Het eerste regresrecht is ingevoerd in 1838 , gelijktijdig met de invoering van het BW. In het verzekeringsrecht werd bepaald dat verzekeraars die krachtens de verzekeringsovereenkomst betaling hadden gedaan aan de verzekerde, in diens vordering tot schadevergoeding werden gesubrogeerd, de voorloper van het huidige art. $284 \mathrm{WvK}$.

De directe aanleiding voor een regeling van die strekking is onduidelijk. De constructie van subrogatic bestond al langer, maar als grondslag voor het regres van de schadeverzekeraar van de benadeelde jegens de schadeveroorzaker schijnt zij in het Oud-Hollandse recht of eerder geen gemeengoed te zijn geweest. ${ }^{572}$ Overigens wijst Zwalve wèl op een plaats in de middeleeuwse glossen waarbij in de Digesten een aanwijzing wordt gevonden dat hen een zelfstandige vordering uit onrechtmatige daad moest tockomen tegen de schadeveroorzaker. ${ }^{33}$

Uit de totstandkomingsgeschiedenis van art. $284 \mathrm{WvK}$ wordt niet duidelijk wat precies is beoogd met deze regeling. ${ }^{574}$ In de literatuur is daarover gespeculeerd. Met name in de oude handelsrechtelijke literatuur klinkt de visie dat subrogatie dubbele vergoeding bij de verzekerde moest voorkomen ${ }^{575}$ Zonder suhogatie zou het aansprakelijkheidsrecht de mogelijkheid bieden tot het verkrijgen van schadevergoeding naast de aanspraak uit verzekering, hetgeen haaks stond op het verzekeringsrechtelijke principe dat de verzekeringsovereenkomst de verzekerde niet in een financieel gunstigere situatie moest brengen. De aan subrogatie inherente rechtsovergang kon deze samenloop van aanspraken voorkomen. 'De heerschende opvatting is', stelt Van Asch van Wijck in $1895,{ }^{576}$ 'dat art. 284 WvK waakt voor het indemniteitsbeginsel der verzekering, dat zonder deze bepaling de verzekering zou ontaarden in spel en weddingschap.' De gedachte was deze, dat het verzekerde risico voor schadeverzekeraars zonder subrogatie zwaarder zou zijn dan de werkelijke schade van de benadeelde omdat de benadeelde nog een vordering tot schadevergoeding jegens de schadeveroorzaker in zijn vermogen had (waarmee verplicht is de kosten die door de Gemeentelijke. Dienst voor Maatschappelijk Hulpbetoon zijn gemaakt te vergoeden nu de Dienst een rechtstrecks vorderingsrecht nict toekomt. 
jij het afsluiten van de verzekering geen rekening was gehouden). De strekking van art. 246 WvK verbood, en verbiedt, echter 'meer ten laste van de verzekeraar te brengen dan de verzekerde onverzekerd zoude kunnen lijden' (nemo plus pericu(i). ${ }^{577}$ Bevoordeling van de benadeelde in zijn hoedanigheid van verzekerde moest worden voorkomen, dààrin lag dan de functie van de rechtsovergang. Voor deze opvatting werd ook wel aangehaakt bij het Franse recht, waarin het risico van dubbele vergoeding van de benadeelde een centrale rol innam. ${ }^{578}$ Een derivatief verhaalsrecht voor schadeverzekeraars ontbrak in het Franse recht namelijk lange tijd, een regeling als ons art. $284 \mathrm{WvK}$ is daar pas in 1930 ingevoerd. Tot die tijd moesten verzekeraars zich behelpen met cessie en eventueel een normale vordering uit onrechtmatige daad. Wellicht, maar dit terzijde, is de discussie over de ratio van het recht van subrogatie daarmee ten onzent wat op een dwaalspoor beland (en is men de ratio van de constructie te zeer met de ratio van het verhaalsrecht gaan vereenzelvigen)..$^{579}$

Een jaar na invoering van het recht van subrogatie in het Franse recht kwam ook de Hoge Raad, in het bekende arrest Spoorweg De Vink, tot het oordeel dat de subrogatie van schadeverzekeraars dubbele vergoeding van de benadeelde moest voorkomen. ${ }^{580}$ Dit arrest heeft betrekking op de vraag of óók ongevallenverzekeraars die uitkeren onafhankelijk van de geleden schade dienden te worden gesubrogeerd. ${ }^{581}$ De Hoge Raad oordeelde dat dit niet zo was en motiveerde dat met de stelling dat art. $284 \mathrm{WvK}$ moest voorkomen dat de verzekerde dubbele vergoeding zou ontvangen. Nu het bij ongevallenverzekeringen niet uitmaakt dat de verzekerde buiten de verzekeringssom nog vergoeding ontvangt van de aansprakelijke, was art. $284 \mathrm{WvK}$ dan dus niet van toepassing. In het arrest Koopmans/Bedrijfsvereeniging in 1936 oordeelde de raad in vergelijkbare zin, ditmaal met betrekking tot een arbeidsongeschiktheidsuitkering voortvloeiend uit een (sociale) ongevallenverzekering ${ }^{582}$ De benadeelde behoorde naast de uitkering uit sommenverzekering zijn recht op schadevergoeding te behouden, dat stond voorop, en dus dienden particuliere sommenverzekeraars niet te worden gesubrogeerd. Ietwat curieus werd deze uitleg van art. $284 \mathrm{WvK}$ (het voorkomen van dubbele vergoeding van de verzekerde), toen in 1941 door de Hoge Raad werd beslist dat subrogatie, anders dan thans het geval is, alleen gold bij betalingen die de verzekeraar aan de bena-

\footnotetext{
577 Asch van Wijck (1895), p. 15: Ledeboer (1927), p. 16.

578 Zie daarover 0.a. Ledeboer (1927), p. 29, Fleming (1978), p. 250 en Zwalve (1993), p. 142 e.v.

579 Zie bijvoorbeeld Ledeboer (1927), p. 33 en 43.

5*o HR 31 december 1931, NJ 1932, $419 \mathrm{nt}$. EMM (Spoonwegongeval/De Vink).

S81 Zie voor de casus paragraaf 7.3 .

5x2 HR 3 januari 1936, NJ 1936, $78 \mathrm{nt}$. EMM (Koopmans/Bedrijfsvereeniging); zie ook HR 28 april 1989, NJI990. $703 \mathrm{nt}$. JCS (Tollenaar/Bundesversichenungsanstalt).
} 
deelde verschuldigd was te doen uit hoofde van de verzekering. ${ }^{583}$ Uitkeringen uit schadeverzekering die onverschuldigd naar aanleiding van het schadevoorval waren gedaan, zou de benadeelde dan kennelijk wèl kunnen cumuleren met zijn recht op schadevergoeding van de aansprakelijke.

\subsubsection{Huidige rechtsopvatting}

De opvatting dat de subrogatie dubbele vergoeding van de benadeelde moet voorkomen wordt inmiddels vrij algemeen verworpen. Ook zònder art. 284 WvK komen uitkeringen uit schadeverzekeringen in mindering op het bedrag van de schadevergoeding dat de schadeveroorzaker verschuldigd is. ${ }^{584}$ De schadeveroorzaker is in zoverre jegens de benadeelde bevrijd; dat heeft met regres niks te maken, maar volgt uit bijzondere regels van schadevergoedingsrecht. ${ }^{585}$ In het arrest inzake Nationale Nederlanden/Woudsend II kiest ook de Hoge Raad als uitgangspunt dat art. $284 \mathrm{WvK}$ moet voorkomen dat de schadeveroorzaker definitief wordt bevrijd. ${ }^{586}$ Het arrest gaat over de vraag of verzekeraars ook bij onverplichte schadeuitkeringen recht hebben op regres. De raad noemt vrijwaring van de schadeveroorzaker in dat verband onwenselijk. ${ }^{587}$ Het is kortom niet het gevolg van de subrogatie, laat staan het doel dat dubbele vergoeding van de benadeelde wordt voorkomen. Zij zorgt er alleen voor dat de uiteindelijke draagplicht rust bij de schadeveroorzaker. ${ }^{588}$

HR 10 januari 1941, NJ 1941, 824 nt. EMM (KPM/Liverpool). Inmiddels geldt art. 284 WvK ook voor onverplicht betaalde schadeuitkeringen, aldus HR 7 januari 2000, NJ 2000, $212 \mathrm{nt}$. MMM (Nationale Nederlanden/Woudsend II)

Dorhout Mees (1935); Van Boeschoten (1950), p. 614; Bolt (1989a), p. 33 en 217; Bolt (1989b), p. 42 e.v; Van Boom (2000a), p. 14. Zie, daarover uitvoerig, hoofdstuk 3.

Zie paragraf 2.4.1. Doot het proces van schadebegroting e.q. voordeelstoerekening in het ansprakelijkheidsrecht (voor gevallen waarin de benadeelde zich eerst tot zijn eigen verzekeraar heeft gewend) en het verzekeringsrechtelijke indemniteitsbeginsel (als de benadeelde zich juist eerst tot de schadeveroorzaker heeft gewend) heeft de benadeelde, ongeacht wie hij aanspreekt, maar eenmaal recht op vergoeding. HR 7 januari 2000, NJ 2000, 212 nt. MMM (Nationale Nederlanden/Woudsend II).

De Hoge Raad wijst hier mede op het wetsontwerp van subrogatie voor komend recht. Volgens ant. 7.17.2.25 BW is niet langer relevant of de uitkering ter zake waarvan subrogatie plaatsvindt verplicht of onverplicht is betaald.

Zie Van Boom \& Storm (1995), p. 149-161. Enigscins anders Asser-Hartkamp 4-1, nr. 446 war het in aanmerking nemen van reeds gecompenseerde schade wordt ondergebracht bij de regeling van voordeelstoerekening (art. 6:100 BW), en de toerekening van schadeverzekeringen een gevolg wordt genoemd van art. 284 WvK (Tengevolge van de subrogatie komt men hier aan het probleem van de voordeelverrekening niet toe'). In die zin ook Sinninghe Damste (1999), p. 23. 


\subsection{Eerste invoering van zelfstandige regresrechten}

\subsubsection{De (oude) Ongevallenwet 1901}

Niet lang na de invoering van de regresregeling van schadeverzekeraars werd de eerste sociale verzekeringswet in ons land ingevoerd, de Ongevallenwet 1901. Deze wet gaf het (semi-)publiekrechtelijke orgaan dat belast was met de uitvoering daarvan, de Sociale Verzekeringsbank, ook een regresrecht voor de aan de benadeelde uitgekeerde bedragen. Voor de vergoeding van personenschade luidde deze ontwikkeling het begin in van een belangrijke kentering; door de opkomst van de industrialisatie was het veroorzaken van schade een maatschappelijk probleem geworden. ${ }^{589}$ Naar aanleiding van zijn rechtssociologisch onderzoek legt Schwitters uit dat:

[t]engevolge van het industrialiseringsproces en politieke veranderingen, (...) mensen in grotere netwerken van onderlinge onafhankelijkheid [werden] opgenomen waardoor de noden van arbeiders die eens alleen maar gevolgen hadden gehad voor de mensen in hun nabije omgeving gevolgen kregen voor zevestigden die voorheen niet rechtstreeks bij het slachtoffer van ongevallen waren betrokken. Zo werd een belangrijke stap in de richting van een ongevallenwet gedaan, toen men de schade van cen

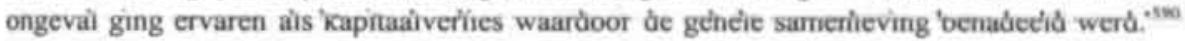

Het liberale kabinet Pierson (1897-1901) zorgde met de (oude) Ongevallenwet 1901 voor een verplichte werknemersverzekering die het risico van bedrijfsongevallen opving van werknemers in grote bedrijven. Werknemers die onder een bepaalde dagloongrens vielen, hadden bij invaliditeit recht op - levenslange doorbetaling van een beperkt percentage van hun loon en de vergoeding van ziektekosten. Nabestaanden ontvingen eveneens een deel van het loon en een vergoeding voor de begrafeniskosten. De vergoeding van de Ongevallenwet ging in zekere zin verder dan het aansprakelijkheidsrecht (dat destijds bijvoorbeeld voor de begrafeniskosten nog geen recht bood op schadevergoeding). Eventuele resterende schade kon de benadeelde nog op de schadeveroorzaker zien te verhalen. In Duitsland en andere ons omringende landen zijn de contouren van dit regime thans nog terug te vinden.

De wet van 1901 gaf, volgens de toelichting, ${ }^{591}$ toepassing aan een 'publiekrechtelijk beginsel dat gemene gevaren zoveel mogelijk gemeenschappelijk moesten worden gekeerd en gemene lasten zoveel mogelijk gemeenschappelijk gedragen'. Maar in feite berustte de wet op een politiek compromis met de werkgevers: die waren - volledig - met de premies belast en daartegenover vrijwel volledig van

Het risico van arbeidsongevallen; zie Van Barneveld (1984), p. 66; Bier (1988), p. II; zie voorts Schwitters (1991).

$590 . \quad$ Schwitters (1991), p. 2

s91 TK 1897-98, 182, p. 26 en zie 1898-99, Bijlagen L. 
het risico van aansprakelijkheid bevrijd. ${ }^{592}$ Grote bedrijven konden ook toestemming krijgen om zelf het financiële risico van de Bank over te nemen of dit op hun beurt overdragen aan een verzekerings- of waarborgmaatschappij (niet rechtstreeks als risicodrager en uitvoerder, maar als herverzekeraar van de Bank). De vrijwaring van aansprakelijkheid gold uiteraard ook dan. ${ }^{593}$ Dit moest voor premiebetalende werkgevers, in de woorden van minister Cort van der Linden, een 'bis in idem' voorkomen en een einde maken aan 'de onaangename hatelijke processen tusschen werkman en werkgever', ${ }^{594}$ Wel werd de hoogte van de werkgeverspremies gerelateerd aan hun individuele bedrijfsrisico en bleef aansprakelijkheid in stand voor schade boven de loongrens alsmede voor bijvoorbeeld dood of zwaar letsel door schuld. De aansprakelijkheid van derden gold onverminderd, ${ }^{595}$ met name doordat de Sociale Verzekeringsbank, net als particuliere schadeverzekeraars, recht had op subrogatie.

De wenselijkheid van deze constructie was echter omstreden. Het werd als onbillijk ervaren dat werknemers, maar niet ook hun werkgever bloot stonden aan regres (in de praktijk overigens schijnt het regres op collega-werknemers vrij uitzonderlijk te zijn geweest) ${ }^{596}$ Misschien kan deze kritiek mede het aanvankelijke achterwege blijven van een regresbepaling in de eerstvolgende sociale wetgeving verklaren, te weten in de (oude) Ziektewet en lnvaliditertswet 1913, de Oorlogszeeongevalienwet en de Zeeongevallenwet 1919 en de Invaliditeitswet $1919 .{ }^{597}$

\subsubsection{Uitbreiding naar andere sociale wetgeving}

Een ingrijpende wetswijziging in 1921 was het begin van een trend tot uitbreiding van het regresrecht voor sociale verzekeraars. De (oude) Ongevallenwet 1921 gaf een uitbreiding van het regres naar grote werkgevers, zoals de Nederlandse Spoorwegen die het verzekerde risico zelf droegen, en naar herverzekeraars. ${ }^{598}$ Bovendien veranderde het subrogatoire karakter van het verhaalsrecht. Het werd een

In die zin ook A-G Minkenhof bij HR 25 november 1966, NJ 1967, 259 (Rotterdamsche Droogdok/Oldermann), en Clausing (1964), p. 408.

593 De vrijwaring gold zowel voor de bijzondere werkgeversaansprakelijkheid van ant. $1638 \times \mathrm{BW}$ (oud) alsook voor de aansprakelijkheid ingevolge art. 1401 BW (oud); HR 8 januari 1960, NJ 1960, 127 nt. LEHR (Daalder's Aannemers/Zandbergen), bevestigd in HR 19 februari 1999, NJ 1999, 428 nt. ARB (LahjajiMMB).

TK 1898-99, Bijlagen I, p. 9 en 40; en daarover Schwitters (1991), p. 4; HR 8 januari 1960, NJ 1960, 127 nt. L.EHR (Daalder's Aannemera/Zandbergen), conclusie A-G Langemeijer opp. 346; en HR 19 februari 1999, NJ 1999, $428 \mathrm{nt}$. ARB (Abdellah LahjailiMMB).

396 Schoordijk (1967), p. 344.

597 Bij de Zeeongevallenwet lag het ongevalsrisico van de bemanning primair bij de reder, die zich ter verzekering van deze verplichtingen veelal kon aansluiten bij de door de Nederlandse rederijen opgerichte Vereeniging Zeerisico. Daarover Hage (1935), p. 123.

Art. 95: 'Degene, die gehouden is tot vergoeding der schade, door den verzekerde of diens nagelaten betrekkingen tengevolge van het ongeval geleden, is veor het bedrag der schadevergoeding krachtens deze wet uitbetaald. aansprakelijk jegens degenen, te wier laste dat bedrag komt. Het is niet de bedoeling dat het regresrecht var het zelfstandige karakter uitbreiding ondergaat', zie TK 1918-19, 469, nr. 3 (MvT), in die zin ook HR 5 december 1929, NJ 1930, $1055 \mathrm{nt}$. EMM (RuhaakFanum). 
zelfstandig recht, los van de eventuele vordering van de werknemer. In 1922 werd en vrijwel gelijkluidende regeling opgenomen in de Land- en Tuinbouwongevallenwet $1922 .^{599}$

De aanieiding daarvan is onduidelijk. Wellicht hing de uitbreiding samen met de sociaal-economische nalaise in de agrarische sector in deze jaren. Het land, bestuurd door het eerste kabinet Ruys de Beerentrouck (ARP/Katholieken/CHU), en de agrarische sector in het bijzonder, kampten met een flinke terugslag van de economische expansie na de oorlog. De Land- en Tuinbouwongevallenwet was bedoeld ter ondersteuning van die sector, de agrarische bedrijven.

Kort daarop werd de Ziektewet herzien en werd bij die gelegenheid alsnog een regresrecht ingevoerd. De Ziektewet gaf recht op loonsvervangende uitkeringen bij ongevallen die buiten dienstverband waren ontstaan, zoals in het wegverkeer. Verwacht werd dan ook dat dit de organen die met de uitvoering van de Ziektewet waren belast in een groot aantal gevallen de mogelijkheid zou bieden het ziekengeld op de veroorzaker te verhalen. ${ }^{600}$

De eerstvolgende relevante sociale regeling was het (later weer vervallen) Ziekenfondsbesluit uit 1941. Dat voorzag zelf niet in een regresbepaling, maar liet wel de mogelijkheid open dat het recht van subrogatie van schadeverzekeraars daarop van toepassing werd verklaard. ${ }^{601}$ De Hoge Raad heeft aanvankelijk dan ook uitdrukkelijk in die zin geoordeeld. Voor de Algemene weduwen- en wezenwet, de voorloper van de sinds 1996 geldende Algemene nabestaandenwet, is uitdrukkelijk afgezien van het opnemen van een regresbepaling. De wetgever kwam tot de conclusie dat het karakter van deze wet een regresrecht ongewenst maakte. ${ }^{022}$

\subsubsection{Kritiek}

Door een paar omstreden beslissingen in de rechtspraak in de jaren vijftig en zestig was het regresrecht van de Ongevallenwet intussen opnieuw in opspraak geraakt. Zo besliste het Amsterdamse hof in 1954 dat indien de omvang van aansprakelijkheid van de schadeveroorzaker beperkt was, bijvoorbeeld omdat sprake was van eigen schuld van de benadeelde, de vordering van de Bank voorrang had boven de vordering van de benadeelde. ${ }^{603}$ Daarmee ontstond het risico dat de benadeelde door toedoen van de Bank met het onverzekerde deel van zijn schade bleef zitten.

\footnotetext{
599 Hage (1935), p. 145.

600 Hage (1935), p. 145.

601 HR 13 maart 1959, NJ 1962, 339 (Ziekenfonds/Hogestijn); vgl. de Conclusie van A-G Ten Kate bij HR 7 november 1975, NJ 1976, $332 \mathrm{nt}$. ARB (Ziekenfonds/Nationale Nederlanden); en Van Bameveld (1984), p. 459. De bedrijfsverenigingen werden blijkens HR 3 januari 1936, NJ 1936, 78 nt. EMM (Koopmans/Bedrijfsereeniging) niet óók gesubrogeerd omdat de Ziektewet geen zuiver indemnitair karakter heeft (maar met een kritische noot van Mejjers). In HR 24 januari 1964, NJ 1964, 465 nt. GJS (Bedrijfsvereniging/Hendriksen) motiveert de raad het 20 , dat uitkeringen krachtens de Ziektewet niet worden verricht uit hoofde van een verzekeringsovereenkomst. In de literatuur is daaraan vrijwel geen aandacht besteed, uitzondering is Van Aalst (1970), p. 758. Inmiddels, bij de invoering van de Algemene nabestaandenwet, is well gekozen voor het opnemen van een regresrecht.

Hof Amsterdam 8 december 1954, NJ 1955, 406 (Raad van Arbeid/Sprengler).
} 
Ook het arrest van de Hoge Raad inzake Eerste Rotterdamsche/Visser uit 1961 heeft tot zware kritiek geleid in de literatuur, met name bij Van der Veen. ${ }^{604}$ Volgens dit arrest had de Sociale Verzekeringsbank, ook als in werkelijkheid maar een deel van de uitkeringen verschuldigd was omdat de rest ingevolge de Algemene weduwen- en wezenwet werd vergoed, onverminderd recht op regres voor het volle bedrag van de uitkering.

In hetzelfde jaar, 1961, publiceerde dezelfde Van der Veen, niet toevallig neem ik aan in de Vereenigde Verzekeringspers,zijn kritische conclusies naar aanleiding van een studie naar het regresvolume en het verhaalsbeleid van de Sociale Verzekeringsbank in eerdere jaren. Daaruit kan worden opgemaakt dat het regres voor de Bank een vaste (en met de uitkeringenlast stijgende) opbrengstenpost was geworden. Het bracht voor de Sociale Verzekeringsbank in 1958 ruim 730000 gulden op. Van der Veen benadrukte de geringe betekenis hiervan in verhouding tot het totaal van de uitgekeerde bedragen (in 1958 omstreeks 75 miljoen gulden). ${ }^{605}$ De opbrengsten waren op het totaal van de uitkeringen namelijk zeer gering, zelfs minder dan $1 \%{ }^{606}$ Verder liet Van der Veen zien dat de uitvoeringskosten in verhouding tot de regresopbrengsten vrij hoog waren.

Een derde punt van onvrede bleef de blootstelling van (collega)-werknemers aan

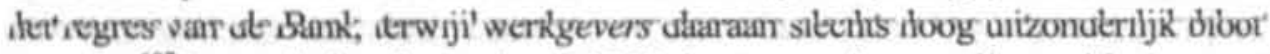
stonden ${ }^{607}$ In een bekend vonnis uit 1965 , kort voor de vervallenverklaring van de Ongevallenwetten, werd de mogelijkheid daartoe zelfs uitdrukkelijk verworpen. ${ }^{608}$

\subsubsection{Rechtspositionele ambtenarenaanspraken}

Ambtenaren vielen in deze jaren onder geen van de genoemde sociale wetten, wel voorzagen een aantal bijzondere rechtspositionele ambtenarenreglementen in uitkeringen en voorzieningen. Met uitzondering van de uitkeringen voor noodwachters (waarvoor bij wetswijziging in het jaar 1960 in een wettelijk regresrecht is voorzien) ontbrak het de overheid als werkgever net als 'gewone' werkgevers aan een wettelijk regresrecht. ${ }^{609}$ Door de restrictieve uitleg van art. 1406 en 1407 BW (oud) leek ook een rechtstreeks beroep op het aansprakelijkheidsrecht voor

604

HR 23 juni 1961, NJ 1961, 397 (Eerste Rottendamsche/Visser); Van der Veen (1961), p. 931; Slagter (1963); Giltay Veth (1969); en zie ook Verwer (1970), p. 89.

Van de 7000 gevallen waarin de Bank jaarlijks overwoog leidden er omstreeks 350 tot regres (en in ongeveer 7 gevallen werd erover geprocedeend), zie de tabellen bij Van der Veen (1961), p. 1.

Giltay Veth (1969), p. 239; Köster (1971), p. 133 stelt overigens dat het percentage van de regresopbrengsten op de totale uitkeringenlast in de navolgende jaren (1958-1967) belangrijk veel hoger heeft gelegen. Zie over het belang van deze informatie als argument voor of tegen regres infra, paragraaf 5.5.7.

6) Het regres op werkgevers komt - in de woorden van de Bank - maar' 'zo sporadisch voor dat het te verwaarlozen is'; aldus weergegeven bij Van der Veen (1961), p. I.

Rb. Amsterdam 19 oktober 1965, NJ 1966, 300 (Centmale Werkgevers/Corbran).

Leede (1965), p. 19. 
verkgevers uitgesloten. ${ }^{610}$ Juist om deze reden werd wel gebruik gemaakt van sessie. ${ }^{611}$ De meeste rechtspositieregelingen bepaalden dat de aanspraak op loonloorbetaling en andere uitkeringen eerst ontstond nadat (eventuele) vorderingen sp de civiel aansprakelijke (of op andere schuldenaren), door de ambtenaar aan jet rijk waren overgedragen. Deze constructie moest voorkomen dat de te cederen sordering op het moment van de uitkering, nog voordat de overdracht heeft plaatszevonden, als gevolg van het al vergoed zijn van de schade van de betrokken umbtenaar zou tenietgaan. Hoewel de ervaring met de cessieregelingen in de prakijk redelijk positief lijkt te zijn geweest, ${ }^{612}$ was er ook veel kritiek. Vanaf 1959 ntstond een ware polemiek over de juridisch-technische houdbaarheid van cessie n regressituaties. ${ }^{613}$

\subsection{De huidige sociale wetgeving}

\subsubsection{Regres in de sociale werknemersverzekeringen}

Na de Tweede Wereldoorlog is de Ongevallenwet zich geleidelijk aan ook gaan uitstrekken over schade die niet of minder direct aan het dienstverband was gerelateerd. Met ingang van 1 juli 1967 ten slotte kwam de Ongevallenwet net als de Land- en Tuinbouwwet, de Zeeongevallenwet en, geleidelijker, ook de Invaliditeitswet, te vervallen. ${ }^{614}$ Daarvoor in de plaats kwam de WAO, werd de Ziektewet ingrijpend gewijzigd en het Ziekenfondsbesluit vervangen door een nieuw in te voeren Ziekenfondswet. Verantwoordelijk KVP-minister Veldkamp van Sociale Zaken en Volksgezondheid, zoals het in die jaren heette, had gedurende drie kabinetsperiodes voorbereidend werk verricht, ${ }^{615}$ en beoogde in essentie een regime zoals we het thans nog kennen: sociale verzekeringen voor alle werknemers, waarbij de aanspraak op een basisuitkering bij ziekte en arbeidsongeschiktheid bovendien

610 Haardt (1970), p. 253; HR 2 april 1936, NJ 1936, 752 nL. EMM (Crasborn/Liverpool); HR 27 juni 1941, NJ 1942, 188 nt. PS (Holland-Amerika Lijn/Delia); HR 10 januari 1958, NJ 1958, 79 nt. LEHR (Van HooflVan der Plas).

611 Troostwijk (1959), p. 505, Van Rossum du Chattel (1964), p. 494, Troostwijk (1966), p. 193, en Mok (1977), p. 166 geven teramen een goede (letterlijke) weergave van de betreffende cessiebepalingen uit de ambtenarenreglementen weer zoals die toen golden.

612 Bloembergen (1965), p. 295, en nadrukkelijk Troostwijk (1966), p. 194.

613 Die ook thans voor gevallen buiten regres nog interessant is. Van Rossum du Chartel (1964), p. 494 heef principièle bezwaren tegen het afhankelijk stellen van het recht op uitkering van cessie. Troostwijk (1959) en Nubé (1961), p. 357 construeren de aanspraak van de ambtenaar als anders dan schadeaanspraak omdat anders van cessie geen sprake kan zjin; Groeneveld (1961), p. 434 bestrijdt dit in heldere taal (maar zie naschrift Nubé), zo ook Schut (1962), p. 87; zie voorts Bloembergen (1965), p. 295.

614 De oude regels van de Ongevallenwet gelden voor een vóór 1 juli 1967 geschied ongeval (art. 38 a Liquidatiewer; HR 20 juni 1969, NJ 1969, 374 nt. GJS (Zirman/Nieume Eerste)). Dat deze regels niet overcenstemmen met de huidige rechtsopvatting staat aan toepassing niet in de weg. HR 19 februari 1999. NJ 1999, 428 nt. ARB (Abdellah Lahiaji/MaMB).

515 Zie daarover uitvoerig Jaspers e.a. (2001), p. 107 c.v. (Fluit \& Wilthagen), en de biografie van Veldkamp op p. 303 (door Noordam). 
onafhankelijk zou zijn van de oorzaakvan de schade (risquesocial). De uitvoering ervan lag bij de (toenmalige) bedrijfsverenigingen, waarvan de organisaties van werkgevers en werknemers van een bepaalde bedrijfstak deel uitmaakten. Die inden de premies en deden uitkering, maar konden hun administratie ook, op hun beurt, overdragen aan een erkend Gemeenschappelijk Administratie Kantoor. ${ }^{616}$

De invoering van dit regime had belangrijke consequenties bij samenloop met het aansprakelijkheidsrecht. Om te beginnen werd bepaald dat de benadeelde voor het bedrag van zijn aanspraak op een uitkering, jegens de civiel aansprakelijke geen recht had op schadevergoeding. Alle sociale verzekeringswetten kenden, en kennen thans nog steeds, bepalingen van verplichte voordeelstoerekening. Die kwamen (en komen) erop neer, dat de benadeelde alleen voor niet-verzekerde schade een (onbeperkt) beroep kan doen op het aansprakelijkheidsrecht. Verder kregen de bedrijfsverenigingen, net als voorheen de Sociale Verzekeringsbank, een regresrecht: voor de krachtens Ziektewet, Ziekenfondswet, en WAO verschuldigde uitkeringen konden ze de schadeveroorzaker aanspreken. ${ }^{617}$ In dat opzicht, handhaving van aansprakelijkheid, bleef dus veel bij het oude. ${ }^{618} \mathrm{De}$ (voormalige) Ziekenfondsraad en Federatie van Bedrijfsverenigingen zijn kort na de invoering van de regresbepaling in de WAO afspraken gaan maken over samenwerking bij de uitvoering van het regres ingevolge de Ziektewet, de WAO en de Ziekenfondswet. ${ }^{619}$ Ten slotte werden ten behoeve van de benadeelde zèlf de beperkingen voor de aansprakelijkheid van werkgevers opgeheven. ${ }^{620}$ De facto lijkt deze uitbreiding van het aantal (potentiële) gevallen van werkgeversaansprakelijkheid echter beperkt. Voor het deel van de schade dat onder de evengenoemde sociale verzekeringswetten viel verloor de benadeelde immers zijn recht op schadevergoeding. Aan regresacties bleven de werkgever en collega's van de benadeelde slechts blootstaan ingeval zij de schade door opzet of bewuste roekeloosheid hadden veroorzaakt. Aanvankelijk had de gedachte voorgezeten de aansprakelijkheid van werkgevers bij de invoering van de WAO ook voor regressituaties onbeperkt te laten gelden. Dit is echter, voordat het uiteindelijke wetsontwerp bij de Tweede Kamer werd ingediend, op grote bezwaren gestuit bij de Sociale Verzekeringsraad. De raad stelde dat, buiten gevallen van opzet of bewuste roekeloosheid, op al degenen die tot de kring van de bij de verzekering betrokkenen behoren geen regres moge-

Thans berust de uitvoering van de sociale verackeringen hoofdrakelijk bij het Uitvoeringsinstituut werknemersverzekeringen.

617 Volgens de toelichting bij de Ziekenfondswet (TK 1961-62, 6808, nt. 3, p. 25) was een (ongewild) bijgevolg van het publiekrechtelijke karakter daarvan, dat dit een breuk zou betekenen met de toepasselijkheid van ant 284 WvK voor de zickenfondsen zoals in HR 13 maart 1959. NJ 1962, 338 (Ziekenfonds/Hogestijn) en (voor verstrekkingen in natura) HR 9 december $1960, N J 1962.339 \mathrm{nt}$. HB) was aanvaard

Afgezien van de beperktere beschermingssfeer van de WAO vergeleken met de oude Ongevallenwetten, vgl Clausing (1964). p. 415. Zo heeft (het regres van) de WAO anders dan de Ongevallenwet 1921 geen betrekking op nabestaanden en neemt de uitkering een einde bij de leeftijd van 65 jaar. Giltay Veth (1969), p. 238 
lijk zou moeten zijn. Het leek de raad logisch en wenselijk dat tot de risico's die aan het sociale verzekeringsorgaan werden overgedragen, óók het risico behoorde om door dat orgaan te worden aangesproken. ${ }^{621}$ Een meerderheid van de raad ging vervolgens trouwens verder door te stellen dat hetzelfde zou moeten gelden voor degene in wiens levensonderhoud de werknemer voorzag omdat dan, vrij vertaald, uit hun gezamenlijke (gezins)budget sociale premies voor het risico van een ongeval waren afgedragen. ${ }^{622}$ Maar uitdrukkelijk tegen het advies van de raad in besloot de regering in zoverre tot het handhaven van de mogelijkheid van regres. Volgens minister Veldkamp was de reden dat 'degene die naar burgerlijk recht tot schadevergoeding is verplicht, in beginsel niet behoeft te profiteren van de omstandigheid dat een sociale verzekeringswet als het ware bepaalde schadevergoedingen overneemt. ${ }^{, 623}$ Dat de werkgever en ook collega's van de benadeelde van het regres waren vrijgesteld (behoudens ingeval van opzet of bewuste roekeloosheid) was omdat ze ook zèlf (destijds) door premieafdracht voor de WAO betaalden en de rust op de werkplek zoveel mogelijk moest blijven bewaard. De rechtspositie van de werkgever ging er als gevolg van de herleving van de werkgeversaansprakelijkheid dus, vergeleken met zijn positie onder het regime van de Ongevallenwetten, maar beperkt op achteruit. Zijn aansprakelijkheid, en die van collega's, strekte zich in feite alleen uit over het onverzekerde deel van de schade.

\subsubsection{Verhaalswet ongevallen ambtenaren}

Bij de Kamervergadering over het regresrecht van de Wet op de arbeidsongeschiktheidsverzekering (WAO), op 6 juli 1965, werd tevens een wetsvoorstel aangenomen voor de invoering van een wettelijk regresrecht voor de Staat, bij ongevallen van haar ambtenaren. Dat moest voorkomen dat enerzijds 'de schuldige schadetoebrenger' bij ongevallen aan ambtenaren overkomen vrijuit ging en anderzijds de Staat als werkgever van die ambtenaren 'redelijkerwijs aan haar toekomende schadeloosstellingen zou derven'. ${ }^{624}$ De uitkeringen voor ziektekosten en invaliditeitspensioenen voor ambtenaren en nabestaanden waren een sterk groeiende uitgavenpost geworden voor de overheid, aangezien de ambtenaren niet vielen onder de sociale verzekeringen en bovendien het aantal verkeersongevallen door het toenemende wegverkeer stijgende was. Zoals ik hiervoor al opmerkte, maakte de Staat ingeval van aansprakelijkheid wel gebruik van cessieconstructies, maar stonden die bloot aan kritiek. Met name het verplichtende karakter ervan was omstreden: speciale clausules in rechtspositionele regelingen verbonden de ambtenaar tot het afstaan van zijn recht op schadevergoeding aan de Staat. Het verplichtende karakter van de cessie was in de jaren vijftig zelfs dermate gevoelig komen te liggen, dat invoe-

\footnotetext{
521 Clausing (1964), p. 419.

622 Clausing (1964), p. 420.

623 TK 1962-63, 7171, nr. 3 (MvT), p. 21.

624 In die bewoordingen TK $1964-65,7812, \mathrm{nr} .3$ (MvT), p. 3.
} 
ring van nieuwe cessiebepalingen in de rijksreglementen voor militairen politiek niet haalbaar leek. Voor uitkeringen aan militairen ontbrak de mogelijkheid van verhaal daardoor volledig. Daar kwam bij, dat cessie relatief hoge administratiekosten met zich meebracht; de cessieakte moest aan de schadeveroorzaker worden betekend als deze de cessie niet schriftelijk had erkend. ${ }^{625}$ De regresregeling in het wetsontwerp voor de WAO was aanleiding om ook hier wat aan te doen. Nu de overheid een verhaalsrecht ambieerde dat óók gold voor de uitkeringen van bepaalde militairen en ander personeel buiten het kader van de Ambtenarenwet, werd een afzonderlijke wet ingevoerd: de Verhaalswet ongevallen ambtenaren. $\mathrm{Bij}$ de inwerkingtreding daarvan kwamen de cessiebepalingen te vervallen. ${ }^{626}$ Dat kon op brede instemming rekenen in de literatuur, nu ook voor de sociale verzekeringen regresrechten golden. ${ }^{627}$ In 1976 zijn voor de (toen nog) dienstplichtige militairen en voor reservisten, beide geen ambtenaar in de zin van het ambtenarenrecht, de regelingen van Ziektewet en WAO van overeenkomstige toepassing verklaard. ${ }^{628}$

Maar de Verhaalswet ongevallen ambtenaren leidde tot grote kritiek toen bleek dat daarin een veel verdergaand regresrecht was geregeld, namelijk één dat zich ook uitstrekte over de loonkosten die de Staat als ambtenarenwerkgever bij arbeids-

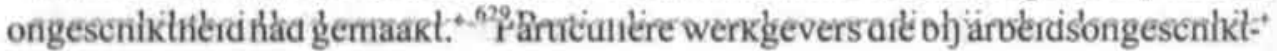
heid loon doorbetaalden (en eventueel ziektekosten voor hun rekening namen) hadden daarvoor geen regresrecht. Het Centraal Sociaal Werkgevers Verbond pleitte tevergeefs voor een algemeen regresrecht voor alle werkgevers. ${ }^{630}$ Ook via een normaal, rechtstreeks beroep op het aansprakelijkheidsrecht had men geen mogelijkheid tot verhaal op de schadeveroorzaker. Volgens constante jurisprudentie had bij letsel of overlijden alleen degene met het letsel en/of zijn nabestaanden jegens de schadeveroorzaker recht op schadevergoeding, niet ook werkgevers. ${ }^{631}$

Sommige werkgevers lieten hun werknemers een verklaring ondertekenen dat de bedragen die men bij arbeidsongeschiktheid zou ontvangen, een (tijdelijk) voorschot waren dat door cessie of het zelf geldend maken van de vordering tot schadevergoeding op de civiel aansprakelijke moest worden terugbe-

TK 1964-65, 7812, nr. 3 (MvT), p. 3; zie daarover ook de conclusie van A-G Ten Kate bij HR 2 april 1976, NJ 1976, 532 nt. ARB (Alliance Company/Siaar); Haardt (1970), p. 253 e.v.; Mok (1977), p. 166; en Mac Lean (1986), p. 282.

Aldus artikel 6 VOA.

De Leede (1965), p. 19.

In de Wet arbeidsongeschiktheidsverzekering militairen.

De Leede (1965), p. 19; Bloembergen (1965), nr. 204; Koster (1971), p. 132; en Mok (1977), p. 168 ('Heeft zich hier geen ongewenste vermenging voorgedaan van de belangen van de personeelsafdeling van de overheid en de verplichting van diezelfde overheid om wetgevend op te treden zonder aanzien des persoons?"). De Leede (1965), p. 19 vermeldt dit (met verwijzing).

HR 2 april 1936, $N J 1936,752 \mathrm{nt}$. EMM (Crasborn/Liverpoo); HR 10 januari 1958, $N J 1958,79 \mathrm{nt}$. LEHR (Van Hoof Van der Plas). 
aald. Die constructies leenden zich niet voor alle situaties en gaven de werkgever bovendien minder rekerheid van verhaal dan een wettelijke regresbepaling. ${ }^{62}$

\section{4 'A growing school of sceptics'}

\subsubsection{Afstand van regres door schadeverzekeraars}

Voor het regresrecht van particuliere verzekeraars ontstonden in de jaren vijftig en zestig, mede als gevolg van de ontwikkeling van de aansprakelijkheidsverzekeing, in toenemende mate problemen op administratie- en uitvoeringsniveau. Van verschillende zijden klonk kritiek op het regresrecht, regres zou niet doelmatig zijn. Bongers stelde wees er in zijn NJV-preadvies op dat het regres vanuit oogpunt van doelmatigheid belangrijke bezwaren kende. Regresacties van gesubrogeerde schadeverzekeraars op aansprakelijkheidsverzekeraar leidden tot hoge kosten, terwijl het resultaat economisch vestzak broekzak was: tegenover het collectief schadeverzekerden stond het collectief van WA-verzekerden terwijl die groepen door nageaoeg dezelfde personen werden gevormd ${ }^{633} \mathrm{Er}$ was volgens hem dan ook veel le zeggen voor afschaffing van het regres van schadeverzekeraars en die gedachte vond in de jaren zestig en zeventig brede steun in de literatuur. ${ }^{634}$ In de praktijk werden de doelmatigheidsbezwaren intussen evenwel op andere wijze het hoofd geboden. Zo werden door autoverzekeraars wel de bekende knock-for-knock overeenkomsten gesloten: over een weer deed men afstand van de (toekomstige) verhaalsrechten op elkaar en op elkaars verzekerden. Ook kwamen schadeakkoorden tot stand: afspraken over de wijze waarop het regres, ongeacht de schuldvraag, zou worden afgewikkeld. Brandverzekeraars hadden in 1953 door een publicatie getiteld 'Afstandverklaring Regres' zelfs in zijn algemeenheid afstand gedaan van het regresrecht van art. 284 WvK behoudens voor bijzondere gevallen, zoals opzet. $^{635}$

Zie over voorschotconstructies o.a. Onrechimatige Daad II, nrs. 358, 361 (Bloembergen); Schadevergoeding. ant 107 (Bolt), aant. 43; Asser-Hartkamp 4-1, nr. 475; Bloembergen (1965), nr. 203; Mok (1977), p. 165; en Hammerstein (1994), p. 4 en Hoogendijk (1994), p. 9.

63 Bongers (1967), p. 224-226.

634 In die zin Bongers (1967), p. 220; Zeelenberg (1968), p. 2; Pestman (1969), p. 91 en 110; Mijnssen (1970), p. 22 . Vgl. ook Köster (1971), p. 97 en Bloembergen (1970), p. 75 (die aan deze kritiek cen steunargument ontleent voor afschaffing van het regres voor sociale verzekeraars, zie hierna).

635 In paragraf 9.1 zal uitvoeriger op deze afspraken over de uitvoering en afwikkeling van het regres worden ingegaan. 


\subsubsection{Vestzak-broekzak argument tegen regres van sociale verzekeraars}

De uitbreiding van het regres naar sociale verzekeraars, ${ }^{636}$ in de jaren zestig en zeventig van de twintigste eeuw, ging gepaard met meer fundamentele kritiek. De benadeelde zag zijn schade in toenemende mate vergoed langs andere kanalen zoals door particuliere en sociale verzekeraars. Het aansprakelijkheidsrecht werd steeds meer een zaak van gesubrogeerde schadeverzekeraars en sociale verzekeraars die verhaal zochten op de schadeveroorzaker, die daarvoor veelal WA-verzekerd was. Het werd kortom meer een zaak van collectiviteiten. Over de vraag of dat wenselijk was werd verschillend gedacht. ${ }^{637}$ Maar er ontstond een

'growing school of skeptics (...) concerning the value and efficiency of subrogation, in view of its high administrative cost and the fact that its supposedly disciplinary edge on tortfeasors is largely blunted by the interposition of liability insurance, so that in effect subrogation merely shifts the costs from one to another of two, usually equally well-placed, loss distributors (...). ${ }^{63 s}$

Het aansprakelijkheidsrecht was volgens deze auteurs een 'nodeloos rondpompen van geld' tussen verzekeraars. Die beeldvorming, dat regres alleen een zaak was van collectiviteiten, was het meest sprekend in de sfeer van sociale verzekeringen. Ook de regresbepaling van het wetsontwerp voor de WAO viel die kritiek ten deel $^{639}$ Clausing bepleitte het schrappen van het regresrecht. Zou de WAO niet gewoon een iets groter stukje van het WA-risico van de sociale premiebetaler kunnen opvangen, zo vroeg hij. ${ }^{640}$ Deze kritiek betrof de besteding van publieke lasten: hoe ver reikt(e) de beschermingssfeer van sociale verzekering en welke risico's konden en moesten langs door het publieke bestel worden gedekt? In de discussie over regres heeft dàt uiteindelijk een bescheiden rol gespeeld. Toch is wel opmerkelijk dat de Memorie van Toelichting bij de invoering van de regresbepaling van de WAO op dit punt zwijgt. ${ }^{641}$

Een fundamenteler bezwaar was dat de regresopbrengsten voor de WAO betaald werden door aansprakelijkheidsverzekeraars. Volgens Clausing kwam dit neer op het doorschuiven van een klein deel van de kosten van de arbeidsongeschiktheidsverzekering naar de aansprakelijkheidsverzekering. Daaraan waren immers kosten verbonden terwijl het collectief premiebetalers van de aansprakelijkheidsverzekering in belangrijke mate samenviel met het collectief werkgevers en werkne-

Het collega-verweer wordt ingevoerd, en door de bijzondere constructie van het restbedrag bij het civiele plafond wordt voorrang van de regresvordering boven de vordering van de benadeelde tegengegaan; zo ook Verwer (1970), p. 94.

637 Fleming (1966a), p. 167; zie ook Bloembergen (1970), p. 76 en Koster (1971), p. 136.

698 Fleming (1974), p. 109 (cursief toegevoegd. EE).

69 Clausing (1964), p. 420 en (1970); Bloembergen (1966) en (1970), p. 75 en Giltay Veth (1969), p. 238.

640 Clausing (1964), p. 420; en ook reeds in die zin Van der Veen (1961), p. 2.

641 Dat geldt overigens niet alleen voor de regresregeling van de $W A O$, maar ook voor regresregelingen van andere sociale wetten. 
mers, de premiebetalers van de arbeidsongeschiktheidsverzekering. ${ }^{642}$ Sterker klonk dit bezwaar bij Bloembergen in diens dissertatie uit 1965, en daar werd het ook betrokken op het regres van particuliere verzekeraars. ${ }^{043}$ Het regres is een zaak tussen verzekeraars of andere deep pockets onderling, zo stelde Bloembergen. Het merendeel van de ongevallen die tot aansprakelijkheid en regres leiden (vermoedelijk rond de negentig procent) wordt immers veroorzaakt in het gemotoriseerde wegverkeer. ${ }^{644}$ Een bespiegeling van deze argumenten volgde toen de toenmalige regering een regresrecht overwoog bij de invoering van een sociale ziektekostenverzekering die zou gelden voor alle ingezetenen (en dus niet alleen voor werknemers). In een kort adres aan de Tweede Kamer en een bekende publicatie in 1966 zette Bloembergen uiteen dat dit regresrecht hoofdzakelijk betrekking zou hebben op verkeersongevallen en dus met name gericht zijn tegen aansprakelijkheidsverzekeraars voor motorrijtuigen. Regres voor sociale uitkeringen waarvoor alle ingezetenen verplicht premies moesten afdragen op verzekeraars die met premies van vrijwel hetzelfde collectief worden gefinancierd was vestzak-broekzak. ${ }^{645}$ De schade zou zich dan immers (uiteindelijk) van het collectief van verzekerden, potentiële benadeelden, verplaatsen naar een vrijwel eraan gelijk collectief betalers (WA-verzekerden en belastingbetalers). Wat dit volgens Bloembergen ronduit onwenselijk maakte was dat er in verhouding tot de marginale opbrengsten hoge kosten mee gemoeid waren: transactiekosten en maatschappelijk gezien, het beslag op de rechterlijke macht. ${ }^{646}$

Interessant is dat in de Verenigde Staten later in datzelfde jaar een eveneens bekend artikel verscheen van gelijke strekking van de hand van (wijlen) professor John Fleming. Ook Flemings kritiek richtte zich met name op het regres van sociale verzekeraars omdat dit grotendeels tot het overhevelen van geld van de ene naar de andere collectiviteit zou leiden terwijl die collectiviteiten grotendeels uit dezelfde personen bestonden, terwijl de kosten, ook maatschappelijk gezien, hoog waren en de doelstellingen niet helder. ${ }^{6+7}$

Clausing (1964), p. 421. Vgl. in die zin ook reeds Van der Veen (1961), p. 931 die van een vestzak-broekzak resultaat spreekt.

Zie Bloembergen (1965), nr. 256, op p. 256 waar voorzichtig wordt geopperd ('Niettemin zou ik ervoor kunnen voelen') het recht op subrogatie ingevolge art. 284 WvK van ziekenfondsen die vergoedingen hebben verstrekt in het kader van een bij hen afgesloten vrijwillige verzekering af te schaffen 'als eerste aanloop tot een verdergaande afschaffing van de subrogatie'.

Bloembergen (1965), nr. 253. $\mathrm{Vgl}$. Hartlief \& Van Maanen (1994), p. 76 die stellen dat er bij arbeidsongevallen en sportongevallen veelal geen mogelijkheid is tot het nemen van regres, omdat regres op werkgevers en collega's van de benadeelde beperkt is tot gevallen van opzet of bewuste roekeloosheid en sportsituaties zeiden aanleiding geven tot aansprakelijkheid.

Bloembergen (1965), p. 254 en (1966), p. 329. Van der Veen (1961), p. 931 gebruikt reeds die uitdrukking voor het effect van regres in individuele gevallen waar de aansprakelijke bij de regresnemende verzekeraar WA-verzekerd is.

547 Fleming (1966a), p. 168: "Whether the ulterior motive is thereby to reduce the cost of social security or to promote deterrence may be left to speculation' ((1978), p. 255). Zeif zoekt Fleming (1970), s. 73 de verklaring in de regresopbrengsten. 
Het bezwaar van Bloembergen kon in de rechtsliteratuur op steun rekenen. ${ }^{648}$ Het appelleerde aan de in de doctrine heersende opvatting in deze jaren dat het aansprakelijkheidsrecht diegenen moest beschermen, die dat het meest nodig hadden: het slachtoffer zelf en niet óók diens regresnemende verzekeraars of andere 'deep pocket' schadedragers. ${ }^{649}$ In confessionele en socialistischekringen verschenen in deze jaren ook kritische rapporten over het verhaalsrecht van de Armenwet van 1912. Dat lag wel buiten de sfeer van het aansprakelijkheidsrecht, maar daarbij speelden vergelijkbare argumenten: publieke uitvoeringsinstellingen, de gemeentelijke sociale diensten, hadden een recht van verhaal voor gemaakte kosten van armenverzorging op individuele familieleden die wettelijk verplicht waren tot het verschaffen van levensonderhoud aan een behoeftige naaste. Speciaal daartoe geformeerde commissiespleitten alle vrijwel unaniem voor afschaffing en vonden gehoor bij KVP-minister Marga Klompé. Het regresrecht zou met name de aanspraken frustreren van de 'armlastige bejaarde' die familieleden wenste te vrijwaren van regres ten behoeve van de gemeentelijke fondsen. ${ }^{650}$ Het resultaat daarvan was een aanmerkelijk beperkter verhaalsrecht in het kader van de Algemene bijstandswet.

\section{4 .3 Geen regres voor voiksverzeḱeringen ${ }^{6.51}$}

Maar in essentie waren de argumenten tegen het regresrecht op basis van aansprakelijkheid uiteindelijk toch vooral zakelijk en pragmatisch: de kosten van regres waren hoog, terwijl het zijn doel - het in rekening brengen van de kosten bij de schadeveroorzaker - maar ten dele zou bereiken. De concept regresbepaling voor de Algemene wet bijzondere ziektekosten is, waarschijnlijk juist om zulke (budgettaire) redenen, tijdens de parlementaire behandeling in 1966 ingetrokken. De ministeriële toelichting stelt daarover alleen dat de benadeelde en de schadeveroorzaker veelal tot de Nederlandse gemeenschap behoren en sociale premies hebben betaald. ${ }^{652}$

Giltay Veth (1969), p. 238. De Studiegroep Verkeersaansprakelijkheid (1978), p. 9 stelt in haar rapport: 'Een aantal tegenstanders van handhaving van het schuldbeginsel in het ongevallenrechr wijst erop dat er inmiddels een verregaande collectivering van het ongevallenrisico heef plaatsgevonden. [...] De gevolgen van verkeersonge vallen worden voor een belangrijk deel reeds afgewenteld op verzekeraars, waardoor de persoonlijke verantwoordelijkheid van de dader, die in de schuldaansprakelijkheid een belangrijk element vormt, op de achtergrond is komen te staan."

649 Ik wees al op de kritiek van Van der Veen en van Clausing (1970), p. 75; voor afschaffing pleit Giltay Veth (1969), p. 238, Ook volgens Koster (1971), p. 97 'wordt reeds geruime tijd in verschillende kringen eraan getwijfeld of het wel juist is dat de regresrechten, welke de verzekerde heeft, overgaan op de assuradeur' - Zie over eenzelfde beweging in de jaren zeventig in Engels recht Atiyah (1997). p. 140.

Naar aanleiding van twee door de Wiarda Beckman Stichting uitgebrachte rapponten steunt en amendeen de PvdA deze plannen van Klompé: Commissie Moltzer (1960), p. 33.

651 Volksverzekeringen zijn, voor alleduidelijkheid, verzekeringen van rechtswege vooralle ingezetenen; ongeacht nationaliteit of werknemerschap. Sociale werknemersverzekeringen gelden ook van rechtswege, maar dan voor werknemers jonger dan vijenzestig jar.' 'Werinemer' zijn ook ambtenaren, al degenen die in privat- of publickrechtelijke dienstbetrekking werkraam zijn, maar ook bijwoorbeeld uitkeringsgerechtigden; Pardaan (2001). p. 20 e.v.

692 TK 1965-66, 8457, MvA, p. 16. Ook Giltay Veth (1969), p. 211 noemt de motivering van de minister genuakkelijk. 
Door de premieafdracht voor de volksverzekeringen wisten de ingezetenen zich de facto ook als potentiële schadeveroorzaker verzekerd tegen het risico dat men schade zou veroorzaken bij een ander en deze schade aanleiding zou geven tot en uitkering krachtens de Algemene wet bijzondere ziektekosten. Bij de invoering tan de (inmiddels vervallen) Algemene arbeidsongeschiktheidswet in 1976 is om dezelfde reden afgezien van het opnemen van een regresrecht. ${ }^{653}$ Als gevolg hiervan nam het totale regresvolume zelfs af omdat de WAO voor het algemene basisdeel van de uitkering door die wet zou worden vervangen. Ook het regresrecht van de WAO gold daarmee alleen nog voor het - minimale - bovendeel van de titkering. ${ }^{654}$

loor uitkeringen buiten het (vroegere) geldingsbereik van deze wet bestond geen regresrecht. De bezwaren tegen regres van sociale verzekeraars zouden in de loop van de jaren zeventig en tachtig bijven aanhouden. ${ }^{65}$ Zelfs toen later, in de jaren tachtig, de AAW-basisuitkering weer onder de VAO werd gebracht, werd het regresrecht daarop niet van toepassing verklaard. Waarschijnlijk mede on nadelige gevolgen daarvan voor de schadelast te vermijden, werd bepaald dat op de WAO-uitkeringen bij regres nog steeds een - nu zuiver fictief - AAW-basisdeel in mindering moest komen. Zoals hema zal worden gezien is de situatie inmiddels opnieuw gewijzigd. ${ }^{656}$

Als gevolg van deze ontwikkelingen had het regresrecht van sociale verzekeraars aanvankelijk alleen betrekking op uitkeringen krachtens de werknemersverzekeringen. ${ }^{657}$ In de volksverzekeringswetten (de AWBZ en de inmiddels vervallen AAW) gold dat de bedragen waarvoor deze wetten aanspraak gaven op een uitkering in mindering kwamen op de civiele schadevergoeding. De schadeveroorzaker was dus voor het deel van de schade dat onder de reikwijdte viel van de volksverzekeringen volledig van zijn vergoedingsplicht bevrijd.

\subsubsection{Toenemende druk op het aansprakelijkheidsrecht}

De bezwaren bij het regres hingen samen met groeiende kritiek op het aansprakelijkheidsrecht als vergoedingssysteem: dat zou 'duur' zijn en leiden tot een ongelijke behandeling van slachtoffers. ${ }^{658}$ Een regresrecht was dan helemaal uit den bo-

\footnotetext{
TK 1974-75, 13 231, nrs. 14, p. 96. Daarover Hantlief \& Van Maanen (1991), p. 293. dat veel WAO-uitkeringen feitelijk maar weinig hoger waren dan de AAW-uitkering en dat de (vroegere) bedrijfsvereniging vaak aan het verhaal van het bovenminimaie deel niet toekwam.

Bloembergen ( 1970 ), p. 75 pleit naar aanleiding van het vervallen van de regresbepaling van het (concept)wetsvoorstel voor de AWBZ voor algehele afschaffing van het regres. Ook Ubbink noemt in reactie op Bloembergen (1978), p. 693 (op p. 995) in het Nederlands Juristenblad afschaffing van het regres van sociale èn particuliere verzekeraars een goede zaak.

TK 1986-87, 19735 , nr. 4, p. 7; en daarover Hartlief \& Van Maanen (1991), p. 294. Inmiddels is dit alweer gewijzigd, de AAW is vervallen en het WAO-regres heeft weer betrekking op de volle arbeidsongeschiktheidsuitkering.

Verzekeringen die uitsluitend gelden voor personen in loondienst en waarvan de uitkeringen veelal gerelateerd zijn aan de hoogte van het verdiende loon.

Bloembergen (1978), p. 696; ook meer recent klinkt die kritiek: Atiyah (1997), p. 144 en Barendrecht (2002).
} 
ze. ${ }^{659}$ Op wetgevingsniveau is het nooit gekomen tot plannen in de richting van een algehele afschaffing van het aansprakelijkheidsrecht voor personenschade (en de daaruit volgende afschaffing van het regres). Wel zijn naast de beperking van het regres bijzondere maatregelen getroffen die tot verbetering moesten leiden van bepaalde gevallen van letsel en overlijden waarvoor het aansprakelijkheidsrecht onbevredigend werkte.

In dat kader moet ook de oprichting van het Schadefonds Geweldsmisdrijven worden gezien, tijdens het kabinet Den Uyl. ${ }^{660}$ Dit vergoedingsfonds was en is bedoeld voor slachtoffers van opzettelijke geweldsmisdrijven en de nabestaanden van deze slachtoffers. Juist voor deze categorie werkt het aansprakelijkheidsrecht in de praktijk onbevredigend. Plegers van opzettelijke misdrijven zijn niet vindbaar, niet WA-verzekerd en vooral ook is de confrontatie met de geweldpleger in persoon voor de benadeelde in de desbetreffende gevallen emotioneel belastend. Sinds de oprichting van het fonds geldt het aansprakelijkheidsrecht voor die gevallen alleen nog als primaire bron voor vergoeding: indien dat volgens een onafhankelijke commissie van de benadeelde gevergd kan worden moet hij zijn vordering jegens de schadeveroorzaker zèlf geldend maken. Zo niet, dan betaalt het Fonds en wordt het gesubrogeerd in de vordering tot schadevergoeding van de benadeelde. ${ }^{661}$

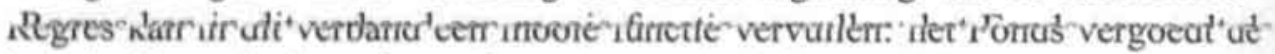
benadeelde opdat hem de confrontatie met de dader wordt bespaard, terwijl het door haar regresrecht toch de geweldpleger is die betaalt.

In de Kamerstukken wordt daartoe gewezen op het belang van solidariteit met onevenredig zwaar getroffen burgers, en voorts op de conflictoplossende werking van het fonds voor de verhouding tussen de benadeelde en de dader en het preventieve effect van (tijdig) schadeherstel. ${ }^{62}$ Maar in de wandelgangen heet het, dat het ministerie van Justitie met een 'imagoprobleem' kampte en iets heeft willen veranderen aan de beeldvorming dat het budget van het departement aan daders werd besteed en aan de opvang en de financiële belangen van slachtoffers en nabestaanden amper iets werd gedaan.

Ook is, onder hetzelfde kabinet, initiatief genomen tot verbetering van de positie van verkeersslachtoffers. ${ }^{63}$ De directe aanleiding daarvan was een voorstel in de Tweede Kamer tot afschaffing van de verkeersaansprakelijkheid voor cascoschade vanwege de administratieve kosten die daaraan verbonden waren. De minister van Justitie heeft daarop, eind 1973, een informele studiegroep geformeerd die zich over een verbeterd vergoedingssysteem voor yerkeersslachtoffers moest buigen.

Clausing (1970); Van Wassenaer van Catwijck (1971); Köster (1972), p. 136; Studiegroep Verkeersaansprakelijkheid (1978), p. 9; en Bloembergen (1978), p. 696.

Bij de Wet voorlopige regeling Schadefonds Geweldsmisdrijven, die inmiddels haar voorlopige status kwijt is en nu de Wet Schadefonds Geweldsmisdrijven heet.

Art. 6 WSG; zie onder meer supra, paragraaf 4.2.5.

TK 1973-74, 12 131, nr. 8; daarover De Beer (1991), p. 2. De regeling is 'voorlopig' genoernd omdat het kabinet (eerst) ervaring wilde opdoen met het fonds en de financiele consequenties ervan.

De directe aanleiding ligt overigens eigenlijk bij de gedachte tijdens de behandeling van de begroting onder eén van de kabinetten Biesheuvel, dat de politie bij afschaffing van de aansprakelijkheid voor cascoschade substantieel ontlast zou kunnen worden van het opmaken van processen-verbaal. 
'anwege het belang daarvan voor de discussie over het regres vraagt dit kort andacht.

\subsection{De Studiegroep Verkeersaansprakelijkheid}

le Studiegroep bestond uit vijf leden: twee medewerkers van de Nederlandse Tereniging van Automobielassuradeuren en één van de ANWB en nog twee leden an het ministerie van Justitie (waaraan vervolgens door het ministerie nog een ecretaris is toegevoegd), allen echter à titre personnel. Sociale verzekeraars of adere regresnemers waren hierbij niet vertegenwoordigd. ${ }^{664}$ In 1978, kort nadat i Engeland het rapport van de Pearson commissie verscheen, kwam de Studiegroep 'erkeersaansprakelijkheid met haar rapport voor personenschade. Het regime van erkeersaansprakelijkheid zou moeten worden vervangen door een systeem van זsicoaansprakelijkheid dan wel een verkeersverzekering, onder gelijktijdige afschafing van het regres van sociale en particuliere verzekeraars. Volgens de Studiegroep iende dit nieuwe regime te bevorderen dat in een zo groot mogelijk aantal gevallen en zo volledig mogelijke vergoeding kon worden geboden. Het bezwaar dat dit e ongelijke behandeling van ongevalsslachtoffers zou bevorderen, vond de studiegroep niet beslissend. Dat zou stelt het rapport slechts ieder voorstel tot verbetering van de positie van verkeersslachtoffers blokkeren. ${ }^{665}$ Het voorstel is echter, juist doordat het gekoppeld was aan de plannen die strekten tot verbetering van de positie van verkeersslachtoffers, in een impasse geraakt.

Gelet op de samenstelling van de Studiegroep konden haar conclusies eigenlijk niet verbazen. ${ }^{666}$ De WA-verzekeraars waarvan haar leden deel uitmaakten hadden als betalende partij, zo lijkt het, financieel belang bij afschaffing van het regres. Van deze zijde was dan ook een commissie ingesteld om de financiële consequenties van een ander stelsel te onderzoeken. Op grond van het rapport van die commissie schatte de studiegroep dat handhaving van het regresrecht van particuliere en sociale verzekeraars bij de invoering van een ander stelsel de totale schadelast voor WA-motorrijtuigenverzekeraars bij personen- en zaakschade zou doen verdubbelen, terwijl de stijging bij afschaffing van het regres beperkt bleef tot vijftien procent. Volgens het in 1981 uitgebrachte rapport 'Geldelijke Ramingen Ander Stelsel' zou de totale schadelast bij volledig regres van sociale verzekeraars en de overheid dan ongeveer drie maal zo groot worden met een navenante stijging van de premies voor de verkeersverzekeringen. $\mathrm{Bij}$ zo hoge verzekeringspremies

Studiegroep verkeersaansprakelijkheid (1978), p. 6. Bloembergen (1978), p. 694, 707 en 708 is kritisch over het ontbreken van 'deskundigen uit de wereld van de sociale verzekeringen', en wijt dat mede aan de departementale verdeling binnen het wetgevende apparaat: het Ministerie van Justitie overlegt wetsontwerpen veelal pas met Sociale Zaken als ze eenmaal afgerond zijn.

sts Studiegroep Verkeersaansprakelijkheid (1978), p. 15; en terecht kritisch daarover Bloembergen (1978), p. 697 .

w66 De vrijheid waarin de leden van de studiegroep tot hun conclusies zijn gekomen wordt overigens ook, maar dan vanwege het terughoudende standpunt over de wenselijkheid van de invoering van een verkeersverzekering. betwijfeld door Bloembergen (1978), p. 705 en 706. 
werd gevreesd voor handhavingsproblemen. $\mathrm{Bij}$ afschaffing van het regres van sociale en particuliere(!) verzekeraars verwacht het rapport dat de kosten maar 1.4 maal hoger zouden worden.

Gelet op de eenzijdige samenstelling van de Studiegroep en haar nogal drastische voorstel tot afschaffing van het regres, vroeg de staatssecretaris van Sociale Zaken ook de Sociale Verzekeringsraad om advies. Deze benadrukte juist het belang van de regresopbrengsten en waarschuwde voor de financiële consequenties daarvan. Hoewel het totaal van de regresopbrengsten ten opzichte van het totaal van de er tegenover staande kosten procentueel gezien van weinig betekenis is, zo stelde de Sociale Verzekeringsraad in haar rapport, gaat het niettemin om een jaarlijks substantieel totaalbedrag. Hoewel afschaffing van het regresrecht bovendien een geringe invloed leek te hebben op het premieniveau van de desbetreffende sociale verzekeringen moest daarmee, in de wat vermanende woorden van de raad, toch voorzichtig worden omgesprongen, "juist in een tijd waarin ook ten opzichte van sociale verzekeringen bezuinigingen worden nagestreefd. ${ }^{167}$ Hoewel ook dat gelet op de positie van de Raad eigenlijk niet mag verbazen, stond het haaks op het advies van de Studiegroep. De staatssecretaris heeft daarom nog een speciale werkgroep in het leven geroepen. Dat was intussen mede met het oog op de invoering van het Burgerlijk Wetboek waarbij het aansprakelijk̈heid'srechit (en dus ook het regres) aanmerkelijke uitbreiding zou ondergaan. Het is deze werkgroep echter niet meer gelukt om nog voor de inwerkingtreding van het Burgerlijk Wetboek met een definitieve oplossing voor het regres te komen. De werkgroep heeft daarom voorgesteld om de status quo van het aansprakelijkheidsregime onder het oude recht voor regresvorderingen die na de invoering van het Burgerlijk Wetboek zouden ontstaan te handhaven. Zonder nadere regeling verwachtte de werkgroep van de introductie van de nieuwe risicoaansprakelijkheden van het Burgerlijk Wetboek in 1992 een 'niet onaanzienlijke' stijging van het regresvolume en een navenante stijging van de schadelast. Dat zou een stijging van de aansprakelijkheidspremies tot gevolg hebben, hetgeen dan weer nadelige consequenties zou hebben voor de verzekerbaarheid. Het kabinet is akkoord gegaan met deze tijdelijke oplossing, in afwachting van een definitief standpunt over regres. Eerst moest duidelijk zijn hoe de regresrechten en het algemene deel van het aansprakelijkheidsrecht op elkaar zouden inwerken en hoe de verhouding was tussen regresnemers en aansprakelijkheidsverzekeraars. ${ }^{668}$

Naast deze kritiek op het regresrecht van verzekeraars klonk juist de roep om een regresrecht voor werkgevers die loonschade voor hun rekening namen. Gewezen werd op de hoge kosten van arbeidsongeschiktheid zoals de aanvulling van de uitkeringen krachtens Ziektewet en WAO, waarmee werkgevers naast de kosten van de sociale premieafdracht werden geconfronteerd. De onmogelijkheid daarvoor 
chadevergoeding te vorderen werd door velen als onbillijk ervaren, ${ }^{669}$ nu sociale rerzekeraars en zelfs ook de overheid voor haar loondoorbetaling bij arbeidsongechiktheid van ambtenaren wèl een regresrecht had. ${ }^{670}$ De invoering van een egresrecht voor werkgevers zou bovendien een einde kunnen maken aan de frustreende schadepraktijk, waarin werkgevers de betaalde bedragen vaak tevergeefs net cessieconstructies op de schadeveroorzaker trachtten te verhalen.

\begin{abstract}
h 1982 werd voor de Invoeringswet van Boek 3-6 van het Burgerlijk Wetboek een regeling voorgesteld be een ruime kring van derden ingeval van letsel een beperkt recht gaf op vergoeding daarvan, 'voor pver ook jegens hen een grond voor aansprakelijkheid bestaat' (art. 6.1.9.11 $\mathrm{aWW}$ ). Daaronder vielen, rast enkele nauwe zakelijke associés en behoeftige familieleden, ook de werkgever die het loon aan ie benadeelde doorbetaalt en al degenen, waaronder ook de werkgever, die herstelkosten of andere shade van de benadeelde overnamen. In 1983 is het voorstel met name vanwege de daarvan te verwachen uitbreiding van aansprakelijkheid weer ingetrokken. Voor wat het belang van de werkgevers betreft, selde de toelichting nu simpelweg dat deze ook in staat moeten zijn om zèlf het (bedrijfs)risico van abeidsongeschiktheid op te vangen. Voorgesteld werd een meer definitieve regeling van het regres vor particuliere en sociale verzekeraars af te wachten. ${ }^{.11}$
\end{abstract}

Sort nadien is echter wèl een beperkt recht op schadevergoeding voorgesteld (en riteindelijk ingevoerd) voor de kosten die derden bereid waren om voor de benadeelde te maken. ${ }^{672}$ Dat had volgens de toelichting het voordeel dat de omvang van aansprakelijkheid niet werd verhoogd en derden zich niet bij gebrek aan verhaal hoefden te laten weerhouden van hun bereidheid om deze kosten voor hun rekening te nemen. ${ }^{673}$

\title{
5.5 Budgettaire belangen
}

\subsubsection{Toenemende druk op het sociale zekerheidsstelsel}

Het stelsel van sociale verzekeringen is echter, als gevolg van de expansie en het toenemende beroep erop in de jaren zeventig en tachtig, zwaar onder druk komen te staan. ${ }^{674}$ De kabinetten Lubbers I, II en III zagen zich genoodzaakt maatregelen te treffen die de kosten van de sociale zekerheid zouden terugbrengen, zowel met betrekking tot het geldingsbereik van de sociale zekerheid als wat betreft de uitvoering ervan. Aanvankelijk heeft men sterk ingezet op kostenbestrijding zoals verla-

Inv. 6,p. 1287 (1983); vgl. Hof Amsterdam 29 december 1983, NJ 1985, 296 (Winterthur/Schuurman) en Mok (1977), p. 164. Overigens lijkt het met de administratiekosten van de premieafdracht mee te vallen. Van Wersch (1971), p. 85 schatte destijds dat met het berekenen en inhouden van de premies ZW, WAO en ZFW jaarlijks minder dan 5 gulden per werknemer was gemoeid.

Aanvankelijk komt kritiek van Bloembergen (1965) en Mok (1977), p. 168.

Inv. 6, p. 1280 en 1288

Ant. 6:107 BW.

Zie Inv. 6, p. 1282-1283 en 1288.

674 Noordam (2000), 6; Pardaan (2001), p. 14. 
ging van de uitkeringen en andere zuiver financiële maatregelen. Onder deze sociaal-economische omstandigheden vond het kabinet afschaffing van het regres niet tot de reële mogelijkheden behoren. De regresopbrengsten die sociale verzekeraars daardoor zouden moeten missen zouden moeten worden gecompenseerd door een evenredige toename van de sociale verzekeringspremies. Dat zou de collectieve lastendruk vergroten. ${ }^{675}$

Pas onder het derde kabinet Lubbers (1989-1994), een coalitie van de confessionelen met de sociaal-democraten, werd gekozen voor een beleid dat verder ging dan alleen kostenbesparing: individuele werkgevers moesten financieel kunnen worden aangesproken op hun verantwoordelijkheid voor het arbeidsongeschiktheidsvolume in hun bedrijf en ingezet werd op preventie van arbeidsongeschiktheid. In dat verband, namelijk bij de voorbereiding van de wet Terugdringing arbeidsongeschiktheidsvolume kwam het regres op de politieke agenda. De 'lobby' van sociale verzekeraars lijkt daarbij een niet onbelangrijke rol te hebben gespeeld. Bij schrijven van 10 september 1991 deed de Federatie van Bedrijfsverenigingen aan bewindslieden en leden van de Kamercommissies van Sociale Zaken en Werkgelegenheid en van Justitie een brief toekomen waarin de federatie stelde dat de verhaalsmogelijkheden door de ontwikkelingen in de WAO waren teruggelopen en dảt dé Kosten van socıảlé̀ verzekerıngen adaraỏor per saidó waren toegenomen. ${ }^{676}$ Ook wees de federatie erop dat door de voortdurende wijzigingen in wetgeving en jurisprudentie de uitvoering van het regres werd belemmerd. Ook door ziekenfondsen en ziektekostenverzekeraars werd gewaarschuwd voor teruglopende regresopbrengsten als gevolg van het op dat moment voorliggende plan Simons (dat een stelselwijziging beoogde waarbij steeds meer ziekenfondsverstrekkingen aan het zorgpakket van de Algemene wet bijzondere ziektekosten zouden worden toegevoegd). ${ }^{677}$

Tijdens de parlementaire behandeling in november 1991 wierpen verschillende Kamerfracties in het licht van dit beleid de vraag op waarom het collectief (de arbeidsongeschiktheidsfondsen) de kosten van arbeidsongeschiktheid zou moeten dragen als duidelijk was dat een persoon of organisatie aansprakelijk is voor het ontstaan daarvan. ${ }^{678} \mathrm{Er}$ was interesse 'in een nadere discussie over het regresrecht (verhaalsrecht) zoals dat in de WAO bestaat maar zelden wordt toegepast, en in de AAW zou kunnen worden opgenomen'. ${ }^{79}$ Van regeringszijde is daarop een afzonderlijke notitie toegezegd waarin meer uitgebreid zou worden ingegaan op (een eventuele herziening van) het regresrecht in arbeidsongeschiktheidsregelingen. ${ }^{60} \mathrm{Bij}$ de parlementaire behandeling van het wetsvoorstel Terugdringing

Zie daarover TK 1995-96, 21 528, nr. 6, p. 19.

676 Kont daarvoor maanden Hartlief \& Van Maanen (1991), p. 302 bedrijfsverenigingen aan zich sterk te maken 'voor cen verbetering van hun - gerechtvaardigde - verhaalsmogelijkheden. 
eroep op de arbeidsongeschiktheidsregelingen in november 1992 is opnieuw het tandpunt van het kabinet gevraagd omtrent een eventuele aanscherping van het egresrecht. ${ }^{681}$ (Oud) staatssecretaris van Sociale Zaken Ter Veld verklaarde aarop bereid te zijn tot het alsnog opnemen van een regresrecht in de volksverzeeringen en daarover namens het kabinet advies te zullen vragen aan de Sociale lerzekeringsraad, de Ziekenfondsraad en de Sociaal Economische Raad. ${ }^{62}$ Bij e voorbereiding van de Wet terugdringing ziekteverzuim herleefde vervolgens ók de kritiek op het ontbreken van een wettelijk verhaalsrecht voor de werkgever. le wet belastte werkgevers met het risico van loondoorbetaling gedurende de eerste wee of zes weken van ziekte of arbeidsongeschiktheid van hun werknemers. Dit ersterkte het gevoelen dat particuliere werkgevers, net als de Staat, daarvoor een vettelijk regresrecht behoorde toe te komen. ${ }^{63}$ Op 1 december 1992 heeft de Laad van Centrale Ondernemingsorganisaties naar aanleiding van de indiening an het wetsvoorstel bij de Tweede Kamer een brandbrief aan de betrokken Kamerracties doen toekomen waarin werd aangedrongen op de invoering van een wettejk verhaalsrecht voor werkgevers. Dat heeft bij verschillende fracties opnieuw t Kamervragen geleid, ${ }^{684}$ die onder verwijzing naar de inmiddels aanhangige dviesaanvraag konden worden afgedaan. ${ }^{685}$

\subsubsection{Een duidelijke missie}

Op 21 januari 1993 heeft het kabinet, bij schrijven van (toenmalig) staatssecretaris Ter Veld de adviesaanvraag doen uitgaan. ${ }^{686}$ Uitbreiding van het regres paste volgens het kabinet bij het beleid van het terugdringen van kosten in de sociale zekerheid. ${ }^{677}$ Een meer consequente toepassing van het regresrecht in de sociale verzekeringen vond men passen in het kabinetsbeleid gericht op sanering van de collectieve sector. Door de kosten ten gevolge van onrechtmatige daden zoveel mogelijk in rekening te brengen bij de laedens zouden de lasten van de sociale verzekeringen kunnen dalen. ${ }^{688}$ De uitbreiding van het regres naar de volksverzekeringen was tevens wenselijk zodat stelselherzieningen waarbij risico's werden overgeheveld van werknemers- naar volksverzekeringen niet tevens van invloed zouden zijn op het regresvolume. Een derde punt was volgens het kabinet dat er steeds meer buitenlandse schadeveroorzakers zijn die, hoewel ze geen premies

TK $1992-93,22824$, nr. 5, p. 74.

TK 1992-93, 22 824, nr. 6, p. 91.

Zo o.m Rb. Roermond 25 juli 1991, NJ I992, 738 (KringsLojd's London); en vgl ook Hartlief \& Van Maanen (1991), nt. 2 die hier de term discriminatie laten vallen; in die zin ook Van der Veen (1993), p. 756 en Hammerstein (1994), p. 3; zie voorts Hoogendijk (1994), p. 9.

TK 1992-93, 22899 , nr. 5, p. 21, 28 en 30.

TK 1992-93, 22 899, nr. 6, p. 24.

Opgenomen in SER-rapport 93/14 (1993) als Bijlage $\mathrm{L}$

SER-rapport 93/14 (1993), p. 5: 'De adviesaanvraag plaatst de beoogde herziening van de regresrechten in het kader van het kabinetsbeieid gericht op sanering van de collectieve sector.'

Aldus SER-rappont 93/14 (1993), p. 21 over de adviesaanvraag. 
hebben betaald voor de volksverzekeringen, daarvan wel profiteren omdat de uitkeringen uit die wetten niet op hen worden verhaald (terwijl buitenlandse regresnemers wel regres kunnen nemen in Nederland en op Nederlandse ingezetenen). Maar er klonk ook een principieel argument. Staatssecretaris Ter Veld:

'Het (volledig) uitsluiten van regres in de volksverzekeringen past niet langer in de huidige opvattingen over de positie die de sociale verzekeringen in het maatschappelijk leven moeten innemen. In het verleden werden bepaalde problemen soms te gemakkelijk afgewenteld op de collectieve sector. Dit heeft niet alleen geleid tot een aanzienlijke lastenstijging, maar heeft ook met zich gebracht dat de negatieve gevolgen van bepaalde maatschappelijke activiteiten verborgen konden blijven in het totaal van de collectieve uitgaven, hetgeen belemmerend heeft gewerkt op het treffen van tegenmaatregelen. De schadelijke neveneffecten van bepaalde maatschappelijke en economische activiteiten moeten in de optiek van het kabinet worden gelegd waar zij worden veroorzaakt.'

De staatssecretaris gaf in de adviesaanvragen ook - summier - aan wat het kabinet van het regres verwàchtte:

\begin{abstract}
'Allocatiebeslissingen binnen de collectieve sector kunnen doelmatiger worden genomen wanneer er adequate informatie bestaat over kosten en opbrengsten van bepaalde activiteiten. Bij de inspanningen sinds de jaren tachtig om de collectieve sector te saneren wordt een sterk accent gelegd op het zoveel als mogelijk toerekenen van baten of kosten aan veroorzaker of genieter. Binnen dit beleid past ook het consequent toepassen van het regresrecht in de sociale zekerheid. In dit opzicht betreft het hier een inspanning om de kosten tengevolge van onrechtmatige daden van derden zo veel mogelijk in rekening te brengen bij de veroorzaker van de schade. Hierdoor zal een juistere prijs tot stand komen voor economische activiteiten die tot de genoemde schade kunnen leiden.'
\end{abstract}

In de optiek van het kabinet zouden de uitvoeringsorganen van de sociale verzekeringen in alle gevallen van uitkering moeten nagaan of er reden was voor regres. ${ }^{689}$ Wèl voorzag het daarbij praktische belemmeringen. Het wilde daarom tevens een eenvoudiger en goedkopere uitvoeringspraktijk mogelijk maken (waarin regresvorderingen bijvoorbeeld collectief zouden kunnen worden afgewikkeld). Van een uitbreiding naar de volksverzekeringen verwachtte het kabinet - bij een verbeterde uitvoeringspraktijk - een opbrengst van enkele honderden miljoenen guldens. Dit vond nadien steun in het SER-advies: van het regres voor de volksverzekeringen kon 200 tot 400 miljoen gulden worden verwacht. ${ }^{600}$ Het kabinet lijkt met zijn adviesaanvraag dan ook geen principiële discussie te hebben be- 
oogd ${ }^{691}$ Het had haar gekozen beleidslijn daarin al grotendeels bepaald, en zocht daarvoor steun bij haar adviesorganen. ${ }^{692}$

\subsubsection{Adviezen SER en Sociale Verzekeringsraad}

Op specifieke punten van dat beleid heeft het kabinet de SER om advies gevraagd. Het voornaamste punt waren de financiële consequenties van uitbreiding van het regres naar de volksverzekeringen. De andere punten betroffen de wenselijkheid van doorwerking van de nieuw ingevoerde risicoaansprakelijkheden van Boek $6 \mathrm{BW}$ bij regresvorderingen en de praktische toepassing en uitvoeringskosten. De raad stelde in zijn rapport 'naar huidige inzichten' geen doorslaggevende argumenten te zien tegen een uitbreiding van regres naar de ervoor in aanmerking komende volksverzekeringen. Mèt het kabinet zag de SER in regres een manier om de kosten van maatschappelijke activiteiten daar te leggen waar zij worden veroorzaakt. ${ }^{693}$ Regres moest leiden tot een juistere prijs van activiteiten die schade veroorzaken en daarmee tot een scherpere verantwoordelijkheidsbeleving van de schadeveroorzaker. Dat zou wellicht ook het ontstaan van nieuwe schade kunnen tegengaan, bijvoorbeeld doordat de vraag naar schadeveroorzakende activiteiten zou afnemen en daarvoor minder gevaarlijke alternatieven in de plaats konden komen (in de woorden van de Raad 'meer doelmatige allocatiebeslissingen'). ${ }^{694}$ De geijkte bezwaren bij regres, het vestzak-broekzak argument en de hoge kosten, achtte de SER niet doorslaggevend. Het vestzak-broekzak argument was volgens de Raad alleen overtuigend op macroniveau. Het argument zou voorbijgaan aan de allocerende werking van regres, dat wil zeggen de.toerekening van kosten van particuliere en sociale verzekering aan de schadeveroorzakende gedragingen en activiteiten. ${ }^{695}$ De mate waarin regres in de sociale verzekeringen kon bijdragen aan de toerekening van de kosten aan de individuele veroorzaker moest weliswaar niet worden overschat, zo meende de SER, die was immers veelal WA-verzekerd. Maar een zekere allocerende werking zou wel plaatsvinden. Zo zouden schadeveroorzakers, op enig moment, wel consequenties van de toerekening ondervinden in de vorm van een individuele of algemene premieverhoging. Ook erkende de SER dat aan de uitvoering van regres in verhouding tot de opbrengsten hoge kosten verbonden zijn. Maar ook op dat punt sloot de raad zich aan bij de visie van het kabinet dat de kosten niet zo hoog waren, dat regres om die reden alleen moest

Van Dam (1993), p. 170 wijst op de gelijkenis met de motivering van het verhaalsrecht van de overheid voor bodemsaneringskosten. De toelichting bij de Wet bodemsanering vermeldt dat daarmee primair werd beoogd het principe de vervuiler betaalt te individualiseren en dat het voorts ging om de opbrengsten (gelet op de aanzienlijke uitgaven voor bodemsanering) en om preventic.

692 Bloembergen (1994), p. 117.

693 SER-rapport $93 / 14$ (1993), p. 5.

694 SER-rapport 93/14 (1993), p. 37.

s9s SER-rapport 93/14 (1993), p. 36. Zie daarover kritisch Hartlief \& Van Maanen (1994), p. 76: 'Zal de verkeersdeelnemer zijn verantwoordelijkheid sterker beleven en dus voorzichtiger rijden? ... Het is een feit dat eerdere kostenverhogingen ten aanzien van het gemotoriseerd verkeer wat dat betreft niet veel resultaat hebben gehad: 
worden afgewezen. ${ }^{696}$ Daartoe was ook volgens de SER nader onderzoek nodig naar een collectieve afwikkeling van regres, dat wil zeggen dat de totale regreslast van individuele dossiers tezamen in één keer wordt afgekocht. Verder werd nog op het gevaar gewezen dat door het toegenomen belang van regres de verhoudingen zullen verharden, hetgeen ook de onderhandelingen tussen regresnemers en aansprakelijkheidsverzekeraars negatief zou kunnen beïnvloeden (waardoor uiteindelijk ook de uitvoerings- en procedurekosten konden toenemen). Om die reden moesten het werkgevers- en collegaverweer, ook voor de volksverzekeringen worden gehandhaafd.

Er is kritiek op deze 'gebiologeerde' manier waarop de SER in zijn advies het standpunt van het kabinet lijkt te volgen. ${ }^{697}$ Verbazen kan het standpunt van de raad echter niet. De SER vertegenwoordigt de belangen van werkgevers en werknemers en het directe gevolg van uitbreiding van het regres (met instandhouding van het werkgevers- en collegaverweer, zoals de raad adviseert) lijkt daarvoor gunstig te zijn. Vanuit de gedachte dat de kosten van schadeveroorzakende activiteiten daar moeten worden gelegd waar ze zijn veroorzaakt, komt de SER dan ook zelf nog met de suggestie van een regresrecht voor werkgevers, voor de door hen uitgekeerde lonen en uitkeringen bij ziekte of arbeidsongeschiktheid van werknemers. ${ }^{\text {nep }}$ Het tweede punt van de adviesaanvraag, doorwerking van de nieuwe gronden van risicoaansprakelijkheid in Boek $6 \mathrm{BW}$ voor regresnemers, achtte de SER onwenselijk. Dat had hoofdzakelijk financiële redenen en berustte op de gedachte dat slachtofferbescherming bij die bepalingen vooropstaat. Op het derde punt ten slotte, de feitelijke toepassing en uitvoering van het regres, bracht het SER-rapport weinig nieuwe informatie. In het kabinetsvoorstel tot intensivering van het regres las de SER een aansporing tot een consequenter en systematischer uitvoeringsbeleid van sociale verzekeraars, dat wil zeggen dat in meer gevallen regres plaatsvindt. Daartoe moest de bestaande gedragslijn worden gevolgd dat regres alleen plaatsvindt als de opbrengsten de kosten duidelijk overtreffen. ${ }^{699}$ Wel overigens zou de benadeelde voorrang moeten krijgen bij samenloop van zijn schadevordering en de regresvordering.

De Sociale Verzekeringsraad deelde deze conclusies. ${ }^{700}$ De raad is echter, met opgave van de eerdergenoemde argumenten, specifiek gevraagd naar de financiële consequenties van de uitbreiding van regres naar de volksverzekeringen. In een

696

De raad wijst in dit verband tevens op het verschil met de verhaalspositie met de overheid die in de hoedanigheid van ambtenarenwerkgever wel een regresrecht heef (art. 2 VOA), SER-rapport 93/14 (1993), p. 39. Tijdens de parlementaire behandeling van de Wet tengdringing ziekteverzuim sprak de staatssecretaris ook al haar verwachting uit dat de SER tevens aandacht zou besteden aan de vraag naar de wenselijkheid van de invoering van regres voor werkgevers; TK 1992-93, 22 899, nr. 6, p. 24

SER-rapport 93/14 (1993), p. 38.

Sociale Verzekeringsraad (1993), p. 18 en 24. 
enkel zinnetje in de adviesaanvraag vraagt het kabinet tevens naar de daarvan te verwachten positieve en negatieve gedragseffecten. ${ }^{701}$ Kennelijk heeft het kabinet daarbij mede het oog gehad op preventie. Volgens de Sociale Verzekeringsraad zouden de opbrengsten van het regres alleen al voor (de vroegere) AAW-uitkeringen liggen tussen 188 en 257 miljoen gulden. ${ }^{702}$ Voor wat betreft de mogelijke gedragseffecten heeft de raad door het bureau Research voor Beleid BV een kleine studie laten uitvoeren. Daaruit concludeerde de Raad dat regres in dit opzicht geen beletsel is. Voor eventuele positieve gedragseffecten in de zin van het door burgers en bedrijven vermijden van risicovolle gedragingen of activiteiten was de conclusie van de Raad echter ronduit negatief. De raad noemt zulke effecten 'zeer onwaarschijnlijk', al heb ik mijn twijfels over het - kleinschalige - onderzoek waarop de raad die conclusie baseert. ${ }^{703}$ Ten slotte had de adviesaanvraag aan de Sociale Verzekeringsraad betrekking op de uitvoeringstechnische aspecten van de uitbreiding; net als de SER zag de Verzekeringsraad heil in collectivering. ${ }^{704}$

\subsubsection{Ernstige kritiek}

Het intussen nieuw aangetreden kabinet Kok I (PvdA, VVD en D66) heeft het SER-advies op alle drie de punten gevolgd, ${ }^{705}$ en is overgegaan tot de indiening bij de Raad van State van een concept-wetsvoorstel 'Uitbreiding regresrechten naar de volksverzekeringen'. Dat zou in een regresrecht moeten voorzien voor de toen geldende volksverzekeringen (AAW, AWBZ en AWW) en voor werkgevers. De status quo van de aansprakelijkheidsregels onder het oude recht zou worden gehandhaafd en voorts introduceerde het, op aandringen van sociale verzekeraars, een apart vorderingsrecht voor het brutodeel van de uitkeringen. ${ }^{706}$

Dit wetsvoorstel is gestuit op naar eigen zeggen, 'ernstige bedenkingen' van de Raad van State. ${ }^{707}$ Als gevolg daarvan is het weer ingetrokken en nooit openbaar gemaakt. De raad kwam met het zeer fundamentele bezwaar dat met de uitbreiding van het regres:

'(...) een richting wordt ingeslagen die aanmerkelijk afwijkt van de ontwikkelingen waarin het socialeverzekeringsstelsel en het civiele aansprakelijkheidsrecht zich gedurende de naoorlogse periode in Nederland hebben ontwikkeld. Het sociale-verzekeringsstelsel heeft zich losgemaakt van de oorzaken

Adviesaanvrag aan de Sociale Verzekeringsraad opgenomen als Bijlage $\mathrm{I}$ in het uiteindelijke rapport, Sociale Verzekeringsraad (1993), p. 7 Bijlage.

702 Het Centrum voor Verzekeringsstatistiek verwachtte in 1994 van de uitbreiding van het regres naar die wetten (AWW, AAW en AWBZ), gericht op het jaar 1991, een stijging van 12\% van de schadelast voor WAM-en WA-verzekeraars; Janssen (1997), p. 160.

703 Sociale Verzekeringsraad (1993), p. 35.

704 Sociale Verzekeringsraad (1993), p. 24.

705 TK 1994-95, 24169, B, p. 6.

Het voorstel is nooit gepubliceerd, zie TK 1994-95, 24 169, B en daarover Beekman (1995), p. 1233.

Zie TK 1994-95, 24 169, B, p. 4. Volgens de MvT bij de Algemene nabestaandenwet had de intrekking van het voorstel niet zozeer te maken met de kritiek van de Raad van State, maar met de plannen voor afschaffing van de AAW (in die zin nr. 3, p. 20). Zie ook Beekman (1995), p. 1233. 
van ziekte en ongeval, terwijl met de invoering van een aantal risico-aansprakelijkheden in het nieuw BW in de eerste plaats is beoogd het individuele slachtoffer extra bescherming te bieden in die gevallen waarin als gevolg van een bepaalde activiteit een extra risico in het leven wordt geroepen voor derden. Deze extra bescherming strekt zich echter niet uit tot de verhaalzoekende instantie die de schade van het slachtoffer heeft vergoed $(. . .)^{\text {roo }}$

Regres zou betekenen dat het uitgangspunt werd verlaten dat de volksverzekeringen zowel bescherming bieden tegen het risico van het schade lijden als het risico van het schade veroorzaken. Dit achtte de Raad van State principieel onjuist. ${ }^{709}$ De Raad vond verder dat regres niet het juiste instrument was voor de door het kabinet beoogde reallocatie. Regres op grond van schuldaansprakelijkheid is, zo stelt de raad het, met het oog op kostendistributie niet efficiënt en gaat bovendien gepaard met - ook maatschappelijk - hoge kosten: verharding van de onderhandelingen tussen de daarbij betrokken partijen, meer en langduriger gerechtelijke procedures en meer proces- en uitvoeringskosten. ${ }^{710}$ De regering heeft het wetsontwerp ingetrokken, maar de kritiek van de Raad van State daarbij volledig naast zich neergelegd. Naar verluidt, ${ }^{71}$ heeft daarbij de gedachte voorgezeten dat de op touw zijnde sociale maatregelen nieuwe mogelijkheden zouden bieden om de beoogde uitbreiding te bereiken. Waar dit de praktische kanten van het regres betreft kan daarvoor in het licht van het hiervóór gezegde begrip worden opgebracht. Maar ook het bezwaar dat het aansprakelijkheidsrecht in beginsel een zaak is tussen schadeveroorzaker en benadeelde en dat het gebruik daarvan legitimatie behoeft, liet het kabinet praktisch onbesproken.

\subsubsection{De nieuwe koers}

Door de noodzaak van bezuinigingen en privatisering van de sociale sector dienden de beoogde sociale wijzigingen zich kort nadien aan. De eerste van deze maatregelen had echter geen betrekking op de volksverzekeringen, maar op de privatisering van belangrijke delen van de Ziektewet door invoering van de Wet uitbreiding loondoorbetalingsplicht. ${ }^{712}$ Deze ingrijpende wet heeft de loondoorbetalingsplicht van werkgevers van twee dan wel zes naar tweeënvijftig weken verlengd. Daartoe is art. 7:629 BW ingevoerd, dat werkgevers verplicht tot doorbetaling van tenminste $70 \%$ van het dagloon aan de zieke werknemer voor een periode van tweeënvijftig

708

TK 1994-95, 24 169, B, p. 7 en 5 .

Zie over deze kritick ook Beekman (1995), p. 1233.

Dat is een periodicke, bijvoorbeeld jaarlijkse, afdoening van alle regresvorderingen van de regresnemer of een collectief regresnemers tezamen, door het vaststellen van een door de WA-verzekeraar of het collectief WAverzekeraars (vertegenwoordigd door het Verbond van Verzekeraars) verschuldigde afkoopsom (lump sum). Zie vrij expliciet TK 1994-95, 24 169, nr. 3 (MvT), p. 20 en daarover Beekman (1995), p. 1234 en Janssen (1997), p. 156.

St. 1996. 134. Over de wordingsgeschiedenis van art. 6:107a BW aa. Sehadewergonfingrecht, ant. 107a (Boit); Hartlief \& Van Maanen (1991); Van Boom (1995), p. 863; Stom (1996); en Hartlief \& Van Maanen (1996). 
weken. ${ }^{713}$ De gedachte was dat werkgevers, doordat ze rechtstreeks worden geconfronteerd met de financiële consequenties van de arbeidsongeschiktheid en het ziekteverzuim van hun werknemers, zoveel mogelijk zouden doen dit te voorkomen. ${ }^{714} \mathrm{Bij}$ die gedachte paste volgens de regering bij monde van toenmalig staatssecretaris Linschoten regres, indien derden aansprakelijk blijken te zijn voor het ontstaan van de ziekte of arbeidsongeschiktheid. Tevens hoopte de regering dat dit het geldend maken van regresvorderingen vergeleken met de situatie onder de Ziektewet zou bevorderen, nu werkgevers zèlf daarbij méér (immers een rechtstreeks financieel) belang hebben dan bedrijfsverenigingen. ${ }^{715} \mathrm{Bij}$ deze opsomming van redenen klinkt nergens het punt (een gefundeerd argument voor regres zou ik het niet willen noemen) dat als gevolg van privatiseringstendensen en de uitbreiding van de verantwoordelijkheid van werkgevers in het arbeidsrecht, op werkgevers een dermate groot financieel risico is komen te rusten, dat maatregelen gewenst zijn, ${ }^{716}$ In wezen lijkt toch vooral dàt het punt te zijn geweest. ${ }^{77}$ Daar komt bij, dat art. 6:107a BW een einde maakte aan de achtergestelde positie die werkgevers vergeleken met de overheid als ambtenarenwerkgever krachtens de Verhaalswet ongevallen ambtenaren hadden. Met name door dit laatste kon de regeling rekenen op instemmende reacties vanuit de rechtsliteratuur. ${ }^{718}$ Maar ook dit punt geeft natuurlijk op zichzelf weinig fundering voor het regresrecht zèlf: men kijkt alleen naar de regeling voor de overheid, ${ }^{719}$ en vraagt op grond daarvan om een gelijke positie.

De eerste stap naar invoering van het regres in de volksverzekeringen was de vervanging van de Algemene weduwen- en wezenwet door de Algemene nabestaandenwet, die burgers beter zou moeten confronteren met hun eigen verantwoordelijkheid voor de financiële gevolgen van overlijden. Daarbij paste volgens de

713 Sib. 1996, 134. Bij CAO of individuele arbeidsovereenkomst kan dit worden uitgebreid, bijvoorbeeld door termijnverlenging en verhoging van het uitkeringspercentage. Voor het regresrecht maakt dit geen verschil. Wel relevant is uiteraard of de werkgever het risico van loonkosten zelf draagt of, wat ook mogelijk is, zich entegen verzekert.

74 De matregelen varièren van het verder terugdringen van de risico's van de werkplek door verbetering van de arbeidsomstandigheden, taakinvulling en indringender verzuimbegeleiding en controle tot het regelen van bijzondere zorg-en verzekeringsarrangementen voor werknemers.

75 TK 1995-96, 24326 , nr. 7.

716. Blijkens de eerdergenoemde van de Ondernemersorganisaties in 1992 en maatschappelijke commotie, ook in juridische kringen, zoals de hartenkreet van Van der Veen (1993), p. 756 in het Nederlands Juristenblad en zie over dat gevoelen ook reeds Mok (1977), p. 165.

717 Ook Hartlief \& Van Maanen (1996), p. 126 noemen dit waarschijnlijk. Vgl. ook Van Boom (1995), p. 863 die het verhaalsrecht duidt als het antwoord op de roep om regres van werkgevers (en daarmee wellicht doelt op de brandbrief van de ondememersorganisaties in 1992 bij de aanvankelijke uitbreiding van de loondoorbetalingsplicht).

73 Daaraan hechten Van der Veen (1993), p. 756; Hammerstein (1994), p. 3; en Hoogendijk (1994), p. 12; voorts Storm (1996); en, voorzichtiger Hartief \& Van Maanen (1994), nt. 2.

719 Die naar ik aangaf primair heeft berust op budgenaire redenen (handhaving en uitbreiding van het verhaalsniveat zoals dat bestond onder het omstreden en inefficiênte regime van de cessieclausules). 
wetgever dat de Sociale Verzekeringsbank een verhaalsrecht had jegens individuele schadeveroorzakers. Het gaat om:

'(...) een principiële verandering, namelijk een beperking van de reikwijdte van de volksverzekeringen als verzekering. Vroeger was het uitgangspunt van de volksverzekeringen dat zowel het risico dat een verzekerde schade zou leiden was verzekerd, als het risico dat een verzekerde een schade zou veroorzaken welke zou leiden tot een uitkering of verstrekking ingevolge een van de volksverzekeringen. Thans wordt het verzekerd risico uitdrukkelijk beperkt tot de eerste situatie. Wie in de nieuwe situatie schade veroorzaakt die bij een ander leidt tot een uitkering krachtens een der volksverzekeringen is hiervoor aansprakelijk. Voor het dekken van dit risico zal men dus - voorzover men dat nog niet heeft gedaan - een particuliere aansprakelijkheidsverzekering moeten afsluiten $(\ldots)^{, 720}$

Hoewel het kabinet dit niet stelt, lijkt het daarmee te bedoelen dat het niet langer hecht aan het vestzak-broekzak bezwaar, dat eerder aan het regres in de volksverzekeringen in de weg stond. Maar de passage kan enig demagogisch gehalte niet worden ontzegd. Want het klopt natuurlijk niet wat er gesteld wordt; het is niet wèrkelijk zo, dat voorheen het risico van aansprakelijkheid onder het bereik van de verzekering viel. De schadeveroorzaker was en is volgens regels van aansprakelijkheids- en schadevergoedingsrecht niet tot vergoeding gehouden voor schade die.al door derdev is vergoed Dat heeft met het sercelkerde risico van de valkswerzekeringen niets te maken. Wat de passage alleen zegt is, dat men ook zèlf het schaderisico van deze gevallen (van aansprakelijkheid) niet langer wil financieren, althans dat de middelen hiervoor ontoereikend zijn. Dat is een sociaal-economisch probleem, ter bestrijding waarvan administratieve instrumenten kunnen worden ingezet: het terugbrengen van het verzekerde risico, extra premieheffing, enzovoort. Vanwaar nu deze verandering? Toenmalig staatssecretaris Linschoten stelde voorop dat doordat in het kader van de volksverzekeringen geen regres plaatsvond de premies voor de volksverzekeringen hoger waren dan strikt noodzakelijk, terwijl die voor de aansprakelijkheidsverzekeringen, in vergelijking met omringende landen, ${ }^{n 1}$ relatief laag waren. Invoering van regres voor uitkeringen krachtens de relevante volksverzekeringswetten betekent dan, daarover is de wetgever vrij uitgesproken, extra opbrengsten voor de sociale verzekeringskas, ${ }^{722}$ Beoogd zijn con-

TK 1994-95, 24 169, nr, 3 (MvT), p. 21.

TK 1995-96, 24 758, nr. 3 (Mv), p. 48. Die vergelijking lijkt echter onder meer voor de vergoeding bij arbeidsongevallen en beroepsrickten niet overtuigend. In de sociale premies van de landen om ons heen zijn waarschijnlijk immers niet de premies verdisconteend voor de (particuliere) beroepsongevallenverzekeringen die men daar kent. Dat geldt ook voor de stelling dat de WA-premies vergeleken met de ons omringende landen aan de lage kant zijn, want veelal is de aansprakelijkheid van werkgevers door de evenbedoelde verzekeringen uitgesloten of beperkt. Meer hicrover in het actuele naslagwerk van Reybroeck, P. van, De geandheidsoorg in de arbeidsongevallen- en beroepssiektemversedering in de lid-staten wan de europese unie, Antwerpen c.a., 1995.

TK 1994-95, 24 169, B, 6; in dezelfde zin TK 1995-96, 24 758, nr. 3 (MvT), p. 47, In Belgiè zijn zulke (financiele) motieven de aanleiding geweest tot hervorming van het verkeersaansprakelijkheidsregime bij de schade door motorrijtuigen, zie Senati (Belg) 1993-94, 980-1 (MvT), p. 4 en 35 en darover Engelhard \& Van Maanen (1998a), p. 23. 
arete bedragen, die moeten bijdragen aan de gewenste besparingen. ${ }^{723}$ Overigens wordt dit belang van de concrete regresopbrengsten soms gebagatelliseerd wegens tet geringe aandeel daarvan op de totale verzekeringsuitgaven. ${ }^{724}$ Maar dat lijkt ne niet terecht: zuiverder zou zijn ze te vergelijken met de uitgaven voor gevallen vaarin tevens sprake is van aansprakelijkheid. Hoe dan ook lijkt me dit geen Iragend argument voor het regres. Nog daargelaten de wijze waarop en tegen welke sosten regres tot opbrengsten moet leiden, is daarmee immers, zoals ik het zie, viet gezegd waarom opbrengsten een argument opleveren voor regres nu daartegenэver immers het bezwaar staat van de (WA)schadelast. ${ }^{725}$ Het probleem van de maatschappelijke kosten van ongevallen wordt dan dus alleen verschoven. Dit bezwaar zal de staatssecretaris hebben beoogd weg te nemen met zijn opmerking over het verschil in ontwikkeling van de premies in het publieke bestel (relatief hoge premies) respectievelijk de WA-branche (relatief lage premies). Maar daargelaten of de hoogte van de premies in dit verband de juiste graadmeter is, ontbreekt elke onderbouwing voor die (naar mijn indruk wat twijfelachtige) ${ }^{726}$ stelling. Maar de uitbreiding van regres was niet louter een financiële aangelegenheid:

Een en ander leidt ertoe dat de kosten van bepaalde maatschappelijke activiteiten, bijvoorbeeld het verkeer en de daarmee gepaard gaande onveiligheid, onvoldoende tot uiting komen. Overigens gaat het hier zeker niet alleen om verkeersonveiligheid. Ook de risico's en kosten van andere maatschappelijke verschijnselen, zoals de milieuproblematiek, foutief medisch handelen en criminaliteit zijn voor een deel verborgen in de uitgaven voor de sociale verzekeringen $(\ldots)^{121}$

Dit betreft een korte maar belangrijke passage, die zou kunnen aangeven wat juist de allocatie van de evenbedoelde kosten naar de schadeveroorzaker zo wenselijk maakt. Het kabinet beoogde de kosten van juist die schadeveroorzakende gedragingen en activiteiten waarvoor aansprakelijkheid bestaat zichtbaar te maken. Met welk doel wordt niet gesteld. Al met al blijft de redengeving dan ook, voor een

723 Van de invoering van het regresrecht in de Wet arbeidsongeschiktheidsvoorziening jonggehandicapten werd, volgens de toelichtingsmemorie (TK 1995-96, 24 760, nr. 3, p. 25), een besparing verwacht van 5 miljoen gulden; van dat in de Wet arbeidsongeschiktheidsverzekering zelfstandigen (TK 1995-96, 24 758, nr. 3, p. 48) een besparing van 15 miljoen gulden. Dit laatste wordt ook genoemd voor het regresrecht in de AWBZ (in de toekomst 25 miljoen gulden, TK 1998-99, 26 238, nr. 3, p. 8).

724 Zuiverder zou zijn te vergelijken met de uitgaven voor gevallen waarin tevens sprake is van aansprakelijkheid. Bloembergen (1978), p. 704 wijst op cijfers van de Studiegroep Verkeersaansprakelijkheid die inhouden dat er in 1974 voor ongeveer 55 miljoen NLG aan regresopbrengsten is verhaald terwijl in dat jaar 14 a 15 miljard NLG is uitgekeerd voor WAO, ZW en ZFW.

723 Zie uitvoeriger Engelhard (2001a), p. 51-52.

726 Wat de WA-premies betreft lijkt de stelling van de staatssecretaris dat deze aan de lage kant zijn wat dubieus. Uit het interdisciplinaire onderzoek van Faure \& Hartlief (1995) blijkt dat in de nabije toekomst veeleer extra kosten voor WA-verzekeraars te verwachten zijn. Verder roept ook de algemeenheid van zijn stelling vragen op. Arbeidsongevallen bijvoorbeeld, zijn zowel in aantal als in (schade)ormvang immers aanmerkelijk minder emstig dan privé-, sport- en verkeersongevallen (ook als rekening wordt gehouden met onderrapportage), zie Klein Hesselink, DJ., Ongevalsregistratie in bedriif. Amsterdam, 1995, p. 20.

227 TK 1994-95, 24 169, nr. 3 (MvT), p. 21. Voor wat betreft de AAW gold dat de WAO daarop slechts een loongerelateerde aanvulling gaf en de kosten van arbeidsongeschiktheid dus hoofdrakelijk voor rekening kwamen van de Staat. 
ingrijpende uitbreiding van de gevolgen van aansprakelijkheid als de onderhavige, wat schimmig; daarin had de Raad van State gelijk. Voor het kabinet leek hiermee echter de weg vrij naar verdere uitbreiding van het regres. De vraag of regres paste bij het karakter van de volksverzekeringen werd 'in feite achterhaald' genoemd. ${ }^{728}$ De stelselherziening na de ingrijpende wijziging van de arbeidsongeschiktheidswetgeving per 1 januari 1998 zou de beoogde uitbreiding vanzelf tot gevolg hebben. Op deze datum trad de zogenaamde Pemba-wetgeving in werking. De bedoeling van de Wet premiedifferentiatie en marktwerking bij arbeidsongeschiktheidsverzekeringen was om werkgevers méér financiële verantwoordelijkheid te geven voor de kosten van langdurige arbeidsongeschiktheid, ${ }^{729}$ zij zouden het beste in staat zijn om het uitkeringenvolume te bewaken en terug te dringen. Men moest de volle WAO-premies gaan betalen, gerelateerd aan het aantal WAO-ers in zijn bedrijf. Om het effect daarvan zo groot mogelijk te maken werd bovendien de AAW ingetrokken; het deel van de uitkeringen dat voorheen door de AAW werd gefinancierd, zou dan vrijwel volledig worden betaald door de WAO-premies. Als gevolg daarvan moest wel ook een regeling worden getroffen voor twee categorieën van arbeidsongeschikten die buiten de WAO vielen: ${ }^{730}$ de Wet Arbeidsongeschiktheidsverzekering zelfstandigen en de Wet Arbeidsongeschiktheidsvoorziening jonggenandicapten.

Het kabinet greep deze ontwikkelingen tevens aan voor een belangrijke uitbreiding van het regresvolume ten behoeve van de sociale fondsen. Door het vervallen van de AAW kwam immers het van het WAO-regres uitgezonderde fictieve AAW-deel te vervallen. ${ }^{731}$ Het trof voor de aanmerkelijke uitbreiding van het regres die daarvan het gevolg zou zijn, geen maatregelen. De redenen hiervan mogen in het licht van het vorengezegde duidelijk zijn. Het kabinet beoogde naar eigen zeggen met dit vervallen van de AAW extra regresopbrengsten. De Sociale Verzekeringsraad had desgevraagd de financiële consequenties van de uitbreiding van het regresrecht naar de AAW begroot op tussen de 145 en 180 miljoen gulden. ${ }^{732}$ Tevens gingen zonder veel omhaal nieuwe regresbepalingen gelden voor de delen van de AAW die door speciale arbeidsongeschiktheidswetten zouden worden vervangen. Dat was vanwege het uitdrukkelijke ontbreken van een regresrecht in de AAW opmerkelijk, eens temeer nu de Wet arbeidsongeschiktheidsvoorziening jonggehandicapten uit de algemene middelen wordt gefinancierd terwijl voor sociale voorzieningen in de regel een regresrecht ontbreekt (een aspect waaraan in de toelichting geen woord wordt gewijd). Vermoedelijk heeft bij het argument voor reallocatie, in elk geval in latere jaren, ook wel een rol gespeeld dat regres zou kunnen bijdragen aan preventie. In het al genoemde SER-rapport uit 1993 wordt daarover gesteld

TK 1998-99, 26 238, nt. 3 (MvT), p. 3.

Wet premiediflerentiatie en marktwerking bij arbeidsongeschiktheidsverzekeringen, Sib. 1997, 175. Bijzondere arbeidsongeschiktheidsregelingen voor werkeloze werknemers zullen buiten beschouwing blijven. Beekman (1995), p. 1234.

Sociale Verzekeringsraad (1993), p. 33. 
dat het regres kan leiden tot een kostenconfrontatie die 'een scherpere verantwoordelijkheidsbeleving en maatschappelijk gezien meer doelmatige allocatiebeslissingen' moet bevorderen. ${ }^{733}$ In die richting gaat een exposé van justitieel minister Korthals over de betekenis van de onderhavige regresrechten, zij het in een andere context. ${ }^{734}$ De minister stelde dat regres eraan zou kunnen bijdragen dat potentiële veroorzakers worden gestimuleerd de nadelige gevolgen van hun handelen voor anderen volop in de afweging te betrekken, hetgeen dan weer een belangrijke preventieve werking tot gevolg kan hebben. Maar de Memorie van Toelichting bij de regresbepalingen zelf is daarover nogal summier. Bij de invoering van de Algemene nabestaandenwet werd wèl opgemerkt dat het noodzakelijk was dat alle sociale zekerheidswetten voor een adequate lastenbeheersing voldoende impulsen bieden. En, daarop volgend, dat dit wilde zeggen dat diegene die het verzekerde risico kan beïnvloeden door het systeem geprikkeld moet worden dat risico te beperken. ${ }^{735}$

Dezelfde argumenten werden aangehaald toen in 1999, kort na het aantreden van kabinet Kok II, werd voorzien in een Wet tot invoering van het regresrecht in de Algemene wet bijzondere ziektekosten en tot versterking van het regresrecht in de Ziekenfondswet. ${ }^{736}$ Deze wet voorziet primair in een uitbreiding van het regres naar de Algemene wet bijzondere ziektekosten. ${ }^{737}$ De SER had in zijn eerdergenoemd advies eigenlijk bezwaren tegen de uitbreiding van het regres naar de Algemene wet bijzondere ziektekosten vanwege de oorspronkelijke doelstelling van die wet, namelijk het bieden van collectieve dekking tegen bijzondere immers zware gezondheidsrisico's. Toch heeft de SER niet negatief geadviseerd omdat het onwenselijk leek om voor bepaalde collectieve uitgaven wèl en voor weer andere géén regres te laten plaatsvinden. De invoering van het onderhavige regresrecht was het sluitstuk van de invoering van het regresrecht voor de volksverzekeringen. ${ }^{738}$ Het beoogde met de invoering van het regresrecht in de Algemene wet bijzondere ziektekosten voor de jaren 1999 en 2000 respectievelijk 15 en 30

733 SER-rapport $93 / 14$ (1993), p. 6.

734. In antwoord op kamervragen naar aanleiding van zijn brief over de dreiging van een 'claimcultuar' (TK 1999-00. 26630 , nr. 2, p. 3). Overigens zijn de wettelijke regresrechten van sociale verzekeraars en werkgevers primair geìnitieerd door het ministerie van Sociale Zaken en Werkgelegenheid, zij het 'mede namens de Minister van Justitic en de Staatssecretaris van Welzijn en Cultuur'.

35 TK 1994-95, 24 169, nr. 6, p. 32. Voor de WAO geldt mede om deze reden dat de hoogte van de premies afhankelijk is van het arbeidsongeschiktheidsrisico van het bedrij, Dit betekent dat naast een algemeen premiedeel een gedifferentiecrde premie wordt geheven die afhankelijk is van de omvang van de arbeidsongeschiktheidslasten van het betrokken bedrijf.

736 TK 1998-99, 26 238; Sib. 1999, 239.

737 Tevens gaf de wet een speciale uitvoeringsbepaling die bestemd was voor de Ziekenfondswet en die het de Ziekenfondsrad en het Verbond van Verzekeraars mogelijk zou maken reyesvorderingen collectief af te wikkelen; zie uitvoeriger paragraaf 4.2 .

738 Toenmalig minister Borst nocmde de discussie of het regres wel past bij de volksverzekeringen 'in feite achterhaald, TK 1998-99, 26 238, nr. 3 (MvT), p. 3. 
miljoen gulden; die bedragen heeft het ook opgeleverd. ${ }^{739}$ Voor latere jaren zijn de bedragen hoger ${ }^{740}$ De betekenis van dit budgettaire belang bij regres lijkt dringend te zijn geweest. Het was eigenlijk de bedoeling van de toenmalige regering om de invoeringswet gelijk al op 1 januari 1999 in werking te laten treden, maar door het aandringen van de Ziekenfondsraad en het Verbond van Verzekeraars heeft de minister er aanvankelijk mee ingestemd die datum een jaar te verschuiven. Kennelijk is voor de begroting van het jaar 1999 op de regresopbrengsten gerekend, want door een amendement van de Tweede Kamer is de wet uiteindelijk al op 1 juli 1999 van kracht geworden. Maar het gaat volgens de toelichting bij de wet niet alleen om budgettaire argumenten. Gewezen wordt opnieuw, kort, op het belang van het zichtbaar maken van de kosten van schadeveroorzakende activiteiten omwille van doelmatigere allocatiebeslissingen. ${ }^{741}$

Dat het gewicht van dit argument van zuivere kostenallocatie voor de invoering van het regresrecht van sociale verzekeraars en werkgevers niet moet worden overschat, blijkt wel uit de ontwikkeling die zich in dezelfde sociaal-liberale regeerperiode voor het regresrecht van pensioenfondsen heeft voltrokken. De achtergrond daarvan is vrij ingewikkeld, maar komt globaal hierop neer. Particuliere pensioenfondsen hadden wat hun verhaalsmogelijkheden op derden betreft dezelfde achtergesteide positie ten opzichte van het overheidspensioenfonds, het vroegere $A B P$, als werkgevers voorafgaand aan de invoering van art. 6:107a BW (ten opzichte van de overheid als werkgever). Het $\mathrm{ABP}$ had verhaal voor de invaliditeitspensioenen aan ambtenaren en nabestaandenpensioenen, terwijl particuliere pensioenfondsen geen regresrecht hadden. Daarop lijkt enige kritiek te zijn geweest. ${ }^{72}$ Zoals bekend is het $\mathrm{ABP}$ in 1995 echter geprivatiseerd. In beginsel zou de nieuwe Stichting Pensioenfonds ABP, zo stelt ook de Memorie van Toelichting, ${ }^{743}$ niet meer of betere verhaalsmogelijkheden moeten hebben dan andere pensioenfondsen. Maar om de vermogenspositie van de Stichting vergeleken met het $\mathrm{ABP}$ te continueren, ${ }^{744}$ is ervoor gekozen aan de stichting ook weer een regresrecht toe te kennen. Kennelijk lag het punt gevoelig, want besloten is de nieuwe regresregeling slechts tot 2001 te laten gelden en om dan de achtergestelde positie van de fondsen opnieuw te bezien. ${ }^{745}$ Het punt is nu dat per 1 januari 1998 ook de ambtenaren onder de sociale arbeidsongeschiktheidsverzekeringen (Ziektewet en WAO) zijn gaan vallen, waardoor het regresrecht voor de Stichting ABP budgettair van beduidend minder belang werd. Het had slechts betrekking op bovenwettelijke uitkerin-

Zie daarover Janssen (1999), p. 80 .

Een premieverlaging mag hiervan overigens niet worden verwacht. De verwachte opbrengsten van het $A W B Z$. regres vallen in het niet bij de uitgaven: 30 miljard(1) NLG, daarover Frenk (1999), p. 41.

TK 1998-99, $26238, \mathrm{nr} .3$ (MvT), p. 4.

$\mathrm{Vgl}$. Sinninghe Damstè (1999), p. 60 ('Bedacht moet worden dat andere pensioenfondsen een verhaalsrecht ontberen!')

TK 1994-95, 24 205, nr. 3 (MvT), p. 70.

In die woorden TK 1994-95, 24 205, nr. 3 (MvT). p. 70.

Uitdrukkelijk bepaald in ant. 75 van de Wet privatisering ABP, en daarover (summier) TK 1994-95, 24205. n. 3 (MvT), p. 70. 
gen en de uitkeringen aan nabestaanden. Daarmee kwam het kabinet in 2001 voor de volgende afweging te staan. Ofwel men zou kiezen voor handhaving van het regresrecht van deze nieuwe Stichting ABP en dan (politiek) gehouden zijn tot uitbreiding van het regresrecht naar de andere particuliere pensioenfondsen. Vanuit allocatieoogpunt gezien zou dàt uiteraard voor de hand hebben gelegen. Ofwel men zou het regresrecht van de stichting afschaffen (en daarmee bijvoorbeeld onder neer een stijging van de WA-schadelast vermijden). Het kabinet heeft, zo blijkt ait navraag bij de stichting $\mathrm{ABP}$, voor afschaffing geopteerd.

\subsubsection{Onwenselijke ontwikkeling}

De argumentatie van de regering bij de invoering van de regresbepalingen kan niet echt sterk worden genoemd. Dat het regres budgettair aantrekkelijk is, is alleen overtuigend als men eenzijdig redeneert vanuit het perspectief van de begroting van het Ministerie van Sociale Zaken. Het is een zuiver politiek argument. Daarnaast wijst de regering op het belang van het bevorderen van zuivere kostenallocatie ('de schadeveroorzaker betaalt'), maar de onderbouwing daarvan is matig. Gesteld wordt dat de kosten van schadeveroorzakend gedrag beter zichtbaar moeten worden gemaakt, maar in het midden blijft waarom dit beperkt blijft tot de kosten van verwijtbaar schadeveroorzakend gedrag (alleen zulk schadeveroorzakend gedrag kan immers aanleiding geven tot aansprakelijkheid). Daarmee lijkt het principe een 'dekmantel' voor de genoemde budgettaire doelstellingen ( $\mathrm{al}$ is het daarmee - als dragende grond voor het regres - niet minder belangrijk).

Naar werd gezien heeft op basis van deze argumentatie cen nogal turbulente uitbreiding van het regres plaatsgevonden waarin de discussie door de regering werd beschouwd te zijn afgerond. De regresbepaling bij de invoering van de Wet op de (re)ïntegratie arbeidsgehandicapten werd zelfs nauwelijks nog gemotiveerd. Als gevolg daarvan kunnen thans ook de kosten die in het kader van die wet ten behoeve van de werknemer moeten worden gemaakt binnen het bedrijf waarin hij werkzaam is, op de schadeveroorzaker (diens WA-verzekeraar) worden afgewenteld. Deze kosten zouden indien de benadeelde ze zelf zou hebben gemaakt kunnen worden aangemerkt als kosten ter beperking van de inkomensschade (en daarmee verhaalbare schade zijn in de zin van art. 6:96 lid $2 \mathrm{BW}$ ). Het ligt echter niet steeds voor de hand dàt de benadeelde zulke kosten zelf zou hebben gemaakt. De benadeelde zou voor deze schade met andere woorden, nu die niet de zijne is, jegens de schadeveroorzaker nimmer recht op schadevergoeding hebben gehad uit hoofde van diens aansprakelijkheid. De reïntegratiemaatregelen in het kader waarvan die kosten worden gemaakt zijn immers primair gericht op terugdringing van het aantal personen met een arbeidsongeschiktheidsuitkering en strekken niet noodzakelijk tot vermindering van de schade waarvoor het aansprakelijkheidsrecht recht geeft op schadevergoeding. Het UWV is bijvoorbeeld ook belast met het verstrekken van subsidies voor werkgevers die arbeidsongeschikte werknemers weer aan het werk moeten helpen, en zou door de uitbreiding van het regres in dit verband óók 
deze subsidies kunnen verhalen. Het regresrecht van de Wet op de (re)integratie arbeidsgehandicapten gaat daarmee (potentieel) verder dan de schade waarvoor de schadeveroorzaker bij het uitblijven van het regres aansprakelijkheid zou hebben geriskeerd, zij het begrensd door het civiele plafond (zie nader paragraaf 7.2).

Dit bezwaar geldt in theorie ook voor de andere zelfstandige regresbepalingen. Ook in de overige regresbepalingen voor sociale verzekeraars en uitvoeringsinstanties strekt het regresrecht zich immers uit over 'de krachtens de wet gemaakte kosten'. In zoverre is de Wet (re)integratie arbeidsgehandicapten niet unick. Zo lijkt mij bijvoorbeeld ook het (vroegere) regres voor herplaatsingstoelagen van art. 17 WPA, art. 75 juncto art. 2 VOA twijfelachtig.

\subsubsection{Regresopbrengsten van sociale verzekeraars}

In het kader van de sociale verzekeringen waren de regresopbrengsten een belangrijk politiek argument voor de uitbreiding van de mogelijkheden tot het nemen van regres. In welke orde van grootte moet worden gedacht? Zoals bekend, ${ }^{746}$ is het geven van concrete bedragen over de voor verzekeraars aan het regres verbonden opbrengsten en kosten niet eenvoudig: cijfers zijn niet steeds voorhanden en ook niet steeds betrouwbaar. De mate waarin sociale zekerheidsinstellingen en werkgevers gebruikmaken van hun regresrecht is zonder 'harde' gegevens moeilijk te schatten omdat zij uitkeren los van de vraag naar aansprakelijkheid (en regres bij deze instellingen niet steeds prioriteit heeft). Bij de invoering van de Tijdelijke regeling verhaalsrechten in 1992 werd uitgegaan van de volgende (afgeronde) cijfers.

Over 1983 is door het regres van de (toenmalige) bedrijfsverenigingen op grond van de Ziektewet en de WAO 47400000 gulden verhaald, door de ziekenfondsen op grond van de Ziekenfondswet 40000000 gulden, door het Rijk krachtens de Verhaalswet ongevallen ambtenaren 5570000 gulden en door het ABP krachtens de Verhaalswet ongevallen ambtenaren 7223000 gulden (bestaande uit pensioenschade). ${ }^{\text {nt? }}$

Deze cijfers geven slechts een beperkt beeld van de orde van grootte waarin moet worden gedacht. Ze zeggen, zeker voor de betreffende sociale wetten afzonderlijk, weinig over de huidige situatie in de sociale verzekeringen, om van de wijzigingen in de toeloop van het aantal uitkeringsgerechtigden tussen 1983 en 2003 nog maar te zwijgen. Met name sinds de tweede helft van de jaren negentig hebben in de sociale zekerheid ingrijpende stelselwijzigingen en wijzigingen op uitvoeringsniveau plaatsgevonden. Wat het verbinden van een oordeel of enige betekenis aan de evengenoemde cijfers voor sociale verzekeraars verder bemoeilijkt, is dat in de praktijk ook uitgerekend in de laatste jaren zeer ingrijpende wijzigingen hebben plaatsgevonden, die speciaal gericht zijn op het terugdringen van de uitvoerings- 
kosten van regres. Bovendien kunnen de regresopbrengsten van jaar tot jaar wisselen.

Illustratief is een onderzoek naar het regres van ziekenfondsen in de periode 1990-1994 waaruit de epbrengsten zowel bij de ziekenfondsen onderling als per ziekenfonds in deze jaren genomen sterk tlijken te verschillen. ${ }^{78}$ De totale opbrengsten van regres in het kader van de Ziekenfondswet (dat vil zeggen van alle ziekenfondsen tezamen) bedraagt volgens het rapport in de periode 1990-1994 gemiddeld 54200000 gulden per jaar, terwijl de regresopbrengst in deze periode aanmerkelijk hoger tad kunnen zijn, namelijk 75000000 gulden per jaar. Het rapport concludeent dat de ziekenfondsen in total over deze periode 104000000 gulden regresopbrengst onbenut hebben gelaten.

Daartegenover staan de uitvoeringskosten van het regres. Voor de afzonderlijke categorieën schadedragers zal nauwkeurig dienen te worden bepaald welk deel van de kosten aan regres gerelateerd is. Niet alleen moet worden gedacht aan procedure- en incassokosten (waaronder ook de administratiekosten zijn te verstaan $\mathrm{en}$ het beslag dat regres legt op de eigen schadeafdeling). Bloembergen wijst ook op de aan het regresdeel van de uitkeringenlast gerelateerde winstmarge van de WA-verzekeraars, de aan het regres gerelateerde deel van de provisie van tussenpersonen en overheadkosten. ${ }^{79}$ Bekend is in elk geval wel dat de afwikkeling van schadevorderingen door WA-verzekeraars in het aansprakelijkheidsrecht zelf, dus bij een rechtstreeks beroep daarop, 'duur' is. Zo publiceerde Van Wersch in 1971 een (in het kader van zijn einddoctoraalscriptie verrichte) studie naar de schadeafwikkeling bij motorrijtuigverzekeraars en de afwikkelingscijfers bij sociale verzekeraars. ${ }^{750}$ Daaruit bleken de uitvoeringskosten voor WA- en/of cascoschade-uitkeringen voor het jaar $196871 \%$ te bedragen van de 'netto' verzekeringsuitkeringen (door Van Wersch is hiertoe een incassopercentage van 5\% in mindering gebracht). Bloembergen stelde in 1994 dat deze cijfers nog steeds representatief zijn. ${ }^{751}$ Aangenomen wordt wel dat door aansprakelijkheidsverzekeraars voor regres in het kader van de volksverzekeringen ten minste 500 miljoen gulden aan premies moest worden geïncasseerd om 300 miljoen gulden aan regresnemers te betalen. De vraag die dit uiteraard oproept is wat in breder maatschappelijk verband de zin daarvan is. Een vaak gehoord punt in de discussie over de wenselijkheid van het regres van particuliere en sociale verzekeraars is dat de regresopbrengsten voor hen een zeer gering aandeel vormen op het totaal van hun uitkeringenlast. ${ }^{752}$ Waar dit als een (op zichzelf staand) argument wordt aangevoerd voor afschaffing

TK 1996-97, 25 025, nrs. 1-2 (tevens gepubliceerd als: Verhaalsnecht in de Ziekenfondswet, 's Gravenhage 1996). Als étn van de belangrijkste oorzaken wordt geweren op de inefficiênte organisatiestructuur bij de zickenfondsen.

Bloembergen (1994), p. 121.

De cijfers betreffen zowel het WA- als het cascodeel van de verzekering. Van Wersch (1971), p. 76. Ze zijn daardoor vermoedelijk voor het WA-deel van de vityoeringsikosten gunstiger, a.w., p. 80).

Blocmbergen (1994), p. 121.

Zie reeds Van der Veen (1961), p. I: Mac Lean (1986), p. 288; Bloembergen (1994), p. I18. 
van het regresrecht van de betreffende verzekeraars, ${ }^{753}$ lijkt het onterecht. Voor particuliere en sociale verzekeraars zijn de opbrengsten uit regres substantieel genoeg om te protesteren tegen de afschaffing van het regres; niet alleen in verband met de betekenis van het regres voor hun lopende begroting, maar ook als structurele inkomstenbron. ${ }^{754}$ Maar ook los daarvan lijkt het zuiverder om te kijken naar het aandeel van de regresopbrengsten op het totaal van de uitkeringenlast in gevallen waarin de schade door derden is veroorzaakt. Als dan zou blijken dat de regresopbrengsten ook in verhouding tot de uitkeringenlast met betrekking tot die gevallen zeer laag zouden zijn, zie ik daarin op zichzelf nog geen argument liggen tegen regres. Wel kan de verhouding tussen de regresopbrengsten en de uitkeringenlast in die zin van betekenis zijn voor de discussie, dat de regresopbrengsten van verzekeraars in de vorm van een (geringe) premieverlaging dan wel het uitblijven of verminderen van een verhoging ten goede zullen komen aan de benadeelde. Daaraan wordt dan juist een argument ontleend ten faveure van regres. ${ }^{755}$ Bekend is echter ook, dat het effect van de netto regresopbrengsten op de premies veelal niet noemenswaardig is. ${ }^{756}$ Regresopbrengsten van verzekeraars komen immers niet onverdeeld ten goede aan de benadeelde als individuele verzekerde, maar aan het collectief premiebetalers waarvan hij deel uitmaakt. Bloembergen noemt regres om deze reden 'onzuiver'. Voor de Wet op de arbeidsongeschiktheidsverzekering, bijvoorbeeld, zal dit collectief het bedrijfsleven zijn en dus niet alleen diegenen, die in het bijzonder blootstaan aan het betreffende schaderisico (bijvoorbeeld intensieve verkeersdeelnemers). Aan te nemen valt niet dat het premievoordeel door regres kan oplopen tot voor de benadeelde substantiële bedragen. ${ }^{757}$

Interessant wordt het pas, en alleen dan, indien men de kosten erbij betrekt. De kosten van regresacties van particuliere of sociale verzekeraars zijn hoog, zo gaat het argument dan, terwijl de opbrengsten, voorzover zij als zodanig al calculeerbaar zijn, over het collectief verzekerden zullen worden gespreid. ${ }^{758}$ Bovendien is nog maar de vraag wat in de praktijk van doorberekening van de regresopbrengsten in de premies terecht komt, terwijl de stijging van de WA-premies wel min of meer vaststaat. ${ }^{759}$ Een hiermee samenhangend bezwaar bij regres kan zijn dat regres hoogstens een negatief effect kan hebben op spreiding van de, al via de sociale premies gespreid zijnde, schade, namelijk indien verhaal wordt gezocht op niet WA-verzekerde personen (hetgeen zich evenwel, dat was het uitgangspunt,

753 Van der Veen (1961), p. I en Giltay Veth (1969), p. 239

754 VgL. Inv 6, p. 1408 (MvA II Inv., achter 1). De minister zelf acht het totaal van de regresopbrengsten van belang 'in een tijd waarin een op bezuiniging gerichte herziening van het sociale verzekeringsstelsel aan de orde is"; Imv 6, p. 1413 (Nota II Inv.).

753 Koster (1971), p. 135 en 140; Boot \& De Waal (1991), p. 175.

756 Koster (1971), p. 136

757. Daargelaten dat de totale verplichte premieafdracht 'een niet onaanzienlijk deel' raakt van het brutoinkomen van alle werkenden en grote groepen niet-werkenden; Jaspers \& Riphagen (1991), p. I5.

758 De sociale premies wonden namelijk niet individueel berekend; Jaspers \& Riphagen (1991), p. 21

759 Dere stijging is niet direct het gevolg van de betreffende regresclaim, maar van de noodrak voor WA-verackerars rekening te houden met de mogelijkheid van regres. 
niet snel zal voordoen). ${ }^{760}$ Beter, want goedkoper en eenvoudiger, is volgens Bloembergen de motorrijtuigenbelasting te verhogen en het meerdere ter beschikking te stellen van de sociale fondsen. ${ }^{761}$ Dat alternatief geldt alleen voor een beperkt aantal regressituaties (gemotoriseerde verkeersongevallen). Maar vanuit de visie dat het louter 'om het geld gaat', het realloceren of spreiden van schade of het genereren van regresopbrengsten lijken zulke alternatieven inderdaad efficienter. Naar in hoofdstuk $6 \mathrm{zal}$ worden gezien geeft die visie echter maar een beperkt beeld van de meerwaarde van het regres.

\subsection{Conclusie}

Sinds halverwege de jaren negentig stimuleert de regering het geldend maken van de onderhavige regresrechten door sociale verzekeraars en de werkgever van het slachtoffer (die gehouden is tot loondoorbetaling). Met het oog daarop zijn nieuwe wettelijke regresbepalingen ingevoerd. Beoogd wordt een tweetal rechtspolitieke doeleinden: het regres moet individuele schadeveroorzakers confronteren met de kosten van hun gedrag en tevens leiden tot extra regresopbrengsten. Uit de wordingsgeschiedenis en de politieke context blijkt dat het gewicht ligt bij de extra regresopbrengsten. Die werden wenselijk geacht in het licht van de toenemende druk op het stelsel van sociale zekerheid, en als (kleine) tegemoetkoming voor de zware lasten die op werkgevers zijn komen te rusten.

Wat van de hieraan ten grondslag liggende politieke keuzes van herverdeling zijn moge, ${ }^{762}$ ik laat die in het midden, als argument voor de wettelijke regresbepalingen is het budgettaire argument niet sterk. Tegenover regres als instrument voor het genereren van opbrengsten staan de toenemende schadelast en de uitvoeringskosten waarmee het gepaard gaat. ${ }^{763}$ Het regres van sociale verzekeraars is, zoals Bloembergen overtuigend heeft laten zien, ${ }^{764}$ vooral een zaak van collectiviteiten, waarbij het collectief van verzekerden dat van de regresopbrengsten profiteert (sociale premiebetalers) daar langs andere weg voor moet betalen (als WA-verzekerde, belastingbetaler of als consument). Het is een vestzak-broekzak operatie. Dat effect geldt wellicht tot op zekere hoogte óók wel bij normale, rechtstreekse toepassing van het aansprakelijkheidsrecht, we betalen er allen aan mee (direct dan wel via hogere WA-premies, belastingen, of prijzen van aansprakelijke

\footnotetext{
700 Aldus ook Bloembergen (1965), nr. 247.

761 Bloembergen (1965), nr. 253.

762 Zoals ik liet zien zijn die niet onomstreden. Bloembergen (1994), p. 118 vraagt, net als Clausing (1964), p 420 destijds, waarom de sociale premies niet tevens het risico van aansprakelijkheid kunnen dekken. Ook de Sociale Verzekeringsrad had daarover twijfels bij de introductie van het regres in de WAO, zie voor de reactic van de minister TK 1962-63, 7171, nr. 3 (MvT), p. 21

763 Zie 0.a. Van der Veen (1961), p. 931; Clausing (1964), p. 421; Bloembergen (1965), nr. 250; Bloembergen (1966), p. 329; Giltay Veth (1969), p. 238; Bloembergen (1993), p. 117; Bloembergen (1996), p. 73.

Bloembergen (1965), nr. 250.
} 
producenten), maar is daar ondergeschikt aan het belang dat de benadeelde heeft bij vergoeding. Dat vergoedingsaspect heeft immers tot gevolg dat burgers als individuele benadeelde méér profiteren dan de gelijktijdige premiestijging die ze daarvan ondervinden. Aansprakelijkheid bij regres is financieel gezien hoofdzakelijk een zaak tussen verzekeraars en/of andere 'deep-pocket ' partijen zoals de overheid en grote bedrijven. Zeker het regres voor uitkeringen uit de volksverzekeringen, dat overigens wel maar een relatief klein deel van het totale regresvolume van sociale verzekeraars beslaat, lijkt dan op een nodeloos rondpompen van geld. Tegenover de sociale premieverlaging die de regresopbrengsten tot gevolg kunnen hebben staan immers weer hogere premies voor WA-verzekeringen. ${ }^{765}$

Dit geldt uiteraard niet voor alle regresacties van sociale verzekeraars. Internationale verkeersongevallen zijn een bekend, en voor de praktijk niet onbelangrijk, voorbeeld van gevallen waarvoor dit anders is ${ }^{766} \mathrm{Het}$ Nederlandse collectief sociaal verzekerden betaalt immers niet mee aan de premiestijging in de Duitse autobranche. De vraag moet bovendien zijn, zo zou ik menen, of juist de doelgroep die blootstaat aan het concrete risico naar aanleiding waarvan de schadeuitkering is gedaan waarvoor regres plaatsvindt, samenvalt met het collectief WA-verzekerden. Bij het regres op de Staat of lagere overheden, producenten en milieu-overtreders lijkt van een vestzak-бroekzak elfect dan niet noodzakeink sprake. Aansprakelıje producenten zullen indien mogelijk de extra premielasten waartoe het regres kan leiden doorberekenen in de kostprijs van hun product. Het collectief dat daarvan de nadelige gevolgen ondervindt (de afnemers van het product) valt niet noodzakelijk samen met het collectief dat blootstaat aan het schaderisico dat het product in het verkeer brengt (en dat van het regres profiteert in de vorm van een lagere premie). Buiten deze bijzondere gevallen lijkt het vestzak-broekzak argument overtuigend. Het onderstreept dat, met name voor het regres van sociale verzekeraars, andere, beter dragende rechtspolitieke argumenten voor de onderhavige regresrechten noodzakelijk zijn. Maar welke? 


\section{Doelstelling en functie}

Al meer dan dertig jaar wordt in de literatuur gediscussieerd over de maatschappelijke betekenis van het regres. In die discussiemoet het regres een zuivere kostenallocatie en preventie bevorderen, maar wordt betwijfeld of het daarvoor wel het geschikte instrument is. De meer intrinsieke functie van het regres ligt intussen elders, het gaat uit van het principe dat de schuldige betaalt. Als A's hond losraakt en voorbijgangers verwondt, als B een schadelijk product op de markt brengt waarvan een deel van de afnemers ziek wordt, en als $C$ door een te snelle inhaalmanoeuvre een kind schept, dienen $A, B$ en $C$ die schade te dragen, al dan niet via hun WA-verzekering. Dat bevredigt het rechtsgevoel, althans dàt is de bedoeling, ook als de schade naar derden is verplaatst. Daar komt het regres in beeld, dat zorgt ervoor dat het de schadeveroorzaker is, die betaalt.

\subsection{Inleiding}

In het vorige hoofdstuk werd gezien dat het kabinet aan de uitbreiding van het regres de laatste jaren twee argumenten ten grondslag legt, namelijk dat dit tot extra regresopbrengsten kan leiden èn dat het de kosten legt bij de veroorzaker. Het eerste, budgettaire argument werd vanuit een breed maatschappelijk perspectief gezien onbevredigend genoemd, aangezien tegenover de regresopbrengsten voor particuliere en sociale verzekeraars hoofdzakelijk de lasten van WA-verzekeraars staan. Op het grotere geheel gezien lijkt dat, zoals Bloembergen het stelt, een vestzak-broekzak operatie. ${ }^{767}$ Dat wil echter nog niet zeggen dat het regres moet worden afgeschaft. Het belang van het macroargument is meer dat het de discussie op scherp zet: waarom verzekeraars uitvoeringskosten laten maken voor transacties die op grote schaal zinloos lijken? Wat brengt ons dat op? De logische vervolgvraag of die functies opwegen tegen de kosten, vergt een puur politieke afweging. Over de eerste vraag valt echter meer te zeggen. 


\subsection{Rechtsherstel}

\subsubsection{Het principe dat de schuldige betaalt}

Het ligt voor de hand om voor de functies van het regres aansluiting te zoeken bij de functies van het aansprakelijkheidsrecht. Maar dat is omstreden; het aansprakelijkheidsrecht bevindt zich op dit punt in een identiteitscrisis. ${ }^{768}$ Die algemene kwestie loopt intussen niet helemaal parallel met de vraag naar het doel of de functies zijn van het aansprakelijkheidsrecht in regreszaken. Die kunnen afwijken van de functies die het aansprakelijkheidsrecht heeft als de benadeelde zelf een claim instelt.

\subsubsection{Individueel rechtsherstel?}

Voor de benadeelde zelf heeft het aansprakelijkheidsrecht een vergoedingsfunctie, dat is onomstreden: ${ }^{769}$ door het inroepen van het aansprakelijkheidsrecht kan de benadeelde een aanspraak krijgen op vergoeding van zijn vermogensschade en kan niet-vermogensschade enigszins worden verzacht. Het compenseren is van b́elang, maar dé betek̉enis daarvan moet gelet op de toegankelijkheid en het ruime bereik van andere vergoedingssystemen (zoals particuliere en sociale verzekeringen) wel wat worden gerelativeerd. ${ }^{770}$ Bovendien ligt bij het vergoed zijn van de schade niet het (eind)doel van het aansprakelijkheidsrecht, ook die gedachte wint de laatste jaren meer terrein. ${ }^{711}$ Wie dat wèl zo zou zien, zou zich moeten verbazen over de vele drempels (beperkingen) die het aansprakelijkheidsrecht opwerpt: compensatie vindt alleen plaats bij verwijtbaar, schadeveroorzakend gedrag. Men zou dit laatste punt dogmatisch nog kunnen omzeilen door te stellen dat het doel is om de gevallen te vinden waarin moet worden gecompenseerd, maar dat roept nog steeds de vraag op met welk doel dat moet gebeuren.

De gangbare opvatting onder auteurs die hechten aan het bevorderen van vergoeding is dan ook dat dit uiteindelijk een vorm van rechtsherstel is voor de bena-

Voor visies op deze discussie, ook in andere landen, zij verwezen naar o.a. Van Dam (1989), p. 213 e. v.; Van Maanen (1991), p. 21 e.v.; Van Dam (1993), p. 161 e.v.; Atiyah (1997), p. 159 e.v.; Bell \& O'Connell (1997), p. 68 e.v:; Hartlief (1997), p. 16 e.v; Hartief \& Tjittes (1999), p. 3 e.v.; Spier e.a. (2000), nr. 9 (Spier); Van Boom (2000a), p. 107 e.v.; Bloembergen \& Lindenbergh (2001), nr. 4 e.v.; Barendrecht (2002), p. 605 e.v.. Verheij (2002), mn. p. 433 e.v.; Du Perron (2003), p. 107 e.v Spier e.a. (2000), nr. 9 (Spier), Bloembergen \& Lindenbergh (2001), nr. 6; Verheij (2002), nr. 350, Du Perron (2003), p. 108.

770 Barendrecht (2002), p. 612 . Bloembergen \& Van Wersch (1973), p. 144 schatten destijds dat bij verkeersongevallen $90 \%$ van de totale schade anders dan via het aansprakelijkheidsrecht werd vergoed. Te denken valt met name aan de 'top' van het inkomen en aan immateriele schade van de benadecide. Zie Bloembergen (1978). p. 704; Van Dam (1989), p. 206: Markesinis (1994), p. 919 en Atiyah (1997), p. 96 en 98; Van Maanen (1998). p. 116: Hartlief (1998), p. 257; Klosse (2003), p. 32 spreckt dan ook van het aansprakelijkheidsrecht 'als sluitstuk' Ze Hartief (1997), p. 17 ev.; Barendrecht (2002), p. 611 ev; Verhej (2002), p. 423 ev. en 430 (voor smantengeld): Du Perron (2003), p. 108 e.v. 
deelde, of dat het hem genoegdoening biedt. ${ }^{772}$ Daarin zou dan tevens het (uiteindelijke) doel liggen. ${ }^{773}$ Een naar ik meen overtuigende benadering komt van Verheij, met name met betrekking tot de functies van het recht op smartengeld. ${ }^{774}$ Verheij kiest het vertrekpunt dat de compensatiefunctie in een aantal opzichten problematisch is. Zo wijst hij er onder meer op dat leed niet goed door geld kan worden gecompenseerd, en dat niet goed verklaarbaar is dat reeds de schending van een persoonlijkheidsrecht (bijvoorbeeld het recht op privacy of van eer en goede naam) recht geeft op smartengeld terwijl voor de aantasting van een vermogensrecht (tevens) sprake moet zijn van psychisch letsel. ${ }^{775} \mathrm{Om}$ ook als leed niet objectiveerbaar en dus niet verifieerbaar is smartengeld toe te kennen is een andere functie vereist; die zou dan idealiter tussen compensatie en straf moeten liggen. Verheij vindt die functie in de noodzaak dat het privaatrecht in staat is om te reageren op de inbreuken op een privaatrechtelijke recht, de rechtshandhavingsfunctie. ${ }^{776}$ Die reactie dient niet te geschieden met het oog op preventie, zo stelt hij, maar is een kwestie van logische noodzaak: zonder (re)actie geen recht. Het is zinloos een bepaald belang van het etiket (subjectief) recht te voorzien als vervolgens na een inbreuk daarop, het privaatrecht nalaat om op die inbreuk te reageren. Het geschonden recht zet zich voort, zo nog Verheij, in de vorm van een rechtsaanspraak.

Maar zulke visies op het aansprakelijkheidsrecht of de wenselijkheid daarvan zijn omstreden. ${ }^{777}$ Betwijfeld wordt met name de redelijkheid (of legitimatie) van een vergoedingssysteem dat berust op verwijtbaarheid. Het aansprakelijkheidsrecht biedt als zodanig immers alleen bescherming voor een klein geprivilegieerd deel van alle schadegevallen. Het zou om deze reden juist willekeurig zijn, en onrechtvaardig. ${ }^{778}$ Het aansprakelijkheidsrecht kiest van honderd daklozen, zo stelt Atiyah metaforisch in het bekende werk Damages as a Lottery, er twee uit met het doel $z e$ in het Ritz hotel te kunnen onderbrengen, terwijl de rekening daarvan zo hoog is dat er niets overblijft om de overige acht-en-negentig daklozen te helpen. ${ }^{779}$ Op de rol van het aansprakelijkheidsrecht als vergoedingssysteem is overigens ook andere kritiek, ik zal hierop terugkomen. ${ }^{780}$

772 Zie daarover o.m. Verheij (2002), p. 406 c.v. en Du Perron (2003), p. 109 e.v. en p. 129

773 Zie daarover o.a. Spier e.a. (2000), nr. 9 (Spier) en Verheij (2002), p. 404 e.v. De visie dat rechtsherstel (mede) het doel is klinkt door bij Bloembergen (1965), nr. 82 en Barendrecht \& Storm (1995), p. 16. Zo kennelijk ook Stapleton (1986), p. 104, die in haar dissertatie spreekt van de 'corrective justice goal' van het aansprakelijkheidsrecht. Bloembergen \& Lindenbergh (2001), p. 12 noemen dit de doelstelling van het schadevergoedingsrecht en benadrukken voor het aansprakelijkheidsrecht het belang van rechtshandhaving.

774 Verheij (2002), p. 430 e.v.

775 Verheij (2002), p. 434.

776 Verheij (2002), p. 445.

77 Zie Verheij (2003), p. 404 e.v, en Du Perron (2003), p. 110 e.v.

778 Sugarman (1985), p. 592; Atiyah (1997), p. 32. In die richting ook Barendrecht (2002), p. 613 en Du Perron (2003), p. 112.

779 Atiyah (1997), p. 32; vgl. Stapieton (1986), p. 115.

7wo Zie paragraaf 6.5 . 


\subsubsection{Correctieve rechtvaardigheid}

In de rechtsfilosofische hoek zijn verschillende pogingen gedaan om te verklaren waarom het aansprakelijkheidsrecht juist iets doet voor de daar aan de orde zijnde gevallen. De gangbare opvatting is dat de redelijkheid daarvan ligt bij de bescherming van de belangen van de benadeelde in diens rechtsverhouding tot de aansprakelijke, de schadeveroorzaker. ${ }^{781}$ De gedachte is dan deze, dat het schadevoorval de toestand van gelijkwaardigheid in de rechtsbetrekking tussen schadeveroorzaker en benadeelde heeft verstoord en dat de schadevergoeding hen beide zoveel mogelijk moet terugbrengen in de oude situatie. Tussen hen moet rechtsherstel plaatsvinden, als een eis van gerechtigheid (correctieve rechtvaardigheid). ${ }^{782}$

Overigens is lang niet duidelijk waaruit die verstorende factor in de verhouding tussen schadeveroorzaker en benadeelde precies bestaat (en wat derhalve de uiteindelijke grond is of zou moeten zijn voor aansprakelijkheid). Op basis van de idee van correctieve rechtvaardigheid zijn in de jaren zeventig door verschillende auteurs theorieën ontwikkeld die juist die ene, algemene grond voor aansprakelijkheid moesten bieden. ${ }^{783}$ Een uitvoerige beschrijving daarvan zou hier te ver voeren, ik noem er enkele. Zo is Epstein's, wat hij noemt, intuïtieve uitgangspunt dat het

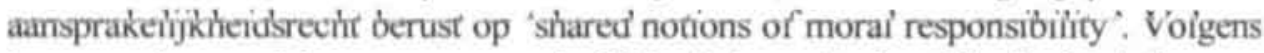
hem zou de grondslag voor aansprakelijkheid dan ook eigenlijk slechts behoeven te bestaan uit het enkele causale verband tussen inbreukmakend gedrag van de aansprakelijke (waarbij de overige omstandigheden niet ertoe doen) en het geschonden beschermde recht of belang van de benadeelde. Onder causaliteit moet dan (uiteraard) niet elk gedrag worden verstaan dat noodzakelijk (conditio sine qua non) is geweest voor het intreden van de schade. ${ }^{784}$ Het gaat om de betekenis van veroorzaking die blijkens normale spreektaal wordt verondersteld aanwezig te zijn: bij het gegeven 'A sloeg B', is duidelijk dat A als veroorzaker moet worden aangemerkt (A wordt immers in actieve en $\mathrm{B}$ in de lijdelijke vorm gezet). ${ }^{785}$ Als daardoor een rechtens beschermd belang van $B$ werd geschonden, dan levert dat voldoende grond op voor aansprakelijkheid. B heeft het subjectieve recht van de benadeelde geschonden, en daarmee diens autonomie en vrijheid, en moet dit

781 Fletcher (1972), p. 537 e.v; Weinrib (1983), p. 38; Stapleton (1986), p. 104 en uitgesprokener (1995), p. 820 e.v. In dezelfde zin Schwartz (1990), p. 363, met de kanttekenening dat van correctieve rechtvaardigheid buj het WA-verzekerd zijn slechts sprake kan zijn als sprake is van enige premierespons of andere maatregelen van de betrokken WA-verzekeraar (en de schadeveroorzaker dus ook daadwerkelijk met de gevolgen van zijn getrag wordt geconfronteerd).

782 Sugarman (1985), p. 607 acht hiermee evenwel onverklaand 'why corrective justice demands that the victim recovers damages from the injurer whenever the injurer "caused" the harm"; vgl. ook Fletcher (1983), p. 66 Volgens Sugarman (1985), p. 590 en Schwartz (1990), p. 315 is er geen alomvattende, bevredigende theoric die ondersteunt dat het aansprakelijkheidsrecht die functie in alle gevallen heeft.

Zie daarover Posner $(1979 b)$, p. 457 e.v 
in de vorm van schadevergoeding herstellen. ${ }^{786}$ Ook Weinrib ziet het oorzakelijke verband tussen het gedrag van de aansprakelijke en de schade van de benadeelde als de kern van correctieve rechtvaardigheid. ${ }^{787}$ Het is door dit onderlinge verband dat vergoeding van dit individuele slachtoffer door deze individuele dader op zijn plaats is.

Het moeilijke met causaliteitstheorieën is dat ze niet verklaren waarom in het positieve recht slechts bepaalde gevallen van schadeveroorzakend gedrag tot aansprakelijkheid leiden en andere niet. Overtuigender lijkt dan de benadering van Fletcher, die de uiteindelijke grond voor aansprakelijkheid zoekt bij een eenzijdige risicoverhoging ('nonreciprocal risk taking') waaraan de aansprakelijke de benadeelde door zijn schadeveroorzakende gedrag heeft blootgesteld. Bij een botsing tussen auto's is het blote feit van het autorijden nog geen eenzijdige vorm van risicoverhoging. Daarvan is pas sprake als slechts één van de automobilisten onvoorzichtig rijdt. Op hem kan dan de aansprakelijkheid rusten. ${ }^{788}$ Dat is een 'principle of faimess': wij allen hebben in het maatschappelijke verkeer recht op bescherming tegen schaderisico's waaraan we eenzijdig worden blootgesteld. ${ }^{789}$ Het beeld dat Fletcher hiermee schetst spoort alleen niet helemaal met de wijze waarop de vraag naar aansprakelijkheid in het (Nederlandse) positieve recht wordt beoordeeld. Voor aansprakelijkheid in gevaarzettende situaties is immers niet steeds noodzakelijk dat de benadeelde werd blootgesteld aan een risico waaraan hij zelf de gevaarzetter niet heeft blootgesteld. Bij schuldaansprakelijkheid is beslissend of de gedaagde meer risico nam dan van 'een goede huisvader' (the reasonableman) mag worden verwacht. Daarvoor is van belang of zijn gedrag gelet op de aard en omvang van het schaderisico, kosten van voorzorgsmaatregelen, enzovoort onaanvaardbaar was. Fletcher's risico-element is bovendien lang niet altijd aanwezig (ik denk aan belediging, misbruik van bevoegdheid, hinder), en de uitwerking daarvan zal ook niet eenvoudig zijn. ${ }^{790}$

Meer in overeenstemming met de complexiteit van de gronden voor aansprakelijkheid en de uiteenlopende situaties waarvoor die gelden lijkt de benadering van Cane. Hij stelt dat het beter is om te erkennen dat het aansprakelijkheidsrecht met verschillende algemene principes kan worden onderbouwd. Hij spreekt van 'four conceptions of justice which underlie and justify the imposition of liability in much of the law of torts.' Een aantal gevallen van onzorgvuldig gedrag berust op correc-

786 In die zin werkt Epstein (1979b), p. 479 zijn ideečn nader uit in reactie op de kritiek van Borgo (die stelt dat het causaliteitscriterium in essentie geen eindcriterium voor aansprakelijkheid biedt omdat het altijd weer berust op normatieve oordeien).

787 Weinrib (1983), p. 39.

78 Fletcher (1972), p. 548.

789 Fletcher (1972), p. 550.

790 Die laatste moeilijkheid onderkent Fletcher (1972), p. 572: 'If one man owns a dog, and his neighbour a cat. the risks presumably offset each other.' Op het gebied van verkeersaansprakelijkheid spreekt de idee van eenzajdige risicoverhoging meer tot de verbeelding, die gedachte is ook terug te vinden bij het systeem van Van Maanen (1998), verder uitgewerkt bij Engelhard \& Van Maanen (1998). In die richting oordeelt ook Hof Den Bosch 17 juli 2001, NJ 2002, 399 (Joosten/Interpolis). 
tieve rechtvaardigheid. Voor de minder evidente gevallen die om een nadrukkelijke afweging van alle betrokken belangen vragen, zoals bepaalde gevallen van hinder (Cane wijst op de Engelse tort of nuisance) overheerst de 'conception of justice as fairness, as the reciprocal sharing of benefits and burdens among the members of a society'. ${ }^{791}$

Het doel van wetsbepalingen die voor de verhouding tussen schadeveroorzaker en benadeelde uitgaan van zulke 'conceptions of justice', om terug te keren naar het vertrekpunt, zou dan zijn dat op dàt niveau, binnen die verhouding, rechtsherstel plaatsvindt.

\subsubsection{Geen (directe) correctieve rechtvaardigheid bij regres}

Dit laatste is een gedachte die best aanspreekt, maar zij verklaart niet waarom de schadeveroorzaker óók moet betalen als de benadeelde zelf bij die betaling geen (rechtstreeks) belang meer heeft. Bij het regres wordt de aansprakelijkheid van de schadeveroorzaker immers ingeroepen zonder dat de individuele belangen van de benadeelde (rechtstreeks) daarbij betrokken zijn. Wèl klinkt soms de visie dat het regres voor particuliere en sociale verzekeraars een vorm van rechtsherstel is. De regresnemer zou zèlf in zijn belangen zijn aangetast door een uitkering verschuldigd te zijn die hij zonder toedoen van de schadeveroorzaker niet verschuldigd zou zijn geweest. ${ }^{792}$ Het regres wordt dan:

'beschouwd als een correctic op een gebeurtenis, waarvan krachtens burgerlijk recht de gevolgen dienen te worden gedragen door de veroorzakers. Immers, de werknemer die arbeidsongeschikt wordt door toedoen van een derde kan (...) aanspraak maken op ziekengeld (...) Daardoor lijdt de bedrijfsvereniging schade waarvoor een ander aansprakelijk is. Dat 'onrecht' heeft de wetgever beoogd te herstellen door uitkeringen krachtens Ziektewet en WAO verhaalbaar te stellen. ${ }^{70 \%}$

Maar het is dunkt me niet dàt belang dat de schadeveroorzaker wordt toegerekend. De verbintenis tot het betalen van de regressom berust op de aansprakelijkheid van de schadeveroorzaker jegens de benadeelde zèlf. Indien die ontbreekt hebben particuliere en sociale verzekeraars, hoewel ze tot uitkering gehouden zijn (en daarmee in hun belangen zijn geschaad) niet de mogelijkheid tot het nemen van regres. Dàt zou ook wat ver gaan; uiteraard treft hen dat ze moeten betalen, maar zou dan niet elk schadevoorval ook voor particuliere en sociale verzekeraars en alle andere risicodragers zelf tot het bedoelde 'onrecht' moeten leiden (en daarmee tot aansprakelijkheid)? De principiële consequentie daarvan, een systeem waarin objectieve verkeersfouten telkens óók onrechtmatig zijn jegens de verzekeraar

201 Cane (1982), p. 44.

792 Overigens kunnen met name regresnemende werkgevers feitelijk well ook zelf betrokken zijn geweest bij het schadevoorval. Zelfs is mogelijk dat ook jegens hen onrechtmatig is gehandeld. Het punt is alleen dat dit niet de grondslag is van de regresvordering.

Boot \& De Waal (1991), p. 175. 
van het primaire slachtoffer, staat haaks op ons huidige wettelijke kader, dat uitgaat van de relativiteit van de geschonden norm. ${ }^{794}$ Onrecht, als men daarvan al wil spreken, speelt zich volgens dat (huidige) wettelijke kader alleen af in de verhouding van de schadeveroorzaker tot de primair benadeelde. Dat schadevergoeding of rechtsherstel plaatsvindt vindt zijn oorzaak in die verhouding, niet in de verhouding van de schadeveroorzaker tot verzekeraars.

\subsubsection{Indirect rechtsherstel. Premieargument}

Om toch de verklaring van het regres nog in het keurslijf van de correctieve rechtvaardigheid te wringen, zou men het zo moeten stellen dat de belangen van de benadeelde daarmee wèl indirect gediend zijn. Het regres zou vanuit die optiek secundaire belangen van de benadeelde moeten waarborgen (de directe schade werd immers al door de regresnemer vergoed). Ongetwijfeld kunnen door het regres tot op zekere hoogte tevens de belangen van de benadeelde worden gediend. Het overheidslichaam of de sociale verzekeraar kan het voortouw nemen bij het feitenonderzoek, bijvoorbeeld door een getuigenverhoor. ${ }^{795}$ Wellicht ook kan de advocaat van de regresnemer tevens voor het onverzekerde deel van de schade schadevergoeding vorderen (tegen betaling uiteraard van een deel van het honorarium). ${ }^{796}$ Het (vooruitzicht van) regres zou verzekeraars bovendien coulanter kunnen maken in hun uitkeringsbeleid.

Die laatste gedachte ligt ook besloten in het arrest Nationale Nederlanden/Woudsend $/ 1{ }^{797}$ De Hoge Raad acht in dat arrest een uitbreiding van het regres naar onverplichte uitkeringen van schadeverzekeraars wenselijk. Daartoe wijst de raad erop dat de schadeveroorzaker (of WA-verzekeraar) anders de verschuldigdheid van schadeuitkeringen zou kunnen betwisten. Dat zou naar 's raads inschatting schadeverzekeraars terughoudender kunnen maken bij het doen van uitkeringen.

Maar als doel van het regres lijken zulke argumenten wat vergezocht, het zijn slechts positieve neveneffecten. Trouwens het regres kan voor de benadeelde ook nadelen hebben (zoals de confrontatie met de pijnlijke herinnering aan het schadevoorval of de schadeveroorzaker). Een ook wel gehoord argument voor het regres is dat de regresopbrengsten aan de (individuele) benadeelde ten goede kunnen komen, bijvoorbeeld in de vorm van een relatief laag premieniveau, ${ }^{798}$ of in de zin dat het regresnemers coulanter maakt in hun premiebeleid. ${ }^{799}$ Gesproken

\footnotetext{
794 Zie paragraaf 4.9 .2 .

795 Daarop wordt gewezen bij Kremer (1991), p. 29; Van Maanen \& Römers (1994), p. 58; Van Maanen (1998), p. 116; en Kremer, thans wat relativerend, bij Lindenbergh e.a. (2000), p. 72.

796 Dit voordeel mist de benadeelde in de gevallen waarin het regres collectief wordt afgewikkeld.

797 HR 7 januari 2000, NJ 2000, 212 nt. MMM (Nationale Nederlanden/Woudsend II).

79s Boot \& De Waal (1991), p. 175.

T9 Bij sommige verzekeraars wordt indien hen de mogelijkheid toekomt tot het nemen van regres op de aansprakelijke geen bomus-mahus verlies bij de benadeelde in rekening gebracht. Een bekend voorbeeld zijn cascoverzekeringer van geparkeerde auto's die worden beschadigd (door Verbond van Verzekeraars gewijzigd bij VB 10 april 1997 ).
} 
kosten van de verzekering voor de verzekerden in het algemeen bij ontbreken van de subrogatie allicht hoger zouden worden dan zij, gegeven de subrogatie hoeven te zijn. ${ }^{812}$

De volgens de P-G ontbrekende reden is er - voor de goede orde - technisch gezien uiteraard wèl. De schadeveroorzaker ontleent zijn 'profijt' rechtstreeks aan regels van schadevergoedingsrecht (paragraaf 3.3). Hij is volgens die regels niets verschuldigd voor schade die al uit andere hoofde wordt vergoed. Er is dan een (positieve) reden nodig om de schadeveroorzaker toch nog te laten betalen. De profijttheorie geeft daarvoor het argument dat de schadeveroorzaker - omdat hij het profijt heeft van het schadeveroorzakende gedrag - daarvan óók de kosten zou moeten dragen. Waarom dat is èn waarom juist regresnemende verzekeraars op die grond regres toekomt is hiermee niet verklaard. De profijttheorie biedt eerder een (begin van een) verklaring voor de grondslag van aansprakelijkheid, dan voor de eraan te verbinden gevolgen. $\mathrm{Zij}$ geldt bovendien maar voor een beperkt aantal gevallen. ${ }^{813}$ Zo is onduidelijk waaruit precies het 'profijt' bestaat van degene die in een verhitte gemoedstoestand een ander schade berokkent, zeker als de schadeveroorzaker nog een strafrechtelijke boete wacht. Wie vermogensrechtelijk gezien sterker lijkt te profiteren is de regresnemende verzekeraar zelf, die immers premies heeft ontvan-

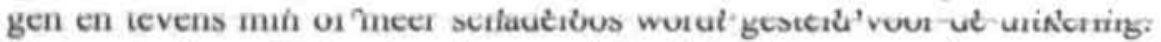

Dat maakt de profijttheorie ook ongeschikt als basis voor een algemene verrijkingsactie (art. 6:212 BW) ${ }^{814}$ Die zou in dit verband erop neerkomen dat de schadeveroorzaker door het schadevoorval verrijkt wordt ten koste van al diegenen die de schade van de benadeelde voor hun rekening nemen, zoals particuliere en sociale verzekeraars. Hun betalingen leiden immers ertoe dat de schadeveroorzaker jegens het primaire slachtoffer is bevrijd. ${ }^{815} \mathrm{Ik}$ betwijfel of dat dogmatisch juist is: de verrijkingsactie berust op de gedachte dat de aansprakelijke een verwijt treft in zijn verhouding tot de verarmde, in casu de verzekeraar. ${ }^{816}$ Regresbepalingen berusten niet op die gedachte, ze strekken niet tot vereffening van het geschade belang (de verarming) van de regresnemende verzekeraar (al kunnen ze wel dat

Cursief toegevoegd, EE. Desondanks beantwoordde de P-G de vraag naar subrogatie van ziekenfondsen overigens om technische redenen - anders dan de Hoge Raad - negatief, zie HR 13 mart 1959, NJ 1962, 338 (Ziekenfondy Hogestijn D. p. 1060 (1.kolom).

s14 Dat overweegt Van Boom (2000a), p. 9: 'Door de min of meer toevallige omstandigheid dat (een deel van) de schade die hij heeft veroorzakt, aan de benadeelde wordt vergoed door cen ander, neemt zijn aansprakelijkheidslast namelijk af zonder dat hij daartoe enige (financiele) opoffering behoeft te doen. (..) Dit profijt zou een ongerechtvaardigde verrijking van de aansprakelijke opleveren ten laste van de uitkerende verzekeraar of risicodrager.'

816 De precieze betekenis van de actie is omstreden, zie uitvoeriger Engelhard \& Van Maanen (1998b). 
gevolg hebben). ${ }^{817}$ De wettelijke regresrechten van sociale verzekeraars die de laatste jaren zijn ingevoerd berusten zelfs niet meer op de

'overweging dat de schadeveroorzaker niet behoeft te profiteren van het feit dat er een sociale verzekering is, maar op de wens om de lasten te laten dragen door degenen die de gewraakte activiteiten ontplooien, teneinde de kosten van die activiteiten zichtbaar te maken." ${ }^{\text {sis }}$

Ook dit laatste raakt trouwens in mijn visie niet de kern, want als het zichtbaar maken van de kosten van schadeveroorzakende activiteiten voorop staat, waarom is het regres dan beperkt tot schadeveroorzakende gedragingen of activiteiten waarvoor aansprakelijkheid bestaat, ofwel: (rechtens) verwijtbaar schadeveroorzakend gedrag? Het aardige van dit nieuwe argument is wèl dat het de vraag naar de functies van het regres naar een hoger niveau 'tilt'. ${ }^{19}$ Volgens het kabinet dient het regres primair een collectief belang, het zichtbaar maken van de kosten van schadeveroorzakend gedrag. Dit vraagt meer aandacht,

\subsubsection{Utilistische benadering}

In de visie van het kabinet op het regres van sociale verzekeraars moet dit (direct) het algemene belang bevorderen: het moet de schadelijke neveneffecten van bepaalde maatschappelijke en economische activiteiten beter zichtbaar maken door ze te leggen waar ze worden veroorzaakt. ${ }^{820}$ Dat past bij de tijdsgeest, zo lijkt het. Want hoewel de visie op het aansprakelijkheidsrecht als een op de belangen van de individu gericht systeem in de rechtsliteratuur nog steeds voorop staat, hebben utilistische opvattingen sinds de jaren zeventig van de twintigste eeuw (en voor het Nederlandse debat vooral de laatste jaren) in belangrijke mate terrein gewonnen. ${ }^{821}$ Wat hen bindt, is dat het belang van het collectief vooropstaat en niet het individuele belang van de benadeelde. ${ }^{822}$ Zeker voor regressituaties spreekt dat aan, dat gaat immers over het hoofd van de benadeelde heen. Maar het stuit ook op weerstand. Hèt punt van kritiek is dat in de utilistische zienswijze de be-

517 Vgl. punt 2 van de NJ-noot van Bloembergen inzake HR 4 maart 1977, NJ 1978, 144 (Providentia/ABP). Een rechtstreekse actie zou bovendien haaks staan op het gesloten systeem van art. 6:107 en 108 BW, vgl. Van Boom (2000a), p. 11 en daarvoor zou ook los daarvan, wil men daarmee de algemene regels van het onrechtmatige daadsrecht niet doorkruisen, métr nodig zijn dan het enkele veroorzaken van schade door een onrechtmatige daad jegens een ander.

318 TK 1995-96, 21 528, nr. 6, p. 19.

sis Vgl. Sugarman (1985), p. 604, waar regres 'far removed from any meaningful sense of individual justice' noemt (cursief toegevoegd, EE).

820. Deze laatste zijn de letterlijke bewoordingen uit de adviesaanvrag van het kabinet aan de SER, zie paragraaf 5.5.2.

s21 $\mathrm{Vgl}$. Fletcher (1972), p. 537: "Tort theory is suffering from declining expectations. $(\mathrm{m})$ the thrust of the academic literature is to convert the tort system into something other than a mechanism for determining the just distribution of accident losses. (...) The fashionable questions of the time are instrumentalist".

52 Wat daarbij onder 'collectief' moet worden verstaan kan varietren en is lang niet altijd duidelijk: het kan bijvoorbeeld gaan om het belang van de omwonenden van een bedrijvenpark of om het belang van de samenleving. waaronder alle inwoners van ons land zouden kunnen worden verstaan of van de wereld. 
scherming tegen inbreuken op subjectieve rechten niet wordt gegarandeerd. De uiterste consequentie van het vooropstellen van het algemeen belang zou immers zijn dat de benadeelde rechtsinbreuken moet dulden van maatschappelijk aanvaardbare risico's omdat die bijdragen aan de welvaart van de rest. Ik zal dat fundamentele punt van kritiek hier als zodanig laten rusten, angezien het directe relevantie mist. ${ }^{823} \mathrm{Wel}$ zal in het navolgende nog op concrete onderdelen worden ingegaan op de vraag in hoeverre acceptabel is dat de benadeelde nadeel ondervindt van (de functies van) het regres nadeel ondervindt.

Het is echter niet zozeer de traditionele (rechts)opvatting van het utilitarisme, die in de doctrine veel gehoor vond. Daarin wordt de betekenis van het rechtssysteem afgemeten aan de te verwachten gevolgen ervan voor welvaart in ruime zin: het welbevinden van alle mensen. De maatstaf voor de beoordeling van gedrag en van rechtsregels ligt dan bij de mate waarin die bijdragen aan welzijn of geluk en aan de vermindering van ongeluk. Bij de inrichting van het rechtssysteem biedt dat te weinig concrete handvaten. Posner illustreert dit aan de hand van een casus waarin hij degene die bereid is van een ander een ketting te kopen voor $\$ 10000$,vergelijkt met de dief die bereid is voor het stelen van de ketting (het risico van) ongerief van die orde van grootte te ondergaan. Het gedrag van de eerste is moreel oezien beter . en ook vanuit economisch (utilistisch) oogpunt is het te verkiezen omdat hij beoogt de welvaart te vergroten voor zichzelf en óók voor de eigenaar (voor wie de ketting immers, blijkens zijn bereidheid tot verkoop tegen de genoemde prijs, een waarde had van minder dan $\$ 10000,-)$. Het traditionele utilitarisme, waarin het welzijn voorop staat, laat onverklaard dat de dief, voor wie de ketting kennelijk meer geluk biedt dan voor de eigenaar, toch niet de eigenaar ervan wordt (of, kan worden toegevoegd, jegens de eigenaar of de regresnemende diefstalverzekeraar tot betaling gehouden is). ${ }^{824}$ Wellicht zou men dat overigens wèl kunnen verklaren door te stellen dat het aansprakelijkheidsrecht (tevens) een bestraffende functie heeft. In sommige rechtsstelsels, zoals het Zwitserse, werd het regresrecht van schadeverzekeraars aanvankelijk om deze reden beperkt tot gevallen van schuldaansprakelijkheid. ${ }^{825}$ Maar de opvatting dat het aansprakelijkheidsrecht een bestraffende functie heeft wordt thans in zijn algemeenheid verworpen. ${ }^{826}$ Straffen is een zaak van het strafrecht, en zou bovendien in het aansprakelijkheidsrecht weinig effectief zijn, aangezien het risico van aansprakelijkheid op zo grote schaal

823 Zie onder de enorme hoeveelheid literatuur op dit punt o.a. Fletcher (1972), p. 564 (onder verwijzing naat John Rawls); Epstein (1979a), p. 74 ('The fundamental weakness of the pure utilitarian point of view is that it fails to explicitly recognize anv antecedent or natural rights that a legal system is called upon not to create but to recognize and protect. Rights and duties are treated as having explicit instrumental origins') en op p 75 vergelukbare kritiek gericht op de rechtseconomische benadering.

s24. Posner (1979), p. 123. Posner voegt hier nog toe dat de hang nas welvaart die in de economische visie vooropstast daarentegen ook de naleving bevordent van traditionele, 'Calvinistische' gedrags- en omgangsnormen zoals eerlijkheid en betrouwbaarheid.

826 Asser-Harkamp 4-III, nr. 7; Van Dam (1989); Sugarman (1985), p. 621; Honoré (1997), p. 74; Schwartz (1990). p. 327: Lindenbergh (1999), p. 65: Bloembergen \& Lindenbergh (2001), p. 12 
is verzekerd. ${ }^{827}$ Weliswaar is een vaak gehoorde uitdrukking voor regressituaties dat het regres voorkomt dat de schuldige of de veroorzaker de dans ontspringt, ${ }^{828}$ maar:

'Het gaat daarbij echter niet zozeer om een echte straf in de zin van extra leedtoevoeging, maar veeleer om verevening door compensatie: de veroorzaker betalt.' 20

Daarmee zijn we weer terug bij het uitgangspunt, want voor de onderhavige regresrechten, waarbij van compensatie geen sprake is, klinkt dan een moderner utilistisch uitgangspunt: het regres zou kunnen bijdragen aan een zuivere kostenallocatie.

\subsubsection{Zuivere kostenallocatie}

Volgens het kabinet moet het regres bevorderen dat de kosten van ongevallen worden toegeschreven aan de schadeveroorzakende activiteiten in het kader waarvan ze plaatsvinden. De gedachte is deze, dat het aansprakelijkheidsrecht dan bevordert dat de 'ware prijs' van de goederen en diensten waarop deze activiteiten betrekking hebben beter zichtbaar wordt. ${ }^{830}$ Ook in de rechtsliteratuur krijgt het aansprakelijkheidsrecht (en regres) die functie de laatste jaren vaker toebedeeld. Zelfs in de visie van Bloembergen, die pleit voor de afschaffing van regresvorderingen van sociale en particuliere verzekeraars zijn er:

'aan (het beginsel motoring 'should pay its way') niet 'wellicht', maar zeker aantrekkelijke kanten. Uit economisch oogpunt bekeken moet de prijs van een product als het gemotoriseerde verkeer de door hem veroorzaakte sociale kosten (waaronder de ongevalskosten) weerspiegelen. Gebeurt dat niet, dan lijkt dat verkeer goedkoper dan het is of - anders gezegd - dan wordt het gesubsidieerd. Dat leidt tot economisch niet verantwoord gebruik van motorvoertuigen. Ook los hiervan lijkt het niet redelijk dat gebruikers van motorvoertuigen de sociale kosten van hun gebruik afwentelen op de gemeenschap. ${ }^{\mathrm{n}}$

Gesproken wordt dan van zuiverekostenallocatie, maar de term wordt in verschillende zin gebruikt. ${ }^{832}$ Men bedoelt er steeds mee, dat de schade aan juist die personen of activiteiten moet worden toegeschreven die om bepaalde redenen het

Lindenbergh (1999), p. 65. Ook speelt daarbij mogelijk een rol dat bestraffing gericht is op de aansprakelijke terwijl men vergoeding van de benadeelde in civilibus hoger waardeent. In die zin Giltay Veth (1969), p. 212 die het aansprakelijkheidsrecht, ook voor regresnemers, uitsluitend aanmerkt ais cen vergoedingssysteem en de handhaving van normen en sancties een zaak noemt van het strafrecht. Zie supra, paragraf 6.3 .1 (met verwijzingen).

Bloembergen \& Lindenbergh (2001), p. 12 (cursief toegevoegd, EE).

Zie o.m. Fletcher (1972), p. 538; Cane (1982), p. 44; Abraham (1986), p. 19; en Schwartz (1990), p. 321. Doelstelling en legitimatie gaan dan veelal samen, vgl. Schwartz, p. 313: 'Tort law oflen is justified as achieving fairness in the allocation of losses.

831 Bloembergen (1978), p. 705. Vgi. ook Hartlief \& Van Maanen (1991), p. 302; Janssen (1997), p. 155.

s32 Calabresi (1970), p. 21 en Stapleton (1986), p. 121. In die zin ook Hartlief (1997), p. 21, waar erop wordt gewezen dat de term de laatste jaren gemakkelijk valt, ook bij de wetgever. 
meest aangewezen zijn daarvoor te betalen, maar de redenen die men daarvoor heeft willen nogal eens uiteenlopen. Bloembergen lijkt het bevorderen van zuivere kostenallocatie zo te verstaan, dat de veroorzaker enkel moet betalen omdat hij zuiver causaal gezien schade heeft veroorzaakt. Als men vindt dat het gemotoriseerde verkeer moet opkomen voor de kosten die het veroorzaakt, zo stelt hij het, ${ }^{833}$ dan valt niet in te zien waarom dat beperkt zou moeten worden tot kosten die verwijtbaar zijn veroorzaakt. De veroorzaker blijft immers veroorzaker, ook al kan men hem geen verwijt maken. En dus:

'Als het kabinetsstandpunt is dat kosten zo veel mogelijk moeten worden toegerekend aan de activiteiten die de kosten veroorzaken, waarom stelt het kabinet dan niet voor een heffing te leggen op alcohol en tabak? ${ }^{2}$ s 4

Het kabinet stelt inderdaad mede aan het regres te hechten omdat het de draagplicht met betrekking tot de schade bij de aansprakelijke legt en daarmee de kosten van schadeveroorzakend gedrag beter zichtbaar maakt. Voorzover het daarbij instrumentele doeleinden nastreeft kan de economische analyse van het aansprakelijkheidsrecht meer inzicht bieden bij de vraag wat daarvan kan worden verwacht.

\subsubsection{Economische benadering}

De economische bijklank van de term zuivere kostenallocatie maakt het voor de hand liggend om daarvoor aansluiting te zoeken bij de betekenis daarvan voor de economische benadering van het aansprakelijkheidsrecht. Kostenallocatie is dan een manier om te komen tot generale preventie (primary cost avoidance), ter verhoging van de maatschappelijke welvaart. ${ }^{835}$ Calabresi is, met andere Amerikaanse (en Britse) wetenschappers zoals Coase en Posner, grondlegger van de economische benadering van het aansprakelijkheidsrecht die sinds de jaren zestig en zeventig van de twintigste eeuw floreert. ${ }^{836}$ Voor een goed begrip moet worden vooropgesteld dat die benadering bestaat uit positieve en normatieve analyses. In de positieve economische analyse wordt gezocht naar een verklaring van het ontstaan van rechtsregels. In de normatieve leer worden rechtsregels goed of slecht beoordeeld, afhankelijk van hun efficiëntie. Het belangrijkste doel van het aansprakelijkheidsrecht is dat optimale welvaart wordt bereikt, dat is de situatie waarin de som van de maatschappelijke kosten van ongevallen en van het voorkomen ervan zo laag mogelijk is ${ }^{837}$ Allocatieve efficiëntie staat dus in het teken van

Vgl. Stapleton (1995), p. 821 en Abraham (1986), p. 19 e.v., die spreken van een 'optimale combinatie van risicodifferentiatie en preventie:

Zie Faure \& Van den Bergh (1989), p. 50 e.v. voor een historische uiteenzetting

s37 Calabresi (1970), p. 26; Stapleton (1986), p. 122; Faure \& Van den Bergh (1989) en Van den Bergh \& Faure (1990), p. 11; Van Dam (1989), p. 208; Harticf (1997), p. 20. 
het optimaliseren van de welvaart, dat is de waarde van goederen en diensten uitgedrukt in geld en afgemeten naar hetgeen mensen onderling bereid zijn voor iets te betalen of te vragen. ${ }^{838}$ Dit kan zowel bijdragen aan billijkheid als aan het terugdringen van de maatschappelijke kosten door preventie, beide staan uiteindelijk in het teken van optimalisering van de welvaart. ${ }^{839}$ Posner noemt welvaart zelfs de uiteindelijke normatieve graadmeter voor de beoordeling van het rechtssysteem, 'Wealth Maximization as an Ethical Concept'. Tussenkomst van het aansprakelijkheidsrecht beperkt de economische en persoonlijke vrijheid. Volgens Posner is daarvoor alleen plaats bij zo ernstige onvolkomenheden van het marktmechanisme dat de maatschappelijke welvaart, ondanks de aan het rechtsingrijpen verbonden kosten, wordt verhoogd. Het welvaartsstreven noopt bijvoorbeeld, in Posner's visie, tot een zakenrechtelijk systeem dat individuen exclusieve subjectieve rechten toekent, en tot een contractenrecht dat bijdraagt aan de vrije markt opdat deze rechten overgaan op degenen die deze economisch gezien het hoogst waarderen. Het schadevergoedingsrecht is nodig om potentiële inbreuken op de aldus toebedeelde rechten te voorkomen (preventie) en om bij voltooide inbreuken vermogensherstel te bevorderen. ${ }^{840}$ In later werk stelt Posner het scherper en dient het recht op schadevergoeding van slachtoffers in het aansprakelijkheidsrecht ertoe hun te stimuleren tot het inroepen van aansprakelijkheid opdat generale preventic wordt bereikt. $^{841}$

Op economische verklaringen zoals deze is intussen vanuit de rechtsfilosofische hoek veel kritick. Voor de beoordeling van de vraag naar aansprakelijkheid zouden de rechtsinbreuk en het aan het schadevoorval voorafgaande gedrag (een belofte of handeling) van de ene partij jegens de andere het enige moeten zijn dat hun onderlinge verhouding (en rechtep en plichten jegens elkaar) beheerst. ${ }^{262}$ Rechtseconomische theorieën zouden slechts meer duidelijkheid bieden over de economische kosten daarvan. ${ }^{\text {su }}$

\subsubsection{Het belang van preventie}

Ook in het Nederlandse recht worden zulke economische doelstellingen of functies wel aan het aansprakelijkheidsrecht toegeschreven. ${ }^{844}$ Het aansprakelijkheidsrecht zou moeten bijdragen aan een zuiverdere toerekening van de kosten van schadelijke of gevaarzettende gedragingen of activiteiten (allocatiefunctie) en aan het voorko-

Posner (1979), p. 119.

Calabresi (1970), p. 24 (nt. 1) en p. 26.

Posner (1979), p. 127

Posner zoals weergegeven bij Schwartz (1994), p. 442.

Epstein (1979), p. 68 (met verdere verwijzingen); Scheinman (2003), p. 21 e.v. verdedigt een integratic van beide benaderingen.

543 Epstein (1979), p. 50: 'These costs demand compromises between principles of utility and principles of justice:

su Zie o.a. Hartlief (1997), p. 21 e.v; Spier e.a. (2000), nr. 9 (Spier); Bloembergen \& Lindenbergh (2001), p. 12; Van Boom (2000a), p. 107. Door die visie lijkt ook Van Boom (2003) geinspireerd, zie met name p. 21 e. $\mathrm{v}$, 
men van ongevallen of van schade (preventiefunctie). ${ }^{845}$ Daartussen bestaat een zekere cohesie: als het aansprakelijkheidsrecht ervoor zorgt dat de maatschappelijke kosten van bepaalde schadeveroorzakende gedragingen of activiteiten 'zichtbaar' worden gemaakt in hun prijs, dan is men beter in staat om voor die gedragingen of activiteiten of de gevolgen ervan preventieve maatregelen te nemen. Verder zou het aansprakelijkheidsrecht een spreidingsfunctie hebben; door het WA-verzekerd zijn van de schadeveroorzaker zouden de schaderisico's van de schouders van de benadeelde overgaan naar het collectief WA-verzekerden. Over de precieze plaats van elk van deze functies is het laatste woord echter nog niet gezegd. ${ }^{846}$ Het regres zou vooral moeten bijdragen aan zuivere kostentoerekening (gespreid is het schaderisico veelal wel al zonder het aansprakelijkheidsrecht), en daarmee aan preventie. Van Dam:

'In 1980 hield het schadevergoedingsrecht voor de meeste schrijvers op bij zo veel mogelijk vergoeding en zo veel mogelijk spreiding. Inmiddels is duidelijk geworden dat het verhaal hiermee niet af is. Het is minstens zo belangrijk om de kosten van bepaalde maatschappelijke activiteiten door middel van gerichte spreiding van de schade in rekening te brengen bij de desbetreffende maatschappelijke groep. Zo kan invloed worden uitgeoefend op het niveau van die activiteiten en dat kan in veel gevallen weer een preventief effect op de schade hebben. ${ }^{\text {wN? }}$

Le gedảchte is̉ dản dèze, dảt đé internalisering van de kosten van particuliere en sociale verzekeringen bij het verzekerd zijn van de schade meebrengt dat, ter hoogte van de verzekerde bedragen, onvoldoende financiële prikkels uitgaan naar buitenstaanders, niet-verzekerden. ${ }^{848}$ Regres zou de (potentiële) gevaarzetter een financiele prikkel kunnen geven om het ontstaan van schade te voorkomen, doordat hij meer moet betalen, rechtstreeks (bij regresvorderingen jegens hemzelf) of indirect: zijn WAM-verzekeraar betaalt de regressom, maar met voldoende premiemaatregelen. Zouden daardoor bijvoorbeeld de WAM-premies stijgen, dan zou dat de beslissing omtrent de aanschaf van een tweede auto nadelig kunnen beïnvloeden. ${ }^{849}$ Zoals in het vorige hoofdstuk werd opgemerkt stelt het kabinet in de totstandkomingsgeschiedenis van de wettelijke regresbepalingen over het belang van preventie als zodanig en over de effecten van het regres op dat punt vrijwel niets. De Sociale Verzekeringsraad is nog gevraagd na te gaan of van uitbreiding van het regres naar de volksverzekeringen positieve of negatieve gedragseffecten waren te verwachten. Op basis van de resultaten van een uitbesteed onderzoek(je) meende de raad dat van positieve gedragseffecten weinig te verwachten viel. In de Memorie van Toelichting bij de regresbepalingen wordt dan ook vooral gewezen op het belang van zuivere kostenallocatie en wordt over preventie nauwelijks gerept. Ook

Zie Spier ea. (2000), nr. 7 (Spier), Van Dam (1989); Hartlief (1997), p. 22; Atiyah (1997), p. 159, Bloembergen \& Lindenbergh (2001). p. 12.

246 Hartlief (1997), p. 16; Hartlief \& Tjittes (2000), p. 3; Bloembergen \& Lindenbergh (2001), p. 12 e.v.

847 Van Dam (1993), p. 162.

ss Zie Van Dam (1993), p. 163; Faure (1996), p. 52 e.v; Hartlief (1997), p. 19.

349 Voorbeeld van Bloembergen (1978), p. 696; Bloembergen (1994), p. 118; Faure (1996). 
de SER stelt het belang dat regres een kostenconfrontatie oplevert voorop. Dat zou de kosten van schadeveroorzakende activiteiten beter zichtbaar moeten maken. De SER lijkt daarvan ook wel preventieve effecten te verwachten, maar stelt enkel dat de beoogde kostenconfrontatie moet leiden tot 'doelmatigere allocatiebeslissingen'. ${ }^{850}$ In een Nota naar aanleiding van het verslag van de vaste kamercommissie over de invoering van de Algemene nabestaandenwet en het regresrecht in die wet is de staatssecretaris daarover wat explicieter. Noodzakelijk is, in zijn woorden, dat alle sociale zekerheidswetten voor een adequate lastenbeheersing voldoende impulsen bieden. Dat wil zeggen, zo stelt hij het, dat degene die het verzekerde risico (in casu het overlijdensrisico) kan beinvloeden door het systeem geprikkeld moet worden dat te beperken. ${ }^{851}$

Het verband tussen het aansprakelijkheidsrecht en het belang van preventie is omstreden, op sommige terreinen meer dan op andere. ${ }^{852}$ In 1989 constateert Van Dam dat naar de 'niet onbelangrijke' vraag naar de doelstellingen van het aansprakelijkheidsrecht in de Nederlandse literatuur nauwelijks systematisch onderzoek is verricht. De functionele benadering van het recht wordt stiefmoederlijk behandeld. ${ }^{853}$ Door de meeste auteurs lijkt, zoals ik aangaf, wel te worden aangenomen dat het aansprakelijkheidsrecht ook zou moeten bijdragen aan preventie, ${ }^{154}$ en duidelijk is verder dat ongevallen niet tegen elke prijs moeten worden voorkomen. ${ }^{855}$ Maar over de precieze betekenis van de preventiefunctie, en haar prioriteit in verhouding tot andere functies van het aansprakelijkheidsrecht, heerst grote onduidelijkheid.

Kan het aansprakelijkheidsrecht, om te beginnen, op preventievlak een reële bijdrage leveren? ${ }^{856}$ De economische benadering van het aansprakelijkheidsrecht biedt hieromtrent meer inzicht. e.v.; Hantlief (1997); Spier e.a (2000), nr. 9 (Spier); Hartlief \& Tjittes (2001), p. 3 e.v.; Bloembergen \& L.indenbergh (2001), p. II e.v.; Barendrecht (2002), p. 605 e.v.

254 Vgl. Köster (1971), p. 139; Bloembergen (1978), p. 699.

855 Daarover heerst eenstemmigheid, vgl. Calabresi (1978), p. 17; Stapleton (1986), p. 122; Faure \& Van den Bergh (1989), p. 54: Van den Bergh \& Faure (1990), p. 11; Van Dam (1989), p. 208; Hartlief (1997), p. 20; doch Fleming (1970), p. 173 stelt: 'Since unreasonable injury to person or property causes a reduction in society's wealth, any detenent therefore serves the aim of economic efficiency". 


\subsubsection{Preventie langs twee wegen}

In dit verband moeten twee manieren worden onderscheiden om te komen tot generale preventie. De dreiging van aansprakelijkheid kan in de eerste plaats het gedrag van de potentiële schadeveroorzaker beïnvloeden, ${ }^{857}$ in die zin dat hij wordt aangemoedigd tot het nemen van voorzorgsmaatregelen. ${ }^{858}$ Als de kosten van het nemen van veiligheidsmaatregelen lager zijn dan de omvang van zijn vergoedingsplicht bij aansprakelijkheid (dat is: de kans dat de schade zich voordoet vermenigvuldigd met de omvang van de schade), dan zullen potentiële daders geneigd zijn die maatregel te nemen ter voorkoming van de schade ${ }^{859}$ Dat kan dan weer ertoe leiden dat de betreffende gevaarzettende activiteit wordt vermeden of dat het toezicht daarop en de research-and-development worden verscherpt. ${ }^{860}$ Op enkele terreinen van het aansprakelijkheidsrecht toont niet-cijfermatig empirisch onderzoek aan, dat de dreiging van het aansprakelijkheidsrecht niet alleen in theorie kan aanmanen tot meer zorg, maar dit - kennelijk - ook daadwerkelijk doet. ${ }^{861}$

Schwartz wijst op onderzoek van Harvard op het gebied van medische aansprakelijkheid, waarin artsen stellen de dreiging van een schadeclaim te ervaren als een factor 2.54 op een schaal van 1-5 die van invloed is op de mate van zorgvuldigheid die ze inachtnemen. Uit andere studies blijkt de dreiging van de - Amerikaanse - medische respectievelijk productaansprakelijkheid ook voor ziekenhuizen en producenten aanieiding te zijn tot verbetering van het veiligheidsbeleid. ${ }^{162}$ Het gaat me er niet om aan de resultaten van deze studies conclusies te verbinden, laat staan conclusies voor het Nederlandse aansprakelijkheidsrecht, maar ze overtuigen in de stelling dat het aansprakelijkheidsrecht een reêle bijdrage kan leveren aan de vermindering van het aantal ongevallen of van de schade bij ongevallen.

Maar andere onderzoeken komen met weer andere onderzoeksresultaten. ${ }^{863} \mathrm{Ge}$ noemd werd al het advies van de Sociale Verzekeringsraad naar aanleiding van een vraag naar de gedragseffecten bij uitbreiding van het regres naar de volksver-

Waabij de rechtseconomische benadering ook vraagt dat hij de 'cheapest cost avoider' is. Het risico van bedrijfsschade door het uitvallen van de stroom na cen ongeval, bijvoorbeeld, kan voor de eigen schadeverzekeraar van het gedupeerde bedrijf nauwkeuriger zijn te (door)berekenen dan het risico van incidentele aansprakelijkheid van de willekeurige (potentiele) veroorzakers.

Degene in wie zich het amalgama aftekent van de beste mogelijkheden tot het afwegen, beheersen en verzekeren van het schaderisico. Bij het vaststellen wie dat in concrete gevallen is, kunnen problemen ontstaan, zie daarover Stapleton (1986), p. 124.

Stapleton (1986), p. 123 en Schwartz (1990), p. 337

In die zin Schwartz (1990), p. 341.

Daarmee is nog niet geregd dat de preventieve werking wenselijk is en of het onrechtmatige daadsrecht, aansprakelijkheid en regres, in dit verband ook efficiênt is; vgl. Sugarman (1985), p. 587.

Schwartz (1994), p. 401 en 403

Schwartz concludeert (1994), p. 423 'that tort law provides a significant amount of deterrence, yet considerably less than the economists' formulae tend to predict'. Hij vermeldt daartoe statistische data en maakte gebruik van andere technicken zoals interviews, om een vollediger beeld te krijgen van de invloed van het onrechtmatige daadsrecht, bijvoorbeeld, op het veiligheidsbeleid van bedrijven. Zie voorts de studies vermeid bij M. van Dam (2001), p. 375 e.v., waar wordt gesteld dat er weinig recent empirisch materiaal voorhanden is (en overigens dat voorrichtigheid past buj studies uit de jaren 1960-70, gelet op een aantal ontwikkelingen in het aansprakelijkheidsrecht nadien). 
zekeringen. De raad noemt het 'hoogst onwaarschijnlijk' dat van deze uitbreiding positieve gedragseffecten zijn te verwachten en baseert zich op literatuurstudies, interviews en een uitbesteed onderzoek(je). ${ }^{804}$ Wellicht heeft daarbij een rol gespeeld dat de WAM-verzekeraars kort tevoren hadden laten weten dat van een uitbreiding van het regres wel een premiestijging, maar geen nieuwe premiedifferentiatie te verwachten was. ${ }^{865}$

Preventie kan ook plaatsvinden doordat in de prijs van schadeveroorzakende producten, diensten of activiteiten de kosten van aansprakelijkheid of van dreigende aansprakelijkheid (moeten) worden doorberekend. De gedachte is deze, dat dan de vraag naar deze (volgens de normen van het aansprakelijkheidsrecht) schadelijke goederen en diensten afneemt, en dat daarmee nieuwe schade wordt voorkomen. Vanzelfsprekend leiden niet alle schadevoorvallen tot aansprakelijkheid en niet alle gevallen waarop het aansprakelijkheidsrecht betrekking heeft tot passende prijsfluctuaties (denk aan latente schade), en kunnen ook andere factoren van invloed zijn op de prijs (zoals overheidssubsidies en belastingen) en op het prijsmechanisme (bijvoorbeeld bij inelasticiteit van de vraag). ${ }^{866}$ Het zijn restricties zoals deze, die aanleiding geven tot sceptische reacties vanuit de rechtsliteratuur, ik noem coryfeeën zoals (wijlen) John Fleming en Stephen Sugarman en in de Europese doctrine onder meer Atiyah, Bloembergen en Tunc.

\subsubsection{Kritiek}

De kritiek is met name gericht op de gedragsbeïnvloedende functie van het aansprakelijkheidsrecht, ${ }^{867}$ en lijkt vooral de nauwkeurigheid te relativeren waarmee kan worden vastgesteld in hoeverre het aansprakelijkheidsrecht leidt tot gedragseffecten. Sommige auteurs verbinden hieraan zelfs de conclusie dat het aansprakelijkheidsrecht (en ook regres) op het punt van preventie gemist kan worden, een reactie die in de Amerikaanse rechtsliteratuur wordt aangeduid als de realists ' critique. $^{868}$ Zo wordt wel gewezen op de betekenis van andere manieren om tot preventie te komen dan door de gedragsbeïnvloeding via het aansprakelijkheidsrecht. ${ }^{869}$ Specifiek voor regresvorderingen zou men kunnen denken aan het preventiebeleid

Sociale Verzekeringsraad (1993), p. 3 en 27 e.v.

Sociale Verzekeringsraad (1993), p. 29.

Zie Stapleton (1986), p. 125. Een uitvoerige bespreking zou hier te ver voeren, verwezen zij naur rechitseconomische literatuur, zie o.a. Van den Bergh \& Faure (1990).

Fleming (1984), p. 1198; Sugarman (1985), p. 561 e.v. en 590 ('tort law is unlikely to promote more desirable behavior than that which would occur in its absence'); Bloembergen (1965), nr. 251 en Atiyah (1997), p. 163. Volgens Atiyah heeft de rechtseconomische benadering van het aansprakelijkheidsrecht "very little utility in the real world: Wel wijst Atiyah intussen op het belang van het voorkomen dat de schadeomvang onnodig oploopt, bijvoorbeeld door het slachtoffer in de procedure niet te stigmatiseren (p. 12).

Schwartz (1994), p. 378. Zie o.a. Fleming (1984), p. 1198 en uitvoerig Sugarman (1985), p. 560. Bij Owen (1997), p. 2 worden kritische reacties vanuit rechisfilosofische hoek op 'de' economische benadering van het aansprakelijkheidsrecht besproken.

Zie met name Sugarman (1985), p. 581 en 585 
van de regresnemende verzekeraar. Dit beleid zal echter veelal slechts betrekking hebben op het gedrag van de verzekerde (de potentiële benadeelde). Bij andere manieren om tot preventie te komen moet worden gedacht aan veiligheidsvoorschriften, verboden en dergelijke. Maar ook die kritiek lijkt niet helemaal terecht, aangezien het aansprakelijkheidsrecht en regulering volkomen verschillend werken: het aansprakelijkheidsrecht is privaatrechtelijk en werkt niet door maatschappelijke dwang, maar indirect: door de dreiging van schadevorderingen in geval schade ontstaat. Veiligheidsvoorschriften, geboden en dergelijke hebben veelal een publiek karakter en een directe gedragsbeïnvloedende werking onafhankelijk van de vraag of door niet-naleving schade ontstaat. ${ }^{870}$

Volgens Shavell noodzaken deze verschillen tussen het aansprakelijkheidsrecht en publieke veiligheidsregulering tot het afwisselend inzetten ervan al naargelang de aard van de potentieel gevaarlijke activiteit, zoals thans ook gebeurt. ${ }^{871} \mathrm{De}$ beslissing over het al dan niet neerhalen van een boom die op het dak van de buren zou kunnen belanden of het in haast naar de bus rennen zal met name worden beïnvloed door het aansprakelijkheidsrecht. De beslissing over het aangeven van de nooduitgang in een winkel hoofdzakelijk door veiligheidsregulering. Verkeersgedrag door beide gelijkelijk. De betekenis van het aansprakelijkheidsrecht vanuit preventieoogpunt is volgens Shavell in deze gevallen, dat de betrokkene zelf meer kennis heeft met betrekking tot de gevaarzettende activiteiten dan de wet- of regelgever en de uitvoeringskosten van preventie door het aansprakelijkheidsrecht in verhouding tot de handhaving van publieke regelgeving laag zijn omdat ze pas ontstaan als er sprake is van schade. Bij boetes en sancties is dat ook wel zo, maar het verschil met het aansprakelijkheidsrecht als middel voor preventie is dat degene van wie de financiêle prikkel komt, de eiser, hier ook zelf belang bij heeft. ${ }^{872}$ Een ander argument waarmee de invloed van het aansprakelijkheidsrecht op preventie wordt gerelativeerd is dat meerdere factoren beslissend kunnen zijn voor het gedrag van potentiële schadeveroorzakers, zoals de persoonlijke moraal, het ontbreken van de neiging tot zelfbehoud, toeval en psychologische miscalculaties. Volgens Schwartz laat dit zien dat de mate waarin het aansprakelijkheidsrecht bijdraagt aan preventie minder nauwkeurig kan worden vastgesteld dan rechtseconomische theorieèn en formules suggereren. ${ }^{873}$ Het betekent natuurlijk nog niet dat het aansprakelijkheidsrecht op het punt van preventie gemist kan worden. Bekend zijn in dit verband studies naar de ongevallenstatistiek in landen waarin het aansprakelijkheidsrecht op bepaalde gebieden is afgeschaft. De centrale vraag is dan of preventie bij verkeersongevallen beter wordt bereikt door no-fault verkeersverzekeringssystemen of door een systeem van verkeersaansprakelijkheid. Die lijken te

Shavell (1984), p. 366. In die zin ook M. van Dam (2001). p. 324

Aan publieke regelgeving als vorm van preventie valt vooral dan te denken, als de gevaarzetter niet gevoelig is voor financiele prikkels, zie Shavell (1984), p. 373.

873 Schwartz (1994), p. 377 e.v. 
bevestigen dat in diverse rechtsstelsels waarin verkeersverzekeringssystemen zijn ingevoerd die een substantieel deel van het aansprakelijkheidsrecht vervangen, het aantal wegongevallen is toegenomen. ${ }^{874}$

Dat enig preventief effect van het aansprakelijkheidsrecht te verwachten valt, lijkt hiermee wel duidelijk (daargelaten tegen welke prijs). Het regres heeft dan als prikkel voor preventie in beginsel dezelfde kaarten als de vordering van de benadeelde. Wellicht zelfs betere kaarten, omdat verzekeraars minder snel dan de benadeelde door emotionele redenen of de hoge uitvoeringskosten van het instellen van hun claim zullen worden weerhouden. Dit zorgt ervoor dat de dreiging van het aansprakelijkheidsrecht niet komt te ontbreken indien de benadeelde particulier of sociaal verzekerd is, en daardoor zelf zijn vordering op de schadeveroorzaker verliest. De WA-verzekeraar van de (potentiële) schadeveroorzaker wordt alsnog aangespoord tot het nemen van maatregelen die de kosten van het schadeveroorzakende gedrag laten doorwerken in de premies, door risicodifferentiatie en een premieaanpassing. Dat ook de vordering van de benadeelde al kan bijdragen aan de betekenis van het aansprakelijkheidsrecht voor preventie doet daaraan volgens de economische analyse geen afbreuk. Uitgangspunt is dat de totale schade aan het schadeveroorzakende gedrag moet worden toegeschreven. ${ }^{875}$ Dat lijkt ook wel logisch, als niet alle gevolgen worden doorberekend, zii, het hinuen. het, hovpelata stramien van regels dat afdeling 6.1.10 BW daarvoor biedt, dan kan het 'goedkoper' zijn het erop te wagen. Uitgaande van dit economische principe lijkt regres met het oog op preventie zelfs noodzakelijk om te voorkomen dat van het aansprakelijkheidsrecht onvoldoende prikkels uitgaan. Dat roept de vraag op waarom het belang van preventie in de totstandkomingsgeschiedenis van de wettelijke regresbepalingen slechts bij uitzondering en dan nog slechts in indirecte bewoordingen is terug te vinden. Eén van de redenen zal zijn dat het preventie-argument in lang niet alle gevallen overtuigend is en er gewoon nog te weinig data zijn om er specifiek voor regres een stevige argumentatie op te bouwen. Maar er is meer, het systeem van aansprakelijkheid en regres kent vanuit economisch perspectief belangrijke gebreken.

\subsubsection{Belangrijke bezwaren}

Naast de eraan verbonden kosten, ${ }^{876}$ is dè belemmerende factor bij de invloed van het aansprakelijkheidsrecht op preventievlak: het WA-verzekerd zijn van de

\footnotetext{
174 Zie daarover o.m. Schwartz (1994), p. 423 en M. van Dam (200I). p. 516 e.v

575 Zie Faure (1996), p. 52; M. van Dam (2001), p. 278; Faure \& Hartlief (2002), p. 95

576 Het nadeel van de kosten weegt voor het regres zwaar, zie daarover Faure (1996), p. 45 en M. van Dam (2001). p. 279 en 286 .
} 
schadeveroorzaker ${ }^{877}$ Bekend is dat het beleid van aansprakelijkheidsverzekeraars in onvoldoende mate aanzet tot het nemen van voorzorgsmaatregelen of het doorberekenen van de kosten van het schaderisico in de prijs van de goederen of diensten in het kader waarvan de schade is ontstaan ${ }^{878}$ In het bijzonder is de hoogte van de premies onvoldoende afgestemd op het aansprakelijkheidsrisico van individuele verzekerden. Gedurende de looptijd van de verzekering zijn er dan onvoldoende financiële prikkels tot risicovermijdend gedrag (moreel risico). De schadeveroorzaker merkt financieel amper iets van het regres, tenzij de WA-verzekeraar daarvoor maatregelen treft door tot de verzekeringsvoorwaarden een eigen risico of bonusmalus systeem te laten behoren. Zo lijkt het in het algemeen wenselijk dat de WApremie van individuele verzekerden wordt afgestemd op het vroegere claimverleden van de betrokkene en vervolgens gedurende de looptijd van de verzekering, retrospectief, op zijn individuele claimgedrag. ${ }^{879}$ Hoe meer declaraties van de schadeveroorzaker, hoe hoger de individuele premie dan wordt, en hoe waarschijnlijker het lijkt dat de verzekerde veiligheidsmaatregelen neemt of de kosten van de producten of diensten in kwestie doorberekent in hun prijs en de vraag ernaar afneemt. Onvoldoende afstemming van de premies op het individuele risico of claimgedrag kan voor grote risico-averse bedrijven ook tot gevolg hebben dat, als de kosten van veiligheidsmaatregelen lager zijn, zij in zoverre onverzekerd blijven en hun schadeverhogende activiteiten tot op zekere hoogte reduceren. ${ }^{800}$

Vooral problematisch schijnt te zijn dat de hoogte van de premies weliswaar gevoelig voor het ex ante aansprakelijkheidsrisico van individuele verzekerden (bijvoorbeeld doordat daarin de leeftijd, ervaring enzovoort zijn verdisconteerd), maar onvoldoende is afgestemd op de individuele mate van gevaarzetting. ${ }^{881}$ Idealiter zou de verzekerde in de premie de kosten naar rato van zijn gevaarzettende gedrag of activiteiten moeten kunnen aflezen. Van zulke methoden van premiecalculatie lijkt in het algemeen weinig terecht te komen. ${ }^{882}$ Als mogelijke redenen worden het (eventuele) risico van concurrentiedruk genoemd, de kosten ervan voor de

Omgekeend kan, als de (potentiele) schadeveroorzaker niet WA-verzekerd is, zijn claimgevoeligheid in theorie ontbreken, voorzover de dreiging van aansprakelijkheid zijn vermogen overstijgt (en hij dus onvermogend is om te betalen); zie Shavell (1984), p. 361. Maar dat is niet erg waarschijnlijk omdat hij niet graag het risico zal nemen al zijn bezittingen en/ of zijn baan te verliezen. Regres op particulieren met financieel onvermogen is hoe dan ook uitzonderlijk.

Juist om deze reden was de toelaatbaarheid van WA-verzekeringen lang omstreden. Zie over het belang van WA-verzekeringen en het belemmerende effect ervan voor preventie o.m. Sugarman (1985), p. 573; Abraham (1986), p. 17: Schwartz (1990), p. 313 (met verdere verwijzingen), Faure (1996), p. 57. Stapleton (1986), p. 129; Schwartz (1990), p. 319

880 Zie Posner (1986), p. 187; Shavell (1987), p. 211; Schwartz (1990), p. 339

sst Sugarman (1985). p. 575; Faure (1996), p. 57. Over het effect van het aansprakelijkheidsrecht op preventieviak in de Amerikaanse WA-verzekeringspraktijk zijn Sugarman (1985), p. 578 en Schwartz (1990), 319 gematigd optimistisch voorzover daarbij wordt gewerkt met experience rating (de WA-premie wordt dan afgestemd op het vroegere claimverleden en vervolgens, retrospectief, op het claimgedrag gedurende de looptijd van de verackering).

882 Zie onder de rijkelijke hoeveelheid literatuur in dit verband o.m. reeds Drion (1955), p. 10; Calabresi (1970). p. 248; Fleming (1970), p. 173; Shavell (1984), p. 361; Abraham (1986), p. 17 en 44; Stapleton (1986), p. 128; Schwartz (1990), p. 313; Faure (1996), p. 57: M. van Dam (2001), p. 431. 
WA-verzekeraar en andere moeilijkheden (zoals dat de gegevens voor aanpassing van de premies op deze basis vaak eigenlijk pas betrouwbaar zijn over meerdere jaren). WA-verzekeraars zijn kennelijk niet bereid of in staat om tegen verantwoorde kosten te beschikken over informatie omtrent de precieze mate van gevaarzetting en eventuele voorzorgsmaatregelen van de verzekerde noch over de benodigde expertise met betrekking tot de mogelijkheden tot risicovermijdend gedrag. ${ }^{83}$ Een ander belangrijk economisch bezwaar tegen regres is dat de kosten hoog zijn, ik wees daar al op. Het gaat om de uitvoeringskosten voor de betrokken partijen (WA-verzekeraars en regresnemers). Die maken het regres tot een 'duur' instrument, aangezien gevalsgewijs meer verschillende partijen delen van de schade voor hun rekening nemen en die afzonderlijk verhalen. Met de maatschappelijke kosten die verbonden zijn aan het extra beslag op het rechterlijk apparaat lijkt het mee te vallen. ${ }^{884}$ Door de gestandaardiseerde afwikkeling van het regres in een aantal gevallen weegt het bezwaar van de kosten niet voor alle regressituaties even sterk. Voor de vraag in hoeverre de kosten bij de vorderingen van de regresnemers afzonderlijk vanuit economisch perspectief prohibitief zijn, lijkt nader empirisch onderzoek dan ook geboden.

Shavell ${ }^{\text {ss }}$ relativeen de kosten voor het Amerikaanse recht enigszins door die te vergelijken met de kosten verbonden aan (de handhaving van) publieke regelgeving. De uitvoeringskosten van het aansprakelijkheidsrecht zijn hoofdzakelijk beperkt tot de meer uitzonderlijke gevallen dat schade is ontstaan. Een ander voordeel van de kosten van het aansprakelijkheidsrecht vergeleken met die van veiligheidsregelgeving is volgens Shavell dat ze kunnen worden beperkt tot beìnvloeding van het gedrag van de gevaarzetters. ${ }^{\text {sis }}$

\subsubsection{Tussenstand}

Hoewel het verleidelijk is om de functies van het regres van particuliere en sociale verzekeraars en overheidslichamen uitsluitend in de economische sfeer te trekken, aangezien dat veelal collectiviteiten zijn en de belangen van de benadeelde daarbij niet meer rechtstreeks betrokken zijn, zijn die bij nader inzien bijzonder moeilijk 'hard' te maken. Hiermee is zeker niet gezegd dat van het aansprakelijkheidsrecht, ook in regressituaties, op preventievlak helemaal niets kan worden verwacht. De rechtseconomische analyse lijkt het belang van het regres vanuit preventief oogpunt in beginsel juist wèl te ondersteunen: het niveau van zorg wordt slechts optimaal gehandhaafd als de potentiële schadeveroorzaker wordt geconfronteerd met de totale kosten die aan de schadeveroorzaker kunnen worden toegerekend. Aangezien

Sugarman (1985), p. 574; Stapleton (1986), p. 128; Schwartz (1990), p. 315; Faure (1996), p. 53; Faure \& Van den Bergh (2000), p. 315 e.v.

su4 Inv. 6, p. 1415 .

s8s Shavell (1984), p. 364.

336 Shavell (1984), p. 364, met die kanttekening dat publieke veiligheidsregulering besparingen mogelijk maakt omdat men voor de handhaving ook kan volstaan met het nemen van steekproeven.
} 
de schadeveroorzaker veelal WA-verzekerd is heeft het regres dan de betekenis dat het de WA-verzekeraar van de (potentiële) schadeveroorzaker kan aansporen tot het nemen van maatregelen die de kosten van het regres laten doorwerken in de premies. Maar als doelstelling voor het aansprakelijkheidsrecht moeten de preventieve effecten kunnen opwegen tegen de daaraan verbonden uitvoeringskosten. Dat is met name voor regressituaties door het beperkte resultaat op preventievlak als gevolg van het WA-verzekerd zijn van de schadeveroorzaker en anderzijds de uitvoeringskosten van het regres onvoldoende het geval. ${ }^{887}$ Het bezwaar dat de uitvoeringskosten te hoog zijn kan weliswaar (inmiddels) voor een aantal gevallen worden gerelativeerd, maar of die maatregelen naar economische begrippen toereikend zijn is dubieus. Ook de collectivering van het regres kan afbreuk doen aan het kostenconfronterende effect van het regres. ${ }^{888}$ In die gevallen zal een individuele premierespons van de WA-verzekeraar mogelijk ontbreken, maar daar staat tegenover dat de uitvoeringskosten aanmerkelijk kunnen worden teruggedrongen (men voert immers geen individuele procedures meer). Vraag is alleen waarom voor de beoordeling van de aansprakelijkheid, indien preventie voorop staat, niet (enkel) beslissend is of de schadeveroorzaker de schade tegen redelijke kosten heeft kunnen voorkomen. Dat is slechts één aspect van de meeromvattende vraag of het gedrag jegens de benadeelde verwijtbaar is geweest (en dus al dan niet sprake was van schuld, overmacht, enzovoort).

\subsection{Regres als reactie van de rechtsorde}

De betere, meer intrinsieke verklaring van het regres is dat dit de draagplicht met betrekking tot de schade bij de schadeveroorzaker legt omdat hem van het ontstaan daarvan (rechtens) een verwijt wordt gemaakt, ${ }^{889}$ en dat sancties op verwijtbaar gedrag moeten bijdragen aan een goede rechtsorde. Drion formuleert dit in 1955 treffend, waar hij stelt dat 'zelfs zij die de wenselijkheid, dat schade zoveel mogelijk wordt vergoed, als enige rechtsgrond van de aansprakelijkheid wensen te zien, de schuldige veelal niet aan aansprakelijkheid willen laten ontsnappen, en aan de verzekeraar een recht van subrogatie toekennen' ${ }^{890}$ Dat is een doel op zichzelf: het regres laat sancties volgen op de schending van gedragsnormen, en bevredigt daarmee het rechtsgevoel, ${ }^{891}$ althans dat is de bedoeling. Niet is uitgesloten dat

Faure (1996), p. 57 ; M. van Dam (2001), p. 279. Vgl. Sugarman (1985), p. 560 die om deze redenen andere doelstellingen voor het aansprakelijkheidsrecht in het algemeen naast preventie nodig acht.

TK 1998-99, 26238 , nr. 5, p. 2.

Vgl. Bolt (1989a), p. 34 en Mulder (1988), p. 16.

Drion (1955), p. 6.

Vgi. ook Van Boom (1996), p. 97, was tevens wordt gewezen op rechtseconomische doeieinden. Anders Bloembergen (1965), nr. 252, die stelt vanuit moreel en praktisch oogpunt te betwijfelen 'of het wel 20 onredelijk is de aansprakelijkheid te beperken in gevallen waarin het stachtoffer zelf al beschermi is', te meer nu geen sprake hoeft te zijn van persoonlijke schuld van de schadeveroorzaker. 
dit daarnaast positieve neveneffecten heeft, zoals vergoeding van de benadeelde en preventie van schade. Maar de belangrijkste functie van het aansprakelijkheidsrecht is dat dit een reactie geeft van de rechtsorde op rechtens verwijtbaar gedrag, een op de concrete situatie toegesneden rechtsoordeel: wie verwijtbaar schade veroorzaakt behoort de gevolgen daarvan te dragen. Of de benadeelde particulier of sociaal verzekerd is heeft daarmee niets te maken, evenmin als de vraag of de schuldige zelf van dat ontsnappen in enigerlei zin profijt ondervindt. ${ }^{892}$ Onder het aansprakelijkheidsrecht moet in dit verband het geheel van regels worden verstaan, die aangeven volgens welke maatstaven de oorzaak van schade moet worden toegerekend aan anderen dan degene die haar lijdt. Het zijn uiteindelijk deze regels, die bepalen of en hoeveel regres verschuldigd is. Ze berusten op het principe dat de schuldige, de schadeveroorzaker, de schade voor zijn rekening behoort te nemen, eventueel door het afsluiten van een daarvoor geldende verzekering. Verwijtbaarheid is het dragende element, dat geldt zowel voor regels van schuld- als risicoaansprakelijkheid.

De risicoaansprakelijkheid voor motorrijtuigen bijvoorbeeld (art. 185 WVW) berust op het verwijt dat eigenaars of houders van motorrijtuigen ongemotoriseende verkeersdeeinemers blootstellen aan het gevaar van hun motorrijtuig (en dit gevaar zich heeft verwezenlijkt). De aard en ernst van dat verwijt staan onder invloed van politieke argumenten zoals het bevorderen van een verbeterde slachtofferbescherming. In het kader van art. 185 WVW heeft dat ertoe geleid dat de bewijslast in het voordeel van de benadeelde is omgekeerd en is verlicht, en dat ook zeer lichte fouten, met het oog op de emstige gevolgen daarvan, verwijtbaar kunnen zijn."

Zo verstaan, berusten alle gronden van schuld- en risicoaansprakelijkheid in de kern op een verwijt (onzorgvuldigheid, gevaarzetting). Dat neemt niet weg dat er - ook bij schuldaansprakelijkheid - gevallen zijn waarin dat aspect van verwijtbaarheid minder goed zichtbaar of omstreden is, ${ }^{894} \mathrm{ik}$ zal hierop terugkomen. Maar met of zonder die gevallen is het - uiteindelijk - een toerekeningssysteem op basis van redelijkheid (fairness): het geeft het signaal af dat de schending van concrete gedragsnormen rechtens niet zonder gevolg blijven, immers de schadeveroorzaker moet betalen bij de schending daarvan (al dan niet door zich daarvoor te verzekeren). Sugarman wijst erop dat de precieze normen van het aansprakelijkheidsrecht helemaal zo bekend niet zijn bij degenen van wie wordt verwacht dat ze deze zullen naleven en dat de signaalfunctie die daarvan uitgaat weinig meer-

192 Zie 0.a. Van Boeschoten (1950), p. 614; De Kok (1965), p. 87; Dorhout Mees (1972), p. 30; Van Bameveid (1984), p. 452; Mulder (1988), p. 5; Bolt (1989a), p. 36; Bolt (1989b), p. 41; Van Dam (1995), p. 101.

s93 Het verweer van overmacht, art. 185 lid I WVW. Op grond van de zogenaamde $100 \%$-regel kan dit niet worden tegengeworpen aan ongemotoriseerde verkeersslachtoffers van jonger dan veertien jaar. Zie paragraf 7.3 .7 .

$194 \mathrm{Vgl}$. HR 11 november 1983, NJ 1984, 331 (Meppelse ree), waarin een automobilist schuldig wordt geacht aan een aanrijding die hij heeft veroorzaakt doordat hij, na een gevarenbord van overstekend wild te hebben gepasseerd. plots moet uitwijken voor een overstekende ree. Sieburgh (2000), p. 143 weerspreekt de kritick op deze uitspraak dat van schuld menselijkerwijs geen sprake is weliswaar door erop te wijzen dat de bestuurder door het gevarenbord gewaarschuwd was en op het gevaar had moeten anticiperen. Maar waar het om gaat is, dunkt me, hoe retel dit verwijt in deze situatie was, zie Engelhard $(2001 b)$, p. 519. 
waarde heeft naast gezin, school en andere sociale opvoedingsmechanismen. ${ }^{895}$ Veelal zullen de concrete gedragsnormen dan inderdaad ook worden nageleefd of geschonden zonder dat men ze als zodanig kent. ${ }^{896}$ Maar het daaraan ten grondslag liggende principe dat de schadeveroorzaker betaalt, al dan niet door zich te hebben verzekerd, heeft die ordenende functie wèl: het legt de schade daar waar dat op basis van de normen die (tevens) deel uitmaken van onze (rechts)cultuur, binnen het gegeven wettelijke kader, het meest redelijk lijkt. Dat de schuldige de schade draagt bevredigt het rechtsgevoel en voorkomt frustratie bij degenen die zich in vergelijkbare omstandigheden van normschendend gedrag onthouden.

\subsection{Kritiek}

\subsubsection{Inleiding}

Maar er is vanuit dit perspectief ook veel kritiek op het aansprakelijkheidsrecht. Het principe dat de schadeveroorzaker behoort te betalen zou sterk zijn 'uitgehold' door de invloed van verzekeringen, en door het (grote) aantal gronden voor risicoaansprakelijkheid. Ook zou het leiden tot een ongelijke behandeling van gevallen.

\subsubsection{De invloed van verzekeringen}

Als eerste punt van kritiek op het principe dat de schadeveroorzaker moet betalen wordt wel erop gewezen dat het goede zin mist als de schadeveroorzaker WAverzekerd is. In feite is het dan immers de verzekeraar, die betaalt. Aangezien ook de benadeelde veelal WA-verzekerd is en dan mogelijk deel uitmaakt van het collectief van verzekerden waarover de schade dan is gespreid betaalt hij in feite ook zelf daaraan mee. Dat zou afbreuk doen aan de overtuigingskracht van het principe in concrete gevallen: ${ }^{897}$ 'at the end of the day' voelt de schadeveroorzaker niet dat hij betaalt. Ook bedrijven en instanties die niet WA-verzekerd zijn zullen (het risico van) aansprakelijkheid in de vorm van hogere belastingen of als extra overheadkosten in een prijsopslag doorberekenen aan het publiek (en bij prijsconcurrentie aan de aandeelhouders waarvan ook pensioenfondsen en verzekeraars deel uitmaken). Atiyah:

Sugarman (1985), p. 612: 'In our society children are socialized by school and family to act reasonably toward others long before they acquire any conception of tort law $(-\ldots)$ it is farfetehed to imagine that this socializing mechanism will break down in a society like New Zealand that has abandoned tort liability'). Overigens komt Schwartz wat dit laatste betreft met overtuigende argumenten die op het tegendeel wijzen, Schwartz (1994), p. 377 e.v.

Dat de concrete godragsnormen van het aansprakelijkheidsrecht als aodanig, als normen van het aansprakelijkheids. recht (waarop een sanetie rust) niet steeds bij de betrokkenen bekend zijn, lijkt wel bezwaarlijk met het oog op de effecten daarvan op preventievlak. 
'This makes nonsense of the whole fault principle. Why should you only be entitled to compensation if you are injured in a fault-caused accident, when the money is really coming from the public anyhow?

(...) Once it is grasped that the public is paying for the whole system, the basic structure of the system - the fault principle - becomes an absurdity. ${ }^{\text {, }}$

Dat het aansprakelijkheidsrecht, met name ook in regressituaties, dit vestzak-broekzak effect heeft, is niet denkbeeldig; ${ }^{899}$ uiteindelijk is iedereen benadeelde èn schadeveroorzaker. Maar dat het principe dat de schuldige de schade behoort te dragen, daardoor feitelijk betekenis mist, zie ik niet zo. De schadeveroorzaker treft in die hoedanigheid het verwijt, en het is in die hoedanigheid dat hij daarvoor de WA-premies opbrengt, en de eventuele sancties van zijn WA-verzekeraar zal ondervinden in individuele gevallen van schadeveroorzaking (zij het dat die bonusmalus sancties vanuit rechtseconomisch oogpunt ontoereikend zijn voor resultaten op preventievlak). De betekenis van dit principe is uiteraard het grootst indien de individuele schadeveroorzaker naast eventuele repercussies op collectief niveau ('autorijden' wordt duurder), persoonlijk met de kosten van zijn individuele gedrag wordt geconfronteerd.

Maar wat blijft er over van de betekenis van het regres als een reactie van de rechtsorde in de gevallen waarin het is gestandaardiseerd? De afwikkeling van het regres van sociale verzekeraars wordt zoals gezegd in vergaande mate beheerst door onderlinge afspraken met WA-verzekeraars. ${ }^{900}$ De partijen bij het Convenant Verhaalsrecht (UWV en de aangesloten WA-verzekeraars) mogen geen verweer voeren met betrekking tot lastige technische onderdelen van het civiele plafond. Het regres ingevolge de ANW en AWBZ wordt zelfs afgewikkeld in de vorm van één jaarlijkse afkoopsom voor alle indivjduele gevallen, los van enige vraag naar aansprakelijkheid in individuele gevallen. Dit collectieve regres is een manier om de kosten van de uitvoering van het regres, zoals gedetailleerd dossier-onderzoek en tijdrovende en kostbare procedures terug te dringen. Voorkomen wordt dat in individuele gevallen onderzoek moet worden gedaan naar de juridische verwijtbaarheid van het gedrag, kwesties als schuld en eigen schuld, en de precieze schadeomvang. Dat maakt de uitvoerbaarheid van het regres voor de betrokkenen aantrekkelijker, en zij zijn het, die met hun regresacties rechtsgevolg verbinden aan de aansprakelijkheidsregels. De aansprakelijkheidsregels worden bij een gecollectiveerde afwikkeling weliswaar gehandhaafd, maar niet concreet toegepast. Het gaat vooralsnog om uitzonderingen, maar het kabinet stimuleert verdere collectivering van het regres. $\mathrm{Bij}$ de parlementaire behandeling van de regresrechten voor de volksverzekeringen zijn hierover door verschillende kamerfracties (PvdA, CDA, klein christelijke fracties) vragen gesteld. Zou het loslaten van de individuele benadering geen afbreuk doen aan 'de centrale gedachte, dat degene die een ander

\footnotetext{
898 Atiyah (1997), p. 113.

199 Paragraaf 5.6.

900 Zie supra, paragraaf $4.2 .2,4.3 .3-4.3 .4 \mathrm{en}$ paragraaf 9.1 .
} 
verwijtbaar schade berokkent, daarvan ook de gevolgen moet ondervinden, in de zin dat de schade op hem verhaald kan worden'? $?^{901}$ De minister stelt voorop dat het beginsel dat de schadeveroorzaker de schade behoort te dragen, ook toepassing kan vinden in de vorm van een stijging van de WA-premies voor alle (potentiële) schadeveroorzakers. ${ }^{902}$

Om de band tussen de schadeveroorzaker na het schadevoorval en de schade (en het verwijt dat hem daarvan treft) zo scherp mogelijk te houden zou het echter mijn voorkeur hebben het uitgangspunt van de individuele afwikkeling te handhaven. Dat heeft het belangrijke voordeel, wellicht ook voor verzekeraars zelf, dat het regres 'zichtbaar' blijft gerelateerd aan concrete gevallen. Dat kan zo nodig gestandaardiseerd: een mooi voorbeeld daarvan biedt het al genoemde Convenant Verhaalsrecht, aangezien het een einde maakt aan de lastige technische punten, maar de aansprakelijkheidsvraag (schuld, eigen schuld, causaliteit, verjaring) onverlet laat. Daarnaast kan de uitvoering van het regres op andere punten beter met zijn doelstellingen in overeenstemming worden gebracht (zoals termijnen, en berichtgeving aan benadeelde en schadeveroorzaker). Ik zal hierop terugkomen in hoofdstuk $9 .{ }^{903}$

\subsubsection{Aansprakelijkheid op risicogrondslag}

Een ander punt van kritiek houdt verband met ontwikkelingen in het aansprakelijkheidsrecht zelf. Traditioneel wordt het principe dat de schadeveroorzaker behoort te betalen immers geassocieerd met gevallen van (zuivere) schuldaansprakelijkheid. Dat maakt het principe omstreden in de gevallen waarin geen sprake is van moreel verwijtbaar gedrag, of zelfs niet van enige persoonlijke gedraging van de schadeveroorzaker. Bloembergen stelt in 1965 te betwijfelen of het systeem dat de schadeveroorzaker behoort te betalen voor het verzekerde deel van de schade bij risicoaansprakelijkheid moreel superieur is boven een systeem waarin hij voor dat deel is gevrijwaard. ${ }^{904}$ Dat valt inderdaad te betwijfelen. Maar in mijn visie ligt daarin, het bevorderen van zuiver morele gerechtigheid, ook niet het doel van het regres. Het gaat er niet om dat we autorijden of andere schadeveroorzakende activiteiten moreel verkeerd vinden. Waar het om gaat is, dat zulke activiteiten door hun schadeveroorzakende vermogen ertoe leiden dat van degene die zich ervan bedient een hogere mate van zorg en verantwoordelijkheidsbesef mag worden verwacht, één die vèrder gaat dan wat zuiver moreel gezien 'juist' is. Indien A een pitbullterriër houdt, en daarmee dagelijks in de supermarkt komt zonder problemen, en het dier op een kwade dag ineens B's kind grijpt, zal iedereen het erover eens zijn dat de schade rechtens, verzekerd of niet, meer bij A of diens WA-verzekeraar

oot Bloembergen (1965), nr. 252; Atiyah (1997), p. 15. 
thuishoort dan bij B. Grijpt C's waakhond inbreker D, dan is het anders. Wie anderen verwijtbaar blootstelt aan dat extra schaderisico, behoort de lasten daarvan te dragen. Daargelaten of partijen daarvoor verzekerd zijn berust de draagplicht rechtens bij de schadeveroorzaker. Ook bij aansprakelijkheid op risico-grondslag is verwijtbaarheid kortom een noodzakelijk funderend element, al ligt dat niet noodzakelijk in de (zuiver) morele sfeer.

\subsubsection{Ongelijke behandeling van gevallen}

Een derde punt van kritiek op het principe dat de aansprakelijke behoort te betalen is ten slotte dat dit zou leiden tot rechtsongelijkheid. Waarom zou de fietser die schade lijdt door een menselijkerwijs niet te vermijden verkeersongeluk, zo stelt Du Perron, in beginsel recht hebben op volledige vergoeding van zijn schade indien bij dat ongeluk een motorrijtuig is betrokken, terwijl hij is aangewezen op het stelsel van de sociale zekerheid als het een eenzijdig ongeval betreft. ${ }^{909}$ Als hij daarmee bedoelt dat voor aansprakelijkheid van de eigenaar/houder of bestuurder van een motorrijtuig die rechtens geen enkel verwijt treft geen plaats dient te zijn, kan ik me helemaal daarin vinden. ${ }^{906}$ Daarbuiten worden beide situaties terecht, dunkt me, niet op één lijn gesteld. Gemotoriseerden brengen met hun motorrijtuig een extra schaderisico in het wegverkeer, voor zwakkere verkeersdeelnemers zoals voetgangers en fietsers. Dat extra risico bestaat niet alleen uit een verhoogde kans van ongevallen, maar ook uit de verhoogde kans van schade (en van ernstige schade). Dat rechtvaardigt dat indien dat risico zich verwezenlijkt, de houder van het motorrijtuig daarvan de gevolgen draagt, tenzij hij zich weet te disculperen. ${ }^{907}$ Dat de aanrijdende automobilist het bewijsrisico draagt lijkt dus best verdedigbaar: zonder zijn tussenkomst was de schade niet ontstaan.

lets anders is dat de fout onvoldoende grond kan lijken om dit onderscheid te rechtvaardigen, ${ }^{908}$ maar dan is het zaak specifiek te zijn: is men het gewoon niet eens met de vergaande aansprakelijkheid voor motorrijtuigen in ons recht of richt de kritiek zich op het funderende principe (dat de schadeveroorzaker betaalt)? Is het eerste het geval, dan zou men voor het betreffende deelterrein van het aansprakelijkheidsrecht kunnen zoeken naar betere alternatieven, zoals een no-fault verzekering. Het gaat dan om vragen als: in hoeverre is er op specifieke

Du Perron (2003), p. 112.

De zogenaamde $100 \%$-regel voor ongemotoriseerde verkeersslachtoffers van jonger dan veertien jaar past eigenlijk niet goed in het aansprakelijkheidsrecht, hoewel zij daar technisch wel deel van uitmaakt. Zie paragraaf 7.3.7. Het bewijsrisico ligt om de bovengenoemde redenen bij de houder van het motorrijtuig.

Zoals geldt voor shockschadegevallen waarin wel onrechtmatig is gehandeld maar niet is voldaan aan de in HR 22 februari 2002, NJ2002, $240 \mathrm{nt}$. JBMV (Taxibus) geformuleende criteria. Een voorbeeld daarvan geeff Rb. Den Haag 5 december 2001 (H/annover Intemational). NTBR 2002, p. 162 (Engelhard), waar cen tienjarig zoon ineens de relatie met zijn vader verliest doordat deze zeer emstig hersenletsel heeft opgelopen bij een verkeersongeval dat door de fout van de bestuunder is veroorzakt. De WAM-rmaatschappij beroept zich op (technisch) goede gronden op het ontbreken van relativiteit. 
deelgebieden van het aansprakelijkheidsrecht zoals bij verkeersongevallen nog voldoende maatschappelijk draagvlak voor een toerekeningssysteem op basis van verwijtbaarheid? Hebben andere doelstellingen zoals vergoeding of preventie prioriteit en wat legitimeert die keuze? Dat geldt bij uitstek op het gebied van verkeersaansprakelijkheid aangezien de ernstige gevolgen bij ongevallen met motorrijtuigen ertoe leiden dat hoge eisen worden gesteld aan het rijgedrag van gemotoriseerde verkeersdeelnemers. ${ }^{909}$ Atiyah richt zijn kritiek op het aansprakelijkheidsrecht op het funderende principe als zodanig. Afschaffing zou bijvoorbeeld ertoe leiden, dat het rechtens geen verschil meer maakt of A's verwonding werd veroorzaakt door een aanval van de hond van B dan wel door een eenzijdig ongeval. Maar zou het ontbreken van een onderscheid rechtens tussen die gevallen niet evenzeer tot kritiek leiden, namelijk dat het rechtssysteem rechtsongelijkheid zou laten voortbestaan?

\subsection{Conclusie}

Het aansprakelijkheidsrecht berust op het principe dat de schadeveroorzaker betaalt, dat wil zeggen degene die rechtens een verwijt treft van het ontstaan van de schade. Daar ligt maatschappelijk gezien ook haar (voornaamste) functie: we kiezen voor een rechtssysteem waarin degene die van het ontstaan van andermans schade een verwijt kan worden gemaakt die schade ook behoort te dragen, ongeacht of het risico daarvan (ook) bij de benadeelde particulier of sociaal verzekerd was. Dat is een doel in zichzelf. Dat neemt overigens niet weg dat het aansprakelijkheidsrecht daarnaast een aantal nevenfuncties kan hebben (zoals preventie en, voor de benadeelde zelf, compensatie en/of genoegdoening). Dat de schade ook vermogensrechtelijk voor rekening komt van de 'schuldige' bevredigt het rechtsgevoel, althans dat is de bedoeling; rechtens verwijtbaar gedrag heeft zijn prijs. Hiervan uitgaande ligt het regres voor de hand, het verzekerd zijn van de schade maakt immers het gedrag niet minder verwijtbaar. In mijn visie moet regres dan ook - uiteindelijk - een gelijke mate van rechtshandhaving waarborgen. Zoals in het navolgende zal worden gezien is het moeilijker om te bepalen welke betekenis daaraan, of aan andere functies van het regres, bij de uitleg van de regresregelingen moet worden toegekend. 


\section{Aansprakelijkheidsnormen bij regres}

Dit hoofdstukgaat over de mate waarin regresnemersderegels van het aansprakelijkheidsrecht kunnen inroepen, en de constructies die daarvoor gelden. De onderhavige regresrechten zijn, elk op hun eigen wijze, zowel naar aard als omvang afhankelijk van de aansprakelijkheid van de schadeveroorzaker jegens de benadeelde. De particuliere of sociale regresnemer moeten dan ook de regels inroepen, die deze rechtsverhouding beheersen. Maar zowel bij vestiging als bij het vaststellen van de omvang van aansprakelijkheid kunnen moeilijkheden ontstaan. Voor de vestigingsfase geldt dat lang niet alle gronden voor aansprakelijkheid ook door regresnemers kamnen worden ingeroepen. Bij de omvangfase ontstaan moeilijkheden indien de regresvorderingzich tevens uitstrekt over 'vreemde' schadeposten, zoals immateriële schade. Ook rijst de vraag in hoeverre de eigen schuld van de benadeelde aan regresnemers kan worden tegengeworpen.

\subsection{Inleiding}

Zoveel is duidelijk, de onderhavige regresrechten bouwen voort op de aansprakelijkheid van de schadeveroorzaker jegens de benadeelde. Om uitkeringen of verstrekkingen te kunnen verhalen zullen particuliere en sociale regresnemers dus tevens de regels van het aansprakelijkheidsrecht moeten inroepen die de rechtsverhouding tussen de schadeveroorzaker en de benadeelde beheersen. Technisch berust dit verband met het aansprakelijkheidsrecht op bijzondere constructies, ze kwamen in het voorgaande al verschillende keren kort ter sprake: ${ }^{910}$ subrogatie en bij de zelfstandige regresrechten het civiele plafond. De ratio van deze constructies is dat de vermogenspositie van de schadeveroorzaker, vergeleken met gevallen waarin de schade onverzekerd zou zijn geweest, niet beter en ook niet slechter mag worden. Van een achteruitgang zal in theorie niet spoedig sprake zijn: voor regresnemers gelden aanmerkelijk meer beperkingen dan voor de benadeelde. Zo kunnen regresnemers lang niet alle gronden inroepen die de aansprakelijkheid van de schuldenaar jegens de benadeelde beheersen, en ook zijn er verschillen met betrekking tot de omvang van de aansprakelijkheid bij regres. 
Ook in een ander opzicht zijn regresnemers meer beperkt bij het inroepen van het aansprakelijkheidsrecht dan de benadeelde, ze kunnen de aansprakelijkheidsregels namelijk tegenover bepaalde categorieën schadeveroorzakers niet inroepen. Dat heeft echter niets te maken met de (inhoud van de) aansprakelijkheidsregels zelf en zal hier daarom blijven rusten. ${ }^{\text {"11 }}$

Dit hoofdstuk gaat over die verschillen tussen de aard en omvang van de aansprakelijkheid van de schadeveroorzaker in en buiten regressituaties. Hierna zal eerst aandacht uitgaan naar de constructies voor het aanknopen bij het aansprakelijkheidsrecht. Daarna wordt ingegaan op de verschillen van het aansprakelijkheidsregime zelf, die bij het regres kunnen optreden: eerst voor de zogenaamde vestigingsfase (paragraaf 7.3), daarna voor de omvangfase van de aansprakelijkstelling (paragraaf 7.4).

\subsection{Regresconstructies: subrogatie en civiel plafond}

Kunnen particuliere en sociale verzekeraars en andere risicodragers in het kader van een regresactie de regels inroepen die de wettelijke aansprakelijkheid van de schuldenaar jegens de benadeelde beheersen, en waaruit volgt dat? Voor het antwoord op die vraag moet onderscheid wordengemaakt tussen de wetteljike regrecrechten die op subrogatie berusten en de zelfstandige regresrechten.

\subsubsection{Afgeleid karakter bij subrogatie}

Bij de regresrechten in dit verband die gebaseerd zijn op wettelijke subrogatie gaat het eigenlijk met name om het regresrecht van schadeverzekeraars die uitkeringen verstrekken krachtens een particuliere verzekeringsovereenkomst. Daarvoor geldt thans nog de regeling van art. $284 \mathrm{WvK}$, binnenkort zal dat art. 7.17.2.25 BW zijn. De hoofdlijnen van beide regelingen kwamen 'schadegewijs' hiervoor al aan de orde; voor een overzicht zij verwezen naar die besprekingen. ${ }^{912}$ Ook het regresrecht van het Schadefonds Geweldsmisdrijven berust op subrogatie (art. 6 lid 3 WSG). Het navolgende geldt daarom, tenzij anders wordt aangegeven, ook voor het fonds.

Subrogatie is een vorm van rechtsovergang onder bijzondere titel. ${ }^{913}$ Voorzover de verzekering ertoe strekt dat schade van de benadeelde wordt vergoed verkrijgt de verzekeraar het recht op schadevergoeding dat de benadeelde met betrekking tot die schade heeft op derden. Twee punten springen daarbij in het oog. De strek-

911 De beperkingen met betrekking tot de kring van personen op wie regres mogelijk is komen in paragraf 9.2 aan de orde.

912 Paragraaf 4.2.4.4.3.7 en 4.5.5.

913 Art. 284 WvK/art. 7.17.2.25 BW; Ledeboer (1928), p. 18: Van der Burg (1990), p. 174; Sinninghe Damste (1999), p. 52. Andere vormen van rechtsovergang onder bijzondere titel zijn cessie, overgang van kwalitatieve rechten (ant. 6:251 BW) en contractsoverneming (art. 6.159 BW). Van Achterberg (1999), nr, 24. 
king van de verzekering is mede bepalend voor de vraag welke schadevorderingen de verzekeraar verkrijgt. Daarnaast is de verzekeraar voor zijn regresrecht afhankelijk van de benadeelde, en met name van de vraag of het recht op schadevergoeding ten tijde van de subrogatie nog wel deel uitmaakt van diens vermogen. Het moment van de subrogatie is het moment waarop de verzekeringsuitkering wordt verstrekt. Worden op verschillende momenten uitkeringen verstrekt in verband met hetzelfde schadevoorval, dan wordt steeds op het moment van de uitkering in het betreffende deel van de vordering van de benadeelde gesubrogeerd. ${ }^{914} \mathrm{Bij}$ toekomstige verzekeringsuitkeringen blijft het risico van benadeling dus voortduren. Van Boom en Storm wijzen er overigens op dat de wetgever dat risico had kunnen beperken, door alle bestaande en toekomstige rechten van de benadeelde al op het moment van het ongeval op de schadeverzekeraar te laten overgaan. ${ }^{\text {915 }}$

De schadeverzekeraar verkrijgt alle 'vorderingen tot schadevergoeding, anders dan uit verzekering'. Zoals gezegd moet worden aangenomen dat die wèl direct op wettelijke aansprakelijkheid moeten berusten. ${ }^{916}$ Dat sluit immers aan bij de ratio die het regresrecht van art. $284 \mathrm{WvK} / \mathrm{art}$. 7.17.2.25 BW volgens de heersende visie toekomt, het gaat erom dat de schadeveroorzaker (of diens WA-verzekeraar) alsnog voor de schade dient te betalen. Toch heerst op dit punt enige onduidelijkheid. Mulder wijst op enkele uitspraken waarbij subrogatie ook is toegelaten voor vorderingen die niet berusten op wettelijke aansprakelijkheid. Met name wordt een geval beschreven waarin de Hoge Raad ook subrogatie ingevolge art. 284 WvK toestaat voor het recht op tegenwaarde dat door een derde aan de benadeelde wordt verleend bij de inbeslagneming van een partij vis. Mulder stelt terecht dat 'deze rechtspraak niet strookt met de alhier verdedigde ratio van art. 284 WvK,${ }^{917} \mathrm{Hij}$ wijst daarvoor echter niet op de grondslag van de vordering van de benadeelde (berust die al dan niet op wettelijke aansprakelijkheid), maar slechts op het gevorderde (de vordering in kwestie strekte niet tot schadevergoeding). Dat zou nog steeds de mogelijkheid openlaten dat de schadeverzekeraar ook de vordering tot schadevergoeding toekomt die bijvoorbeeld berust op de arbeidsovereenkomst van de benadeelde (immers elke vordering tot schadevergoeding 'anders dan uit verzekering'), uiteraard mits die betrekking heeft op dezelfde schade. De schadeverzekeraar zou dan de volledige schade kunnen afwentelen op de werkgever, óók als die rechtens in beginsel niet voor méér schade verbonden zou zijn dan hij zelf. Dat mist goede zin: de verzekeraar (schuldenaar) zou dan in staat zijn de volledige draagplicht af te wentelen op andere schadedragers, medeschuldenaren.

9i4 In die zin Van Boom $(2000 a)$, p. 19 e.v. Men zou ook kunnen stelien dat in verschillende onderdelen van éen vordering wordt gesubrogeerd, maar dat levent met name complicaties op bij verjaring, zie paragraaf 8.6.5. Zie voor bijzondere perikeien in de sfeer van zaakschade Dorhout Mees (1972), p. 29 e.v.

915 Van Boom \& Storm (1995), p. 151 en nt. 12. Van reeds bedongen exoneraties van de schadeveroorzaker vooraf zou het regresrecht nog well beperking kunnen ondervinden

916 Zie supra, paragraaf 4.2.4. De action directe jegens de WAM-verzekeraar wordt rechtstreeks verkregen, zie paragraal 8.6 .2 .

917 Mulder (1988), p. 53. 
Hij dient alleen de vordering tot schadevergoeding te verkrijgen die berust op wettelijke aansprakelijkheid. ${ }^{918}$

Vanaf het moment dat de schadeverzekeraar uitkering doet aan de benadeelde en subrogatie plaatsvindt, kan hij de vordering jegens de schadeveroorzaker (en dus óók diens aansprakelijkheid jegens de benadeelde) inroepen. Afdeling 6.2.2 $\mathrm{BW}$ geeft daarvoor aanvullende regels. Art. 6:145 BW stelt zeker dat de overgang de verweermiddelen van de schuldenaar, zoals het beroep op het ontbreken van schuld, eigen schuld van de benadeelde, of verjaring, onverlet laat. Dat geldt ook voor exoneraties, afstand, en schikkingen met de benadeelde van voor het moment van de rechtsovergang. ${ }^{919}$

\subsubsection{Afgeleid karakter bij zelfstandig regres}

Hiermee is tevens het belangrijkste verschil gegeven met de wettelijke regresrechten voor sociale verzekeraars, particuliere werkgevers en de overheid. Dat zijn rechtstreeks aan henzelf toegekende vorderingsrechten, los van de vordering van de benadeelde. Dit betekent niet dat de regresnemer een normaal, zelfstandig beroep zou moeten doen op het aansprakelijkheidsrecht; het bijzondere van regres is juist dat dàt niet nodig is. De zelfstandige vorderingsrechten zijn, net als bij subrogatie, gericht tegen degene die aansprakelijk is jegens de benadeelde. Het verschil met subrogatie is enkel dat de regresnemer voor zijn vordering niet afhankelijk is van de benadeelde. Hij heeft een eigen vordering, zij het dat het daaraan ten grondslag liggende recht gebaseerd is op de aansprakelijkheid van de schuldenaar jegens de benadeelde. Over hetgeen met deze constructie als zelfstandig verhaalsrecht is beoogd valt alleen te speculeren. ${ }^{920}$ Volgens de Hoge Raad heeft men willen voorkomen dat de benadeelde en de schadeveroorzaker door een regeling buiten de risicodrager om het regresrecht waardeloos kunnen maken. Het maakt regresnemers onafhankelijk van het vorderingsrecht van de benadeelde. ${ }^{921}$ De verzelfstandiging maakt het bovendien mogelijk het zo te regelen, dat de regresnemer door het enkele bestaan van zijn uitkeringsplicht jegens de benadeelde recht heeft op regres. Het moment van de rechtsverkrijging staat dan los van het moment waarop de regresnemer overgaat tot uitkering of betaling aan de benadeelde. Dat is een belangrijk voordeel boven subrogatie, daar is immers het moment van uitkering beslissend.

Maar het uiteindelijke vorderingsrecht dat hierdoor ontstaat verschilt volgens de Hoge Raad niet wezenlijk van het vorderingsrecht bij subrogatie. Dat lijkt bij de

De regels van het onrechtmatige daadsrecht, de schadevergoedingsregels bij tekortkoming in de nakoming. enzovoort.

919 Van Boom \& Storm (1995), p. 150.

920 Ook de Memorie van Toelichting (TK 1918-19, 469, nr. 3) biedt daarover weinig informatie.

921 HR I5 februari 1935, NJ 1935, 417 nt. EMM (Rijksverzekeringsbank/Tolenaars). In die zin ook: Giltay Veth (1969). p. 235; Beekman (1995), p. 1225; Van Boom \& Storm (1995), p. 151; Van Boom (2000a), p. 31. 
invoering van deze regresregelingen in de oude Ongevallenwet van 1921 ook niet de bedoeling te zijn geweest, nu $^{922}$

'uit niets blijkt, immers noch bij de schriftelijke noch bij de mondelinge behandeling van het ontwerp der wijzigingswet van 1921 [dat] ook maar met éen woord is toegelicht, dat de wetgever dit stelsel heeft willen laten varen en heeft willen overgaan tot het losmaken van [het nauwe verband tussen de burgerrechtelijke verantwoordelijkheid van den schuldige en de vraag hoeveel hij aan den risicodrager zou hebben te betalen] (...).'

Net als bij subrogatie moet dus ook de regresnemer met een eigen recht (sociale verzekeraars, werkgevers) de aansprakelijkheid inroepen van de schadeveroorzaker jegens de benadeelde. De wettelijke regresbepalingen kunnen worden ingeroepen ten opzichte van 'de persoon die in verband met het veroorzaken van de schade jegens de verzekerde naar burgerlijk recht tot schadevergoeding is verplicht', ${ }^{923}$ Hieruit volgt eigenlijk tevens al dat de schadeveroorzaker (of diens WA-verzekeraar) de regresnemer alle verweermiddelen kan tegenwerpen die het aansprakelijkheidsrecht hem zou hebben geboden jegens de benadeelde zelf. ${ }^{924}$ Dat geldt ook voor de verweermiddelen die betrekking hebben op de omvang van aansprakelijkheid, zoals eigen schuld. ${ }^{925}$ Om dat zeker te stellen, kennen alle zelfstandige regresrechten een bepaling van de strekking dat de schadeveroorzaker door het regres, vergeleken met de omvang van zijn aansprakelijkheid zonder regres, niet erop achteruit mag gaan. ${ }^{926}$

\subsubsection{Het civiele plafond}

Basisprincipe bij het regres, zowel bij subrogatie als bij de zelfstandig regresrechten, is dat de schadeveroorzaker weliswaar niet in een gunstigere maar ook niet in een ongunstigere positie mag komen te verkeren, vergeleken met die waarin hij zou hebben verkeerd als hij voor de betreffende schade zou zijn aangesproken door de benadeelde zelf. ${ }^{927}$ Als de uitkering of betaling waarvoor de regresnemer verhaal zoekt méér bedraagt dan het totale bedrag waarvoor de schadeveroorzaker aansprakelijk is, zijn schadeveroorzaker of WA-verzekeraar over dat meerdere dan ook in beginsel geen regres verschuldigd. Het typische geval waarin daarvan

HR 5 december 1929, NJ 1930, 1055 nt. EMM (Ruhaak/Fatum).

Voor de goede orde wijs ik erop dat hoewel de zelfstandige regresbepalingen, zoals art. 49 REA, spreken van de aansprakelijke 'persoon', het regres op rechtspersonen niet uitgesloten (veeleer zelfs regel) is.

In die zin Hartief \& Van Maanen (1991), p. 293: 'Doordat het verhaalsrecht (...) is gekoppeld aan het recht van het slachtoffer jegens de aansprakelijke kan deze de verweermiddelen die hij heeft jegens het slachtoffer ook inroepen (...)'. Zie voorts Van Boom (2000a), p. 43 e.v.

$\mathrm{VgL}$ ook ant. 6:107 lid 2 en art. 6:108 lid $3 \mathrm{BW}$, waarin de wet dit uitdrukkelijk bepaalt. Schadevergoeding, ant. 108 (Bolt), aant. 68. Het onderscheid tussen de vestigings- en de omvangfase $k$ wam hiervoor al ter sprake, in paragraaf 6.2 .1 (en eerder in paragraal 2.2 .2 ).

In gelijke zin HR 12 januari 1973, NJ 1973, 177 nt. ARB (Nutsziekenfonds/Mahieu) en HR 23 februari 1990, NJ 1991, 574 nt. CJHB (Centraal Beheer/Bedrijfsvereniging).

Vgl. HR 5 december 1929, NJ 1930, 1055 nt. EMM (Ruhaak/Fatum); Van Boom (2000a), p. 34. 
sprake kan zijn, doet zich voor bij eigen schuld van de benadeelde indien die leidt tot vermindering van de aansprakelijkheid. Regresnemers plegen daarmee zelf, bij het doen van hun uitkering aan de benadeelde, buiten opzet veelal geen rekening houden. Toch kunnen ze de uitkering slechts verhalen tot het bedrag van aansprakelijkheid onder aftrek van de eigen schuld. Van het al dan niet verzekerd zijn van de benadeelde behoort de schadeveroorzaker geen nadeel te ondervinden. De draagplicht met betrekking tot de schade moet weliswaar naar de schadeveroorzaker, maar ook niet méér dan dat. ${ }^{928}$ Voor particuliere schadeverzekeraars volgt dat impliciet al uit het derivatieve karakter van hun regresrecht (ze worden voor hun uitkeringen aan de benadeelde slechts gesubrogeerd voorzover de benadeelde met betrekking tot die schade een vordering tot schadevergoeding heeft). Voor de zelfstandige regresrechten is een aparte regeling nodig: de regeling van het zogenaamde civiele plafond. Zoals in hoofdstuk 4 werd gezien, kennen alle zelfstandige regresrechten afzonderlijk een regeling voor het civiele plafond. Daarin wordt het regresrecht beperkt tot: ${ }^{92}$

ten hoogste tot het bedrag, waarvoor (de aansprakelijke persoon) bij het ontbreken van de aanspraken krachtens deze wet naar burgerlijk recht aansprakelijk zou zijn, verminderd met een bedrag, gelijk aan dat van de schadevergoeding tot betaling waarvan de aansprakelijke persoon jegens de verzekerde near burgerlijk rach is gehouden.

Dit komt erop neer dat de schadeveroorzaker nooit méér verschuldigd is dan wat hij verschuldigd zou zijn geweest aan de benadeelde zelf. De Hoge Raad trekt dat principe door naar de stelplicht en bewijslast. Die rust bij de regresnemer. ${ }^{930}$ De toepassing van de regeling is in de praktijk voor een aantal gevallen gestandaardiseerd. Bij het regres van de sociale arbeidsongeschiktheidswetten kan er, voorzover dit onder de werkingssfeer valt van Convenant Verhaalsrecht 2001 , niet meer over worden geprocedeerd. Dat is echter niet helemaal zo, want over schuld, en daartoe wordt ook de eigen schuld van de benadeelde gerekend, en medische causaliteit wordt nog wèl normaal verweer gevoerd. Ook mist het civiele plafond directe praktische relevantie voor de buitengerechtelijke kosten bij personenschade waarvoor de zogenaamde NORA-regeling geldt, ${ }^{931}$ en (uiteraard) voor het regres dat gecollectiveerd is (ANW, AWBZ). Daarbuiten is de regeling echter nog een bron voor geschillen.

Hoe moet men voor de berekening van het civiele plafond globaal te werk gaan? Voor de berekening van het civiele plafond en de daarop in mindering te brengen resterende vordering tot schadevergoeding moeten de vraag naar de aard en de

Cursief toegevoegd, EE De regeling staat in alle zelfstandige regresregelingen, o.a. ant 90 WAO, an. 69 WAZ. art. 61 WNONG, ant. 49 REA en ant. 836 ZFW.

930 In die zin HR 13 december 1985, $N J 1986,246 \mathrm{nt}$. G ( $A B P / W$ ink $)$, r.o. 3.6. Bij subrogatie lijkt het eveneens primair de gesubrogeerde, die de omvang van ansprakelijkheid moet aantonen.

931 Zie over de Nora-regeling paragraaf 8.3.2. 
omvang van de aansprakelijkheid net zó worden beoordeeld, als het geval is voor de benadeelde. Voor de berekening van het civiele plafond voor uitkeringen aan een weduwe in het kader van de Algemene nabestaandenwet zal bijvoorbeeld, net als rechtstreeks gebeurt op basis van art. 6:108 $\mathrm{BW}$, onder meer haar onderhoudsvoorziening door hertrouwen worden verdisconteerd. ${ }^{932} \mathrm{Om}$ te beginnen zal dan de precieze omvang van die schade of schadepost moeten worden vastgesteld, zoals deze zonder de uitkering van de regresnemer zou zijn geleden. Dat kan met name bij inkomensschade of de derving van levensonderhoud tot moeilijke vragen leiden: hoe lang is de benadeelde niet in staat om te werken, geniet hij inmiddels inkomsten uit vervangende arbeid of ligt dat in het verschiet? Is de weduwe, die stelt levensonderhoud te derven hertrouwd (en hoe zijn haar kansen daarop) ${ }^{933}$ Nadat het bedrag vaststaat waarvoor de benadeelde zonder de uitkering van de regresnemer schade zou hebben ondervonden, moet worden vastgesteld hoeveel schadevergoeding de schadeveroorzaker daarvoor in dat geval verschuldigd zou zijn geweest. De vraag of de benadeelde zonder de regresnemer wellicht ook wel alternatieve wegen zou hebben gehad om tot vergoeding van die schade te komen moet daarbij (uiteraard) buiten beschouwing blijven. Dat geldt óók als de schade dan bijvoorbeeld onder de dekking zou vallen van een andere sociale verzekering (denk aan de mogelijkheid van een WW-uitkering indien de aanspraak op de WAO ontbreekt), ongeacht of daarvoor eveneens regres verschuldigd zou zijn geweest. ${ }^{934}$ Het gaat bij het civiele plafond namelijk niet zozeer erom om na te gaan hoeveel gunstiger de positie van de schadeveroorzaker of WA-verzekeraar had kunnen zijn. Slechts moet worden vermeden dat hij, eenmaal tot regres verplicht, méér komt te betalen dan het maximale bedrag van de hem toerekenbare schade(post).

Om het vaststellen van het civiele plafond zo eenvoudig mogelijk te houden wordt ervan uitgegaan dat de benadeelde voor de betreffende schade(post) een som ineens (lump sum) zou hebben gevorderd. De Hoge Raad besliste dat aanvankelijk alleen voor de VOA, maar het wordt ook daarbuiten aangenomen. ${ }^{935}$ In essentie is de civiel-plafond regeling niet veel anders dan het nemo-plus beginsel bij subrogatie: ook dan zal het bedrag moeten worden vastgesteld dat de schadeveroorzaker zonder de uitkering van de gesubrogeerde verschuldigd zou geweest aan de benadeelde. ${ }^{936}$

932 Zie HR 29 april 1994, NJ 1995, 609 nt. CJHB (Nationale Nederlanden/ABP).

933 Op dat moment eindigt in zoverre de vergoedingsplicht van de schadeveroorzaker, aldus HR 13 december 1985 . NJ 1986, $246 \mathrm{nt}$. G (ABP/Wink). Over de vraag of de hertrouwkansen in overweging mogen worden genomen geeft de lagere rechtspraak een wisselend beeld, zie Schadevergoeding, art. 108 (Bolt), aant. 51.

In HR 25 maar 1983, NJ 1984, 681 (ABP/Delia Lloyd) oordeelde de Hoge Raad in die zin voor een zaak waarin de benadeelde zonder de uitkering waarvoor regres plaatsvond ingevolge de VOA, waarschijnlijk aanspraak zou kunnen maken op een andere uitkering en idem HR 25 februari 1994, NJ 1995, $608 \mathrm{nt}$. CJHB (Staat/Sterpolis). In gelijke zin voor sociale verzekeraars: HR 2 juni 1989, NJ 1990, $726 \mathrm{nt}$. MMM (Zwolsche Algemeene/Bedrijfsvereniging); en HR 23 december 1994, NJ 1996, 349 (Douma/Bedrijfsvereniging), Zie ook Van Boom $(2000 a)$, p. 38.

935 Zie infra, paragraaf 8.2 .4 .

936 Van Boom $(2000 a)$, p. 38. 
Een verschil is echter dat bij de zelfstandige regresrechten alleen eventuele exoneraties of andere contractuele afspraken ter beperking van de aansprakelijkheid kunnen worden ingeroepen die voorafgaand aan het ongeval tussen schadeveroorzaker (WA-verzekeraar) en benadeelde werden overeengekomen. Afspraken die na het ongeval, en dus na het ontstaan van het zelfstandige regresrecht, zijn gemaakt kunnen niet worden tegengeworpen. ${ }^{937}$

\subsubsection{Ratio van civiel plafond}

De ratio van het civiele plafond is zoals gezegd dat de schadeveroorzaker relatief gezien geen nadeel mag ondervinden van het regres. Volgens de Hoge Raad is het verzekerd zijn van de benadeelde een toevallige omstandigheid die niet mede bepalend behoort te zijn voor de op de schadeveroorzaker rustende schuld. ${ }^{938}$ Daaruit kan worden afgeleid dat de schadeveroorzaker terzake van zijn aansprakelijkheid dezelfde verweermiddelen toekomen als die hij jegens de benadeelde zelf zou hebben gehad (exoneraties en overmacht). ${ }^{939}$ Het civiele plafond werd tevergeefs echter aangevoerd voor verweren met een andere strekking. Zo biedt het civiele plafond de schadeveroorzaker of WA-verzekeraar geen bescherming tegen het risico van dubbele betaling dat te wijten is aan het feit dat hij reeds (onverschuldigd) aan de benadeelde betaalde (zonder dat daarbij verplichte voordeelstoerekening plaatsvond) ${ }^{940}$ Ook bevrijdt het hem niet van het regres van sociale verzekeraars of de Staat; het gevorderde levert hen, anders dan de benadeelde, geen schade op..$^{941}$

Voorzichtigheid past verder bij benaderingen waarin de regeling van het civiele plafond wordt opgeworpen als argument voor een eigenlijk te ruime uitleg van het regresrecht. Geredeneerd wordt dan dat de schadeveroorzaker per saldo toch wel aansprakelijk zou zijn geweest tegenover de benadeelde. Dat kan natuurlijk niet, het civiele plafond is geen dragend argument voor uitbreiding van de inhoud van het regresrecht zelf. Men kan dus niet stellen dat het niet uitmaakt met betrekking tot welke uitkeringen of verstrekkingen de regresnemer zijn vordering instelt omdat de schadeveroorzaker toch nooit méér verschuldigd is dan het bedrag dat hij anders aan de benadeelde verschuldigd zou zijn geweest. Van Leeuwen en

937 HR 15 februari 1935, NJ 1935, $417 \mathrm{nt}$. EMM (RVB/Tolenaars).

938 HR 5 december 1929, NJ 1930, 1055 (Ruhaak/Fatum) met kritische noot van Meijers; voorts Verwer (1970), p. 86. Vgl. ook HR 24 mei 1985. NJ 1985, 732 (Zeven Provincièn/Staat) en HR 23 december 1994, NJ 1996. 349 (Douma/Bedrifswereniging), r.o. 3.4.

940 Dat is een redenering die de A-G opzet in de zaak RVB/Tolenaars, maar die de Hoge Raad niet volgt, HR IS februari 1935, NJ 1935, $417 \mathrm{nt}$. EMM (RVB/Tolenaars).

941 Zie paragraaf 8.1. Terecht daarom verwerpt Hof Den Bosch 26 september 1995, NJ 1997, 460 (Thijssen/ABP) de stelling dat het civiele plafond in de weg staat aan het regres voor uitkeringen ingevolge de Verhaalswet ongevallen ambtenaren waarvoor Staat en ABP tevens een uitkering uit het AAF-fonds hebben ontvangen. 
Bouma stellen het kernachtig: het civiele plafond kan alleen de gevolgen van een civielrechtelijk gezien te ruim regresrecht repareren. ${ }^{942}$

\subsubsection{Perikelen}

Vanwege de beperkte dekking die verzekeringen in het algemeen bieden kan het echter gemakkelijk zo zijn, dat de regresnemer maar een deel van de schade van de benadeelde voor zijn rekening heeft genomen. Voor het resterende deel zal de schadeveroorzaker dan schadevergoeding verschuldigd zijn aan de benadeelde zelf. Daarmee moet rekening worden gehouden bij het regres teneinde hem niet méér te laten betalen dan het in de fictieve situatie verschuldigde bedrag. Op het civiele plafond komt daarom het bedrag in mindering dat de schadeveroorzaker daadwerkelijk nog verschuldigd is aan de benadeelde zelf, het restbedrag. De regeling is bedoeld ter bescherming van de schadeveroorzaker (of WA-verzekeraar) tegen het risico van dubbele betaling voor dezelfde schade, ${ }^{943}$ en dus niet als voorrangsregeling voor de vordering van de benadeelde. Die loopt door het zelfstandige karakter van het regresrecht immers ook zonder de regeling van het restbedrag niet het risico dat door de eerdere actie van zijn regresnemende verzekeraar of werkgever zijn mogelijkheden van verhaal op de schadeveroorzaker worden beperkt. Regresnemers zouden weliswaar voor het volle civiele plafond (zonder aftrek van het restbedrag) regres kunnen nemen, maar dit laat de verhaalsmogelijkheden van de benadeelde onverlet. ${ }^{944}$

Betwijfeld kan worden in hoeverre het ingewikkelde systeem van civiel plafond en restbedrag haar doel treft, en dus daadwerkelijk voorkomt dat de schadeveroorzaker bij regres méér verschuldigd is dan zonder regres. Het bedrag dat de schadeveroorzaker of WA-verzekeraar uiteindelijk als schadevergoeding aan de benadeelde moet betalen kan lager of hoger zijn dan het restbedrag zoals het werd ingeschat in de regreszaak. Dat kan zijn reden vinden in het materiële recht, maar ook in miscalculaties of andere praktische onvolkomenheden.

Het is zoals gezegd aan de schadeveroorzaker (of diens WA-verzekeraar) om te stellen, en zonodig te bewijzen, dat de regresvordering hoger is dan het in de regeling van het civiele plafond bedoelde bedrag. ${ }^{945}$ Dat vergt feitenkennis die

\footnotetext{
942 Van Leeuwen \& Bouma (1993), p. 234

96 Zo stelt ook de Hoge Raad het inzake HR I2 januari 1973, NJ 1973, $177 \mathrm{nt}$. ARB (Nutsziekenfonds/Mahieu).

94 Zoals gold voor het regres van de Ongevallenwet 1921. Een regeling voor vermindering met het bedrag van de vordering van de benadeelde ontbrak; daarover Clausing (1970), p. 209.

9. Blijkens HR 24 mei 1985, N.J 1985, 732 (Zeven Provinciên/Staat) en HR 13 december 1985, NJ 1986, 246 $\mathrm{nt}$. $\mathrm{G}(A B P /$ ink) liggen de stel-en bewijsplicht voor art. 3 VOA bij de schadeveroorzaker (of WA-verzekeraar) Voor het regime van de Ongevallenwet lag die juist bij de regresnemer: HR 20 februari 1942, NJ 1942. 352a (Gemeente Groningen/ATO) en NJ 1942, $352 b$ (Centrale Werkgewera/Muskens). Volgens Rb. Den Haag 3 oktober $1950, N J$ 1952, II 9 hoeft de regresnemer niet in de dagvaarding aannemelijk te maken dat zijn vordering het civiele plafond niet overschrijdt.
} 
hij waarschijnlijk mist, ${ }^{946}$ want voor de berekening moet niet alleen worden uitgegaan van de fictieve situatie waarin de schade waarop de uitkering betrekking heeft onverzekerd zou zijn geweest, maar ook van de eventuele in werkelijkheid nog resterende schade bij de benadeelde (en de vraag of de benadeelde hem daarvoor aansprakelijk kan stellen). Daarvoor zijn onder meer gegevens nodig die kunnen aantonen welke invloed de uitkering heeft op het recht op schadevergoeding, bijvoorbeeld over de vraag of door het schadevoorval de sterftekans van de benadeelde is toegenomen. ${ }^{947}$

Met de regeling van het civiele plafond vraagt de regreszaak kortom om een driedubbele beoordeling van vorderingen: een oordeel over wat de omvang van aansprakelijkheid behoort te zijn in de fictieve situatie, een oordeel over wat die behoort te zijn in de niet aan de orde zijnde zaak van de benadeelde zelf en een oordeel over het regresrecht sec. Problemen ontstaan indien verschillende rechters in verschillende procedures over de verschillende vorderingen moeten oordelen..$^{948}$ Om onnodig risico van miscalculatie te vermijden zou beter zijn de civiel-plafond regeling zo te verstaan, dat zij alleen betrekking heeft op de schadepost waarvoor de regresnemer juist de uitkering deed aan de benadeelde, en waarvoor hij regres zoekt. Met betrekking tot de betreffende schadepost zal dan het bedrag van de schadevergoeding moeten worden berekend, waarop de benadeelde recht zou hebben gehad als hij de schade zelf had moeten dragen.

Dit illustreert bijvoorbeeld het geval waarin de benadeelde zònder de loondoorbetalingsplicht van zijn werkgever, inkomensschade en smartengeld van de schadeveroorzaker zou hebben kunnen vorderen, bijvoorbeeld 10000 en 2000 Euro, terwijl de werkgever in werkelijkheid het loon volledig doorbetaalt en de benadeelde jegens de schadeveroorzaker daarom alleen recht heeft op 2000 Euro smartengeld. De werkgever kan dan voor de betaalde 10000 Euro krachtens art. 6:107a BW regres zoeken, en zou bij een sommenstelsel maximaal het bedrag kunnen vorderen dat de schadeveroorzaker in de fictieve situatie aan de benadeelde zèlf verschuldigd zou zijn geweest, 12000 Euro (het civiele plafond), minus het bedrag dat de schadeveroorzaker daadwerkelijk nog aan de benadeelde moet vergoeden, 2000 Euro (resterende schadevordering). Het bedrag waarvoor de werkgever op grond van art. 6:107a lid $2 \mathrm{BW}$ dan ten hoogste recht heeft op regres, ${ }^{949}$ bedraagt 10000 Euro.

$V_{\mathrm{g}} \mathrm{l}, \mathrm{Rb}$.Zwolle 30 december 1970, VR 1971.82 (Bedriffsvereniging/Visscher) waar de aansprakelijke het risico van overschrijding van het civiele plafond niet aannemelijk heeft gemaakt door gegevens te verschaffen over de totale sehade c.q. resterende schade van de benadeelde. De rechtbank wijst de vordering daarom zonder veel omhaal toe; als later blijkt dat de aansprakelijke teveel heeft betaald, moet hij dit meerdere maar als onverschuldigd betaaid terugvorderen. 
Gecompliceerd wordt het bovendien als het bedrag van de uitkeringen waarvoor de regresnemer verhaal zoekt hoger is dan het bedrag dat de benadeelde zonder die uitkeringen op de schadeveroorzaker had kunnen verhalen. In theorie kan daarvan sprake zijn als het doorbetaalde loon waarvoor de werkgever krachtens art. 6:107a BW regres zoekt hoger is dan de werkelijke (loon)schade van de benadeelde. ${ }^{950}$ Vaak zal dat niet voorkomen omdat de uitkeringen waarvoor sociale verzekeraars en werkgevers regres zoeken in de regel zijn afgestemd op de schade van de benadeelde en deze schade dezelfde zal zijn als die waarop de aansprakelijkheid van de schadeveroorzaker betrekking heeft. ${ }^{951}$ In de praktijk zal het risico dan ook eerder zijn, dat de omvang van aansprakelijkheid die op de schadeveroorzaker (of diens WA-verzekeraar) rust ontoereikend is, bijvoorbeeld omdat sprake is van eigen schuld van de benadeelde (art. 6:101 BW). Voeg aan het evengenoemde voorbeeld toe dat de benadeelde voor $50 \%$ zelf heeft bijgedragen aan het ontstaan van de totale schade. Het civiele plafond brengt dan mee dat de regresnemer de eigen schuld van de benadeelde op dezelfde wijze als de benadeelde zelf tegen zich moet laten werken. Regresnemer en benadeelde zouden dan ieder, behoudens een eventuele billijkheidscorrectie, recht hebben op slechts $50 \%$ van het eigenlijke bedrag, te weten 5000 Euro (voor de regresnemende werkgever) en 1000 Euro (voor de benadeelde).

Voorwaar een slachtoffervriendelijk systeem, zo schrijven Boot en De Waal. ${ }^{952}$ In de visie van hen beide, op het moment van hun schrijven werkzaam bij het GAK, zou zonder de beperking die het civiele plafond oplegt voorrang van de regresnemer boven de benadeelde onder omstandigheden meer voor de hand hebben gelegen. De benadeelde heeft van de regresnemer immers sowieso al méér gekregen dan het bedrag waarop hij naar burgerlijk recht jegens de schadeveroorzaker aanspraak zou hebben gehad. De eigen schuld van de benadeelde dient daarom, in hun optiek, volledig in mindering te worden gebracht op de vordering van de benadeelde zèlf. ${ }^{953}$ De regresnemer heeft dan, in het gegeven voorbeeld, een regresvordering die slechts beperkt is tot 6000 Euro, en de benadeelde is zijn vordering geheel kwijt. Dit regime lijkt me om verschillende redenen onwenselijk. In de eerste plaats doet aan het recht op loondoorbetaling waarvan in het gegeven geval sprake is, ook in het algemeen de eigen schuld in beginsel geen afbreuk. Door de benadeelde niet slechts $50 \%$ van zijn resterende vordering (1000 Euro), maar het volle bedrag (2000 Euro) te doen verliezen doet men hem dan per saldo te kort (hetgeen ook gelet op art. 2 lid 1, laatste volzin VOA onwenselijk lijkt). Daar komt bij, dat in de wèrkelijke smartengeldprocedure van de benadeelde, zeker

Zoals onder het regime van de Ongevallenwet 1921. Het reges van de Sociale Verzekeringsbank kon dan nadelig zijn voor de benadeelde met onverzekerde andere schade, zie Gilthay Veth (1969), p. 233 en Clausing (1970), p. 209.

95t En voor regres terzake van andere, rechtstreekse schade van de sociale verzekeraar of werkgever zelf (bijvoorbeeld de als gevolg van het aan de benadeeide overkomen ongeval gederfde premies) is geen plaats. 
als men daarbij niet op de hoogte is van de inkomensschade (en het werkgeversregres van art. 6:107a BW), de benadeelde wèl recht op 1000 Euro kan worden toegekend. De schadeveroorzaker zou dan uiteindelijk teveel verschuldigd worden.

\subsection{6 'Civiel plafond' bij subrogatie}

Als gevolg van de rechtsovergang bij subrogatie kan de regresnemer kortom in beginsel niet méér verkrijgen dan de omvang van de vordering tot schadevergoeding van de benadeelde. Het passieve deel van de verbintenis dient, behoudens nog te noemen uitzonderingen, ongewijzigd blijven, met dien verstande dat de schadeveroorzaker ten belope van de door de verzekeraar verkregen vordering aan deze moet betalen. Voor het beoordelen van de vraag naar de omvang en het precieze bedrag van aansprakelijkheid moet dan worden aangesloten bij de rechtsverhouding tussen de schadeveroorzaker en de benadeelde, en de regels die daarvoor gelden. ${ }^{954}$ De schadeveroorzaker mist wel verweren die hem jegens de benadeelde zouden toekomen voorzover die eigenlijk niets met het vorderingsrecht zelve te maken hebben, zoals het beroep op verrekening (art. 6:127 BW) of de mogelijkheid van betaling van schadevergoeding in natura."

Duidelijk is dat het daarbij lastig kan worden. Nagegaan moet dan immers tevens worden in welke vorm de uitkering zou zijn verricht (door een bedrag ineens of periodieke verstrekkingen, of wellicht zelfs door de aankoop van een lijfrente) ${ }^{956}$ en de financiële consequenties daarvan. Moet bijvoorbeeld ervan worden uitgegaan dat de benadeelde schadevergoeding op netto-basis zou hebben ontvangen of juist dat de schadevergoeding van de benadeelde belastbaar zou zijn geweest en daar, nu belastingschade eveneens verhaalbaar is, ${ }^{957}$ een bedrag aan verschuldigde loonbelasting bij zou komen? Zoals eerder werd opgemerkt, zijn delen van het WAO-risico thans via de werkgever ondergebracht bij particuliere schadeverzekeraars. Mede met het oog daarop ligt het voor de hand om voor vragen als deze aansluiting te zoeken bij de uitleg en invulling die de Hoge Raad van het civiele plafond geeft voor de zelfstandige regresrechten van sociale verzekeraars en werkgevers.

Van substantiële wijzigingen is verder eigenlijk alleen sprake aan de actieve zijde van de verbintenis: de schadeverzekeraar treedt in de plaats van de oorspronkelijke schuldeiser, de benadeelde. ${ }^{958}$ Ook in dit opzicht draagt het derivatieve karakter eraan bij dat de schuldenaar financieel en rechtspositioneel niet slechter wordt dan dat hij tegenover de benadeelde die onverzekerd zou zijn geweest. Als de

Zo reeds Kortmann (1969), p. 47 en Van Boom (2000a), p. 37.

Art. 6:104 BW. Ook beperkingen van de aansprakelijkheid die voorafgaand aan het moment van subrogatie met de benadeelde zijn overeengekomen kunnen aan regresnemers worden tegengeworpen.

Voorbeeld bij Van Boom \& Storm (1995), p. 156.

Schadevergoeding, ant. 105 (Bolt), aant. 13.

Hierin verschilt de constructie bij subrogatie wezenlijk van de constructie van het zelfstandige regresrecht. Daar vaagt vooral de passieve zijde van de verbintenis aandacht. 
benadeelde door voordeelstoerekening al geen beperking zou ondervinden van zijn vorderingsrecht tegen de schadeveroorzaker wegens het ontbreken van schade, dan verliest hij bij subrogatie in elk geval zijn vordering. In dit opzicht is het regres door subrogatie aanmerkelijk veel eenvoudiger dan bij de zelfstandige regresrechten, waar het immers wordt bemoeilijkt door de (potentiële) samenloop met de vordering van de benadeelde. Toch lijkt er bij subrogatie dogmatisch wel enig verschil met de rechtstreekse vordering van de benadeelde. De verbintenis die door subrogatie ontstaat tussen schadeveroorzaker en schadeverzekeraar strekt immers niet tot vergoeding van de schadeverzekeraar zelf. Op de schadeveroorzaker rust door de rechtsovergang dan ook, in mijn visie, niet langer een 'actieve' wettelijke verplichting tot schadevergoeding. De omvang van de op hem rustende schuld wordt bepaald door de regels van het aansprakelijkheids- en schadevergoedingsrecht zoals deze zouden gelden in de verhouding tussen de schadeveroorzaker en de benadeelde, maar het schadevergoedende karakter is als het ware gefixeerd door het moment van de subrogatie.

Het derivatieve karakter helpt ten slotte ook in praktisch opzicht te voorkomen dat de schadeveroorzaker (of diens WA-verzekeraar) door samenloop met de vordering van de benadeelde teveel betaalt. Subrogatie vindt plaats op precies het moment dat de benadeelde zijn 'aanspraak' ${ }^{\text {'959 }}$ op de verzekeringsuitkering geldend maakt (en gelijktijdig zijn recht op schadevergoeding van de schadeveroorzaker verliest). Daarmee worden onnodige extra betalingsrisico's, bijvoorbeeld van een - naar achteraf blijkt - onverschuldigde betaling aan de benadeelde die vervolgens geen verhaal biedt, vermeden. Het derivatieve karakter garandeert niet alleen dat de rechtspositie van de schuldenaar door het feit van de rechtsovergang in beginsel niet zal verbeteren of verslechteren, maar voorkomt voorts dat de rechtspositie van de schuldenaar verslechtert door de mate waarin rechten op de schadeverzekeraar overgaan. De verzekeraar kan immers geen beter of meeromvattend recht verkrijgen dan het vorderingsrecht dat de benadeelde onmiddellijk voorafgaand aan de subrogatie heeft toebehoord. Deze zogenaamde nemo-plus regel geeft een uiterste bovengrens die kan voorkomen dat de rechtspositie van de schuldenaar door de rechtsovergang op de schadeverzekeraar slechter wordt dan in de situatie dat hij uitsluitend te maken zou hebben met de benadeelde zelf. Hij kan worden beschouwd als het civiele plafond voor het regres van particuliere verzekeraars. ${ }^{960}$ Mulder hanteert daarvoor - met het oog op de functie die art. $284 \mathrm{WvK}$ in zijn optiek heeft, te weten zuivere kostentoerekening aan de schadeveroorzaker - een wenselijk criterium: alleen die rechten van de benadeelde, die anders door betaling van de schadeverzekeraar zouden tenietgaan dienen over te gaan. ${ }^{961}$ Hetgeen

Schadeverzekeraars subrogeren inmiddels ook bij vrijwillig aan de verzekerde uitgekeerde bedragen in diens recht op schadevergoeding.

Pierson (1941), p. 27; Van Vrijberghe de Coningh (1943), p. 117; De Kok (1965), p. 28; Van Boom (2000a), p. 35 .

\%1 Mulder (1988), p. 49. 
afdeling 6.2.1 $\mathrm{BW}$ (de algemene regeling van overgang en afstand van vorderingen) in dit verband bepaalt, lijkt daar mee in overeenstemming. Art. 6:142 BW laat naast de vordering tot schadevergoeding alle nevenrechten mee overgaan (waaronder ook het recht op de bedongen rente wordt verstaan van na de rechtsovergang). ${ }^{962}$ Gaat de vordering alleen over voor een bepaald gedeelte, dan gaan, tenzij anders is overeengekomen, ook de nevenrechten alleen voor dat breukdeel over. ${ }^{963}$

Blijkens eerdergenoemd arrest Spoorwegongeval De Vink geldt het recht van schadeverzekeraars op subrogatie alleen voor verzekeringsuitkeringen die strekken tot vergoeding van concrete schade (uitkeringen met een indemniteitskarakter); bij sommenverzekeringen wordt niet gesubrogeerd. Het verhaalsrecht van schadeverzekeraars is beperkt tot het bedrag waarvoor de schade van de verzekerde uit hoofde van de verzekering werd vergoed. Ook hierdoor wordt voorkomen dat de schuldenaar bij regres gehouden is tot betaling van méér dan het bedrag dat hij verschuldigd zou zijn indien de schade van de benadeelde onverzekerd zou zijn geweest. Wat dit indemniteitsbeginsel bij regres als zodanig niet voorkomt, is dat verzekeraars die meer uitkeren dan het bedrag dat de schadeveroorzaker voor de met de verzekeringsuitkering corresponderende schade aan schadevergoeding is verschuldigd, ook vorderingen verkrijgen die de benadeelde heeft terzake van andere schadeposten, bijvoorbeeld smartengeld. Dat kan zich voordoen als de schade waarvoor de verzekeringspolis de benadeelde recht geeft op vergoeding, naar aard en omvang niet gelijk is aan de schade waarvoor de schuldenaar bij toepassing van afdeling 6.1.10 BW aansprakelijk is. Aangenomen wordt evenwel dat de tekst van art. 284 WvK in de weg staat aan de rechtsovergang van de vordering die de benadeelde heeft terzake van zijn andere, niet-verzekerde schadeposten. Het spreekt immers van vorderingen terzake van 'die' schade, terugverwijzend naar de schade in het kader waarvan de verzekeraar heeft betaald. Voor de hand ligt dat daar alleen die schadepost onder moet worden verstaan, waarvoor de uitkering is verstrekt. ${ }^{964}$ Overigens lijkt dat niet anders te moeten zijn indien de verzekering voor de schadeposten waarvoor geen uitkering is verstrekt wèl dekking biedt.

Sonja loopt als passagier in een verkeersongeval met een dronken chauffeur cen kaakfractuur op en een beschadigd gebit. In rechte komt vast te staan dat de schade voor $25 \%$ te wijten is aan haarzelf. De ziektekostenverzekering dekt zowel de kosten van chirurgische ingreep als tandheelkundige zorg, maar Sonja besluit om haar moverende redenen de tandartsrekening zelf te betalen. De ziektekostenverzekeraar wordt alleen gesubrogeend voor de rekening van de kaakchirurg en kan zich voor de

Art. 6:153 $\mathrm{BW}$. In de wettelijke rente wordt niet gesubrogeend. Het komt de regresnemer wel uit eigen hoofike toe mits aan bepaalde wettelijke voorwaarden is voldaan.

Zie in het kader van art. 6:150 BW PG 6. p. 528; Asser-Hartkamp 4-I, nr. 580; vgl. ook Verbintenissennecht. art. 6:150 (Van Mierlo), aant. 14; en Van Achterberg, nt. 24.

Ledeboer (1927), p. 53 (met verwijzingen naar literatuur en rechtspraak); vgl. ook Van Boom \& Storm (1995). p. 150 . 
resterende $25 \%$ niet beroepen op de post tandheelkundige zorg. Dat men daarvoor tevens dekking biedt is niet relevant; de verzekering zou de verzekerde anders in zijn aanspraken beknotten.

\subsection{Toepasselijkheid van de gronden voor aansprakelijkheid}

\subsubsection{Hoofdregel}

Zowel bij subrogatie als bij zelfstandig regres worden door de regresnemer de regels van het aansprakelijkheidsrecht ingeroepen die de verhouding tussen schadeveroorzaker en benadeelde beheersen, en wel tot ten hoogste het bedrag van die aansprakelijkheid. Zoals eerder werd gesteld, gaat het om alle regels, die de oorzaak van schade toeschrijven aan gedragingen of activiteiten van anderen dan degene die haar lijdt (de benadeelde). Dat zijn met name de regels van het onrechtmatige daadsrecht (schuld- en risicoaansprakelijkheid) en, in de sfeer van letsel of overlijden wat uitzonderlijker, de regels voor schadevergoeding bij niet-nakoming van contractuele verplichtingen. ${ }^{965}$ Hieruit volgt tevens dat particuliere of sociale verzekeraars met hun regresrecht (in beginsel) ${ }^{966}$ ook elkaar niet kunnen aanspreken.

Behoudens uitzonderingen moeten deze aansprakelijkheidsregels door de regresnemer precies zò worden ingeroepen, zoals de benadeelde dat zelf had gekund indien de schade voor zijn rekening zou zijn gebleven. Ook bij de uitleg en concrete toepassing van deze normen en bij de verdeling van de verdere bewijslast (art. $150 \mathrm{Rv}$ ) zullen dezelfde maatstaven moeten gelden, tenzij er op inhoudelijke gronden reden is voor het maken van onderscheid (en de rechterlijke motivering hierin voldoende inzicht geeft). Dat indirect niet toch een rol speelt dat het niet gaat om het persoonlijke belang van de benadeelde is echter moeilijk uit te sluiten. Zo is goed mogelijk dat bij de bewijslastverdeling of bij de concrete toepassing van de aansprakelijkheidsregels in een procedure van de benadeelde het belang van slachtofferbescherming gewicht in de schaal zou hebben gelegd, terwijl dit bij de regreszaak impliciet achterwege blijft. ${ }^{967}$ Interessant is in dit verband een bindend advies dat Bouman enkele jaren geleden uitbracht over een regreszaak met een casus gelijk aan die van het bekende Kelderluik-arrest. ${ }^{968}$ Een werknemer

\footnotetext{
क5 $\mathrm{Vgl}$. bij intem regres is Hof Den Bosch 15 april 2003, C0100972/HE (niet gepubliceerd), waar een door het Waarborgfonds Motorverkeer aangesproken verhuurder van een aanrijdend voertuig opzijn beunt verhaal zoekt bij zijn huurder op grond van hun huurovereenkomst.

966 Niet uitgesloten is dat deze verzekeraars vervolgens wel ook zèlf aansprakelijk zijn, denk aan vertragingsschade bij een tekortkoming in de nakoming van de betalingsplicht. Ze zijn dan voor die schade wêl als aansprakelijke. als schadeveroorzaker, aan te metken en staan in zoverre ook bloot aan eventuele regresclaims van verzekeraan bij wie het risico van zulke schade kan zijn ondergebracht.

967 Akkermans wijst hierop in zijn noot bij het nader te bespreken Bindende advies 4 november 1999, VR 2002. p. 135-139.

Ws Bindend advies 4 november 1999, VR 2002, $81 \mathrm{nt}$. Akkermans; vgl. HR 5 november 1965, NJ 1966, $136 \mathrm{nt}$ GJS (Kelderiuik).
} 
had ernstig letsel opgelopen van een val die te wijten was aan een in de kruipruimte tewerkgestelde die het vloerluik had opengelaten. De rechtbank had in het zonder noodzaak openlaten van het luik en de daarop volgende val voldoende grond gevonden voor een eindoordeel. Na toetsing van de nalatigheid aan de criteria van het Kelderluik-arrest werd de vordering toegewezen. In hoger beroep stelde ook het hof voorop dat met het openlaten van het luik zonder voorafgaande waarschuwing aan het slachtoffer, een gevaarlijke situatie was gecreëerd. Het had bij dat uitgangspunt voor de hand gelegen de verweerder aannemelijk te laten maken dat voldoende voorzorgsmaatregelen waren getroffen, maar het hof achtte een nadere bewijslevering van het ziekenfonds noodzakelijk. Het ziekenfonds moest aantonen dat ook in ander opzicht dan de ontbrekende waarschuwing onvoldoende voorzorgsmaatregelen waren getroffen om een val te vermijden. Nu het fonds hierin niet slaagde werd de regresvordering door het hof afgewezen. Op basis van het procesdossier concludeerde Bouman dat indien de benadeelde zelf zou hebben geprocedeerd, de kans op succes om die reden vermoedelijk groter zou zijn geweest (deze kans schatte Bouman op tweederde). ${ }^{969}$

Het is natuurlijk uitermate lastig om in te schatten hoe de zaak zonder regresaspect zou hebben geluid. Zeker als men in aanmerking neemt dat wegingsfactoren zoals het bevorderen van slachtofferbescherming ook impliciet een rol kunnen spelen is de achterstelling van de regresnemer moeilijk 'hard' te maken. Maar gelet op dit risico van een nadeliger oordeel wijst Akkermans erop dat regresnemers er goed aan doen de benadeelde met de hem resterende vordering voor te laten gaan. Als de zaak eenmaal bewezen is, ligt het immers voor de hand dat in een andere (regres)procedure over hetzelfde feitencomplex feitelijk daarbij wordt aangesloten. ${ }^{970}$ Ook de raadsman van de benadeelde zal er goed aan doen, zo meent Akkermans, om de benadeelde en niet, bijvoorbeeld om financiële redenen, de regresnemer voor te laten gaan. Dat zou als het misgaat, wegens het te voorziene extra procesrisico waarvan bij regres sprake is, zelfs als beroepsfout kunnen worden aangemerkt. ${ }^{971}$

Inhoudelijk maken de regels van het positieve recht in beginsel geen onderscheid tussen de positie van regresnemers en die van de benadeelde bij het inroepen van de aansprakelijkheid van de schuldenaar. De wet geeft één uitzondering van die strekking: de Tijdelijke regeling verhaalsrechten.

\subsubsection{De Tijdelijke regeling verhaalsrechten (TRV)}

De directe aanleiding van de Tijdelijke regeling verhaalsrechten ligt bij het in 1978 door de Studiegroep Verkeersaansprakelijkheid uitgebrachte rapport 'Vergoeding 
van schade door dood en letsel'. Eén van de aanbevelingen in dat rapport was een algehele afschaffing van de verhaalsmogelijkheden voor particuliere en sociale verzekeraars, ${ }^{972}$ dat kwam al ter sprake. ${ }^{973}$ Vanwege de budgettaire moeilijkheden die daarvan op korte termijn voor regresnemers werden verwacht is het voorstel van de Studiegroep blijven liggen. Een speciale werkgroep slaagde er niet in vóór de inwerkingtreding van het Burgerlijk Wetboek in 1992 met een definitieve beslissing te komen. De werkgroep kwam echter tot de slotsom dat het nieuwe wetboek tot een belangrijke (ongewilde) uitbreiding van het regres zou leiden. De nieuwe gronden van risicoaansprakelijkheid die het introduceerde zouden immers zonder ingrijpen van de wetgever óók gelden voor regresnemers. Bovendien zou de WAschadelast door de uitbreiding van het regres niet onaanzienlijk kunnen stijgen. De werkgroep kwam daarom met het voorstel van een tijdelijke regeling die de onbeperkte doorwerking van het nieuwe aansprakelijkheidsrecht zou moeten voorkomen. Dat moest voorkomen dat afschaffing van het regres feitelijk onmogelijk zou worden. Naar aanleiding daarvan is in 1983 in het kader van de stofkamoperatie een eerste Nota van Wijziging voor Boek $6 \mathrm{BW}$ ingediend, waarin óók cen voorstel lag dat uiteindelijk heeft geresulteerd in de TRV. ${ }^{974}$ De regeling hield in dat de nieuwe gronden van risicoaansprakelijkheid die het BW zou introduceren niet zouden gelden voor regresnemers. Voor regresnemers moest het niveau van de gronden voor aansprakelijkheid van het oude recht worden gehandhaafd.

Ook uit de Memorie van Toelichting bij de regeling blijkt dat dit een noodoplossing was om voorlopig uit de ingewikkelde discussie over de financiële gevolgen van het regres te raken. ${ }^{975}$ Volgens toenmalig (VVD)-minister Korthals Altes zou de blootstelling van particulieren en het bedrijfsleven aan onverminderde doorwerking van de nieuwe gronden voor risicoaansprakelijkheid bij regresclaims onverantwoord zijn. Gevreesd werd voor een verhoging van de WA-premielast en ook dat gevaarzetters dan zouden nalaten zich te verzekeren (met alle gevolgen vandien). ${ }^{976}$ Anderzijds was er volgens de minister, gelet op het (budgettaire) belang van regresnemers, evenmin ruimte de regresopbrengsten ineens geheel of grotendeels te ontnemen. Eerst moest meer inzicht worden verkregen in het regresvolume van sociale verzekeraars en de overheid en moest er meer duidelijkheid komen over gevolgen van de nieuwe gronden voor risicoaansprakelijkheid. Ook wees de minister op een tweetal andere argumenten voor invoering van de TRV. Het regres was niet alleen omstreden, gevreesd werd ook voor een toeloop van procedu-

\footnotetext{
972 Niet alleen de regresrechten, maar cok de mogelijkheid van cessie of andere wijzen van overgang van vorderingen moesten volgens de Studiegroep worden uitgesloten, Studiegroep Verkeersaansprakelijkheid (1978), p. 49.

973 Zie paragraf 5.4.5.

$974 \quad$ Inv. 6. p. 1403 e.v. De stofkamoperatie had tot doel de invoering van het BW versneld te realiseren door vereenvoudiging of opschorting van een aantal bepalingen. Tezamen met de nota die daarvoor bedoeld was diende de minister ook een aantal wijzigingsnota's in (met daarin ook een voorstel voor de TRV).

578 Van Dam (1993), nt. 26 noemt de regeling een 'politiek compromis' tussen voor- en tegenstanders van het afschaffen van de verhaalsrechten van particuliere en sociale verzekeraars.

n76 Imv. 6, p. 1409.
} 
res. Volle doorwerking naar regresnemers zou dat wellicht versterken. ${ }^{977}$ Een fundamenteler punt was dat het nieuwe aansprakelijkheidsrecht volgens de minister primair was bedoeld ter bescherming van de benadeelde. De belangen van regresnemende particuliere en sociale verzekeraars, de overheid en fondsen waren in zijn visie van andere aard dan die van de benadeelde. ${ }^{978}$ Die laatste zou zonder de nieuwe gronden voor aansprakelijkheid het risico lopen om met onvergoede schade te blijven zitten. Voor regresnemers speelt dat vergoedingsaspect geen rol. Dit heeft geleid tot de slotsom dat voor regresnemers de stand van het aansprakelijkheidsrecht van dat moment moest worden gehandhaafd op het niveau van het oude recht, totdat een definitief standpunt over de handhaving of afschaffing van het regres kon worden bepaald. Van Maanen en Römers laten intussen zien dat de TRV de positie van regresnemers verslechtert vergeleken met het oude recht, omdat daarin ook aansprakelijkheidsgronden worden genoemd die niet echt nieuw zijn te noemen vergeleken met het aansprakelijkheidsregime van vóór $1992 .{ }^{979}$

Kamerlid Van der Burg heeft nog een vergeefse poging gedaan bij amendement de regeling een zogenaamd 'sunset' karakter te geven van drie jaar, ${ }^{980}$ maar de minister heeft elke mogelijke toezegging over de geldingsduur weten te vermijden. Zoals dat wel vaker gaat met als tijdelijk bestempelde wettelijke regelingen, ${ }^{981}$ is de TRV nog onverminderd van kracht. Doorde nienuve beleidsljin.vande laatste jaren - uitbreiding van het regres - klinken wel steeds meer geluiden tot afschaffing. ${ }^{982} \mathrm{Bij}$ de invoering van een regresrecht in de volksverzekeringen enkele jaren geleden werden daarover kamervragen gesteld, maar de toenmalige regering Kok zag vooralsnog geen reden tot heroverweging. De minister achtte de argumenten die destijds waren aangevoerd nog steeds overtuigend. ${ }^{983}$ Een belangrijke reden hiervan lijkt te zijn geweest dat ook de SER, toen hij in 1993 naar de wenselijkheid van uitbreiding van het regres werd gevraagd, steun gaf aan de TRV. Dit zal hierna aan de orde komen, eerst volgt meer over de regeling zelf.

Inv. 6.p. 1404. De discussie over het regres is tevens aanleiding geweest om de kring van personen wier schade het gevolg is van het letsel van anderen te beperken, zie Inv, 6, p. 1288 en 1307 en Schadevergoedingsnechl. art. 107 (Bolt), aant. 2. Van Boom (2000a), p. 123 wijst erop dat het inmiddels met de toeloop van procedures lijkt mee te vallen. Volgens hem zijn er 'geen ervarinysregels die de opvatting staven dat nieuwe aansprakelijkheden tot een merkbare toename van het aantal civiele procedures leiden' en heeft de invoering van het nieuwe BW ook niet tot rechterlijke overbelasting geleid.' Imv. 6, p. 1409.

Hartlief \& Van Maanen (1991), p. 299; Hartlief \& Van Maanen (1994), p. 77; Van Maanen \& Romers (1994). Inv: 6, p. 1416.

Voor de Wet voorlopige regeling schadefonds geweldsmisdrjiven (Wet van 26 juni 1975, Sib. 382) is het predikat 'voorlopig' na bijna twintig jaar zonder ingrijpende wijzigingen komen te vervallen; sinds 1994 geldt de Wet Schadefonds Geweldsmisdrijven.

In die zin o.a. Kottenhagen-Edzes (1993), p. 308; Van Maanen (1998), p. 116 e. v; Van Boom (2000a), p 124. 


\title{
7.3.3 Inhoud en wetstechniek
}

De TRV bestaat uit maar één wetsartikel, art. 6:197 BW. Het geeft een uitzondering op de genoemde hoofdregel dat het aansprakelijkheidsrecht, óók de gronden voor risicoaansprakelijkheid, bij regres gewoon van (overeenkomstige) toepassing zijn. ${ }^{984}$ De TRV handhaaft dit uitgangspunt, maar bepaalt dat de gronden voor aansprakelijkheid die vergeleken met het oude recht 'nieuw' zijn te noemen niet kunnen gelden. Lid 1 geeft daarvoor een regeling die gericht is op de zelfstandige regresrechten. ${ }^{985}$ Het luidt volgens de huidige stand van zaken:

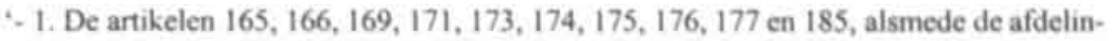
gen 4 van titel 6,4 van titel 11,1 van titel 14 en 4 van titel 19 van Boek 8 blijven buiten toepassing:
}

\begin{abstract}
a. bij de vaststelling van het totale bedrag waarvoor aansprakelijkheid naar burgerlijk recht zou bestaan, vereist voor de berekening van het bedrag waarvoor verhaal bestaat krachtens artikel $107 a$ en de artikelen 90 van de Wet op de Arbeidsongeschiktheidsverzekering, 68 van de Wet arbeidsongeschiktheidsverzekering zelfstandigen, 60 van de Wet arbeidsongeschiktheidsvoorziening jonggehandicapten, $52 a$ van de Ziektewet, 61 van de Algemene nabestaandenwet, $83 \mathrm{~b}$, eerste lid (?, EE) van de Ziekenfondswet, $65 \mathrm{~b}$ van [de] Algemene Wet Bijzondere Ziektekosten en 8 van de Wet Arbeidsongeschiktheidsvoorziening Militairen;

b. bij de vaststelling van het bedrag, bedoeld in artikel 3 van de Verhaalswet ongevallen ambtenaren waarboven de gehoudenheid krachtens die wet of krachtens artikel 70 van de Wet privatisering ABP zich niet uitstrekt.'
\end{abstract}

De opgesomde gronden voor aansprakelijkheid mogen door regresnemers met een zelfstandig regresrecht niet worden ingeroepen. Onnodig ingewikkeld is de technische constructie die daarvoor werd gekozen: de opgesomde aansprakelijkheidsgronden blijven buiten beschouwing bij het vaststellen van het civiele plafond. In de gevallen waarvoor de TRV geldt is de schadeveroorzaker dus niet op andere gronden aansprakelijk, dan hij tegenover de benadeelde zou zijn geweest (al wordt de regeling vaak zo verstaan). Wèl, daar zit de spreekwoordelijke adder, zijn de financiële gevolgen van zijn aansprakelijkheid beperkter dan ze zonder de TRV zouden zijn geweest. Bij het vaststellen van het civiele plafond moeten de in de TRV opgesomde gronden voor aansprakelijkheid immers alsnog buiten beschouwing blijven. Als dan blijkt dat niet tevens aan de voorwaarden voor aansprakelijkheid buiten de TRV is voldaan (bijvoorbeeld de voorwaarden van art. 6:162 BW), en het civiele plafond derhalve nihil is, dan is de schadeveroorzaker - ondanks zijn risicoaansprakelijkheid - geen betaling verschuldigd. Het is het civiele plafond, dat door de TRV wordt beperkt. Aan de grondslag van aansprakelijkheid doet 
dit - strikt genomen - geen afbreuk: ${ }^{986}$ pas bij het bepalen van de omvang van de verschuldigde regressom moeten de opgesomde aansprakelijkheidsgronden erbuiten blijven, en is het zaak dat tevens aan de voorwaarden van één van de gronden buiten de TRV is voldaan. Eenvoudiger was geweest om te bepalen dat de in de TRV opgesomde gronden van aansprakelijkheid 'überhaupt' niet door regresnemers kunnen worden ingeroepen, los van het civiele plafond. In de zelfstandige regresrechten wordt bepaald dat ze alleen kunnen worden ingeroepen jegens degene die 'volgens de regels van burgerlijk recht' aansprakelijk is. De wetgever had dus ermee kunnen volstaan te bepalen, dat de regresrechten alleen kunnen worden ingeroepen tegen degene die (ook) op andere dan de in de TRV opgesomde gronden met aansprakelijkheid wordt belast. Zo wordt de TRV meen ik ook wel verstaan.

Voor wat betreft het resultaat zal dit, linksom of rechtsom, veelal hetzelfde blijven. Hoewel immers de aansprakelijkheid strikt genomen eenvoudig is gevestigd (op basis van de opgesomde gronden voor risicoaansprakelijkheid), zal bij de vaststelling van het civiele plafond alsnog een persoonlijke fout moeten worden aangetoond. Maar om processuele redenen zal het vanuit het perspectief van de regresnemer gezien beter zijn de aansprakelijkheidsgrond buiten de TRV gelijk al op te voeren als primaire of subsidiaire grondslag voor aansprakeliikheid. Dat gebeurt ook al wel (maar dan wellicht alleen subsidiair).

A heeft bij de uitvoering van een opdracht voor $\mathrm{C}$ in een café zonder enige waarschuwing een kelderluik opengelaten. $\mathrm{Z}$ is daardoor ten val is gekomen. A biedt geen verhaal, maar $\mathrm{C}$ is in zijn hoedanigheid van opdrachtgever WA-verzekerd. Strikt genomen zou C volgens de constructie van de TRV weliswaar aansprakelijk zijn op grond van art. 6:171 BW, maar zou in het kader van het civiele plafond tevens aan de voorwaarden van art. 6:162 BW moeten zijn voldaan (en dus moet sprake zijn van een toerekenbare onrechtmatige daad van $\mathrm{C}$ jegens Z). Als de regresnemer dàt echter kan aantonen, dan zal het eenvoudiger en minder risicovol zijn om de onrechtmatige daad van $\mathrm{C}$ gelijk te laten dienen als de grondslag van aansprakelijkheid (opdat niet, naast de voorwaarden van art. 6:162 BW, ook nog eens de voorwaarden van art. 6:171 BW vervuld moeten zijn).

Ook in ander opzicht is de eigenlijke wettelijke constructie van de TRV ongelukkig. In het Convenant Verhaalsrecht 2001 is immers bindend met WA-verzekeraars afgesproken dat alle regresvorderingen die het UWV heeft met betrekking tot inkomensschade (ZW, WAO, WAZ en WAJONG), worden geacht (dat is onweerlegbaar) beneden het civiele plafond te blijven. Voor zulke vorderingen vindt een forfaitaire aftrek plaats, van de werkelijke beperkingen van het civiele plafond hebben verzekeraars afstand gedaan. ${ }^{987}$ Zou men nu de constructie van de TRV volgen, dan zou de TRV voor deze regresvorderingen 'überhaupt' geen beperkingen

Dere constructie past bij het karakter van de regeling De TRV benust immers niet op een principied onderscheid tussen aansprakelijkheid in regressituaties en daarbuiten. De regeling benust op pragmatische overwegingen, met name over de hoogte van de WA-premies en het ontbreken van de noodzaak van slachtofferbescherming voor regresnemende verzekeraars.

Aldus de artikelsgewijze toelichting bij het Convenent Verhaalsnecht 2001, p. 2. 
opleggen: zij zou pas haar intrede doen bij het vaststellen van het civiele plafond, terwijl die kwestie tussen partijen is gestandaardiseerd. Dat is natuurlijk niet de bedoeling. De meest redelijke uitleg van het Convenant is dan ook dat de regresvorderingen van het UWV ook dan alleen gelden voor de aansprakelijkheidsgronden buiten de TRV.

Het tweede lid van de TRV (art. 6:197 BW) geeft een regeling voor particuliere verzekeraars (sub $a$ ) en het Schadefonds Geweldsmisdrijven (sub $b$ ). Daarin worden dezelfde gronden voor aansprakelijkheid als in het eerste lid niet vatbaar verklaard voor subrogatie krachtens art. $284 \mathrm{WvK} / \mathrm{art}$. 7.17.2.25 BW en art. 6, derde lid, van de Wet Schadefonds Geweldsmisdrijven. Een uitzondering wordt gemaakt voor verzekeraars van de aansprakelijke, die regres zoeken op medeaansprakelijken of op andere WA-verzekeraars (lid 2 sub $a$, slot). Door de WA-verzekeraar kunnen de opgesomde gronden van risicoaansprakelijkheid dus wèl gewoon worden ingeroepen. De ratio hiervan is dat het geen verschil moet maken wie als eerste door de benadeelde wordt aangesproken. ${ }^{988}$ Zonder deze uitzondering zou de eerst aangesproken WA-verzekeraar immers in een ongunstigere positie verkeren dan de rest (terwijl de grondslag voor de betalingsplicht van ieder dezèlfde is). Hij zou ten opzichte van de benadeelde blootstaan aan de in de TRV genoemde risicoaansprakelijkheid, maar zou die vervolgens in een interne regresactie jegens medeschuldenaren niet mogen inroepen. Deze uitzondering binnen de TRV geldt volgens de bewoordingen van lid 2 slechts voor 'verzekeraars'. Dat zijn WA-verzekeraars inclusief WAM-verzekeraars, ${ }^{989}$ maar óók dunkt me het Waarborgfonds Motorverkeer (dat verkeersslachtoffers van een onbekende of onverzekerde dader schadeloos stelt). ${ }^{990}$ Haar positie is daardoor weliswaar beter dan die van het Schadefonds Geweldsmisdrijven, maar wat het Waarborgfonds in dit opzicht anders maakt is dat het net als WA-verzekeraars uitkeert op basis van de aansprakelijkheid van de schadeveroorzaker. ${ }^{991}$ Het is met betrekking tot de grondslag van haar betaling aan de benadeelde dus gelijk te stellen met medeaansprakelijken of WA-verzekeraars. Gelet op de genoemde ratio van de uitzondering zou het dan inconsequent zijn om het regresrecht van het Waarborgfonds Motorverkeer wèl aan de beperkingen van de TRV te onderwerpen: het fonds moet niet met een zwaardere aan-

\footnotetext{
$958 \quad \ln v, 6$, p. 1407.

959 De Bosch Kemper (1995), p. 81 stelt dat art. 284 WvK 6́ók geldt voor de WA-verzekeraar voor motorrijuigen, WAM-verzekeraars, en wijst daarvoor op lagere rechtspraak.

990 Art. 27 Wet aansprakelijkheidsverzekering motorrijtuigen geeft het Waarborgfonds Motorverkeer een regresrecht voor gevallen waarin het fonds de benadeelde heeft moeten schadeloosstellen, bijvoorbeeld omdat de aansprakelijke onverzekerd is (art. 25 lid 1 WAM). Het fonds heeft dan recht op verhaal op alle aansprakelijke personen, en op degene die zijn verplichting tot verzekering niet was nagekomen. Ook de minister merkt op dat art. 27 WAM gelijk is te stellen met het inteme regres van WA-verzekeraars, zie (uiterst summier) Inv. 6, p. 1409.

991 Zie art. 25 WAM. Het Warborgfonds is op die grond ook zelf aansprakelijk; haar aansprakelijkheid is hoofdelijk (Asser-Hartkamp 4-1, nr. 99). Zie voor een frai voorbeeld HR 3 november 1989, NJ 1990, 402 nt. JBMV (Ziekenfondsraad/Waarborgfonds Motorverkeer), waarin de Ziekenfondsraad (overigens in haar hoedanigheid als werkgever!) vanwege de onbekend gebleven dader regres zoekt op het fonds.
} 
sprakelijkheid belast zijn dat de schadeveroorzaker (in persoon). Een beperkt verhaalsrecht zou het Waarborgfonds terughoudender kunnen maken in haar uitkeringsbeleid. Maar dit laatste geldt natuurlijk óók en zelfs sterker nog voor het Schadefonds Geweldsmisdrijven en 'normale' particuliere en sociale verzekeraars. Anders immers dan deze 'normale' verzekeraars keert het Waarborgfonds Motorverkeer slechts uit bij verkeersongevallen; van de opgesomde gronden voor risicoaansprakelijkheid zullen dan ook eigenlijk met name art. 6:165 BW, art. 6:169 BW en afdeling 8.14.1 BW voor haar van belang zijn. ${ }^{992}$ Ook gevoelsmatig blijft het onderscheid dat de TRV maakt dubieus: de partijen uit 'het kamp van' de aansprakelijke (WA-verzekeraars, Waarborgfonds Motorverkeer) profiteren wèl van de opgesomde gronden, terwijl niet zelf aansprakelijke partijen (met name particuliere en sociale verzekeraars, werkgevers en het Schadefonds Geweldsmisdrijven) daarvan niet kunnen profiteren.

Als laatste onderdeel kent de TRV een nogal ingewikkeld geformuleerd derde lid. Regresnemers wier vordering door de TRV wordt beperkt, zo bepaalt dit, kunnen ook door overeenkomst aan de genoemde gronden voor aansprakelijkheid geen rechten ontlenen. Nu geen geldige overeenkomst kan worden gesloten kan de vordering van de benadeelde voorzover die berust op de uitgesloten gronden voor risicoaansprakelijkheid evenmin door cessie worden verkregen (dit zou dan immers een titelgebrek opleveren, vgl. art. 3:84 lid 1 BW). Verder bepaalt het derde lid dat voor de betrokken regresnemers ook namens de benadeelde geen betaling kan worden gevorderd.

$\mathrm{Al}$ met al zorgt de regeling dus voor een substantiële beperking van het regres. Op het gebied van letsel- en overlijdensschade springen dan in het bijzonder de uitsluiting van de drie titels van Boek $8 \mathrm{BW}$ (denk aan ongevallen in scheepvaart en transport), productaansprakelijkheid, en de aansprakelijkheid voor opstallen in het oog. Regresnemers moeten het doen met de niet in de TRV genoemde gronden voor risicoaansprakelijkheid in en buiten het Burgerlijk Wetboek, en waar relevant de regels van het contractenrecht en ongerechtvaardigde verrijking. Die gelden wèl nog gewoon voor regresnemers. ${ }^{993}$ Wel wijst de minister bij de totstandkoming van de TRV op de mogelijkheid om indien de omstandigheden het toelaten de bewijslast om te keren ten behoeve van de regresnemer. ${ }^{994}$ Het enkele

De risicoaansprakelijkheid van ant. 185 WVW gold ook al onder het oude recht en is daarom niet in de TRV opgenomen;vgl. reeds Rb. Rottendam 15 mei 1931,NJ1932, p. 202 (Centrale Werkgevers Risicobank/leman) waar haar voorloper, art. 25 Motor- en Rijwielwet (vervallen), van overeenkomstige toepassing wordt verklasud op het regresrecht van de oude Ongevallenwet.

993 Inv. 6, p. 1405. Daarin vindt het hof inzake Hof Leeuwanden 7 mei 1997, NJ1998, 292 (RZG/Stichting Savant) een argument tegen uitbreiding van de TRV: 'In grote lijnen gaat het bij art. 6:197 BW om een regeling ter zake van delictuele aansprakelijkheid, en niet - zoals in het onderhavige geval - om de contractuele aansprakelijkheid.' Inv 6, p. 1405. 
gegeven dat de schadeveroorzaker naar huidige maatstaven risicoaansprakelijk zou zijn geweest, lijkt me daarvoor onvoldoende. Alleen bij bijzondere materie̋le bewijsperikelen zal omkering van de bewijslast de nadelige gevolgen die de TRV vanuit het perspectief van de regresnemer gezien heeft, dan kunnen verzachten.

\subsubsection{Kritiek op TRV}

In de rechtsliteratuur is overwegend kritisch op de TRV gereageerd. ${ }^{995} \mathrm{Al}$ in 1984 wijst Van Maanen op het bezwaar van een tweedeling van het aansprakelijkheidsrecht die daarvan het gevolg is. ${ }^{996}$ In de gevallen van de TRV kent het aansprakelijkheidsregime immers belangrijke verschillen, vergeleken met het regime dat geldt voor de vordering tot schadevergoeding van de benadeelde zelf. Eén schadevoorval kan dan aanleiding geven tot twee regimes: cen 'slachtoffer'-regime van risicoaansprakelijkheid en een regime van foutaansprakelijkheid bij regres. ${ }^{997}$ Dat wordt overigens ook wel principieel onwenselijkgenoemd: men differentieert naar de hoedanigheid van een eiser. ${ }^{98}$ Of dàt zo overtuigend is betwijfel ik. Ongetwijfeld zou een beperking van de verhaalsmogelijkheden binnen het aansprakelijkheidsrecht zelf die de inhoud of geldingskracht van de norm uitsluitend afhankelijk zou laten zijn van de hoedanigheid van de eiser, dus zonder enig verband met de aard van aansprakelijkheid, verwerpelijk zijn. Indien de geschonden norm strekt tot bescherming van eisers belang gaat het niet op hem al bij voorbaat bescherming te ontzeggen op grond van zijn hoedanigheid of zijn vermogenstoestand. Het aansprakelijkheidsrecht moet gelijke bescherming bieden aan alle rechtssubjecten. Maar aan regresvorderingen ligt uiet de gedachte ten grondslag dat inbreuk is gemaakt op de belangen van de eiser. Regresrechten verbinden slechts vermogensrechtelijke consequenties aan de eenmaal gevestigde aansprakelijkheid van de schadeveroorzaker, net als de verhaalsrechten van art. 6:107 en 108 BW. ${ }^{999}$ Dat dan voor de toepasselijkheid van de aansprakelijkheidsregels wordt gedifferentieerd tussen benadeelde en verzekeraar lijkt me dan ook niet op principiële gronden verkeerd (in de zin van rechtsongelijkheid).

Ook vanuit praktisch oogpunt oogt de TRV bij eerste oogopslag bezwaarlijker dan zij vermoedelijk is: de achterstelling van regresnemers zou tot ingewikkelde toestanden kunnen leiden. Dat geldt hoofdzakelijk voor de zelfstandige regresrech-

Zie voor kritische reacties o.m. Mulder (1988), p. 136 e.v.; Hartlief \& Van Maanen (1991), p. 297 e.v.; Moller (1992), p. 1109 e.v.; Kottenhagen-Edzes (1993), p. 304 (met verdere verwijzingen naar kritische reacties); Van Maanen \& Rômers (1994), p. 57 e.v.; Van Maanen (1998), p. 116 e.v.; Van Boom (2000a), p. 124.

97. Zie ook Hartlief \& Van Maanen (1991), p. 292; Van Maanen \& Römers (1994); Van Maanen (1994); Faure \& Hartlief (1995), p. 59.

Zie o.a. Mulder (1988), p. 136, waar wordt gesteld dat de TRV ertoe leidt dat 'in vergelijkbare situaties, bij vergelijkbare aansprakelijkheden juridisch geheel verschillende gevolgen, en dus cen emstige vorm van rechtsongetijkheid ontstaat' (cursief toegevoegd, EE). 
ten, die staan immers los van de vordering van de benadeelde. Om dan te voorkomen dat de schadeveroorzaker (of WA-verzekeraar) door de cumulatie van beide vorderingen meermaals betaling verschuldigd is voor dezelfde schade, zijn beide vorderingen nauw op elkaar afgestemd. Daartoe wordt gebruik gemaakt van de constructie van het civiele plafond (de maximaal verschuldigde regressom). Daarvan moet het deel dat de schadeveroorzaker nog daadwerkelijk aan de benadeelde zelf verschuldigd is (het zogenaamde restbedrag) uiteraard worden afgetrokken (anders zou het risico van dubbele betaling immers nog steeds bestaan). ${ }^{1000}$ De omvang van het regres is dus afhankelijk van de vordering van de benadeelde. Door de TRV kan echter de grondslag van aansprakelijkheid voor de vordering van de benadeelde anders zijn (risicoaansprakelijkheid) dan voor de regresvordering (schuldaansprakelijkheid). Dit betekent dat voor het berekenen van het restbedrag alsnog moet worden nagegaan of aan de voorwaarden van de grond voor risicoaansprakelijkheid is voldaan, en welk bedrag dan op die grond nog aan de benadeelde verschuldigd is. Daar wordt de TRV dan wat problematisch, want de grondslag van aansprakelijkheid (risico- of schuldaansprakelijkheid) kan van invloed kan zijn op de omvang van de vordering: ${ }^{1001}$ het schadevergoedingsrecht biedt de mogelijkheid om bij het vaststellen van de omvang van aansprakelijkheid gewicht toe te kennen aan de aansprakelijkheidsgrond. ${ }^{1002}$

In de regresprocedure kan men er dan natuurlijk voor kiezen de zaak eenvoudig te houden. Men zal daarom wellicht aan de uiteenlopende grondslag van aansprakelijkheid bij het vaststellen van de omvang van het restbedrag geen betekenis toekennen. Dat zou de zaak alleen maar onnodig compliceren. Maar dat laat het risico onverlet dat in de wèrkelijke procedure van de benadeelde (waarvan de uitspraak voor de regresnemer geen gezag van gewijsde heeft) de omvang van aansprakelijkheid anders worden gewaardeerd dan in de regresprocedure. Enige realiteitszin gebiedt echter te zeggen dat het risico van een uiteenlopende beoordeling zich ook zonder de TRV al zal voordoen (met als eventuele consequentie dat de schuldenaar door het regres teveel betaalt of juist te weinig). Dat wordt nog eens extra in de hand gewerkt door de open normen van afdeling 6.1.10 BW. Dit risico bevordert de TRV hooguit, doordat óók de uiteenlopende grondslag van aansprakelijkheid reden kan zijn voor een andere beoordeling in de omvangfase. Ook daarbij past enige relativering. De grondslag van de vordering mag dan anders zijn bij regres, maar de feitelijke gedraging die tot de schade heeft geleid blijft dezelfde: het veroorzaken van letsel of overlijden. Voor één van de wellicht meest heikele punten die bij het vaststellen van het civiele plafond (c.q. het restbedrag) moeten worden ingeschat, het causale verband (art. 6:98 BW) geldt dan dat, ook

1000 Zie daarover uitvoeriger supra, paragraaf 7.2 .3 e.v.

1001 De minister miskent dit, zie Ink 6, p. 1406: "In de praktijk zal dit [de uiteenlopende grondslag van aunsprakelijkheid, EE] slechts zelden verschit maken, omdat het voor de hoogte van de schadevergoeding in beginsel niet uitmaakt welke aansprakelijkheidsgrond kan worden ingeroepen'.

1002 Zie met name art. 6:98 BW en 0.a. Spier e.a. (2000), nr. 198 (Hartlief) en Bloembergen \& Lindenbergh (2001). p. 33. 
daargelaten de precieze grondslag voor aansprakelijkheid, ruim wordt toegerekend. De grondslag van aansprakelijkheid biedt dan slechts een 'kapstok' voor een oordeel dat wellicht ook op grond van de aard van de schade al wel zou zijn gegeven.

Van Maanen en Römers wijzen erop dat de TRV een zeker stralingseffect zou kunnen hebben voor de overige, niet opgesomde gronden voor aansprakelijkheid. Op het gebied van verkeersaansprakelijkheid is de TRV inderdaad een aanknopingspunt geweest voor een achterstelling van regresnemers. ${ }^{1003}$ Afgezien daarvan lijkt van een stralingseffect echter (vooralsnog) geen sprake, zoals een arrest van het Leeuwardense hof illustreert. ${ }^{1004}$ Ook denkbaar is volgens hen dat de rechter in de TRV een aanwijzing ziet om zich bij het aannemen van aansprakelijkheid in de daarop betrekking hebbende gevallen terughoudend op te stellen. ${ }^{1005} \mathrm{Niet}$ uitgesloten is natuurlijk dat dàt ook gebeurt zonder de TRV, maar in de toelichting bij de TRV wordt de rechter voor enkele specifieke gevallen uitdrukkelijk de ruimte gelaten om terughoudender te zijn bij het aannemen van aansprakelijkheid in regreszaken. ${ }^{1006}$ Daar staat tegenover dat de minister, voor de toepassing van de TRV in het algemeen, juist de mogelijkheid benadrukt om indien de omstandigheden daartoe aanleiding geven regresnemers tegemoet te komen door omkering van de bewijslast. ${ }^{1007}$ Een ander punt van bezwaar is dunkt me, dat de TRV in de praktijk aanleiding geeft tot verwarring (en informatieperikelen), ${ }^{1008}$ hetgeen de uitvoering van het regres natuurlijk niet ten goede komt. In kringen van particuliere en sociale verzekeraars wordt nog wel eens gemeend dat het inroepen van gronden voor risicoaansprakelijkheid door regresnemers in het algemeen uitgesloten is. Het regres zou beperkt zijn tot aansprakelijkheid op schuldgrondslag. Die misvatting lijkt zelfs bewindslieden niet vreemd.

In een brief van (thans oud-)minister Sorgdrager over een nieuw voorstel van verkeersaansprakelijkheid stelt de minister: 'Nu het kabinet van oordeel is dat het regresrecht beperkt moet blijven tot de gevallen van schuld van de veroorzaker, is het mogelijk om tot een voorstel te komen voor een evenwichtige regeling van de verkeersaansprakelijkheid. ${ }^{1009}$ Nergens uit de kamerstukken blijkt daarvan. Sprake

1003 Van Maanen \& Römers (1994), p. 47 en hiema, paragraaf 7.3.7.

1004 Hof Leeuwarden 7 mei 1997, NJ 1998, 292 (RZG/Stichting Savant). Het hof ziet in art. 6:197 lid 2 BW geen reden voor het uitsluiten van de risicoaansprakelijkheid van de organisator van pakketreizen voor personenschade van deelnemers aan die reis (art. 7:507 BW), van het regres van schadeverzekeraars.

1005 In die zin reeds Van Maanen (1984), p. 173. Zo ook Mulder (1988), p. 136; Van Dam (1993), p. 170; Van Maanen \& Römers (1994), p. 47. Op het risico van dexe 'reflexwerking' bij het aansprakelijkheidsoordeel wordt ook gewezen in de toelichting Inv. 6, p. 1405.

1006 Dat geldt (Inv. 6, p. 1405) zowel met betrekking tot gevallen waarvoor art. 6:165 BW (aansprakelijkheid voor geestelijke of lichamelijke tekortkomingen) geldt, als die waarvoor 6:166 BW (groepsaansprakelijkheid) geldt.

1007 Inv. 6, p. 1405. Vgl. Kottenhagen-Edzes (1993), p. 306.

1008 In de zin dat het risico bestaat dat de rechter (en de aangesprokene) niet op de hoogte zijn van het verzekerd zijn van de benadeelde. Daarop wordt gewezen bij Onrechrmatige Daad 2, art. 6:197 BW (Van Maanen), aant. 10. Zie voorts: Van Maanen \& Rómers (1994), p. 46; Hartlief \& Tjittes (1999), p. 105; Van Boom (2000a), p. 125.

1009 Brief van minister Sorgdrager aan de voorzitter van de Twoede Kamer dd. 23 mei 1995, als Bijlage II opgenomen in TK 1994-95, 21 528, nr. 5 (Notitie Verkeeraansprakelijkheid). 
lijkt te zijn van de misvatting, dat de TRV zou berusten op een principiēle keuze van het kabinet voor beperking van het regres tot schuldaansprakelijkheid. Bij het herlezen van die passage lijkt dat ook te kunnen verklaren dat regresnemers volgens het onder deze minister geconcipieerde wetsontwerp Verkeersongevallen niet langer zouden profiteren van de risicoaansprakelijkheid van art. 185 Wegenverkeerswet (noch van de voorgestelde nieuwe regeling Verkeersongevallen). ${ }^{1010}$

Maar zulke misverstanden zeggen misschien meer over de rechtskennis van de betrokkenen. Valt het met de bezwaren bij de TRV dan toch eigenlijk, dit zo overziende, wel mee?

\subsubsection{Functies van het regres}

\subsubsection{HET PRINCIPE DAT DE SCHADEVEROORZAKER BETAALT}

Een wèl onoverkomelijk bezwaar is dat de TRV haaks staat op de ratio van het regres: het zorgen dat de schadeveroorzaker - ook het verzekerde deel van - de schade draagt. ${ }^{1011}$ De meerwaarde van het regres is dan juist, dat het de normen voor schuld- en risicoaansprakelijkheid handhaaft die onze visie op gerechtigheid (moeten) weerspiegelen. ${ }^{1012}$ Men hoeft deze opvatting uiteraard niet te delen, de kwestie rondom de doelstellingen van het regres is omstreden. Maar waar het om gaat is, dat als men regresnemers vanuit oogpunt van algemeen belang wil aanmoedigen tot het nemen van regres op de schadeveroorzaker (of WA-verzekeraar), hen dit niet extra moeizaam en kostbaar moet worden gemaakt. De TRV hinkt juist hierom op twee sporen.

Nu geeft het kabinet bij de invoering van de TRV daarvoor ook wel een principieel argument: slachtofferbescherming zou het belangrijkste motief vormen voor de in de TRV opgenomen aansprakelijkheidsregels. ${ }^{1013}$ De betekenis van dat argument is niet gering: de SER, de 'motor' voor de uitbreiding van het regres die de laatste jaren plaatsvond, stelt daarin het voornaamste argument te zien om de TRV te ondersteunen. ${ }^{1014}$ Maar dit is een bezwaarlijk argument voor wat betreft de visie op het aansprakelijkheidsrecht die eraan ten grondslag ligt. Het bevorderen van slachtofferbescherming kan wel een argument zijn geweest voor uitbreiding van het aansprakelijkheidsrecht, maar de gedragsnormen die door het argument

1010 In de Memorie van Toelichting bij het wetsvoorstel wordt die verslechtering van de positie van regresnemers echter nauwelijks gemotiveerd. zie TK 1997-98, 25 759, nr. 3 (MvT), p. 34 en 60; zie Van Maanen (1998), p. 116 c.v.; Hartlicf (1998), p. 257 c.v.: Engelhard \& Van Maanen (1998a), p. 62.

1011 Zie paragraaf 6.3.1. In die zin ook Van Dam (1993), p. 172; Van Maanen \& Rómers (1994), p. 55; Van Maanen (1998), p. 116 e. .; Van Boom (2000a), p. 124.

1012 Dat is de centrale doelstelling. In hoeverre het aansprakelijkheidsrecht die ook waarmaakt is omstreden, ne daarover paragraaf 6.5 .

1013 Inv. 6, p. 1409.

1014 SER-rapport 93/14 (1993), p. 39: 'vooral gelet op het feit dat slachtofferbescherming het belangrijkste motief voor deze nieuwe aansprakelijkheden [de in de TRV opgenomen gronden, EE] vormt: De passage wordt ook aangehaald door het Hof Lecuwarden 7 mei 1997, NJ 1998, 292 (RZG/Srichting Savant) als argument voor de uitbreiding van de TRV met art. 7:507 BW. 
van slachtofferbescherming zijn ingegeven en de rechtsverhouding tussen (potentiele) slachtoffers en schadeveroorzakers beheersen houden niet ineens op te bestaan indien de schade verzekerd blijkt te zijn. Bovendien verklaart het argument nog niet waarom de uitgesloten gronden van risicoaansprakelijkheid niet tevens zouden kunnen of behoren te gelden voor de regresnemende verzekeraars van de benadeelde. Gedragsnormen van het aansprakelijkheidsrecht geven precies aan onder welke omstandigheden de schadeveroorzaker rechtens een verwijt treft van de schade, dat is niet anders indien de benadeelde voor de schade is verzekerd. Juist ook de nieuwe, in de TRV uitgesloten gronden voor aansprakelijkheid reflecteren de geldende rechtsopvattingen over de verwijtbaarheid van bepaald schadeveroorzakend gedrag.

Denk aan het geval dat een groep jongeren een flinke rel ontketent in de buurt, naar aanleiding waarvan een vechtpartij ontstaat. Indien vaststaat dat één van hen daarbij ernstige schade heeft veroorzaakt en daarbij zelf is omgekomen, is er volgens art. 6:166 BW voldoende grond om de overige groepsdeelnemers voor die schade hoofdelijk aansprakelijk te stellen. Dat moet voorkomen dat ze erin slagen zich te bevrijden op de grond dat de schade ook zonder hun individuele bijdrage aan de rel zou zijn ontstaan. De gedachte is deze dat, nu ook hen daarvan een verwijt kan worden gemaakt, de financiële consequenties voor hun rekening behoren te komen. ${ }^{1015}$ Dat geldt niet voor deelnemers die zich, juist om die schade te voorkomen, tijdig hebben teruggetrokken uit de groep. Evenmin geldt het voor degene die het gevaar wegens zijn gebrekkige geestelijke ontwikkeling niet kon onderkennen. ${ }^{1016}$ Normen als deze maken deel uit van de thans geldende rechtsopvatting, en zijn geworteld in de rechtscultuur en het maatschappijbeeld. ${ }^{1017}$ Door de TRV komt alleen betekenis toe aan deze normen bij het onverzekerd zijn van de schade.

Het genoemde argument dat de uitgesloten aansprakelijkheidsgronden specifiek bedoeld waren ter bescherming van de benadeelde zelf, is voor art. 6:166 BW bovendien onjuist. Volgens de Toelichting Meijers berust deze regeling op het principe dat groepsgenoten zich niet aan hun verantwoordelijkheid behoren te kunnen onttrekken en op de solidariteit die het handelen in een groep met zich meebrengt. ${ }^{1018}$ De regeling blijkt vooral te zijn ingevoerd met het oog op het tweede lid waarin een onderlinge bijdrageplicht in gelijke delen wordt voorgeschreven (ongeacht de ernst van de door ieder gemaakte fouten). De hoedanigheid

1015 PG 6, p. 662.

1016 Art. 6:165 BW staat daaran niet in de wez; Imv, 6, p. 1351 en 1355. Hetrelfde geldt indien hij omdat hij invalide was niet in staat was zich terstond aan de betreffende situatie te onttrekken.

1017 De minister stelt dat ook het Wetboek 1809 al een regeling van die strekking kende, en dat zij ook geldt in verschillende omringende landen, PG 6. p. 662. Van Maanen \& Römers (1994), p. 20 wijzen erop dat de regeling in essentie ook goid onder het oude BW en dus ten onrechte is opgenomen in de TRV. 
van het slachtoffer of iets in die geest ${ }^{1019}$ bleef blijkens de wordingsgeschiedenis naar letter en geest onopgemerkt. ${ }^{1020}$ Als sprake is geweest van rechtens verwijtbare groepsdeelname, dan behoort het individuele groepslid zich -behoudens de genoemde restricties - niet aan aansprakelijkheid voor de schade te kunnen onttrekken op de grond dat hij het niet is geweest die de schade heeft veroorzaakt maar een ander. ${ }^{1021}$ Dat is een kwestie van rechtsopvatting, redelijkheid of gerechtigheid, die niets te maken heeft met de vraag wie de schade lijdt en of zij al door een verzekeraar van de benadeelde wordt vergoed. Het element van verwijtbaarheid maakt dat de schade dient te worden gedragen door de schadeveroorzaker, ongeacht of de benadeelde welgesteld of verzekerd is dan wel of het diens verzekeraar is die de vordering instelt.

Precies daarin ligt het bezwaarlijke van de TRV: het gaat er niet om dat een tweedeling naar eiser-type niet zou mogen, het gaat erom dat de differentiatie naar de inhoud van de norm onwenselijk is. Het is van tweeën één: of de enkele deelname aan gevaarzettend groepsgedrag is rechtens verwijtbaar (maar dan behoort daaraan rechtsgevolg te worden toegekend), of zij is dat niet.

\subsubsection{AfSCHAFFING OMWILLE VAN ZUIVERE KOSTENALLOCATIE?}

Zoals in hoofdstuk 6 werd aangegeven, wordt over de functies van het aansprakelijkheidsrecht echter verschillend gedacht. Volgens de meest gangbare opvatting, ook van de wetgever, staan andere functies dan rechtshandhaving en rechtsbeleving voorop. Regres wordt met name geassocieerd met het belang van zuivere kostenallocatie. Die functie voor het regres kwam al ter sprake en komt erop neer dat regresclaims de 'werkelijke' prijs van schadeveroorzakend gedrag duurder maken (degene die ervan het profijt heeft moet betalen), en daarmee de werkelijke kosten ervan beter zichtbaar maken. Dat zou van invloed kunnen zijn op het gedragsdan wel het activiteitenniveau en daarmee kunnen bijdragen aan preventie. Met het oog daarop stelt het kabinet, daarin ondersteund door de SER, 'dat regres op basis van schuldaansprakelijkheid een zuiverder kostentoerekening mogelijk maakt dan het verdergaande regres op basis van risicoaansprakelijkheid. ${ }^{1022}$ Dat is een opmerkelijk, omdat noch de wettelijke regresbepalingen noch de TRV op het onderscheid tussen fout- en risicoaansprakelijkheid berusten. Alleen gronden van

1019. Zoals de voordelen van de hoofdelijkheid of de andere specificke bewijsvoordelen voor de positie van de (persoon van de) eiser.

1020 Slechts wortt vermeld dat de concrete toepassing van de regeling mede betrekking heeft op schade aan de grasmat van het park of het plantsoen bij demonstraties, Imv, p. 1355. De CDA-fractie noemt nog de 'schade door vandalisme gepleegd in trein, bus, tram en voetbalstadions. 'Wellicht is dat typisch onverzekerde schade, maar uit niets blijkt dat dat punt van belang is geacht.

1021 Van Maanen \& ROmers (1994), p. 20 wijzen erop dat de gedragsnom die in art. 6:166 BW aan groepsoptreden is gesteld eigenlijk ook al besloten ligt in de zorgvuldigheidsnom van art. 6:162 BW. De meerwaarde ervan is technisch gezien vooral dat met het voldaan zijn aan de norm niet alleen de onrechtmatigheid vaststaat, maar ook het causale verband met de schade. 
risicoaansprakelijkheid die vergeleken met het oude aansprakelijkheidsregime nieuw zijn, zijn opgenomen. Zo is de aansprakelijkheid voor in turba gepleegde onrechtmatige daden (art. 6:166 BW), die eerder ter sprake kwam, een vorm van schuldaansprakelijkheid en toch opgenomen in de TRV. Hoe dit zijn mag, de stelling is dat het belang van zuivere kostenallocatie het beste gediend is met schuldaansprakelijkheid. ${ }^{1023}$ In de doctrine is er juist kritiek op de beperking van het regres tot schuldaansprakelijkheid vanuit het oogpunt van zuivere kostenallocatie. ${ }^{1024}$ Volgens Bloembergen strookt met het streven om 'ongevallen zo veel mogelijk toe te rekenen aan de veroorzakers van die ongevallen', veel beter een regresrecht waarbij ook risicoaansprakelijkheid geldt en niet alleen aansprakelijkheid op basis van persoonlijke fouten van de schadeveroorzaker. ${ }^{1025}$ Dat is tevens één van de overwegingen die ten grondslag liggen aan het negatieve advies van de Raad van State over uitbreiding van het regresrecht naar volksverzekeringen. De raad wijst erop dat van zuiverder kostentoerekening naar schadeveroorzakende activiteiten nauwelijks sprake zal zijn voorzover het regresrecht gebaseerd blijft op het schuldbeginsel. ${ }^{1026}$ Daarbij valt te bedenken, de raad stelt dit zelf niet, dat een groot deel van de vorderingen op het gebied van personenschade juist door regresnemers wordt afgewikkeld. ${ }^{1027}$ Dat betekent volgens Van Maanen ${ }^{1028}$ dat als verzekeraars niet over adequate verhaalsmogelijkheden beschikken, er van kostenallocatie weinig terecht zal komen.

\subsubsection{AFSCHAFFING VANUIT (ALGEMEEN) ECONOMISCH GEZICHTSPUNT}

Of is de beperking van het regres tot schuldaansprakelijkheid wenselijk uit oogpunt van preventie? Die gedachte schijnt te hebben voorgezeten bij de beperking van het regres tot gevallen van schuldaansprakelijkheid in het Zwitserse recht. ${ }^{1029}$ Ook zo bezien overigens zou de genoemde regeling van art. $6: 166 \mathrm{BW}$ dan beter uit de TRV worden geschrapt. Dat is immers een vorm van schuldaansprakelijkheid, die bovendien door het kabinet uitdrukkelijk een preventieve rol is toebedeeld. ${ }^{1030}$ De economische benadering biedt voor het $a$ priori uitsluiten van aansprakelijkheid op een risicogrondslag, echter geen steun. Deze benadering gaat zoals gezegd uit

1023 SER (1994), p. 11; in die richting ook Kremer (2000), nt. 29.

1024 Van Maanen (1984), p. 173; Hartlief \& Van Maanen (1991), p. 302; Van Dam (1993), p. 172; Van Maanen \& Römers (1994), p. 55; Van Maanen (1998), p. 116; Van Boom (2000a), p. 124

1025 Bloembergen (1994), p. 122.

1026 TK 1994-95, 24 169, B, p. 5.

1027 Bloembergen schatte in 1985 alleen al tweederde van de procedures van sociale verzekeraars, zie $\operatorname{lnv} 6, \mathrm{p} .1410$ Sinds toen is het aantal regresrechten fors uitgebreid, denk aan het werkgeversregres, volksverzekeringen en is het uitvoeringsbeleid actiever, denk aan de gestandaardiseerde afwikkeling en de bijzondere financiele prikkels voor ziekenfondsen, werkgevers en bepaalde schadeverzekeraars. Van Maanen (1998), p. 116 e.v.

1029 Fleming (1970), nt. 63. Beekman (1995), p. 1233 schrijft dat het regres in het aanvankelijke conceptwetsvoorstel voor uitbreiding van het regres naar de volksverzekeringen beperkt zou blijven tot schuldaansprakelijkheid.

1030 Zie Inv. 6, p. 1356, waar gesteld wordt dat 'het feit dat de vandaal uit eigen zak voor de schade moet opdraaien' preventief kan werken. 
van de potentiële schadeveroorzaker als 'homo economicus', ${ }^{1031}$ rationeel handelend met het doel zijn kosten te minimaliseren. Niet alleen schuld-, maar óók risicoaansprakelijkheid kan dan aanzetten tot preventie. Welke vorm van aansprakelijkheid het meest efficiënt is, is dan ook niet zo algemeen te zeggen. De voorkeur van schuld- boven risicoaansprakelijkheid veronderstelt dat sprake is van optimale zorgvuldigheidsnormen (zie art. 6:162 lid 3 slot), terwijl dat door het ontbreken van informatie of kennis bij de rechter dat lang niet altijd het geval is. ${ }^{1032} \mathrm{Bij}$ risicoaansprakelijkheid wordt aangeknoopt bij het schaderisico van bepaalde activiteiten en niet bij de verwijtbaarheid van de wijze waarop die activiteiten tot het verwezenlijken van dat risico hebben bijgedragen. ${ }^{1033}$ Wie wéét dat zijn activiteiten risicovol zijn en dat bij het verwezenlijken daarvan aansprakelijkheid dreigt, zal geneigd zijn voorzorgsmaatregelen te treffen of het erop te wagen. Wie wéét dat zijn activiteiten risicovol zijn en dat aansprakelijkheid alleen dreigt als dit risico zich door zijn schuld verwezenlijkt, kan geneigd zijn om meer zorg te betrachten, maar óók om niets te veranderen aan de mate waarin hij gebruik maakt van (potentieel) gevaarzettende activiteiten. Overigens kan daarnaast een verscheidenheid van andere factoren van invloed zijn op de mate van voorzichtigheid: gaat het om meer routinematige of bewust verrichte handelingen, welke alternatieven heeft de actor en handelt hij onder tijdsdruk, heeft hij voldoende kennis. ${ }^{1034}$ Een ander aandachtspunt dat bepalend is voor de voorkeur voor schuld- boven risicoaansprakelijkheid of omgekeerd zijn volgens de economische theorie de uitvoeringskosten. In het algemeen zullen gronden voor risicoaansprakelijkheid eenvoudiger (en met meer succes) kunnen worden ingeroepen. ${ }^{1035}$ Schuldaansprakelijkheid kan met relatief hogere uitvoeringskosten gepaard gaan, maar daar staat tegenover dat de uitvoeringskosten bij risicoaansprakelijkheid kunnen oplopen door het (potentieel) grotere aantal procedures. ${ }^{1036}$ Voor de gevallen waarin het regres is gecollectiveerd, makt het bovendien niet direct verschil. De keuze voor risico- of schuldaansprakelijkheid wordt ook in dit opzicht bemoeilijkt door de uiteenlopende varianten die daarbij mogelijk zijn (schuldvermoeden, eigen schuld).

Een keuze in abstracto is hierdoor eigenlijk niet te maken. ${ }^{1037}$ Duidelijk is hiermee wèl dat scepsis past bij (eventuele) voorstellen tot handhaving van de TRV

1031 Term bij M. Van Dam (2001), p. 149.

1032 Van den Bergh \& Faure (1990), p. 12 e.v.; Faure (1999), p. 260; Schafer \& Schōnenberger (2000), p. 597; M. van Dam (2001), p. 194 e.v.: Van Boom (2003), p. II e.v. Van Dam (1989), nr. 159 (noot 17); zie ook Faure (1999), p. 26I; M. van Dam (2001), p. 170.

Van Dam (1989), p. 217 e.v. en M. van Dam (2001), p. 149.

Hetgeen tevens tot gevolg kan hebben dat juist hiervan een sterkere prikkel uitgaat voor schadeveroorzakers om voorzorgsmaatregeien te treffen of zich van zijn activiteiten te onthouden; zie Van Dam (1989), p. 217: Sehafer \& Schonberger (2000), p. 597. Het hoge aantal procedures kan wel leiden tot meer uítvoeringskosten, M. van Dam (2001), p. 211.

1036 Faure (1996), p. 48; Schafer \& Schōnenberger (2000), p. 614. Zie ook M. van Dam (2001), p. 211, die voor aannjdingen van fietsers door automobilisten coneludeert dat een regel van risicoaansprakelijkheid met een absolut eigen schuld-verweer tot meer rechtsvorderingen leidt, gewone schuldaansprakelijkheid tot hogere procedurekosten, en de keure dus afhangt van de vraag waar kostenbesparing het zwaarst weegt. Zo ook M. van Dam (2001), p. 212 (op het gebied van verkeersaansprakelijkheid) 
(of een algehele beperking van het regres tot schuldaansprakelijkheid) omwille van het bevorderen van 'zuivere kostenallocatie' en preventie.

\subsubsection{Conclusie}

De commentaren in de literatuur, waarvan een deel in het voorgaande de revue passeerde, wijzen in de richting van afschaffing van de TRV. Die conclusie kan worden onderschreven. De TRV komt voort uit een tijd dat afschaffing van het regres in de rede lag; zij moest een uitbreiding van het regres ontmoedigen, althans voorkomen dat het nieuwe recht daartoe zou aanzetten. Zoals in hoofdstuk 4 werd gezien stimuleert de regering schadeverzekeraars, werkgevers en ziekenfondsen inmiddels juist om uitvoering te geven aan het regres. De TRV is ingehaald door de rechtsontwikkeling. Voorzichtigheid past wel, zoals bleek, bij sommige van de inhoudelijke argumenten voor afschaffing; met name de visie dat de TRV tot rechtsongelijkheid zou leiden moet worden verworpen. Dat uitbreiding van het regres naar de daarin genoemde gronden voor risicoaansprakelijkheid in het algemeen maatschappelijk efficiënter is, wordt door de rechtseconomische analyse niet ondersteund. Dat vergt gericht nader onderzoek voor elk van de deelterreinen van aansprakelijkheid waarop de TRV betrekking heeft.

\subsubsection{Differentiatie bij verkeersaansprakelijkheid}

Enkele jaren geleden echter vond de Hoge Raad in de Tijdelijke regeling verhaalsrechten een argument voor het uitsluiten van regresnemers van bijzondere bescherming die ongemotoriseerde verkeersslachtoffers volgens een vaste reeks arresten toekomt. De betekenis hiervan is redelijk groot, aangezien een belangrijk deel van het aantal regresvorderingen, en verreweg het grootste deel van de regresopbrengsten voor verzekeraars bij personenschade, ${ }^{1038}$ betrekking heeft op verkeersongevallen. In een rapport van de Algemene Rekenkamer uit 1996 wordt het aantal regreszaken van sociale verzekeraars dat daarop betrekking heeft geschat op $90 \%{ }^{1039}$ Wel heeft vermoedelijk, het rapport zegt dit niet, maar een beperkt aantal gevallen betrekking op aanrijdingen van voetgangers en fietsers door motorrijtuigen. Juist voor deze - meest kwetsbare -groep van verkeersslachtoffers geldt (vooralsnog) de bijzondere aansprakelijkheid voor motorrijtuigen, art. 185 Wegenverkeerswet 1994. Deze regeling is niet opgenomen in de TRV en geldt dus ook gewoon voor regresnemers. Zij houdt de eigenaar of houder van een motorrijtuig

1038 Van de 120 miljoen gulden die de Federatie van Bedrijfsverenigingen begin jaren negentig beraamde voor de uitbreiding van het regres als gevoig van het vervallen van de AAW, bijvoorbeeld, had 110 miljoen gulden betrekking op verkeersongevallen; Sociale Verzekeringsraad (1993), p. 33.

1039 Opgenomen in TK 1996-97, 25 025, nr. 2, p. 8. De Studiegroep Verkeersaansprakelijkheid (1978), p. 106, en meer recent ook de Sociale Verzekeringsraad (1993), p. 7, scharten op basis van gegevens van de (oude) bedrijfsverenigingen dat ongeveer $95 \%$ van het WAO-regres betrekking had op verkeersongevallen. Duidelijk is dat het gaat om een groot percentage. 
aansprakelijk voor de schade van deze slachtoffers buiten dat voertuig, tenzij sprake is van overmacht. Zij berust op de gedachte dat men door het hebben of houden daarvan, indien daarmee aan het verkeer wordt deelgenomen, niet-gemotoriseerde verkeersdeelnemers blootstelt aan het extra schaderisico van massa en snelheid. ${ }^{1040}$ Ter aanvulling van deze regeling geldt een aantal arresten. Die moeten worden gezien tegen de achtergrond van de falende pogingen van de wetgever om te komen tot een verbeterd regime van slachtofferbescherming bij verkeersaansprakelijkheid. ${ }^{1041}$ De Hoge Raad ontwikkelde op basis van (thans) art. 185 WVW een vergaand regime van aansprakelijkheid voor de bescherming van ongemotoriseerde verkeersdeelnemers. Met name de mogelijkheid van het beroep op overmacht dan wel vermindering van aansprakelijkheid wegens eigen schuld van het slachtoffer zijn in die arresten vergaand beperkt. Het voert te ver, en is ook niet nodig, daarvan hier een volledige beschrijving te geven. ${ }^{1042}$ Volstaan zal worden met een overzicht en bespreking van de relevante ontwikkelingen voor regresnemers.

Aanvankelijk leek de Hoge Raad in dit verband geen onderscheid te maken tussen het belang daarvan voor het ongemotoriseerde slachtoffer en regresnemende verzekeraars. Het bekende voorbeeld is het arrest Dillema $I^{1043}$ het ziekenfonds zocht regres voor de schade van een vierjarig kind na een aanrijding en kreeg van de zijde van de aanrijdende automobilist eigen schuld van het kind tegengeworpen. Dat zou dan een beperking opleveren van het civiele plafond, en daarmee van het regresrecht van het fonds. De Hoge Raad stelde echter voorop dat het gemotoriseerde verkeer voor zeer jeugdige kinderen extra risico's meebrengt vanwege hun onvermogen daarmee op passende wijze rekening te houden. Als het kind wordt aangereden door een automobilist aan wiens onvoorzichtigheid de aanrijding is te wijten, dan dient de - aan de leeftijd inherente - eigen schuld van dat kind dan ook niet te kunnen leiden tot beperking van zijn recht op schadevergoeding. Dat impliceerde dat ook de vordering van het ziekenfonds daarvan geen beperking onderging. Een eerste voorzichtige aanwijzing dat dit laatste anders moest was een obiter dictum in het belangrijke Kolkman-arrest uit $1990 .{ }^{1044}$ In dat arrest oordeelde de Hoge Raad voor het eerst dat eigen schuld van ongemotoriseerde verkeersslachtoffers die jonger zijn dan veertien jaar oud, behoudens opzet of aan

1040 Zie 0.a. TK 1997-98, 25 759, nr. 3 (MvT), p. 2 en 13 en p. 16 e.v.; Asser-Hartkamp 4-III, nr. 222; Engelhard \& Van Maanen (1998a), p. 14; Van Maanen (1999), p. 54; Hartlief (2001b), p. 53; Van Dam (2001), p. 116.

1041 Aanvankelijk door Meijers' ontwerp voor een risicoaansprakelijkheid, art. 6.3.14 BW (zie PG 6, p. 772 e.v.) dat zonder veel omhaal is geschrapt (PG 6, p. 782), gevolgd door het genoemde voorstel tot invoering van een risicoaansprakelijkheid of verkeersverzekering van de Studiegroep Verkeersaansprakelijkheid (1978), de Notitie Verkeersaansprakelijkheid (TK 1989-90, 21 528, nr. 1), het wetsvoorstel tot Vaststelling en invoering van afdeling 8.14.1 (Verkeersongevallen), TK 1997-98, 25 759, nr. 1-3; gewijzigd bij TK 1998-99, 25759 , nr. 5. Zie uitvoerig M. van Dam (2001), p. 79 e.v en voorts Engelhard \& Van Maanen (1998a), hoofdstuk 2 en $(1999 b)$, p. 135.

1042 Zie voor een actuele en grondige bespreking M. van Dam (2001), p. 82 c.v.

1043 HR 30 juni 1978, NJ 1978, 685 nt. GJS (APF Ziekenfonds/De Boer).

1044 HR I juni 1990, NJ 1991, 720 nt. CJHB (Kolkman/Nationale Nederlanden). 
opzet grenzende roekeloosheid van het kind 'überhaupt' niet in aanmerking mag worden genomen bij het vaststellen van hun recht op schadevergoeding. Dat sprake was van schuld aan de zijde van de automobilist is daarvoor (kennelijk) niet meer van belang. Maar de raad benadrukte dat alleen de vraag naar bescherming van het aangereden kind zèlf ter beoordeling stond. In het midden kon blijven of hetzelfde behoort te gelden als de particuliere of sociale verzekeraar de schade van het kind voor zijn rekening heeft genomen en daarvoor verhaal zoekt. Daarbij zijn namelijk, zo stelt de Hoge Raad het, de belangen van het kind niet betrokken. De bescherming van deze jeugdige verkeersslachtoffers in de zin van art. 185 WVW werd voltooid door 's raads oordeel inzake De Backer/Van Uitregt. De Hoge Raad besliste dat in die gevallen behoudens opzet of aan opzet grenzende roekeloosheid van het kind ook geen overmacht kan worden tegengeworpen. ${ }^{1045}$ In beginsel heeft deze categorie verkeersdeelnemers dus, ongeacht de verdere toedracht van het ongeval, recht op $100 \%$ vergoeding van hun schade. ${ }^{1046}$ In HR 28 februari 1992, NJ 1993, 566 nt. CJHB (IZA/Vrerink) formuleerde de Hoge Raad een regel voor ongemotoriseerden van veertien jaar en ouder. Zij hebben bij eigen schuld recht op vergoeding van ten minste $50 \%$ van hun schade, tenzij sprake is van opzet of daaraan grenzende roekeloosheid van henzelf. Regresnemende particuliere en sociale verzekeraars mogen echter niet van de $50 \%$ regel profiteren, omdat het schaderisico van het slachtoffer in die gevallen al door verzekering was gespreid. Deze differentiatie tussen regresnemers en de benadeelde strookt volgens de raad met de Tijdelijke regeling verhaalsrechten, nu daaraan de gedachte ten grondslag ligt dat:

'uitbreidingen van aansprakelijkheidsgronden met het oog op de belangen van de slachtoffers niet zonder meer ook voor de regresrechten van hun verzekeraars behoren te gelden.'

In de zogenaamde 2 -Juni-arresten ${ }^{1047}$ oordeelde de raad in dezelfde zin voor de $100 \%$ regel voor jeugdige ongemotoriseerden. Net als bij fietsers en voetgangers van veertien jaar en ouder:

\footnotetext{
'verliest dit billijkheidsargument zijn gewicht ingeval de schade ten laste van een verzekeraar is gekomen, omdat het risico aan de zijde van het slachtoffer, zij het tegen betaling van premie, reeds door middel van een verzekering was gespreid. Mede in aanmerking genomen dat beide regels de resultante zijn van dezelfde rechtsontwikkeling (...), bestaat voor een uiteenlopend regime ten aanzien van regresvorderingen dan ook geen genoegzame rechtvaardiging, ${ }^{\text {, }}$
}

1045 HR 31 mei 1991, NJ 1991, 721 nt. CJHB (De Backer/Van Vitregf).

1046 Vgl. HR 24 december 1993, NJ 1995, $236 \mathrm{nt}$. CJHB (Sikes/Kellenaers). De regels van Van Vitregi (in alle gevallen behalve opzet of daaraan grenzende roekeloosheid vergoeding) en Kolkman (alle schade wordt in die gevallen vergoed) vormen tezamen de zogenaamde 100 \%-regel. Ze worden technisch gebascerd op de billijkheids correctie van art. 6:101 lid I BW, slot (hoewel dat voor het Van Vitregt-arrest wat minder zuiver is).

1047 HR 2 juni 1995, NJ 1995, $700 \mathrm{nt}$. CJHB (Klaverblad/TZA).

104 Spier (1996), nt. 9 wijst erop dat de Hoge Raad niet meer naar de TRV verwijst. 
Uit meer recente verkeersarresten is duidelijk geworden dat de Hoge Raad blijft vasthouden aan deze lijn. ${ }^{1049}$ In de zogenaamde Sinterklaas-arresten wordt daarvoor nog een nieuw argument aangevoerd. ${ }^{1050}$ De raad stelt voorop dat de $50 \%$ en $100 \%$ regels zijn ingegeven door het grote gewicht van het persoonlijke belang dat het slachtoffer zelf heeft bij vergoeding van zijn schade en het maatschappelijke belang van bescherming van deze verkeersslachtoffers. Een extra argument ter onderbouwing van het verschil tussen eisers (verzekeraar of benadeelde zelf) ligt bij de noodzaak van een doelmatige slachtofferbescherming. De 'standaardisering' van de $50 \%$ en $100 \%$ regels is mede ingegeven door de behoefte van verkeersslachtoffers met onverzekerde schade aan een eenvoudig en snel vast te stellen aansprakelijkheid. ${ }^{1051} \mathrm{Bij}$ regresvorderingen van verzekeraars is voor een standaardisering die is ingegeven door de behoefte aan compensatie geen plaats. Verzekeraars moeten in beginsel in staat worden geacht om zelf door collectief overleg tot de door hen nodig geachte mate van standaardisering te komen. Hartlief wijst erop dat dit een snelle en efficiënte afwikkeling van regresdossiers niet ten goede komt. ${ }^{1052}$ Dit lijkt juist, vooralsnog zijn alleen in het ANW-en het AWBZ-Convenant afspraken neergelegd die tevens tot gevolg hebben dat de discussies over schuld en eigen schuld worden vermeden. Daarbuiten, ook in het WAO-Convenant Verhaalsrecht, is men in het maken van algemene afspraken niet geslaagd. Welke regels gelden dan wèl voor regresnemende verzekeraars? ${ }^{1053}$ Voor alle regresnemers geldt de normale regeling van art. $185 \mathrm{WVW}$ en de algemene rechtspraak in dat verband, zoals de al genoemde rechtspraak over de uitleg van de term overmacht van art. 185 WVW. Het is aan de eigenaar of houder van het motorrijtuig dan wel de WAM-verzekeraar, om de feiten te bewijzen op grond waarvan kan worden aangenomen dat daarvan sprake is. Overmacht in de zin van art. $185 \mathrm{WVW}$ wordt in de rechtspraak echter zeer restrictief uitgelegd en daarbij worden hoge eisen gesteld aan de bestuurder van het motorrijtuig. ${ }^{1054}$ Het beroep

1049 HR 5 december 1997, NJ 1998, 400-402 nt. JH (Terminus/Z1O enz); HR 10 november 2000, NJ 2000, 718 (LevobVan den Bes); HR 17 november 2000, NJ 2001, 260 nt. CJHB (FBTODelta Lloyd). Zie o.a. Hartlief (1996), p. 1047; Spier (1996), p. 41 e.vi; Hartlief (1998), p. 258; Van Boom (2000a), p. 43 e.v.; Engelhard (2001d), p. 107: Hartlief (2001b), p. 50: M. van Dam (2001), p. 93 e.v.

HR 5 december 1997, NJ 1998, 400-402 nt. JH (Terminua/Z1O enz).

Zie de NJ-noot van Hijma bij het arrest; en vgl. Van Boom (2000a), p. 46 en M. van Dam (2001), p. 96. Hartief (1998), p. 257 e.v. Hij krijgt daarin bijval van Van Boom (2000a), p. 48 en op p. 116.

Hartlief (1996), p. 1314; Spier (1996), p. 35 e.v.; M. van Dam (2001), p. 93 e.v. Vgl. ook Van Maanen \& Römers (1994), p. 47; en Engelhard \& Van Maanen (1998a), par. 2.10.2.

Aannemelijk moet zijn dat de bestuurder 'rechtens geen enkel verwijt' te maken valt van het ongeval. Dat is niet spoedig het geval: gebreken van het motomijtuig bevrijden niet en aan het rijgedrag van de bestuurder worden hoge eisen gesteld. Fouten van anderen, wasronder de beradeelde zelf, kunnen alleen overmacht opleveren als ax voor de bestuurder van het motorrijtuig zo onwaarschijnlijk waren dat hij daarmee geen rekening behoefde te houden, aldus o.a. HR 22 mei 1992, NJ 1992, 527 (ABP/Winterthur): HR 4 oktober 1996, NJ 1997, 147 nt. CJHB (DV/sona Klaverblad); HR 5 december 1997, NJ 1998, 209 (Wijnings Klaverblad). Zie Hartlief (1996). p. 1314 e.v. en M. van Dam (2001), p. 82 e.v. 
daarop wordt dan ook veelvuldig afgewezen, óók in regreszaken. ${ }^{1055}$ Als het beroep op overmacht van de eigenaar of houder van het motorrijtuig niet aannemelijk is, dan staat daarmee zijn aansprakelijkheid vast, maar is er wel nog ruimte voor een beroep op eigen schuld van het slachtoffer. Een geslaagd beroep op eigen schuld kan leiden tot een vermindering van de verschuldigde regressom, mogelijk zelfs van $100 \%$. De leeftijd van het slachtoffer staat daaraan niet reeds bij voorbaat in de weg. Voor de vraag naar eigen schuld wordt de regeling van art. 6:101 lid $1 \mathrm{BW}$ 'normaal' toegepast. Dit houdt in dat primair moet worden beoordeeld op basis van een causale verdeling moet worden gemaakt naar de mate waarin het gedrag van de bestuurder enerzijds en anderzijds het gedrag van het slachtoffer onderling tot de schade hebben bijgedragen. Bij het maken van die verdeling dient uitsluitend te worden gekeken naar het bloot-causale gedrag van beide, niet naar de mate van verwijtbaarheid daarvan. ${ }^{1056}$ Anders dan bij vorderingen van de benadeelde zelf (waarvoor de $50 \%$ en $100 \%$ regels gelden) is slechts plaats voor een beperkte billijkheidscorrectie, indien de bijzondere omstandigheden van het geval daartoe aanleiding geven (zie art. 6:101 lid $1 \mathrm{BW}$ slot). Het gaat om een individuele correctie, zonder $50 \%$ en $100 \%$ regels. De mogelijkheid daartoe is: ${ }^{1057}$

'anders dan het middel voorstaat - niet beperkt tot 'uitzonderlijke omstandigheden. Rekening moet hier derhalve worden gehouden met alle relevante omstandigheden zowel aan de zijde van de bestuurder als aan de zijde van het verkeersslachtoffer, waaronder zowel de ernst van ieders fout als de mate waarin zijn gedragingen hem kunnen worden verweten.'

Aan welke gevallen moet dan worden gedacht? Een typisch voorbeeld is het geval dat een kind door zijn jeugdige leeftijd geen ernstig verwijt kan worden gemaakt van diens eigen verkeersfout, ${ }^{1058}$ terwijl die fout wèl bepalend is geweest voor het ontstaan van zijn schade (zoals bij het plotseling het wegdek oprennen). ${ }^{10 s 9}$ Ook het aan motorrijtuigen inherente gevaar van massa en snelheid ('Betriebsgefahr'), dat tevens de grondslag vormt voor aansprakelijkheid ingevolge art. 185

1055 O.m. in HR 17 november 2000, NJ 2001, $260 \mathrm{nt}$. CJHB (FBTOVDelta Lloyd) wordt het beroep op overmacht ten voordele van de regresnemende instantie afgewezen. In HR 16 februari 1996, NJ 1996, 393 (Staat, ABP, Plomp/Royal) wordt het echter wèl gehonorcerd. In HR 31 mei 2002, saaksnr. C00/107HR (Bijlsma/Srichting Pensioenfonds ABP), werd het beroep opovermacht ook gehonoreerd ten behoeve van de regresnemer, namelijk in het kader van de 'reflexwerking' van ant. 185 WVW (men volge de hoofdtekst).

1056 Zie o.a. Hartlief (1996), p. 1310 e.v.; Hartlief (1998), p. 258; Hartlief (2001b), p. 50; M. van Dam (2001), p. 95. Het aan motorrijtuigen inherente gevaar ('Betriebsgefahr') is geen omstandigheid waaraan bij de causale afweging gewicht mag worden toegekend, aldus HR 10 november 2000, NJ 2000, 718 (Levob/Van den Bos) en daarover Engelhard (2001d). p. 108.

1057 HR 5-december 1997, NJ 1998, 400-402 nt. IH (Terminus/2AO enz).

1058 Asser-Hartkamp 4-1, nr. 451a; vgl. ook HR 30 juni 1978, NJ 1978, 685 nt. GJS (Ebele Dillema) en HR 8 december 1989, NJ 1990, $778 \mathrm{nt}$. CJHB (Vrieling/Rurdde).

HR 5 december 1997, NJ 1998, $400 \mathrm{nt}$. JH (Terminus/ZAO enz). 
WVW, lijkt als afzonderlijke factor te mogen meewegen. ${ }^{1060}$ Hoe zwaarwegend de factor Betriebsgefahr dan moet tellen is nog onduidelijk. Hartlief oppert dat het wellicht beter zou zijn regresvorderingen alleen af te handelen op basis van de causale verdeling van art. 6:101 lid $1 \mathrm{BW}$ en de billijkheidscorrectie voor wel heel bijzondere gevallen te reserveren. Als alleen de meer objectieve mate van gevaarzetting wordt meegewogen, bevordert dit volgens hem een vlotte afhandeling en dat kan de kosten beperkt houden. ${ }^{1061}$ De precieze betekenis hiervan is nog onduidelijk. ${ }^{1062}$

De Hoge Raad benadrukt dat het gewicht dat aan dergelijke omstandigheden toekomt slechts tot een bijstelling van beperkte omvang zal kunnen leiden. Door deze billijkheidscorrectie mag dus niet met een omweg het resultaat worden bereikt waartoe de $50 \%$ of $100 \%$-regel zouden hebben geleid. Goed mogelijk is, dunkt me, dat dit tot gevolg heeft dat men in meer gevallen zal verkiezen om maar met een causale verdeling te volstaan, en zich niet zal wagen aan deze (onduidelijke) billijkheidscorrectie van meer dan het causale resultaat en minder dan $50 \%$ of $100 \%{ }^{1063}$ Dat is, dunkt me, opmerkelijk omdat daarmee een beperking wordt geỉntroduceerd die niet geldt regresprocedures voor gemotoriseerde slachtoffers, zoals passagiers of andere bestuurders! Daar geldt de mogelijkheid van een billijkheidscorrectie immers in beginsel óók gewoon (al zal daaryoor wellicht minder snel aanleiding zijn dan bij ongemotoriseerde slachtoffers). Als een passagier gewond is geraakt door een verkeersfout van de bestuurder (art. 6:162 BW), dan kan de bestuurder het ziekenfonds in de regresprocedure tegenwerpen dat de passagier geen veiligheidsgordel droeg. ${ }^{1064}$ Als de omstandigheden in het voertuig (of: voor de passagier) van dien aard waren dat de passagier een goede reden had om geen gordel te dragen kan dan heel wel aanleiding zijn voor een billijkheidscorrectie. Dat geldt met name als de verkeersfout van de bestuurder zo gering was (kleine onoplettendheid) dat deze causaal in het niet valt in verhouding tot dit nalaten van de passagier. Daarvan kan onder meer sprake zijn bij een klein ongeval dat door eigen schuld van het slachtoffer toch tot enorme schade leidt, bijvoorbeeld een ernstige whiplash door het niet dragen van de gordel. Anders dan bij ongemotoriseerde slachtoffers kan het resultaat van de causale afweging voor regresnemers in die gevallen, als daarvoor reden is (de passagier was fysiek onwel geworden

1060 HR 10 november 2000, NJ 2000, 718 (Levob/Van den Bos). Daarover kritisch Hartlief (2001b), p. 50 die het meer voor de hand liggend had geleken dat de factor 'Betriebsgefahr' bij de causale afweging in aanmerking wordt genomen. Juist daarbij gaat het immers om weging van de mate van gevaarzetting. Het Betriebsgefahr zou dan bij de waardering van de door de bestuurder gemaakte fout kunnen worden meegewogen, zo stelt Hartlief, en dus niet noodzakelijk als extra factor er bovenop.

106) Hartlief (1998), p. 260; daarover ook M. van Dam (2001), p. 99.

1062 Hartlief $(2001 b)$, p. 51.

$1063 \mathrm{Vgl}$. Hof Amhem 16 november 1999, NU 2000, 727 (Klawerblad/RA) (causale verdeling, geen biltijkheidscorretie), en daarover NTBR 2001, 158 (Engelhard); voorts Hartlief (1996), p. 1047 e.v.; Hartlief \& Tjittes (1999). p. 144; Van Boom (2000a), p. 47; M. van Dam (2001), p. 93 c.v.

1064 Voorbeeld ontleend aan Imv. 6, p. 1286, maar vgl. ook Hof Den Bosch 3 februari 1953, NJ 1953, 735 (Van der Heiden/Jansen). 
of werd onheus bejegend door de bestuurder), eventueel wèl gewoon volledig worden bijgesteld.

Zoveel is duidelijk, de 'standaard' $50 \%$ en $100 \%$ vergoedingsregels voor ongemotoriseerde verkeersslachtoffers gelden niet voor regresnemers. Daarbuiten moeten de regeling van art. 185 WVW en art. 6:101 BW in beginsel 'normaal' worden toegepast. Voor eigen schuld betekent dit dat de schade op basis van ieders (gemotoriseerde bestuurder en de benadeelde) causale bijdrage aan het ontstaan van de schade moet worden verdeeld. Bij bijzondere omstandigheden is een beperkte billijkheidscorrectie mogelijk in het voordeel van de regresnemer; het resultaat daarvan mag echter geen benadering zijn van het resultaat waartoe de $50 \%$ of $100 \%$ regel zouden leiden.

Ten slotte verdient nog opmerking dat ook sprake lijkt van een onderscheid tussen regresnemers en de positie van het verkeersslachtoffer, maar dan op een aanmerkelijk genuanceerder niveau, bij de situatie waarin de regeling van art. $185 \mathrm{WVW}$ zogenaamde reflexwerking heeft: gemotoriseerden die zèlf slachtoffer worden van een ongeval dat te wijten is aan een fietser of andere ongemotoriseerde verkeersdeelsnemer hebben alleen dan recht op volledige schadevergoeding als ze kunnen aantonen dat, naast de onrechtmatige daad van de fietser, voor henzèlf sprake is geweest van overmacht. ${ }^{1065}$ In het arrest Bijlsma/Stichting Pensioenfonds ABP werd dit laatste ook gehonoreerd ten behoeve van de regresnemer. ${ }^{1060}$ In de bedoelde zaak was fietser Bijlsma, toen zij op het fietspad door een bromfietser werd gepasseerd, ineens linksaf geslagen, zonder richting aan te geven. De bromfietser is daarbij ten val gekomen en heeft zijn heup gebroken. De Stichting Pensioenfonds $\mathrm{ABP}$ heeft de schade voor haar rekening genomen en daarop met succes de (overigens WA-verzekerde) fietser aangesproken. ${ }^{1067}$ Aan de $50 \%$ en $100 \%$ regels komt dan, zo volgt uit het eerdere arrest Chan/Maalsté, ${ }^{1068}$ met of zonder regres geen reflexwerking toe. Wel lijkt het verzekerd zijn van de schade van gemotoriseerde slachtoffers, naast het Betriebsgefahr, ook voor hun regresnemende verzekeraar de mogelijkheid van een billijkheidscorrectie bij eigen schuld nadelig te beïnvloeden. ${ }^{1069}$ Het maakt het verkeersaansprakelijkheidsregime in het kader van art. $185 \mathrm{WVW}$, het totaal overziende, niet bepaald eenvoudig.

1065 HR 6 februari 1987, NJ 1988, 57 nt. CJHB (GAFLICMulder); zie voorts Spier e.a. (2000), nr. 232 (Hartlief) waar ook voorbeelden van reflexwerking van andere gronden voor aansprakelijkheid worden genoemd. HR 31 mei 2002, zaaksnr. C00/107HR (Bijlsma/Stichting Pensioenfonds ABP).

1067 Zie voor een overzicht Engelhand (2001c), p. 478 e.v.

1068 HR 4 mei 2001, NJ 2002, 214 nt. CJHB (Chan/Maalste).

1069 HR 4 mei 2001, NJ 2002, 214 nt. CJHB (Chan/Maalste), r.o. 3.7.2. Zie meer uitvoerig Hanlief (2001), p. 73 en Engeihard (2001c), p. 482. 


\subsubsection{Uitsluiting van $50 \%$ en $100 \%$ regels juist?}

De reacties in de rechtsliteratuur op de door de Hoge Raad geïntroduceerde tweedeling bij verkeersaansprakelijkheid zijn verschillend, maar overwegend kritisch. ${ }^{1070}$ Het principiële argument dat de Hoge Raad geeft voor het uitsluiten van regresnemende verzekeraars van de $50 \%$ en $100 \%$ vergoedingsregels is dat deze regels strekken tot schadeloosstelling van het slachtoffer en het maatschappelijke belang van het bevorderen van de vergoeding van verkeersslachtoffers. ${ }^{1071} \mathrm{Bij}$ regresvorderingen heeft het slachtoffer zijn schade al vergoed gekregen. ${ }^{1072}$ Meer in het algemeen is dat voor het uitsluiten van aansprakelijkheidsregels bij regres weinig overtuigend. Dat het slachtoffer al is vergoed geldt immers voor alle regressituaties in de sfeer van personenschade: het belang van slachtofferbescherming zal tot op zekere hoogte altijd wel aan aansprakelijkheidsregels ten grondslag liggen en dat belang ontbreekt in regreszaken altijd. Voor regres zou zo bezien nooit plaats zijn.

Maar in onderhavig verband komt dit argument mij niet onwenselijk voor. ${ }^{1073}$ De belangrijkste functie van de regels van het aansprakelijkheidsrecht is dat ze een oordeel moeten geven over de verwijtbaarheid van schadeveroorzakend gedrag (het principe dat de schuldige betaalt). Wat 'verwijtbaar' is in de zin van het aansprakelijkheidsrecht hangt samen met rechtspolitieke opvattingen: het hoge aantal verkeersongevallen noopt tot een strenger regime van verkeersaansprakelijkheid. ${ }^{1074} \mathrm{Bij}$ de algemene bescherming die art. $185 \mathrm{WVW}$ en de algemene jurisprudentie bieden 'bijten' beide componenten (verwijtbaarheid en slachtofferbescherming) elkaar niet: kleine fouten van gemotoriseerde bestuurders kunnen, door de massa en snelheid van het motorrijtuig, bij ongemotoriseerden gemakkelijk ernstige gevolgen veroorzaken. Dat verklaart dat de bewijslast is omgekeerd ten nadele van de gemotoriseerde en dat slechts onder bijzondere omstandigheden een beroep op overmacht kan slagen. De 100\% regel voor jeugdige verkeersdeelnemers gaat echter een belangrijke stap verder: het gedrag van de schadeveroorzaker is daarvoor volstrekt irrelevant, tenzij sprake was van opzet of aan opzet grenzende roekeloosheid van het kind. Denk aan het geval waarin een jong kind van het 'zitje' achterop

1070 O.a. Van Maanen \& Römers (1994), p. 49: Hartlief (1996), p. 1049; zie voorts met name Brunners noot bij HR 28 febnari 1992, NJ 1993, 566 nt. CJHB (IZJ/Vrerink). Met het resultaat instemmend is Spier (1996). p. 43: 'Het afwijzen van subrogatie in zieligheid is m.i. een goede beslissing. Wanneer, buiten de wet om, een specifieke slachtofferbeschermende 'rechterivike regeling' wordt ontworpen, dan blijven de gevolgen daarvan beperkt tot diegenen voor wie zij is bestemd (dat wil zeggen: de slachtoffers zelf)!"

1071 Ook is zoals gezegd tussen verzekeraars volgens de Hoge Raad aan standaardisering minder behoefte. Wellichi is dere jurispnudentie bovendien ingegeven door budgettaire argumenten: een zo vergaand regime van slachtofferbescherming moet betaalbaar (en verzekerbaar) blijven.

1072 HR 5 december 1997, NJ 1998, 400-402 nt. JH (Terminus/Z1O enz).

1073 Zij het dat dit argument van de Hoge Raad cen aantal vragen omtrent de precieze betekenis en reikwijdte ervan onbeantwoond laat, zie daarover Bolt \& Spier (1996), p. 231 c.v. (Spier) en verdere beschouwingen in dit verband bij Spier (1996), p. 36 c.v.

1074 In die zin ook TK 1995-96, 21528, nr. 6, p. 16 
de fiets ten val komt en wordt aangereden. Dat de eigenaar of houder van het motorrijtuig daarvan in beginsel de rekening krijgt toebedeeld, óok als hij stapvoets reed, is in zoverre wel uit te leggen dat de massa en (relatieve) snelheid van zijn voertuig mede beslissend zullen zijn geweest voor de schade. Maar dat hij zonder mogelijkheid van tegenbewijs (overmacht of eigen schuld) gehouden is de gehele som te betalen, is alleen vol te houden als men het bevorderen van schadeloosstelling laat prevaleren boven het principe dat de schade moet worden gelegd bij degene die daarvan een verwijt te maken valt. De grondslag van art. $185 \mathrm{WVW}$ lijkt voor een zo vergaande regel dan ook niet dragend. ${ }^{1075}$ Zelfs voor gevallen waarin sprake is van aan opzet grenzende roekeloosheid van het slachtoffer is twijfelachtig welke betekenis overblijft voor het oordeel over de mate van gevaarzetting en de verwijtbaarheid van het gedrag van de bestuurder van het motorrijtuig. In verhouding tot de fout van het slachtoffer (alle andere omstandigheden weggedacht), zal die in zulke gevallen sowieso in het niet vallen.

Dit alles laat zich moeilijk verenigen met de (hoofd)functie die het aansprakelijkheidsrecht in mijn visie heeft in regreszaken (handhaving van concrete gedragsregels, en daardoor bijdragen aan een goede rechtsorde). Kennelijk prevaleren voor het slachtoffer zelf het maatschappelijke belang van een zo snelle en volledig mogelijke schadeloosstelling en het belang dat zijn schade door het verplicht WAverzekerd zijn van de gemotoriseerde kan worden gespreid. ${ }^{1076}$ In regreszaken, waarin het belang van vergoeding niet meer aan de orde is, valt er dan veel voor te zeggen deze gestandaardiseerde regels niet te laten gelden. Waarom zou een regel die schadeloosstelling van het slachtoffer moet bevorderen en daarvoor het normale wettelijke kader opzij zet, óók gelden als dat belang helemaal niet meer aan de orde is? Met het oog op de hanteerbaarheid en eenvoud van het systeem valt dan wellicht óók wel wat te zeggen voor het uitsluiten van de $50 \%$ regel. Die heeft specifiek betrekking op de situatie waarin bij het slachtoffer sprake is van eigen schuld; zij komt pas in het geding nadat de aansprakelijkheid is vastgesteld. Dogmatisch heb ik daarmee echter minder moeite. Het lijkt me zelfs wel consequent om de factor gevaarzetting bij de verdeling van de schade van invloed te laten zijn naast het rijgedrag.

\footnotetext{
$1075 \mathrm{Vgl}$. ook Spier (1996), p. 232: 'Het konijn van de ratio van ant. 185 WVW zou zo snel mogelijk weer in de hoge hoed terug moeten kruipen.'

1076 Zie kritisch Bolt \& Spier (1996), p. 232 (Spier) en Spier (1996), p. 37.
} 


\subsection{Omvang van aansprakelijkheid}

\subsubsection{Postenstelsel}

Nadat is vastgesteld dat aan de voorwaarden voor aansprakelijkheid is voldaan moet worden nagegaan in hoeverre dit de regresnemer recht geeft op civielrechtelijk verhaal. De vraag die dan opkomt, en waarover de wettelijke regresbepalingen geen uitsluitsel bieden, is of in dat verband moet worden onderscheiden tussen het bedrag van de specifieke schadepost waarvoor de uitkering die tot het regres leidt is verstrekt (postenstelsel) of dat men de som van alle schadeposten zal moeten vaststellen waarvoor de schadeveroorzaker (of diens WA-verzekeraar) zonder de uitkering aan de benadeelde schadevergoeding verschuldigd zou zijn geweest (sommenstelsel). Zijn de wettelijke regresrechten met andere woorden gerelateerd aan afzonderlijke schadeposten?

De Hoge Raad heeft hierover negatief beslist, in een zaak die betrekking had op het regime van de later vervallen Ongevallenwet 1921. Naar het oordeel van de raad destijds moest voor het vaststellen van het civiele plafond worden uitgegaan van de (totale) som van de schade waarvoor de benadeelde bij het ontbreken van de uitkering recht zou hebben gehad op schadevergoeding. ${ }^{1077}$ Ook voor de huidige zelfstandige regresrechten wordt nog wel aangenomen, dat het civiele plafond de omvang van het regres beperkt tot het totale bedrag dat de schadeveroorzaker in de fictieve situatie waarin de wet die recht geeft op regres zou ontbreken en alle schade voor rekening van de benadeelde zou zijn gebleven, aan schadevergoeding verschuldigd zou zijn geweest. ${ }^{1078}$ Zelfstandige regresnemers zijn dan in beginsel niet gebonden aan de specifieke schadeposten waarvoor de benadeelde bij het ontbreken van de bewuste uitkering recht zou hebben op schadevergoeding. Zou daaronder ook smartengeld vallen, dan zou dit in beginsel ook vallen onder het maximaal te verhalen bedrag. Het regresrecht zou zich dan immers uitstrekken over alle schadeposten waarvoor de schadeveroorzaker in die (fictieve) situatie schadevergoeding verschuldigd zou zijn. ${ }^{1079}$ Dat lijkt me bedenkelijk. Onder het oude regime van de Ongevallenwet 1921 deed zich dat met name voor bij het regres van de Risicobank voor de - toen nog levenslange - rente aan een bejaarde wegens hem op hoge leeftijd overkomen invaliditeit. Juist dan immers was de post inkomensschade veelal te laag voor de gevorderde regressom. Het gevorderde civiele plafond kon zich dan mede uitstrekken over de aanspraak op

1077 HR 8 januari 1960, NJ 1960, $127 \mathrm{nt}$. L.EHR (Daalder's Aannemers/Zandbergen), maar A-G Wijnveldt ziet dit anders. Ook anders: Rb. Breda 9 november 1937, NJ 1938, 372 en Rb. Groningen 25 juni 1954, NJ 1955. 107. Daarover ook De Kok (1965), p. 102; en Giltay Veth (1965), p. 234 
smartengeld van de bejaarde zelf. ${ }^{1050}$ Deze voorrang van het regresrecht vond steun bij een enkeling, ${ }^{1081}$ maar op dubieuze gronden. Giltay Veth stelde dat de benadeelde per saldo niets tekort kwam, omdat bij de bejaarde geen sprake was van substantiële inkomensschade en de bejaarde het smartengeld dat hij zonder het regres van de schadeveroorzaker had kunnen ontvangen, in feite ruimschoots in de vorm van de uitkering krachtens de Ongevallenwet terugkreeg. Dit lijkt onjuist. Zonder het regres zou de benadeelde immers twee zelfstandige aanspraken toekomen, elk berustend op een eigen grondslag. De aanspraak op smartengeld van de benadeelde strekt (onder meer) tot genoegdoening; de (toenmalige) aanspraak op levenslange rente van de Risicobank tot vergoeding van zijn inkomensschade. Beide zijn niet zonder meer onderling te verrekenen, hier ontstaat geen toevallige samenloop van prestaties.

De situatie is uitzonderlijk maar, wellicht, nog steeds reéel. Sommige ambtenarenregelingen geven een weduwe die als gevolg van een dodelijke aanrijding haar echtgenoot, ambtenaar, verliest recht op een levenslang pensioen ( 50000 Euro), ${ }^{1082}$ ook als dit meer bedraagt dan haar financiele schade zou bedragen volgens de normen van art. 6:108 lid I BW (30 000 Euro). De regresvordering zou dan ten belope dat surplus (20 000 Euro), ten koste gaan van haar aanspraak op schadevergoeding voor, bijvoorbeeld, de begrafeniskosten of immateriele schade (indien het wetsvoorstel voor de vergoeding van affectieschade van kracht wordt).

Bij een normale, individuele afwikkeling van regresvorderingen (voor het gecollectiveerde regres van de volksverzekeringswetten ANW en AWBZ is de kwestie uiteraard zonder direct belang) compliceert het sommenstelsel bovendien de regeling van het civiele plafond. ${ }^{1083}$ In een postenstelsel hoeft voor het regresrecht voor ziekenfondsverstrekkingen bijvoorbeeld slechts het bedrag van de verhaalbare ziektekosten te worden vastgesteld. Ook voor het vaststellen van het restbedrag dient dan alleen het aan de desbetreffende schadepost (waarvoor het regres plaatsvindt) gerelateerde bedrag van schadevergoeding van de benadeelde worden afgetrokken. ${ }^{1084}$ In het sommenstelsel strekt het regresrecht zich uit over alle schadeposten waarop de aansprakelijkheid van de schadeveroorzaker jegens de benadeelde betrekking heeft. Dat betekent dunkt me dat ook voor alle schadeposten de (mate van) verhaalbaarheid moet worden nagegaan (met alle materieelrechtelijke perikelen van dien, zoals de medische causaliteit).

1080 Zie HR 23 juli 1946, NJ 1946, 545 nt. DJV (Centrale Werkgevers/Ferwerda), waarin een sommenstelsel wordt gesanctioneerd en, in andere zin, Hof Amhem 21 februari 1961, NJ 1961, 371; beiden ook vermeld bij Bloembergen (1965), nt. 1 op p. 354

1081 Giltay Veth (1969), p. 234; maar anders Slagter (1963), p. 8.

1082 Zie HR 18 februari 1994, NJ 1995, 607 nt. CJHB (Bureau Motorrijtuigverzekeraars/ABP)

1083 Van Boom \& Storm (1995), p. 151 noemen dat het enige voordeel van het zelfstandige verhaalsrecht boven dat bij subrogatic.

104 Zo ook Köster (1971), p. 127: 'Heeft S. [= het slachtoffer, EE] meer schade geieden dan door de sociale verzekering is gedekt, waarbij vooral te denken is aan idecele schade, dan behoudt hij voor dat meerdere zijn rechten op [de aansprakelijke]: 
Maar de keuze voor een sommen- of postenstelsel is met name van betekenis voor het betalingsrisico dat de schadeveroorzaker loopt indien meerdere regresnemers verhaal zoeken en de aansprakelijkheid ontoereikend is. Denk aan het geval waarin de verminderde verdiencapaciteit van de benadeelde die aan de schuld van een ander is te wijten wegens eigen schuld lager is dan het loon waarop de benadeelde jegens zijn werkgever aanspraak maakt. Gesteld dat tevens sprake is van ziektekosten die een andere derde, de ziektekostenverzekeraar, voor zijn rekening neemt, kan de omvang van de aansprakelijkheid van de schadeveroorzaker voor het totaal van deze schadeposten even hoog (of hoger) zijn als (dan) het bedrag aan loonkosten waarvoor de werkgever recht heeft op regres. Bij een sommenstelsel zou de werkgever in gevallen waarin de aansprakelijkheid ontoereikend is het regresrecht van de ziektekostenverzekeraar kunnen frustreren.

Het is de vraag wie daar, ervan uitgaande dat de vordering zou worden toegewezen, het nadeel van ondervindt: de (concurrerende) ziektekostenverzekeraar of de schadeveroorzaker. Kan de ziektekostenverzekeraar de schadeveroorzaker tòch aanspreken, dan betaalt deze laatste immers dubbel. Aan te nemen valt dat de ziektekostenverzekeraar buiten de verhouding van de werkgever en de schadeveroorzaker staat en van de eerdere betaling dus geen nadeel ondervindt.

\subsubsection{Postenstelsel nader beschouwd}

Een postenstelsel zou de uitvoering minder compliceren dan een sommenstelsel, maar hoe ziet het postenstelsel er meer concreet uit? Giltay Veth stelt, onder verwijzing naar de letterlijke bewoordingen van art. 90 WAO, dat moet worden uitgegaan van een postenstelsel dat het WAO-regres beperkt tot alle aan de arbeidsongeschiktheid gerelateerde schade. Maar dat zou impliceren dat óók de aan de invaliditeit gerelateerde ziektekosten en immateriële schade daaronder kunnen vallen. ${ }^{1085}$ Beter lijkt daarom, zoals ik eerder aangaf, de schadeposten van afdeling 6.1.10 BW) tot uitgangspunt te nemen. Voorzover de uitkering verband houdt met juist die schade kan zij worden verhaald. Een praktisch bezwaar kan men wellicht noemen dat dit alleen goed werkt bij een duidelijke afbakening tussen de te onderscheiden schadeposten, terwijl de inhoud en begrenzing van schadeposten in de praktijk niet altijd scherp is. Maar dat probleem is er óók, bij een sommenstelsel; men kan dan immers niet volstaan met een beoordeling van de betreffende schadepost. Wel kunnen er bij een postenstelsel wellicht, omdat het verfijnder is, gemakkelijker verschillen ontstaan met de afwikkeling van het regres in vreemde rechtsstelsels. Maar uitgaande van de landen direct om ons heen lijken de nadelen van een postenstelsel ook in dat opzicht minder groot dan bij een sommenstelsel. Ook in de Franse schadepraktijk bijvoorbeeld wordt onderscheid gemaakt tussen schadeposten bij personenschade, zij het nogal grofmazig (inkomensschade, ziektekosten

Giltay Veth (1969), p. 234. 
en immateriële schade). ${ }^{1086}$ In het Duitse recht wordt juist niet alleen gedifferentieerd tussen de schadeposten, maar ook daarbinnen: naar de periode waarop de uitkering aan de benadeelde betrekking had. Het regres voor immateriële schade is er van regres uitgesloten.

Het koppelen van de uitkering aan de aard en de periode van de schade van de benadeelde lijkt het meest precies, en voorkomt dus het beste dat de regresvorderingen elkaar doorkruisen en dat de schadeveroorzaker door een cumulatie van regresvorderingen teveel verschuldigd is:

Eerst moet dan worden beoordeeld in hoeverre de uitkeringen of verstrekkingen afzonderlijk betrekking hebben op één concrete schadepost van de benadeelde, zowel naar de aard van de schade (inkomensschade of ziektekosten) en de periode waarin die plaatsvond (inkomensschade uit het eerste of uit het tweede ziektejaar).

Voor de vraag in hoeverre ze verhaalbaar zijn moet worden nagegaan tot hoeveel schadevergoeding de corresponderende schadepost zou hebben geleid (het civiele plafond).

Het regresrecht is dan gerelateerd aan het bedrag waarvoor de schadeveroorzaker in de fictieve situatie voor de met de betrokken uitkering corresponderende schadepost schadevergoeding zou zijn verschuldigd, en dus niet slechts, zoals thans ook wel gebeurt, het totaal van de schadeposten waarvoor de schuldenaar aansprakelijk is. ${ }^{1087}$ Dat sluit aan bij de gedachte die aan de regresbepalingen ten grondslag ligt. Zonder dit verband tussen uitkering en schade is immers evenmin sprake van samenloop tussen de uitkering en de vergoedingsplicht van de schuldenaar, als bij het verstrekken van een algemene ouderdomspensioenen aan iemand die de pensioengerechtigde leeftijd heeft bereikt. ${ }^{1088}$

Met name voor de vraag naar voordeelstoerekening wordt zoals gezegd al wel uitgegaan van een postenstelsel. Voor het regres kan worden gewezen op het Convenant Verhaalsrecht voor de arbeidsongeschiktheidswetten. Daarin is een aparte afspraak gemaakt over het civiele plafond met betrekking tot de inkomensschade. Die wordt geacht beneden het civiele plafond te zijn, en dus zonder meer voldaan met een forfaitaire aftrek van $22 \%$ (mits de aansprakelijkheid tussen partijen vaststaat). In de doctrine heeft met name Van Boom een lans gebroken voor een postenstelsel. ${ }^{1089}$ Regresrechten dienen volgens hem beperkt te blijven tot de aansprake-

\footnotetext{
10s6. Fleming (1983), p. 42 spreekt van een politiek compromis.

toe? De Haas \& Hantlief (1996), p. 51; vgl. voor het Nederlandse recht Van Boom \& Storm (1995), p. 150; Van Boom (1996), p. 99; Van Boom (2000a), p. 54 spreekt in dit verband van een 'congruentievereiste'.

1093 Dat sluit aan bij HR 22 juni 1990, NJ 1991, $760 \mathrm{nt}$. CJHB (ABP/Baguw)

toss Van Boom (2000a), p. 53; zo ook Giltay Veth (1969), p. 234 en Koster (1971), p. 127.
} 
lijkheid van de schadeveroorzaker voor de schadepost waarvoor de regresnemer de benadeelde schadeloos heeft gesteld. Het regresrecht strekt zich dan niet ook uit over die schadeposten, waarvoor de door de regresnemer aan de benadeelde uitgekeerde bedragen niet zijn verstrekt, zoals immateriële schade. Dat bevordert een uniforme afwikkeling in verschillende instanties, en kan eraan bijdragen dat het risico van onnodige betaling voor de schadeveroorzaker (of diens WA-verzekeraar) zoveel mogelijk worden vermeden. Aangenomen wordt wel dat bij de subrogatie van schadeverzekeraars van een zodanig postenstelsel sprake is. ${ }^{1090}$

\subsubsection{Differentiatie in de omvangfase}

\subsubsection{INLEIDING}

Zowel bij een sommen- als bij een postenstelsel zal men voor de omvang van het regres moeten aanknopen bij de omvang van aansprakelijkheid zoals die zou zijn geweest indien de schade voor rekening zou zijn gebleven van de benadeelde zelf. ${ }^{1091}$ In hoeverre zou de schadeveroorzaker voor de schadeposten waarop de uitkering betrekking heeft, jegens de benadeelde schadevergoeding verschuldigd zijn geweest? Zoals ik eerder aangaf, zijn voor de regresvorderingen van sociale verzekeraars die betrekking hebben op arbeidsongeschiktheidsuitkeringen de meeste geschilpunten met betrekking tot het civiele plafond a priori uitgesloten. Behoudens aansprakelijkheid, schuld, eigen schuld en medische causaliteit wordt het bedrag van de uitkering dan met aftrek van een forfaitaire korting voldaan. Voor de buitengerechtelijke kosten van rechtsbijstandverzekeraars in letselschadezaken is een vast bedrag afgesproken. Daarbuiten hangt de hoogte van de regressom nog wèl (volledig) af van de vraag in hoeverre de schadeveroorzaker voor de afzonderlijke schadeposten aansprakelijk is. ${ }^{1092}$ Men zal daarvoor te rade moeten gaan bij de regels van het materiële recht, met name afdeling 6.1.10 BW. Net als bij de vestigingsfase geldt ook hierbij het uitgangspunt dat de regels net zò gelden, als voor de benadeelde het geval zou zijn geweest. ${ }^{1093}$ Maar er zijn toch ook hier belangrijke verschillen, al is van een zo vergaande differentiatie als in de verkeersjurisprudentie (vooralsnog) geen sprake. ${ }^{1094}$ Een aantal bijzonderheden voor het vaststellen van de omvang van aansprakelijkheid bij regres kwam al aan de orde, zoals het regres bij immateriële schade (paragraaf 4.4). Hierna worden nog

Van Boom (2000a), p. 54. Dat volgt niet noodzakelyk uit de rechtsfiguur van subrogatic, dunkt me, noch uit de wettekst van ant. 284 WvK/art. 7.17.2.25. Maar men kan die bewoordingen zo uitleggen (de verzekerar wordt gesubrogeerd voor vorderingen die de benadeelde heeft ter zake van 'die' schade).

1091 Paragraf 4.8 .3 en 7.2.

1002 Behalve uiteraard bij het regres voor de ANW en de AWBZ

1093 Dat is ook het uitgangspunt van de Hoge Raad in het arrest inzake HR 13 januari 1995, NJ 1997, $175 \mathrm{nt}$. CJHB (Koner/De Heel); ze voorts o.m. Hartief \& Tjittes (1999), p. 105 en Van Boom (2000a), p. 49. Spier (1996), p. 41. 
enkele bijzonderheden besproken met betrekking tot de toepasselijkheid van die regels.

\subsubsection{CAuSAliteitSPERIKELEN (ART. 6:98 BW)}

Voor het regres bij gevallen van letsel en overlijden zijn met name de vergaande causale toerekening van schade en schadeposten bij de schending van verkeersof veiligheidsnormen een belangrijk discussiepunt. Met name voor sociale verzekeraars, particuliere invaliditeitsverzekeraars, en de Stichting ABP roept de regeling van art. 6:98 BW - in het kader van het civiele plafond - gemakkelijk vragen op, omdat de uitkeringen waarin ze voorzien en waarvoor ze regres zoeken betrekking hebben op langlopende en vaak complexe schade. ${ }^{1095}$ Op dit punt lijkt het voor regrespartijen moeilijk om tot afspraken te komen, in het Convenant Verhaalsrecht voor de sociale arbeidsongeschiktheidswetten is de mogelijkheid van discussie over de medische causaliteit zelfs uitdrukkelijk toegestaan. Dat is ook wel begrijpelijk, de uitkering of verstrekking die naar aanleiding van het schadevoorval krachtens WAO (of andere verzekeringen) zijn verstrekt, en waarvoor die wetten recht geven op verhaal, houden qua aard, omvang en duur immers niet noodzakelijk verband met schade die civielrechtelijk nog aan de schadeveroorzaker toerekenbaar is. Illustratief is in dat opzicht de zaak Staat/Vermaat. ${ }^{1096}$ Het ABP (thans: de Stichting Pensioenfonds ABP) was naar aanleiding van een verkeersongeval invaliditeitsuitkeringen verschuldigd aan de benadeelde en zocht daarvoor verhaal op de veroorzaker. De regresvordering van het $\mathrm{ABP}$ had echter mede betrekking op de uitkeringen die het was blijven verstrekken nadat de benadeelde - zeven jaar na de datum van het ongeval - een hartinfarct had gekregen dat ook zonder het ongeval wel zou zijn ontstaan en tot de betreffende inkomensschade zou hebben geleid. De Hoge Raad oordeelde dat de op de schadeveroorzaker rustende vergoedingsplicht niet zover gaat, dat degene die voor de uit het ongeval voortvloeiende schade aansprakelijk is, de benadeelde moet behoeden voor schade die ook zonder dat ongeval zou zijn ontstaan. Door de beperking van het civiele plafond was de schadeveroorzaker dan evenmin regres verschuldigd voor de uitkeringen die het $\mathrm{ABP}$ was blijven doorbetalen nadat de benadeelde een hartinfarct had gekregen. Maar ook de vèrstrekkende, 'slachtoffervriendelijke' causaliteitsnormen van de Hoge Raad in dit verband gelden voor regresnemers. Dat die hoofdzakelijk zijn ingegeven door het belang van bescherming van de benadeelde, ${ }^{1097}$ doet daaraan geen afbreuk. In het arrest inzake Korver/De Heel besliste de Hoge Raad uitdrukkelijk, naar aanleiding van een daarop toegespitste klacht in cassatie, dat zulke

1095 HR 4 november 1988, NJ 1989. $751 \mathrm{nt}$ CJHB (ABP/Van Stuyvenberg); HR 22 juni 1990, NJ 1991, $760 \mathrm{nt}$. CJHB (ABP/Baarw) waarover hiema in de hoofdtekst; vgl ook HR 2 februari 1990, NJ 1991.292 nL CJHB (Vermaat/Staat en ABP).

1096 HR 2 februari 1990, NJ 1991, $292 \mathrm{nt}$. CJHB (Vermaat/Staat en ABP).

1097 Zie o.a. Asser-Harkamp 4-1, nr. 434 en Hartlief (1995), p. 161. 
regels ook gelden bij de vaststelling van de omvang van aansprakelijkheid in regreszaken. ${ }^{1098}$ In de bewoordingen van de Hoge Raad moet de vraag of de schade in causaal verband staat tot de gebeurtenis waarvoor de schadeveroorzaker jegens de benadeelde aansprakelijk is, naar geen andere maatstaven worden beslist dan die welke voor de vordering van de benadeelde zelf gelden.

Een aardig voorbeeld van een zaak over die discussie liep meer recent bij het Haagse Gerechtshof. ${ }^{100}$ Mevrouw Bos had een WAO-uitkering ontvangen in verband met cen heupfractuur die zij had opgelopen van een verkeersongeval waarvoor aansprakelijkheid was erkend. Vervolgens was zij echter thuis van de trap gevallen, met een nieuwe fractuur tot gevolg, en betwistte Ament aansprakelijk te zijn voor de gehele duur van de arbeidsongeschiktheid en daarmee de omvang van de regresvordering. Ament wist die stelling alleen onvoldoende te onderbouwen; het hof hechtte daarom vooral aan de (wat matige) verklaring van Bos' arts dat de schade nog steeds wel tot het ongeval was te herleiden.

Van Boom en Storm merken op dat het differentiëren tussen de regresvordering en de vordering van de benadeelde (kennelijk) alleen tot regel wordt gemaakt wanneer dat zonder veel moeite kan plaatsvinden. Differentiëren kan slechts wanneer het bepalen van de aard en omvang van de aansprakelijkheid er niet moeilijker op wordt. ${ }^{.100}$

\subsubsection{EIGEN SCHULD VAN DE BENADEELDE (ART. 6:101 BW)}

Als de schade die de regresnemer voor zijn rekening nam mede een gevolg is van omstandigheden die aan de benadeelde kunnen worden toegerekend, dan wordt de omvang van aansprakelijkheid verminderd overeenkomstig de maatstaven van art. 6:101 BW. ${ }^{1101}$ Ook dat volgt uit het afgeleide karakter van de onderhavige regresrechten, en kent tevens een wettelijke grondslag. ${ }^{1102}$ De regeling van art. 6:101 BW moet bij het regres in beginsel precies zo worden toegepast, zoals zij zou gelden indien het beroep op eigen schuld rechtstreeks zou zijn tegengeworpen aan de benadeelde zelf. Dat houdt in dat de schade in beginsel over de benadeelde en de schadeveroorzaker wordt verdeeld in evenredigheid met de mate waarin de aan de benadeelde en de aan de schadeveroorzaker toe te rekenen omstandigheden aan de schade hebben bijgedragen (lid 1). Een correctie van dat resultaat is mogelijk indien de billijkheid dat eist (lid 1, slot). Het verzekerd zijn van de schade kan in dat verband een factor zijn die tot meer terughoudendheid noopt bij de

1009 HR 13 januari 1995, NJ 1997, $175 \mathrm{nt}$ CJHB (Kanver/De Heed).

1099 Hof Den Haag 29 april 1998. rolnr. 95/1113 (niet gepubliceerd).

1100 Van Boom \& Storm (1995), p. 156.

IroI Aangenomen wordt wel dat ook het recht op vergoeding van de buitengerechtelijke kosten wordt beperka naar rato van de schulddeling bij eigen schuld van de benadeelde, in die zin Hof Amsterdam 9 december 1993, rolnr. $254 / 92$ (niet gepubliceerd)

1102 Bij subrogatie (en andere vormen van rechtsovergang) volgt dit uit ant. 6:145 BW en voor de zelfstandige regresrechten (waarbij van rechtsovergang immers geen sprake is) uit de regeling van het civiele plafond. Vgl. voorts art. 6:107 lid $2 \mathrm{en}$ ant. 6:108 lid $3 \mathrm{en}$ daarover Schadevergoedingsrecht, art. 107 (Bolt), aant. 59. 
afweging van een billijkheidscorrectie. Zoals ik eerder aangaf, ${ }^{1103}$ moet dat argument in het algemeen worden verworpen; het heeft immers wat tegenstrijdigs om de regresnemer een verhaalsrecht te geven voor het door hem gecompenseerde deel van de schade, en dat argument dan vervolgens te gebruiken om die aansprakelijkheid te matigen. Maar onder bepaalde omstandigheden kan er reden zijn om te differentiëren tussen de regresvordering en de vordering van de benadeelde. Dat geldt zoals zal worden gezien indien de schadeveroorzaker in persoon wordt aangesproken en er daarbij reden is tot matiging. Daarvoor is naar geldend recht ook plaats, zie paragraaf 8.4. Voor eigen schuld werd gewezen op de gestandaardiseerde invulling van de billijkheidscorrectie in de vorm van de $50 \%$ en $100 \%$ regels, bij verkeersaansprakelijkheid in de zin van art. 185 WVW. Die is bedoeld ter bescherming van het verkeersslachtoffer met onverzekerde schade, en gelden niet voor regresnemers. ${ }^{1104}$ Daarbuiten, ook bij de reflexwerking van de regeling van art. $185 \mathrm{WVW}$, lijken me voor het uitsluiten van regresnemers van de mogelijkheid van een billijkheidscorrectie meer omstandigheden nodig dan het verzekerd zijn van de schade. ${ }^{1105}$

Overigens zal van eigen schuld bestaande uit wèrkelijk buitensporig gedrag van de benadeelde in regreszaken wellicht minder gauw sprake zijn dan bij (normale) ohhadervaduingeri. vei<ekeraars zijn dan mogelijk ook zèlf niet tot uitkering gehouden (of bereid). ${ }^{1106}$ De Commissie die beoordeelt of de benadeelde in aanmerking komt voor een uitkering van het Schadefonds Geweldsmisdrijven laat bij de beoordeling of en in hoeverre het verzoek om een uitkering van de benadeelde moet worden ingewilligd zelfs uitdrukkelijk meewegen of en in hoeverre de schade van de benadeelde aan zijn eigen schuld te wijten is. ${ }^{1107}$

\subsubsection{AAN DE BENADEELDE OPKOMEND VOORDEEL (ART, 6:100 BW)}

De omvang van de aansprakelijkheid van schadeveroorzakers wordt naast de toerekenbare schade van de benadeelde óók bepaald door eventuele voordelen die hij van het schadevoorval ondervindt. Die komen voorzover dat redelijk is op het bedrag van de schadevergoeding in mindering (art. 6:100 BW). Maar kunnen aan de benadeelde opkomende voordelen, los van de bedragen die hij van de regresnemer ontving, op de voet van art. 6:100 BW, ook aan zijn regresnemende verzekeraar worden tegengeworpen? Hier is meer reden tot differentiatie dan bij de vragen over aansprakelijkheid, toerekenbaarheid, causaliteit en eigen schuld die hiervóór

\footnotetext{
1103 Paragraaf 7.3.8.

1 to4 Zie supra, paragraf 7.3.7.

1105 Maar de Hoge Raad lijkt wèl reden te zien voor differentiatie, zie paragraaf 7.3.7.

$106 \mathrm{Vgl}$ art. 276 WvK en 294 WvK (eigen schuld die aan schadeuitkering in de weg staat) en art. 28 WAO, met name sub $c$ (bij bepaalde eigen schadeveroorzakende gedragingen geen uitkering)

1197 Integendeel, aansluiting lijkt te worden gezocht bij ant. 6:101 BW, zie Jalink (1989), p. 119. De Commissie verstaat onder eigen schuld onder meer uitiokking het zich war mogetijk niet aan het gebeuren hebben onttrokken, en overmatig alcoholgebruik.
} 
de revue passeerden. Weliswaar beheerst ook de regeling van voordeelstoerekening de uiteindelijke omvang van de aansprakelijkheid, ${ }^{1108}$ maar dan toch primair voor de benadeelde. Zijn voordeel is, net als de uitkering waarvoor de regresnemer dan verhaal zoekt, slechts een gevolg van het schadevoorval. De normen die betrekking hebben op het schadevoorval zèlf gelden in alle gevallen waarin daaraan rechtsgevolg moet toekomen; regels die het rechtsgevolg daaraan verbinden (schadevergoeding, voordeelstoerekening, regres), gelden alleen voor de rechtstreekse betrokkenen. Maar wie treft het rechtsgevolg van de voordeelstoerekening (verminderde omvang van aansprakelijkheid) in regressituaties: de regresnemer of de benadeelde? Of komt het voordeel pro rata op ieders aanspraak in mindering? De Hoge Raad oordeelde voor het regres krachtens de Ziekenfondswet dat het voordeel zoveel mogelijk aan de benadeelde zelf moet worden toegerekend, en slechts voor het (eventuele) restantdeel aan de regresnemende verzekeraar.

In de zaak Stichting Nutsziekenfonds/Mahieu was die kwestie aan de orde, naar aanleiding van een verkeersongeval tussen Zagwijn en Mahieu. ${ }^{1109}$ Zagwijn was door Mahieu aangereden en moest als gevolg daarvan ruim drie maanden in het ziekenhuis worden opgenomen. Het ziekenfonds had de kosten van het ambulancevervoer en de verpleging betaald en zocht daarvoor verhaal bij Mahieu op grond van art. $83 \mathrm{~b}$ Ziekenfondswet. Mahieu wierp het fonds tegen, dat Zagwijn door haar ziekenhuisopname een besparing had van de kosten van levensonderhoud, van (omgerekend) ongeveer 3 Euro per verpleegdag. De rechtbank oordeelde dat dit alleen in aanmerking moest worden genomen bij een eventuele vordering van Zagwijn zelf en dan nog alleen voorzover zij daarbij zou stellen op het vlak van haar huishouding schade te hebben geleden (denk aan de kosten van vervangende huishoudelijke hulp). In mijn visie zouden de besparingen, ervan uitgaande dat die toerekenbaar zijn (volgens de maatstaven van art. 6:100 BW), tevens op het (eventueel) nog door haar verschuldigde onverzekerde deel van de ziekenhuisrekening in mindering moeten komen. Die zal immers mede betrekking hebben op de door het ziekenhuis gemaakte kosten om in het levensonderhoud van de betrokken patiënt te voorzien. In cassatie is dat (meer specifieke) punt niet zozeer aan de orde, maar gaat het om de vraag of ook de regresnemer de besparing kan worden tegengeworpen. De Hoge Raad stelt voorop dat de regeling van het civiele plafond minus restbedrag (zie paragraaf 7.2.3) op de gedachte berust dat de schadeveroorzaker van het verzekerd zijn van de schade niet beter en niet slechter mag worden. Dit betekent volgens de raad dat de besparingen:

'alleen dan het maximumbedrag waarvoor het ziekenfonds verhaal kan nemen doet dalen beneden het bedrag van de door het zickenfonds gemaakte kosten, wanneer de door de verzekerde bespaarde kosten méér bedragen dan de niet door de verplichte verzekering gedekte schade die hij ter zake van het opgelopen letsel lijdt: 
Dit lijkt een ingewikkelde manier van stellen dat de besparingen in beginsel alleen worden toegerekend op de schade van de benadeelde zelf. Hij is het ten slotte die daarvan het profijt heeft, niet ook het ziekenfonds. De besparingen moeten dus met het restbedrag worden verrekend. Voor het tegenwerpen van die besparingen aan de regresnemer is volgens de raad alleen plaats als ze hoger zijn dan de vordering van de benadeelde. De stelplicht daarvan, zo volgt nog, berust bij de schadeveroorzaker (of WA-verzekeraar). ${ }^{110}$ Het in mindering brengen van de besparingen op de vordering van de benadeelde en als die niet toereikend is, op de regresvordering moet dunkt me beperkt blijven tot de corresponderende schadeposten. De besparing die uit de ziekenhuisverpleging voortvloeit behoort dan zoals gezegd slechts in mindering te (kunnen) komen op de ziekenhuisrekening, en eventueel de kosten voor huishoudelijke hulp, en niet op de eventuele verdere vordering van de benadeelde, zoals het smartengeld. "' niet volstrekt ongekend is, ${ }^{112}$ lijkt de heersende opvatting anders. ${ }^{1113}$ Zo stelt A-G Langemeijer, terecht overigens, over het regime zoals mij als het beste wil voorkomen, dat dit zou leiden tot een verrijking van de schadeveroorzaker of van de benadeelde ten koste van het ziekenfonds. Maar de juridische relevantie van de besparing ligt in mijn visie bij het tegenwicht dat zij biedt naast de schade. Het enkele feit dat de benadeelde een besparing (of ander voordeel) heeft betekent dan nog niet dat die ten koste moet gaan van zijn recht op smartengeld. Is dat tegenwicht er in het onderhavige geval immers wèrkelijk? Moet men willen zeggen dat het leed en de pijn van een ziekenhuisopname van drie maanden ten belope van het bedrag van de besparingen elkaar rechtens opheffen?

Er zijn goede argumenten om dit regime van voordeelstoerekening ook te laten gelden bij subrogatie. In dit verband vraagt de zaak Geenen/VGZ aandacht. ${ }^{\prime \prime 14}$ Mejuffrouw Santegoeds was als passagier in de auto van Geenen emstig gewond geraakt, en moest als gevolg daarvan 131 dagen in het ziekenhuis worden opgenomen. Santegoeds was verzekerd bij het ziekenfonds, maar had een aanvullende verzekering klasse $2 b$ afgesloten bij VGZ. Voor de krachtens die laatste verzekering gemaakte kosten zocht VGZ verhaal bij Geenen, die aansprakelijkheid erkende, maar de bespaarde kosten van levensonderhoud tegenwierp. VGZ stelde daar de extra kosten tegenover die het ziekenhuisverblijf met zich meebrengt (onder meer

1110 HR 12 januari 1973, NJ 1973, 177 nt. ARB (Nutsziekenfonds/Mahieu).

III Voor de omgekeende situatie, het toerekenen van immaterieel voordeel op materiéle schadeposten ziet de Hoge Raad in elk geval niet gauw plaats, zo blijkt uit HR 2 I februari 1997, NJ 1999, $145 \mathrm{nt}$. CJHB (Wrongful birth): 'Veeleer moet ervan worden uitgegaan dat immateriele voordelen slechts in rekening behoren te worden gebracht bij de vaststelling van eventucle immateriele schade.'

1112 In die zin oordeelt Rb. Almelo 21 oktober 1970, NJ 1971, 216 (Ziekenfonds/Oosterwijk).

1113 Zo ook Hof Den Haag 6 januari 1977, NJ 1977, 469 (Waarborgfonds/Ziekenzorg) en Hof Den Bosch I mei 1980, NJ 1981, 671 (Herber/Algemene Ziekenfonds). Beide van de strekking, dat het voordeel indien de overige schade van de benadeelde onvoldoende is, $60 \mathrm{k}$ op het smartengeld van de benadeelde in mindering behoort te komen (en pas als dat niet toereikend is op de regresvordering). Zie voorts Schadevergoeding, ant. 107 (Bolt), aant. 29 en Bouman \& Tilanus-Van Wassenacr (1998), nr. 25. 
de kosten van controlebezoek, lectuur, en 'het gebruikelijke cadeau voor de verpleegsters bij het verlaten van het ziekenhuis)'. Op die stelling (omtrent de extra kosten) zette VGZ al haar kaarten. In appèl was echter vastgesteld dat deze extra kosten niet behoorden tot de kosten waarvoor de aanvullende verzekering dekking bood, de verzekering gold alleen voor (het aanvullende deel van) de uiteindelijke ziekenhuisrekening. Op basis daarvan oordeelde de Hoge Raad dat Santegoeds voor deze extra kosten haar recht op schadevergoeding had behouden. Die konden daarom niet ook nog eens ten behoeve van het VGZ met het voordeel worden verrekend (een daarop gericht polisbeding had dat wellicht kunnen voorkòmen). VGZ moest genoegen nemen met de reeds door Geenen voldane regressom (die was reeds voldaan met aftrek van de besparingen). De principiële vraag van het toerekenen van de besparingen aan schadeverzekeraars bleef daarmee in het midden. Dat is, gelet op de negatieve afloop van de zaak voor de regresnemer, wat ongelukkig. Want daaruit zal toch niet moeten worden afgeleid dat de schadeveroorzaker (of WA-verzekeraar) dit voordeel willekeurig aan de regresnemer en/of de benadeelde kan tegenwerpen. Dit laatste is dunkt me ook waar NJ-annotator Wachter op doelt. Hij benadrukt dat het noodzakelijk is, dat de beslissing ten opzichte van alle betrokkenen identiek is ('exceptio plurium litis consortium').

Aan wie moet nu, is dan dus de vrasg, dat voordeel worden toegerekend indier schade(post) waarop het kan worden toegerekend gedeeltelijk voor rekening komt van de regresnemer en gedeeltelijk voor rekening blijft van de benadeelde zelf? Het ligt dan zou ik menen voor de hand om de positie van schadeverzekeraars (en andere regresnemers) niet te laten afwijken van de koers die de Hoge Raad in het arrest inzake Stichting Ziekenfonds/Mahieu uitzette voor ziekenfondsen. Wachter lijkt daarvoor ook te voelen, maar stelt dat de uiteenlopende aard van het regresrecht bij subrogatie daaraan in de weg staat; de schadeverzekeraar verkrijgt immers de vordering van de benadeelde en is dus behept met alle daaraan klevende voorwaarden en beperkingen. ${ }^{1116}$ Maar wat hij bij die redenering dunkt mij nalaat na te gaan is of die beperking (voordeelstoerekening) aan de vordering van de benadeelde waarin de schadeverzekeraar is gesubrogeerd kleeft, of kàn kleven. Ik zou menen dat dit niet zo is. Het deel van de schade(post) waarvoor de schadeverzekeraar uitkering doet, is noodzakelijkerwijs, dunkt me, niet hetzelfde deel als waarop de benadeelde de besparing geniet. Men kan het voordeel maar op 1 Euro tegelijk toerekenen. Santegoeds had verschillende voordelen: particuliere en ziekenfondsuitkeringen en besparingen. Voorzover de particuliere verzekeringsuitkering op haar vordering in mindering kwam, ging dat deel van de vordering verloren. Voor andermaal voordeelstoerekening op datzèlfde deel van de vordering kàn dus geen plaats zijn. Het andere voordeel moet noodzakelijkerwijs op weer een ander deel van de vordering (andere Euro's) in mindering gebracht, een deel dus dat geheel losstaat van de verzekeraar. Indien de verzekeraar het volle bedrag 
van de ziekenhuisrekening vergoedt dan is er dus voor voordeelstoerekening van de besparingen aan de benadeelde in het geheel geen plaats. De conclusie moet dan ook zijn dat besparingen op de kosten van levensonderhoud in beginsel niet in mindering kunnen komen op de vergoeding voor (daarmee corresponderende) schade van de benadeelde zèlf. Hetzelfde zou moeten gelden voor de zelfstandige regresrechten: voor het tegenwerpen van het voordeel van de benadeelde aan de regresnemer is geen plaats. In Stichting Ziekenfonds/Mahieu koos de Hoge Raad zoals hiervoor al werd gesteld hetzelfde uitgangspunt, maar voegde hij toe, dat als het bedrag van de schadevergoeding van de benadeelde ontoereikend is, het restant nog wèl in mindering kan komen op de uitkeringen waarvoor de regresnemer verhaal zoekt. Beter ware, ook vanuit praktisch oogpunt, de vraag naar voordeelstoerekening met betrekking tot besparingen die de benadeelde zelf geniet uitsluitend te laten spelen binnen de rechtsverhouding tussen de benadeelde en de schadeveroorzaker (WA-verzekeraar).

Dit alles geldt wat mij betreft overigens evenzeer voor de (aanspraak op de) uitkering of verstrekking waarvoor de regresnemer verhaal zoekt. Zoals eerder werd gesteld, ${ }^{1112}$ ligt immers bij het in mindering brengen dààrvan juist de aanleiding voor het regres. Die voordeelstoerekening is behoudens de gevallen waarin sprake is van subrogatie (en de benadeelde dus reeds om die reden zijn vordering jegens de schadeveroorzaker verliest), noodzakelijk voor een kloppend eindresultaat; zij gaat buiten de regresnemer om. Zulk voordeel (mede) in rekening brengen bij de regresnemer is onzinnig. Daarmee zou immers hetzelfde worden bereikt als wat men nu juist door het regres wil vermijden, namelijk dat de schadeveroorzaker voor de betreffende bedragen definitief van zijn vergoedingsplicht is bevrijd.

\subsubsection{IMMATERIËLE SCHADE (ART. 6:106 BW)}

In paragraaf 4.4 werd ingegaan op de vraag of regresnemers de schadeveroorzaker (of diens WA-verzekeraar) ook kunnen aanspreken voor het deel van de aansprakelijkheid van de schadeveroorzaker dat betrekking heeft op de immateriële schade. Zoals ik daarbij aangaf, is voor het inroepen van de regels voor immateriële schade door regresnemers die niet ook zèlf daarvoor uitkering deden, wat mij betreft geen plaats. Hoewel over de kwestie enige onduidelijkheid heerst, ${ }^{1118}$ lijkt zich in die richting met name voor wat betreft de wenselijkheid van die differentiatie bij het smartengeld, een zekere consensus af te tekenen. ${ }^{1119}$ Als voorbeeld van een uitkeringsinstantie die wèl tevens smartengeld uitkeert geldt het Schadefonds Ge-

1117 Paragraf 2,4.1.

118 Zie paragraf 7.4.1.

1119 Zie voor voordeelstoerckening Bolt (1989a), p. 20; Bouman \& Tilanus-Van Wassenaer (1998), p. 73; Schadevergooding, art. 100 (Bolt), aant. 8. Voor het regres: Giltay Veth (1969), p. 234; Kóster (1971), p. 127; Bloembergen in NJ-noot inzake HR 12 januari 1973, NJ 1973, 177 nt. ARB (Nutsziekenfonds/Mahiew); Van Boom (2001a), p. 53. 
weldsmisdrijven. De ontwikkelingen op dat gebied zijn dus mede interessant voor het fonds. Dat geldt met name voor het al genoemde wetsvoorstel met betrekking tot de vergoeding voor affectieschade. Hoewel het fonds, voor de goede orde, zèlf niet uitkeert namens of ten behoeve van de schadeveroorzaker of op basis van diens aansprakelijkheid (zoals het Waarborgfonds Motorverkeer), zal het indien het wetsvoorstel van kracht wordt, analoog aan die regeling óók zelf vergoedingen voor affectieschade gaan uitkeren. Voor de hand ligt dan dat het Schadefonds daarbij dan wordt gesubrogeerd in de vordering tot schadevergoeding die de benadeelde zonder de fondsuitkering aan de regeling had kunnen ontlenen (maar die hij bijvoorbeeld uit angst voor represailles niet zelf geldend wilde maken, en daarom door het fonds werd vergoed). ${ }^{1120}$

Een bij uitstek voor het fonds belangwekkende ontwikkeling lijkt verder het arrest inzake $R / V$ an de $W$. Daarin besliste de Hoge Raad dat voor schadevergoeding van anderen dan de primair benadeelde ook plaats is indien het oogmerk bestond om juist hen leed te berokkenen door het ombrengen van de primair benadeelde. ${ }^{1121}$ Een moeder wier zoontje was omgebracht door haar ex-man met het oogmerk hààr te schaden (hetgeen, zo wordt verondersteld, jegens haar onrechtmatig was), vorderde op die grond een vergoeding voor haar leed (zie art. 6:106 sub $a \mathrm{BW})$. De Hoge Raad oordeelde dat haar vordering niet werd gehinderd door het feit dat haar schade het gevolg was van de kwetsing van een ander. Voor het immateriële deel van de schade zou ook het Schadefonds Geweldsmisdrijven, met inachtneming van de genoemde wettelijke restricties (art. 6:106 lid 2 BW) worden gesubrogeerd in deze vordering tot smartengeld. Onduidelijk is nog hoe de wettelijke regeling voor affectieschade (indien zij van kracht wordt) zich zal verhouden tot deze jurisprudentie. Naast het belang daarvan voor de benadeelde, zou dat ook wel interessant zijn voor het fonds. ${ }^{1122}$

Het arrest inzake $R /$ Van de $W$ leidt tot het resultaat dat het leed van de moeder wèl in aanmerking komt voor een vergoeding van de dader krachtens art. 6:106 sub $a$ BW (en cen daarop gebaseerde regresvordering van het Schadefonds Geweldsmisdrijven), maar niet óók haar aan het verdriet gerelateerde vermogensschade zoals de kosten van therapie. Dààraan en aan daarop gebaseerde regresvorderingen van het fonds (of van particuliere of sociale verzekeraars) zou in de weg staan dat bij schade door letsel van een ander geen plaats is voor rechtstreekse aansprakelijkheid. iiz

\footnotetext{
1120 Overigens schijnt het aantal gevallen waarin cen beroep wordt gedaan op het fonds vergeleken met het aantal gevallen waarin de mogelijkheid daartoe bestaat niet bijster groot te zijn. De regering beoogt hierin verbetering te brengen door meer bekendheid te geven aan het fonds, TK 2000-01, 274000 , VI, nr. 54.

1121 HR 26 oktober 2001, NJ 2002, $216 \mathrm{nt}$. JBMV (RVan de W), NTBR 2002, p. 77 (Engethard).

1122 Zoals ik aangaf in hoofdstuk 4 is het regresrecht van het fonds procedureel nogal omslachtig en werkt het fonds daarom hoofdzakelijk met voorschoteonstructies en dus niet met subrogatic.

1123 Zie HR 8 april 1983, NJ 1984, $717 \mathrm{nt}$. CJHB (Van der Heijden/Holland).
} 


\subsection{Conclusie}

In het voorgaande werd gezien dat niet alle regels van het aansprakelijkheidsrecht die gelden voor de benadeelde zelf ook gelden voor regresnemers. In het eerste deel van het hoofdstuk ging het erom in hoeverre voor het inroepen van de aansprakelijkheid van de schadeveroorzaker jegens de benadeelde bij regres dezelfde regels en maatstaven gelden als bij een vordering van de benadeelde zelf. De wettelijke regresrechten berusten op het principe dat de schade uiteindelijk behoort te worden gedragen door degene die daarvoor aansprakelijk is jegens de benadeelde. Zowel bij de zelfstandige regresrechten als bij subrogatie moet dus worden aangeknoopt bij de regels van het aansprakelijkheidsrecht die gelden voor de rechtsverhouding tussen de schadeveroorzaker en de benadeelde. Bij subrogatie volgt dat uit de afgeleide constructie van het regresrecht: de gesubrogeerde verzekeraar verkrijgt de vordering tot schadevergoeding van de benadeelde. ${ }^{1124}$ In de zelfstandige regresbepalingen wordt daartoe aangeknoopt bij de regels van burgerlijk recht die de aansprakelijkheid van de schadeveroorzaker jegens de benadeelde beheersen. Voor de omvang van het regres geldt dan voorts het zogenaamde civiele plafond: het regres is beperkt tot ten hoogste het bedrag waarvoor de schuldenaar bij het onvergoed blijven van de schade aansprakelijk zou zijn geweest jegens de benadeelde. Zowel bij subrogatie als bij zelfstandig regres gelden op een drietal punten uitzonderingen. In de eerste plaats zijn als gevolg van de Tijdelijke regeling verhaalsrechten bepaalde gronden voor aansprakelijkheid uitgesloten voor regresnemers. Die regeling staat haaks op het principe dat de schadeveroorzaker betaalt en zij bemoeilijkt de uitvoering van het regres in de praktijk. Om die redenen zou het beter zijn dat ze wordt afgeschaft. In de tweede plaats zijn als gevolg van de verkeersjurisprudentie in het kader van art. 185 WVW de zogenaamde $50 \%$ en 100\%-regels uitgesloten van regres. (Alleen) voor de 100\%-regel valt daarvoor veel te zeggen. Die maakt voor de vraag naar aansprakelijkheid elke discussie over de verwijtbaarheid van het schadeveroorzakende gedrag volstrekt irrelevant. Tevens werd gezien dat voor regresnemers ook wat beperkingen gelden bij de invulling van deelregels, zoals bij eigen schuld en bij de zogenaamde reflexwerking op het gebied van verkeersaansprakelijkheid. Uit de genoemde constructies volgt tevens dat, net als bij subrogatie, óók de regels en de maatstaven die bepalend zijn voor de omvang van de aansprakelijkheid van de schadeveroorzaker in beginsel onverminderd bij regres blijven gelden. Toch is er ook dan op sommige punten goede reden voor differentiatie: voor de toepasselijkheid van de regeling van voordeelstoerekening en smartengeld.

1124 Verdedighaar is overigens wel dat het rechtskaraiker van het vorderingsrecht door de rechtsovergang verandering ondergaat, dit komt in het volgende hoofdstuk aan de orde. 



\section{Rechtskarakter van regresvorderingen}

Het vorige hoofdstuk ging over het spanningsveld tussen het aansprakelijkheidsregime bij regres en het beginsel dat de schuldenaar, vergeleken met de vermogensrechtelijke positie waarin hij jegens de benadeelde zou hebben verkeerd, erop vooruit noch achteruit mag gaan. Gezien werd dat de wisseling van crediteuren die bij het regres intreedt aanleiding kan zijn om bij de aard en/of omvang van aansprakelijkheid te differentiëren tussen 'gewone' vorderingen en regresvorderingen. Maar ook de aard en omvang van het regresrecht, en de pluraliteit van crediteuren die daarbij kan ontstaan zetten het beginsel onder druk. Als voor regresnemers dezelfde rechten en bevoegdheden gelden als voor de benadeelde zelf, is de schuldenaar immers toch weer slechter af. Geven de regresrechten bijvoorbeeld recht opeen 'gebruteerde' regressom, en op vergoeding van buitengerechtelijke kosten? En ook: kan de schuldenaar het 'oude' verjaringsregime inroepen of brengt het regres (ook) daarin een wijziging teweeg?

\subsection{Rechtskarakter van regresvorderingen}

\subsubsection{Inleiding}

In het vorige hoofdstuk werd gezien dat het leidende beginsel voor het vaststellen van de verschuldigde regressom is, dat de schadeveroorzaker (of WA-verzekeraar) niet méér en ook niet minder verschuldigd is dan het bedrag waarvoor hij met betrekking tot de betreffende schade aansprakelijk zou zijn geweest jegens de benadeelde zelf. De regresnemer heeft als betalende partij alleen recht op betaling van het hem toekomende deel. Dat kan nooit méér zijn dan het bedrag dat de schadeveroorzaker in diens verhouding tot de schuldeiser aangaat. In zoverre is immers geen sprake van samenloop. ${ }^{1125}$ Aangenomen wordt dat de regresrechten dan ook niet strekken tot schadevergoeding van de regresnemer: de schadeveroorzaker betaalt het bedrag dat hij eigenlijk zelf aan de benadeelde verschuldigd was, niet ter vergoeding van de regresnemer.

II25 Zie daarover paragraaf 4.8 .3 . 
Voor de zelfstandige regresrechten vindt die gedachte steun in het arrest Rijksverzekeringsbank/Schönberger. ${ }^{1126}$ De Rijksverzekeringsbank had op basis van de oude Ongevallenwet 1921 uitkeringen verstrekt aan de benadeelde en vorderde onder verwijzing naar de regresregeling van die wet (art. 95 Ongevallenwet) vergoeding van Schönberger van de daarmee gepaard gaande kosten, nader op te maken bij staat. De Hoge Raad zag in deze regeling echter geen grond voor een schadestaatprocedure. Het recht van de Bank was geen recht op schadevergoeding; het was een zelfstandig recht, van geheel eigen aard. Hoewel dit laatste bij subrogatie uiteraard anders is, strekt het regres ook dan niet tot schadevergoeding. De gesubrogeerde verzekeraar wordt door rechtsovergang rechthebbende van een recht op schadevergoeding, dat voorafgaand aan het moment van subrogatie toebehoorde aan de benadeelde. De consequentie daarvan is dat de aard en inhoud van zijn recht wordt bepaald door de aard en inhoud van het recht op schadevergoeding van de benadeelde. Maar de strekking van dat recht is ook dan niet dat de gesubrogeerde zèlf wordt teruggebracht in de toestand waarin hij zonder het schadevoorval zou hebben verkeerd. De subrogatie roept geen nieuwe verbintenis tot schadevergoeding in het leven.

De onderhavige regresrechten hebben geen vergoedend karakter, en zijn dan ook niet, op hun beurt, onderworpen zijn aan de regels van afdeling $6.1 .10 \mathrm{BW} .^{1127}$ Dat is, naar nog zal worden gezien, onder meer van belang voor de vraag of regresnemers eigen schuld kan worden tegengeworpen en of ze recht hebben op vergoeding van hun buitengerechtelijke kosten. Rechtstreekse toepasselijkheid van afdeling 6.1.10 BW is in elk geval gelet op de aard en strekking van het regresrecht - ook bij subrogatie - uitgesloten.

Uiteraard neemt dat niet weg, dat nieuwe gebeurtenissen in de rechtsverhouding tussen schadeveroorzaker en regresnemer, al dan niet naar aanleiding van het regres, wèl tot het ontstaan van een verbintenis tot schadevergoeding zouden kunnen leiden. Daarvan zou bijvoorbeeld sprake kunnen zijn als éen van beide de ander in het kader van de procedure met apert onredelijke discussies en onkosten belast, ${ }^{113}$ of er niet tijdig wordt betaald en dat tot schade leidt (renteschade, buitengerechtelijke kosten, zie hierna).

\subsubsection{Geen schade vereist}

Maar niet alleen wordt aangenomen dat de regresrechten niet strekken tot vergoeding, zelfs is niet vereist dat de regresnemer van de uitkeringen of verstrekkingen waarvoor hij verhaal zoekt zelf nadeel ondervindt (in de zin van een definitief vermogensverlies). Een schadekarakter zou op zich inderdaad niet passen bij de

\footnotetext{
1120. HR 8 december 1938, NJ 1939, $545 \mathrm{~nL}$. EMM (Rijkversekeringsbank/Schönberger); Van Leeuwen \& Bouma (1993), p. 234; Van Boom \& Storm (1995), nt. 17; Van Boom (2000a), p. 58 en 72.

1127 Weliswaar is niet nodig dat de wetsbepaling die tot schadevergoeding verplicht de term schadevergoeding of schade noemt, maar de inhoud moet wel van die strekking zijn: PG 6, p. 331; Tekst \& Commentaar, Deventer 1998, p. 1638 (Oosterveen). De regels van die afdeling lenen zich overigens wel voor analoge toepassing.

Kremer (1994), p. 62 en (1996), p. 94.
} 
ratio van het regres: dat strekt alleen ertoe de schadeveroorzaker alsnog te laten betalen voor het hem toekomende deel (de volle schade). Het zou ook op praktische bezwaren stuiten: allerlei moeilijke actuariële discussies en discussies over de efficiency van de interne bedrijfsvoering. ${ }^{1129}$ Mij dunkt is nog wèl nodig dat voldoende aannemelijk is dat de betreffende uitkeringen ook daadwerkelijk aan de benadeelde zullen worden verstrekt. Indien daarover onzekerheid bestaat dient van de regresnemer een (voorlopig) toekenningsbesluit te kunnen worden gevraagd (of slechts een voorwaardelijke toewijzing van de vordering te volgen). Het is de vraag of dat ook geldend recht is; de Hoge Raad lijkt in een aantal uitspraken in dit verband - terecht overigens - nogal terughoudend. Ze kunnen vanwege het nogal feitelijke karakter ervan het beste afzonderlijk worden weergegeven, met een kort commentaar.

De eerste uitspraak van de Hoge Raad in deze richting, het arrest Eerste Rotterdamsche/Visser, speelt zich nog af onder het oude regime van de Ongevallenwet. ${ }^{1130}$ Risicodrager De Eerste Rotterdamsche vorderde de contante waarde à 26 401,58 gulden pensioenen die zij krachtens de Ongevallenwet aan nabestaanden moest verstrekken. Op het bedrag konden echter aanspraken in mindering worden gebracht, die de naasten tevens toekwamen krachtens de (eveneens vervallen) Algemene Weduwen- en Wezenwet. Feitelijk had De Eerste Rotterdamsche dus voor een aanmerkelijk lager bedrag uitgekeerd dan waarvoor ze krachtens de wet tot uitkering was gehouden. Het hof zag hierin geen beletsel om de vordering toch volledig toe te wijzen. In cassatie bleef dat oordeel overeind. Ondanks het kritische commentaar waarmee het arrest in de literatuur werd ontvangen, ${ }^{1131}$ komt die uitspraak niet als onredelijk voor. De precieze herkomst van de financiering of samenstelling van het uitkeringsbedrag dient, zo lees ik het, buiten het oordeel van de civiele rechter in de regreszaak te blijven. Een vergelijkbare situatie deed zich voor in de zaak Risicobank/Staat, uit 1970. De (toenmalige) bedrijfsvereniging zocht regres ingevolge de Ziektewet, maar kreeg tegengeworpen een overeenkomst te hebben gesloten met de werkgever van de benadeelde, waarbij de werkgever de financiële last van de uitkeringen overnam. Voor uitkeringen aan de benadeelde die feitelijk voor rekening kwamen van de werkgever zou de bedrijfsvereniging geen regresrecht toekomen ingevolge de Ziektewet. De Hoge Raad besliste echter dat het regresrecht van de Ziektewet gold voor alle 'krachtens de wet gemaakte kosten'. Daarvoor was alleen nodig dat de bedrijfsvereniging krachtens die wet gehouden was tot het verstrekken van de uitkeringen. Dat de bedrijfsvereniging de betreffende bedragen door de overeenkomst op derden kon afwentelen deed - terecht dunkt me niet ter zake. ${ }^{1132}$ In deze zin besliste de raad opnieuw inzake Peters/Bedrijfsvereniging. De Bedrijfsvereniging Overheidsdiensten zocht regres voor ziekengeld

\footnotetext{
1129 Van Boom (2000a), p. 57.

1130 HR 23 juni 1961, NJ 1961, 397 (Eerste Rottendamuche/Visser).

1131 Kritisch daarover is Van der Veen (1961), p. 931, in het Nederlands Juristenblad.

1132 HR 3 april 1970, NJ 1970, 379 nt. GJS (Risicobank/Staaf).
} 
dat door haar aan een militair was verstrekt. Feitelijk werden die uitkeringen gef. nancierd door de Staat; de bedrijfsvereniging was alleen belast met de uitvoering Ook dat was geen beletsel voor het toewijzen van haar vordering ingevolge ar 8 WAMIL (waarin de regresbepalingen van $Z W$ en WAO van overeenkomstig. toepassing worden verklaard). Noch voor het regresrecht van art. $52 a \mathrm{ZW}$ noci voor art. 90 WAO was volgens de Hoge Raad vereist dat de uitkeringen ook feite lijk door de bedrijfsvereniging waren gefinancierd. Van ' $k r a c h t e n s$ de wet gemaakt. kosten' is ook sprake bij kosten die slechts door de bedrijfsvereniging zijn verstrek maar feitelijk niet voor haar rekening kwamen. ${ }^{1133}$

De vraag of voor regres sprake moet zijn van schade bij het uitkerende lichaan is nadrukkelijker aan de orde in het arrest inzake Alliance/Staat, dat betrekking heeft op de Verhaalswet ongevallen ambtenaren (VOA). ${ }^{1134}$ De overheidsinstantic kreeg daar tegengeworpen dat haar regresrecht niet gold voor kosten die net zc goed zouden moeten worden gemaakt als het schadevoorval niet zou hebben plaatsgevonden (en dus geen echt nadeel opleverden). In lijn met de eerdergenoemde arresten verwierp de Hoge Raad die stelling, en besliste uitdrukkelijk dat de VOA slechts vraagt dat voorzieningen in de zin van die wet verschuldigd waren. Dat vereist zou zijn dat ten belope van de kosten van geneeskundige verstrekkingen feitelijk uitkeringen waren gedaan of sprake,wassvangeiledernecorromicthradeer,' vond volgens de raad geen steun in de wet. Het ligt voor de hand dit ook te laten gelden voor het regres ingevolge de Ziektewet en de WAO.

Een enigszins verwante kwestie was aan de orde in het arrest inzake Zwolsche Algemeene/Staat. ${ }^{1135}$ In het cassatiemiddel, zoals de Hoge Raad het leest, was gesteld dat het regresrecht van art. 2 lid 2 VOA bij arbeidsongeschiktheid mede beperkt wordt door de mate waarin de betrokken ambtenaar in staat was passende arbeid te verrichten. Dit zou betekenen dat als de Staat, zoals in cassatie vaststond, had uitgekeerd op basis van volledige arbeidsongeschiktheid terwijl de ambtenaar eigenlijk gedeeltelijk in staat was geweest om passende arbeid te verrichten, voor dat deel geen regres mogelijk zou zijn. De gedaagde beriep zich voor die stelling op de bewoordingen van art. 2 lid 2 VOA, dat geldt voor de ' $k r a c h t e n s$ de betreffende rechtspositieregelingen over de periode van die gehele of gedeeltelijke verhindering verschuldigde bezoldiging'. Maar de Hoge Raad verwierp dat, voor het regresrecht van de VOA is slechts nodig dat uit hoofde van de rechtspositie is betaald. Dat zou volgens de raad niet alleen de toepassing van de VOA in de praktijk eenvoudig houden, maar spoort ook met de strekking van de VOA, te weten: 'opheffing van door de overheid geleden financieel nadeel zoals hier is ontstaan doordat de bezoldiging en de daarmee verband houdende uitkeringen in feite zijn betaald zonder dat daar een arbeidsprestatie tegenover stond'. 136

1139 HR 18 juni 1982, NJ 1983, 369 (Peters/Bedritifsveneniging).

1134 HR 2 april 1976, NJ 1976, 532 nt. ARB (Alliance Company/Staat).

ius HR 9 december 1983, NJ 1984, 708 (Zwolsche AlgemeeneStaat).

1136 HR 9 december 1983, NJ 1984, 708 (Zwolsche Algemeene/Staat). 
Hoewel de raad met dit laatste waarschijnlijk niet méér heeft willen zeggen dan dat de VOA mede om financiële redenen is ingevoerd (betere verhaalsmogelijkheden dan voorheen bij cessie), deed het geciteerde toch weer even twijfel rijzen over de in Alliance/Staat gekozen lijn. Korte tijd later, in 1985 bevestigde de Hoge Raad echter zijn eerdere standpunt dat voor het regres ingevolge de VOA geen feitelijke schade of nadeel is vereist, nu met betrekking tot reeds opgebouwd pensioen. ${ }^{1137}$ Ook bij andere op de herkomst van de middelen waaruit de uitkering werd gefinancierd gebaseerde verweren lijkt de Hoge Raad overigens terughoudend.

De Ziekenfondsraad moest het salaris doorbetalen toen éen van haar eigen ambtenaren als gevolg van een verkeersongeval arbeidsongeschikt was geraakt en zocht op grond van de VOA regres op het Waarborgfonds Motorverkeer. Het fonds stelde dat de gevorderde bedragen door de raad werden betaald uit werkgevers- en werknemerspremies, en dus niet uit de openbare middelen, en dat de benadeelde daardoor niet kon worden beschouwd ambtenaar te zijn in de zin van art. 1 VOA. De Hoge Raad gaat uit van de meest eenvoudige (en extensieve) uitleg: beslissend is niet de herkomst van de middelen, maar de hoedanigheid van de beheender: indien de geldmiddelen onder beheer staan van een (al dan niet zelfstandig) deel van de overheid is sprake van openbure geldmiddelen, ongeacht hoe ze worden gefinancierd. ${ }^{113}$

\subsection{Bruto-netto kwestie}

\subsubsection{Inleiding}

De keerzijde van de medaille is dat het regresrecht zich niet noodzakelijk mede uitstrekt over het (eventuele) nadeel dat regresnemers zelf ondervinden van de uitkering waarvoor ze recht hebben op verhaal. ${ }^{1139}$ Dat is met name van betekenis voor regresnemers die over de uitkering van de benadeelde loonbelasting en sociale premies verschuldigd zijn, zoals doorbetaald loon, WAO-uitkeringen en ambtenarenen overlijdenspensioenen. Hebben de verstrekkers daarvan (veelal werkgevers, het UWV, en het ABP) dan recht op regres op bruto basis, dat is de uitkering met daarover betaalde loonbelasting en de verschuldigde sociale premies, of op netto basis? De belangen van de regresnemer zijn duidelijk: ${ }^{1140}$ de uitkeringen die ze aan de benadeelde doen worden bruto afgeboekt. Daar staat tegenover dat het bedrag dat de benadeelde bij het ontbreken van de sociale verzekering zelf als schadevergoeding zou hebben ontvangen lang niet altijd belastbaar is. De scha-

1137 HR 15 februari 1985, NJ 1986, $687 \mathrm{nt}$. FHJM (Stad Rotterdam/ABP).

1138 HR 3 november 1989, NJ 1990, 402 nt. JBMV (Ziekenfondsraad/Waarborgfonds Motorverkeer). Overigens is omstreden in hoeverre de Ziekenfondsraad als zodanig kan worden aangemerkt, zie daarover Veegens' NJ-noot bij het arrest.

1139 In die zin ook, maar dan voor de buitengerechtelijke kosten, HR 18 februari 1994, NJ 1995, 607 nt. CJHB (Bureau Motorrijtuigverzekeraars/ABP): 'Nu de kosten van deuitkeringen (...) kunnen worden verhaald zonder dat vereist is dat het verhalend lichaam schade of nadeel heeft geleden, brengt daartegenover de redelijkheid niet mee dat het verhaalsrecht zou behoren te worden uitgebreid tot de (...) buitengerechtelijke kosten."

1140 Een aardig overzicht van de argumenten biedt, met enige voorzichtigheid, ook lezing van HR 25 februari 1994 , NJ 1995, $608 \mathrm{nt}$. CJHB (Staat/Sterpolis). 
deveroorzaker (WA-verzekeraar) zou dan méér verschuldigd zijn dan hij zonds tussenkomst van de regresnemer aan de benadeelde zelf verschuldigd zou zij geweest (het civiele plafond). Deze kwestie is - met uitzondering van het ANW regres - hèt struikelblok geweest om te komen tot afspraken tot collectivering va regresvorderingen. ${ }^{1141}$ Ook de laatste jaren is zij nog veelvuldig onderwerp va geschil. ${ }^{142}$

Wèl hebben sociale verzekeraars en verreweg het grootste deel van de WA-verzeke raars (vertegenwoordigd door het Verbond van Verzekeraars) afspraken gemaak die nieuwe geschillen moeten vermijden. De eerste regeling in die richting wa het oude TICA-Convenant, dat betrekking had op het regres van de Ziektewet $\mathrm{Na}$ de privatisering van die wet is het beëindigd en zijn voor het regres van alle arbeidsongeschiktheidswetten (ZW, WAO, WAZ, WAJONG) afspraken van dic strekking neergelegd in het al genoemde Convenant Verhaalsrecht. Afgesproker is dat de bruto-uitkering wordt betaald onder aftrek van een forfaitaire korting. ${ }^{114}$ Volgens het Convenant wordt niet geprocedeerd en verbinden partijen zich on jegens elkaar zelfs in het geheel geen beroep te doen op rechterlijke uitspraker over 'het civiele plafond, waaronder begrepen de bruto-netto problematiek'. Dat neemt intussen niet weg, dat de partijen bij het Convenant het ondanks de gemaakte afspraken uitdrukkeljik over de kwestiesneenshljiver Linon'Juiternuéwerk'ıng van dit Convenant (en de afkoopsom van de ANW) blijft zij nog een bron van discussie. ${ }^{1144}$

De navolgende bespreking zal primair gericht zijn op de zelfstandige regresrechten van sociale verzekeraars, werkgevers, de Staat en het ABP. In paragraaf 8.2.4 zal ook de positie van de particuliere verzekeraar erbij worden betrokken, met betrekking tot schadeuitkeringen waarover loonbelasting verschuldigd is. De vraag is dan, of die voor het bruto-deel van de uitkering in de rechten van de benadeelde kan worden gesubrogeerd. ${ }^{1145}$ Voor de zelfstandige regresrechten ligt de zaak in die zin wat gecompliceerder dan bij subrogatie, dat eerst moet worden nagegaan of de afgedragen loonbelasting en sociale premies 'überhaupt' onder de kosten vallen, waarvoor deze regresrechten recht geven op verhaal.

1141 Zie o.a. Schadevergoeding, art. 108 (Bolt), aant. 68; Hartlief \& Van Maanen (1994), p. 76; Beekman (1995), p. 1230: Sinninghe Damsté (1999), p. 68.

It Z2 Zie o.a. Hof Amsterdam 14 november 1996, molnr. 760/88 (Bedrijfsvereniging/Aegon) (niet gepubliceerd); Rb. Groningen 7 augustus 1998. saaksnr. 222768/HA ZA 96-910 (niet gepubliceerd).

1143 Voor regresvorderingen die betrekking hebben op schadevoorvallen die op of na 1 januari 2001 en vóor 1 januari 2004 plaatsvonden geldt een korting van $22 \%$. Het Convenant loopt af op 31 december 2003 en zal dan zeer waarschijnlijk, zij het wellicht met cen herzien kortingspercentage, worden voortgezet. Voor regresvorderingen met een ongevalsdatum voór 1 januari 2001 geldt, dat als ze voor die datum zijn ingediend, nog het WAOconvenant uit 1998 (dat net als het TICA-Convenant een korting inhield van 24\%).

Zie Hof Amsterdam 14 november 1996, rothr. $760 / 88$ (niet gepubliceerd); Rb. Groningen 7 augustus 1998. saaksnr. 222768/HA ZA $96-910$ (niet gepubliceerd).

1145 Mits diens vordering niet al afstuit op het sommenkarakter van de verackering, dat is voor verzekeringen warbin het risico van de kosten van loondoorbetaling verzekerd is zoals gezegd omstreden, zie paragraf 4.6 .5 . 


\subsubsection{Bruto of netto kostenpost?}

Moeten onder de kosten waarvoor de zelfstandige regresrechten recht geven op verhaal naast het bedrag van de uitkering, ook de ingehouden loonbelasting en premies voor sociale voorzieningen worden verstaan? Alleen in de Verhaalswet ongevallen ambtenaren (VOA) wordt dat uitdrukkelijk bepaald. ${ }^{1146}$ Art. 2 lid 2 VOA geldt voor 'de bezoldiging of beloning en hiermee verband houdende uitkeringen, met inbegrip van loonbelasting en van de premie voor sociale voorzieningen'. Onder 'de hiermee verband houdende uitkeringen' worden volgens de Memorie van Toelichting onder meer verstaan de kinderbijslag en de vakantieuitkering (maar 'uiteraard niet de premie ingevolge de premiespaarregeling'). Onder 'de premie voor sociale voorzieningen' valt óók de door het lichaam verschuldigde pensioenbijdrage. ${ }^{1147}$

Maar de betreffende bedragen - de afgedragen loonbelasting, sociale premies en pensioenpremie - kunnen niet ten volle worden verhaald. In het arrest Sneek/Gemeente Oosterhof rekent de Hoge Raad tot deze kostenposten slechts het deel, dat ten laste van de betrokken ambtenaar komt. ${ }^{1148}$ De Hoge Raad verwerpt de benadering waarbij men de vraag of de betrokken kostenposten voor regres vatbaar zijn afhankelijk stelt van de vraag in hoeverre de verplichting tot belastingrespectievelijk de premieafdracht voor de benadeelde schade oplevert (en die schade door het uitkeringsorgaan werd weggenomen). Dat zou tot 'ernstige complicaties' leiden, terwijl het volgens de raad aannemelijker is dat de wetgever het regresrecht in dit opzicht eenvoudig heeft willen houden. ${ }^{1149}$

Aangenomen moet worden, dunkt me, dat ook de zelfstandige regresrechten van sociale verzekeraars en particuliere werkgevers zich uitstrekken over de (over de betreffende uitkering afgedragen) loonbelasting en sociale premies. 'Harde' uitspraken daarover ontbreken, we moeten het doen met indicaties in de wordingsgeschiedenis van de betrokken regresbepalingen en de rechtspraak. Zo voorzag het eerdergenoemde, vervallen (en nooit gepubliceerde) concept-wetsvoorstel dat een regresrecht moest introduceren voor de volksverzekeringen, naar verluidt in een apart vorderingsrecht voor de over de uitkering betaalde inkomensbelasting en sociale premies. Voor de (korte tijd later ingevoerde) regresbepaling van de Algemene nabestaandenwet werd afgezien van een expliciete regeling, maar wordt een voorzichtige voorkeur aan de dag gelegd voor brutoregres. ${ }^{1150}$ Dat is ook het beeld

\footnotetext{
1446 Wellicht hangt dat samen met de financiele motieven die aan de invoering van de wet ten grondslag hebben gelegen.

1147 Dat zijn de bewoordingen van de minister, TK 1964-65, 7812, nr, 3 (MvT), p. 4 (linkerkolom).

1148 HR 5 december 1969, NJ 1970, 140 (Gemeente Sneek/Oosterhof), De raad laat hetzelfde nog gelden voor de pensioenbijdrage.

$1149 \mathrm{Vgl}$. HR I februari 1974, NJ 1974, 391 (Bedrijfsvereniging/Visscher).

I150 Zie TK 1994-95, 24 169. B, p. 6 en nr. 3 (MvT), p. 26; 'Dit [de VOA-jurisprudentic van de Hoge Raad in het kader van het civiele plafond, EE] maakt dat het maximaal verhaslbare bedrag afgezet moet worden tegen het civiele plafond."
} 
voor het werkgeversregres. In een (eveneens vervallen) conceptregeling voor ant. 6:107 BW werd aanvankelijk in een regresbepaling voorzien voor door werkgevers doorbetaald loon (vergelijkbaar met art. 6:107a BW), waartoe uitdrukkelijk óók de ingehouden belasting en premies werden gerekend. Die is mede vanwege de voorstellen tot afschaffing van het regres komen te vervallen. ${ }^{1151}$ Ook de wordingsgeschiedenis van het werkgeversregres, art. 6:107a BW, biedt daarvoor aanknopingspunten. Niet alleen is voor de omvang van het regresrecht van art. 6:107a BW uitdrukkelijk aansluiting gezocht bij de regresbepaling van de Ziektewet (waarvoor zij immers als het ware in de plaats is gekomen). Ook merkte de staatssecretaris desgevraagd daarover op dat de civiel-plafond jurisprudentie van de Hoge Raad in het kader van de VOA, ook hier beperkingen oplegt. Om die reden zou sprake zijn van een netto regres. Dat veronderstelt dat het regresrecht zich in beginsel (dus behoudens de restricties in het kader van het civiele plafond) ook uitstrekt over de door de werkgever afgedragen loonbelasting. ${ }^{1152}$ Ik ga ervan uit dat hetzelfde geldt voor (het werknemersdeel van) de sociale premies. ${ }^{1153}$ Sociale premies zijn volgens de Hoge Raad echter uitsluitend verhaalbaar voorzover ze betrekking hebben op de sociale verzekering in het kader waarvan ook de betreffende uitkering werd verstrekt. ${ }^{1154}$

\subsubsection{Bruto of netto civiel plafond}

De zelfstandige regresrechten bieden kortom naast de uitkering zelf in beginsel óók verhaal voor de verschuldigde loonbelasting en sociale premies, maar de aanspraak daarop blijft net als het regres voor de (netto) uitkering zelf beperkt tot het civiele plafond. De discussie spitst zich dan ook toe op de vraag, of ook de door de schadeveroorzaker in de (fictieve) civiel-plafond situatie verschuldigde schadevergoeding op netto of bruto basis moet worden uitgekeerd. Zou de schadeveroorzaker (of WA-verzekeraar) het belastingdeel ook aan de benadeelde hebben moeten vergoeden indien die zelf schadevergoeding zou hebben gevorderd en de schadevergoeding belastbaar zou zijn geweest? Indien dat aannemelijk is, dan is ook het ten behoeve van de benadeelde afgedragen deel van de loonbelasting en de sociale premies over de uitkering, verhaalbaar. ${ }^{1155}$ Daar beginnen de moeilijkheden, want het als schadevergoeding ontvangen bedrag, gesteld dat de benadeelde

1151 Ink 6. p. 1280, 1288 en 1307; daarover Schadevergoeding, art. 107 (Bolt), aant. 49

1152 TK 1994-95, 24 326, B, p. I en zie de artikelsgewijze toelichting: TK 1994-95, 24 326, nr. 3 (MvT), p. 48; in geluke zin TK 1994-95, 24 326, nr. 7. p. 7; zie voorts Hartlief \& Van Maanen (1996), p. 127 en Van Boom (2000a), p. 41 .

1153 Bij de werkgever rust immers tevens het risico dat de door dienstverband verschuldigde premies (ZW, WAO. WW) worden afgedragen, niet bij de werknemer (tenzij die beter had moeten weten), aldus HR 3 novembet 1989, NJ 1990, 699 nt. JBMV (Denksen/Schothen).

IIS4 Zie HR 1 februari 1974, NJ 1974, 391 (Bedrüfsweneniging/Visscher).

1155 Dat stelt de Hoge Rad voor weduwe- en werenuitkeringen van de (thans) Stichting Pensioenfonds ABP voorop inzake HR 13 december 1985. NJ 1986, $246 \mathrm{nt}$. G (ABP/Wink), t.0. 3.3. 
zelf het aansprakelijkheidsrecht zou hebben ingeroepen, is slechts onder bepaalde omstandigheden belastbaar. ${ }^{1156}$

Voor heffing van inkomstenbelasting over schadevergoeding is met name van belang of de schadevergoeding dient ter vervanging van te derven inkomsten dan wel ter schadeloosstelling voor de verminderde arbeidskracht als zodanig, los van het inkomen. Rensema en Van Dort verklaren dit, door erop te wijzen dat de invaliditeit het dan onmogelijk heeft gemaakt om uit het eigen beroep inkomsten te blijven verwerven en een aanslag voor inkomstenbelasting daarom niet op zijn plaats is. ${ }^{1157}$ Daarnaast zal veel afhangen van het tijdelijke of blijvende karakter van de schade, en de vorm waarin de vordering wordt gegoten. Zou de benadeelde gekozen hebben voor een som ineens, zoals in de letselschadepraktijk gebruikelijk is, ${ }^{1158}$ dan is het meest waarschijnlijk dat hij over de schadevergoeding geen loonbelasting en sociale premies verschuldigd zou zijn. Hamer concludeert uit haar analyse van de fiscale rechtspraak in dit verband echter dat de invaliditeit in deze gevallen zodanig is, dat het voor het ongeval uitgeoefende beroep of bedrijf niet meer op dezelfde wijze kan worden uitgeoefend (en dus veelal sprake is van blijvende invaliditeit). ${ }^{1159}$ In de meeste gevallen lijkt daarvan geen sprake. Zou de schadevergoeding belastbaar zijn geweest, dan zou daarmee, naar moet worden aangenomen, a priori rekening zijn gehouden bij het bepalen van de omvang van de schadevergoeding. Ook daarvoor zou de schadeveroorzaker kortom schadevergoeding verschuldigd zijn. Afhankelijk van de concrete omstandigheden van het geval zou het civiele plafond dus, als men het precies zou willen doen, soms inclusief, maar meestal exclusief een toeslag loonbelasting worden berekend.

De Hoge Raad hecht voor het regres ingevolge de VOA echter sterker aan de eenvoud en hanteerbaarheid: de toepassing van het regres moet zo eenvoudig mogelijk worden gehouden. ${ }^{1100}$ In het bekende arrest $A B P /$ Wink uit 1985 oordeelt de raad met die woorden dat bij de berekening van het civiele plafond moet worden uitgegaan van de 'in de regel' gevolgde wijze van schadeafwikkeling voor de benadeelde, ongeacht hoe de uitkeringen waarvoor het regres plaatsvindt zijn verstrekt. Zo wordt de toepassing van de VOA zo eenvoudig mogelijk gehouden en dus beter hanteerbaar. ${ }^{1161}$ De zaak betreft een regresvordering van de (thans) Stichting Pensioenfonds ABP. Ambtenaar Beun is omgekomen bij een verkeersongeval, waaraan Wink rechtens schuld had. Krachtens de rechtspositionele regeling

1156 Zie voor een uitvoerige bespreking Van Dort \& Rensema (2002), p. 89 c.v.

1157 Rensema \& Van Dort (2002), p. 103.

1158 Schadevergoeding, art. 107 (Boit), aant. 41. Zie echter o.a. Hof Den Bosch 24 december 1974, NJ 1977, 214 (DerkvIBC), waar de benadeelde er de voorkeur aan gaf betaling van een maandelijks bedrag als smartengeld te ontvangen. Dat is ook bij overlijdensschade de meest gebruikelijke vorm van afrekening, zie a.w, ant. 108 (Bolt), aant. 51.

1159 Hamer (1989), p. 633.

1160 HR 13 december 1985, NJ 1986, $246 \mathrm{nt}$. G $(A B P / W i n k)$; HR 27 november 1987, NJ 1989, $48 \mathrm{nt}$. CJHB (Staat/Piers).

1161 HR 13 december 1985, NJ 1986, 246 (ABP/Wink), r.0. 3.3 
die op dat moment gold voor Beun, waren door het $\mathrm{ABP}$ aan weduwe en zoon Beun periodieke nabestaandenuitkeringen verstrekt. $\mathrm{ABP}$ had daarbij echter aanmerkelijk meer uitgekeerd dan het bedrag van de schadevergoeding waarop de weduve en zoon krachtens art. $1406 \mathrm{BW}$ oud, thans art. 6:108 BW, aanspraak zouden hebben gemaakt. Maar volgens het $\mathrm{ABP}$ lag het wèrkelijke civiele plafond hoger, omdat de weduwe en de zoon schadevergoeding in de vorm van periodieke bedrgen hadden kunnen vorderen, en die aan de heffing van loonbelasting zou zin onderworpen. De Hoge Raad stelt dat het hof dat verweer terecht heeft verworpen. Omwille van de eenvoud moet worden uitgegaan van wat in de regel zou zin gevorderd en dat is, zo stelt de raad het, een bedrag ineens. In de regel zou dat niet zijn belast. Aangezien een som schadevergoeding ineens pleegt te worden aangemerkt als een vergoeding voor de verloren gegane arbeidskracht, niet zozeer het inkomen zelf, wordt deze veelal niet is onderworpen aan heffing van loonbelating en sociale premies. ${ }^{1162}$ De facto komt 's raads oordeel dan ook neer $\infty$ een netto civiel plafond.

Tot een vergelijkbaar oordeel komt de Hoge Raad twee jaar later inzake Staav Piers, ${ }^{163}$ opnieuw in het kader van de Verhaalswet ongevallen ambtenaren, maar nu voor uitkeringen die verstrekt zijn bij blijvende arbeidsongeschiktheic. De uitkeringen waarvoor regres worut gezocht zijn periodiek aan de betrokken ambtenaar verstrekt. Volgens de Staat zou het berekenen van het civiele plafond op brutobasis dan op zich wel voor de hand liggen indien ook de schadevergoeding in de civiel-plafond situatie niet - zoals in het arrest uit 1985 het geval was - als een som ineens zou zijn uitgekeerd. Periodieke uitkeringen die dienen als vergoeding van de inkomensschade plegen immers te worden belast. Maar volgens de raad prevaleert ook hier een zo eenvoudig mogelijke toepassing van het regres. Ook bij blijvend letsel is in de regel sprake van een som ineens. De raad gaat er daarbij vanuit dat de schadevergoeding ineens (lump sums) 'in de regel' wordt aangemerkt als een vergoeding voor de verloren arbeidskracht (en dus niet als inkomensvervangende vergoeding), en daarom onbelast zijn. ${ }^{1164}$ Ook hier moet daarom worden uitgegaan van een netto vergoeding. ${ }^{1165}$ De Hoge Raad kiest voor een pragmatische benadering: als de benadeelde door het ongeval (geheel of gedeeltelijk) blijvend arbeidsongeschikt is geraakt, wordt in de rechtspraak

1162 Beekman (1995), p. 1232 noemt het argument van een zo eenvoudig mogelijke regeling te begrijpen, maat stelt dat het resultaat (netto-regres) ingaat tegen de bedoeling van de wetgever (art. 2 VOA geeft immers recht op het brutobedrag).

Harner (1989), p. 633 gaat mijins inviens hieraan voorbij met haar kritiek dat de Hoge Raad miskent dat schadevergoeding bij blijvend letsel soms wel wordt belast. De raad beslist nu juist dat zulke uitzonderlijke gevallen niet maatgevend zijn. Het gaat erom wat "in de regel' gebeurt. Wel deel ik haar interpretatie dat het arrest uit 1989 de mogelijkheid openlaat dat het civiele plafond bij tjjelijk ketsel wel op bruto-basis moet worden berekend HR 27 november 1987, NJ 1989, 48 nt. CJHB (Staat/Piers). Kritisch daarover Beekman (1995), p. 1232 
vrijwel steeds aangenomen dat daarvan sprake is. ${ }^{1106}$ Het is dan het meest eenvoudig om dan voor alle gevallen van blijvende arbeidsongeschiktheid, ongeacht de vorm waarin de uitkering is gegoten, uit te gaan van een netto civiel plafond. Kortom: of dat in het concrete geval anders zou zijn geweest doet niet ter zake; het brutodeel is niet verhaalbaar.

's Raads argumentatie inzake Staat/Piers liet nog enige ruimte bestaan voor de mogelijkheid van een andersluidend oordel bij het regres voor uitkeringen wegens tijdelijke arbeidsongeschiktheid. In het arrest Staat/Sterpolis geeft de Hoge Raad hierover meer duidelijkheid. ${ }^{1167}$ De betrokken WA-verzekeraar had daartegen in stelling gebracht dat het in essentie ging om een verlies aan arbeidskracht en dat die onbelast is. Tussen de benadeelde en de schadeveroorzaker zelf bestaat nu eenmaal geen dienstbetrekking die als bron zou kunnen dienen voor een bruto vergoeding. Het regres op netto basis zou de toepassing van de VOA relatief eenvoudig houden. Ten slotte wees de WA-verzekeraar erop dat wat eerst tijdelijke arbeidsongeschiktheid lijkt later blijvend kan blijken te zijn. A-G Hartkamp stelt op basis van een bespreking van relevante fiscale rechtspraak dat van een duidelijke en consistente lijn geen sprake is. Soms wordt het als schadevergoeding ontvangen bedrag belast, dan weer niet. Dit brengt hem tot de conclusie dat het beter ware 's raads eerdere jurisprudentie ook hier te laten gelden. Hij wordt hierin gevolgd door de Hoge Raad. Van Dort en Rensema stellen dat dit oordeel begrijpelijk was in het licht van de uiteenlopende fiscale rechtspraak op dat moment, maar wijzen erop dat die rechtspraak inmiddels een ander beeld laat zien: uit de fiscale rechtspraak maken ze op dat het bedrag dat bij tijdelijke arbeidsongeschiktheid wordt ontvangen in het algemeen met een heffing voor de inkomensbelasting is belast. ${ }^{1168}$ Volgens hen is niet uitgesloten dat dit de Hoge Raad in de nabije toekomst ertoe zal brengen in zulke gevallen wel regres op bruto basis toe te staan.

Hoewel de regel van de Hoge Raad betrekking heeft op het regres in het kader van de Verhaalswet ongevallen amtenaren, wordt aangenomen dat voor andere zelfstandige regresbepalingen (met name het regresrecht van de sociale verzekeringswetten) hetzelfde heeft te gelden. ${ }^{1169}$ Ook daar zou dus voor het vaststellen van het civiele plafond van het nettobedrag moeten worden uitgegaan. Bij de invoering van het werkgeversregres (art. 6:107a BW) werd daarbij aansluiting gezocht, en, ervan uitgaande dat een vergoeding ineens niet wordt belast, een netto regresrecht voorgestaan. ${ }^{1170}$ De kwestie is echter omstreden, hetgeen mede is

1166 Hamer (1989), p. 633. In 2001 besliste de Hoge Rad in dezelfde zin (schadevergoeding is bij blijvende arbeidsongeschiktheid onbelast, tenzij sprake is van bijzondere omstandigheden), zie daarover uitvoerig Rensema \& Van Dort (2002), p. 98.

1167 HR 25 februari 1994, NJ 1995, $608 \mathrm{nt}$. CJHB (Staat/Sterpolis).

1168 Van Dort \& Rensema (2002), p. 45.

1169 Van Boom \& Storm (1995), p. 157; Hartlief \& Tjittes (1999), p. 83; Van Boom (2000a), p. 40; Van Dort \& Rensema (2002), p. 44

1170 TK 1994-95, 24 326, nr. 3 (MvT), p. 48 
toe te schrijven aan de ambivalente houding van de wetgever. Mede naar aanleiding van kritiek van de Raad van de Centrale Ondernemingsorganisaties, ${ }^{1171}$ merkt de staatssecretaris nog daarover op dat het wenselijk is om voor particuliere werkgevers en de Staat als ambtenarenwerkgever in de zin van de VOA hetzelfde regime te laten gelden. ${ }^{1172}$

\subsubsection{Efficiency vóór dogmatiek?}

Met het oogmerk het regres niet te ingewikkeld te laten worden, is schadevergoeding op nettobasis in de rechtspraak van de Hoge Raad regel geworden bij de berekening van het civiele plafond voor regresnemers. De - belangrijke - consequentie van deze jurisprudentie lijkt thans dat, daargelaten of loonbelasting en sociale premies tot de kostenposten behoren die deel uitmaken van het regresrecht, het civiele plafond daaraan in de weg staat. 's Raads jurisprudentie komt echter uit een tijd waarin over de belastbaarheid van de schadevergoeding in de fiscale rechtspraak nog weinig helderheid bestond. ${ }^{1173} \mathrm{Zijn}$ er redenen voor het verlaren van het uitgangspunt van de Hoge Raad? De Hoge Raad stelt de hanteerbaarheid van de gekozen oplossing voor de bruto-netto kwestie bij het civiele plafond vootop en zoekt daarvoor aanslưting bij de gebruikelijke vorm van schadeafwikkeling (som ineens of periodiek) en kijkt naar wat dan gebruikelijk is (belastbaarheid of niet) volgens de fiscale rechtspraak. Dat lijkt, mede gelet op de handhavingsfunctie van regres, geen onwenselijk uitgangspunt. Handhaving en efficiency bijten elkaar niet, integendeel: een gecompliceerde regresregeling bemoeilijkt de uitvoering en daarmee wellicht de handhavingsfunctie van regres. Onzekerheid over het civiele plafond betekent immers onzekerheid over de grenzen van het regresrecht.

\subsubsection{Ook netto regres bij tijdelijke arbeidsongeschiktheid? Kritiek}

Van Boom plaatst vraagtekens bij een civiel plafond op nettobasis waar dat het werkgeversregres betreft voor doorbetaald loon (in de zin van art. 6:107a BW). Hij wijst erop dat het waarschijnlijker is dat de benadeelde 'bij kortlopende verplichtingen zoals de loondoorbetalingsplicht' schadevergoeding in de vorm van een som ineens zou hebben kunnen vorderen, aangezien het dan enkel gaat om de loonschade gedurende de eerste twaalf maanden van ziekte of arbeidsongeschiktheid. Weliswaar stelt de Hoge Raad de eenvoud en hanteerbaarheid van de regeling voorop, maar dàt botst volgens hem met de beoogde kostenconfrontatie van de aansprakelijke. ${ }^{1174}$ Bovendien verdient het weinig sympathie, zo stelt Van Boom, om een loondoorbetalingsplichtige werkgever met een substantieel deel van de

1171 TK 1994-95, 24326 , nr. 6, p. 5 en tijdens de integrale parlemenaire behandeling d.d. 23 november 1995 ,

1172 TK 1994-95, 24326, nr. 7, p. 7.

1173 Zie voor besprekingen van die rechtspraak Hamer (1989), p. 631 en Van Dort \& Rensema (2002), p. 45.

1174 Van Boom (2000a), p. 41. 
loondoorbetalingskosten te laten zitten ten voordele van de schadeveroorzaker. Dit laatste (dat het eerder de schadeveroorzaker moet zijn dan de werkgever, óók vanuit oogpunt van zuivere kostenallocatie) lijkt me echter niet overtuigend. Het is de schade van de benadeelde, waarmee de schadeveroorzaker volgens het argument van kostenallocatie moet worden geconfronteerd. Overtuigender is het eerste punt, te weten dat de genoemde civiel-plafond jurisprudentie, waarin wordt uitgegaan van een som ineens en 'dus' van een netto civiel plafond, voor art. 6:107a BW mogelijk geen recht doet aan de werkelijke situatie. De principiële vraag die dit oproept is wie, indien de omvang van het civiele plafond onzeker is, daarvan de nadelen moet ondervinden: de schadeveroorzaker of de regresnemer.

Zelf zou ik moeite hebben met een bruto regres dat het eigenlijke civiele plafond te boven gaat, en om die reden geneigd zijn tot terughoudendheid; de schadeveroorzaker moet niet méér betalen dan volgens het wettelijk gekozen kader mogelijk is. Het grote voordeel van de genoemde jurisprudentie van de Hoge Raad is in mijn visie dat daarmee wordt vermeden dat door eventuele miscalculaties de grenzen van het wettelijke kader (alleen regres, geen schadevergoeding) worden overschreden. Dat heeft met de functies van het regres, het bevorderen van zuivere kostenallocatie, niet direct te maken. Een aan de functies ontleend argument vind ik hier niet zo overtuigend, omdat daarmee het wettelijke systeem (wat in die visie daarop juist berust) zou worden doorkruist. Regres strekt niet tot schadevergoeding, dit zijn daarvan de consequenties. Dat werkgevers onder relatief zware lasten gebukt gaan, ${ }^{1175}$ heeft met het schadevoorval niet direct te maken, maar heeft andere redenen (privatisering Ziektewet, premiedifferentiatie WAO). Het nadeel van regres op netto basis is echter dat het regres voor werkgevers daardoor in concrete gevallen, in het licht van de daaraan verbonden kosten, onvoldoende rendabel kan zijn, en dit zonder meer zal ontmoedigen in het voeren van een actief regresbeleid. Overigens is het wel zo, dat de werkgever, in die gevallen waarin hij het risico van langdurige inkomensschade van zijn werknemers gewoon bij het publieke bestel van de WAO heeft ondergebracht, het voordeel heeft van bijstelling van het gedifferentieerde premiedeel. Maar zoals ik eerder opmerkte, ${ }^{1176}$ kan van deze stimuleringsmaatregel niet veel worden verwacht. Niet alleen 'voelt' de werkgever de correctie van het premiedeel pas na enkele jaren, ook geldt dit voordeel niet voor 'de kruidenier' (kleine ondernemers wier premies sinds kort los zijn gekoppeld van de WAO-instroom in hun bedrijf). Dat lijkt me een goede reden om in die gevallen waarvoor de 'standaardisering' van de Hoge Raad wellicht toch al niet zo overtuigend is de normale bewijsgang open te houden: als de werkgever aannemelijk weet te maken dat in het gegeven geval een bruto civiel plafond meer voor de hand ligt, dan moet een bruto regres in zijn geval gewoon mogelijk zijn. 
Resumerend kan worden gesteld dat het rechtskarakter van regresvorderingen (afgeleid karakter, zonder vergoedingselement) voor het bruto maken van de regressom buiten de grenzen van het civiele plafond geen ruimte biedt. Dat betekent niet dat vergoeding niet mogelijk is of zou moeten zijn: binnen de grenzen van het civiele plafond zou voor een bruto vergoeding gewoon plaats moeten tijn. De VOA-jurisprudentie van de Hoge Raad lijkt op dit punt, indien ze als abselute bovengrens is bedoeld (nimmer meer dan het netto bedrag), wat te streng. De Hoge Raad stelt efficiëntie en eenvoud voorop, maar indien de regresnemer aannemelijk weet te maken dat de benadeelde gerechtigd zou zijn geweest tot een bruto schadevergoeding behoort hij niet te worden beperkt in zijn recht.

Een analogie kan worden gemaakt met de gevallen van 'abstracte' schadeberekening. In een antal gevallen, veelal buiten de sfeer van personenschade, ${ }^{11} 7$ is er reden om gegevens omtrent de schade te standaardiseren, bijvoorbeeld uit oogpunt van doelmatigheid (autoschades) of uit oogpunt van rechtshandhaving (inbreuk op octrooirecht). Ook daarvan wordt aangenomen dat slechts sprake is vas een minimum niveau van bescherming, als 'praktisch hulpmiddel' om moeizame discussies te vermị den. De abstract berekende schade vormt dan ook geen bovengrens voor het recht op schadevergoeding. ${ }^{\text {. }}$ In deze zin zou ik ook's raads civiel-plafond jurisprudentie willen aanmerken: ook die moet rimte laten om - binnen de grenzen van het civiele plafond - tot het bruto-bedrag te komen indien ook de benadeelde bruto schadevergonding zou hebben kunnen vorderen.

\subsection{Buitengerechtelijke kosten van regresnemers}

\subsubsection{Inleiding}

Een ander omstreden kwestie betreft de vraag, in hoeverre regresnemers aanspraak kunnen maken op vergoeding van hun buitengerechtelijke kosten, de kosten die verband houden met het geldend maken van de regresvordering. Ook meer recent nog blijkt dit een bron van geschillen in procedures. ${ }^{1179}$ Regresnemende verzeke-

Inkomensschade, ziektekosten enzovoort worden conereet berekend; zie Barendrecht \& Storm (1995), p. 23 e.v.; Bouman \& Tilanus-Van Wassenacr (1998), p. 32; Spier c.a. (2000), nr. 207 (Hartlief). Dé uitzondering is HR 28 mei 1999, NJ 1999, 564 nt. ARB (Gemeente Losser/De Vries), waarin de Hoge Raad toeliet dat indien ouders bij emstig letsel van hun kind dat ziekenhuisopname en langdurige verpleging behoeft zelf de verzorging op zich nemen de schade wordt gesteld op de kosten van professionele hulp, hoewel die kosten eigenlijk als zodanig niet zijn gemaakt. In HR 6 juni 2003, C02/062HR (Krüter-Van de Pol/Holding BV) sanctioneert de raad echter het oondeel dat daarvoor geen plaats is indien het inschakelen van professionele hulp niet normaal en gebruikelijk is.

Zie o.a. de NJ-noot van Meijers inzake HR 18 november 1937, NJ 1938, 269 nt. EMM (Van Rompu/Cleeves); HR 16 juni 1961, NU 1961444 nt. LFHR (Telefoonkabe). Bloembergen (1965), nr. 31 e.v. benadrukt de argumenten met betrekking tot zaakschade voor herstel op basis van de waarde van de zaak in dit laatste arrest. Zie kritischer Aser-Hartkamp 4-I, nr. 418, war de term 'praktisch hulpmiddel' valt (als tegensteld aan cen rechteregel).

1179 Zie o.a. Hof Amsterdam 9 december 1993. rolnr. 25492 (ESVZiekenfonds Amstendam) (in beginsel verhaalhaar); ook meer recent Hof Den Haag 29 april 1998, rolnr. 95/1113 (waarin werd toegewezen); en naar aanleiding van het arrest Termimus/ZAO besliste inmiddels o.a. het Hof Amsterdam 19 maart 1998, rolnr. $96 / 1028$ (niet gepubliceerd), waarbij de vordering van art. 6:96 onder c niettemin wordt afgewezen op de grond dat de kosten 
raars, denk ook aan UWV en ziekenfondsen, hebben veelal een eigen juridische afdeling, maar kampen bijvoorbeeld met de kosten van correspondentie en de kosten van externe rechtshulp (zoals de kosten van de raadsman voorafgaand aan het geding). ${ }^{1180}$ Zoals bekend, kunnen daarmee (en bij vergoeding mede de wettelijke rente), vrij substantiële bedragen gemoeid zijn. ${ }^{1181} \mathrm{De}$ wet, afdeling $6.1 .10 \mathrm{BW}$, voorziet wel in de mogelijkheid tot vergoeding van zulke kosten voor de benadeelde zelf en al degenen die recht hebben op schadevergoeding (waarbij aangetekend zij dat de regels van deze afdeling ook analoog kunnen worden toegepast). ${ }^{1182}$ Art. 6:96 lid 2 BW geeft recht op vergoeding van de kosten ter voorkoming of beperking van schade die als gevolg van de gebeurtenis waarop de aansprakelijkheid berust mocht worden verwacht (sub $a$ ), de kosten ter vaststelling van schade en aansprakelijkheid (sub $b$ ) en de kosten ter verkrijging van voldoening buiten rechte $(\operatorname{sub} c) .{ }^{1183}$ Om voor vergoeding in aanmerking te kunnen komen moet voldoende vaststaan dat het redelijk was om zulke kosten te maken en dat ook de omvang waarin die kosten gemaakt werden redelijk is (dubbele redelijkheidstoets). ${ }^{1184}$

\subsubsection{Rechtsbijstandverzekeraars en de NORA-regeling}

De regeling van art. 6:96 lid $2 \mathrm{BW}$ geldt rechtstreeks alleen voor partijen tussen wie het geschil speelt in het kader waarvan de buitengerechtelijke kosten zijn gemakt. ${ }^{1185}$ Wèl is de vordering die de benadeelde aan deze bepaling ontleent vatbaar voor subrogatie op de voet van art. $284 \mathrm{WvK} / \mathrm{art}$. 7.17.2.25 BW, indien schadeverzekeraars juist die kosten voor hun rekening moeten nemen op basis van de verzekeringsovereenkomst. Rechtsbijstandverzekeraars die de bij hen verzekerde kosten, intern of extern, primair maken ten behoeve van de benadeelde worden in zoverre dan ook gewoon gesubrogeerd in diens op art. 6:96 lid $2 \mathrm{BW}$ gebaseerde vordering tot schadevergoeding. ${ }^{186}$ Specifiek met betrekking tot personenschadehebbenrechtsbijstandverzekeraarsen WA-verzekeraars afspraken gemaakt over de daarbij te hanteren tarieven. Op 1 januari 1993 is daartoe de zoge-

naar's hofs oordeel niet voldoende waren gespecificeerd. Zie voor afwijzende oordelen voorts de rechtspraak vermeld bij Lindenbergh e.a. (2000), p. 78 e.v. (Kremer).

1130 Zie Kremer (2000), p. 72, die erop wijst dat kosten ter vaststelling van de schade dan, bij regresnemende veracketaars en werkgevers, minder gauw hoeven te worden gemaakt. Die blijkt veelal wel voldoende, 20 stelt hij het, uit de ziekenhuisrekening of salarisstrook.

1181 Bij Lindenbergh e.a. (2000), p. 33 (Tromp) wordt erop gewezen dat verzekeraars de ontwikkelingen op dat gebied mede als oorzak voor de schadelast noemen.

1182 Dat is een codificatie van een reeds onder het oude recht bestaande praktijk, zie m.n. HR 3 april 1987, NJ 1988, $275 \mathrm{nt}$. CJHB (L\&LDrenth); vgl. Bloembergen (1965), nr. 153, die wijst op de voordelen van vergoeding. Voor de kosten die verband houden met het voeren van het geding, of die daarmee overlappen zoals van de voorbereiding van de dagvaarding, geldt de regeling van 241 Rv (voorheen art. 57 lid 6 Rv).

1124 Overigens lijkt de afweging voor de drie in ant. 6:96 lid 2 BW onderscheiden kostenposten niet noodzakelijk dezelfde, zie Lindenbergh e.a. (2000), p. 16 (Lindenbergh).

Zie Kremer (1994), p. 60. 
naamde NORA-regeling gesloten, ${ }^{1187}$ een naar het schijnt goed werkende regeling, die erop neerkomt dat de aangesloten WA-verzekeraars bij individuele gevallen van letsel of overlijden een vast bedrag (in 1999: 1875 gulden) uitkeren voor de buitengerechtelijke kosten. De vraag of art. 6:96 lid 2 BW ook rechtstreeks geldt, is voor deze regresnemers in concrete gevallen dan ook van geringe betekenis. ${ }^{118}$ Voor anderen dan verzekeraars die kosten van de benadeelde voor hun rekening nemen, zou art. 6:107 lid 1 BW uitkomst kunnen bieden (tezamen met de grondslag voor aansprakelijkheid die de verhouding tussen de schadeveroorzaker en de primair benadeelde beheerst). Onzeker is of art. 6:107 BW ook voor zulke kosten kan worden aangewend, maar ik zie daarvoor wetssystematisch geen bezwaar: men zou dan moeten stellen ten behoeve van de benadeelde juridische bijstand te hebben ingeschakeld, medische deskundigen geconsulteerd et cetera (in beginsel alle kosten zoals bedoeld in het tweede lid van art. 6:96 BW) en dat de benadeelde daarvoor, er vanuit gaande dat de aansprakelijkheid vaststaat, recht zou hebben gehad op verhaal binnen de grenzen van art. 6:96 lid $2 \mathrm{BW}$. In zoverre zou men die kosten dan op de voet van art. 6:107 BW juncto art. 6:96 lid 2 BW kunnen verhalen. Ook in zoverre is de toepasselijkheid van art. 6:96 lid 2 BW dunkt me niet exclusief.

\subsubsection{Zelfstandig beroep op art. 6:96 lid $2 \mathrm{BW}$}

Interessanter is de vraag of schadeverzekeraars in het algemeen en voorts degenen met een zelfstandig regresrecht tevens een zelfstandig beroep toekomt op die regeling. Dat wil zeggen voor de eigen kosten in de zin van die regeling, die men in verband met het geldend maken van zijn vorderingsrecht heeft moeten maken. Die vraag is met name interessant voor regresnemers; daarbuiten lijdt dit wat mij betreft geen twijfel: art. 6:96 lid $2 \mathrm{BW}$ geldt ook voor derden die een geslaagd beroep doen op art. 6:107 BW en voor de nabestaanden van art. 6:108 BW (en dan hun rechtsbijstandverzekeraars incluis, ik wees daarop al). Denk aan de werkgever van de benadeelde die het onverzekerde deel van de revalidatiekosten voor zijn rekening neemt. Zowel het vorderingsrecht van art. 6:107 als van art. 6:108 BW geven een secundaire verplichting tot schadevergoeding. ${ }^{1189}$ De omvang daarvan wordt dan ook, met uitzondering van art. 6:106 BW, beheerst door de normale regels van afdeling 6.1.10 BW. Zoals ik eerder opmerkte, is dat anders voor de wettelijke regresrechten. Die vallen niet rechtstreeks onder het geldingsbereik van afdeling 6.1.10 $\mathrm{BW}$ omdat ze geen verbintenis tot schadevergoeding in het leven roepen (althans niet rechtstreeks).

1187 De regeling van de Nederlandse Organisatie van Rechtsbijstand Assuradeuren, thans de Afdelingscommissic Rechtsbijstand; zie Lindenbergh e.a. (2000), p. 96 (De Vries). Deze regeling geldt zowel bij letsel als overlijden. De NORA-regeling is integral opgenomen als Bijlage 91 bij Lindenbergh e.a. (2000), p. 579. 
Vallen de buitengerechtelijke kosten bij de zelfstandige regresbepalingen dan wellicht onder de 'gemaakte kosten' waarvoor die de mogelijkheid bieden tot verhaal? De wet zwijgt op dit punt, maar uitgaande van de rechtspraak van de Hoge Raad over buitengerechtelijke kosten lijkt het er niet op. Tot 1994 werden daarop geënte vorderingen in de lagere rechtspraak soms toegewezen. ${ }^{1190}$ Ook in de literatuur gingen stemmen op om de buitengerechtelijke kosten van regresnemers voor verhaal in aanmerking te laten komen. ${ }^{1191}$ De Hoge Raad besliste echter anders in een tweetal belangrijke uitspraken in 1994, beide in het kader van de Verhaalswet ongevallen ambtenaren. De regresnemende instantie, (thans) Stichting Pensioenfonds ABP, beriep zich daartoe op de redelijkheid: de wet zou, zo lijkt de gedachte, een regresrecht geven maar zou het nadeel dat de rechthebbende (ABP) ondervindt bij het effectueren daarvan zelf laten dragen. Maar de Hoge Raad oordeelt dat onder de 'kosten' waarvoor art. 2 lid 1 VOA recht geeft op regres niet ook de buitengerechtelijke kosten vallen. Ook de redelijkheid is volgens de raad geen argument voor een uitbreiding van die strekking. Voor de kosten waarop het regresrecht betrekking heeft is het criterium immers niet of ze schade of nadeel opleveren voor het verhalende lichaam. ${ }^{1192}$

Het ligt in dit verband voor de hand om hetzelfde uitgangspunt te laten gelden in het kader van de overige wettelijke regresbepalingen; ook onder de 'gemaakte kosten' waaraan in die bepalingen wordt gerefereerd, vallen niet de buitengerechtelijke kosten. ${ }^{1193}$ Niet alleen vanuit systematisch oogpunt, maar met name ook om inhoudelijke redenen lijkt dat juist; als men ook eigen schade van de regresnemer onder het regresrecht brengen (zoals de kosten bedoeld in art. 6:96 lid $2 \mathrm{BW}$ ), dan zou dat haaks staan op het principe dat de schadeveroorzaker financieel of vermogensrechtelijk niet slechter mag worden van het regres vergeleken met de situatie waarin hij zou hebben verkeerd als hij tot schadevergoeding zou zijn aangesproken door de benadeelde. De ultieme consequentie daarvan zou zijn, Kremer wijst daarop, ${ }^{1194}$ dat de schadeveroorzaker met evenzovele vorderingen tot vergoeding van de buitengerechtelijk kosten wordt geconfronteerd als met eisers in de procedure (ziekenfonds, ziektekostenverzekeraar, werkgever en UWV). Bij een cumulatie van regresvorderingen, zoals bij ziekenhuisopname en/of langdurige arbeidsongeschiktheid, kan dat aardig oplopen. ${ }^{1195}$ Dat kan natuurlijk niet, om

1190 Zie de rechtspraak genoemd bij Van Leeuwen \& Bouma (1993), nt. 10 en 11.

$1191 . T$ Tot de voorstanders behoren o.m. Van Leeuwen \& Bouma (1993), p. 235.

1192 HR 18 februari 1994, NJ 1995, $607 \mathrm{nt}$. CJHB (Bureau Motorrijtuigverzekeraars/ABP); in gelijke zin oordeelt de raad inzake HR 29 april 1994, NJ 1995, 609 nt. CJHB (Nationale Nederlanden/ABP). Brunner wijst in zijn NJ-noot bij het eerstgenoemde arrest (NJ 1995, 607) ook op cerdere jurisprudentic waarin de Hoge Raad een strikte uitleg geeft van art. 2 VOA, o.m. HR I februari 1974, NJ 1974, 391 (Bedrijfsvereniging/Visscher) en HR 4 maart 1977, NJ 1978, 144 nt. ARB (Providentia/ABP).

$1193 \mathrm{Vgl}$. voor het werkgeversregres TK 1995-96, 24 326, nr. 1196, p. 3 en zie in dezelfde zin Kremer (1994), p. 62 en Kremer (2000), p. 74.

1194 In die zin ook Kremer (1994), p. 60 en dezelfde (2000), p. 82.

1195 Kremer (1996), p. 93 wijst op dat bezwaar. Ook Hartlief \& Tjittes (1999), p. 84 voelen om deze reden voor enig plafond. 
zulke resultaten te vermijden geldt nu juist de beperking van het civiele plafond. Daarvoor zou het overigens geen verschil moeten maken of men daartoe komt door een interpretatie van de bewoordingen van het zelfstandige regresrecht, dan wel door regresnemers een analoog beroep te laten op art. 6:96 lid 2 BW. Beide leiden tot hetzelfde (met de ratio en systematiek van de regresrechten strijäge) resultaat. Gelet op het wetssystematische onderscheid met de vorderingsreciten van art. 6:107 en 108 BW kan dit echter wel tot wat curieuze gevolgen leiden: de werkgever kan bij het betalen van de medische kosten in de zin van art. 6:107 $\mathrm{BW}$ de kosten van zijn vorderingsrecht wèl afwentelen op de schadeveroorziker, maar bij loondoorbetaling in de zin van art. 6:107a BW kan hij dit niet.

Wèl heeft de Hoge Raad in het arrest Terminus/ZAO de vergoeding van buitengerechtelijke kosten voor regresnemers toewijsbaar geoordeeld op een andere (directe) grondslag dan de regresvordering zelf. WA-verzekeraar Terminus had eennaal tot regres aangesproken betaling geweigerd. Volgens de raad heeft het ziekenfonds onder deze omstandigheden 'als iedere crediteur van een geldvordering welkeniet wordt voldaan' krachtens art. 6:96 lid 2 aanhef en onder $c$ BW recht op vergoeding van de redelijke kosten ter verkrijging van voldoening buiten rechte. ${ }^{1196}$ De raad lijkt hierin zijn A-G Hartkamp te hebben gevolgd, ${ }^{\mathrm{IIT}}$ die erop wijst dat regresnemers zoals alle crediteuren van een geldsom bij verzuim wegens nietnakoming door schadeveroorzaker of WA-verzekeraar recht hebben op schadevergoeding, bestaande uit vertragingsschade (art. 6:119 BW). Vanaf dàt moment, het moment van de niet-nakoming, heeft men dan óók recht op vergoeding van de kosten bedoeld in art. 6:96 lid 2, sub $c$ BW. Die regeling geldt volgens A-G Hartkamp, daarvoor refererend aan de wordingsgeschiedenis van die bepaling, voor alle geldschulden en dus ook voor regresvorderingen, tenzij uit geschreven of ongeschreven recht anders blijkt. ${ }^{1198}$ Nodig is dan wèl, zo stelt de A-G het, dat het recht op schadevergoeding berust op de schade die de regresnemer ondervindt van het feit dat de schuldenaar zijn (regres)schuld niet nakomt. De Hoge Raad beslist dat ZAO 'als iedere crediteur van een geldvordering welke niet wordt voldaan' recht heeft op vergoeding van de buitengerechtelijke kosten als bedoeld in art. 6:96 sub $c$ BW. Dit lijkt me helder: regresvorderingen mogen dan zelf geen schadevordering zijn in de zin van afdeling $6.1 .10 \mathrm{BW}$, ze kunnen dat wèl worden of althans een vordering tot schadevergoeding in het leven roepen. ${ }^{1199}$ Het regime van Termimus/ZAOlijkt hiermee te gelden voor elke toerekenbare tekortkoming

1196 HR 5 december 1997, NJ 1998, 400 (Termimue/ZAO).

1197 Ook Lindenbergh en Kremer leren het arrest zo, zie respectievelijk Lindenbergh ea. (2000), p. 15 en 17 (Lindenbergh) en p. 76 (Kremer).

1198 Voor toewijzing op grond van de redelijkheid en billijkheid die de rechtsverhouding tussen regresnemer en WA-verzekeraar zouden beheersen (art. 6:2 BW) is, naast de meer specifieke grond van art. 6:96 lid 2 onder c BW, geen plaats. Zie Conclusie Hartkamp (nr. 19) invake HR 5 december 1997, N 1998, 400 (TominasZ1O). Ook Lindenbergh e.a. (2000), p. 19 (Lindenbergh) leest het arrest zo: 'De formulering van de Hoge Raad (...) doet vermoeden dat de grond voor toewijzing is gelegen in de niet-nakoming van de verplichting tot betaling'. 
in de nakoming bij de voldoening van de regressom. ${ }^{1200}$ Alleen in zulke gevallen is plaats voor de vergoeding van de buitengerechtelijke kosten, en verhaalbaar zijn dan enkel de kosten die verband houden met de schade die de regresnemer van de niet-nakoming ondervindt.

\subsubsection{Alleen de kosten van niet (tijdige) nakoming}

Duidelijk is hiermee wel dat deze aanspraak - in theorie - (terecht) beperkter is: alleen de buitengerechtelijke kosten (en andere schade) die verband houden met de niet (tijdige) nakoming worden vergoed. Dat vergt naast de dubbele redelijkheidstoets als het ware een derde toets: hebben de kosten betrekking op het vaststellen en instellen van de regresvordering zelf of op het opnieuw vaststellen en opnieuw instellen? Wat betekent dit nu concreet voor de verhaalbaarheid van de buitengerechtelijke kosten van regresnemers in deze gevallen? In het regime waarvoor de Hoge Raad opteert in Terminus/ZAOligt een belangrijke beperking besloten: als de genoemde uitleg van het arrest de juiste is, komen de kosten voor het berekenen van de omvang van het regresrecht die op eerste verzoek gewoon worden voldaan immers niet voor vergoeding in aanmerking. ${ }^{1201}$ Ook op enig later moment zal voor het opvoeren van zulke kosten in dat geval geen plaats zijn. Alleen de kosten die dàn weer, door de weigering tot betaling, ter verkrijging van voldoening buiten rechte moeten worden gemaakt komen voor vergoeding in aanmerking. ${ }^{1202}$ Lindenbergh raakt precies de kern:

'Aldus komt men in deze verhouding in zekere zin uit op een civiel plafond, in die zin dat de regresnemer niet meer kan vorderen dan de bij de gelaedeerde zelf bespaarde buitengerechtelijke kosten, met dien verstande dat voorzover de kosten het gevolg zijn van de weigering tot betaling door de aansprakelijke of diens verzekeraar, de te vergoeden schade niet door het plafond wordt gekeerd."1203

Noch de kosten van de berekening of vaststelling (inclusief juridisch bijstand en correspondentie), noch die van het eerste aanschrijven zijn verhaalbaar; de kosten moeten het gevolg zijn van de niet-nakoming. Lindenbergh noemt de kosten van extra aanmaningen, nadere onderbouwing van de vordering en nadere adstructie van de begroting of het causaal verband. ${ }^{1204}$ Wel plaats ik vraagtekens bij de praktische hanteerbaarheid van het gemaakte criterium (of al dan niet op eerste aanzegging is betald). In het arrest Bijlsma/Stichting Pensioenfonds ABP werd het volle bedrag van de buitengerechtelijke kosten, ongeveer 10000 gulden, ge-

\footnotetext{
1200 Op dit punt anders Lindenbergh e.a. (2000), p. 80 (Kremer).

1201 Lindenbergh e.a. (2000), p. 19 (Lindenbergh); in die zin ook Kremer, a.w., p. 80 (Kremer) die dit echter als ik het goed zie reeds baseert op de redelijkheidstoets van art. 6:96 lid 2 BW en dus niet noodzakelijk op de grondslag van de vordering.

1202 In die zin Lindenbergh e.a. (2000), p. 19 (Lindenbergh), waar tevens wordt opgemerkt dat het hier eigenlijk om de kosten van ant. 96 lid 2 sub $b$ gaat.

1203 Lindenbergh e.a. (2000), p. 20 (Lindenbergh).

1204 Lindenbergh e. (2000), p. 20 (Lindenbergh).
} 
noegzaam toegewezen. Nu lijkt dat naast de regressom van ongeveer 170000 gulden niet bijzonder veel, maar desondanks kan worden betwijfeld of die ksten uitsluitend betrekking hadden op de inspanningen in de tweede ronde (de ksten verbonden aan de herhaalde vordering). Ook lijkt het niet denkbeeldig dz dit regime regresnemers zal aanmoedigen om te trachten, binnen de grenzen va de dubbele redelijkheidstoets, ${ }^{1205}$ bij het indienen van hun vordering op devoet van art. 6:96 lid 2 sub $c$ BW wat met de kostenposten te schuiven. Zulle de buitengerechtelijke incassokosten voor de regresvordering respectievelijk /oor de naleving daarvan niet gemakkelijk 'op één hoop' belanden?

Hoewel het uitgangspunt ook in het kader van art. 6:96 lid 2 BW is dat de scade zoveel mogelijk moet worden vergoed, ${ }^{1206}$ legt de dubbele redelijkheidoets daarbij zekere beperkingen op. De vergoeding blijft beperkt tot de 'redelike' buitengerechtelijke kosten, dat wil zeggen kosten waarvan het èn verantword was om ze te maken (eerste redelijkheidstoets) èn die tevens naar hun omung, mede gelet op de omvang van de hoofdvordering en de overige omstandighden van het geval, ${ }^{1207}$ in redelijkheid zijn gemaakt (tweede redelijkheidstoets. ${ }^{1208}$ In het algemeen geldt daarbij het uitgangspunt dat ook de (eventueel) gemakte interne bedrijfskosten, zoals de kosten van de eigen juridische afdeling of advcaat, binnen deze grenzen zullen moeten worden vergoed. ${ }^{1209}$ Voor de omvang van interne bedrijfskosten kan worden aangehaakt bij de kosten die bij het wèl uit handen geven van de werkzaamheden zouden zijn gemaakt. Dat zijn wat mij betreft ook de 'eenvoudige' handelingen, hoewel daarover wisselend wordt gedacht, ${ }^{1210}$ mits - nogmaals - terug te voeren op de noodzaak van herhaalde aanzegging.

\subsubsection{Is sprake van een algemene regel?}

Kort na het verschijnen van het arrest Terminus/ZAO was onduidelijk wat de betekenis daarvan was op het punt van de buitengerechtelijke kosten, voor het al genoemde regime van de VOA. ${ }^{1211}$ In het arrest Bijlsma/Stichting Pensioenfonds $A B P$ biedt de Hoge Raad daarover meer duidelijkheid: de nieuw ingezette koers geldt ook voor het regres van de VOA. ${ }^{1212}$ In slechts één volzin stelt de

Kremer (1994), nr. 4 en (1996), p. 93 stelt dat voor regresnemers met name het eerste criterium van de dubbele redelijkheidstoets (was het redelijk om kosten te maken) aandacht verdient, met name bij pure incassokosten, en wijst op lagere rechtspraak over de redelijkheidstocts. Zie voor verwijzingen ook zijn bijdrage in Lindenbergh e.a. (2000), p. 78.

1206 Lindenbergh e.a. (2000), p. 21 (Lindenbergh).

1207 HR 9 december 1994, NJ 1995, 250 (Smiv/De Moor).

1208 VgL HR 16 oktober 1998, NJ 1999, $196 \mathrm{nt}$. ARB (Amew/Siaat).

1200 PG 6. p. 338; HR 16 oktobet 1998, NJ 1999, $196 \mathrm{nt}$. ARB (Amew/Staat).

1210 Kremer (1999), nr. 7 pleit voor meer ferughoudendheid bij wat hij noemt 'bagatelschadeposten'; alleen de kosten van handelingen waarvoor specifieke kennis is vereist zouden moeten worden vergoed. Hij oppert zelfs om voor bepaalde schadecomponenten (telefoonkosten, invullen formulieren) drempels in te stellen.

1212 HR 31 mei 2002, saakenr. C00107HR (Bylsma/Srichting Pensioenfonds ABP). 
raad vast te houden aan zijn oordeel in de genoemde arresten: de buitengerechtelijke kosten komen niet op de voet van art. 2 VOA voor vergoeding in aanmerking, maar er is - net als bij het regres van sociale verzekeraars - wèl ruimte voor een vordering op de voet van art. 6:96 lid 2, aanhef en onder $c$ BW. De raad refereert voor zijn beslissing over de toewijsbaarheid van de buitengerechtelijke kosten uitdrukkelijk aan het arrest Terminus/ZAO. ${ }^{1213}$ Dat duidt erop dat de daarmee ingezette koers ook geldt voor de overige zelfstandige regresrechten; alle regresnemers zijn immers crediteur van een geldvordering. ${ }^{1214}$

Dit lijkt meniet anders voor gesubrogeerde schadeverzekeraars. Opdit punt heerst enige onduidelijkheid. Voorop staat dat het door de schadeverzekeraar verkregen vorderingsrecht weliswaar tot schadevergoeding strekt (en dus mede worden beheerst door de regels van afdeling 6.1.10 BW), maar op zich nog geen verplichting tot vergoeding van schade van de verzekeraar zèlf in het leven roept. Afdeling 6.1.10 BW is niet rechtstreeks van toepassing. Voor de vergoeding van buitengerechtelijke kosten uit hoofde van art. $284 \mathrm{WvK} / \mathrm{art}$. 7.17.2.25 BW wordt daarom aangenomen, ik stelde dit al, dat nodig is dat de buitengerechtelijke kosten herleidbaar zijn tot schade van de benadeelde zelf. ${ }^{1215}$ Minder eenvoudig is om uit te maken wanneer daarvan sprake is; de verzekeraar kan immers ook een expertise laten verrichten vanuit het belang minder uitkering te hoeven doen. ${ }^{1216} \mathrm{Om}$ zulke kosten als schade van de benadeelde te laten gelden wordt in de polis wel bepaald dat ook het risico van expertisekosten verzekerd is en dat de verzekeraar is gemachtigd tot het maken van die kosten ten behoeve van de verzekerde. ${ }^{1217}$ Zo bezien lijkt de verhaalspositie van schadeverzekeraars met betrekking tot de kosten van art. 6:96 lid 2 BW gunstiger dan voof sociale verzekeraars en werkgevers. Mijns inziens past daarbij terughoudendheid. Nagegaan moet worden of het beding in de gegeven omstandigheden reëel is of dat het om 'schade' van de verzekeraar gaat. In het laatste geval geldt ook voor de schadeverzekeraar het regime van de Hoge Raad: geen opeenstapeling van buitengerechtelijke kosten, tenzij die bestaan uit de schade door niet tijdige betaling. Voor de vergoeding van de eigen buitengerechtelijke kosten is dus ook dan alleen plaats indien daarvoor een zelfstandige grondslag bestaat, los van het regresrecht als zodanig en het schadevoorval waarop dit betrekking heeft.

Zoveel is duidelijk: de schadeveroorzaker mag van het regres niet relatief slechter worden, zowel het oprekken van de kosten waarvoor de regresbepalingen recht geven op verhaal als analoge toepassing van art. 6:96 lid 2 BW zouden dat beginsel

HR 5 december 1997, NJ 1998, 400 (Terminus/Z1O).

1214 Zoals werkgevers; in zijn bijdrage aan Lindenbergh e.a. (2000), p. 78 stelt Kremer dat werkgevers de uitvoering van loonvorderingen regelmatig uitbesteden en bespreekt enkele kantonzaken in dat verband.

1215 Kremer (1994), p. 62 (met rechtsprakverwijzingen); Van Boom \& Storm (1995), p. 152; Hartlief \& Tjittes (1999), p. 81.

1216 Mulder (1988), p. 71 (met betrekking tot expertisekosten); Stolker (1994), ĥr. 2; Kremer (1994), nr. 7.

1217 Zie instemmend Stolker (1994), nr. 2. 
frustreren. Daarvoor is volgens de Hoge Raad dan ook terecht geen plats. Dat effect kan echter wèl worden bereikt buiten de regresregelingen om: aeen de kosten die verbonden zijn aan de gevolgen van de niet-nakoming dienen tevorden vergoed. Gelet op de praktische bezwaren van dat onderscheid zou het de vorkeur verdienen indien verzekeraars op dit punt tot onderlinge afspraken zouden omen.

\subsection{Verrekening of matiging van de regressom}

\subsubsection{Aan de regresnemer opgekomen voordeel (art. 6:100 BW)}

De analogie met de regels van afdeling 6.1.10 BW kan intussen ook omekeerd worden gebruikt. Als regresnemers naar analogie met art. 6:100 BW, ar 6:101 $\mathrm{BW}$ of art. 6:109 BW respectievelijk voordeelstoerekening, eigen schulcof een grond voor matiging kan worden tegengeworpen, en op basis daarvan de vischuldigde regressom kan worden verminderd, dan leidt dit ertoe dat de schadevioorzaker niet ten volle met de schade wordt geconfronteerd. Bestaan daarvoo goede gronden en in hoeverre is zulks naar geldend recht mogelijk?

In het arrest inzake Providentia/ABP onder het oude recht wijst de Hog Raad het beroep op voordeelstoerekening af met betrekking tot de vervroegde sterftekans van de benadeelde. ${ }^{1218}$ Waar ging het om? Peters had zeer ernstig letsel opgelopen van een ongeval waarvoor Providentia aansprakelijk was. Het ABP had hem daarom een invaliditeitspensioen uitgekeerd en zocht daarvoor regres op de voet van art. 2 lid 1 VOA. Het voerde daarbij echter naast de uitgekeerde pensioenen ook de schade aan van de pensioenpremies die door haar, nu Peters invalide was geworden, werden misgelopen. Het Hof zag reden voor toewijzing van die vordering, maar verminderde de regressom met het 'voordeel' dat het ABP in feite had van de verhoogde sterftekans van de betrokken ambtenaar na het ongeval. De Hoge Raad zag dat gelukkig anders. Het $\mathrm{ABP}$ had krachtens de VOA recht op al hetgeen krachtens rechtspositieregelingen was uitgekeerd, en de omvang van dat regresrecht wordt alleen beperkt door het civiele plafond, niet door het genoemde voordeel. Dat sluit volgens de Hoge Raad het meest aan bij de strekking en woorden van de VOA en houdt de toepassing daarvan in de praktijk zo eenvoudig mogelijk. ${ }^{1219}$ Overigens wijst Bloembergen er in zijn NJ-noot op dat de vervroegde sterftekans wèl als factor voor de berekening van het civiele plafond ten nadele van de regresnemer zou kunnen meewegen. Als immers de sterftekans van de benadeelde door het ongeval wordt verhoogd, dan zal daarmee in theorie ook zijn inkomensschade (en eventuele andere schade) verminderen. Door die vermindering van de schade is ook het civiele plafond lager (en aangezien het VOA-regres niet in het nadeel 
van de ambtenaar kan worden uitgeoefend treft dat uitsluitend de regresnemer). ${ }^{1220}$

Ook voor het langs deze weg verrekenen van de verzekeringspremies die regresnemers met betrekking tot de uitkering waarvoor ze regres zoeken hebben ontvangen lijkt dan bij het (VOA-)regres geen plaats. ${ }^{1221}$ Dat lijkt trouwens ook niet goed te passen bij de wel gehoorde opvatting dat de benadeelde de door hem verschuldigde premies zèlf niet op de schadeveroorzaker kan verhalen op de schadeveroorzaker omdat er tussen ongeval en betaling onvoldoende verband is. De premies dekken het totale schaderisico van de benadeelde (in zijn hoedanigheid als verzekerde), waardoor het verband met het concrete schadevoorval ontbreekt. Het grote voordeel van het regime waarvoor de Hoge Raad koos in het kader van de VOA is, dunkt me, dat zulke (wat onzinnige) discussies a priori worden vermeden. Wenselijk en ook wel voor de hand liggend lijkt daarom dat regime ook voor de overige regresrechten te laten gelden. Voor gesubrogeerde schadeverzekeraars is die gelijkschakeling, gelet op de motivering van de Hoge Raad, wellicht wat minder evident, zeker als men ervan uitgaat dat afdeling 6.1.10 BW voor hen geldt. Ik zou echter - nogmaals - menen dat dit laatste niet zo is, en ook meer heil zien in aansluiting bij de benadering van de Hoge Raad in dit verband.

\subsubsection{Matiging (art. 6:109 BW)}

Als de benadeelde zelf schadevergoeding vordert, heeft de rechter de bevoegdheid de aansprakelijkheid uit hoofde van bijzondere omstandigheden te matigen. De mogelijkheid daartoe ontbreekt voorzover de aansprakelijkheid WA-verzekerd is, of had kunnen (of zelfs moeten) zijn (art. 6:109). Voor matiging van het bedrag van de schadevergoeding is alleen plaats onder bijzondere omstandigheden. ${ }^{1222}$ Nodig is dat het betalen van volledige schadevergoeding tot 'kennelijk onaanvaardbare gevolgen' zou leiden. Dat vergt een afweging van de specifieke omstandigheden van degenen die daar rechtstreeks bij betrokken zijn. ${ }^{1223}$ Daarvoor zijn onder meer de aard van aansprakelijkheid, de tussen schadeveroorzaker en benadeelde bestaande rechtsverhouding en de draagkracht van hen beide van belang. Kunnen zulke omstandigheden ook aan regresnemers worden tegengeworpen? In het algemeen wordt aangenomen dat tegenover een nieuwe schuldeiser wel een beroep op matiging kan worden gedaan, maar dat de afweging dan betrekking dient te hebben op de belangen van de schuldenaar en de belangen van deze nieuwe

Zie NJ-noot Bloembergen, nr. 3 inzake HR 4 maan 1977, NJ 1978, 144 nt. ARB (Providentia/ABP), lets vergelijkbaars geldt bij de causale toerekening (art. 6:98 BW) van schade die (mede) het gevolg is van een predispositie van de benadeelde zelf of van andere minder evidente schadeposten geldt eveneens dat zulke factoren nog wél cen rol mogen spelen bij de schadebegroting, zie Spier e.a. (2000), nr. 224 (Hartlief).

1221 Daarover Schadevergoeding, ant. 100 (Bolt), aant. 69.

$1222 \mathrm{Vgl}$. Lindenbergh c.a. (2000), p. 22 (Lindenbergh).

i223 PG 6, p. 450; Asser-Hartkamp 4-1, nr. 494. 
schuldeiser (en hun onderlinge rechtsverhouding). ${ }^{1224}$ De benadeelde valt er dan dus als het ware tussenuit. Daardoor is het óók mogelijk dat de regresvordering wordt gematigd terwijl daarvoor bij de primaire vordering geen plaats of zou zijn geweest. Dat lijkt voor regreszaken tegen schadeveroorzakers in persoon zelfs vrij goed mogelijk, met name indien de schadeveroorzaker daarbij een beroep doet op zijn beperkte draagkracht. Bij de invoering van de regresrechten voor de volksverzekeringen werd uitdrukkelijk ervan uitgegaan dat de rechter ingrijpt indien de schadeveroorzaker desondanks onvermogend blijkt te zijn. ${ }^{1225}$ Het zal uiteraard lang niet altijd eenvoudig zijn de werkelijke vermogenssituatie van de schadeveroorzaker te achterhalen. Voorzover hij zich daarbij op een absoluut financieel onvermogen zou beroepen (denk aan inkomen op bijstandsniveau), zou dat nog wel objectiveerbaar zijn, maar dat het in zulke gevallen tot regres komt lijkt vrij zeldzaam. ${ }^{1226}$ Als de schuldenaar concrete stukken kan overleggen die zijn armlastige financiële status of onvermogen kunnen staven, ik denk aan het geval dat een aantal regresvorderingen concurreert, en de WA-verzekerde som zoals die blijkt uit de polis daardoor wordt overschreden, ${ }^{1227}$ dan zal men tot een afweging moeten zien te komen. Voor vorderingen van de benadeelde zelf wordt het verzekerd zijn van de schade als één van de omstandigheden aangemerkt, die tot matiging kunnen aanzetten. ${ }^{1228}$ Dat de vordering bij het regres komt van een verzekeraar (of andere risicodrager) die de schade heeft gedekt en daarvoor regres zoekt zal de afweging wellicht in dezelfde richting (het matigen van de regressom) laten gaan.

\section{5 'Eigen schuld' van regresnemers en schadebeperkingsplicht}

\subsubsection{Aanknopingspunten binnen de regresregeling}

Kan de regresnemer analoog aan art. 6:101 BW eigen schuld worden tegengeworpen indien door omstandigheden binnen zijn risicosfeer de omvang van zijn uitkering aan de benadeelde (of diens schade) onnodig is opgelopen? Voorop staat dat

Zie in die zin voor gevallen van subrogatic: Asser-Hartkamp 4-I, nr. $494 \mathrm{en} 571$; Verbintenissenrecht, art. 6:145 BW (Van Mierlo); Van Achterberg (1999), nr. 17. In dezelfde zin voor de regeling van ant. 6:107 BW: AsserHarkamp 4-1, nr, 476 en Schadevergoeding, art. 107 (Bolt), aant. 59.

1225 TK $1998-99,26238$, nr. 5. p. 3.

1226 De belangrijkste reden daarvan voor sociale verzekeraars is, dat vooraf de inschatting moet worden gemaakt of het regres de kosten waard is en '[d]aarbij speelt uiteraard mee dat - hoewel het principe geldt dat degene die verantwoordelijk is voor de toegebrachte schade, deze schade zal moeten vergoeden - uiteindelijk de vraag zal moeten worden beantwoord in hoeverre van een kale kip (nog) veren geplukt kunnen worden', aldus desgevraagd de minister (TK 1998-99, 26 238, nr. S, p. 3). De praktijk bij sociale en overigens ook particuliere verzekeraars schijnt dan ook te zijn dat regres uitblijt, indien sprake is van geen of een ontoereikende WA. verzekering. zie Bouman \& Tilanus-Van Wassenaer (1998), nr. 24.

Ook Hartlief \& Tjittes (1999), p. 106 noemen dat 'zeker niet denkbeeldig' en wijzen daartoe op de uitbreiding die het aantal wettelijke tegresrechten de laatste jaren heeft ondergaan.

1228 Vgl. reeds Drion (1955), p. 20. Zie voorts PG 6, p. 450; Asser-Hartkamp 4-1, nt. 491; Hartief \& Tjittes (1999), p. 42; Bouman \& Tilanus-Van Wassenaer (1998), nr. 24; Spier e.a. (2000), nr. 260 (Hartlief) 
het regresrecht om die reden ook al op andere gronden beperking kan ondergaan: gronden die besloten liggen in de wettelijke regresbepalingen of algemene gronden daarbuiten. Als die een oplossing kunnen bieden, dan lijkt voor analoge toepassing van de eigen-schuld regeling om systematische redenen geen plaats. Zo zal in ernstige gevallen het deel van de schade dat door een aan de regresnemer (of derden) toe te rekenen omstandigheid is ontstaan, al in zodanig verwijderd verband staan met het ongeval, dat die schade niet aan de schadeveroorzaker kan worden toegerekend (art. 6:98 BW). Het civiele plafond en de nemo-plus regel bij subrogatie staan dan aan het regres voor dat deel van de schade in de weg. Dat zal, zeker in de sfeer van letsel en overlijden, niet snel het geval zijn. ${ }^{122}$ Mogelijk rust ook op de regresnemer zelf aansprakelijkheid jegens de benadeelde voor het ontstaan van diens schade. Medeaansprakelijkheid voor de schade waarop de uitkering of verstrekking aan de benadeelde betrekking had, staat aan de aanspraak krachtens de onderhavige regresrechten in de weg. ${ }^{1230}$ De regresnemer (denk aan loondoorbetalende werkgevers op wie tevens werkgeversaansprakelijkheid rust) is dan in zijn verhouding tot de benadeelde, naast de schuldenaar hoofdelijk aansprakelijk voor de totale schade. ${ }^{1251}$ Intern is de schuldenaar slechts gehouden tot betaling van het hem toekomende deel, ${ }^{1232}$ en dus niet noodzakelijk voor de totale schade. In andere gevallen kan de fout van de regresnemer ertoe leiden dat de uitkering of verstrekking waarvoor hij verhaal zoekt niet werden gedaan 'ter zake van het ongeval' (in de bewoordingen van de zelfstandige regresbepalingen), 'ter zake van de schade' (art. 284 WvK/art. 7.17.2.25 BW), 'verplicht' (art. 6:107a BW), dan wel 'krachtens de wet of het ambtenarenreglement' (art. 2 VOA). Daartoe mag niet te snel worden geconcludeerd: de genoemde clausules van de wetsbepalingen plegen ruim te worden geïnterpreteerd. ${ }^{1233}$ Maar te denken valt bijvoorbeeld aan het geval waarin na het overlijden van de benadeelde de uitkeringen waarop hij voorafgaand aan en los van het ongeval recht had, ten onrechte, naast de nabestaandenuitkeringen zijn voortgezet. Zo ook geldt, dat als de werkgever door een fout in zijn loonadministratie als gevolg van het ongeval loon blijft doorbetalen gedurende een periode of ter hoogte van een bedrag waarvoor hij daartoe niet verplicht is, dit teveel betaalde niet op de schadeveroorzaker kan worden verhaald. Moeilijker ligt het voor fouten die het gevolg zijn van een te hoge inschaling door administratieve instanties. Als bijvoorbeeld door een fout in de administratie van het bestuursorgaan ten onrechte een WAO-uitkering of ambtenarenpensioen

1229 In het kader van art. 6:98 BW wordt met name bij de schending van verkeers- en veiligheidsnormen ruim toegerekend: ook niet in de normale lijn der verwachting gelegen schadelijke gevolgen (hartinfarct kort na de blootstelling aan cen klein verkeersongeval) worden dan veelal tocgerekend, zie Spier e.a. (2000), nr. 212. Zie supra, paragraaf 4.8 .2 en 4.9 .4 .

123 Mits de schadeposten waarvoor ieder jegens de benadeelde aansprakelijk is nog kunnen worden aangemerkt als 'dezelfde' schade in de zin van art. 6:102 BW.

1232 Art. 6:102 BW juncto ant. 6:101 en 10 BW, vgL. Van Boom (2000a), p. 94

1233 Zie paragraaf 4.2 .3 . 
werd verstrekt, kan dat de schuldenaar duur komen te staan, daarop zal hìrna uitvoeriger worden ingegaan.

De derde grond waarop de regresvordering door een zeker toedoen van de regrenemer zelf beperking kan ondergaan, is de redelijkheid en billijkheid (art. 6:2 EW). Zoals elke schuldeiser en schuldenaar zijn ook de regresnemer en schadeverooraker of WA-verzekeraar verplicht zich jegens elkaar te gedragen 'overeenkomsti' de eisen van redelijkheid en billijkheid'. Daaruit kunnen bijkomende rechten enverplichtingen ontstaan, die niet rechtstreeks uit wet of rechtshandeling voortvloien (lid 1). Ook kunnen de redelijkheid en billijkheid meebrengen dat een tusserhen krachtens wet, gewoonte, of rechtshandeling geldende regel niet van toepasing is ('indien dat in de gegeven omstandigheden naar maatstaven van redelijkeid en billijkheid onaanvaardbaar zou zijn', lid 2). Een voor de hand liggend geval waarin het tegen de regresnemer kan worden aangewend is dat, waarin de regrenemer pas na lang stilzitten zijn vordering instelt. In de zaak Schotamus/Bedrijfsveeniging onder het oude recht, waarin de verjaringstermijn zoals gezegd aanmerklijk langer was dan thans het geval is, had dat stilzitten zeven jaar geduurd. ${ }^{1234}$ S:hotanus wierp de bedrijfsvereniging daarop tegen dat zij zich na een zo lang stilztten 'terwijl zij reeds jarenlang over belangrijk bewijsmateriaal beschikte', niet te geder trouw (respectievelijk in strijd met een goede procesorde) op dat bewijs kon beroepen. Die enkele omstandigheid was daarvoor volgens de Hoge Raad echter onvoldoende. Ook werd nog door Schotanus aangevoerd dat de bedrijfsvereniging het moeilijk had gemaakt tegenbewijs te leveren in de vorm van getuigenverhoor, maar zij slaagde er niet in dit nader te onderbouwen met feiten en omstandigheden waaruit zou kunnen worden afgeleid dat daardoor bewijsmogelijkheden verloren waren gegaan. Hierna zullen nog andere specifieke punten aan de orde komen, waarvoor een beroep op art. 6:2 BW van betekenis is (of zou kunnen zijn). Ten slotte lijkt het in het algemeen weinig vruchtbaar om in het kader van een eigen-schuld verweer analoog aan art. 6:101 BW, de stelling op te werpen dat de regresnemer in zijn verhouding tot de benadeelde heeft miskend dat van minder schade sprake is dan waarvoor een uitkering of verstrekking werd verleend. Wie verwijtbaar onverschuldigd betaalt, zou de dan gekozen redenering zijn, moet maar zèlf de gevolgen daarvan dragen. Dat veronderstelt echter dat de schade van de benadeelde in werkelijkheid lager is dan door de regresnemer, bij het vaststellen van de uitkering, werd aangenomen. Maar als dàt zo is, kan de schuldenaar zich beter gewoon tegen de regresvordering verweren met de stelling dat de benadeelde van het schadevoorval geen schade heeft geleden of minder schade dan de door de regresnemer toegekende uitkeringen. Daarvoor is immers geen toerekenbaarheid nodig aan de zijde van de regresnemer. Maar wat geldt als de schadeveroorzaker of WA-verzekeraar de stelling dat de benadeelde minder schade lijdt dan waarvoor 
is uitgekeerd moeilijk kan onderbouwen? Als dan wèl vaststaat dat het uitkeringsorgaan een beoordelingsfout heeft gemaakt bij het toekennen van de uitkering, zou het vanuit zijn perspectief mogelijk aantrekkelijker zijn om op die grond verweer te voeren. Zijn stelling zou dan luiden dat de fout van het uitkeringsorgaan tot gevolg heeft dat onnodig aan de benadeelde uitkering is verricht. Die stelling valt dan ook zo te lezen, dat als gevolg van de beoordelingsfout het causale verband ontbreekt tussen de gevorderde regressom (voorzover die betrekking heeft op de onnodig uitgekeerde bedragen) en het schadevoorval waarvoor de schuldenaar jegens de benadeelde aansprakelijk is. ${ }^{1235}$ Zoals gezegd, moet aan het vereiste verband tussen de uitkering waarvoor het uitkeringsorgaan regres zoekt en het schadevoorval echter niet te zwaar worden getild. Met name voor die gevallen kan het dus interessant zijn of analoge toepassing van art. 6:101 BW een optie is.

\subsubsection{Analogie met art. 6:10I BW}

Kan de schadeveroorzaker of WA-verzekeraar de regresnemer (ook) buiten de genoemde gronden analoog aan art. 6:101 BW eigen schuld tegenwerpen met betrekking tot de schade waarvoor de betrokken uitkering is gedaan? Het ligt voor de hand dat daarvoor wel plaats moet zijn: ook op de regresnemer rust, dunkt me, binnen de grenzen van zijn verantwoordelijkheid voor de schade van de benadeelde, een schadebeperkingsplicht jegens de schadeveroorzaker (zie art. 6:2 lid $1 \mathrm{BW}$ ). De schade van de benadeelde kan, bijvoorbeeld ingeval van arbeidsongeschiktheid, door nalatigheid van de regresnemer hoger zijn dan op zichzelf genomen het geval had hoeven te zijn. Daarvan zou bijvoorbeeld sprake kunnen zijn indien de werkgever van de benadeelde of het UWV is tekortgeschoten in de naleving van de op hem rustende inspanningsverplichtingen voor een adequaat begeleidingstraject, Een ander verwijt zou kunnen zijn dat men naliet sancties te stellen bij de niet-naleving van bepaalde formaliteiten door de benadeelde. Werkgevers kunnen hebben nagelaten te onderkennen dat de arbeidsongeschiktheid voortvloeit uit een lichamelijk gebrek waarover de werknemer bij de aanstellingskeuring onjuiste informatie heeft verstrekt, indien dat gebrek als gevolg van het schadevoorval is geactiveerd en tot de verschuldigde loondoorbetaling heeft geleid. Voor het beroep op eigen schuld in dit verband lijkt me overigens niet noodzakelijk dat de eigen schuld van de regresnemer plaatsvond in zijn hoedanigheid van schadedrager, dus in dezelfde hoedanigheid als waaraan het regresrecht wordt ontleend. Te denken valt aan het geval dat de benadeelde toevallig in dienst was bij de uitkeringsinstantie en de fouten in de sfeer liggen van zijn dienstbetrekking (of: als de uitvoeringsinstelling krachtens meer dan één wet uitkeringen verschuldigd is 
aan de benadeelde). ${ }^{1236}$ Ook kan de schade (en daarmee uiteindelijk tevens de bedragen waarvoor die verzekeraar uiteindelijk regres zoekt) hoger zijn doordat de aanspraak van de benadeelde op een uitkering van zijn schadeverzekeraar door de laatste is getraineerd, dan wel dat die naliet om te controleren of de benadeelde voldeed aan zijn informatieplicht (het doen van opgave van eventuele gebreken of schade bij aanvang van de verzekering).

Omgekeend zou ook de WA-verzekeraar in de regresprocedure een verwijt kunnen treffen van een te passieve, vrijwel alles afhoudende houding, indien zij eigenlijk door de benadeelde als eerste wend aangesproken. Terughoudendheid past echter bij de stelling dat de WA-verzekeraar door het getraineer het recht heeft verspeeld om het regres te betwisten. In Delta Lloyd/Interlloyd rees die vraag ussen twee WA-verzekeraars van een werkgever, met strikt gescheiden ('spiegelbeeld') dekking. De ene verzekeraar schikte de zaak en betaalde aan de benadeelde, nadat de ander zich volkomen passief en afhoudend had opgesteld. Eenmaal aangesproken tot verhaal betwistte die ander de aansprakelikheid kennelijk op goede gronden. De klacht van de eerste dat het hof had miskend dat de passief gebleven verzekeraar haar recht om voor de regresvordering de schuldvraag te betwisten had verspeeld (art. $6: 2$ lid 2 BW), ging de Hoge Raad een brug te ver. ${ }^{123 ?}$

Het is in het algemeen, ongeacht de precieze grond die wordt aangevoerd, niet eenvoudig het uitkeringsbeleid van de regresnemer in het $k$ ader van een door hem ingestelde verhaalsactie aan de orde te stellen. Verzekeraars, werkgevers en fondsen genieten een zekere mate van bestuursvrijheid en de regreszaak is niet de plaats de beslissing over toekenning en de duur van uitkering (opnieuw) te beoordelen. De schadeveroorzaker (of WA-verzekeraar) zou bovendien geen invloed moeten kunnen hebben op de bedragen waartoe de benadeelde gerechtigd is. ${ }^{1238}$ Aangenomen wordt daarom wel dat slechts marginaal kan worden getoetst. ${ }^{1239} \mathrm{Op}$ argumenten van die strekking wijst ook de Hoge Raad bij zijn beslissing inzake Nationale Nederlanden/Woudsend II, om het regresrecht van particuliere schadeverzekeraars ook te laten gelden voor onverplichte schadeuitkeringen. Het oude regime, waarin schadeverzekeraars alleen in de vordering van de benadeelde werden gesubrogeerd indien ze verplicht uitkering deden, kon de schadeveroorzaker (WA-verzekeraar) ertoe aanzetten de verschuldigdheid van de uitkering te betwisten, hetgeen schadeverzekeraars terughoudender kon maken in hun uitkeringsbeleid. ${ }^{1240}$ Daarnaast geldt, specifiek voor administratieve instanties (sociale verzekeraars en de ambtenarenwerkgever), dat de burgerlijke rechter in het geheel niet mag beoordelen

VgL. HR 3 november 1989, NJ 1990, 402 nt. JBMV (ZiekenfondonadWaurbongfonds Motonerkeer). De Ziekenfondsraad zocht daar regres voor uitkeringen die ze in de hoedanigheid van ambtenarenwerkgever had gedaan.

1237 HR 19 april 1997, NJ 1997, 24 nt. MMM (Delia Loyd/Interlloyd). Het hof had voor het oordeel dat van rechtsverwerking geen sprake was, gehecht aan de omstandigheid dat een aanvankelijk voorstel van de niet-betalende WA-verzekeraar tot betaling van $50 \%$ zonder erkenning van aansprakelijkheid door de verhalzoekende WAverzekeraar was afgeslagen en deze laatste daarop eigenhandig was gaan schikken.

1238 Slagter (1963), p. 4; De Kok (1965), p. 101; Verwer (1970), p. 87; Van Boom \& Storm (1995), p. 151; Van Boom (2000a), p. 64; vgl. voor de Ongevallenwet HR 23 juli 1946, NJ1946, 545 nt. DJV (Cenirale Werkgevera Fenwerda).

1239 Pandaan (2001), p. 34.

1240 HR 7 januari 2000, NJ 2000, 212 nt. MMM (Nationale Nederlanden/Woudsend Ih). 
of het uitkerende lichaam verplicht was tot het doen van de uitkering, de verstrekking of de bezoldiging waarvoor het regres zoekt.

\subsubsection{Beoordelingsvrijheid in civilibus}

In deze laatste zin besliste de Hoge Raad inzake Van Geffen/Staat voor het regresrecht van de Verhaalswet ongevallen ambtenaren. De rechter mag bij de beoordeling van de vraag of plaats is voor regres niet nagaan of voor het overheidslichaam de plicht bestond tot het doen van de uitkering. ${ }^{1241}$ Van Geffen betwistte dat het ongeval van twee militairen die wegens dienstverlof huiswaarts keerden een dienstongeval was. De verhoogde invaliditeitsuitkeringen waarvoor de Staat regres zocht zouden daarom onterecht zijn verstrekt. In het cassatiemiddel werden zowel de toekenning van het pensioen als de hoogte ervan betwist. Dat verweer bleef, ook als cassatieklacht, zonder succes: het stond de burgerlijke rechter niet vrij dat te beoordelen. A-G Ten Kate wijst er daarbij met name op dat de vraag, of invaliditeitspensioen moet worden toegekend en tot welk bedrag aan een afzonderlijke rechtsgang onderworpen is. Van de bedoeling om de administratieve beslissing daarover in de regreszaak te kunnen hertoetsen blijkt immers noch uit de tekst van de VOA, noch uit de geschiedenis van die wet.

Voor sociale verzekeringen is dat niet anders. ${ }^{1242}$ Voor het WAO-regres oordeelt de Hoge Raad uitdrukkelijk in die zin in zijn arrest inzake Centraal Beheer Schadeverzekering/Bedrijfsvereniging. De benadeelde werkte ten tijde van het ongeval bij zijn vader. Volgens de WA-verzekeraar waren de WAO-uitkeringen ten onrechte aan hem uitgekeerd omdat daarbij geen sprake zou zijn geweest van een dienstbetrekking tussen vader en zoon. De (toenmalige) bedrijfsvereniging was bij het toekenningsbesluit wèl daarvan uitgegaan, en had de zoon daarom aangemerkt als verzekerde in de zin van de WAO. Maar volgens de Hoge Raad mag de rechter die over het regres heeft te oordelen daarbij niet zelfstandig nagaan of de WAO ten tijde van het toekenningsbesluit recht gaf op een uitkering. Men heeft te aanvaarden dat de beslissing van de bedrijfsvereniging of de beroepsrechter in overeenstemming met de WAO is gegeven. ${ }^{1243}$ Wellicht betekent dit ook dat niet mag worden beoordeeld of verplicht is uitgekeerd (waaraan dan de conclusie verbonden zou worden dat voor regres geen plaats is). Ik denk aan het geval dat de WAOuitkering werd verstrekt terwijl de arbeidsongeschiktheid (of het vooruitzicht daarvan) enkele maanden na het intreden van de sociale verzekering is ontstaan. ${ }^{1244}$ Ook Hartlief en Van Maanen verstaan 's raads oordeel in die zin, dat de gewone

\footnotetext{
1241 HR 4 juni 1976, NJ 1977, 4 nt. ARB (Van Geffen/Staat); in die zin meer recent Rb. Zwolle 31 maart 1993 , NJ 1993, 684 (ABP/SGHB).

1242 In die zin ook reeds A-G Ten Kate inzake HR 4 juni 1976, NJ 1977, $4 \mathrm{nt}$. ARB (Van Geffen/Staaf).

1243 HR 23 februari 1990, NJ 1991, 574 nt. CJHB (Centraal Beheer/Bedrijfrvereniging). In die zin ook Hof Den Haag 29 april 1998, rolnr. $95 / 1113$ (niet gepubliceerd).

1244 Zie art. 18 e.v. WAO.
} 
rechter zich aan een inhoudelijke beoordeling van de vraag of terecht is uitgekeerd in de regreszaak dus nooit mag wagen. ${ }^{1245}$ De Hoge Raad spreekt bij zijn oordeel over het ontbreken van beoordelingsvrijheid van alle gevallen waarin sprake is van krachtens de WAO gemaakte kosten, en legt dat uit als kosten die 'krachtens een door de bedrijfsvereniging of de beroepswet gegeven beslissingzijn gemaakt'. Het lijkt erop dat hij daarbij niet heeft willen meegaan met zijn A-G, die op dit punt een uitzondering wilde maken voor geheel onverplicht gedane uitkeringen (zoals uit coulance). Dat daarvan sprake is zou moeten worden afgeleid uit de beslissing van de bedrijfsvereniging. ${ }^{1246}$ Maar het lijkt er niet op dat de Hoge Raad dat onderschrijft. Eerder lijkt het erop dat indien de uitvoeringsinstelling positief heeft beslist, ongeacht de redenen die ze daarvoor heeft, onbetwistbaar is voldaan aan de voorwaarde van het regresrecht dat sprake is van krachtens de wet gemaakte kosten. Ook een beroep op de derogerende werking van art. 6:2 lid 2 BW zal wellicht geen uitkomst kunnen bieden. Het toekenningsbesluit van de uitkeringsinstantie zou dan weliswaar gewoon in stand blijven (alleen het rechtsgevolg, de verbintenis tot het betalen van de regressom, wordt buiten toepassing gelaten), maar dat zou toch weer om een inhoudelijk oordeel vragen.

Betekent dit dat de uitvoeringsinstantie civielrechtelijk dus eigenlijk maar wat raak kan beslissen, en het risico van onverschuldigde betaling in beginsel onbeperkt kan afwentelen op de schadeveroorzaker (of diens WA-verzekeraar)? Is dat niet onredelijk? De WA-verzekeraar richtte in evengenoemd arrest Centraal Beheer Schadeverzekering/Bedrijfsvereniging zijn pijlen (mede) op art. 6 van het Europese Mensenrechtenverdrag (EVRM). Door de formele rechtskracht van het besluit tot toekenning van de WAO-uitkering aan de benadeelde zou hij in zijn burgerlijke rechten zijn aangetast omdat hem dat (ten onrechte) bloot stelde aan het regres, zonder beroepsmogelijkheid. Maar de Hoge Raad ziet het anders: als de uitkering ten onrechte zou worden verstrekt, kan het civiele plafond tegengaan dat de schuldenaar teveel verschuldigd is. ${ }^{1247}$ Dat (steun)argument van de Hoge Raad zal echter niet opgaan als de uitvoeringsinstelling een uitkering toekent waarvoor de schadeveroorzaker tot regres gehouden is, terwijl hij bij het wèl correcte besluit noch op een andere grond of aan een andere uitkeringsinstantie regres verschuldigd zou zijn geweest, noch tot schadevergoeding zou zijn gehouden jegens de benadeelde zelf. Van Boom onderkent dat probleem, maar acht het profijtargument

\footnotetext{
1245 Hartlief \& Van Maanen (1991), p. 295; zie ook Brunner in zijn noot onder het arrest (punt 1).

1246 Zie de Conclusie bij HR 23 februari 1990, NJ 1991, 574 nt. CJHB (Centraal Beheer/Bedrijfsvereniging), nt. 2.5.

1247 HR 23 februari 1990, NJ 1991, 574 nt. CJHB (Centmal BeheeriBedrijfsvereniging). De toekenning van de WAO-uitkering aan de benadeelde maakt volgens de raad slechts dat de WAO-instantie in de plaats treedt van de benadeelde. In die zin ook: A-G Ten Kate inzake HR 4 juni 1976, NJ 1977, $4 \mathrm{nt}$. ARB (Van GeffentStaat); Hof Amsterdam 14 november 1996, nolnr. 76088 (Bedrüfsveneniging/Agen) (niet gepubliceerd); voorts Slagter (1963), p. 4; De Kok (1965), p. 101; Verwer (1970), p. 87; Van Boom \& Storm (1995), p. 151; Van Boom (2000a), p. 64 .
} 
doorslaggevend. ${ }^{1248}$ Zoals ik eerder aangaf, lijken me zulke argumenten echter niet overtuigend voor een uitbreiding van het regres die haaks staat op het gekozen wettelijke kader. ${ }^{1249}$ Niettemin lijkt herbeoordeling door de civiele rechter bezwaarlijk. Een uitspraak van het Amsterdamse hof kan illustreren. ${ }^{1250}$ Volgens de WA-verzekeraar had de bedrijfsvereniging ten onrechte een volledige WAOuitkering toegekend aan de benadeelde; dat had een AAW-uitkering met aanvullende WAO moeten zijn. Het belang van de WA-verzekeraar daarbij was duidelijk: in de voormalige AAW stond geen regresrecht. Het hof stelt voorop dat moet worden uitgegaan van de formele rechtskracht van het oorspronkelijke besluit tot toekenning van de WAO-uitkering. De vraag of dat op goede gronden is genomen kan in het algemeen, zo stelt het hof, bij regreszaken niet aan de orde komen. Maar dat is naar 's hofs oordeel anders indien het regresrecht dat de uitkeringsinstantie aan die beslissing kan ontlenen ertoe leidt dat de schadeveroorzaker per saldo méér komt te betalen dan bij een juiste toepassing van de bepalingen van het sociale recht het geval zou zijn geweest. Op die grond acht het hof (de civiele kamer) zich bevoegd de zaak te onderzoeken. Als de civiele rechter zich zoals het Amsterdamse hof in casu ten onrechte hiertoe bevoegd acht, dan zal overigens óóknog moeten worden beoordeeld of de benadeelde bij het correcte (afwijzings)besluit evenmin aanspraak zou hebben gehad op andere uitkeringen waarvoor een wettelijk regresrecht geldt. ${ }^{1251}$

Het moet erop worden gehouden dat de benadeelde de bestuurlijke weg moeten hebben bewandeld en dat bij het oordeel van de bestuursrechter of arbiter moet worden aangesloten. Als dat is gebeurd, dan kan dat oordeel ook inhouden dat de uitkering of verstrekking ten on rechte heeft plaatsgevonden. De bestuursrechter kan hebben geoordeeld dat de benadeelde in een lagere schaal van arbeidsongeschiktheid had behoren te worden ingedeeld, ${ }^{1252}$ of dat de uitkeringsinstantie buiten de grenzen van zijn discretionaire bevoegdheid is getreden. Het moeilijke is dat de termijn om het gewraakte toekenningsbesluit van het uitkeringsorgaan voor de bestuursrechter aan te vechten, tegen de tijd dat de regresprocedure is aangevangen, veelal zal zijn verstreken. Wel mogelijk is om in het kader van het civiele plafond het gedrag van de benadeelde aan de orde te stellen, los van de reactie daarop van de regresnemer. ${ }^{1253} \mathrm{Te}$ denken valt aan het geval waarin het overheidslichaam naar aanleiding van het ongeval ambtenarenpensioenen ver-

\footnotetext{
1248 Het profijtargument werd besproken in paragraaf 6.3.1. Van Boom (2000a), p. 65: 'gegeven de lijn van de rechtspraak moet men de aansprakelijke in die gevallen echter toevoegen dat hij niet wordt benadeeld, doch dat hem slechts een voordeel ontgaat'.

1249 Het wettelijke kader waarbinnen het regres geoorloofd is werd besproken in paragraf 4.8 en 4.9.

1250 Hof Amsterdam 14 november 1996, rolnr. 760/88 (Bedrijfsvereniging/Aegon).

1251 Overigens komt het hof in deze zaak alsnog tot de conclusie dat de regresvordering toewijsbaar is omdat het toekenningsbesluit uiteindelijk toch terecht is genomen.

1252 Voorzover het regres niet collectief wordt afgewikkeld.

1253 Voor de regresvorderingen die onder het Comvenant Verhaalsnecht 200I vallen (ZW, WAO, WAZ en WAONG) wordt over het civiele plafond in beginsel niet meer geprocedeerd.
} 
strekt, maar wegens onvoldoende controle en begeleiding niet (tijdig) onderkent dat de genezing van de betrokken ambtenaar door eigen toedoen ernstig is belemmerd of vertraagd. Het verwijt aan de regresnemer houdt dan direct verband met fouten van de benadeelde die ook kunnen worden meegewogen bij de vaststelling van het civiele plafond. Eventueel zal de uitkeringsinstantie de betreffende bedragen in gevallen als deze ook al wel kunnen terugvorderen van de benadeelde (bijvoorbeeld krachtens art. 6:203 BW). ${ }^{1254}$ Dat zou in het algemeen als een schending van de schadebeperkingsplicht moeten worden aangemerkt.

Dat de schadeveroorzaker (of diens WA-verzekeraar) door analoge toepassing van de regels van voordeelstoerekening, matiging en eigen schuld alsnog 'de dans ontspringt' lijkt over de gehele linie gezien uitzonderlijk. Daarvoor bestaan niet gauw goede gronden; gewezen werd op omstandigheden die wèl voldoende grond kunnen opleveren voor een vermindering van zijn aansprakelijkheid.

\subsection{Aanverwante regels}

\subsubsection{Inleiding}

Het centrale punt van aandacht lag in het voorgaande bij de regels van het materiële recht. Maar ook door verschillen daarbuiten, op een meer praktisch, feitelijk niveau kan de handhavingsfunctie van het regres worden gefrustreerd: de niet-toepasselijkheid van aanverwante regels voor het inroepen van de regresvordering kan eraan bijdragen dat de schuldenaar onvoldoende of zelfs niet met de gevolgen van zijn aansprakelijkheid wordt geconfronteerd. Hebben regresnemers voor het geldend maken van hun vordering, net als benadeelde, de mogelijkheid van een action directe (paragraaf 8.6.2), een bevoorrechte positie boven anderen (paragraf 8.6.3), de mogelijkheid tot besparing van proceskosten door voeging (paragraaf 8.6.4)? En: worden ze in verband met het derivatieve karakter van de aansprakelijkheid bij regres beperkt in hun recht door reeds lopende verjaringstermijnen (paragraaf 8.6 .5$)$ ?

\subsubsection{Action directe}

\subsubsection{HET WAM-REGIME (ART. 6 WAM)}

De Wet aansprakelijkheidsverzekering motorrijtuigen geeft slachtoffers van verkeersongevallen waarvoor de eigenaar of houder van een motorrijtuig (mede) aansprakelijk is een eigen recht op schadevergoeding jegens diens aansprakelijkheidsverzekeraar (art. 6 lid 1 WAM). Deze zogenaamde action directe (rechtstreeks 
vorderingsrecht) stelt hen in staat de verzekeraar rechtstreeks aan te spreken tot verhaal. Zonder deze regeling zou de benadeelde (in beginsel) alleen indirect van het WA-verzekerd zijn van de schadeveroorzaker kunnen profiteren. De op WAverzekeraars rustende uitkeringsplicht berust immers primair op de verzekeringsovereenkomst, en die geldt tussen de verzekeraar en de schadeveroorzaker. In het algemeen is het overigens wel gebruikelijk dat verzekeraars in de polisvoorwaarden bedingen dat ze als gevolmachtigde rechtstreeks aan de benadeelde kunnen betalen. ${ }^{1255}$ Robben merkt op dat dit echter onder meer het nadeel heeft dat de volmacht door de verzekerde kan worden herroepen. Tot een onherroepelijke volmacht zal ook de verzekeraar niet gauw geneigd zijn. ${ }^{1256}$ De action directe geeft de benadeelde een stevigere positie: de benadeelde heeft niet alleen een actie jegens de WAM-verzekeraar, opdat de verzekerde som buiten het vermogen van de schadeveroorzaker kan blijven, maar óók een eigen recht dat los staat van de verhouding tussen WAM-verzekeraar en schadeveroorzaker (zij het dat de aard en inhoud daarvan wordt beheerst door de aansprakelijkheid van de WAM-verzekerde, de schadeveroorzaker). Het tenietgaan van de uitkeringsplicht in die verhouding tot de schadeveroorzaker bevrijdt de WAM-verzekeraar dan ook niet jegens de benadeelde. Dit geldt echter niet indien de benadeelde, zoals in regressituaties het geval is, al werd schadeloos gesteld (aldus art. 6 lid 1, laatste volzin WAM). De action directe is het sluitstuk van de overige regels van het WAM-regime (verzekeringsplicht, verbod tot het tegenwerpen van verweermiddelen door de WAM aan de benadeelde), dat extra bescherming moet bieden tegen de oninbaarheid van vorderingen van de slachtoffers van gemotoriseerde verkeersongevallen. Hun vordering moet niet afstuiten op het niet WA-verzekerd zijn van de schadeveroorzaker, of op een beroep op verrekening door de WA-verzekeraar van door de schadeveroorzaker nog verschuldigde premies, ${ }^{1257}$ om maar wat te noemen. Vanuit die beschermingsgedachte, het minimaliseren van het risico van oninbaarheid van de vordering, heeft art. 6 WAM sinds de invoering ervan een ruim toepassingsgebied gekregen. ${ }^{1258}$ Het geldt volgens de algemene definitie (art. 1 WAM) niet alleen voor de primair benadeelde (degene die feitelijk slachtoffer werd van het verkeersongeval), maar ook voor al zijn rechtsverkrijgenden. Uit de Memorie van Toelichting blijkt dat dit ruim moet worden verstaan, ${ }^{1259}$ Alle categorieën slachtoffers die ik eerder onder de term benadeelde bracht, ${ }^{1260}$ lijken probleemloos eronder te

Robben (1993), p. 25; Van Dam (1995), p. 121; Mok (1998), p. 11.

Robben (1993), p. 26.

Vgl. art. 7.17.1.10a BW: 'De verzekeraar kan opeistare premie (-.) verrekenen met hetgoen hij an de tot uitkering gerechtigde verschuldigd is, ook indien deze geen schuldenaar van de premie is', zoals de benadeelde, maar bók de regresnemer (cursief toegevoegd, EE). Die laatste mogelijkheid zou krachtens art. 6:127 derde lid BW in de onderhavige gevallen ontbreken. Zie daarover Van Dam (1995), p. 118 e.y. en Mok (1998), p. 76. Robben (1993), p. 12.

Robben (1993), p. 197 wijst daarop, in de door haar aangehaalde passage wordt gesproken van 'een ieder met cen eigen recht:

Panagraaf 1.4.2. 
kunnen vallen. Het verschil dat hiermee is ontstaan tussen de bevoorrechte positie van deze groep eisers en die van 'normale' slachtoffers van ongevallen waervan de gevolgen ernstig zijn kan niet anders worden verklaard dan zuiver rechtspolitiek: de stijging van het aantal (ook internationale) verkeersongevallen in de jaren 1960 en '70, die tevens de druk op de sociale stelsels in verschillende groter maakte. ${ }^{1261}$ Het feit dat deze groep slachtoffers herkenbaar is en hun schadeloosstelling maatschappelijk als nijpend werd ervaren, heeft verkeersongevallen op de 'politieke agenda' gezet. De 'rekening' van dat probleem (de noodzaak van een adequate schadeloosstelling) werd bij de schadeveroorzaker gelegd: de gemotoriseerde verkeersdeelnemer op wie aansprakelijkheid rust en zijn WAM-verzekeraar. Vanuit deze gedachte ligt het niet direct voor de hand om ook regresnemende particuliere en sociale verzekeraars van deze bescherming te laten profiteren. Daar speelt het belang van bevorderen van een adequate schadeloosstelling immers geen enkele rol. Uit oogpunt van doelmatigheid is daarvoor echter wèl veel te zeggen: regreszaken zijn veelal gericht tegen WA-verzekeraars, niet tegen de schadeveroorzaker in persoon. Omwille van het belang van een vlotte en efficiënte afwikkeling van regresvorderingen, waaraan thans sterk wordt gehecht, ${ }^{1262}$ ligt een action directe voor regresnemers (niet noodzakelijk het droit propre) dan zelfs in de rede. Hoe is dat naar geldend recht? Zoals ik aangaf, worden ook rechtsverkrijgenden van het verkeersslachtoffer aangemerkt als benadeelde in de zin van art. 1 WAM. Daartoe worden ook ziektekostenverzekeraars en andere schadeverzekeraars gerekend. Concreet betekent dit dus dat de ziektekostenverzekeraar omdat hij krachtens art. $284 \mathrm{WvK} /$ art. 7.17.2.25 BW wordt gesubrogeerd in de vordering tot schadevergoeding jegens de aansprakelijke, hij tevens rechtstreeks een eigen recht verkrijgt jegens diens WAM-verzekeraar. ${ }^{1263}$ Sociale verzekeraars, de Staat en het ABP zijn geen 'rechtsverkrijgende' in de zin van art. 1 WAM, hun regresrechten zijn zelfstandige rechten. Toch worden zij door de Hoge Raad eveneens aangemerkt als 'benadeelde' in de zin van art. 1 WAM (wel verwerpt de raad overigens de opvatting dat de uitkeringslast voor de sociale verzekeraar zelfstandige schade zou opleveren). ${ }^{1264}$ Voor de gevallen van aansprakelijkheid waarvoor de verplichte WAM-dekking geldt hebben regresnemers dus - ook als hun vordering jegens

1201 De achterliggende gedachte is denk ik niet geweest dat het bevorderen van cen verbeterde schadeloosstelling voor verkeersslachtoffers via het aansprakelijkheidsrecht diàrin enige verbetering zou kunnen brengen (de regeling van verplichte voordeelstoerekening dwingt de benadeelde eerst zijn sociale aanspraken geldend te maken).

1262 Zie paragraaf 9.1

1263 Robben (1993), p. 198.

1264 Eerst in die zin voor sociale verzekeraars de Conclusie van A-G Ten Kate inzake HR 7 november 1975, $N$ 1976, 332 nt. ARB (Ziekenfonds/Nationale Nederlanden), onder verwijzing naar de wetsgeschiedenis van art 1 WAM, en daarin met weinig omhaal gevolgd door de Hoge Raad. De kwestie is door het Benelux Gerechtshof met zoveel woonden overgelaten aan het materiele recht, zie Robben (1993), p. 201. Ook voor de Staat en ABP bij het VOA-regres besliste de raad in die zin, HR 10 augustus 1994, NJ 1995, 58 (General AccidentStaat en ABP). Idem voor de WAO HR 10 maart 1995, NJ $1997,525 \mathrm{nt}$. MMM (TUS/lepenburg), en hetzelfde lijkt dan te moeten gelden voor werkgevers met het regresrecht van art. 6:107a BW (en hun rechtsverkrijgende vernekeraars). 
de schadeveroorzaker berust op subrogatie - een zelfstandig recht op betaling van de WAM-verzekeraar. ${ }^{1265}$ In die gevallen waarin de aansprakelijkheid en de inhoud van de regresvordering voldoende vaststaan is het risico van oninbaarheid daarvan wegens insolvabiliteit door gebreken of het ontbreken van de verzekering dus uiterst gering.

\subsubsection{Algemene ACTION DIRECTE (TITEL 7.17 BW)}

De regeling van de action directe is vooralsnog beperkt tot gevallen van aansprakelijkheid waarvoor een verplichte WAM-dekking bestaat (en bijzondere gevallen, zie art. 12a Jachtwet), maar daarin zal binnenkort enige verandering komen. In het wetsontwerp voor het verzekeringsrecht van titel 7.17 van het Burgerlijk Wetboek is inmiddels namelijk ook voor normale (vrijwillige) WA-verzekeringen een (wat minder vergaande) regeling in die richting voorgesteld. ${ }^{1200}$ Het verschil met de action directe van art. 6 WAM is dat de benadeelde volgens de ontwerpregeling weliswaar een vordering in de zin van een actie verkrijgt tegen de WAverzekeraar, maar niet óók een eigen recht, zoals bij art. 6 WAM. ${ }^{1267}$ Dat wil zeggen dat de WA-verzekeraar op basis van zijn gehoudenheid tot betaling jegens de schadeveroorzaker tevens gehouden is tot betaling aan de benadeelde, en dus niet op basis van een eigen - zelfstandige - rechtsverhouding tot de benadeelde. Praktisch betekent dit dat de WA-verzekeraar jegens de benadeelde onder dezelfde voorwaarden en met de beschikbaarheid van dezelfde bevoegdheden en dezelfde verweermiddelen tot betaling gehouden is als die hem toekomen tegenover de schadeveroorzaker. Het nieuwe recht gaat dus niet zo ver als het WAM-regime, waar ook zulke verweermiddelen niet aan de benadeelde kunnen worden tegengeworpen (zie art. 11 WAM). Het maakt de benadeelde enkel onafhankelijk(er) van de schadeveroorzaker en diens vermogen.

Te verwachten valt dat de nieuw voorgestelde action directe ook zal gelden voor regresnemers, de tekst van het ontwerp biedt daarvoor in elk geval voldoende ruimte. ${ }^{1268}$ Vanuit het perspectief van regresnemers valt daarvoor zoals gezegd veel te zeggen (denk voor particuliere verzekeraars óók aan het regres buiten het gebied van personenschade). Het zou hen voor de afwikkeling van regresvorderingen

1265 Robben (1993), p. 197; De Bosch Kemper (1995), p. 43; Van Boom (2000a), p. 69. Dat gold overigens ook al onder het regime van de Ongevallenwet 1921, Giltay Veth (1969), p. 233.

1266 De regeling ontbreekt in het aanvankelijk op 16 mei 1986 bij de Tweede Kamer ingediende wetsvoorstel, zij is voorgesteld bij (de zoveelste) Nota van Wijziging. De Raad van State heeft er inmiddels gematigd positief over geadviseerd (de regeling gaat de raad niet ver genoeg), zie TK 1999-00, 19529, D, p. 4 (met nader rappont van minister Korthals). 
onafhankelijker maken van de bereidwilligheid van schadeveroorzakers en VAverzekeraars en tevens beter aansluiten bij het regime van art. 6 WAM.

\subsubsection{Voorrecht art. 3:287 BW}

Totdat het nieuwe verzekeringsrecht zal gelden (vermoedelijk in het jaar 2105) hebben regresnemers, net als de benadeelde zelf, buiten de WAM-gevallen aleen een aansprakelijkheid op de schadeveroorzaker in persoon. De aanspraak dit hij heeft uit hoofde van zijn WA-verzekering staat in beginsel los van de aanspaak die regresnemers (of de benadeelde) op hem hebben. Regresvorderingen zijn darmee voor de inbaarheid van hun vordering net als de benadeelde in beginsel aflankelijk van de vermogenstoestand van de schadeveroorzaker, en van concurrernde vorderingen van andere schuldeisers. Dit zou betekenen dat de regresvordeing bij faillissement van de schadeveroorzaker, net als de schadevordering vat de benadeelde in de boedel zou vallen en beide slechts een concurrerende vordeing zou hebben. Maar zulke risico's worden tot op zekere hoogte het hoofd gebden met het voorrecht van art. 3:287 BW. Deze regeling bepaalt dat de vorderin̨̧ tot schadevergoeding bevoorrecht is op de vordering die de schadeveroorzaker leeft jegens zijn WA-verzekeraar (lid 1). Op die manier moeten de verzekeringspenningen toch nog terechtkomen bij degene die de aansprakelijkheid inroept. In het tweede lid wordt bovendien bepaald dat de schuldeiser (regresnemer of benadeelde) zich zelfs op de verzekeringspenningen kan verhalen zònder dat hem rechten van derden (bijvoorbeeld een pandhouder) op de verzekeringspenningen kunnen worden tegengeworpen (lid 2). Voor deze constructie is naar het schijnt gekozen omdat Meijers een eigen aanspraak van de benadeelde op een verzekeraar die niet de zijne was (zoals ingevolge art. 6 WAM) te ver vond gaan. ${ }^{1269}$

De regeling van art. 3:287 $\mathrm{BW}$ geldt ook in regressituaties. Voor subrogatie volgt dat uit de algemene regeling van art. 6:142 lid $1 \mathrm{BW}$. Dat laat, zoals gezegd, bij overgang van een vordering op een nieuwe schuldeiser de daarbij behorende nevenrechten mee overgegaan. Voorrechten zijn nevenrechten in de zin van art. 6:142 BW, en daaronder valt óók art. 3:287 BW. ${ }^{1270}$ Particuliere verzekeraars (en het Schadefonds Geweldsmisdrijven) op wie door subrogatie de vordering tot schadevergoeding van de benadeelde overgaat hebben daarmee óók het wettelijke voorrecht van art. 3:287 BW..$^{1271}$ Voor regresnemers met een zelfstandig regresrecht is dit anders. Aangezien zij niet de vordering tot schadevergoeding van de benadeelde verkrijgen, zou ook het voorrecht van art. 3:287 BW, nu dit volgens de tekst van die bepaling is verbonden aan 'vorderingen tot vergoeding van schade', voor hen niet gelden. Dat zijn natuurlijk technische redenen, vanuit het belang

1271 Art. 6:142 BW. Asser-Hartkamp 4-1, nr. 563 (over voorrechten als nevenrecht); Van Boom (2000a), p. 69 stelt voorts dat ook de action dinecte van art. 6 WAM als nevenrecht kan worden aangemerkt. 
van een gelijke behandeling van regresnemers (ter bevordering van rechtsgelijkheid en hanteerbaarheid van de regresrechten) is er veel voor te zeggen om hun vordering dezelfde gevolgen te geven tegenover derden. Door een extensieve interpretatie wordt echter, aangenomen dat art. 3:287 BW óók, maar dan rechtstreeks, geldt voor de zelfstandige regresrechten. ${ }^{1272}$ Het voorrecht van regresnemers gaat daarmee zoals gezegd tevens, volgens het tweede lid, voor op alle rechten van derden op de vordering van de schadeveroorzaker jegens zijn WA-verzekeraar. Dat de regresvordering vóórgaat op de aanspraak op de verzekeringspenningen van de schadeveroorzaker sluit aan bij de strekking van de WA-verzekering. Maar wat rechtvaardigt die betere positie van regresnemers? ${ }^{1273}$ Dogmatisch gezien zou men daartoe kunnen aanvoeren dat aan de regresrechten het principe ten grondslag ligt dat de schade zoveel mogelijk behoort te worden gedragen door de schadeveroorzaker (of diens WA-verzekeraar). Het voorrecht van art. 3:287 BW bevordert dat dit ook daadwerkelijk gebeurt, maar gaat daarin een stap verder dan de action directe: het geeft een (echte) voorrangsregeling. Of het principe dat de schuldige betaalt daarvoor voldoende argument oplevert betwijfel ik. Dat principe (en de daarop gebaseerde doeleinden van het regres) heeft betrekking op de rechtsverhouding tussen de regresnemer en de schadeveroorzaker. Binnen die verhouding is het de schadeveroorzaker die al dan niet door middel van zijn WA-verzekering) de schade behoort te dragen. Daarmee is echter niets gezegd over de plaats en betekenis van de regresvordering vergeleken met andere, concurrerende vorderingen. Voorrang van de regresnemer zou achterstelling betekenen van andere (zakenrechtelijke of contractuele) gerechtigden (schuldeisers van de schadeveroorzaker). Waaruit volgt dat het principe dat de schuldige betaalt zo zwaar zou moeten wegen? Het voorrecht van art. 3:287 BW moet eenvoudigweg bevorderen dat schadeloosstelling plaatsvindt, zonder dat de benadeelde in zijn vordering wordt gefrustreerd. Dat heeft met de grondslag van zijn vordering en het principe dat de schadeveroorzaker behoort te betalen, in mijn visie niet direct te maken. Dogmatisch gezien lijkt er dan ook geen speciale reden om deze regeling specifiek bij regres te laten gelden.

De bescherming van art. 3:287 BW kent voor de praktijk intussen ook belangrijke beperkingen. Weliswaar geeft art. 3:287 BW de vordering voorrang, en beschermt zij in zoverre bij faillissement. Maar deze regeling blijft behept met de beperking dat schadeuitkeringen van WA-verzekeraars door het vermogen gaan van de aansprakelijke. Het risico van oninbaarheid blijft in zoverre dus bestaan. Bovendien zal de benadeelde daardoor bij faillissement van de aansprakelijke moeten delen

1272 Van Boom (2000a), p. 70 en uitvoeriger Van Boom (2000c), p. 195 e.v.

1273 Tot die conclusie komt ook Van Boom (2000a), p. 48: 'Een ander gebied waarop verdere tweedeling (naast de TRV, EE) mogelijk en mijns inziens wenselijk is, betreft het voorrecht van art. 3:287 BW (en naar komend recht de directe actie) van de benadeelde jegens de aansprakelijkheidsverzekeraar van de aansprakelijke persoon', en eveneens Van Boom (2000c), p. 195 e.v. 
in de faillissementskosten. ${ }^{1274}$ Juist met het oog daarop heeft Van Dam in zijn preadvies over het nieuwe verzekeringsrecht een ontwerp regeling gemaakt voor een algemene, directe actie voor titel 7.17 BW. ${ }^{1273}$ Zoals gezegd zou die regeling in mijn visie wèl moeten gelden voor regresnemers. Dit voorstel ligt aan de basis van de thans voorliggende ontwerpregeling voor Boek $7 \mathrm{BW}$. De nadelen van art. 3:287 BW zouden daarmee het hoofd kunnen worden geboden. Van Boom stelt voor om tot die tijd art. 3:287 lid $1 \mathrm{BW}$ zo te lezen, dat de benadeelde daaraan een exclusieve inningsbevoegdheid kan ontlenen. ${ }^{1276}$

\subsubsection{Voeging in strafproces}

Voor wat betreft de procedure tegen de schadeveroorzaker zèlf, in persoon, verdient vermelding dat regresnemers zich niet als civiele benadeelde in het strafproces kunnen voegen ingevolge de wet Terwee. 'Derden', dat wil zeggen anderen dan degene die door het strafbare feit waarop de strafzaak betrekking heeft rechtstreeks schade heeft geleden, zijn uitdrukkelijk uitgesloten van de bevoegdheid tot voeging in dit verband. ${ }^{1277}$ In 1966 besliste de Hoge Raad in een daaromtrent ingesteld cassatieberoep 'in het belang der wet' dat ook gesubrogeerde verzekeraars zich niet in de plaats van het slachtoffer als beledigde partij in het strafproces kunnen voegen. ${ }^{1278}$ Het praktische belang daarvan was toen overigens minder groot omdat de maximumbedragen van de vordering waarvoor om voeging kon worden verzocht toen aanmerkelijk veel lager waren (vorderingen tot maximaal 200 gulden voor de kantonrechter en 500 gulden voor de rechtbank) dan thans het geval is.

\subsubsection{Bevrijdende verjaring}

\subsubsection{INLEIDING}

Ook met betrekking tot de vraag welk regime geldt voor de bevrijdende verjaring van regresvorderingen, heerst enige onduidelijkheid. Het instituut van de bevrijdende verjaring berust op de gedachte dat schuldenaren of hun erfgenamen bescherming behoeven tegen oude aanspraken (dat wil zeggen aanspraken waartegen zij zich door het lange tijdsverloop tussen het ontstaansmoment van de rechtsvordering en het geldend maken ervan moeilijk meer kunnen verweren). Daarnaast dient verjaring het belang van de gemeenschap als zodanig, omdat het rechtszekerheid biedt. ${ }^{1279}$ Voor het recht op schadevergoeding van de benadeelde zelf geldt be-

Zie o.a. Robben (1993), p. 28; Van Boom (1994), p. 635 e.v.; Van Dam (1995), p. 125; Mok (1998), p. 89. Van Dam (1995), p. 128 en op de hier relevante onderdelen instemmend Mok (1998), p. 90.

Van Boom (1994), p. 638; instemmend Van Dam (1995), nt. 165.

1278 HR 5 oktober 1965, NJ 1966, 292 (J/Liverpool and London Globe).

1279 Asser-Hartkamp 4-1, nr. 653; Akkermans (1998), p. 33. 
houdens bijzondere regelingen de algemene regeling, art. 3:310 BW. ${ }^{1280}$ Deze regeling geeft een verjaringstermijn van vijf jaar na het moment dat de benadeelde zowel met de schade als met de daarvoor aansprakelijke persoon (de schadeveroorzaker) bekend is geworden, en een langere termijn van twintig jaar. De 'korte', vijfjaren termijn is de belangrijkste, maar ook de moeilijkste termijn. Het criterium van bekendheid met schade en schadeveroorzaker is immers een subjectief criterium. Aangenomen wordt dat voor elke nieuwe termijn waarin de benadeelde met een nieuwe schade of schadepost wordt geconfronteerd, de vijfjaren termijn opnieuw gaat lopen. ${ }^{1281} \mathrm{Bij}$ voortdurende, toekomstige schade waarvoor art. 6:105 BW de mogelijkheid biedt schadevergoeding te vorderen, past voorzichtigheid. Men hoeft uiteraard geen gebruik te maken van de mogelijkheid van art. 6:105 BW, maar doet er wel goed aan de verjaring te stuiten. ${ }^{1282}$ Dat geldt bij uitstek bij inkomensschade, en dus ook in regressituaties. Maar daarmee stuiten we, in verjaringsterminologie, op een meer algemene moeilijkheid. Want gelden dezelfde regels ook voor regresvorderingen? Over het antwoord op die vraag heerst grote onduidelijkheid, ${ }^{1283}$ een manco dat hoofdzakelijk op conto komt van de wetgever. De invoering van het vijfde lid van art. 3:310 BW had wellicht de aanleiding kunnen zijn om op dit punt meer duidelijkheid te bieden, maar dat is niet gebeurd. Wellicht zal daarin met het verstrijken van de termijnen van art. 3:310 BW de komende jaren verandering komen.

Overigens verdient het opmerking dat een bijzonder regime geldt voor de verjaring van de action directe die regresnemers krachtens art. 6 WAM toekomt. Dat regime staat, ook bij subrogatie, los van de benadeelde; de action directe is zoals gezegd immers ook voor schadeverzekeraars een zelfstandig recht. Het verjaart op grond van art. 10 lid 1 WAM na drie jaar. Indien die termijn verlopen is, maar de vordering jegens de schadeveroorzaker nog niet is verjaard, dan kan men hèm aanspreken (en hij kan de schade declareren bij de WAM-verzekeraar, op grond van hun beider verzekeringsovereenkomst). Robben stelt dat dit óók geldt indien het omgekeerd is, de regresnemer verliest dan zijn aanspraak jegens de schadeveroorzaker weliswaar, maar blijft die op de WAM-verzekeraar net zo lang houden totdat ook die verjaard is. ${ }^{1284}$

1280 Voor het oude recht gold voor schadevorderingen de algemene regeling van ant. 2004 BW (oud), die de vordering dertig jaar na het intreden van de schade liet verjaren.

1281 Zie daarover o.m. Asser-Hartikamp 4-1, nr. 674 en Akkermans (1998).

1282 PG 3, p. 928; Asser-Hartkamp 4-1; Spier c.a. (2000), nr. 335 (Spier); Akkermans (1998), p. 34.

1283 Zie de Conclusie A-G De Vries Lentsch-Kostense bij HR 7 november 1997, NJ 1998, 384 (Younis/Waarboryfonds Motorverkeer); Van Boom \& Storm (1995), p. 149; Akkermans (1998), p. 33 e.v.; Van Boom (2000a), p. 94-97.

1284 Robben (1993), p. 218. 


\subsubsection{GELDEND RECHT: ONDUIDELIJKHEID IS ER TROEF}

Welke regels en termijnen gelden nu precies voor de bevrijdende verjaring van regresvorderingen? ${ }^{1285}$ Voor het regresrecht door subrogatie van particuliere verzekeraars (en het Schadefonds Geweldsmisdrijven) geldt de regeling dieóók geldt voor de benadeelde, daarover lijken de meningen onverdeeld. De gesubrogeerde verkrijgt zijn vordering tot schadevergoeding. Aangezien de gesubrogerde geen beter of meeromvattend recht kan verkrijgen dan de benadeelde zelf, blijft het verjaringsregime dan volkomen hetzelfde. ${ }^{1286}$ De vraag naar de verjaring van zijn vordering moet kortom worden beoordeeld op grond van het regime zoals dat geldt sinds het ontstaan van die vordering bij de benadeelde. Over de wijze waarop dat regime moet worden toegepast heerst echter, met name in de sfeer van personenschade, grote onduidelijkheid. Vangt bij voortdurende schade op elk nieuw schademoment (maandelijks inkomensschade) een nieuw verjaringsmoment aan? Het regres maakt het er niet eenvoudiger op: indien de verjaringsternijn voltooid is, ligt de zaak helder, maar wat geldt indien de verjaringstermijn nog loopt op het moment van de subrogatie?

Voor de zelfstandige regresrechten lijkt de vraag naar de toepasselijke regeling nog een gradatie ingewikkeider, aangezien die niet gebonden zijn aan de vordering van de benadeelde. In het arrest Bijlsma/Stichting Pensioenfonds $A B P$ oordeelde de Hoge Raad voor het regres in het kader van de Verhaalswet ongevallen ambtenaren (VOA) echter in andere zin. ${ }^{1287}$ De zaak heeft betrekking op een verkeersongeval tussen een fietser en een bromfietser, waarbij de laatste (een gemeenteambtenaar) zijn heup had gebroken. De Staat en het ABP zochten regres bij de WAverzekeraar van de aanrijdende fietser, die zich ter afwering daarvan beriep op de bevrijdende verjaring van art. 3:310 BW. $\mathrm{Zij}$ had daarin in hoger beroep gelijk gekregen: volgens het hof was de regresvordering van art. 2 VOA inderdaad onderworpen aan de in art. 3:310 lid $1 \mathrm{BW}$ bepaalde verjaringstermijn van vijf jaar. In cassatie stelde het $\mathrm{ABP}$ zich hierin niet te kunnen vinden, en beriep zich daartoe op het zelfstandige karakter van haar regresvordering en haar bijzondere aard (een geldvordering strekkende tot terugbetaling van gemaakte kosten, geen vordering tot schadevergoeding). Volgens het $\mathrm{ABP}$ zou daarom de algemene verjaringstermijn van twintig jaar van art. 3:306 BW moeten gelden. De Hoge Raad verwerpt die stelling. Het hof heeft, in de woorden van de raad, terecht geoordeeld dat de regresvordering van art. 2 VOA dient als een vordering tot vergoeding van schade als bedoeld in art. 3:310 $\mathrm{BW}$ zodat de algemene verjaringstermijn van twintig jaar van toepassing is. Dit staat meen ik echter haaks op het uitgangspunt in 's raads

De vraag naar de toepasselijkheid van de verjaringstermijnen van de action directe van art. 6 WAM blijt hier buiten beschouwing (al zal veel van het hiema over ant.3:310 BW gezegde op dezelfde wijze gelden voor de WAM-bepalingen). Verwezen zij daarvoor naar Robben (1993), p. 185 e.v. en De Bosch Kemper (1995). p. 68-70.

1286 In die zin Akkermans (1998), p. 35 en Van Boom (2000a), p. 95.

1287 HR 31 mei 2002, C00/107HR (Bijlsma/Stichting Pensioenfonds ABP). 
jurisprudentie dat de regresvordering van de VOA, net als de overige regresrechten, niet tot schadevergoeding strekt, ${ }^{1288}$ en losstaat van de vordering tot schadevergoeding van de benadeelde zelf. De Hoge Raad motiveert zijn oordeel als volgt:

'Immers het verhaalsrecht van het verhalend lichaam [het ABP, EE] mag ingevolge de bepaling van art. 3 VOA niet ertoe leiden dat de laedens in een slechtere positie komt te verkeren dan waarin hij zou hebben verkeend ingeval hij door de getroffene zelf tot schadevergoeding zou zijn aangesproken en zulks geldt niet alleen voor de hoogte van de vordering doch ook voor de beantwoording van de vraag aan welke verjaringstermijn de verhaalsvordering is onderworpen.

Deze redenering laat zich echter moeilijk verenigen met de benadering die de raad in hetzelfde arrest kiest voor de buitengerechtelijke kosten. Die berust immers op de gedachte dat nu een schadekarakter voor de regresregeling van art. 2 VOA ontbreekt, deze regeling zèlf zich niet uitstrekt over de buitengerechtelijke kosten van de regresnemende instantie. ${ }^{1289}$ Het gaat, zo bevestigt de raad inzake Bijlsma/ Stichting Pensioenfonds $A B P$, om een normale geldvordering, die echter wel aanleiding kan geven tot een schadevordering (bij niet-nakoming). Uitsluitend wanneer dàt het geval is ontstaat een daarbij behorende aanspraak op vergoeding van de buitengerechtelijke kosten. Heeft diezelfde vordering dan wèl 'ineens' voldoende schadekarakter om als vordering tot schadevergoeding in de zin van art. 3:310 $\mathrm{BW}$ te worden aangemerkt? Anderzijds moet de raad worden toegegeven dat de gedachte dat de schadeveroorzaker (diens WA-verzekeraar) niet 'slechter' mag worden van het regres, aanspreekt. Welk regime zou dan wèl dienen te gelden?

\subsubsection{VOORSTELLEN IN DE LITERATUUR}

Over de vraag naar het meest wenselijke verjaringsregime voor regresvorderingen is nog weinig gediscussieerd, maar voorzover daarvan wèl sprake is lopen de meningen uiteen. Overwegend lijkt te worden aangenomen dat ook de verjaring van de zelfstandige regresvorderingen door de regeling van art. 3:310 BW wordt beheerst. Die opvatting wordt op verschillende manieren onderbouwd. In de eerste plaats wordt wel gesteld dat zelfstandige regresvorderingen een schadevergoedingskarakter hebben en om die reden vallen onder het bereik van art. 3:310 BW. ${ }^{1290}$ Dat staat echter haaks op het rechtskarakter van deze regresvorderingen. Van Boom wijst in dit verband terecht, dunkt mij, op rechtspraak waarin de Hoge Raad het eigen karakter benadrukt: zelfstandige regresvorderingen strekken (oorspronkelijk) niet tot schadevergoeding. ${ }^{1291}$ Een ander argument dat wel voor de toepasselijk-

\footnotetext{
1288. Zie paragraaf 8.1 .

1259 HR 29 april 1994, NJ 1995, $609 \mathrm{nt}$. CJHB (Nationale Nederianden/ABP); zie daarover supra, paragraaf 8.3.

1290 Zie daarover Van Boom (2000a), p. 96 (met verdere verwijzingen).

1291 Van Boom (2000a), p. 95, onder verwijzing naar HR 8 december 1938, NJ 1939, $545 \mathrm{nt}$. EMM (Rijksversekeringsbank/Schönberger) en HR 18 februari 1994, NJ 1995, 607 nL. CJHB (Bureau Motorrijtuigverzekeraars/ABP). In het arrest inzake HR 7 november 1997, NJ 1998, 384 (Younis/Waarborgfonds Motorverkeer) hecht de Hoge
} 
heid van art. 3:310 BW voor zelfstandige regresvorderingen wordt aangetoerd is dat deze regeling - gelet op de tekst - ruim dient te worden geïnterpreterd. Volgens het eerste artikellid geldt art. 3:310 BW voor 'rechtsvorderingen to vergoeding van schade'. De ruime interpretatie zou steun vinden in de wordin;sgeschiedenis van art. 3:310 BW. Hoewel die daarover niet concreet is, word dan betoogd dat art. 3:310 BW zou moeten gelden voor alle vorderingen die betrelking hebben op aansprakelijkheid, óók regresvorderingen. ${ }^{1292}$ Te betwijfelen valt of dat wenselijk is. In art. 3:310 BW wordt immers uitdrukkelijk gesproket van een vordering tot schadevergoeding (en overigens de vordering uit een boeebeding). Een uitbreiding naar regresvorderingen enkel en alleen omdat in die gevillen sprake is van aansprakelijkheid zet de deur open voor uitbreiding van de toepisselijkheid naar willekeurig elke andere vordering die verband houdt met gevillen van aansprakelijkheid. Juist bij verjaring, waar het belang van rechtszekeneid zwaarweegt, lijkt dat onwenselijk.

In de derde plaats wordt de toepasselijkheid van art. 3:310 BW wel onderbolwd met een beroep op de ratio van het zogenaamde civiele plafond. De gedache is dan deze, dat de schadeveroorzaker door het regres niet in een ongunstigere vemogensrechtelijke positie mag komen te verkeren dan die wanneer hij zou zijin aargesproken door de benadeelde zelf. Akkermans volgt die benadering: ${ }^{1293}$ bij niettoepasselijkheid van art. 3:310 BW op regresvorderingen zou de schadeveroorzaker of WA-verzekeraar zich geconfronteerd zien met een verjaringstermijn van twintig jaar. Dat zou dus, zo stelt Akkermans, aanmerkelijk nadeliger zijn dan het verjaringsregime voor de vordering van de benadeelde. Het bijkomende voordeel van deze benadering is dat dan (in beginsel) een-en-dezelfde verjaringsregeling (en dus ook dezelfde verjaringstermijnen) gelden voor de bevrijdende verjaring van alle regresvorderingen. Toch zijn de onderlinge verschillen hiermee dunkt me niet verdwenen. Bij subrogatie heeft het regime van art. 3:310 BW immers betrekking op het recht op schadevergoeding van de benadeelde zelf, terwijl het bij deze benadering voor de zelfstandige regresrechten betrekking zou gaan hebben op de regresvordering zelf. Dat heeft allerlei consequenties, die ook het resultaat (het verjaringsmoment) bij beide regimes heel verschillend maken. Zo zal de vijfjaren termijn van art. 3:310 BW bij subrogatie aanvangen op het moment dat de benadeelde bekend is geraakt met de schade en met de aansprakelijke. Bij de toepasselijkheid van deze regeling en het aanvangscriterium op de zelfstandige regresvorderingen zal het daarentegen gaan om de bekendheid bij de regresnemer, en niet de benadeelde. Als de vijfjaren termijn daardoor bij subrogatie eerder aanvangt dan bij de zelfstandige regresvorderingen zal ook het moment van verjaring anders

Raad in dit verband aan het zelfstandige karakter van de regresvordering voor de vraag naar verjaring ingevolge de WAM.

1292 Die benadering kiest $A-G$ De Vries Lentsch Kostense in de zelfstandige regreszaak van het Waarborgfonds Motorverkeer, HR 7 november 1997, NJ1998, 384, nr, 8 (Younis/Waarborgfonds Motorverkeer), en dasrover Akkermans (1998), p. 35.

1293 Akkemans (1998), p. 36. 
zijn. Ook Akkermans wijst op dit laatste en stelt ook zelf geen inhoudelijke rechtvaardiging te zien voor de verschillende uitkomst die de technische verschillen tussen de regresvorderingen hier opleveren. ${ }^{1294} \mathrm{Hij}$ wijst op de mogelijkheid die verschillen te elimineren door bijvoorbeeld ook bij regresvorderingen krachtens subrogatie uit te gaan van de subjectieve kennis van de regresnemer, en niet die van de benadeelde. ${ }^{1295}$ Een belangrijk bezwaar lijkt me dan echter dat daarmee het doel dat men met de toepasselijkheid van art. 3:310 BW nu juist voor ogen had, niet wordt bereikt. Het uitgangspunt was immers dat deze regeling ook voor de zelfstandige regresvorderingen zou moeten gelden om te voorkomen dat de schadeveroorzaker door het regres in een nadeligere positie komt te verkeren dan indien hij voor de schade zou zijn aangesproken door de benadeelde zelf. Dat wordt echter niet bereikt als voor het aanvangsmoment van de korte termijn van art. 3:310 BW de bekendheid bij de regresnemer beslissend is.

Dat de bevrijdende verjaring voor de zelfstandige regresvorderingen door art. 3:310 BW zou worden beheerst is dus moeilijk te onderbouwen. Maar wat dan wèl? Van Boom stelt voorop dat zelfstandige regresvorderingen geen vordering zijn tot schadevergoeding, maar tot het vergoeden van uitkeringen. Volgens hem heeft daarvoor dan ook - naar geldend recht - de algemene regeling voor de verjaring van rechtsvorderingen te gelden, art. 3:306 BW. Dat zou betekenen dat een verjaringstermijn geldt van maar liefst twintig jaar, te rekenen vanaf het moment waarop de regresvordering opeisbaar is. ${ }^{1296}$ Van Boom stelt dat er weliswaar gelet op de gedachte achter de regeling van het civiele plafond wel wat voor te zeggen valt om aansluiting te zoeken bij art. 3:310 BW. Daaraan, zo voegt hij toe, zou dan wèl de consequentie moeten worden verbonden dat voor het aanvangsmoment van de korte termijn van art. 3:310 lid $1 \mathrm{BW}$ de bekendheid van de benadeelde, en dus niet van de regresnemer beslissend zou zijn. Het bijkomende voordeel is dat dan exact hetzelfde verjaringsregime geldt als voor de regresvordering op basis van subrogatie. ${ }^{1297}$ Maar of dat geldend recht is stelt Van Boom te betwijfelen. Aannemelijker is dat, gegeven de zelfstandigheid van de verhaalsrechten, de twintigjarige termijn van art. 3:306 BW geldt. ${ }^{1298}$

Inderdaad ligt het bij regres meer voor de hand om het regime van art. 3:306 BW gewoon te laten gelden dan het regime voor schadeclaims, art. 3:310 BW, ware het niet dat de Hoge Raad dit voor het VOA-regres (en daarmee wellicht ook voor de overige zelfstandige regresrechten) verwerpt. Bovendien zou dat impliceren, dat de regeling van art. 3:306 BW alleen zou moeten gelden voor zelfstandige regresvorderingen en dat voor vorderingen van particuliere verzekeraars de regeling

\footnotetext{
1294 Akkermans (1998), p. 36

1295 Akkermans (1998), p. 36.

1296 Van Boom (2000a), p. 96.

1297 Van Boom (2000a), p. 97.

$129 \mathrm{~s}$ Van Boom $(2000 a)$, p. 97.
} 
van art. 3:310 BW zou blijven gelden. Het resultaat daarvan zou in elk geval zijn dat het moment van verjaring voor deze vorderingen sterk zou uiteenlopen: sociale verzekeraars zouden behoudens bijzonderheden twintig jaar de tijd hebben roor het indienen van een vordering, te rekenen vanaf het moment van het schadevoorval, terwijl gesubrogeerde schadeverzekeraars maar vijf jaar zouden hebben, te rekenen vanaf het moment dat de benadeelde bekend wordt met de schade en de schadeveroorzaker. Een zo ver uiteenlopen van het moment van verjaring ijkt me, ook trouwens vanuit het perspectief van de schadeveroorzaker en WA-verzckeraars bezien, bezwaarlijk. Losse vorderingen op specifieke schadeposten zulen nog tot vele jaren na betaling aan de ene verzekeraar kunnen leiden tot een vordering van de andere verzekeraar. Een belangrijker nadeel van de exclusieve toepasselijkheid van art. 3:306 BW op zelfstandige regresvorderingen lijkt me nog dat de schadeveroorzaker er daarmee aanmerkelijk op achteruit gaat vergeleken net de situatie waarin hij voor de betreffende schade zou zijn aangesproken door de benadeelde. Op dat bezwaar wijst Van Boom ook zelf, ${ }^{1299}$ en naar werd gezien was dit voor Akkermans reden om ook voor de verjaring van zelfstandige regresrechten de regeling van art. 3:310 BW te laten gelden.

\subsubsection{NAAR EEN UNIFORM VERJARINGSREGIME VOOR REGRESNEMER'S?}

Het meest verdedigbaar lijkt me daarom een derde benadering, waarin de schadeveroorzaker niet erop achteruit gaat maar evenmin wordt voorbij gegaan aan het eigen karakter van het regres (vergeleken met vorderingen tot schadevergoeding): zelfstandige regresvorderingen behoren te verjaren door verloop van twintig jaar na het moment van opeisbaar worden van de regresvordering (art. 3:306 BW), met dien verstande dat indien de vordering van de benadeelde reeds daarvoor is verjaard (op grond van art. 3:310 BW) er geen ruimte meer is voor regres. Daartoe kan rechtstreeks worden aangeknoopt bij de regeling van het civiele plafond: op het moment dat de vordering tot schadevergoeding van de benadeelde is verjaard is de schadeveroorzaker niet langer schadevergoeding verschuldigd. Dat de regresvordering een zelfstandig karakter heeft en dus los van de vordering van de benadeelde staat, doet daaraan geen afbreuk. Dàt is alleen relevant met betrekking tot de nog resterende vordering van de benadeelde (voor het onverzekerde deel van de schade). Beslissend voor de inwerkingtreding van het verjaringsregime voor de regresnemer behoort het moment te zijn waarop de wettelijke aanspraak op de uitkering of op loondoorbetaling ontstaat. Reeds door het ontstaan van die aanspraak verliest de benadeelde zijn vordering ${ }^{1300}$ Is die vordering op dat beslissende moment al verjaard, dan is, aanknopend bij de regeling van het civiele plafond, ook voor de regresvordering geen plaats.

1299 Van Boom (2000a), p. 97.

1300 Zie o.a. art. $6: 107 a$ lid 1 BW, an. 89 WAO, ant $83 a$ ZFW 
Concreet betekent dit dat bij regresvorderingen eerst dient te worden nagegaan of de vordering tot schadevergoeding die de benadeelde tot dat moment zelf zou zijn toegekomen al is verjaard. Veelal zal daarvoor de regeling van art. 3:310 lid 1 BW gelden. Volgens die regeling geldt zoals gezegd dat als de 'langlopende' termijn van twintig jaar niet al is verstreken, voor het intreden van de verjaring beslissend is op welk moment de benadeelde met de schade en de daarvoor aansprakelijke persoon bekend is geworden (zie paragraaf 8.6.5.1). De omvang van de schade hoeft op dat moment nog niet vast te staan. ${ }^{1301}$ Wat geldt als een door het ongeval veroorzaakte verwonding een voortdurende schade teweegbrengt, bijvoorbeeld regelmatig terugkerende inkomensschade en ziekenhuiskosten? Veelal wordt de benadeelde reeds bij het eerste ontstaan daarvan (veelal het moment van de verwonding) verondersteld daarmee bekend te zijn geraakt. Dan reeds gaat de vijfjaren termijn lopen. Daarvoor maakt het geen verschil dat op dat moment slechts wordt verwacht dat (een deel) van die schade in de toekomst geleden zal worden. ${ }^{1302}$ Een aparte termijn gaat volgens Hartkamp slechts lopen voor schade(posten) die ten tijde van het ongeval niet behoefde(n) te worden verwacht. ${ }^{130.3}$ Gelet op deze uitleg van art. 3:310 BW lijkt het goed mogelijk dat de vordering van de benadeelde reeds is verjaard voordat de regresvordering is ontstaan. Het principe dat de schadeveroorzaker vermogensrechtelijk niet in een nadeligere positie mag geraken dan waarin hij bij een vordering van de benadeelde zelf zou hebben verkeerd, maakt dan dat hij ook van het regres is bevrijd.

A loopt in 1995 letsel op van een verkeersonge'al waarvoor B aansprakelijk is. A raakt hierdoor voor $5 \%$ blijvend arbeidsongeschiktheid. Zeven jaar na het ongeval, het jaar 2002, verergert A's toestand als gevolg van het ongeval zodanig dat A voor $20 \%$ arbeidsongeschikt raakt en een reeds overwogen operatie alsnog noodzakelijk wordt. In beginsel moet worden aangenomen dat A bij de aanvang van zijn arbeidsongeschiktheid in 1995 bekend was met zijn schade, en ook met de verwachting dat deze kon oplopen zoals ook is geschied. A's vordering is dan mogelijk al verjaard in het jaar 2000 . Voor de regresvorderingen in het jaar 2002, op het moment dat de benadeelde een (aanvullende) WAO-aanspraak of aanspraak krachtens Ziekenfondswet of AWBZ verkrijgt, dient daarbij dan te worden aangesloten. De regresnemer zal bij het op art. 3:310 BW gebaseerde verweer van de schuldenaar moeten stellen en zonodig bewijzen dat de schade die in het jaar 2002 is ontstaan door A in 1995 niet werd of behoefde te worden voorzien (dan wel dat de verjaring tijdig tussentijds is gestuit) ${ }^{1304}$

Moet, als de verjaringstermijn van de vordering van de benadeelde zelf ingevolge art. 3:310 $\mathrm{BW}$ (of een bijzondere verjaringsregeling) is aangevangen maar nog niet is voitooid rekening worden gehouden met reeds verstreken jaren? Het civiele plafond zegt daarover niets; zolang de termijn nog niet is voltooid blijft de schade-

1302 Zie 0.a. Asser-Hartkamp 4-1, nr. 674a; Akkermans (1998), p. 34; Spier e.a. (2000), nr. 335 (Spier).

1903 Asser-Hartkamp 4-1, nr. 674a; instemmend Akkermans (1998), p. 35.

1304 Slaagt de regresnemer hierin, dan is de vijfjarentermijn van art. 3:310 BW niet gaan lopen, maar is in het jaar 2002 voor de regresvorderingen krachtens onder meer WAO, AWBZ en ZFW een nieuw verjaringsregime voor zelfstandige regresvorderingen aangevangen, de algemene twintigarentermijn van art. 3:306 BW. 
veroorzaker gewoon voor het volle bedrag aansprakelijk. Vanuit het perspctief van de schuldenaar lijkt er bij eerste oogopslag best wat voor te zeggenje al verstreken jaren te verrekenen. Vanuit het perspectief van de regresnemer in de ratio van zijn regresrecht) ligt dat minder voor de hand. De regresnemer zo dan immers zijn vordering verloren zien gaan op de enkele grond dat de benacelde niet tijdig heeft gestuit. Dat lijkt me zwaarwegend, aangezien de benadeele bij stuiting van zijn vordering, bij het vooruitzicht op een wettelijke aansprak op een uitkering voor zijn schade, zelf geen of weinig belang heeft. Praktisch gzien zou verrekening van reeds verstreken jaren bovendien tot ingewikkelde vigen leiden, zoals de vraag welke termijn van art. 3:310 BW dan beslissend moc zijn (als beide reeds zijn aangevangen). Wat dit laatste betreft zou aanknoping ij de lange termijnen van art. 3:310 lid 1 en 2 BW overigens wellicht het meestroor de hand liggen, omdat daarvoor een enigszins vergelijkbaar criterium gelt als voor de aanvang van de termijn van art. 3:306 BW. Maar gelet op het zelfstadige karakter van de regresrechten zou het me beter lijken om op het moment warop de regresvordering ontstaat (en de vordering van de benadeelde nog niet is verjard) de termijn van art. 3:306 BW 'schoon' te laten aanvangen.

Ten slotte kan nog worden overwogen om de toepasselijkheid van art. 3:306 BW óók te laten gelden voor de door subrogatie verkregen vordering jegens de aansprakelijke. De regresnemer verkrijgt bij subrogatie de vordering tot schadevergoeding van de benadeelde. Op die grond lijkt overwegend te worden aangenomen dat voor de vraag naar verjaring de regels gelden zoals ze voor de benadeelde zelf gelden, dus in beginsel slechts de algemene regeling van art. 3:310 BW. Onzeker is echter nog wat de betekenis hiervan is indien de verjaringstermijnen van art. 3:310 BW op het moment van de rechtsovergang nog niet aangevangen of verlopen zijn (bijvoorbeeld omdat de benadeelde nog niet bekend was met de aansprakelijke). Aangenomen wordt wel dat de schadeverzekeraar dan de onder de benadeelde (voor het moment van subrogatie) aangevangen termijn voortzet. ${ }^{1305} \mathrm{Om}$ op dit punt geen verschil te laten bestaan met het verjaringsregime voor zelfstandige regresvorderingen lijkt het me beter verdedigbaar om ook voor de gesubrogeerde verzekeraar de termijn van art. 3:306 BW te laten aanvangen (mits de vordering van de benadeelde op het moment van subrogatie nog niet is verjaard). De reeds verstreken verjaringstermijnen maken dan geen deel uit van de vordering zelf. Het lijkt er echter niet op dat dàt ook geldend recht is, waarschijnlijk geldt alleen de regeling van art. 3:310 $\mathrm{BW}$ en lopen nog niet voltooide verjaringstermijnen nadat de vordering in handen is gekomen van de verzekeraar gewoon verder door.

Dogmatisch zou men het zo kunnen stellen dat de vordering nadat deze door de gesubrogeerde verzekeraar is verkregen van karakter verandert: de vordering verliest zijn schadevergoedingskarakter. Het is immers niet de bedoeling dat de gesubrogeerde verzekeraar bij het ten gelde maken van de vordering 
zelf wordt schadeloosgesteld, maar dat hij een bedrag ontvangt ten belope van het bedrag van de schadevergoeding waarop de benadeelde aanspraak zou hebben kumnen maken. Het lijkt dan verdedigbaar om voor deze vordering wanneer zij na de rechtsovergang haar schadevergoedingskarakter verliest, en ervan uitgaande dat de verjaring van art. 3:310 BW op dat moment niet al is ingetreden, het verjaringsregime van art. 3:306 $\mathrm{BW}$ te laten gelden.

Om kort te gaan komt het vorengezegde dus hierop neer: voor alle regresvorderingen moet in mijn visie eerst worden nagegaan of reeds verjaring zou zijn ingetreden, indien de benadeelde zijn vordering was blijven behouden. Als dat zo is, prevaleert de rechtszekerheid en is voor regres geen plaats. Is het verjaringsregime voor de benadeelde nog niet voltooid op het ontstaansmoment van de regresvordering (bij subrogatie het moment waarop de schade wordt vergoed, bij zelfstandig regres het moment waarop de gehoudenheid tot uitkering of loondoorbetaling bij ziekte ontstaat), dan gaat een nieuw regime lopen: het normale regime voor geldvorderingen (die niet strekken tot vergoeding van eisers belang), art. 3:306 BW. De schadeveroorzaker (WA-verzekeraar) gaat dan in zoverre, als gevolg van de wisseling van de crediteuren (en de gedachte dat hen dezelfde positie moet toekomen als andere crediteuren van een geldvordering) erop achteruit.

\subsubsection{DEROGERENDE WERKING VAN DE BILLIJKHEID}

De toepasselijkheid van art. 3:310 BW voor regresvorderingen is mede van belang met het oog op de bescherming die Hoge Raad en wetgever in dat verband bieden tegen (de onredelijke gevolgen van) de lange verjaringstermijnen. In het kader van art. 3:310 BW geldt tevens, voor het geval de korte termijn al niet tot verjaring zou hebben geleid, een 'lange' verjaringstermijn van twintig jaar na het moment van het schadevoorval. Het tweede lid spreekt zelfs van dertig jaar voor schade veroorzaakt door bepaalde gevaarlijke stoffen. In een tweetal arresten met betrekking tot asbestschade heeft de Hoge Raad de mogelijkheid geopend om de verjaring krachtens deze lange termijn, in uitzonderlijke gevallen buiten beschouwing te laten. ${ }^{1306}$ Het gaat om gevallen waarin de schade pas na het verstrijken van de verjaringstermijn is ontstaan (zogenaamde sluipende schade, niet noodzakelijk asbestgerelateerd), zodat de benadeelde gedurende de looptijd van de verjaringstermijn niet in staat is geweest een vordering in te stellen. In zulke gevallen is er, volgens de raad in deze arresten, ruimte om indien de concrete omstandigheden van het geval ertoe nopen, de lange verjaringstermijn met een beroep op art. 6:2 lid $2 \mathrm{BW}$ buiten toepassing te laten. De raad geeft een opsomming van een zevental gezichtspunten die de rechter daarbij in zijn oordeel moet betrekken. Gelet moet worden op het al dan niet WA-verzekerd zijn van de aansprakelijke, de mate van

I306 HR 28 april 2000, NJ 2000, 430-431 nt. ARB (Van Hese/De Schelde en Rouwhof/Eternit), zie Hartlief (2001), p. $58 \mathrm{e.v}$. Beide arresten hebben betrekking op de dertigjaren termijn van an. $3: 310$ lid $2 \mathrm{BW}$, bij asbestgerelateerde schade. De bewoordingen en ratio van de Hoge Raad lijken de toepusselijkheid ervan voor de twintigjaren termijn van het eerste lid (en ook bij andere gevallen van latente schade), niet uit te sluiten. 
verwijtbaarheid, maar ook of de gevorderde schadevergoeding ten goede komt aan de benadeelde zelf (daaronder vallen ook de categorieën benadeelden met een verhaalsrecht ingevolge art. 6:107 BW en $108 \mathrm{BW}$ ). En voorts in hoeverre terzake van de schade van de benadeelde een aanspraak bestaat op een uitkering van derden. ${ }^{1307}$

Uitgaande van de twee laatstgenoemde factoren lijkt de mogelijkheid van bescherming tegen verjaring, die de Hoge Raad in deze arresten biedt in regressituaties weinig kans te hebben op succes. Aangenomen wordt daarom wel, dat regresnemers langs deze weg uitgesloten zijn van de speciale bescherming tegen verjaring. ${ }^{1008}$ Daarbij is er op gewezen dat uitsluiting van regresnemers zou passen bij 's raads jurisprudentie inzake verkeersaansprakelijkheid. Daar differentieert de raad immers, voor de toepasselijkheid van de $50 \%$ en $100 \%$ regel, eveneens tussen de ('zuiver financiële') belangen van regresnemende verzekeraars en het belang dat de benadeelde zelf heeft bij vergoeding van zijn schade. ${ }^{1309}$ Het principe lijkt in beide gevallen hetzelfde: waarom zouden regels die geen andere ratio en strekking hebben dan om de benadeelde aan schadevergoeding te helpen (en niets zeggen over de vraag naar de verwijtbaarheid van het schadeveroorzakend gedrag) óók moeten gelden als dat belang helemaal niet meer aan de orde is? Maar er is een belangrijk verschil: de $50 \%$ en $100 \%$ regels inzake verkeersaansprakelijkheid moeten bevorderen dat onverzekerde schade van verkeersslachtoffers zo volledig en efficiënt mogelijk wordt vergoed en nu daarvan bij regres geen sprake is, ligt niet-toepasselijkheid in de rede. De billijkheidsregels bij bevrijdende verjaring in asbestzaken (of andere gevallen van sluipende schade) strekt ertoe een dogmatische inconsequentie te corrigeren, een probleem dat ook schadeverzekeraars ingeval van subrogatie aangaat: rechtsvorderingen die door het feitelijke schadeverloop al verjaard zijn nog voordat ze daadwerkelijk konden worden geëffectueerd. Hoe wil men enerzijds de onbillijkheid daarvan onderkennen en toch, op basis van de hoedanigheid van de eiser, de vordering verjaard laten zijn?

De vraag naar de toepasselijkheid van billijkheidsregels bij verjaring is juridisch gezien intussen maar van tijdelijk van belang. Voor vorderingen tot vergoeding van personenschade die na de inwerkingtreding van een nieuw, aan art. 3:310 $\mathrm{BW}$ toe te voegen vijfde lid is veroorzaakt geldt inmiddels alleen nog de korte vijfjaren termijn. ${ }^{1310}$ Dat heeft in de onderhavige gevallen immers het voordeel dat de vordering niet kan zijn verlopen zonder dat de benadeelde daarmee bekend was. Dat reduceert tevens het risico dat de vordering van de benadeelde al verjaard

HR 28 april 2000, NJ 2000, 430 (Van Hese/De Schelde), r.o. 3.3 .3 (sub a, slot en b).

Zie A-G Spier, nr. 10.4 van Conclusie inzake Van Hese/De Schelde, idem Bloembergen in zijn NJ-noot bij het arrest, punt 6; Van Boom (2000b), p. 65; Hartlief (2001), p. 65 (mede onder verwijzing naar A-G en annotator): 'Duidelijk lijkt wel dat de Hoge Raad regresnemers niet snel zal laten profiteren van ant. 6:2 lid 2 BW (gezichtspunten a en b)'.

Hartlief (2001), nt. 45 wijst erop dat, bï sluipende schade het regres op de werkgever van de gekwetste (zoals in de onderhavige anesten het geval was), als gevolg van het collegaverweer uitzonderlijk is.

TK 1999-2000, 26824. 
is voordat de regresvordering is ontstaan. Ook regresnemers zullen daarvan dus profiteren. Indien de vordering van de benadeelde nog niet is verjaard op het moment dat de regresvordering ontstaat dan dient daarvoor in mijn visie op dàt moment (bij subrogatie het moment waarop de schade werd vergoed, bij zelfstandig regres het moment van de uitkeringsplicht) het regime van art. 3:306 BW' 'schoon' aan te vangen.

\subsection{Conclusie}

De hoofdregel bij het regres is dat de schadeveroorzaker er daardoor per saldo, vergeleken met de vermogensrechtelijke positie waarin hij jegens de benadeelde zou hebben verkeerd, niet op vooruit of achteruit mag gaan. Dit wordt ten dele gewaarborgd doordat wordt aangeknoopt bij de aard en omvang van de aansprakelijkheid die de benadeelde zelf had kunnen inroepen (het civiele plafond). Maar ook het rechtskarakter van het regresrecht moet voorkomen dat de schadeveroorzaker (diens WA-verzekeraar) beter of slechter af is. Het regres strekt tot 'terug'betaling van hetgeen door de regresnemer werd of wordt uitgekeerd aan de benadeelde; noch de zelfstandige regresrechten noch het regres door subrogatie strekken tot (integrale) vergoeding van de regresnemer zelf. Zou het wel zo zijn dat de regresnemer behoorde te worden vergoed (zoals het geval is bij het vorderingsrecht dat art. 6:107 BW geeft aan 'derden' in de zin van die bepaling), dan zou de schadeveroorzaker bezwaard worden met een meeromvattend vorderingsrecht dan zonder tussenkomst van de regresnemer het geval zou zijn geweest.

Eén van de consequenties van de visie dat regres niet strekt tot vergoeding is dat het niet vanzelfsprekend is dat regresvorderingen worden 'gebruteerd' (in de zin dat de regresnemer naast terugbetaling van de uitkering recht heeft op een toeslag voor de daarover verschuldigde premies en belastingafdracht). Voor het verhalen van het brutodeel van de uitkering door regresnemers is, net als voor het verhalen van de uitkering zelf, alleen ruimte voorzover vergelijkbare onkosten hadden moeten worden vergoed aan de benadeelde zelf. Daarvan zou, bij een actie van de benadeelde, sprake zijn indien het bedrag van de schadevergoeding vermeerderd had moeten worden met compensatie voor loonbelasting die de benadeelde daarover verschuldigd zou zijn. Regres van het brutodeel dat door de regresnemer namens de benadeelde verschuldigd is lijkt in zulke gevallen niet alleen geoorloofd, maar ook aangewezen. Alleen dan zou het regres immers consequent blijven in het principe dat de schadeveroorzaker de schade van de benadeelde, al diens schade, behoort te dragen. Of dat het geval zou zijn geweest ('bruto' schadevergoeding in de civiel-plafond situatie) hangt met name ervan af, of de schade(vergoeding) als inkomen(sverlies) zou zijn aangemerkt. Aangezien dat lang niet altijd duidelijk is, kiest de Hoge Raad als uitgangspunt voor een civiel plafond dat berekend is op nettobasis. Hierop klinkt terecht kritiek. Verdedigd werd, dat, wenselijk (althans doelmatig) als het regime van de Hoge Raad zijn mag, dit ruimte moet laten voor 
een 'bruto' civiel plafond indien de regresnemer in staat blijkt te zijn aan te tonen dat daarvan sprake zou zijn geweest (dus dat de schadevergoeding voor de benadeelde zou zijn belast, en daarom vermeerderd met het bedrag van de belasting). Dit kan in evidente gevallen, met name gevallen van tijdelijke arbeidsongeschiktheid, het regres van (met name) werkgevers stimuleren, immers voor hen aantrekkelijker maken. De jurisprudentie van de Hoge Raad lijkt dan ook met name voor gevallen van tijdelijke arbeidsongeschiktheid te strikt. Voorgesteld werd dit als uitgangspunt te laten gelden, maar met de mogelijkheid van brutoregres binnen de grenzen van het civiele plafond.

Een andere consequentie van het ontbreken van een vergoedend karakter bij het regres is, dat dit zich nimmer uitstrekt over de buitengerechtelijke kosten die de regresnemer zelf heeft moeten maken. Ook de redenering dat aan de benadeelde eveneens vergoeding van zulke - zij het dàn door hemzelf gemaakte - kosten verschuldigd zou zijn geweest (het civiele plafond) kan in zoverre geen uitkomst bieden. Anders dan het brutodeel van de uitkering zijn de buitengerechtelijke kosten immers gerelateerd aan de vordering als zodanig. Iets anders is dat de regresnemer, los van de aard en inhoud van zijn vordering als zodanig, gerechtigd moet zijn tot vergoeding van de buitengerechtelijke kosten die betrekking hebben op zijn vordering van vervangende schadevergoeding bij wanbetaling of niet-nakoming van de schadeveroorzaker (of een andere vorm van schadeveroorzaking in de verhouding tussen schadeveroorzaker en regresnemer, die de laatste aanspraak geeft op schadevergoeding van de eerste). Dat behoort in mijn visie ook in het algemeen te gelden: de regresnemer moeten de 'normale' rechten en bevoegdheden toekomen, die hem net als andere crediteuren van een geldvordering, in staat stellen tot het effectief geldend maken van zijn vordering.

Vanuit die visie werd betoogd dat de algemene action directe, die bij de wijziging van titel 7.17 BW op 21 juni 2000 werd geïntroduceerd, ook voor regresnemers behoort te gelden. Vanuit die visie past ook kritiek op 'blindelingse' toepassing van het verjaringsregime voor regresnemers met het regime dat voor de benadeelde geldt (of: zou hebben gegolden indien hij het was geweest, die de actie had ingesteld). Een iets genuanceerder regime werd door mij voorgesteld. Uitgangspunt is dat de regeling van art. 3:310 BW (of een lex specialis) voor de regresnemer de consequenties heeft die het ook voor de benadeelde zou hebben gehad, zoals ook de Hoge Raad beslist heeft inzake Bijlsma/ABP. Indien de schadevordering van de benadeelde bij het ontstaan van het regresrecht op die grond nog niet is verjaard, dan behoort echter, in mijn visie, het normale regime van art. 3:306 BW intree te doen. Enerzijds immers vraagt de rechtszekerheid erom dat de schadeveroorzaker (WA-verzekeraar) die wel al blootstaat aan de vordering van de benadeelde, in de periode waarin de regresnemer er nog niet is tussengekomen, wordt beschermd. Daarvan afgezien dienen regresvorderingen niet van andere geldvorderingen waarvoor de algemene van art. 3:306 BW geldt, te verschillen.

Regresnemers behoren voor wat betreft het (kunnen) instellen van hun vordering zoveel mogelijk dezelfde rechten te hebben als elke crediteur van een geldvordering. 
maar staan ze ook bloot aan bijzondere beperkingen? In dat verband kwamen enkele bijzondere punten aan de orde: kan regresnemers eigen schuld, of een grond voor voordeelstoerekening of matiging worden tegengeworpen? Verwezen zij daarvoor naar de desbetreffende paragrafen. 



\section{Functies op uitvoeringsniveau}

In dit hoofdstuk vraagt nog een aantal aspecten aandacht met betrekking tot de uitvoering van het regres (het ten gelde maken van regresrechten). Zo stimuleert het kabinet sociale verzekeraars en WA-verzekeraarsom op basis van één afkoopsom alle individuele regresvorderingen tezamen af te wikkelen. Voor de individuele gevallen waarop deze vorderingen betrekking hebben wordt dan geen aansprakelijkheid meer vastgesteld. Hoe verhoudt zich dat tot de functies van het regres? Een ander bekend twistpunt betreft de vraag in hoeverre de benadeelde nadeel van het regres behoort te dulden. Is bijvoorbeeld regres op zijn gezinsleden mogelijk. en: wiens vordering krijgt voorrang als de regresactie samenloopt met de resterende vordering van de benadeelde? Ten slotte wordt nog kort ingegaan op de vraag of de uitkeringen van derden aan de benadeelde ook via een onrechtmatige daadsactie of cessie kunnen worden verhaald.

\subsection{De afwikkeling van regresvorderingen}

\subsubsection{Inleiding}

In dit hoofdstuk zal aandacht uitgaan naar het ten gelde maken van regresvorderingen (de uitvoering van het regres), en enkele bijzondere kwesties die zich daarbij kunnen voordoen. De uitvoering van het regres wordt in belangrijke mate beheerst door minnelijke afspraken tussen regresnemers en WA-verzekeraars. Te denken valt aan schikkingen in concrete gevallen opdat niet eindeloos kan of hoeft te worden onderhandeld over het voorliggende geval. De laatste jaren zijn echter óók nieuwe methoden in zwang geraakt, waarbij de regresvorderingen worden afgewikkeld op basis van gestandaardiseerde afspraken die losstaan van individuele gevallen. Het bijzondere daarvan is, dat reeds los van het concrete schadevoorval (dat bij het sluiten van de overeenkomst veelal nog in de toekomst ligt), afspraken worden gemaakt over de afwikkeling. Hiermee wordt a priori voorkomen dat het tot een geschil komt, en de partijen jarenlang over de nodige gegevens moeten beschikken met betrekking tot de precieze toedracht en finesses bij elke individuele regresvordering. Zulke gegevens zijn immers voor elk geval afzonderlijk weer 
anders, en vergen dus een goede administratie. ${ }^{131}$ Op die manier kan me zich de kosten die verbonden zijn aan de afwikkeling van individuele regresvordengen besparen (denk aan de administratiekosten, de buitengerechtelijke en de gerchtelijke kosten). Aan de andere kant ligt bij het vinden van die gegevens, en devaardering daarvan - gemeten langs de lat van de gedragsnormen van het aanspraelijkheidsrecht -juist ook de functie van het regres. Dat wijst op een zeker spanninsveld tussen een doelmatige uitvoering en de aldoor verdedigde visie op de rol ce het regres behoort te spelen: in hoeverre is van het beginsel dat de schadeveroozaker de schade behoort te dragen (en de daaraan verbonden functies) nog sprake idien - reeds vóór en onafhankelijk van het concrete feitenrelaas - de aansprakelitheid of de verplichting tot betaling van de WA-verzekeraar reeds vaststaat? De afsraken die regresnemers op het gebied van personenschade met WA-verzekeraars raken zullen achtereenvolgens worden besproken.

\subsubsection{Het regres van sociale verzekeraars}

\subsubsection{CONVENANT VerhaAlsRecht}

De wellicht meest verstrekkende afspraken in dit verband komen van het Convenant Verhaalsrecht; ze kwam al fragmentarisch ter sprake. Dit convenant heeft betrekking op het regres krachtens de sociale arbeidsongeschiktheidswetten (Ziektewet, WAO, WAZ, WAJONG). Het is gevolgd op het bekende (vervallen) TICA-Convenant uit 1996. Het (toen geheten) Tijdelijke Instituut voor coördinatie en afstemming, de rechtsvoorganger van het LISV en later UWV, had over de afwikkeling van het regres ingevolge de Ziektewet afspraken gemaakt met het Verbond van Verzekeraars (over het civiele plafond, met name de bruto-netto kwestie). Dit convenant was een groot succes: alle uitvoeringsinstellingen waren toegetreden en daar tegenover stond een aantal WA-verzekeraars met tezamen ongeveer $96 \%$ van het totale WA-marktaandeel. Als gevolg van de privatisering van de Ziektewet werd de praktische betekenis van het convenant gering, en is het komen te vervallen. Het werd op 27 november 1998 gevolgd door een (behoudens overgangswerking vervallen) convenant tussen het (toenmalige) LISV en het Verbond van Verzekeraars, dat betrekking had op het regresrecht van de WAO. Het convenant is op 1 december 1998 ingegaan, maar ook alle oude reeds lopende regresacties werden geacht eronder te vallen. Afgesproken werd met name om voor die regresvorderingen het civiele plafond op het gebied van inkomensschadebuiten werking te stellen. ${ }^{1312}$

1311 Hartief \& Van Maanen (1994), p. 77.

1312 Over oude vorderingen en aangrenzende kwesties kan uiteraard nog wêl worden geprocedeerd. Zo bijvoorbeeld Hof Amsterdam 19 maan 1998, nolnr. 96/1028 (niet gepubliceerd), waarin ter discussie staat of ook cen door de benadeelde gesloten dading of vaststellingsovereenkomst (zie ant. 7:900 BW) de regresvordering raakt (het hof oordeelt, mede vanwege het zelfstandige karakter van de vordering van art. 90 WAO, in ontkennende zin). 
Over de ervaringen op dit gebied lijkt tevredenheid te bestaan, zo bleek uit berichtgeving van het Verbond van Verzekeraars. ${ }^{1313}$ Sinds 1 januari 2001 is daarom een nieuw convenant van kracht gegaan, dat zich uitstrekt over alle regresvorderingen van het UWV die verband houden 'met een arbeidsongeschiktheid veroorzakende gebeurtenis' die zich vanaf die datum hebben voorgedaan (en voorafgaand aan 1 januari 2004, op welke datum het convenant naar verluidt zal worden vervangen). Vergelijkbaar met het oude WAO-convenant wordt bij regresvorderingen ingevolge de $\mathrm{ZW}$, WAO, WAZ en WAJONG de bruto-uitkering aan het UWV betaald, verminderd met een forfaitaire korting van $22 \%$. Daarbij kunnen zowel het UWV als de aangesloten WA-verzekeraars nog gewoon verweer blijven voeren ten aanzien van schuld, toerekening, medische causaliteit, verjaring en ook, hoewel het convenant dit niet expliciet bepaalt: eigen schuld. Voor het overige wordt de vordering met aftrek van de forfaitaire korting geacht voor wat betreft de inkomensschade beneden het civiele plafond te blijven. Rechterlijke uitspraken over het civiele plafond, waaronder begrepen de bruto-netto kwestie, kunnen wederzijds niet worden ingeroepen.

Daarnaast kent het Convenant Verhaalsrecht nog enkele belangrijke procedurele afspraken. Het UWV en de betrokken WA-verzekeraars brengen elkaar bij de afwikkeling van de genoemde regresvorderingen (in beginsel) ${ }^{1314}$ geen buitengerechtelijke kosten in rekening. Interessant is verder dat men concrete termijnen en vormvoorschriften is overeengekomen: ${ }^{1315}$ het UWV moet de regresvordering zo tijdig mogelijk kenbaar maken zodat de WA-verzekeraar in staat is het onderzoek naar de schuldvraag in het kader van de regresvordering en de vordering van de benadeelde zelf zoveel mogelijk te doen samenvallen. ${ }^{1316}$ Op zijn beurt moet de WA-verzekeraar het overeengekomen bedrag binnen vier weken na ontvangst van de vordering voldoen. Voor eventuele geschillen voorziet het convenant in een bijzondere overlegronde op managersniveau. Indien de partijen er ook op dat niveau niet uitkomen, dan wordt de kwestie door een (bindende) uitspraak van een geschillencommissie beslecht. Die commissie bestaat uit drie leden: één van het Verbond van Verzekeraars, één van het UWV en één lid dat door beide leden gezamenlijk wordt benoemd.

De Volkskrant, 28 november 1998; Kremer (2000), p. 423.

Uit de Toelichting bij het convenant (p. 3) blijkt dat het LISV (thans UWV) zich wèl het recht voorbehoudt om indien partijen binnen het kader van het convenant niet tot overeenstemming komen en alsnog de rechter adiëren, de concrete kosten daarvan in haar vordering te betrekken.

13 Door het kabinet werd de noodraak van wettelijke termijnen voor de schadeafwikkeling meer in het algemeen nog gebagatelliseerd om de reden dat het resultaat dat daarmee geboekt kan worden mede afhangt van tal van andere factoren (zoals het geconsolideerd zijn van het letsel); TK 1996-97, 21 528, nr. 7, p. 9.

Art. 6 en 7 van het convenant (en daarover de Toelichting bij het convenant, p. 3). 


\subsubsection{ANW-CONVENANT}

De voorkeur van het kabinet ligt echter bij een ingrijpendere manier om de kosten van de afwikkeling van regresvorderingen te beperken, namelijk door het gezanenlijk afwikkelen van alle individuele regresvorderingen die men voor een gegeven periode verwacht te hebben. ${ }^{1317}$ Het bijzondere van collectivering van het regres, zoals het wordt genoemd, is dat de band met de individuele regresvordering volledig wordt doorgesneden. Dit vereenvoudigt de afwikkeling van het regres, en het leidt, naar mag worden aangenomen, ook tot minder gerechtelijke procedures dan bij dossiersgewijze afwikkeling. In theorie zijn er daarbij verschillende mogeliikheden: men kan een vast bedrag afspreken aan de hand van het type gevallen, een vast percentage van de uitkering en eventueel nog een vast bedrag of percentage voor de bijkomende kosten (naast die van de uitkering zelf) voor de regresnemer. Reeds in een adres aan de Tweede Kamer in het kader van het wetsontwerp voor de Tijdelijke regeling verhaalsrechten halverwege de jaren tachtig, had ook Bloembergen erop aangedrongen, voor als de wetgever zou besluiten tot handhaving van de regresrechten van particuliere en sociale verzekeraars, het regres in ieder geval te collectiveren. ${ }^{1318}$ Toenmalig justitieel minister Korthals Altes achtte die gedachte 'in theorie mogelijk en aantrekkelijk', maar wees op moeilijkheden van praktische aard. ${ }^{1319}$ Regresnemers vormen een heterogene groep van schadedragers die in wisselende combinatie vorderingen had op een heterogene groep aansprakelijken en WA-maatschappijen, terzake van uiteenlopende schadeposten. Zonder medewerking van de betrokkenen zou collectivering niet mogelijk zijn. Wat het maken van afspraken nog zou bemoeilijken was, dat onduidelijk was welke bedragen met de afwikkeling van het regres gemoeid zouden zijn. De minister wilde eerst de op touw zijnde herziening van het sociale verzekeringsstelsel en de invoering van het aansprakelijkheidsrecht van Boek $6 \mathrm{BW}$ afwachten. ${ }^{1320}$

De kwestie kwam tot ontwikkeling naar aanleiding van een adviesaanvraag van de staatssecretaris van Sociale Zaken en Werkgelegenheid in 1993. Daarin werd een aantal colleges (SER, SVR, Ziekenfondsraad) gevraagd te adviseren omtrent de uitbreiding van het regres naar de volksverzekeringen. In een poging de met regres gepaard gaande (uitvoerings)kosten te beperken heeft de staatssecretaris erop aangedrongen de mogelijkheden tot collectivering te onderzoeken. De SER heeft het belang hiervan in zijn rapport onderkend, zo ook de Algemene Rekenkamer in haar eerdergenoemde rapport over het verhaalsrecht in de Ziekenfondswet. ${ }^{1321}$ De Raad van State achtte een nader onderzoek naar collectivering wenselijk alvorens tot verdere uitbreiding zou worden besloten, maar dit advies heeft 
het kabinet bij de invoering van de Algemene Nabestaandenwet naast zich neergelegd. ${ }^{1322}$

In de Algemene nabestaandenwet werd een regresregeling opgenomen die de daarbij betrokkenen de keuze laat een generale afkoopsom (lump sum) overeen te komen. Op grond van art. 61 lid 2 kunnen de Sociale Verzekeringsbank en het Verbond voor Verzekeraars afspraken maken over de afkoop van de regresaanspraken in het kader van de Algemene nabestaandenwet. Op 9 juli 1996 hebben de Sociale Verzekeringsbank en het Verbond van Verzekeraars een convenant ondertekend. ${ }^{1323}$ Dit houdt in dat de Sociale Verzekeringsbank zich tegenover de aangesloten WA-verzekeraars ertoe heeft verbonden af te zien van regres op dossierniveau en in plaats daarvan, bij wijze van afkoop derhalve, een door partijen overeengekomen bedrag ineens zal ontvangen. Deze afkoopsom wordt jaarlijks opnieuw vastgesteld. Dit convenant, dat per 1 juli 1996 van kracht is gegaan, heeft een looptijd van vier en een half jaar. Het werkt naar tevredenheid en is inmiddels hernieuwd. De collectivering van het ANW-regres levert, voor beide partijen, belangrijke voordelen op. Het belangrijkste voordeel is dat beiden kosten besparen die met de afhandeling van het regres zijn gemoeid. Deze besparing wordt thans voor de looptijd van het Convenant geschat op vijftien miljoen gulden. Een belangrijk voordeel voor de aangesloten WA-verzekeraars is dat het bedrag waarvoor regres wordt genomen vooraf bekend is. ${ }^{1324}$

Het Verbond van Verzekeraars kan individuele WA-verzekeraars niet aan het Convenant binden. ${ }^{1325}$ De voordelen zijn dus sterk afhankelijk van het aantal WA-verzekeraars dat zichzelf daarbij aangesloten heeft. Op het onderhavige convenant heeft echter aanvankelijk $90 \%$ van de WA-verzekeraars (auto-, transporten algemene aansprakelijkheidsverzekeraars) ingetekend, en bij de hernieuwing van het Convenant eind 2000 is dit percentage nog wat hoger komen te liggen. Op de niet aangesloten verzekeraars is wel nog individueel regres mogelijk. Daarnaast blijft de Bank vrij om regres te zoeken op individuele schadeveroorzakers indien hun aansprakelijkheid niet WA-verzekerd is. ${ }^{1326}$ Dit zal namens hen worden afgehandeld door het Bureau Schadeafwikkeling van het Ministerie van Financiën.

1322 TK 1994-95, 24 169, B, p. 5.

1323 Convenant inzake collectivering van het regres $A N W$ d.d. 9 juli 1996, opgenomen als Bijlage 3 bij Sinninghe Damsté, p. 87.

1324 Artikel 5 tweede lid van het ANW-Convenant laat de ruimte voor een herziening van het bedrag van de afkoopsom, indien de omstandigheden op grond warvan deas is berekend zich dermate wijzigen dat het overeengekomen bedrag 'niet meer in redelijke verhouding staat tot' het bedrag van de regresvorderingen van de Bank. Dat vindt zijn reden naar verluidt in mededingingswetgeving, verwezen zij daarvoor naar Kremer (2000), p. 423.

1926 Art. 4 tweede lid van het ANW-Convenant bepaalt dat de Bank de overuengekomen afkoopsom niet als bevrijdend beschoum voorzover het gat om vorderingen 'die hun grondslag vinden in een aansprakelijkheid naar burgerlijk recht die door verzekeraars van dekking pleegt te worden uitgesloten.' 


\subsubsection{AWBZ-CONVENANT}

In de jaren na de invoering van de Algemene nabestaandenwet is het aantal regresrechten van sociale verzekeraars fors uitgebreid en heeft het kabinet ook aan die wettelijke regresbepalingen afzonderlijk een regeling toegevoegd, strekkende tot collectivering van het regres. Daarin worden centrale uitvoeringsorganen (zoals de Ziekenfondsraad voor de regresvorderingen van de ziekenfondsen) aangewezen die tot het maken van afspraken over het bedrag van de afkoopsom bevoegd zijn. ${ }^{1327}$ Die moesten regresnemers stimuleren om generale afkoopsommen af te spreken, op basis waarvan alle potentiële vorderingen die betrekking hebben op een daartoe overeengekomen periode tezamen, los van de toedracht in concreto, worden afgekocht. ${ }^{1328}$ Alleen voor het regresrecht van werkgevers (art. 6:107a BW) was dat moeilijker en bleef een regeling dan ook achterwege. Particuliere werkgevers zijn weliswaar vertegenwoordigd in de werkgeversorganisaties, maar die bezitten geen rechtspersoonlijkheid.

Alleen voor het nieuw ingevoerde regresrecht van de AWBZ is daaraan (vooralsnog) gehoor gegeven. ${ }^{1329}$ Op 24 november 1998 hebben het College voor Zorgverzekeringen $(\mathrm{CvZ})$ en het Verbond van Verzekeraars een convenant afgesloten om de individuele regresvorderingen ingevolge de AWBZ collectief af te wikkelen. Het schijnt de bedoeling te zijn dat beide partijen voor het vaststellen van de afkoopsom een rekenmodel ontwikkelen waarmee de omvang van de totale regreslast kan worden berekend. Met betrekking tot de verrekening van de afkoopsom, ${ }^{1330}$ is ervan uitgegaan dat vijfennegentig procent van het regres betrekking heeft op verkeersongevallen en maar vijf procent uit overige ongevallen. Omwille van de eenvoud heeft men ervoor gekozen vijfennegentig procent van het regres voor rekening te brengen van WAM-verzekeraars en vijf procent door de algemene WA-verzekeraars die zich bij het convenant hebben aangesloten. Daar staat tegenover dat de schade die voortvloeit uit ongevallen tijdens de looptijd van het convenant volledig beschouwd wordt te zijn afgekocht.

\subsubsection{Kritiek en verdere ontwikkeling}

De genoemde methoden tot vereenvoudiging van de afwikkeling van het regres hebben tevens (inherente) beperkingen. Zo binden ze alleen de erbij aangesloten partijen, en bijvoorbeeld niet buitenlandse verzekeraars voor schade die in het buitenland is opgelopen. Die acties moeten dus in beginsel wel nog volgens de

Zie paragraaf 4.2.1 (ZFW) en 4.2.2 (AWBZ), 4.3.3 (ZW), 4.3.5 (WAZ en WAONG), 4.3.8 (REA) en 4.5.2 (ANW) voor een korte toelichting op de desbetreffende bepalingen.

Al langer gingen stemmen op voor collectivering. zoals bij Hartlief \& Van Maanen (1991), p. 302 en dezelfden (1994), p. 77.

1329 Wel hebben het UWV (in overleg ook met de Sociale Verzekeringsbank) en zelfs de werkgeversbonden zich georiènteerd op de mogelijkheden van een gecollectiveerde afwikkeling van regresvordering.

Zie voor de wijze van vaststelling van de afkoopsom Janssen (1999), p. 80. 
normale, individuele regels worden afgewikkeld. ${ }^{1331}$ Voor collectivering geldt dat vooralsnog slechts een relatief klein deel van het regres van sociale verzekeraars wordt afgewikkeld in de vorm van een generale afkoopsom voor alle regresvorderingen tezamen: enkel voor de relatief lage regreslast ingevolge de Algemene nabestaandenwet en de AWBZ is de beoogde collectivering bereikt. Tot veel resultaat hebben de daarop gerichte wettelijke regelingen dus nog niet geleid. Faure wijst op het bezwaar dat hierdoor slechts een deel van de uitvoeringskosten van het regres wegvalt. Het is bepaald nog niet zo, zo stelt hij het, dat de totale afdelingen regres bij de betrokken verzekeraars kunnen worden gesloten. ${ }^{1332} \mathrm{Het}$ is zeer de vraag of een uitbreiding naar andere regresvorderingen, bijvoorbeeld in het kader van de WAO nog te verwachten valt; ook het kabinet realiseerde zich bij de invoering van deze regelingen:

'dat ten gevolge van de vele problemen en procedures uit het recente verleden de verhoudingen tussen de uitvoeringsinstellingen en de schadeverzekeraars verstoord zijn. Dit zal [echter] moeten veranderen. Met de veel grotere rol die particuliere verzekeraars in de sociale verzekeringen gaan spelen, mag van hen ook verwacht worden dat zij zich ten opzichte van de uitvoeringsinstellingen toeschietelijker opstellen. Ook omgekeerd zullen bedrijfsverenigingen de tegenstellingen niet op de spits moeten drijven. Teneinde één en ander te vergemakkelijken is [in de wettelijke regresregelingen] een aanknopingspunt voor collectivering opgenomen.'

Te betwijfelen valt of de wettelijke regelingen daarvoor toereikend zijn. Bepaald wordt daarin slechts dat men een afkoopsom kan overeenkomen; daadwerkelijk vergemakkelijken doen die de evenbedoelde problemen niet. Hoewel collectivering door regresnemers en het Verbond van Verzekeraars als een fraaie oplossing wordt gezien, is er ook wederzijds wantrouwen en onenigheid over de daartoe vast te stellen bedragen, ${ }^{1333}$ die door partijen als weinig rendabel worden ervaren. ${ }^{1334}$ Naast de genoemde praktische bezwaren kan men, zoals ik hiervoor al aangaf, principiële vraagtekens zetten bij de wenselijkheid van de tendens om het regres in de vorm van één collectieve afkoopsom op jaarbasis af te doen. Zelf meen ik dat de 'prijs' die daarvoor wordt betaald (geen vaststelling van aansprakelijkheid meer in individuele gevallen) te hoog is, althans dat dit het regres grotendeels 'uitkleedt'. De meerwaarde van het regres bestaat in mijn visie uit de toepassing van (en het toekennen van rechtsgevolg aan) de gedragsnormen van het aansprakelijkheidsrecht in concrete, individuele gevallen. Bij collectivering is amper zichtbaar dat het de schadeveroorzaker is, die betaalt. Dit vraagt om gericht nader onderzoek: in hoeverre gaat het - gecollectiveerde - regres ten koste van de mogelijkheid van een individuele premierespons door de betrokken WA-verzekeraar (gericht op

\footnotetext{
1331 Zie Sinninghe Darnsté (1999), p. 72.

1332 Faure (1996), p. 68.

1333 Zie o.a. Janssen (1999), p. 80 en Barendrecht \& Weterings (2000), p. 13.

1334 Brief 24 maart 1993, opgenomen in het rapport van de Sociale Verzekeringsraad (1993), Bijlage I; zie daarover Sinninghe Damsté (1999), p. 70; vgl. ook de conclusie uit de vraaggesprekken van Barendrecht \& Weterings (2000), p. 13 ('Partijen hebben bij collectivering soms het gevoel dat zij wat laten liggen').
} 
de individuele schadeveroorzaker)? Als de collectivering ertoe leidt dat men tot op zekere hoogte het zicht verliest op de kostenveroorzaker in individuele gevallen, verliest het regres veel van haar betekenis.

Meer in overeenstemming met de dogmatische uitgangspunten is het genoemde Convenant Verhaalsrecht, dat de moeilijke, technische onderdelen van de regresvordering buiten werking stelt, maar het eigenlijke aansprakelijkheidsregime (kwesties als schuld en eigen schuld en causaliteit onverlet laat). Dat neemt niet weg dat men ook bepaalde onderdelen van de aansprakelijkheidsvraag zelf zou kunnen standaardiseren. Met het oog op de genoemde praktische moeilijkheden on te komen tot een collectieve afwikkeling van regresvorderingen, heeft de (toenmalige) Federatie van Bedrijfsverenigingen in 1993 in een brief aan de Sociale Verzekeringsraad voorgesteld, om het regres minder vergaand te normeren, namelijkdoor afstand te nemen van bepaalde omstandigheden van het geval en door andere omstandigheden in overeenstemming met vooraf daartoe overeengekomen nomen (barema's) te waarderen. ${ }^{1335}$ Die normen zouden door een speciale commissie van deelnemers moeten worden vastgesteld en periodiek, mede op grond van de rechtsontwikkeling, kunnen worden bijgesteld. De raad toonde zich daarvan niet afkerig. ${ }^{1326}$ Een uitgewerkt voorstel om te komen tot standaardisering op grond van barema's komt van Barendrecht en Weterings. Zij benadrukken dat het proces van normering niet alleen bestaat uit het opstellen van normen; ook het verkrijgen van draagvlak en acceptatie zijn belangrijk. Hun voorstel houdt in dat onafhankelijke derden (door hun 'de opstellers' genoemd) in samenspraak met de betrokken partijen geleidelijk betere normen voor de afdoening van regresvorderingen laten ontwikkelen waaraan dan geleidelijk ook een sterkere binding ontstaat. Bovendien is naast het systeem van barema's een protocol voor concrete geschillenbeslechting aangewezen. Die gedachte wordt, zoals blijkt uit het eerder gezegde, ondersteund door het genoemde Convenant Verhaalsrecht. Barendrecht en Weterings formuleren de doelstellingen van hun voorstel van normering als volgt: ${ }^{1337}$

1. Het zoveel mogelijk beperken van de gegevens die nodig zijn voor de afwikkeling tot die welke eenvoudig beschikbaar zijn en die welke gemakkelijk te interpreteren zijn.

2. Het scheppen van zoveel mogelijk duidelijkheid over de manier waarop de toepasselijke juridische normen moeten worden toegepast.

3. Het scheppen van een eenvoudige, weinig kostbare en toegankelijke manier van geschiloplossing."

In het buitenland zijn voorbeelden te zien van soms zeer vergaande partijafspraken om de afwikkeling van de dossiers te vereenvoudigen. In Frankrijk heeft men standaard normen (barema's) weten te ontwikkelen op grond waarvan regresvorde- 
ringen bij verkeersongevallen worden afgewikkeld. Het bewijs kan slechts met een beperkt aantal bewijsmiddelen worden geleverd en de overige omstandigheden van het geval worden buiten beschouwing gelaten. Vanuit de praktijk van schadeafwikkeling klinken overwegend positieve geluiden. In Duitsland ontvangt de regresnemer een standaard percentage van het gevorderde bedrag $(45-60 \%)$.

Het zou dunkt me niet misstaan om ook de benadeelde, degene jegens wie onrechtmatig is gehandeld en over wiens hoofd heen het regres plaatsvindt, van het regres alsmede van het eindoordeel op de hoogte te stellen. Daartoe zou men voor alle regresnemers kunnen bepalen dat de regresnemer tezamen met zijn vordering een bericht doet uitgaan naar de benadeelde (uitkeringsgerechtigde), waarin ten minste de grondslag en de omvang van de regresvordering worden vermeld.

\subsubsection{Andere kostenbesparende maatregelen dan standaardisering}

Daarnaast staan er, bij handhaving van de huidige praktijk van individuele vorderingen, nog andere wegen open ter beperking van de uitvoeringskosten. Ik noem een vijftal punten. In de eerste plaats valt te denken aan een verscherpte controle op de uitvoering van het regres. Hoewel het kabinet het belang van een actief regresbeleid stimuleert, ${ }^{1338}$ zijn regresnemers slechts bevoegd en niet verplicht om regres te nemen. In het arrest Tiel Utrecht Schadeverzekering/Ipenburg oordeelde de Hoge Raad uitdrukkelijk in die zin met betrekking tot het regresrecht van art. 90 WAO.$^{1339}$ Dat was in die zaak aangevoerd door de WA-verzekeraar van de schadeveroorzaker, met het doel de regresnemer als crediteur te blijven houden om te voorkomen dat het desbetreffende deel van de schade met daarover verschuldigde rente aan de benadeelde moest worden betaald. ${ }^{1340}$ De Hoge Raad volgde zijn A-G in het oordeel dat bij de invoering van de WAO slechts is beoogd een bevoegdheid te creëren, een standpunt dat ook voor de meer recent ingevoerde regresbepalingen dunkt me moet worden onderschreven. De moeilijkheid is om een balans te vinden tussen een actief regresbeleid en, anderzijds, het maken van onnodig hoge kosten. Het regres krachtens de Ziekenfondswet is in dat opzicht illustratief. Het beleid van de Ziekenfondsraad en de CTZ komt erop neer dat het regres aangewezen is indien de opbrengsten de aan het regres verbonden kosten overstijgen. Een efficiënt toezichts- en stimuleringsbeleid ontbreekt. ${ }^{1341}$ Het is aan de afzonderlijke ziekenfondsen om zelfstandig uitvoering te geven aan hun regresmogelijkheden. Wel is er enig toezicht op de regresactiviteiten door het jaarlijkse toezicht van de accountantsdienst van de Ziekenfondsraad op het functio-

\footnotetext{
1338 Zie TK $1996-97,25025$, nr. 2, p. 17.

1339 HR 10 maart 1995, NJ 1997, 525 (TUS/lepenburg), zie ook nt. MMM (bij NJ 1997, 526).

1340 De beide regresnemers met wie de vordering van de benadeelde concurreerde hadden geen wettelijke rente aangezegd, zie Conclusie A-G Harkamp bij het arrest, nr. 10.

134 Zie ook de conclusies van het rapport van de Algemene Rekenkarner (1996), ook gepubliceerd in de Kamentukken: TK 1996-97, 25 025, nr. 2, p. 18.
} 
neren van de fondsen afzonderlijk en op de aanvaardbaarheid van de gemaakte kosten.

Een mogelijkheid om het regresbeleid efficiënter te maken kan verder zijn door de regresvorderingen aan een zekere minimale regressom (als benedengrens) te verbinden. Dat gebeurt thans al voor het regres van brandverzekeraars, aangesbten bij de Bedrijfsregeling Regres: voorzover die regeling het instellen van regresverderingen nog toelaat, is het aan een minimum, en overigens ook aan een maximum, regresplafond gebonden (zie hierna, paragraaf 9.1.5.3). In Engeland was het lange tijd zo, dat in het algemeen slechts regres kon worden gezocht voor verstrekte uitkeringen boven een bepaalde som $(£ 2,500) .{ }^{1342}$ Deze benedengrens bestaat in het huidige Engelse recht niet meer, omdat het gevolg naar verluidt was dat verzekeraars een eigen dekkingsrisico van dezelfde omvang pleegden te bedingen. De eind 1997 in werking getreden Social Security (Recovery of Benefits) Act 1997 legt beperkingen op met betrekking tot de verhaalbare uitkeringen. Regres is slechts mogelijk voor uitkeringen ten behoeve van inkomensschade, 'loss of care' en 'loss of mobility'. De verzekeraar heeft geen regres voor andere uitkeringen die werden verstrekt, zoals vergoeding van de ziektekosten. Bovendien worden in de wet oudere beperkingen van het regres gehandhaafd. Zo bestaat slechts aanspraak roor uitkeringen die in de afgelopen vijf jaar werden verstrekt.

Ook verbeteringen op het punt van de informatievoorziening van regresnemers kunnen kostenbesparend werken. ${ }^{1343}$ Het verhaalsproces kan een aanvang nemen bij een door de benadeelde ingevuld formulier met vragen omtrent het ongeval naar aanleiding waarvan uitkeringen of verstrekkingen zijn verricht. Aanvullende informatie zoals politierapporten of een proces verbaal kan worden opgevraagd bij het Verbond van Verzekeraars, de politie en/of de officier van justitie. Op grond van de ministeriële richtlijn van 7 januari 1970 moet het Verbond voor Verzekeraars regresnemers op hun verzoek een gratis kopie toezenden van het procesverbaal. Art. 61 Organisatiewet sociale verzekeringen biedt uitvoeringsorganen van sociale zekerheid voorts de mogelijkheid kosteloos gegevens op te vragen uit het kentekenregister en het Centraal Register Wet Aansprakelijkheidsverzekeringen Motorrijtuigen. Het ziekenfonds is, op verzoek van de voorzitter van de Ziekenfondsraad in 1966, vrijgesteld van de kosten verbonden aan het in regresacties opvragen van stukken uit het strafrechtelijk dossier. Aan de hand van de verkregen informatie kunnen de schadeveroorzaker en/of WA-verzekeraar worden aangesproken. Slechts bij uitzondering komt het tot een gerechtelijke procedure. Ziekenfondsen bijvoorbeeld procederen slechts indien het om een principekwestie gaat of bij een financieel belang van meer dan 10000 gulden. Het gaat dan om één à

1342 De Haas \& Hartlief (1998), nr. 2.7.2.

1343 Dat aspect speelt overigens, dat kan niet verbazen, ook in andere landen. In zijn preadvies in 1971 voor de Vereniging voor de vergelijkende studie van het recht van Belgie en Nederland zoekt Fredericq (1971), p. 18 de verklaring voor het geringe aantal regresclaims van sociale verzekeraars in Belgiê mede in het gegeven daf zij geen informatie krugen over het verloop van strafrechtelijke procedures. 
twee gevallen per jaar. ${ }^{1344}$ Vaak wordt de betreffende zaak na een bepaalde periode, bijvoorbeeld een jaar, opnieuw bekeken om te zien of er na de aanvankelijk verhaalde kosten nog verdere kosten zijn die verhaald kunnen worden.

In de vierde plaats (naast toezicht, drempels, en informatievoorziening) heeft de interne organisatie van de instellingen met regresrecht een belangrijke invloed op de regresopbrengsten. Indien dossiers te lang blijven liggen vergen ze veelal ook meer behandeltijd. ${ }^{1345}$ Wellicht zouden vaste normen kunnen worden gehanteerd voor de duur van de afwikkeling van de regresvordering, vergelijkbaar met het Convenant Verhaalsrecht (waarin ook aansluiting wordt gezocht bij de normen van het Nationaal Platform Personenschade) ${ }^{1346}$ Eerder wees ik al op het onderzoek uit 1996 van de Algemene Rekenkamer naar het regres van ziekenfondsen in het kader van de Ziekenfondswet, met de bedoeling de uitvoering van regres te optimaliseren. In het op dit onderzoek gebaseerde rapport 'Verhaalsrecht in de Ziekenfondswet' constateert de Rekenkamer sterke verschillen tussen de verhaalsopbrengsten van ziekenfondsen onderling als per ziekenfonds in verschillende jaren in de periode 1990-1994. Volgens de Rekenkamer zijn de verschillen in opbrengst vrijwel uitsluitend te verklaren uit de verschillen in kwaliteit van de interne verhaalsorganisatie. De Rekenkamer vertaalt dit in een aantal, wat zij noemt, minimumeisen voor een optimale uitvoering. De hoogste regresopbrengsten kunnen worden verwacht bij een ziekenfonds dat beschikt over 'een effectieve en efficiënte signalering van verhaalsgevallen, een schriftelijk vastgelegde procedure, periodieke managementinformatie (onder andere over kosten en baten) en een periodieke, schriftelijk vastgelegde interne controle, in combinatie met een adequate personeelsbezetting. ${ }^{1347}$ Met de signalering van verhaalsgevallen worden nota's van ziekenhuisopname, ambulancevervoer, de EHBO en zo verder bedoeld, die het ziekenfonds bekend zouden kunnen maken met de mogelijkheid van een (potentiële) regresvordering. Het is namelijk veelal juist aan de hand van zulke 'signaleringsbronnen', dat regresvorderingen bij een individuele afwikkeling van vorderingen worden geïnitieerd. begint veelal het verhaalsproces. Een optimale regresuitvoering betekent volgens de Rekenkamer echter, dat is een opmerkelijk punt, dat met zo min mogelijk signaleringsbronnen zoveel mogelijk (potentiële) regressituaties in beeld moeten komen. Eén van de negen door de Rekenkamer onderzochte ziekenfondsen voldeed weliswaar aan de genoemde minimumeisen voor een optimale uitvoering, maar behaalde daarmee niet meer dan een gemiddelde regresopbrengst. De Rekenkamer verklaart dit uit het feit dat, naast het relatief lage aantal verhaalsmedewerkers in dat fonds, met een zo groot aantal signaleringsbronnen gewerkt

\footnotetext{
1344 Zo blijkt uit het rapport van de Algemene Rekenkamet (1996), ook gepubliceerd bij TK 1996-97, 25 025, nr 2, p. 8.

1345 Reckens (2003), p. 181 .

1346 Reckens (2003), p. 181.

1977 Aldus het rapport van de Algemene Rekenkamer (1996), ook gepubliceerd in de Kamerstukken TK $1996-97$. 25025 , nr. 2, p. 11
} 
werd dat van de bronnen minder systematisch en efficiënt gebruik werc gemaakt. ${ }^{1348}$ De Ziekenfondsraad zou volgens de Rekenkamer erop moeten toeien dat aan deze eisen is voldaan.

Ten slotte zij nog een vijfde punt van aandacht in herinnering gebracht, ter veretering van de praktijk van individuele regresvorderingen. Dat heeft vrij specfiek betrekking op de ziekenfondsen. Zoals in hoofdstuk 4 werd aangegeven, is vozens de ziekenfondsen en de Ziekenfondsraad een belangrijk knelpunt in de uitvoring van regres op grond van de Ziekenfondswet het ontbreken van een finaniële prikkel om kosten te verhalen. De regresopbrengsten moesten aanvankelijk volsdig worden afgedragen ten behoeve van de Algemene Kas, terwijl de kosten verboden aan de uitvoering van het regres wel voor rekening komen van het beheersbulget van de ziekenfondsen afzonderlijk. Sinds een aantal jaren mogen de ziekenforisen één-derde van de behaalde regresopbrengsten behouden. Hoewel de Algerene Rekenkamer in bovengenoemd rapport het effect van deze maatregel als vrij gring inschatte, benadrukken de Ziekenfondsraad en, namens de ziekenfondsen, Zorverzekeraars Nederland juist het belang van een financięle prikkel voor de fonsen afzonderlijk. ${ }^{1349}$ Een vergelijkbare maatregel (maar waarvan naar me voorbmt

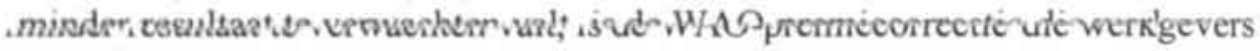
bij het instellen van het regres ingevolge art. 6:107a BW wordt voorgehouden. Tevens wees ik al op de subsidiemaatregel voor particuliere ziektekostenverzekeraars. Beide regelingen hebben een vrij beperkt bereik; voor een bespreking zij verwezen zij naar hoofdstuk 4 .

\subsubsection{Het regres van particuliere verzekeraars}

\subsubsection{AlgemeEN}

Verbeteringen van de uitvoering van het regres met behoud van de individuele afwikkeling van vorderingen sluit ook het meeste aan bij de regrespraktijk van particuliere schadeverzekeraars. Voor hen is de afwikkeling van regresvorderingen veelal wat eenvoudiger. Het regres heeft er hoofdzakelijk betrekking op zaakschade, de regresconstructie is eenvoudiger en ook procederen particuliere verzekeraars minder snel omdat ze in den minne tot overeenstemming geraken. Aanvankelijk zijn wel bedrijfstechnische problemen ontstaan, door de grote toename van het aantal regresvorderingen als gevolg van de opkomst van nieuwe verzekeringen zoals de WA-verzekering en verzekeringen voor motorrijtuigen in de jaren vijftig en zestig. ${ }^{1350}$ Dat heeft in combinatie met een toenemend aantal schadegevallen geleid tot de behoefte aan een meer efficiënte oplossing in de vorm van knock-forknock regelingen tussen motorrijtuigverzekeraars en tot het prijsgeven van hun

1348 TK 1996-97, 25 025, nr. 2, p. 12.

1349 De Algemene Rekenkamer (1996), p. 13 is hierover, overigens om onduidelijke redenen, sceptisch.

1350 Constatering in Köster's preadvies (1971), p. 111. 
regresrechten bij brandschade. ${ }^{1351}$ Thans komen knock-for-knock regelingen echter bijna niet meer voor. Veeleer worden ten behoeve van een vereenvoudigde afwikkeling andere afspraken gemaakt. Bekend zijn de zogenaamde schadeakkoorden van motorrijtuigverzekeraars, regelingen waarin een bepaalde wijze voor het afwikkelen van regresvorderingen wordt vastgelegd, ongeacht de schuldvraag. Een ander voorbeeld van standaardisering van individuele regresvorderingen, dat specifiek betrekking heeft op het regres bij personenschade, biedt de al genoemde NORA-regeling met betrekking tot de buitengerechtelijke kosten van rechtsbijstandsverzekeraars.

\subsubsection{NORA-REGELING}

Specifiek met betrekking tot personenschade hebben rechtsbijstandverzekeraars en (met name) WA-verzekeraars op 1 januari 1993 de zogenaamde NORA-regeling gesloten. Deze kwam hiervoor uitvoeriger ter sprake. ${ }^{1352}$ De regeling heeft betrekking op de vergoeding van buitengerechtelijke kosten van rechtsbijstandsverzekeraars. Deze - goed werkende - regeling houdt in dat aangesloten WA-verzekeraars bij individuele gevallen van letsel of overlijden een vast bedrag (in 1999: 1875 gulden) uitkeren voor de buitengerechtelijke kosten. De omstreden vraag of art. 6:96 lid 2 BW ook geldt, is zoals gezegd daardoor van geringe betekenis. ${ }^{1353}$

\subsubsection{BEDRIJFSREGELING REGRES ${ }^{1354}$}

Ten slotte wil ik niet helemaal voorbijgaan aan het regresbeleid van brandverzekeraars, aangezien dit zo opmerkelijk is (en het óók de uitvoering van het regres aangaat). Brandverzekeringen zijn schadeverzekeringen en vallen onder de subrogatie-regeling van art. $284 \mathrm{WvK}$. In beginsel is het dus zo dat brandverzekeraars worden gesubrogeerd in de rechten die de verzekerde heeft op derden terzake van schade die onder de dekking van deze verzekeringen valt. ${ }^{1355}$ In de jaren veertig van de twintigste eeuw zijn brandverzekeraars steeds vaker gaan besluiten hiervan gebruik te maken, in de vorm van regresacties tegen de brandstichter. Dat heeft voor onrust gezorgd, omdat men geen rekening hield met het onverzekerd zijn van de aansprakelijkheid in kwestie: ook brandstichters die niet WA-verzekerd

1351 Zie Kóster (1971), p. 103, 111 en nader par. 117 e.v.; vgl. ook supra, paragraaf 5.4.I.

1352 De regeling van de Nederlandse Organisatie van Rechtsbijstand Assuradeuren, thans de Afdelingscommissie Rechtsbijstand; zie Lindenbergh e.a. (2000). p. 96 (De Vries). Deze regeling geldt zowel bij letsel als overlijden. De NORA-regeling is integraal opgenomen als Bijlage 91 bij Lindenbergh c.a. (2000), p. 579.

1353 Zie paragraf 8.3.2.

1354 De oorspronkelijke naam, vóór de herziening met ingang van het jaar 2000, was het Bindend Besluit Regres. Zie over dezeoorspronkelijke regeling de Voorlichtingsbrochure Regres Brand (1983). Smit (1985) en Lieverse (1999), p. 37 e.v.

1355 Overigens bieden brandverzekeringen tegenwoordig een veel ruimere dekking bieden dan alleen voor het risico van brandschade; ook het risico van schade door onder meer inbrak, storm en zelfs valiende vliegtuigen is veelal verzekerd; zie Oosenbrug e.a. (1996), p. 58. 
waren stonden bloot aan regres. In de praktijk treft het regres juist in deze branche gemakkelijk familieleden, vrienden of andere bekenden van het slachtoffer (de verzekerde), en daarmee mogelijk ook de verzekerde zelf. ${ }^{1356}$ Het regresbeleid verhoogde dan ook de concurrentiestrijd binnen de branche zelf, en zette de verhouding tussen brand- en WA-verzekeraars onder druk. ${ }^{1357}$ Om deze redenen hebben brandverzekeraars in 1954 een verklaring doen uitgaan waarin afstand werd gedaan van het regres op particulieren en bedrijven, de Afstandverklaring Regres. De verklaring hield zoals de naam al zegt in, dat men afstand deed van regres behalve bij opzet of bij goedvinden van de aangesprokene, dan wel bij diens veroordeling tot een misdrijf of bij schade die was veroorzaakt door het Nederlandse of een ander militair apparaat. ${ }^{1358}$ Hoewel de afstand overigens in het belang van de verzekerde is, in de zin dat op zijn gezinsleden en andere dierbaren geen regres plaatsvindt, kan deze hem wellicht ook in zekere zin raken, aangezien hij met zijn eigen vordering niet zou kunnen 'meeliften' (zo daarvan in de praktijk sprake is).

Toen bleek dat steeds minder brandverzekeraars zich bij de Afstandverklaring gingen aansluiten, althans voorzover deze betrekking had op het regres op bedrijven, werd de verklaring in 1984 vervangen. Hier kwam een in breder kring ondersteunde regeling van de Vereniging van Brandassuradeuren voor in de plaats: ${ }^{1359}$ de (thans geheten) Bedrijfsregeling Regres (BR). Naar schatting is $98 \%$ van de brandverzekeraars, ook niet-leden van de Vereniging van Brandassuradeuren, bij de BR aangesloten. Niet aangesloten zijn veelal de verzekeraars die uitsluitend brandverzekeringen aanbieden. Voor hen is het regres als inkomensbron wellicht belangrijk genoeg om er geen afstand van te willen doen.

Met de Bedrijfsregeling Regres doen de aangesloten brandverzekeraars nog enkel afstand van het regres op particulieren. Een uitzondering geldt voor gevallen waarin de schade opzettelijk is veroorzaakt, of is veroorzaakt door de Staat en een beperkt aantal andere gevallen. Buiten deze bijzondere gevallen zal men alleen regres nemen op 'rechtspersonen en bedrijfsmatig en/of beroepsmatig handelende natuurlijke personen', zoals dakdekkers- en loodgietersbedrijven. Het regres op bedrijven is bovendien slechts toegelaten voor vorderingen van bepaalde omvang (ten hoogste tot het bedrag van de wettelijk verplichte WA-dekking per schadegebeurtenis en begrensddoorvastesommen). De(bedrijfs)aansprakelijkheidsverzekeraars, vertegenwoordigd door de Nederlandse Vereniging van Algemene Aansprakelijkheidsver-

De schade door eigen onvoorzichtigheid valt wettelijk niet onder de verzekering, zie art. 249 WvK. Maar in de praktijk wordt veelal aangenomen dat de polis aan ant. 249 renuncieert en dus ook in deze gevallen dekking biedt.

1357 Koster (1971), p. 118.

1358 Zie daarover uitvoerig Köster (1971), p. 118 (met verdere verwijzingen).

1399 De Vereniging van Brandassuradeuren is overigens inmiddels ontbonden en valt onder het Verbond van Verackeraars. Maar het besluit blijft bindend voor de leden en ook nieuwe niet-leden hebben zich, eventueel door een bijzonder beding in de polis, bij de BR aangesloten. 
zekeraars, waarmee in het kader van het preventiebeleid nauw overleg moest worden gevoerd, werden bereid gevonden door middel van een premieverhoging voldoende dekking te verlenen. Hiertegenover werd de voorwaarde van de AAV ingewilligd dat het (wel toegestane) regres beperkt zou blijven tot gevallen van schuldaansprakelijkheid. Op grond van de Bedrijfsregeling Regres is het regres slechts toegestaan onder de bovengenoemde omstandigheden (versus bedrijven en binnen de overeengekomen marges) en mits er sprake is van onzorgvuldigheid van de schadeveroorzaker. Het regres kan dus alleen worden uitgeoefend bij schuldaansprakelijkheid; het kan niet worden gebaseerd op contractuele en risicoaansprakelijkheid. In de toelichting staat dat men dit beter bij het preventiebevorderend karakter van het BR vond passen, omdat het bedrijven zou stimuleren om maatregelen te treffen waarmee de brand zoveel mogelijk kan worden voorkomen. ${ }^{1360}$ De bedrijfsaansprakelijkheidsverzekeraars 'gunnen' de bedrijven op deze grond een eigen risico bij regresschade. Drion oppert dat de verzekeraars met de afstandsverklaring hebben willen voorkomen dat het brandrisico een te zwaar WA-risico zou worden. ${ }^{1361}$ De verklaring geldt naar mijn weten alleen in Nederland; de Europese Commissie is evenwel van oordeel dat de regeling binnen EG-verband geen ontoelaatbare kartelvorming oplevert.

Meer recent is onduidelijkheid ontstaan over de vraag, of onder het BR-regime nodig is dat degene op wie regres wordt genomen zelf onrechtmatig heeft gehandeld. In het arrest inzake Mastum Dakbedekking/Nationale Nederlanden oordeelt de Hoge Raad over de vraag, of het regres op een zorgvuldig handelende hoofdaannemer mogelijk is indien zijn onderaannemer of een werknemer van zijn onderaannemer een fout heeft gemaakt. ${ }^{1362}$ Deze vraag is opmerkelijk; het regres op basis van risicoaansprakelijkheid (ook die voor ondergeschikten en bij onderaanneming) is zoals gezegd uitgesloten. Het Hof had echter, volgens de Hoge Raad niet ten onrechte, gehecht aan een passage in de toelichting op de BR, waaruit kan worden afgeleid dat regres reeds mogelijk is indien de onzorgvuldige brandstichter deel uitmaakt van het bedrijf van degene die tot regres wordt aangesproken. Hiervan was in het onderhavige geval sprake nu de werkzaamheden onder supervisie van de tot regres aangesprokene zijn verricht. ${ }^{1363}$ Het gevolg van deze uitspraak lijkt te zijn, dat de hoofdaannemer onder de Bedrijfsregeling Regres nu ook aansprakelijk is voor de fouten van zijn onderaannemers (of hun werknemers) indien hij de supervisie had over de werkzaamheden waarbij de brand is ontstaan. Deze aansprakelijkheid voor hulppersonen heeft niettemin een risicogrondslag, in die zin dat zelfs indien vaststaat dat de hoofdaannemer niet nalatig is geweest in zijn toezicht, zoals in casu het geval was, hij toch (risico) aansprakelijk is.

1361 Drion (1955), p. 19.

1362 Zie hierover Lieverse (1999), p. 37 e.v. (met verwijzingen).

1363 HR IS januari 1999, NJ 1999, 242 (Mastum Dakbedekkingen Amsterdam BV/Nationale Nederlanden). 


\subsection{Uitgesloten categorieën schadeveroorzakers}

\subsubsection{Regres op gezinsleden van de benadeelde}

Niet alleen in het kader van de Bedrijfsregeling Regres heeft het bezwaar van het regres op gezinsleden van de benadeelde tot een beperking geleid van het regres. Ook meer in het algemeen is een bekend twistpunt de vraag, in hoeverre regresnemende instanties regres mogen zoeken op dierbaren of op personen jegens wie de benadeelde zich in zakelijk of financieel opzicht in een afhankelijkheidspositie bevindt, zoals gezinsleden, collega's en de werkgever van de benadeelde. Wordt tussen gezinsleden onderling schade veroorzaakt, ${ }^{1364}$ denk aan ongevallen in de huiselijke sfeer, dan ondergaat het aansprakelijkheidsregime daarvan in beginsel geen wijziging. Dat geldt zowel voor wat betreft de normen voor aansprakelijkheid, ${ }^{1365}$ alsook voor wat betreft het behoud van de vordering op de WA-verzekeraar indien de benadeelde met de schadeveroorzaker in gemeenschap van goederen is getrouwd (en bij zijn aanspraak op schadevergoeding dus wellicht boedelmenging optreedt). ${ }^{1306}$ Hieraan doet geen afbreuk dat ook de schadeveroorzaker dan van de schadevergoeding van de benadeelde kan profiteren (en dat dit wellicht fraude in de hand werkt). In materiële zin kan het familieverband hooguit een grond zijn voor het matigen van de schadevergoeding, ${ }^{1367}$ maar daarvoor is beneden het bedrag van de WA-dekking geen plaats (art. 6:109 lid 2).

Het belang van de mogelijkheden tot schadevergoeding van de benadeelde staat, kennelijk, voorop: hij moet zijn mogelijkheid tot het inroepen van het aansprakelijkheidsrecht onverminderd blijven behouden. Bij regresvorderingen ontbreekt dit vergoedingsbelang, de benadeelde is of wordt immers al door de regresnemende verzekeraar of schadedrager vergoed. Het regres zou dan hoogstens ertoe kunnen leiden dat de benadeelde er (financieel) slechter van wordt. Dat stelt de vraag naar de functies van het regres op scherp. Door het regres op de gezinsleden van de benadeelde - waarvoor wordt aangeknoopt bij aansprakelijkheidsregels die mede

Hartief \& Tjittes (1991), p. 225 en Van Dam (1995), p. 109 definietren gezinsleden als degenen die een huishouding delen om meer of andere motieven dan alleen economisch. Gedacht moet worden aan echtgenoten, ouders en kinderen, samenwonende stellen en broer en zus die een gemeenschappelijke huishouding voeren.

1365 Zie o.a in een regreszaak van het zickenfonds HR II april 1975, NJ 1975, 373 nt. GJS (Zopp Mijnwerkersfonds); NJ-noot Veegens (nr. 6) bij HR 26 juni 1987, NJ 1988, $536 \mathrm{nt}$. JBMV (Nieuw Rottendam/Bedrijfsvereniging); HR 12 mei 2000, NJ 2001, 300 nt. JH (JansenJlansen); NTBR 2000, p. 341 (Engelhard). Zie voorts o.m. Wachter (1983), p. 136; Hartlief \& Tjittes (1991), p. 225; Hammerstein (1994), p. 5; en Asser-De Boer (1998), p. 159 (over aansprakelijkheid van echtgenoten).

Reeds in die zin HR 3 december 1982, NJ 1983, $400 \mathrm{nt}$. W (Nationale Nederlanden/Timmermans) en expliciet HR 12 juni 1987, $N J$ 1988, 39 nt. G en EAAL. (Holland/Beek), op grond van de nietszeggende overweging dat de echtgenoten er belang bij hebben dat de WA-verzekeraar de schade draagt. Zie daarover ook AAe 1988, p. 37 e.v. (Kortmann) en $V R$ 1987, ur. 130 en 131 (Van Wassenacr van Catwijck). Of de verbintenis tot schadevergoeding wèl - door boedelmenging - tenietgaat indien de in gemeenschap van goederen gehuwden, al dan niet voorafgaand aan hun huwelijk, verhaal zoeken op elkaar in persoon, is (nog) onduidelijk.

1367 Zie de NJ-noot van Veegens (nr. 6) bij HR 26 juni 1987, NJ 1988, 536 nt. JBMV (Nienw Ronterdam/Bedriffsereniging)- 
strekken tot zijn bescherming - zou deze dan in feite zijn schadevergoeding verliezen. In hoeverre kan dat resultaat, mede gelet op de in hoofdstuk 6 besproken handhavingsfunctie van het regres, worden gerechtvaardigd?

Voor de afzonderlijke categorieën regresnemers - particuliere en sociale verzekeraars, werkgevers en overheidsdiensten - gelden hiervoor uiteenlopende regels. Het is het meest overzichtelijk deze in afzonderlijke paragrafen te bespreken. Uiteraard zullen daarbij onderlinge verbanden worden gelegd.

\subsubsection{Regres van sociale verzekeraars op gezinsleden}

In de jurisprudentie is het regresrecht van sociale verzekeraars uitgesloten voorzover het zou worden aangewend tegen gezinsleden van de benadeelde, de verzekerde. In de bekende Rijnstreek-arresten sluit de Hoge Raad die mogelijkheid voor ziekenfondsen uit met betrekking tot krachtens de Ziekenfondswet hoofd- of meeverzekerde gezinsleden. Ziekenfonds Rijnstreek krijgt een afwijzend oordeel op haar regresvorderingen jegens de WA-verzekeraar van de hoofdverzekerde, een moeder, nadat het fonds haar kinderen heeft vergoed. ${ }^{1368}$ Eveneens een afwijzing volgt van het regres op de ene meeverzekerde zus nadat het fonds de door haar roekeloze verkeersgedrag veroorzaakte letselschade van de andere zus moet vergoeden. ${ }^{1369}$ De ziekenfondsverzekering is, volgens de Hoge Raad, een typische gezinsverzekering, hetgeen meebrengt dat het ziekenfonds zich door regres op meeverzekerde gezinsleden niet jegens hen aan zijn verplichtingen mag onttrekken. ${ }^{1370}$ Dat is volgens de Hoge Raad niet strijdig met de strekking van het regresrecht (het principe dat de schadeveroorzaker alsnog moet betalen), aangezien het niet waarschijnlijk is dat de benadeelde ook zelf een vordering jegens hem zou hebben ingesteld. Dat dit anders kan zijn indien het schadeveroorzakende gezinslid WAverzekerd is, doet niet ter zake. Daaraan kan volgens de Hoge Raad voor het toekennen van een regresrecht aan het ziekenfonds geen invloed worden toegekend. ${ }^{1371}$

Wat de Rijnstreek-arresten omstreden maakt, ${ }^{1372}$ is dat de Hoge Raad vervolgens beslist, in Rijnstreek III, dat op zelfstandig verzekerde (dus niet meeverzekerde) gezinsleden in beginsel wèl onbeperkt regres mogelijk is. Op de minderjarige, nog thuiswonende doch zelfstandig bij het ziekenfonds verzekerde broer (met WA-

Zie voor dit laatste geval reeds HR II juni 1982, NJ I983, 583 (Rijnstreek I).

1370 HR II juni 1982, NJ 1983, 583 (Rijnstreek I) en HR 6 mei 1983, NJ 1983, 584 nt. FHJM (Rijnstreek If). Reeds Giltay Veth (1969), p. 212 acht een wettelijke regeling daartoe naar morele maatstaven wenselijk, maar bepleit dan een consequent doortrekken van deze lijn naar normale schadeacties; zie voorts Van Boom \& Storm (1995), p. 153. 
verzekering) die op de bromfiets schade heeft veroorzaakt aan zijn broer saat dus onbeperkt bloot aan de regresactie van het fonds. ${ }^{1373} \mathrm{Het}$ al dan niet meererzekerd zijn is beslissend, het belang van gezinsvrede of economische argumerten (zoals het argument dat de schadelast dan mogelijk toch weer 'drukt' op het geznsbudget) brengen de raad in dit arrest niet tot een ander oordeel. De raad laat $10 \mathrm{~g}$ enige ruimte om op àndere gronden tot een ander oordeel te komen:

'Voor uitsluiting van het verhaalsrecht enkel op grond van [de omstandigheid dat beide broer ten tijde van het ongeval als inwonende kinderen tot hetzelfde gezin behoorden, EE] is noch in de ekst van de wet noch in haar strekking steun te vinden. ${ }^{1314}$

A-G Asser oppert dat als de omstandigheid daarbij komt (dus naast het behoren tot hetzelfde gezin) dat de benadeelde de kostwinner is van de schadeveroorzaler, dit wellicht wel ertoe kan leiden dat de schadeveroorzaker niet of slechts beperkt blootstaat aan het regres, ondanks dat hij zelfstandig verzekerd is. Maar veel ljkt hiervan niet te verwachten; ondanks de kritiek in de literatuur houdt de Hoge R aad ook in latere jurisprudentie vast aan zijn standpunt. ${ }^{1375}$ Het ligt voor de hand om dan voor het regres van de AWBZ hetzelfde regime te laten gelden De kaicstie is echter zonder direct praktisch belang; het regres ingevolge de AWBZ wordt zoals gezegd immers collectief afgewikkeld.

Voor inkomensvervangende uitkeringen ingevolge de Ziektewet, WAO en de VOA is het regres op gezinsleden ook wel beperkt, ${ }^{1376}$ maar de redenen daarvoor zijn anders en dat maakt dat significante verschillen kunnen ontstaan. Het inkomensgerelateerde karakter van de uitkering staat dan voorop: waar het (enkel) om gaat is, dat de benadeelde door het regres niet feitelijk verstoken moet zijn van zijn ziekengeld (zijn basisinkomen). Het meeverzekerd zijn is in dit verband zonder belang. Die beperking heeft de Hoge Raad in de eerste plaats aanvaard voor regresacties tegen in gemeenschap van goederen gehuwde echtgenoten. De blootstelling aan het regres zou betekenen dat de benadeelde als verzekerde 'tengevolge van het enkele feit, dat zij in algehele gemeenschap van goederen was gehuwd met de schuldige aan het ongeval, in feite zou worden verstoken van het haar krachtens de Ongevallenwet 1921 toekomende recht op schadeloosstelling (waarvoor huwelijk noch schuld aan het ongeval een rol speelt).' De woorden van de Hoge Raad wijzen erop dat het de feitelijke vermogenstoestand van de

1373 HR 19 april 1985, NJ 1986, 209 nt. FHUM (Rijnstreek III).

1374 HR 19 april 1985, NJ 1986, 209 nt. FHJM (Rijnstreek III) (cursief toegevoegd, EE).

1375 In die zin HR II februari 1994, NJ1995, $494 \mathrm{nt}$. CJHB (NOVORZG) ('De rechtsontwikkeling sedert het wijzen van zijn arrest geeft de Hoge Raad geen aanleiding om op dat oordeel terug te komen '). In deze zaak kon RZG de kosten van de ziekenhuisopname van de vrouw van een samenwonend koppel, die bij een verkeersongeval waaraan de man schuld had, op hem verhalen.

1376 Zie HR 2 februari 1973, NJ 1973, 225 nt. ARB (Centrale Wenkgevers/Millenaar); HR 26 juni 1987, NJ 1988, $536 \mathrm{nt}$. JBMV (Nieuw Rottendam/Bedrüfsvereniging); zie ook in die lijn maar dan voor het VOA-regres: HR 25 januari 1991. NJ 1992, 706 nt. CJHB (ABP/Elsenga). 
benadeelde is, die bescherming behoeft, hoewel dat voor het voorliggende geval wat merkwaardig voorkomt omdat de echtgenoot WA-verzekerd was. ${ }^{1377}$ In latere arresten laat de Hoge Raad de uitsluiting van het regres dan ook mede gelden voor echtgenoten die onder het maken van huwelijkse voorwaarden gehuwd zijn, ${ }^{1378}$ en in het kader van de VOA ook voor een geval waarin de uitkeringen werden genoten en bekostigd door de gemeenschappelijke huishouding (zie hierna). ${ }^{1379}$ Tevens stelt de raad waarom hij het WA-verzekerd zijn voor de vraag of de uitsluiting van het regres op zijn plaats is niet wil laten meewegen. In het arrest Nieuw Rotterdam/Bedrijfsvereniging is het argument dat in al de vorengenoemde gevallen:

'de uitkeringen aan het slachtoffer in feite (veelal zullen) worden aangewend ter bestrijding van de kosten van de gemeenschappelijke huishouding, terwijl anderzijds hetgeen de aansprakelijke echtgenoot schuldig zou worden aan de bedriffsvereniging in feite zou worden betaald uit de gezamenlijke inkomsten, waaronder de uitkeringen, zodat het slachtoffer in feite zou worden verstoken van zijn uitkeringen. Ook indien dit onder bijzondere omstandigheden anders zou zijn, is het met het oog op de hanteerbaarheid van het verhaal onwenselijk voor die gevallen een uitzondering te maken. ${ }^{1390}$

$\mathrm{NJ}$-annotator Veegens werpt de vraag op hoe ver de uitsluiting van het regres voor financieel bij de benadeelde betrokkenen reikt. De situatie in een ander samenlevingsverband dan het huwelijk (of ongehuwd samenwonenden) verschilt daarvan vaak feitelijk noch rechtens (contractueel). Hij wijst op relaties tussen ouders, grootouders en kinderen, broers en zussen, ooms, neven en nichten. Zou het oordeel van de Hoge Raad dan hetzelfde zijn? ${ }^{1381}$ Het lijkt daar wel op: het funderende beginsel is immers, dat de benadeelde door het regres niet feitelijk verstoken moet zijn van de inkomensvervangende uitkering. Daarbij moet worden geabstraheerd van het al dan niet WA-verzekerd zijn van de schadeveroorzaker. Voldoende is thans, zo lijkt het, dat de schadeveroorzaker en de benadeelde duurzaam samenwonend zijn en een gemeenschappelijke huishouding voeren. In het arrest $A B P / E l$ zenga heeft de Hoge Raad ook voor het regres ingevolge de Verhaalswet ongevallen ambtenaren beslist dat de levenspartner daaraan niet blootstaat. ${ }^{1382}$ Aangenomen moet worden dat, nu het loonvervangende karakter van de ambtenarenuitkeringen voor de Hoge Raad beslissend was, hetzelfde geldt voor de inkomensvervangende verzekeringen ingevolge de $\mathrm{ZW}$, WAO (en daaraan gelieerde wetgeving zoals

Aldus HR 2 februari 1973, NJ 1973, $225 \mathrm{nt}$. ARB (Centrale Wenkgevers/Millenaar). In zijn noot wijst Bloembergen erop dat de uitsluiting van aansprakelijkheid tegenover echtgenoten van de verzekeringnemer, de eigenaar, houder of bestuurder van het voertuig (art. 4 lid I WAM) op dat moment in Nederland gebruikelijk was, en dat dit vermoedelijk was omdat men niet bedacht is geweest op regresacties. Zie voons de noot van Mijnssen bij HR I6 april 1980, NJ 1981, 109 nt. FHJM (Centrale Levenswerzekeringsmaatschappij/General Accident). HR 26 juni 1987, NJ 1988, 536 nt. JBMV (Nieww Rotterdam/Bedrijfsvereniging). Aldus HR 25 januari 1991, NJ 1992, 706 nt. CJHB (ABPIElzenga); en daarover Hartlief \& Van Maanen (1991), p. 296; Van Boom \& Storm (1995), p. 153. 
REA) en voorts, dunkt me, art. 6:107a BW. Het onder de werking van de werknemersverzekeringen brengen van ambtenaren maakt gelijkschakeling van de be jerkingen van het regres in dat verband met dat ingevolge de Verhaalswet ongevallen ambtenaren op zich ook wenselijk.

Wel zal men al ten tijde van het ongeval duurzaam samenwonend moeten zijn. In het al genoemde arrest Nieiw Rotterdam/Bedrijfsvereniging waren de echtgen twee jaar na het ongeval (en het ontstaan van de regresvordering) gehuwd. Dan geldt de regel dat geen regres mogelijk is, niet. Het huwelijk dient volgen; de Hoge Raad geen wijziging te kunnen brengen in de mogelijkheid tot het nemen van regres. Voor de uitkeringen waarop de benadeelde voorafgaand aan het hu,velijk recht heeft gekregen blijft het regresrecht daarom ook na het huwelijk gewoon in stand. Beslissend is dus het moment waarop de aanspraak op de uitkerinz̧ of voorziening (en daarmee het regresrecht) is ontstaan: was dat voorafgaand aan het huwelijk dan is nog wel regres mogelijk, voor tijdens het huwelijk ontsłane aanspraken is regres uitgesloten. ${ }^{1383}$ Beter zou zijn het regres niettemin uitge;loten te achten indien en zolang de betrokkenen een duurzame huishouding zijn gaan delen. ${ }^{1384}$

Yoor de uitsluiting yan het regres maakt het volgens de Hoge Raad, net als bij het regres krachtens de Ziekenfondswet, geen verschil of de aansprakelijkheid van het betrokken gezinslid door WA-verzekering wordt gedekt. ${ }^{1385}$ Hartlief en Van Maanen wijzen er op dat het sociale karakter van de verzekering ('van iedereen en voor iedereen') het leidende criterium is voor de uitsluiting van gezinsleden van het regres van de Ziektewet en de WAO. Regres zou in strijd met de strekking van de WAO ertoe leiden dat de benadeelde in feite verstoken zou worden van hetgeen hem in het kader van die wet toekomt. ${ }^{1386}$ Deze argumenten ter bescherming van de vermogenspositie van de benadeelde lijkt de Hoge Raad alleen te laten prevaleren bij het regres met betrekking tot loonsvervangende uitkeringen. Ze zijn voor de geoorloofdheid van het regres van de Ziekenfondswet op gezinsleden niet beslissend. ${ }^{1387}$ De Hoge Raad houdt voor het regres van de Ziekenfondswetnamelijk, zo blijkt in het arrest $N O V O / R Z G$ andermaal, vast aan zijn standpunt in de Rijnstreek-arresten dat het meeverzekerd zijn beslissend is. Dat doet wat willekeurig aan: de toevalligeomstandigheid dat de schadeveroorzaker meeverze-

HR 26 juni 1987, NJ 1988, 536nt. JBMV (Nieuw Rottendam/Bedrijfsvereniging); HR 25 januari 1991, NJ 1992. 706 nt. CJHB (ABP/Elsenga); en daarover Hartlief \& Van Maanen (1991), p. 296; Van Boom \& Storm (1995), p. 153 ,

1384 NJ-noot Veegens (nr. 7) inzake HR 26 juni 1987, NJ 1988, 536 (Nieuw Rotterdam/Bedrijfsvereniging), die er tevens op wijst dat het toeval dan wel erg beslissend kan worden: de schadeveroorzaker zou het huwelijk kunnen bespoedigen. Hij acht dat zelf echter een weinig voor de hand liggende gang van zaken. HR 26 juni 1987, NJ 1988, 536 nt. JBMV (Nieaw Rotendam/Bedriffsereniging). Zie ook, daarmee instemmend, Brunners noot (nt. 2) bij HR 11 februari 1994, NJ 1995, 494 nt. CHHB (NOVORZG).

1386 Hartlief \& Van Maanen (1991), p. 296 en in gelijke zin Van Boom \& Storm (1995), p. 153.

1387 In HR II februari 1994, NJ 1995, 494 nt. CIHB (NOVORZG) was tevergeefs door de WA-verzekeraar(5) betoogd dat het belang van de benadeelde om niet met de regreslast te worden geconfronteord, ook voorop zou moeten staan bij het regres krachtens de Ziekenfondswet. 
kerd is met de benadeelde bepaalt of de benadeelde van zijn uitkering verstoken blijft. De reden daarvan lijkt te zijn, dat de Hoge Raad voor alle ziektekostenverzekeringen naar uniformiteit streeft. Zijn A-G, Asser, wijst op de destijds voorliggende plannen tot afschaffing van de Ziektewet. Aansluiting bij het regresregime voor particuliere verzekeraars zou dan op zijn plaats zijn. Dat argument blijft in zoverre actueel, dat de grens tussen risico's die op een zeker moment deel uitmaken van het AWBZ- of ziekenfondspakket dan wel van particuliere verzekeringen met de tijd verschuift. Volgens het regime van art. $284 \mathrm{WvK}$ zoals het gold ten tijde van het derde Rijnstreek-arrest en NOVO/RZG was het meeverzekerd zijn vooralsnog als enige criterium beslissend. Afdeling 7.17.2 BW biedt weliswaar een ruimere kring van personen bescherming tegen de nadelige gevolgen die ze van het regres kunnen ondervinden, maar daarop lijkt de Hoge Raad in navolging van zijn A-G niet te hebben willen anticiperen (hetgeen begrijpelijk is in het licht van de langdurige, moeizame en onzekere wordingsgeschiedenis van het wetsvoorstel voor afdeling 7.17 BW. Thans echter is die situatie anders: het wetsontwerp is ingediend bij de Eerste Kamer, en zal binnen niet onafzienbare tijd kracht van wet krijgen. Het biedt niet alleen een inspiratiebron voor het regres in het kader van de sociale ziektekostenverzekeringen, maar ook voor het regresregime inzake de loonvervangende uitkeringen en betalingen (te weten: het werkgeversregres ingevolge art. 6:107a BW, VOA, en voorts $\mathrm{ZW}$, WAO, WAZ, WAJONG en REA).

\subsubsection{Regres van schadeverzekeraars op gezinsleden}

Volgens het regime van art. $284 \mathrm{WvK}$, dat wellicht tevens als rolmodel heeft gefungeerd voor Rijnstreek III en NOVO/RZG, werd aangenomen dat geen subrogatie kon plaatsvinden in rechten tegen iemand die op dezelfde verzekering is verzekerd als de benadeelde. Hoewel de wettelijke regeling zelf dat niet uitdrukkelijk bepaalt, lijkt te kunnen worden gesproken van een heersende leer op dit punt. ${ }^{1388}$ Die beperking werd ook wel afgeleid uit de woorden dat regres plaatsvindt op 'derden'; derden zijn degenen die buiten de verzekeringsovereenkomst staan. Daaronder zouden dan niet mede de verzekerde en meeverzekerden zijn te verstaan: degenen die partij zijn bij de overeenkomst en degenen die als verzekerde betrokken zijn bij dezelfde overeenkomst. ${ }^{1389}$ Hiervan uitgaande geldt de beperking van het regres dus alleen voor de meeverzekerde gezinsleden. Of en wanneer daarvan sprake

1388 Zie 0.a. NJ-annotator Mijnssen (bij nr. I) inzake HR 6 mei 1983, NJ 1983, $584 \mathrm{nt}$. FHJM (Rijnstreek II); Rb. Zwolle 19 juni 1985, NJ 1988, 88 (Nieindewsen/Hengeveld); Asser-Clausing/Wansink, nr. 325; Scheltema/Mijinscen (1998), p. 273; Mulder (1988), p. 54; Van der Burg (1990), p. 165: Hartlief \& Tjittes (1991), p. 226; Hartlief \& Tjittes (1999), p. 85.

1389 Mulder (1988), p. 54; Hartief \& Tjittes (1991), p. 226; Van Dam (1995), p. 108; Scheltema-Mijnssen (1998), p. 267; vgl ook Hof Den Bosch 10 december 1974, NJ 1975, 141 (MijnstreekVick), waarin de ziektekostenverzekeraar van een moeder, na de schade te hebben vergoed van haar kind, de subrogatie in de vordering van het kind zag afstuiten op het gegeven dat de moeder als medeverzekende geen 'derde' was aan wie art. 284 WvK kon worden tegengeworpen. 
is, bepalen de verzekeringsvoorwaarden en/of de strekking van de verzkering; ${ }^{1390}$ niet vereist is dat er tussen deze personen een familierechtelijke reatie is of anderszins (een vorm van samenwonen). Uiteraard kunnen verzekeraarsvel zelf het regresrecht verder beperken, bijvoorbeeld door afstand te doen van venaal of gezinsleden. Voor het Schadefonds Geweldsmisdrijven geldt overigens dt in beginsel wèl verrekening of een vordering tot terugbetaling plaatsvindt ten bespe van de eventuele schadevergoeding waarop de benadeelde aanspraak maakt, aar aanleiding van het verzoek om een schadevergoedingsmaatregel bij voegin in de strafprocedure tegen een gezinslid.

Naar komend recht echter, afdeling 7.17.2 BW, is de uitsluiting van het reres op verzekerden en meeverzekerden niet alleen wettelijk verankerd, maar is boendien de kring van gevrijwaarde personen aanmerkelijk ruimer. Art. 7.17.2.2. lid $3 \mathrm{BW}$, zoals het op 24 april 2003 aan de Eerste Kamer is voorgelegd, ${ }^{1391}$ bepalt dat de verzekeraar door de subrogatie geen vordering krijgt op:

'de verzekeringnemer, een mede-verzekerde, de niet van tafel en bed gescheiden echtgenoot $c$ de

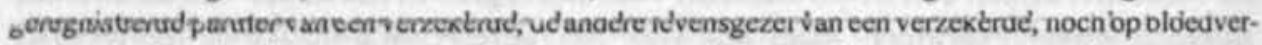
wanten in de rechte lijn van een verzekerde, op een werknemer of de werkgever van de verzekerde, of op degene die in dienst staat tot dezelfde werkgever als de verzekerde.'

De kring van uitgesloten personen is voor gezinsleden thans wat restrictiever en wat ruimer geformuleerd dan in het aanvankelijk ontwerp; toen waren ook de echtgenoten van de bloedverwanten uitgesloten en de wat ambigue categorie 'huisgenoten'. De categorie huisgenoten is geschrapt. ${ }^{1392}$ Daaronder vielen in elk geval niet de personen die ieder zelfstandig een kamer in een huis huren, en dat is ook thans niet zo, maar wèl 'personen die een gemeenschappelijke huishouding voeren die niet slechts door economische motieven is bepaald, bijvoorbeeld samenwonende broers of zusters of niet met elkaar gehuwde levensgezellen. ${ }^{1393} \mathrm{De}$ minister wijst er tevens op dat de materie sterk de neiging heeft om uit te dijen. De voorstellen om subrogatie ook uit te sluiten als deze gericht is tegen levensgezellen van de bloedverwanten in rechte lijn en broers en zusters worden door de minister verworpen. ${ }^{1394}$ Alleen de categorie levensgezellen (en bloedverwanten in rechte lijn: ouders, kinderen enzovoort) is gehandhaafd. De minister definieert levensgezellen als: 'twee meerderjarigen die, anders dan als elkaars echtgenoot, met elkaar een nauwe persoonlijk betrekking hebben'. Het is deze nauwe persoon-

1390 Mulder (1988), p. 61; en Hartlief \& Tjittes (1991), p. 226.

1391 EK 2002-03, 19529,206 , Gewijzigd voorstel van wet 24 april 2003.

1392 TK 1999-2000, 19529 , nr. 5, p. 44: met de term levensgezel 'kan de uitsluiting van subrogatie op een huisgrnoot vervallen. Dere juridisch nict omschreven term is te vaag, en anders dan voor in één huis wonende levensgexellen kan voor huisgenoten in het algemeen niet altijd volgehouden worden dat subrogatie op hen hun onderlinge relatie zou verstoren."

1393 TK 1985-86, 19529 , nt. 3 (MvT), p. 34.

1394 TK 1985-86, 19529, nr. 3 (MvT), p. 34. Zie hierover ook Mulder (1988), p. 124 en Van Dam (1995), p. 109. 
lijke betrekking, die door het regres verstoord zou kunnen worden. ${ }^{1395}$ Het meeverzekerd zijn is niet het enige criterium, voor bloedverwanten en de levensgezel geldt dat zij - meeverzekerd of niet - niet blootstaan aan het regres van schadeverzekeraars. Of de genoemde categorieën schadeveroorzakers WA-verzekerd zijn of niet lijkt daarvoor niet relevant. Een uitzondering geldt slechts indien de aansprakelijkheid betrekking heeft op omstandigheden die - als ze aan de benadeelde toerekenbaar zouden zijn geweest - afbreuk zouden hebben gedaan aan diens recht op de verzekeringsuitkering. ${ }^{1396}$ Denk aan opzettelijke schadetoebrenging door de huisgenoten of grove schuld, of de schending van een reddingsplicht (voorzover die aanleiding geeft tot aansprakelijkheid). ${ }^{1397}$ Evenmin als voor het regres van de ziekenfondsen maakt het uit of het van regres gevrijwaarde gezinslid WA-verzekerd is. ${ }^{1398}$ Deze beperkingen zijn van dwingend recht, er kan niet van worden afgeweken, zo bepaalt art. 7.17.2.25a lid $1 \mathrm{BW}$. Ook via cessie kunnen aan de verzekeraar dus geen rechten toekomen. De wetgever wijst op verschillende redenen voor uitsluiting van de opgesomde categorieën van schadeveroorzakers: ${ }^{199}$

'Het betreft hier personen van wie mag worden aangenomen dat de verzekering mede in hun belang is gesloten, voorzover zij al niet uitdrukkelijk zijn meeverzekerd. Hun relatie met de verzekeringsnemer is van duurzame aard, voortvloeiend uit het familierecht, een arbeidsverhouding of een woonsituatie. Het uitoefenen van verhaal zou deze relatic kunnen verstoren en de verzekeringnemer, bij echtgenoten ook economisch, kunnen treffen. Een dergelijk gevolg verdraagt zich niet met het doel waartoe de nemer de verzekering sloot.'

Voor de uitsluiting gelden kortom drie argumenten: ${ }^{1400}$ een zakelijk-commercieel argument (regres zou de benadeelde weinig 'waar bieden voor zijn geld'), een relationeel aspect (regres zou de familieband kunnen verstoren) en een economisch argument (regres zou de benadeelde de facto zijn uitkering weer ontnemen, indien hij om zakelijke of emotionele redenen aan het regres zou meebetalen). Deze argumenten hebben gemeen dat ze de strekking van de verzekering moeten waarborgen: de benadeelde moet door het regres niet de bescherming worden onthouden, die hij met het afsluiten van een verzekering heeft beoogd. Om vergelijkbare redenen werd in 1964 het verhaalsrecht van door gemeentelijke sociale diensten verstrekte armenzorg op bepaalde onderhoudsplichtige familieleden afgeschaft. Het argument was dat het vooruitzicht van regres de bijstandsgerechtigde, met

\footnotetext{
1395 TK. 1999-2000, 19 529, nr. 5, p. 44, onder verwijzing naar Aanwijzing $72 a$ van de Aanwijzingen voor de regelgeving.

1396 Art. 7.17.2.25, derde lid tweede volzin BW. Zie kritisch daarover Mulder (1988), p. 125 ("het gevolg daarvan kan zijn dat ook de bescherming van de verzekerde wordt aangetast'); Hartlief \& Tjittes (1991), p. 226; en voorts Van Dam (1995), p. 112 en Hartlief \& Tjittes (1999), p. 86.

1397 TK 1985-86, 19 529, nr. 3 (MvT), p. 34.

1393 Zie HR 6 mei 1983, NJ 1983, 584 nt. FHUM (Rijnstreek II) waar de Hoge Raad in een regresactie tegen de WA-verzekeraar beslist dat het regresrecht ontbreekt.

1399 TK 1985-86, 19 529, nr. 3 (MvT), p. 34.

1400 Vgl. Mulder (1988), p. 123 e.v.
} 
name bejaarden, zodanig zou kunnen bezwaren, dat het hen zou beletten om ich voor het verkrijgen van die bijstand tot de betrokken sociale dienst te wenden ${ }^{1401}$ De verzekerde zou vanwege het risico van regres op zijn gezinsleden kunnen afien van het geldend maken van zijn aanspraak op de verzekeringsuitkering. Het riico van een regresactie tegen gezinsleden zou de verzekerde dan beletten in zijn migelijkheden om tot vergoeding te komen.

\subsubsection{Aansluiting bij afdeling 7.17.2 BW?}

Voorgesteld wordt wel om de hiervoor besproken regimes in het kader var de sociale verzekeringen met deze regeling van afdeling 7.17.2 BW in overeenstmming te brengen. ${ }^{1402}$ Dat heeft het voordeel van de eenvoud en het bevoriert de hanteerbaarheid en (gestandaardiseerde) uitvoering van het regres. Maaide vraag lijkt gerechtvaardigd of een zo vergaande uitsluiting van het regres als thns geldt in het kader van art. 7.17.2.25 BW ook past in het kader van de socale verzekeringen. Bij het afsluiten van een schadeverzekering spelen immers tal an persoonlijke keuzes en voorkeuren een rol. Of de evengenoemde commercsle en relảtionelè argumenten in dát verband voldoende overtuigend zijn wil ik in het midden laten, voor het regres met betrekking tot de sociale verzekeringen en loondoorbetaling benadrukt het kabinet het belang van individuele verantwoordelijkheid en het belang dat de schadeveroorzaker de schade draagt. Als het relationele argument voldoende dragend is voor de uitsluiting van het regres op gezinsleden, waarom geldt dat dan niet ook voor regresacties tegen de buren of aangetrouwde familieleden? Van meer belang lijkt me het genoemde economische argument: de benadeelde mag door het regres niet worden verstoken van zijn uitkering. De aanleiding voor het regres ligt bij de gedachte dat moet worden voorkomen dat de benadeelde naar aanleiding van het schadevoorval meer dan eens vergoeding ontvangt voor dezelfde schade. Door de regeling van voordeelstoerekening verliest hij onvrijwillig zijn aanspraak op schadevergoeding; elke keuzemogelijkheid wordt hem in dit verband ontnomen (verplichte voordeelstoerekening). Voorkomen moet dan worden dat hij, doordat hij als deel van de huishouding meebetaalt aan het regres, de facto ook zijn uitkering verliest. Dat geldt eens te meer nu het kabinet wijst op de eigen verantwoordelijkheid tot het verzekeren van risico's die niet langer tot het sociale vangnet worden gerekend (het moeten derven van de voorziening in het levensonderhoud of de top van het inkomen). Om te voorkomen dat dit tot moeilijk feitenonderzoek leidt naar de financiële positie van de benadeelde (in hoeverre draagt hij daadwerkelijk bij aan het regres?), lijkt er dan veel voor te zeggen om, zoals de Hoge Raad ook doet, het beslissende criterium te laten zijn of sprake is van een duurzame gemeenschappelijke huishouding.

1401 Vitvoerig Commissie Moltzer (1960), p. 18.

1402 Voorstander daarvan is Veegens in zijn NJ-noot (nr. 5) bij HR 13 februari 1987, NJ 1987, 602 nt. JBMV (Bedriifsocreniging/Delta Loyd). 


\subsubsection{Naar een verbeterde bescherming van de benadeelde?}

Resumerend kan worden gesteld dat thans sprake lijkt te zijn van drie regimes. Het eerste regime geldt voor de loonvervangende sociale uitkeringen en loondoorbetaling en komt er, ruim uitgelegd, op neer dat geen regres mogelijk is op personen met wie de benadeelde een gezamenlijke huishouding voert (ABP/Elzinga). Aangenomen moet worden dat ook andere personen dan de geliefde van de benadeelde, met wie hij een duurzame gemeenschappelijke huidshouding deelt van het regres uitgesloten zijn. Het tweede regime geldt voor de ziekenfondswet (en in theorie geldt hetzelfde, opperde ik, gelet op de dunne scheidslijn met het verzekerde risico, ook voor de AWBZ) ${ }^{1403}$ Het komt erop neer dat op meeverzekerde gezinsleden geen, en op niet-meeverzekerde gezinsleden wèl, regres mogelijk is (Rijnstreekarresten en $\mathrm{NOVO} / \mathrm{RZG}$ ). Daarop past kritiek: niet valt immers in te zien waarom een ziekenfondsverzekerde kostwinner (of ander gezinslid) de bescherming tegen het risico dat hij door het regres de facto zijn uitkering verliest, zou moeten missen. ${ }^{1404}$ Het argument dat de benadeelde feitelijk niet verstoken mag zijn van zijn uitkering zou in beginsel beslissend moeten zijn (zij het, vanuit oogpunt van hanteerbaarheid, wellicht beperkt tot gevallen waarin sprake is van een gemeenschappelijke huishouding). Voor art. $284 \mathrm{WvK}$ geldt thans nog een vergelijkbaar regime (waarin het meeverzekerd zijn beslissend is), maar zal bij inwerkingtreding sprake zijn van een ruimere kring van uitgesloten personen: van de medeverzekerde en de echtgenoot tot de andere levensgezel en bloedverwanten in rechte lijn. Invoering van een gelijkluidend regime voor het regres van sociale verzekeraars en werkgevers lijkt niet wenselijk. Beter ware voor alle zelfstandige regresbepalingen het eerstgenoemde regime te laten gelden.

\subsubsection{Het werkgeversverweer tegen het regres van sociale verzekeraars}

Niet alleen is het regres op gezinsleden van de benadeelde is beperkt, ook voor het regres op zijn werkgever en op zijn collega's gelden bijzondere beperkingen. De wettelijke regresbepalingen voor sociale verzekeraars beperken de mogelijkheid van het nemen van regres op de werkgever en op collega's van de benadeelde, als die hem schade hebben berokkend. Behoudens opzet of bewuste roekeloosheid is geen regres mogelijk op de werkgever van de benadeelde alsmede op de 'verzekerde, die in dienstbetrekking staat tot dezelfde werkgever als de verzekerde jegens wie naar burgerlijk recht een verplichting tot schadevergoeding bestaat' (collega's van de benadeelde). Deze beperking geldt dus kennelijk alleen voor het regres

\footnotetext{
1403 Praktische betekenis heeft dit niet direct, aangezien de individuele regresvorderingen in het kader van de AWBZ tesamen, collectief, in de vorm van écn jaarlijkse lump sum worden afgekocht.

1404 Zie o.a. Mulder (1988), p. 130; Hartlief \& Tjittes (1991), p. 236; Hartlief \& Tjittes (1999), p. 90 met verwijzingen; Van Boom (2000a), 87.
} 
op schadeveroorzakende collega's die (verplicht) krachtens de betrokken sociale verzekeringswet zijn verzekerd.

Het werkgevers- en collega-verweer worden ruim uitgelegd. Niet nodig is bijvorbeeld dat het ongeval zich op de werkplek heeft afgespeeld, en ook staat het VAverzekerd zijn van de betrokken werkgever of collega niet aan de beperking van het regres op hen in de weg. ${ }^{1405}$ Voor bijzondere arbeidsverhoudingen lijken de beperkingen onverminderd ook te kunnen gelden. ${ }^{1406}$ Bovendien is niet alken het regres op de directe collega's van de benadeelde, waarmee hij in zijn directe werkgeving te maken heeft, aan deze beperking onderhevig. Gesproken wordt veel ruimer van degene 'die in dienstbetrekking staat tot dezelfde werkgever'. Om te kunnen spreken van een dienstverband in deze zin is voorts niet nodigdat ook loonbetaling plaatsvond ten tijde van het ongeval. Zo gold de beperkte blootstelling aan regres ook voor de automobilist die met zijn inzittende collega op weg was naar een herscholingscursus en een ongeval veroorzaakte, in een periode dat beiden geen arbeid verrichtten voor hun werkgever en ook geen loon maar een uitkering ontvingen. Beslissendwas of er, afgaande op de concrete omstancigheden van het geval, ten tijde van het ongeval nog steeds sprake was van zen dienstverband. ${ }^{1407}$ Volgens de Hoge Raad gelden deze beperkingen óók als de werkgever of collega voor het risico van aansprakelijkheid verzekerd is; de WAverzekeraar kan dan het werkgevers- of collegaverweer inroepen. ${ }^{1408}$ Voor de benadeelde die zèlf (rechtstreeks) een beroep doet op het aansprakelijkheidsrecht gelden ze niet. ${ }^{1409}$

Een uitzondering geldt slechts indien de schade door 'opzet of bewuste roekeloosheid' van de werkgever of collega is veroorzaakt. ${ }^{140}$ Aan het aannemen van opzet of bewuste roekeloosheid worden zware eisen gesteld. ${ }^{1411}$ In een arrest uit 1975 sanctioneert Hoge Raad het oordeel dat het voor 'bewuste roekeloosheid' van de collega (hetzelfde geldt wellicht voor de werkgever) niet voldoende is,

1405 HR 7 november 1975, NJ 1976, $332 \mathrm{nt}$. ARB (Ziekenfonds/Nationale Nederlanden).

1406 'Inleners' worden ook beschermd, en ook de persoon die indirect bestuurder is van het bedrijf kan als werkgever worden aangemerkt, HR 13 februari 1987, NJ 1987, $602 \mathrm{nt}$. JBMV (Bedrijfsvereniging/Delta Loyd). Volgens Van Boom (2000a), p. 81 is verdedigbaar om ook niet-ondergeschikte arbeidskrachten zoals freelancers en andere zelfstandige opdrachtnemers als werknemer en als collega in de hier bedoelde zin aan te merken. In HR 13 februari 1987, NJ 1987, 602 nt. JBMV (Bedriifswereniging/Delta Loyd) beslist de Hoge Raad dat 's hofs oordeel dat tijdens de omscholingsperiode het dienstverband van de betrokkenen i blijven voortduren, waarvoor het met name had gehecht aan brieven van de werkgever zelf (directeur sector Personeelszaken), geen blijk geeft van een onjuiste rechtsopvatting.

1408 HR 7 november 1975, NJ 1976, $332 \mathrm{nt}$. ARB (Ziekenfonds/Nationale Nederlanden). Echt duidelijk is dit niet: de Hoge Raad beperkt zich tot de enger geformuleerde klacht terwijl het bovendien niet de collega zelf is die wordt aangesproken, maar diens WAM-verzekeraar (zie $N J$-p. 1012 linksboven).

Schoordijk (1967), p. 344 en Giltay Veth (1969), p. 212 pleiten, tegen de heersende leer in, ook voor immuniteit van aansprakelijkheid voor collega's tegenover elkaar voor schade op de werkplek.

1410 Naast art. 91 WAO zijn dat art. $52 b$ ZW, ant. $83 \mathrm{c} \mathrm{ZFW,} \mathrm{art.} 62 \mathrm{ANW}$, art. 65c AWBZ en ant. 6:107a lid 3 BW. Bij gebrek aan relevantie ontbreken het werkgevers- en het collegaverweer in de WAJONG en naast het werkgeversverweer óok - dat is opmerkelijker - het collegavenweer in de WAZ. Het argument van het bewaren van de arbeidsvrede geldt in dat verband dus kennelijk niet.

1411 In die zin voor art. 83e ZFW HR 7 december 1990, NJ 1991, 596 (Zickenfonds/De Vries). 
dat deze twee ernstige verkeersfouten heeft gemaakt, omdat tevens nodig is dat hij zich van de ernst van die fouten bewust is geweest. ${ }^{1412}$ Niet nodig is echter dat de collega of de werkgever zich er ook van bewust is geweest dat hierdoor ook daadwerkelijk schade zou ontstaan, voldoende is dat de collega of werkgever (ten onrechte) uit ging van de veronderstelling dat de schadelijke gevolgen van zijn fouten wel niet zouden intreden. ${ }^{1413}$ Het begrip bewuste roekeloosheid lijkt ook feitelijk gezien echter zeer restrictief te worden uitgelegd, vergelijkbaar met het eigen-schuld begrip dat in de huidige jurisprudentie voor de werknemer in zijn hoedanigheid van benadeelde geldt. ${ }^{1414}$ Van opzet of bewuste roekeloosheid is evenmin sprake bij het enkele gegeven dat veiligheidsvoorschriften niet in acht zijn genomen, zelfs niet als daarop een strafrechtelijke veroordeling volgt wegens schending van de Veiligheidswet $1934 .^{1415}$

Het regres op de werkgever en op collega's van de benadeelde blijft dus beperkt tot de zeldzame gevallen van opzet of grove schuld. Indien daarvan overigens sprake is bij de collega van de benadeelde, dan blijft de werkgever nog steeds van het regres gevrijwaard. ${ }^{1416}$ Gelet op het principe 'de schadeveroorzaker betaalt' ligt de beperking van het regres op werkgevers en collega's van de benadeelde niet in de rede. Alleen de benadeelde heeft in feite, voor het onverzekerde deel van zijn schade, recht op schadevergoeding van de werkgever. Bestaan daarvoor goede redenen?

\subsubsection{Rationes}

Dat werkgevers niet blootstaan aan regres is uitdrukkelijk zo door de wetgever beslist nadat het regime van de Ongevallenwet is komen te vervallen en berust op de behoefte aan voortzetting van dat regime. Onder dat regime waren werkgevers niet alleen vrij van regres door de Sociale Verzekeringsbank, maar zelfs geheel vrij van alle aansprakelijkheid. Het waren immers ook (primair) de werkgevers die voor de verzekering de premies opbrachten (premieargument). Nadat de Ongevallenwet in 1967 door de WAO is vervangen, is de aansprakelijkheid van werkgevers jegens arbeidsongeschikt geraakte werknemers en derden gaan herleven. Bij de Liquidatiewet ongevallenwetten is de beperkte vrijwaring van aansprakelijkheid

1412 Zie de Conclusie van A-G Ten Kate voor HR 7 november 1975, NJ1976, $332 \mathrm{nt}$. ARB (Ziekenfonds/Nationale Nederlanden).

1413 Zie de $N J$-noot van Bloembergen bij het zoevven genoemde arrest uit 1975; vgL ook HR 20 mei 1988, NJ 1988, $1032 \mathrm{nt} . J B M V$ (Bank-en Versekeringswezen/Fireco) en voorts de rechtsprask vermeld bij Van Boom (2000a), p. 79.

1414 HR 20 september 1996, NJ 1997, 198 (Pollemans/Hoondern) en de NJ-noot van Stein bij dat artest.

1415 Zoals in HR 7 december 1990, NJ 1991, 596 (Ziekenfonds De Vries), waar een werknemer onvoldoende uitgerust met degelijk materiaal een val van ongeveer 10 meter had gemaakt en door de gevolgen van de val levenslang invalide was geraakt. Hoewel de werkgever in belangrijke mate was tekortgeschoten in haar zorg jegens de werknemers, en ter zake ook door de politierechter was veroordeeld, was het gedrag van de benadeelde niet dermate onverantwoord dat de werkgever ook daarvan een verwijt trof.

1416 Zie Van Boom (2000a), p. 79. 
van de werkgever vervallen; volgens de overgangsbepaling geldt deze nog wel voor een vóór de intrekking voorgevallen schadefeit. ${ }^{1417}$ Maar voor een navenunte uitbreiding van de werkgeversaansprakelijkheid naar gevallen waarin de WAOinstantie regres zocht bestond weinig draagvlak. De werkgever zou dan worden belast met de verzekeringspremies voor de uitkeringen die vervolgens krachtens diezelfde verzekeringen aan de benadeelde werd verstrekt. Dat zou neerkomen op een 'bis in idem'. De werkgever zou dubbel worden belast met verantwootdelijkheid terzake van dezelfde schade. Deze visie vond steun in de literatuur; met name het premieargument werd onderschreven. ${ }^{1418}$

Dat óók schadeveroorzakende collega's in het kader van de sociale verzekeringen alleen bij opzet of bewuste roekeloosheid tot regres kunnen worden aangesproken, houdt nauw verband met het genoemde premieargument. Onder het regime van de Ongevallenwet stonden collega's van de benadeelde, anders dan de werkgever, wel gewoon bloot aan het regres. Hoewel het regres op collega's in de praktijk maar weinig voorkwam ontstond hierop kritiek. Men beschouwde de positie van collega's (wel risico van aansprakelijkheid, ook bij regres) als achtergesteld bij die van werkgevers (zeer beperkte aansprakelijkheid, ook bij regres). ${ }^{1419}$ Eerder was in het conceptwetsvoorstel voor de WAO echter, aansluitend bij het regime van de Ongevallenwet, alleen de beperkte blootstelling aan regres van werkgevers geregeld. Kort na de indiening van het aanvankelijke concept, in 1963, verdedigt Slagter in een bekend geraakt artikel van het blad Verkeersrecht, dat door de blootstelling van collega's aan regres onder het regime van de Ongevallenwet 1921 van de beperking van het regres op werkgevers niet veel terecht kwam. ${ }^{1420} \mathrm{Clau}$ sing stelt in 1964 dat dit ook moet gelden voor het werkgeversverweer van de WAO. ${ }^{1421}$ Werkgevers zouden geneigd zijn de schuldige collega, uit sociale overwegingen of om de werknemer niet te verliezen, vergoeding aanbieden van de door hem aan regresnemers of de benadeelde zelf verschuldigde som. In 1965 werd bovendien in de lagere rechtspraak een regresactie krachtens de Ongevallenwet op een collega-werknemer van de benadeelde afgewezen. ${ }^{1422}$

$\mathrm{Bij}$ de invoering van de WAO heeft de (aanvankelijke) bedoeling van de wetgever om het regres op andere werknemers onbeperkt toe te laten, tot grote commotie

Art. $38 a$ Liquidatiewet. Dat sprake is van een gewijzigde verhouding tussen werknemers en werkgevers doet daar niet aan af, HR 19 februari 1999, NJ 1999, 428 nt. ARB (Lahjaji/MMB).

1418 Clausing (1964), p. 420.

1419 Schoordijk (1967), p. 344

$14 \geq 0$ Slagter (1963), p. 196.

1421 Clausing (1964), p. 419: 'Het feit, dat de wet de bedrijfsvereniging geen regres op de werkgever geeft, helpt deze laatste in deze gevallen dus niets. Dit is een onbevredigende uitkomst.' $\mathrm{Vgl}$. ook Giltay Veth (1969), p. 212 .

1422 Zie Rb. Amsterdam 19 oktober 1965, NJ1966, 300 (Centrale Wenkgevers/Corbran), waar de regresvordering jegens een collega werd afgewezen, doch Hof Amhem 28 oktober 1969, N 1970, 72 (Geerlings Centrale Werkervers) dat het regres op een collega toewees. Het regres op werkgevers kwam echter volgens een rapport van de Sociale Verzekeringsbank maar 'zo sporadisch voor dat het te verwaarlozen is'; aldus weergegeven bij Van der Veen (1961), p. I. 
geleid. De Sociale Verzekeringsraad stelde in zijn advies over de regresbepaling in het (concept-)wetsontwerp voor de WAO, dat regres op al degenen die ook zelf premies betalen voor de WAO, werkgevers en werknemers, in beginsel onwenselijk was omdat dit zou betekenen dat men in feite tweemaal voor dezelfde schade zou betalen. ${ }^{1423}$ Een uitzondering moest volgens de raad alleen gelden indien sprake was van opzet of bewuste roekeloosheid van de schadeveroorzakende werkgever of collega-werknemer. Bij de ontwerpers van de WAO stuitte dit echter op het bezwaar dat de individuele veroorzaker dan ten laste van het collectief van aansprakelijkheid zou worden gevrijwaard. Wel zag men goede redenen voor het beperken van het regres op de werkgever van de benadeelde omdat deze in het individuele geval een belangrijk deel van de premies opbracht voor juist die uitkering waarvoor men in het individuele geval verhaal zocht. Bij de invoering de WAO is dit argument wat vertroebeld nadat kamerlid Van Lier (Partij van de Arbeid) met succes bij amendement voorstelde om dezelfde bescherming tegen regres te bieden aan collega's van de benadeelde omdat, naar het kamerlid stelde, ook zij bijdroegen aan de WAO-premies van het betrokken bedrijf. Bij vrijwaring van alleen de werkgevers zou, zo meende het kamerlid, sprake zijn van een ongeoorloofd onderscheid. ${ }^{1424}$ Wellicht had de minister daartegen nog een ander weerwoord kunnen voeren, namelijk door erop te wijzen dàt daar helemaal geen 'bis in idem' dreigt. Het premiedeel dat collega's hebben betaald heeft immers anders dan dat van de werkgever betrekking op hun eigen (zij het niet geĩndividualiseerde) risico van arbeidsongeschiktheid. Als ook dat voldoende is voor de beperkte blootstelling aan het regres, dan zouden niet alleen collega's van de benadeelde maar àlle schadeveroorzakers die in een dienstbetrekking werkzaam zijn (en dus WAO-premies afdragen), óók de werknemers buiten het bedrijf van de benadeelde, vrijgesteld moeten zijn van regres. ${ }^{1425}$ Anderzijds spoort dat niet met de solidariteitsgedachte die aan de premiebetaling ten grondslag ligt, en is het ook maar de vraag of dat in het politieke krachtenspel dat de discussie destijds beheerste indruk zou hebben gemaakt. Bovendien treft de onbeperkte blootstelling van collega's aan het regres van sociale verzekeraars uiteindelijk toch met

1423 In zijn recente advies (supna, paragraaf 5.5.3) houdt de rad hier aan vast en stelt dat het coliega- en werkgevers. verweer moeten worden gehandhaafd, Sociale Verzekeringsraad (1993), p. 21. Dat ook de SER zich op dat standpunt had gesteld kan natuurlijk niet verbazen, SER-rapport (1993), p. 28.

$1424 \mathrm{Hij}$ verwoordt een opvatting die steun vond in de rechtspraak. Volgens Rb. Amsterdam 19 oktober 1965, NJ 1966, 300 (Centrale Werkgevers/Corbran) volgde uit een redelijke wetsuitleg dat ook de aansprakelijkheid van collega's van regres uitgesloten was, behoudens opvet of dronkenschap. Want waren het niet in feite de werknemers die de premies opbrachten doordat de verplichte verzekering de lonen zou drukken? Dat een uitdrukkelijke bepaling in de Ongevallenwet ontbrak kwam volgens de Rechtbank doordat regres op collega's in 1921 amper voorkwam: zij boden immers geen verhal. Het Amsterdimse Hof (NJ 1967, 26) acht evenwel een uitdrukkelijke wettelijke grondslag nodig.

1425 Dit laatste (beperking van het regres op allen die de sociale verzekeringspremies opbrengen in of buiten het bedrijf van de benadeelde) was immers, zoals gezegd, wat de Sociale Verzekeringsraad had voorgesteld en de minister uitdnikkelijk had verworpen. 
name de werkgever (al lijkt dit bij de invoering van het collegaverweer geen significante rol te hebben gespeeld). ${ }^{1426}$

Naar de huidige rechtsopvatting (en maatschappelijke verhoudingen) is het premieargument zelf, als daarmee zou zijn volstaan, wat achterhaald. De visie dat cen risicodragend lichaam verzekerden niet aan datzelfde risico behoort bloot te stelen, heeft jarenlang aan de invoering van wettelijke regresrechten voor de volksverzekeringen in de weg heeft gestaan, maar wordt thans door het kabinet verworpen. De gedachte was dat allen die daarvoor de premies opbrachten zich gevrijwarrd moesten weten van het risico van aansprakelijkheid voor schade die door diezelide verzekeringen werd gedekt. Premies voor de volksverzekeringen moesten in feite mede het individuele risico van aansprakelijkheid jegens de betreffende regresnemende volksverzekeringsorganen dekken. Het zou dan voor de hand liggen om die visie ook te volgen voor de betalers van de werknemers- en werkgeverspremies: ${ }^{1427}$ met de premieafdracht voor de werknemersverzekeringen ( $\mathrm{ZW}, \mathrm{ZFW}$ en WAO) zou de schadeveroorzaker (werkgever of collega) zich niet moeten kunnen vrijwaren van zijn individuele risico van aansprakelijkheid tegenover de betreffende sociale verzekeraars. Maar er is een belangrijk verschil: anders dan de algenele uitsluiting van het regres voor de volksverzekeringen (de premiebetaler, alle Nederlandse ingezetenen, werd beschermd tegen willekeurige regresacties) hebben het collega- en werkgeversverweer immers uitsluitend betrekking op de werkgever en collega's die binnen de onderneming van de benadeelde zelf werkzaam zijn. Dit verschil hangt samen met een overtuigender argument, dat met name voor het collega- en werkgeversverweer in de volksverzekeringswetten een voorname rol heeft gespeeld en thans als het belangrijkste argument voor het collega- en werkgeververweer: de onderneming vormt een eenheid waarbinnen een zekere mate van solidariteit moet gelden tussen degenen die sociale premies moeten betalen (het 'solidariteitsargument'). ${ }^{1428}$ De sociale verzekeraar zou daarom op niemand binnen de onderneming verhaal mogen nemen, het bedrijf is als het ware als een eenheid verzekerd. Net als de Hoge Raad later is gaan beslissen voor gezinsleden in het kader van de Ziekenfondswet, zijn allen binnen de onderneming als medeverzekerde te beschouwen. Op die grond genieten ze extra bescherming in de vorm van een beperking van hun aansprakelijkheid voor schadevoorvallen binnen de

De werkgever zal veelal medeaansprakelijk zijn, zie art. 6:170 BW en art. 7:658 BW; vgl. ook de NJ-noot van Veegens (bij nr. 1) inzake HR 13 februari 1987, NJ 1987, $602 \mathrm{nt}$. JBMV (Bedriffsveneniging/Delta Loyd) en ook Van Boom (2000a), p. 77.

1427 Clausing (1964), p. 420.

1428 In die zin meer recent nog voor het regresrecht van de AWBZ. TK 1998-99, 26 238, brief d.d. 8 februari 1999 (waar onbeperkt regres 'in verband met een mogelijk daruit voortvloeiende verstoring van de arbeidsverhoudingen. ongewenst geacht' genoemd wordt). Ook de Hoge Raad noemt dit de ratio van het werkgeversverweer. HR 20 mei 1988, NJ 1988, 1032 nt. JBMV (Bedriffsvereniging/Fireco), r.o. 3.2; HR 7 december 1990, NJ 1991. 596 (Ziekenfonds/De Vries), r.o. 3.2.1. Zie voorts 0.2. Van Boom \& Storm (1995), p. 154 met verwijzingen naar buitenlandse literatuur (nt. 39). 
onderneming. ${ }^{1429}$ Die solidariteit wordt volgens de Hoge Raad niet doorbroken door het gegeven dat niet de werkgever, maar een uitkeringsorgaan, ten tijde van het ongeval de WAO-premies voor de betrokkenen verschuldigd was. ${ }^{1430}$ Hierop is meer recent terecht kritiek ontstaan. Het kabinet Kok I heeft naar aanleiding daarvan op een zeker moment overwogen deze beperking van het regres in het kader van de sociale verzekeringen af te schaffen. ${ }^{.431}$ Het solidariteitsargument zou minder overtuigend zijn nu de werkgevers veelal over een WA-bedrijfspolis beschikken; aansprakelijkheid is 'gedepersonaliseerd'. Bovendien zou een beperking van het regres tot gevallen van opzet en bewuste roekeloosheid niet passen bij de met het regres beoogde kostentoerekening. Dat lijkt terecht; niet valt in te zien waarom het premieargument dat in het kader van de volksverzekeringen werd verlaten, nog wèl zou moeten gelden voor de werkgever. Uiteindelijk is echter toch besloten het werkgeversverweer nog te handhaven. ${ }^{1432}$ De reden hiervan is dat art. 7:658 BW op dat moment in voorbereiding was en tevens gewerkt werd aan wetgeving ter verscherping van de arbeidsomstandigheden (en dus van de aan de zorgplicht te stellen eisen). Kennelijk achtte het kabinet het openstellen van het regres op werkgevers politiek niet haalbaar. ${ }^{1433}$ Handhaving van het werkgevers- en het collegaverweer zou bovendien, mits de betrokkenen WA-verzekerd zijn voor die gevallen waarin nog wèl regres mogelijk is, ${ }^{1434}$ de arbeidsvrede ten goede komen. Net als in het kader van het gezinsverband vind ik dit argument niet zo overtuigend. Het lijkt me veeleer het schadevoorval te zijn, dat de arbeidsrust en goede betrekkingen verstoort. Onduidelijk is of de beperking van het regres met behulp van cessie(constructies) kan worden omzeild. Met Van Boom zou ik menen dat zulke constructies te zeer ingaan tegen de bedoeling van de wetgever. $^{1435}$

\subsubsection{Het werkgeversverweer van afdeling 7.17.2 $\mathrm{BW}$}

Hoewel ik zoals gezegd meer argumenten zou zien voor afschaffing van het werkgeversverweer, werd dit onlangs uitgebreid naar het regres voor particuliere verzekeraars. Thans geldt nog de subrogatieregeling van art. $284 \mathrm{WvK}$, en die is slechts

1429. Een goede illustratic van zulke consequenties biedt HR 6 november 1970, NJ 1971, $76 \mathrm{nt}$. GJS (Geerlings/Centrale Werkgevers).

1430 Zie r.o. 3.4 van de Hoge Raad inzake HR 13 februari 1987, NJ 1987, $602 \mathrm{nt}$. JBMV (Bedrijfsvereniging/Delia Loyd).

1431 TK 1994-95, 24 169, nr. 6, p. 32: 'Op zich is het kabinet van mening dat het wenselijk is de beperking van het regres van de bedrijfsvereniging voor feiten binnen de werksfeer te laten vervallen.' Maar vanwege de plannen tot uitbreiding van de werkgeversaansprakelijkheid (thans ant 7:658 BW) werd besloten het werkgeversverweer 'voorlopig nog te handhaven' (p. 33). De Sociale Verzekeringsraad (1993), p. 21 en het SER-rapport 93/14 (1993), p. 28, hadden zich (begrijpelijkerwijs) op het standpunt gesteld van handhaving.

1632 TK 1994-95, 24169, nr. 3 (MvT), p. 26.

1433 TK 1994-95, 24 169, nr. 6, p. 32: 'Op zich is het kabinet van mening dat het wenselijk is de beperking van het regres van de bedrijfsvereniging voor feiten binnen de werksfeer te laten vervalien (...).'

1434 Schoordijk (1967), p. 349.

1435 Van Boom (2000a), p. 79. Dat geldt in elk geval voor de subrogatieregeling, zie art. 7.17.2.25a BW, lid 1 . 
in zoverre beperkt dat de verzekerde en meeverzekerden erbuiten vallen. Van 'meeverzekerd zijn' is dan alleen sprake zijn als het de schadeverzekeraar van de werkgever, van het bedrijf, is die de schade moet vergoeden. Zo kan regres op collega's wel in de polisvoorwaarden uitgesloten zijn of kan het bedrag van de uitkering de moeite (en kosten) niet waard zijn. Voor het nieuwe recht van titel 7.17 BW gold daarop aanvankelijk slechts de uitbreiding naar het regres op werknemers van de verzekerde; ook niet meeverzekerde werknemers waren (en zijn) daarmee dus van het regres uitgezonderd. ${ }^{1436}$ Het gevolg daarvan was dat het regresrecht voor particuliere verzekeraars, zowel voor art. $284 \mathrm{WvK}$ als voor afdeling 7.17.2 $\mathrm{BW}$, aanmerkelijk gunstiger was dan voor sociale verzekeraars: ${ }^{1437}$ de werkgever bleef in beginsel net als collega's volledig blootgesteld aan het regres. Het argument dat de werkgever de premies opbrengt en dus ook zelf deel uitmaakt van de risicogemeenschap waarvoor de verzekering bestaat, geldt hier ook minder sterk (tenzij de werkgever bijvoorbeeld een collectieve ziektekostenverzekering heeft afgesloten ten behoeve van zijn werknemers). ${ }^{1.38}$ Zoals eerder werd opgemerkt is art. 7.17.2.25 BW, zoals ingediend bij de Eerste Kamer op 24 april 2003, als gevolg van de Nota van Wijziging in juni 2000 ruimer geformuleerd. ${ }^{1439}$ Het bepaalt dat de verzekeraar door de subrogatie geen vordering krijgt op:

'de verzekeringnemer, een mede-verzekerde, de niet van tafel en bed gescheiden echtgenoot of de geregistreerde partner van een verzekerde, de andere levensgezel van een verzekerde, noch op bloedverwanten in de rechte lijn van een verzekerde, op een werknemer of de werkgever van de verzekerde, of op degene die in dienst staat tot dezelfde werkgever als de verzekerde.

Ook de werkgever en collega's van de benadeelde zijn dus nu - meeverzekerd of niet - uitgesloten van het regres van schadeverzekeraars. Daarmee loopt de nieuwe regeling beter in de pas met de sociale verzekeringswetgeving. Ook voor het regres van particuliere verzekeraars moet worden aangenomen dat het verhaal op de nog wèl daarvan uitgesloten personen via cessie uitgesloten is. Krachtens art. 7.17.2.25 $\mathrm{aW}$ mag van het in het derde lid van art. 7.17.2.25 $\mathrm{BW}$ bepaalde, niet worden afgeweken.

Voor overeenkomstige toepassing van het collega-en werkgeversverweer van de sociale verzekeringen is naar het oordeel van de Hoge Raad geen plats; HR 16 september 1994, NJ 1996, 329 nt. CJHB (Nationale Nederianden/Woudsend A. Zie ook Van Dam (1995), p. 111; en Hantief \& Tjittes (1999).

Zie de NJ-noot van Brunner bij HR 16 september 1994, NJ 1996, 329 (Nationale Nederlanden/Woudsend $)$ Zie Nota van Wijziging d.d. 21 juni 2000, TK 1999-2000, $19529 . \mathrm{nr} .5$ en EK 2002-03, 19 529. 206 (Gewijzigd voorstel van wet 24 april 2003 ). 


\subsubsection{Bijzonderheden van het werkgeversregres ${ }^{1440}$}

Ook voor werkgevers met een regresrecht voor het doorbetaalde loon bij arbeidsongeschiktheid geldt dat het regres op collega's van de benadeelde alleen mogelijk is indien sprake was van opzet of bewuste roekeloosheid van de collega. ${ }^{1441}$ Het collegaverweer sluit - dat geldt voor alle relevante regresregelingen - goed aan bij de bescherming van werknemers in het arbeidsrecht. Daar rust op de werkgever aansprakelijkheid voor tekortkomingen van collega's, als zijnde de personen van wie hij bij de uitvoering van zijn zorgplicht van art. 7:658 BW gebruik maakt. Voor arbeidsongevallen die door andere tekortkomingen van werknemers zijn ontstaan is de werkgever onder omstandigheden eveneens aansprakelijk. ${ }^{1442}$ Ook in hun onderlinge verhouding rust de draagplicht dan in beginsel behoudens opzet of grove roekeloosheid van de werknemer bij de werkgever. Krachtens art. 7:661 BW geldt eveneens dat werknemers ook jegens de werkgever zelf voor bij de uitvoering van de arbeidsovereenkomst veroorzaakte schade in beginsel slechts aansprakelijk zijn bij opzet of bewuste roekeloosheid. Bij deze draagkrachtverdeling heeft mede een rol gespeeld dat werknemers zich niet tegen deze (WA)schade plegen te verzekeren; voorzover de werknemer wèl verzekerd is afwijking van deze regels mogelijk. ${ }^{1443}$

Voor ziektekosten en andere medische herstelkosten die de werkgever voor zijn rekening neemt kan hij zoals gezegd als 'derde' een beroep doen op art. 6:107 $\mathrm{BW}$. Deze regeling kent echter geen collegaverweer. Voor de hand ligt dunkt me om het collegaverweer dan analoog aan art. 6:107a BW te laten gelden. De beperking van de aansprakelijkheid van de collega tot opzet of bewuste roekeloosheid volgt ook met zoveel woorden uit art. 7:661 lid $1 \mathrm{BW} .^{1444}$

Deze bepaling van het arbeidsrecht heeft alleen betrekking op gevallen waarin op de (collega)werknemer rechtstreeks aansprakelijkheid rust jegens de werkgever. Daarvan is in de onderhavige gevallen niet spoedig sprake omdat het veroorzaken van letselschade alleen aansprakelijkheid oplevert jegens de benadeelde zelf en niet ook jegens anderen die daarvan schade ondervinden (zie paragraaf 4.8). Art. 6:107 BW geeft evenwel een uitbreiding van aansprakelijkheid ten behoeve van derden die kosten maken ten behoeve van de benadeelde. Zou de werkgever de collega-werknemer aansprakelijk stellen

1440 Het (belangrijke) gebied van beroepsziekten blijft buiten beschouwing. Onder bedrijfsongevallen kan worden verstaan: de plotseling bij de arbeid optredende gebeurtenissen met snel darop volgend letsel of andere feitelijke schade van degene die dat werk verrichtte.

144 Alleen collega's zijn uitgesloten, niet ook de inlenende werkgever. Het collegaverweer geldt, merken Hartlief \& Van Maanen (1996) en Storm (1996) op, ondanks de ruime formulering (geen regres 'indien de aansprakelijke een werknemer is') alleen voor werknemers van de regresnemende werkgever zèlf.

1442 Ant. 6:70 respectievelijk $170 \mathrm{BW}$. In het laatste geval (kwalitatieve aansprakelijkheid van ant. 170) moet het gaan om fouten in de zin van art. $162 \mathrm{BW}$ indien de werkgever over de bewuste gedragingen zeggenschap had en de kans op deze fout door cen door hem opgedragen taak is vergroot.

1443 Ant. 7:661, lid 2 BW.

144 Daarin wordt bepaald dat werknemers behoudens opzet of bewuste rockeloosheid niet aansprakelijk zijn jegens hun werkgever voor schade die ze in dienstverband toebrengen aan de werkgever dan wel aan derden jegens wie de werkgever tot schadevergoeding gehouden is. De tweede volan lat ruimte voor een afwijkende regeling maar niet ten nadele van WA (AVB)-verzekerde werknemers (zie lid 2). 
op de voet van art. 6:107 BW (dan wel rechtstreeks uit hoofde van de arbeidsovereenkomst, voor bedrijfsschade die losstaat van het letsel), dan vindt hij art. 7:661 BW op zijn weg. ${ }^{1425}$

Ook met het oog op preventie lijkt meer te zeggen voor de afschaffing van het werkgeversverweer. Deze beperking van het regres is uiteraard met name van belang bij arbeidsongevallen. ${ }^{1446}$ Voor de werkgever zal dan reeds een belangrijke prikkel tot het voorkomen van arbeidsongevallen gelegen zijn in het risico op bedrijfsschade als gevolg van deze ongevallen. Het productieproces kan gevaar lopen, een belangrijk deel van de schade bij arbeidsongeschiktheid komt voor rekening van het bedrijf en daarnaast bestaat er de dreiging van schadevordering als gevolg van het ongeval. Door het maken van een risicoanalyse moet dan worden onderzocht of de schade beter kan worden toegerekend aan de werkgever of voor rekening moet worden gelaten van de werknemer zelf. Het lijkt het goedkoopst dit schaderisico te laten verzekeren door de werkgever en niet de werknemer. Niet alleen is de werkgever veelal beter dan zijn werknemers in staat het schaderisico in zijn bedrijf goed in te schatten, de werkgever is bovendien veelal geëquipeerd algemene en meer structurele voorzorgsmaatregelen te treffen om de schade te voorkomen. Bovendien beschikt de werkgever veelal reeds over een bedrijfspolis en is hij beter in staat de extra kosten verbonden aan dit schaderisico te spreiden door het bijvoorbeeld door te berekenen aan zijn afnemers. ${ }^{1447}$ Dit zou een argument kunnen zijn voor afschaffing van het collega en werkgeversverweer.

Bovendien beschikken de meeste werkgevers over een WA-bedrijfspolis en zijn de preventiemaatregelen van WA-verzekeraars minimaal. Van Dam wijst in het kader van preventie in zijn algemeenheid op het belang van het doorberekenen van het schaderisico in de WA-premie. Bij arbeidsongevallen kan dit risico vrij nauwkeurig worden doorberekend. Het aantal schadegevallen uit het recente verleden is vrij nauwkeurig vast te stellen en levert redelijk betrouwbare gegevens op voor de nabije toekomst. ${ }^{1448}$ Van Dam wijst evenwel op factoren die aan een zuivere doorberekening van de schade in de WA-premies in de weg staan. Te denken valt aan minder vaak voorkomende maar kostbare schadevoorvallen (waardoor de gegevens op basis waarvan de premie wordt berekend minder betrouwbaar kunnen zijn), maar ook meer algemeen aan de invloed van concurrentieoverwegingen op het premieprijsbeleid. ${ }^{1449}$ Bovendien is niet alle schade in de WA-premies

1445 Voor gevallen van medeschuld (gevallen waarin de werkgever ook zèlf aansprakelijk is) geeft art. 6:170 lid 3 BW een vergelijkbaar principe: de interne draagplicht rust dan behoudens opzet of bewuste roekeloosheid van de (collega)werknemer volledig op de werkgever, zij het dat dit alleen geldt indien de werkgever kort geargd zelf in die gevallen ook enig verwijt treft.

Zie Conclusie A-G Ten Kate bij HR 7 november 1975, NJ 1976, 332 nt. ARB (Ziekenfonds/Nationale Nederlan: den).

1447 Calabresi (1970), p. 244-245.

1448 Van Dam (1989), p. 225.

1449 Van Dam (1989), p. 224. Een toenemend aantal schadeverzekeraars leidt, mede als gevolg van de Europese anti-kartelwetgeving, in beginsel tot een toenemendeconcurrentie (daargelaten de invloed van concemverhoudingen); zie Oosenbrug ea. (1996), p. 29. Met name in de branches waar het schadeverloop moeilijk voorspellatar is, spelen marktcondities een grote rol (a.w., p. 42). 
verdisconteerd, onder meer niet doordat niet alle slachtoffers met een potentiële vordering tot schadevergoeding deze vordering geldend maken en doordat geen rekening wordt gehouden met maatschappelijke kosten van schadevoorvallen, zoals (de kosten van) het verlies van levens, filevorming en de belasting van de (sociale) hulpverlening. ${ }^{1450}$ Bovendien zegt Van Dam moet, voor een goede beheersing van de primaire kosten, de premie 'niet alleen een afspiegeling zijn van de collectieve maar ook van het individuele verzekeringsrisico.' De WAM-verzekeraars zoeken aansluiting bij het feitelijk risico door rekening te houden met de kilometerstand en dergelijke; voor andere WA-verzekeringen kan dat lastiger zijn. ${ }^{1451}$ Voor premiedifferentiatie bij bedrijfspolissen moet onder meer rekening worden gehouden met de omvang en de aard van de werkzaamheden van het bedrijf.

Voor het regresrecht van de Verhaalswet ongevallen ambtenaren geldt geen collegaverweer; overheidsinstanties die uitkeringen doen aan ambtenaren of loon moeten doorbetalen hebben in dit opzicht dus een onbeperkt recht op verhaal. ${ }^{1452}$ In het arrest Zwolsche Algemene/Staat raakten twee militairen langdurig arbeidsongeschikt als gevolg van het verkeersongeval waarvoor een derde, collega-militair, die bij het ongeval was overleden aansprakelijk was. De aangesproken WAMverzekeraar van de derde stelde zich op het standpunt dat aansprakelijkheid van de derde ontbrak omdat anders zijn eigen aanspraak op een ongevallenuitkering geheel of gedeeltelijk door zijn schuld teniet zou worden gedaan. De Hoge Raad oordeelde dat voor die stelling in de geschiedenis en strekking van de Verhaalswet ongevallen ambtenaren geen aanknopingspunt was te vinden. Ook meer recent heeft de raad dit bevestigd. ${ }^{1453}$ Opmerking verdient dat, nu voor regres in het kader van de WAMIL aansluiting moet worden gezocht bij de regresbepalingen van de Ziektewet en de WAO, het regres op collega-militairen door overeenkomstige toepassing van art. $52 b$ van de Ziektewet en art. 91 WAO beperkt is tot opzet of bewuste roekeloosheid van de betrokken collega-militair (en de invulling van deze criteria in de praktijk). ${ }^{1454}$

Annotator Mijnssen is kritisch over het eindresultaat: een ongelijke behandeling van in wezen gelijke gevallen. Die ongelijkheid geldt zelfs voor individuele gevallen nu ambtenaren immers onder de werking van de sociale werknemersverzekeringen zijn gebracht. Maar volgens Mac Lean wordt de overheid beperkt in het regresrecht van de Verhaalswet ongevallen ambtenaren door de bijzondere regeling van de interne draagplicht tussen ondergeschikten en degene in wiens dienst ze stonden

\footnotetext{
1450 Van Dam (1989), p. 225.

1451 Van Dam (1989), p. 226.

1452 In die zin HR 29 juni 1979, NJ 1980, 33 (Zwolsche Algemene/Staat); HR 10 december 1993, NJ 1995, $493 \mathrm{nt}$. CJHB (Gemeente Haarlem/ABP). Zie daarover kritisch Van Boom (2000a), p. 83.

1453 HR 10 december 1993, NJ 1995, 493 nt. CJHB (Gemeente Haarlem/ABP).

1454 HR 20 mei 1983, NJ 1984, 649 nt. FHJM (Bedrijfsvereniging/Brok). Annotator Mijnssen wijst er daarom op dat dit niet betekent dat de Hoge Raad is teruggekomen van zijn standpunt over de VOA in Zwolsche Algemene/Staat.
} 
in het Burgerlijk Wetboek (art. 6:170 lid $3 \mathrm{BW}$ ). Indien de ondergeschikt, en degene in wiens dienst hij stond beiden voor de schade aansprakelijk zijn beheft de ondergeschikte in hun onderlinge verhouding niet aan de schadevergoeting bij te dragen, tenzij de schade een gevolg is van zijn opzet of bewuste roekelıosheid of, mede gelet op de aard van hun verhouding, uit de omstandighedenvan het geval anders voortvloeit. Onder deze bepaling valt ook de overheid als ambtnarenwerkgever. ${ }^{1455}$ Overigens pleiten Van Boom en Storm voor uniformeing van de wettelijke regresregelingen op dit punt. Zij doen de suggestie aansluting te zoeken bij art. $2 \mathrm{VOA}$, in die zin dat het regres niet ten nadele van de benadelde mag worden uitgeoefend. ${ }^{1456}$

\subsection{Concurrerende vorderingen}

\subsubsection{Drie standaardregelingen}

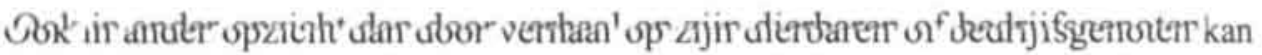
de benadeelde hinder ondervinden van het regres. Wat is rechtens indien de regresvordering en de vordering van de benadeelde samenlopen en daarbij in een concurrerente positie komen te verkeren omdat het te verhalen bedrag ontoereikend is? Dit laatste kan verschillende redenen hebben. De omvang van aansprakelijkheid kan lager zijn dan de totale schade die voor rekening is gekomen van regresnemer en benadeelde. Denk aan gevallen waarin sprake is van eigen schuld of rechterlijke matiging van de schadevergoeding. Ook kan de schadeveroorzaker insolvent zijn en niet WA-verzekerd, en als gevolg daarvan niet in staat zijn het totale bedrag waarvoor hij aansprakelijk is te voldoen. Welke rangorde geldt in deze gevallen tussen regresnemer en benadeelde?

Een voorbeeld kan dit illustreren. ${ }^{1457}$ De Groot is tijdelijk arbeidsongeschikt geraakt als gevolg van het ongeval en heeft daarvoor nog recht op smartengeld, 2000 Euro. Zijn werkgever heeft het loon moeten doorbetalen en andere kosten moeten maken, tezamen voor 20000 Euro en zoekt daarvoor verhaal. Voor het loon heeft hij het regresrecht van art. 6:107a $\mathrm{BW}$, voor de overige kosten recht op schadevergoeding ingevolge art. 6:107 BW. De aansprakelijkheid beloopt slechts $50 \%$ van de totale schade in verband met eigen schuld: 11000 Euro. Drie standaardregelingen zijn mogelijk: 
De vordering van de benadeelde gaat voor boven de regresvordering (De Groot ontvangt in dit systeem 2000 Euro, de werkgever ontvangt 9000 Euro).

De vordering van de regresnemer gaat voor boven de vordering van het slachtoffer (de werkgever ontvangt 11000 Euro, De Groot krijgt niets)

Beide claims worden gelijk verdeeld, ieder heeft recht op $50 \%$ van de schade (de werkgever ontvangt 10000 Euro, De Groot ontvangt 1000 Euro)

\subsubsection{Afdeling 7.17.2 BW, art. 2 VOA, art. $90 \mathrm{WAO}$}

De vraag welke van deze regelingen het meest wenselijk is, houdt de meningen in binnen- en buitenland al jaren verdeeld. Wel constateerde Fleming in zijn belangrijke rechtsvergelijkende studie voor de International Encyclopedia of Comparative Law in 1970 dat regresvorderingen van sociale verzekeraars in een aantal landen voorrang hadden boven de vordering tot schadevergoeding van de benadeelde. ${ }^{1458}$ Dat lijkt opmerkelijk, maar ook onder het regime van de Ongevallenwet gold dat als de regresvordering van de Centrale Werkgevers Risicobank concurreerde met die van de benadeelde, de laatste genoegen moest nemen met het resterende bedrag. Door het regres liepen werknemers bij arbeidsongevallen dus het risico dat een deel van hun schade onvergoed bleef.

In het licht van de wijzigende maatschappelijke inzichten in het aansprakelijkheidsrecht en in sociaal-economische verhoudingen (zoals de verhouding tussen werkgever en werknemer) lijkt die opvatting wat ouderwets. Voor een aantal regressituaties gelden juist wettelijke voorrangsregeling ten behoeve van de benadeelde. Zo bepaalt de subrogatieregeling voor schadeverzekeraars van afdeling 7.17.2 $\mathrm{BW}$ dat de verzekeraar de vordering waarin hij is gesubrogeerd of die hij door overdracht heeft verkregen niet kan uitoefenen ten nadele van het recht op schadevergoeding van de verzekerde. ${ }^{1459}$ Hoewel het er niet met zoveel woorden staat lijkt de bepaling zo te worden verstaan dat de vordering van de benadeelde voorgaat. ${ }^{1460}$ Al veel langer bepaalt ook art. 2 van de Verhaalswet ongevallen ambtenaren dat het regres niet ten nadele van de betrokken amtenaar kan worden uitgeoefend. Uit de wordingsgeschiedenis blijkt dat deze bepaling zo moet worden uitgelegd, dat de vordering van de benadeelde bij insolventie van de aansprakelijke door

1458 Fleming (1970), p. 40. Voor het regesrecht van particuliere verzekeraars was Fleming's conclusie met betrekking tot de door hem onderzochte rechtsstelsels juist het omgekeerde: dan gaat de vordering van de benadeclde veelal vóor.

1499 Art. 7.17.2.25 lid 2 BW.

$1460 \mathrm{Vgl}$ ook met zoveel woorden Van Boom (2000a). p. 99 
het regres geen vermindering kan ondergaan, zelfs geen evenredige vermindering. ${ }^{1461}$ In de praktijk geldt dat indien het voor de benadeelde als gevolg van een eerdere regresactie van BSA Schaderegeling onmogelijk blijkt vergoeding te krijgen voor het onverzekerde deel van de schade, hij dit deel van BSA kan vorderen. Nu ook ambtenaren inmiddels onder de bescherming van de sociale verzekeringen vallen, valt er wellicht veel voor te zeggen hun die bescherming niet te laten verliezen (voor het deel van de uitkeringen dat thans van de sociale verzekeringen komt).

Voor sociale verzekeraars en voor gewone werkgevers ontbreekt een wettelijke regeling op dit punt echter. ${ }^{1462}$ Aangenomen wordt echter wel dat de vordering van de benadeelde voorrang heeft. ${ }^{1463} \mathrm{Al}$ bij de invoering van de WAO is op aandringen van de kamerfracties door de Sociale Verzekeringsraad een circulaire uitgegaan waarin het belang werd benadrukt van een redelijke wijze van het regresrecht gebruik te maken en voorts gesteld dat de regresregeling zonodig, indien de uitvoering ervan in de praktijk tot onbevredigende resultaten zou leiden, zou worden aangepast. ${ }^{1464}$ In de praktijk lijken sociale verzekeraars de vordering van de benadeolde in hot algemeon inderdaad corot to later gaan dau wel ecin bedrag van hun regresopbrengsten voor hem te reserveren. ${ }^{1465}$

\subsubsection{Onduidelijkheid}

Uit het al genoemde rapport van de Algemene Rekenkamer uit 1996 blijkt dat hierover onder ziekenfondsen enige onduidelijkheid heeft bestaan. ${ }^{1466}$ Zeven van de negen onderzochte ziekenfondsen gaf aan bij ontoereikende aansprakelijkheid voorrang te geven aan de vordering van de benadeelde, maar twee fondsen lieten de eigen regresvordering voorgaan. Een 'harde' wettelijke regeling lijkt op dit punt niet overbodig, dat zou meer zekerheid kunnen bieden van een uniform beleid en voor de benadeelde het voordeel hebben van afdwingbaarheid. Bovendien lijkt in het 'kamp' van sociale verzekeraars soms aan de redelijkheid van voorrang voor de vordering van de benadeelde te worden betwijfeld. ${ }^{1467}$ Men wijst daartoe op het eerdergenoemde voorbeeld dat voor 12000 Euro schade ontstaat, waarvan 10000 Euro verzekerd is (waarvoor het regres plaatsvindt) en 2000 Euro niet. Bij een voorrangsregeling voor regresnemers blijft bij $50 \%$ eigen schuld niets over voor de benadeelde. Volgens de voorstanders daarvan is dat echter niet onredelijk omdat de benadeelde bij het ontbreken van de uitkering maar recht zou hebben

1461

TK $1964-65,7812$, p. 3-4.

Van Boom (2000a), p. 98 bestrijdt, terecht dunkt mij, dat de bewoordingen van de zelfstandige regresrechten op enige voorrangsregeling zouden duiden.

Vgl. Inv, 6, p. 1285. Zo ook de Hoge Raad inzake HRI0 maart 1995, NJ 1997, $525 \mathrm{nt}$. MMM (TUS/lepenburg). Circulaire SVR 27 november 1967, nr. 333.

TK 1989-90, 21 528, nr. I. p. 17; Hartlief \& Tjittes (1999), p. 107; Van Boom (2000a), p. 98. Algemene Rekenkamer (1996), ook opgenomen in TK 1996-97, 25 025, nr. 2.

Boot \& De Waal (1991), p. 175. 
op 6000 Euro en hij al voor 10000 Euro door de regresnemer is vergoed. ${ }^{1468}$ Daar valt uiteraard op af te dingen. Het deel van de schade dat al door de regresnemer is vergoed staat immers los van het deel van de schade waarvoor de benadeelde recht op schadevergoeding heeft van de schadeveroorzaker. Overigens maakt het nog verschil of, net als voor niet-concurrerende regresclaims, een sommenstelsel geldt of dat het regresrecht beperkt is tot de schadeposten waaraan de uitkering waarvoor het regres plaatsvindt moeten worden gerelateerd. ${ }^{1459}$ Is dat het geval dan blijft ook de voorrang van de regresnemer beperkt tot de schadepost waarop de door hem verstrekte uitkeringen betrekking hadden.

In de rechtsliteratuur heeft de regeling waarbij de resterende vordering van de benadeelde voorrang heeft voor die gevallen waarin de aansprakelijke onvoldoende verhaal biedt, meer voorstanders. ${ }^{1470} \mathrm{Bij}$ het regres van verzekeraars pleit voor de voorrang van de benadeelde uiteraard dat de verzekeraar zich tegen premieafdracht heeft verbonden tot vergoeding van de volledige schade van de benadeelde. Fleming meent dat het tekort daarom eerder tot zijn (bedrijfs)risico behoort dan het verlies van de benadeelde. Het heeft zijn voorkeur hetzelfde regime te laten gelden voor regres in het kader van de sociale verzekeringen. Slachtoffers met hoge inkomens die voor het risico van inkomensschade een (vervangende) particuliere verzekering hebben afgesloten bij particuliere verzekeraars zouden anders in een voordeligere positie verkeren dan slachtoffers wier inkomen door sociale verzekeraars wordt vergoed. Het bezwaar tegen voorrang van de regresvordering van sociale verzekeraars boven de vordering van de benadeelde is bovendien, meent Fleming, ${ }^{1471}$ dat deze verzekeringen de benadeelde daarmee de facto minder dekking bieden voor zijn schade. De benadeelde ontvangt juist vanwege zijn verzekering minder dan hetgeen waartoe hij zonder regres gerechtigd zou zijn.

Er zijn ook voorstanders van een ponds-ponds verdeling bij samenloop van de regresvordering met de vordering van de benadeelde. ${ }^{1472}$ Een pondsgewijze verdeling klinkt vooral voor gevallen waarin de vorderingen concurreren omdat de aansprakelijke onvoldoende verhaal biedt. Een voorrangsregeling zou dan haaks staan op het uitgangspunt van paritas creditorum in de wettelijke rangorde ( $\mathrm{vgl}$. art. 3:277 BW). Dat zou ook voor de onderhavige gevallen een gelijke verdeling over alle crediteuren naar rato van ieders aandeel betekenen. Een buitenwettelijke preferentie ten behoeve van regresnemer of benadeelde wordt om die reden afgewezen. ${ }^{1473}$ Giltay Veth stelt dat voorrang in strijd zou zijn met het gesloten systeem

1468 Boot \& De Waal (1991), p. 175, zie reeds in dezelfde zin Giltay Veth (1969), p. 235.

1469 $\mathrm{Vgl}$. paragraaf 7.4 .1 .

1470 Zie in die richting Verwer (1970), p. 92; Van Boom \& Storm (1995), p. 158; vgl. ook Beekman (1995), p. 1231: Hartief \& Tjittes (1999), p. 107. Zie ook Van Boom (2000a), p. 99 waar gesproken wordt van een beginsel van algemene gelding dat de uitoefening van het regresrecht nimmer ten nadele van de benadeelde mag strekken.

1471 Fleming (1970), p. 40 merkt dit zijdelings op en zonder nadere toelichting.

1472 Daarover Clausing (1964), p. 414; en verdere verwijzingen bij Schadevergoeding, art. 108 (Bolt), aant 69.

1473 Schadevergoedingsrecht, ant. 108 (Bolt), aant. 69; zie Slagter (1963), p. 5; en Giitay Veth (1969), p. 236 en Van Boom (2000a), p. 98. 
van wettelijke preferentie en zekerheidsrechten. De wijze van berekening doet er niet aan af dat de 'samenlopende' vorderingen concurrent zijn. Ongeacht de wijze van berekening van het civiele plafond en het restbedrag (en de vraag of sprake is van een sommen- of postenstelsel) zijn beide vorderingen daarom in rangorde gelijk. ${ }^{1474}$ Genuanceerder is Slagter, die de oorzaak voor de ontoereikendheid van de omvang van aansprakelijkheid bij regres beslissend laat zijn: in rechterlijke matiging ziet hij reden voor een ponds-ponds verdeling, bij eigen schuld van de benadeelde past voorrang van de regresvordering. ${ }^{1475}$

\subsubsection{Voorstel algemene regel}

De heersende opvatting is zoals ik aangaf, dat de benadeelde voorrang heeft. ${ }^{1476}$ Ook op enkele plaatsen in de parlementaire geschiedenis wordt een voorkeur voor die regeling niet onder stoelen of banken gestoken. Zo kwam de kwestie in 1990 zijdelings aan de orde in een notitie over verkeersaansprakelijkheid. Oud-minister Hirsch Ballin noemt als bezwaar van een aansprakelijkheidslimiet voor verkeersaansprakelijkheid dat de benadeelde door het regres van sociale verzekeraars een deel van zijn schade onvergoed zou kunnen zien. ${ }^{1477}$ Zou men overgaan tot het invoeren van een limiet voor aansprakelijkheid dan zou daarbij tevens een voorrangsregeling voor de benadeelde moeten worden opgenomen. Dat zou volgens de minister tevens overeenstemmen met de praktijk van sociale verzekeraars. ${ }^{1478} \mathrm{Ik}$ kan me, uitgaande van de ratio en functie die het regres in mijn visie heeft, ${ }^{1479}$ hierin vinden. Wat mij betreft valt niet in te zien waarom het recht op schadevergoeding van de benadeelde van het regres beperking zou moeten ondergaan. De aanleiding van het regres ligt nota bene bij de gedachte dat moet worden voorkomen dat de benadeelde dubbel wordt vergoed voor zijn schade.

In een voorontwerp voor art. 6:107 BW uit 1982 is een poging gedaan tot een algemene regeling. Gekozen werd toen voor een algemene voorrangsregeling voor de benadeelde die luidde:

Aanspraken van derden ter zake van als gevolg van het letsel geleden schade, daaronder begrepen vorderingen tot verhaal, die krachtens wet, subrogatie of overdracht aan de derde toekomen, kunnen niet ten nadele van het recht op schadevergoeding van de gekwetste worden uitgeoefend. ${ }^{140}$

Giltay Veth (1969), p. 236.

Slagter (1963), p. 194.

Koster (1971), p. 134; Van Boom (2000), p. 42.

TK 1989.90, 21 528, nr. I, p. 16.

TK 1989-90, 21 528, nr. I, p. 17 onder verwijaing naar een enquete uit 1975 waarbij betrijfsverenigingen stelden de vordering van de benadeelde voorging 'dan wel een belangrijke rol diende te spelen'.

Met name in paragraaf 5.3.6.

Art. 6.1.9.11a, tweede lid van het ontwerp voor de Invoeringswet van Boeken 3-6 van het BW, zie Inv. 6. p 1277 e.v. 
De bepaling was bedoeld voor de al genoemde gevallen waarin de schadeveroorzaker onvoldoende verhaal bood of de aansprakelijkheid ontoereikend was, en dus een rangordeprobleem ontstond. ${ }^{1481}$ Daarbij werd het wenselijk geacht om de voorrang zoveel mogelijk voor alle soorten aanspraken van derden gelijk te regelen. ${ }^{1482}$ Doorslaggevend voor deze keuze werd geacht 'dat het belang van de benadeelde het zwaarst behoort te wegen en dat deze niet de dupe behoort te worden van het feit dat de wetgever ook aan derden een aanspraak toekent ter zake van schade die op de veroorzaking van zijn letsel is terug te voeren, zonder dat deze derden zelf letselschade hebben opgelopen.' Kennelijk heeft de minister hierbij alleen gedacht aan de verhouding tussen de regresnemer en de benadeelde zelf en niet aan de verhouding tussen regresnemers en de andere benadeelden met recht op schadevergoeding ingevolge art. 6:107 of 108 lid 2 BW. Krijgen ook zij in de verhouding tot hun regresnemende verzekeraar dezelfde bescherming bij insolventie van de schadeveroorzaker? Met de argumentatie van de minister lijkt het daar niet op. De derden van art. 6:107 en 108 BW hebben immers zèlf evenmin letsel opgelopen als de regresnemer en alleen de vordering van degene met het letsel krijgt van de minister prioriteit. ${ }^{1483}$ Toch laten dezelfde vragen zich binnen die verhouding stellen. Heeft de vordering van de schadeverzekeraar van ouders die een deel van de naar hen verplaatste schade voor zijn rekening neemt wèl voorrang boven hun vordering voor het restant van die verplaatste schade (art. 6:107 BW)? En kan de vordering van de begrafenisverzekeraar ten koste gaan van de restvordering van de nabestaanden ingevolge art, 6:108 lid 2 BW? En die van de bedrijfsverzekeraar ten koste gaan van de restvordering van de werkgever ingevolge art. 6:107 of 6:107a BW? Het antwoord luidt voor al deze gevallen ontkennend. Het verzekeringsrecht geeft naar komend recht een regeling waarin de vordering van de verzekerde voorgaat op de regresvordering van zijn schadeverzekeraar. ${ }^{1484}$ Beschermd wordt niet zozeer degene met het letsel, maar 'de verzekerde' en dat kunnen óók de derden zijn van art. 6:107, 107a en 108 BW.

$\mathrm{Er}$ is veel voor te zeggen deze derden dezelfde bescherming te bieden indien hun vordering concurreert met die van hun sociale verzekeraar of werkgever. Ook de regresvordering van de Sociale Verzekeringsbank zal bij een insolvente schadeveroorzaker plaats moeten maken voor de vordering van de nabestaanden van art. 6:108 BW. De benadeelden van art. 6:107 en 108 BW verdienen in hun verhouding tot hun regresnemende verzekeraars dezelfde bescherming als de benadeelde. Dat sluit aan bij de voorrangsbepaling van het schadeverzekeringsrecht (en van art. 2 VOA) en komt de eenvoud ten goede: sociale verzekeraars hoeven er dan, net als particuliere verzekeraars, niet op te letten in welke hoedanigheid de benadeelde

\footnotetext{
1481 Inv. 6. p. 1284

1482 Inv. 6, p. 1285.

1483 Bovendien strekte de voorgestelde regeling juist entoe om hun vordering, evenzeer als die van de fegresnemer, achter te stellen bij die van de gekwetste.

1484 Art. 7.17.2.25 tweede lid BW bepaalt namelijk dat het regres niet ten koste mag gaan van de verzekerde.
} 
zijn vordering aan het aansprakelijkheidsrecht ontleent (als primair slachtofier, als derde met verplaatste schade of als nabestaande). De regeling zou dus als volgt moeten luiden:

Aanspraken van derden terzake van als gevolg van het letsel of overlijden geleden schade, daaronder begrepen vorderingen tot verhaal, die krachtens wet, subrogatie of overdracht aan de derde toekomen, kunnen niet ten nadele van het verhaalsrecht ingevolge art. 6:107, 107a of $108 \mathrm{BW}$ worden uitgeocfend. . . $^{4}$

Tot slot verdient opmerking dat de voorrang van de benadeelde alleen geldt voor gevallen van insolventie van de schadeveroorzaker en niet ook het materiële recht voor hem gunstiger maakt. Over deze laatste kwestie heerst onduidelijkheid die zijn oorsprong vindt in een misverstand dat kort na de inwerkingtreding van de WAO is ontstaan. Het geijkte voorbeeld is weer dat de benadeelde voor 10000 Euro recht heeft op een WAO-uitkering en nog maar voor 2000 Euro zelf schade heeft, terwijl voor $50 \%$ sprake is van eigen schuld. Clausing verdedigde met argumenten ontleend aan de parlementaire geschiedenis van de WAO dat de benadeelde dan ook in die zin voorrang heeft dat zijn eigen schuld volledig ten laste moet komen van de regresnemer. Op diens regresvordering voor 10000 Euro zou dan de totale eigen schuld in mindering moeten komen (dus 50\% van 12000 Euro $=6000$ Euro) ${ }^{1486}$ Dat lijkt me geen wenselijk systeem. De benadeelde heeft immers $50 \%$ van de betrokken schade zelf veroorzaakt. Voor het (mede)veroorzaken van schade die onder de reikwijdte valt van verzekeringen waarvoor een regresrecht geldt, zou dan dus een gunstigere wijze van toerekening gelden dan voor onverzekerde schade.

Clausing en latere voorstanders hiervan verwijzen naar opmerkingen in die richting bij de invoering van de WAO. De regeling van het civiele plafond en het restbedrag is toen in verband gebracht met de situatie dat de omvang van aansprakelijkheid bijvoorbeeld door eigen schuld van de benadeelde of rechterlijke matiging niet toereikend is. ${ }^{1487}$ Uit de evenbedoelde passage volgt echter niet noodzakelijk dat de eigen schuld van de benadeelde volledig ten laste moet komen van de regresnemer. Wat de regeling van het restbedrag slechts doet is: ook bij eigen schuld voorkomen dat de aansprakelijke dubbel komt te betalen. In het genoemde voorbeeld immers voorkomt de regeling dat de regresnemer zich voor 6000 Euro (het totale civiele plafond) zou kunnen verhalen. Minstens even aannemelijk is dat dàt is wat minister Veldkamp met zijn verwijzing naar de noodzaak van een regeling voor samenloop bij eigen schuld heeft bedoeld.

Het door Clausing en anderen gestelde moet naar geldend recht worden verworpen: het percentage eigen schuld treft regresnemer en benadeelde beide in dezelfde 
mate ( $50 \%$ van de regresvordering en $50 \%$ van de vordering van de benadeelde). Ook zonder het regres zou de benadeelde zich het beroep op de eigen schuld moeten laten welgevallen. In dit opzicht ondervindt hij van de regresvordering dan ook geen nadeel (en de regresnemer evenmin van hem nu voor de aansprakelijke bij regres dezelfde verweren gelden als daarbuiten). ${ }^{1488}$

\subsection{Andere verhaalsacties}

\subsubsection{Normale onrechtmatige daadsactie}

De wettelijke regresrechten worden zo uitgelegd, dat zij een limitatieve opsomming geven van de kring van verhaalsgerechtigden buiten de grenzen die het aansprakelijkheids- en schadevergoedingsrecht zelf daarvoor geven. ${ }^{1489}$ Denk aan kosten die exclusief thuishoren in de sfeer van de schadedrager en waarvoor geen regres mogelijk is, zoals het brutodeel van het doorbetaald loon. ${ }^{1490}$ De vraag is dan of in deze gevallen plaats is voor een rechtstreeks beroep op het aansprakelijkheidsrecht. ${ }^{1491} \mathrm{Te}$ denken valt ook aan de schadedragers die uitgesloten zijn van de wettelijke regresregelingen, met name particuliere verzekeraars die sommenuitkeringen verstrekken, bepaalde sociale verzekeraars en vrijwel alle verstrekkers van sociale voorzieningen (zie paragraaf 4.6). Er lijkt geen goede reden verzekeraars met of zonder regresrecht te beperken in hun recht om een 'normale' actie in te stellen, mits uiteraard aan de voorwaarden daarvoor is voldaan. Een uitzondering geldt in beginsel slechts indien men verhaal zoekt bij de categorieěn personen die van het regres zijn uitgesloten; voorzover die uitsluiting geldt, is ook geen normale verhaalsactie mogelijk. Die mogelijkheid bestaat uiteraard wèl indien de schade waarvoor men vergoeding vraagt losstaat van de verhouding tussen verzekerde en verzekeraar.

Zoals bekend, is een beroep op het aansprakelijkheidsrecht naar aanleiding van een schadevoorval dat tot eens anders letsel of overlijden heeft geleid in beginsel uitgesloten. Voor het onrechtmatige daadsrecht geldt dat in de meeste gevallen het relativiteitsvereiste aan de mogelijkheid van een normale, rechtstreekse vordering tot schadevergoeding in de weg zal staan. Bij schuldaansprakelijkheid wordt de geschonden norm verondersteld de belangen van een ieder te beschermen, tenzij de gedaagde het tegendeel aantoont (art. 6:163 BW). Voor direct getroffenen levert

1488 In die zin ook $\ln$. 6, p. 1286.

1489 HR 17 januari 1958, NJ 1958, 80 (Sociale Versekeringabank/Snijden). Zie voor de darvoor gekozen systematick paragraaf 4.9.1-4.9.3.

1490 Zie A-G Van Lier in zijn conclusie voor HR 24 januari 1930, NJ 1930, p. 300 en voorts de literatuur vermeld bij Bloembergen (1965), nt. 3 op p. 386.

1491 Zwalve (1993), p. 142 laat zien dat de mogelijkheid van een rechtstreekse actie voor de schadeverzekeraar reeds ter sprake komt in de eerste gemeenrechtelijke literatuur, warin de schadeverzekeraar op basis van aldaar aangehaalde Digestenplaatsen een zelfstandige actie had uit onrechtmatige daad. 
dat in beginsel geen bijzondere problemen op. ${ }^{1492}$ Dat is echter anders bor schadeverzekeraars, ${ }^{1493}$ zo volgt uit het bekende Brandstichting-arrest ${ }^{1494}$ De schadeverzekeraar beriep zich op verrekening van de door hem verschuldizde schadeuitkering met het recht op schadevergoeding dat de verzekeraar stelé te hebben jegens de echtgenote die de brand had gesticht en met wie de verzekrde in gemeenschap van goederen is getrouwd. Volgens rechtbank en hof wa: de brandstichting jegens de verzekeraar niet onrechtmatig. De Hoge Raad stelt vocop dat de vrouw geschreven en ongeschreven betamelijkheidsnormen heeft overtreen, maar stelt dat deze niet strekken ter bescherming van het belang van de branderzekeraar om niet te hoeven uitkeren. Dat zou slechts anders zijn indien daaniee het oogmerk heeft bestaan om de verzekeraar te benadelen.

Schadeverzekeraars wordt hiermee dus niet de mogelijkheid van een zelfstancige actie als zodanig ontzegd, geoordeeld werd alleen dat het onrechtmatig handien jegens de verzekerde, buiten gevallen van opzet gericht op de verzekeraar alf, niet ook een onrechtmatige daad oplevert jegens de verzekeraar. De Hoge Rad geeft een invulling van het relativiteitsvereiste; als zodanig lijkt het arrest lan

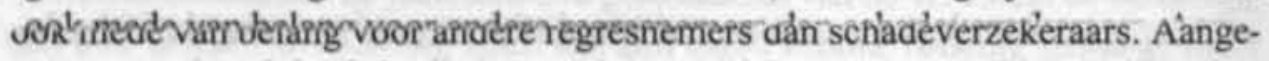
nomen wordt wel dat de beslissing van het arrest bij sommenverzekering niet anders zou zijn geweest. ${ }^{1495}$ Ook kan worden aangenomen dat de mogelijkheid van een rechtstreeks beroep op gronden voor risicoaansprakelijkheid ontbreekt. Bij de schending van normen die wèl specifiek bedoeld zijn ter bescherming van de belangen van de verzekeraars zelf, los van de verzekerde, is in beginsel nog wel plaats voor een onrechtmatige daadsactie. Gedacht moet worden aan het geval dat de Hoge Raad ook zelf al noemde in het Brandstichting-arrest, namelijk opzettelijke benadeling van de verzekeraar.

\subsubsection{Een 'super' beperkende uitleg}

Zelfs als daarvan al aantoonbaar sprake is lijkt nog een beperking besloten te liggen in de beperkende uitleg die de Hoge Raad geeft aan art. 6:107 en $108 \mathrm{BW}$. Zoals gezegd zijn de mogelijkheden voor een normale, rechtstreekse vordering tot schadevergoeding bij personenschade vanwege de gesloten kring van vergoedingsgerech-

Bij zaakschade kunnen ook derden gemakkelijk rechtstreeks in hun belang worden aangetast, denk aan zakelijk gerechtigden, huurders en huurkopers. Het relativiteitsvereiste staat dan niet aan vergoeding in de weg, zie HR 18 december 1987, NJ 1988, 439 nt. G. (Amro/Joy Coats); Asser-Hartkamp L, p. 372 en Bloembergen (1965), nt. 102, nt. 5 .

Anders in Frankrijk waar de sociale verzekeraar vóór de Lol Badinter volgens vaste jurisprudentic een zelfstandige vordering uit onrechtmatige daad toekwam tegen de schadeveroorzaker. De werkgever kon zich verhalen voor het doorbetaald loon; niet duidelijk was of ook vergoeding van bedrijfsschade kon worden gevorderd HR 24 januari 1930, NJ 1930, 299 nt. EMM; Asser-Hartkamp 4-III, nr. 102; Spier e.a (2000), nr. 59 (Van Maanen): Schadevergoedingsrecht, art. 107 (Bolt), aant. 51; Mijnssen (1970), p. 6; Mulder (1988), p. 29. 
tigden immers beperkt. ${ }^{1496}$ Alleen het primaire slachtoffer zelf en een beperkte groep andere benadeelden heeft recht op schadevergoeding. Voor een normaal, rechtstreeks beroep op het aansprakelijkheidsrecht is alleen plaats voor schadevergoeding voor schade die niet is gerelateerd aan het letsel of overlijden. ${ }^{1497} \mathrm{Om}$ die reden heeft het bestuur van de Nederlandse Vereniging van Ongevallen- en Ziekteverzekeraars zijn leden geadviseerd om, zolang ongevallenverzekeraars van regres krachtens art. $284 \mathrm{WvK}$ zijn uitgezonderd, af te zien van de overige juridische mogelijkheden waarmee verhaal op de aansprakelijke zou kunnen worden uitgeoefend. ${ }^{1998}$ Volgens de Hoge Raad echter geldt de exclusiviteit van art. 6:107 BW (en van art. 1407 oud) óók als derden op een andere grond dan enkel het veroorzaken van andermans letsel een beroep doen op het aansprakelijkheidsrecht. ${ }^{1499}$

Eigenlijk liggen in deze uitleg van de Hoge Raad twee beperkingen besloten. De Hoge Raad geeft in de eerste plaats een beperking van art. 6:107 BW, dat wil zeggen dat het recht op vergoeding wegens het veroorzaken van letsel alleen toekomt aan degene met het letsel. Art. 6:107 BW is met andere woorden exclusief en dus limitatief: de aansprakelijkheid wegens het veroorzaken van letsel geldt uitsluitend ter bescherming van degene met het letsel. Een hierop gebaseerd beroep op art. 6:162 BW van anderen dan degene met het letsel is uitgesloten. Te denken valt dan aan door het letsel gedupeerde opdrachtgevers van de benadeelde of werkgevers met bedrijfsschade, maar ook aan ongevallenverzekeraars, werkgevers of de partner van de benadeelde die zijn schade voor hun rekening hebben genomen. Voorts geeft de Hoge Raad met zijn uitleg een nog verdergaande, 'super'- beperking van art. 6:162 BW, want de derde kan het aansprakelijkheidsrecht ook op andere gronden niet inroepen als zijn schade, al dan niet toevallig, verband houdt met het letsel van de benadeelde. Ter illustratie, werkgevers die productieverlies lijden door het toedoen van een concurrent hebben daarvoor, mits aan alle voorwaarden voor aansprakelijkheid is voldaan, recht op vergoeding tenzij de concurrent aannemelijk kan maken dat hij daarbij tevens schade heeft toegebracht aan de werknemers van het bedrijf en juist dit de oorzaak is van het productieverlies. ${ }^{1500}$

1496 Paragraf 4.8. Zie voor een vroeg voorbeeld Rb Rotterdam 20 maart 1930, W 1930, 12180, p. 6 (Van Luijk/Banis), waarin gedaagdeniet verplicht is de kosten die door de Gemeentelijke Dienst voor Maatschappelijk Hulpbetoon zijn gemaakt te vergoeden nu hem een rechtstreeks vorderingsrecht niet toekomt.

1497 Zie o.a. Knol (1985), p. 265; Bolt (1989a), p. 45.

1498 Van Bameveld (1984), p. 455.

1499 Eerst in HR 12 december 1986, NJ 1987, 958 nt. CJHB (Rockwool/Poly); vgl. eerder HR 16 juni $1972, N J$ 1972,375 (Van Wetten/Courtois). Affectieschade als gevolg van letsel en overijiden wordt overigens ook los van het exclusieve karakter van art. 6:107 BW niet vergoed, HR 8 april 1983, NJ 1984, $717 \mathrm{nt}$. CJHB (Van der Heijden/Holland). Inmiddels is een wetsvoorstel ingediend dat een beperkte kring naasten bij emstig letsel of overiijden recht geeft op een vast bedrag voor hun leed, TK 2002-03, 28 781, nr. 1-2.

1500 . Wat gekunsteld werd dit onder het oude recht met name bij bejockkosten. Dexe werden aangemerkt als verplaatste schade van de gekwetste (waarvoor de ouders als wettelijk vertegenwoordiger van het kind vergoeding konden vorderen). Vgl. ook HR 28 mei 1999, NJ 1999, 564 nt. ARB (Gemeente Losser/De Vries). 
Dit tweede, 'super'-beperkende aspect van 's raads uitleg van art. 6:107 BW en art. 1407 BW (oud) houdt kortom in dat voor derden tevens de weg afgesloten is van een op een andere grond dan het veroorzaken van letsel gebaseerd beroep op het aansprakelijkheidsrecht (voorzover hun schade mede het gevolg is van het letsel van een ander). Het is de vraag of een zo restrictieve uitleg van het exclusieve karakter van art. 6:107 BW ook door de wetgever is bedoeld. In de toelichting ontbreekt niet alleen elke verwijzing naar exclusiviteit die verder gaat dan het beperken van het recht op schadevergoeding wegens het veroorzaken van andermans letsel. Het aantal gevallen waarvoor deze tweede beperking in de praktijk van betekenis is, is waarschijnlijk overigens wel gering. Binnen de sfeer van zuivere vermogensschade valt met name te denken aan boze opzet zoals in het bovengenoemde voorbeeld van onrechtmatige concurrentie of aan het geval dat werkgevers bedrijfsschade ondervinden van het wegvallen van werknemers als gevolg van de overtreding van de hinderwetvergunning op een naburig perceel. ${ }^{1501}$ De superrestrictieve uitleg van de Hoge Raad geldt in beginsel ook voor gevallen waarin de derde van het aan de eerste veroorzaakte letsel zèlf letsel oploopt (en daanit voor hem materiële of immateriële schade ontstaat). Ook dan zal de veroorzaking van het letsel slechts bij uitzondering tevens - op een andere grond - jegens de derde zelf onrechtmatig zijn. Voor de meest schrijnende van deze gevallen, namelijk opzettelijke letseltoebrenging waarmee (tevens) wordt beoogd een ander te verdriet te doen of te traumatiseren, heeft de Hoge Raad deze uitleg inmiddels verlaten. ${ }^{1502}$ Ook wel wordt de super-beperking ingeval van trauma door andermans letsel omzeild, door het trauma te kwalificeren als rechtstreekse schade van de derde zelf (dus buiten het letsel van de eerste om). ${ }^{1503}$

Onduidelijk is intussen of de restrictieve uitleg die de Hoge Raad geeft aan de exclusieve regeling van art. 6:107 BW alleen geldt binnen de sfeer van het onrechtmatigedaadsrecht of ook in het contractenrecht. Het arrest Baby Joost ${ }^{1504}$ biedt hierover geen duidelijkheid omdat in dat geval de ouders geen contractuele remedie hadden; zij waren immers geen partij bij de tussen de arts en het kind (wettelijk vertegenwoordigd door de ouders) gesloten behandelingsovereenkomst. Maar stel, dat samenwonende of niet in gemeenschap van goederen gehuwde partners (of: ouders met inwonende kinderen) verhuiskosten moeten maken omdat hun partner (of: hun kind) door een fout van de verhuurder of woningcorporatie ziek is geworden van de woon- of leefomgeving. Naar huidig recht geldt de werkingssfeer van

1501 In HR 16 juni 1972, NJ 1972, 375 (Van Wetten Courtois) beriep de werkgever wiens werknemers op een snelweg schade opliepen van een verkeersongeval zich er terecht tevergeefs op dat weliswaar niet het veroorzaken van hun letsel mar wel de verkeersfout van de aanrijdende automobilist ook jegens hem als werkgever onrechtmutig was. Van een externe grond voor rechtspreekse onrechtmatigheid is well sprake in HR 12 december 1986, NJ 1987, 958 nt. CJHB (Rockwool/Poly).

1502 HR 26 oktober 2001, NJ 2002, 216 nt JBMV (RVan de W) en NTBR (2002), p. 77 e.v. (Engelhard).

1503 Door aan te nemen dat de derde getraumatiseerd is van zijn waameming van het ongeval zelf, niet van het letsel of overijjden van de eerste. In HR 22 februari 2002, NJ 2002, $240 \mathrm{nt}$. JBMV (Taxibus) heeft de Hoge Raad daartoe een speciale relativiteitsregel geformuleerd. HR 8 september 2000, NJ 2000, $734 \mathrm{nt}$. ARB (Baby Joost). 
art. 6:107 BW ook dan; afdeling 6.1.10 BW waarvan het deel uitmaakt geldt zowel voor gevallen van contractuele als van buitencontractuele aansprakelijkheid. Dat betekent dat ook de daarop gebaseerde rechtspraak geldt. Het is niet te hopen dat de beperking die de Hoge Raad aanvaardt voor gevallen van onrechtmatige daad (te weten dat derden met zelfstandige schade evenmin een vordering hebben die op een andere grond berust dan het hebben veroorzaakt van letsel) óók geldt voor gevallen van wanprestatie. Dat zou immers betekenen dat óók als de partner met verhuiskosten de verhuurder met succes zouden kunnen aanspreken uit hoofde van het huurcontract, zij - op grond van de restrictieve uitleg die de Hoge Raad aan de exclusieve werking van art. 6:107 BW - geen recht hebben op de door hun geleden schade.

\subsubsection{Bijzondere perikelen}

Volgens een vrij recent exposé van de minister is de beperkte kring van personenschade echter aan heroverweging toe. ${ }^{1505}$ Zou dit gebeuren, dan wordt de mogelijkheid van een normaal beroep op het aansprakelijkheidsrecht en de betekenis van het Brandstichting-arrest op het gebied van personenschade uiteraard van groter praktisch belang. Het arrest is in de rechtsliteratuur bekritiseerd. ${ }^{1506}$ Het zou te ver voeren die hier te herhalen, ik beperk me tot een tweetal aspecten. Een eerste aspect betreft de vraag of verzekeraars wel de mogelijkheid van een onrechtmatige daadsactie moet toekomen. Dat voor de aan de benadeelde uitgekeerde bedragen geen sprake zou zijn van schade omdat de verzekeraar premies heeft ontvangen, wordt over het algemeen verworpen. ${ }^{1507}$ Bloembergen noemt het echter 'niet onredelijk' dat de vordering van de verzekeraar niet wordt toegewezen, omdat deze 'uit commerciële overwegingen tegen premie risico op zich genomen heeft. ${ }^{1508}$ Zelf zie ik die principiële bezwaren niet zo. Wel zou me verdedigbaar lijken om bij een vordering tot schadevergoeding de personele beperkingen van de wettelijke regresrechten, zoals de uitsluiting van regres op inwonende gezinsleden en de werkgever van de benadeelde, van overeenkomstige toepassing te laten zijn. Wat bij de huidige stand van het recht interessanter lijkt is de invulling die de Hoge Raad geeft aan het relativiteitsvereiste.

Wat dit laatste betreft, is omstreden of de schadeveroorzaker 'de dans moet ontspringen' als de schade zich als gevolg van omstandigheden waar hij buiten staat

\footnotetext{
1505 TK 2002-03, 28 78I, nr. 3 (slotzin van par. 7); vgl. ook reeds Inv. 6, p. 1278.

1506 Zie Meijers in zijn NJ-noot bij het arrest en 0.m. Mijnssen (1970), p. 4 (met het wetssystematische argument dat de wet (ook) in andere gevallen van subrogatie een rechtstreekse actie verleent, zoais bij borgtocht). De uitsluiting van verzekeraars van een 'normaal' gebruik van het aansprakelijkheidsrecht zou volgens Mijnssen in de wet moeten zijn verankerd (p. 8 ).

1507 In die zin Meijers' noot onder HR 31 januari 1930, NJ 1930, p. 304 (Brandstichting); Bloembergen (I965), nr. 267 ('met even veel reden zou men kunnen zeggen, dat de winnende roulettespeler geen voordeel heeft. omdat tegenover zijn winst zijn inzet staat') en Mijnssen (1970), p. 4.

Bloembergen (1965), p. 250.
} 
naar de verzekeraar heeft verplaatst. Bloembergen acht het onredelijk derden in een gunstiger positie te plaatsen dan degene naar wie de schade zich heeft verplaatst: het gaat hier om dezelfde schade en waarom zou de een daarvan wèl en de ander niet vergoeding mogen vragen.' Als vaststaat dat sprake is van verplaatste schade èn dat onrechtmatig is gehandeld dan is bij het veroorzaken van die schade óók onrechtmatig gehandeld jegens degene naar wie de schade is verplaatst. ${ }^{199}$ Dit lijkt mij ver gaan; de belangrijkste voorwaarde in het onrechtmatige daadsrecht is dat een ter bescherming van de belangen van de eiser strekkende gedragsregel geschonden is. Gedragsnormen behoren de concrete, geïndividualiseerde belangen te beschermen die - als zodanig - voor de aansprakelijke op het moment van de schadeveroorzaking kenbaar en voorzienbaar (behoren te) zijn geweest. ${ }^{1510}$ Degene die jegens de benadeelde aansprakelijk is behoeft niet, als regel, mede te hebben geanticipeerd op de eventuele belangen van derden zoals verzekeraars. ${ }^{1511}$ Dat lijkt slechts dan het geval, als hij de concrete belangen van de derde kende of in verband met bijkomende omstandigheden had behoren te kennen, en daarmee ten onrechte geen rekening hield. ${ }^{1512}$

Dat lijkt eigenlijk alleen aan de orde bij opzet; het klassieke voorbeeld is degene die opzettelijk brand sticht in een pand daarbij het oogmerk heeft gehad om de schadeverzekeraar van de eigenaar op kosten te jagen. Dàt levert - in geval van zaakschade - een normovertreding op waaraan de brandverzekeraar bescherming ontleent en hij heeft dan, indien jegens hem ook aan de overige voorwaarden voor aansprakelijkheid is voldaan, recht op een integrale vergoeding van zijn schade. In essentie sluit het Brandstichting-arrest dan ook goed aan, dunkt mij, bij ons relatieve systeem van onrechtmatige daad. De gedachte daarbij moet zijn dat de geschonden norm strekt ter bescherming van de belangen die voor de schadeveroorzaker op het moment van handelen als zodanig kenbaar moeten zijn geweest. Het verzekerd zijn van het risico van personenschade is weliswaar zo veel voorkomend dat ook dat als kenbaar kan worden beschouwd, maar dat lijkt niet voldoende. Een vergelijking kan worden gemaakt met het persoonlijke belang van naasten bij het behoud van de persoonlijke en lichamelijke integriteit van de benadeelde. Wie letsel of overlijden veroorzaakt handelt daarmee niet onrechtmatig jegens de naasten, ook al zal hem bekend zijn dat ook zij daardoor diep kunnen worden getroffen. ${ }^{1513}$

Zie Bloembergen (1965), nr. 267 en dezelfde (1992), p. 21.

1510 Zie paragraaf 4.92; Rb. Den Haag 5 december 2001 (H/Hannover Intemational), NTBR 2002, p. 162 (Engelhard).

1511 HR 24 januari 1930, NJ 1930, 299 nt. EMM (Brandstichting). In het Duitse recht heeft men in zulke gevallen slechts een aanspraak krachtens $\oint 826$ BGB, zie Frick (1985), p. 7, nt. 14. Kennelijk wordt het relativiteitsvereiste van $\$ 82.3$ II BGB voor schadeverzekeraars even restrictief geinterpreteerd als in bovengenoemd arrest. Vgl. HR 27 januari 1984, NJ1984, $536 \mathrm{nt}$. G (Verstekeling). Zie Bloembergen (1965), nr. 172; Mijnssen (1970), p. 6; Mulder (1988), p. 30 .

1513. Dat is alleen dan anders indien zij direct betrokken zijn geraakt bij het ongeval op de manier waarop de Hoge Raad dat omschrijt in HR 22 februari 2002. NJ 2002, $240 \mathrm{nt}$. JBMV (Taxibus). 


\subsubsection{Cessie}

Een alternatief voor regres waarvan met name verzekeraars en werkgevers wel gebruik maken is de overdracht van de vordering tot schadevergoeding door cessic. Wil de overdracht geldig zijn, dan moet een levering zijn verricht krachtens geldige titel 'door hem die bevoegd is over de vordering te beschikken', ${ }^{1514}$ Voor de leveringshandeling is een daartoe bestemde akte vereist en mededeling daarvan aan de schadeveroorzaker (art. 3:94 BW; de action directe van art. 6 WAM dan overigens óók, van rechtswege, aan de rechtsverkrijger toe, als rechtsverkrijger van de 'benadeelde' in de zin van de WAM). In verzekeringspolissen en arbeidscontracten bijvoorbeeld kan voor de vereiste akte van cessie een cessiebeding worden opgenomen, inhoudende dat de vordering ter hoogte van de uitgekeerde bedragen geheel of gedeeltelijk overgaat op de verzekeraar of werkgever. ${ }^{1515}$ Nodig is verder dat de vordering bij het sluiten van de akte van overdracht bestaat. Volgens de Hoge Raad ${ }^{1516}$ is dat het geval als de rechtsverhouding waarin de vordering zijn onmiddellijke grondslag vindt reeds bestaat, ook al is de schade dan nog niet (of slechts ten dele) ingetreden. In de literatuur wordt de rechtsgeldigheid van cessie bij het ontbreken van regres door subrogatie of een zelfstandig regresrecht in beginsel aanvaard. ${ }^{1517}$

Omstreden is echter of het gesloten systeem van verhaal bij personenschade de rechtsgeldigheid van cessie wèl ingeval van letsel of overlijden uitsluit. ${ }^{1518} \mathrm{On}$ duidelijk is nog of bij cessie van schadevorderingen met betrekking tot personenschade strijd ontstaat met de gesloten kring vergoedingsgerechtigden van art. 6:107 en $108 \mathrm{BW} .{ }^{1519}$ Anderen dan de benadeelde hebben zoals gezegd immers zelfs bij een 'normaal', rechtstreeks beroep op het aansprakelijkheidsrecht geen recht op vergoeding van vermogensschade die zij als gevolg van het letsel of overlijden ondervinden. ${ }^{1520}$

Art. 3:84 juncto ant. 3:94 BW. De vordering moet door de akte voldoende zijn bepaaid. Voldoende is dat de akte zodanige gegevens bevat dat, eventueel achteraf, aan de hand daarvan kan worden vastgesteld om welke vorderingen het gaat, zie HR 19 september 1997, NJ 1998, 689 (Verhagen qq/INB II) en daarover Van Achterberg (1999), nr. 4 (met verdere verwijzingen) Zie daarover Fleming (1983), p. 43 e.v.; Mulder (1988), p. 26 e.v.

1516 Bloembergen (1965), nr. 96 (nt. 1). Zie o.m. Köster (1971), p. 121; Van Maanen \& Römers (1994), p. 9; Hammerstein (1994), p. 4; Hartief \& Tjittes (1999), p. 69; Van Boom (2000a), p. 13. Ook Van Boom (2000a), p. 14 betwijfeh sterk of cessie dan rechtsgeldig is. 
De Hoge Raad baseent dit op wetssystematische gronden, niet op de relativiteit die besloten ligt in het inbreukcriterium van art. 6:162 BW, en noemt vorderingen van niet in art. 6:107 en $108 \mathrm{BW}$ bedoelde personen bij letsel en overlijden 'niet-ontvankelijk' ${ }^{1521}$

Ik zie dit niet: het exclusieve karakter van deze regeling beperkt de uitbreiding van aansprakelijkheid naar ànderen dan de benadeelde (= degene jegens wie aan de voorwaarden voor aansprakelijkheid is voldaan). Dat het recht op verhaal van de benadeelde, uitzonderingen daargelaten (art. 6:106 lid 2 BW), overdraagbaar is komt met de ratio van deze bepalingen niet in strijd. Als particuliere en sociale verzekeraars het hun gecedeerde recht geldend maken, oefenen ze nog steeds het recht uit van de benadeelde, geen eigen vorderingsrecht uit aansprakelijkheid. Een ander punt betreft de vraag in hoeverre de beperkingen van de wettelijke regresrechten van invloed zijn op de rechtsverkrijging (of rechtsuitoefening) bij cessie. Aangenomen wordt wel, dat door vaststellingsovereenkomsten rechtsgeldig voorbij kan worden gegaan aan de beperking van het civiele plafond bij regres. Ook lijkt dus niet vereist dat de vordering correspondeert met de schade waarvoor de rechthebbende zich jegens de benadeelde heeft verbonden. Het meest sprekende voorbeeld is dat naast de verzekerde vermogensschade sprake is van immateriēle schade, zij het dat de overgang van het recht op schadevergoeding terzake van die schadepost slechts onder bepaalde omstandigheden is toegestaan (zie art. 6:106 lid $2 \mathrm{BW}$ ). In de Tijdelijke regeling verhaalsrechten wordt de mogelijkheid van het omzeilen daarvan uitdrukkelijk uitgesloten (art. 6:197 lid derde lid BW). Het lijkt me voor de hand te liggen om de aan de Tijdelijke regeling verhaalsrechten gelieerde beperkingen in de jurisprudentie op dezelfde restrictieve wijze te interpreteren (geen cessie).

Cessie heeft intussen wel voordelen boven regres. De betrokkenen zijn, in beginsel, zelfvoorzienend. Dat kan voor henzelf onder omstandigheden uiteraard als wenselijk worden ervaren, maar heeft ook vanuit oogpunt van het algemeen belang zekere voordelen (bijvoorbeeld dat niet telkens specifieke wetgeving nodig is waarin het recht op vergoeding is geregeld). Een nadeel voor de betrokkenen is dat voor cessie toestemming van de benadeelde vereist is. Cessie biedt bovendien minder zekerheid dan wettelijke regresbepalingen, met name indien de schadeveroorzaker of diens WA-verzekeraar nadat een rechtsgeldige cessie heeft plaatsgevonden weigert om te betalen. De rechter kan er dan namelijk, bij de beoordeling van de gecedeerde vordering, rekening mee houden dat de benadeelde geen schade meer lijdt. ${ }^{1522}$ Hiervan lijkt alleen sprake indien sommenverzekeraars, schadedragers voor wie een regresrecht uitdrukkelijk ontbreekt, toch langs deze weg (cessie)verhaal zoeken. Om de afwijzing tegen te gaan wordt in de praktijk zoals bekend gewerkt met

1521 HR 12 december 1986, NJ 1987, $958 \mathrm{nt}$. CHHB (Rockwool/Poly). Voor dese beperking van het recht op vergoeding lijkt, ook met het oog op de beheersbarheid van schadeclaims, geen reden; zonder die beperking geldt immers nog well de voorwaarde dat een jegens de eiser zelf geldende rechtsnorm moet zijn geschonden. Art. 6:107 en 108 BW geven slechts een (beperkte) uitbreiding van aansprakelijkheid, geen beperking ervan. 
zogenaamde voorschot- of koopsomconstructies, waarbij verzekeraars uitkeren bij wijze van een koopsom als tegenprestatie voor de overdracht van de vordering en waarbij de verzekerde afstand doet van de verzekeringsuitkering. Ook zulke constructies blijken in de praktijk veelal te mislukken omdat de rechter niettemin rekening houdt met de uitkering, zo niet bij het vaststellen van de schade dan toch door gebruik te maken van zijn bevoegdheid tot matiging van de schadevergoeding. ${ }^{1523}$ In het arrest Stad Rotterdam/Brunt ${ }^{1524}$ deed een weduwe afstand van haar aanspraak op een uitkering uit een ongevallenverzekering, die het gevolg was van het overlijden van haar echtgenoot. De vordering tot schadevergoeding uit onrechtmatige daad wegens gederfd levensonderhoud werd voor 10000 gulden (de verzekerde som) verkocht aan de verzekeraar en overgedragen. Volgens de Hoge Raad doet de afstand echter geen afbreuk aan de invloed van de vermogensrechtelijke aanspraak van de weduwe op de behoefte aan levensonderhoud. Ook in het arrest NBM/Eagle Star ${ }^{1525}$ is sprake van samenloop van de aanspraak uit ongevallenverzekering en het recht op vergoeding van gederfd levensonderhoud in de zin van art. $1406 \mathrm{BW}$ (oud). De ongevallenverzekeraar was in dit geval niet tot uitkering gehouden indien de verzekerde, Flierman, tevens recht had op schadevergoeding. Dit recht zou dan eerst door cessie overgaan gevolgd door de betaling van een koopsom ten bedrage van de verzekeringsuitkering. De Hoge Raad meende ook in dit geval dat de weduwe er op kon rekenen de waarde van de verzekerde som (25 000 gulden) te ontvangen en dat reeds daarmee het recht op vergoeding van het gederfd levensonderhoud werd beïnvloed. Voor andere schadevorderingen dan voor de vergoeding van gederfd levensonderhoud zijn deze constructies nog wèl van belang; ${ }^{1526}$ uitkeringen uit sommenverzekering komen immers in beginsel niet in mindering op het recht op schadevergoeding (behoudens uitzonderingen en met de mogelijkheid van matiging van de schadevergoeding).

Wat de gevolgen van de cessie betreft geldt, net als bij subrogatie, dat de positie van de schadeveroorzaker en de WA-verzekeraar door de cessieniet mag veranderen. Afdeling 6.2.1 BW geeft daarvoor ${ }^{1527}$ bijzondere regelingen, zoals art. 6:142 BW (de nevenrechten gaan mee over) en art. 6:145 BW (de overgang laat de verweermiddelen onverlet), die kwamen in hoofdstuk 7 al aan de orde. Anders dan bij subrogatie heeft de benadeelde bij de cessie van vorderingen, als oude schuldeiser zijnde, ook in te staan voor eventuele verplichtingen van de schadeverzekeraar die uit het schuldeiserschap voortvloeien (zoals die als pandhouder). ${ }^{1528}$

1523 Bolt $(1989 b)$, p. 42.

1524 HR 8 maan 1963, NJ 1963, $317 \mathrm{nt}$. HB (Stad Rotterdam/Brunt en Zoon). Hierover Mulder (1988), nt. 28.

is2s HR 19 juni 1970, NJ 1970, 380 nt. GIS (NBM/Eagle Star); Mulder (1988), nt. 28.

I526 Vgl. Mulder (1988), p. 27.

1527 Asser-Hartkamp 4-1, nr. 569; Verbintenissennecht (Van Mierlo), art. 6:142 BW en Van Achterberg (1999), nr. 8.

1528 Art. 6:145 BW Asser-Hartkamp 4-1, nr. 568 en Van Achterberg (1999), nr, 14. 
Hiervoor kwam de mogelijkheid ter sprake tot het maken van afspraken tussen regresnemer en benadeelde ( $\mathrm{al}$ dan niet gevolgd door cessie). Omgekeerd kan men de vraag stellen of de wettelijke regresbepalingen verplichten tot het nemen van regres. Kan, beter gesteld, de mogelijkheid van regres door regresnemers ten behoeve van de benadeelde via beleidsregels of contractueel worden uitgesloten? Köster constateert in zijn preadvies in 1971 dat de mogelijkheid voor particuliere verzekeraars om rechtsgeldig afstand te doen van hun regresrecht, ongeacht of het gat om een afstand bij voorbaat of nadat de schade reeds is ontstaan, in de literatuur onomstreden is. ${ }^{1529}$ Voor sociale verzekeraars ligt de zaak enigszins anders omdat dit publieke instanties zijn die primair moeten handelen in het algemeen belang. Dit vraagt nu meer aandacht.

\subsubsection{Afspraken tussen (potentiële) regresnemer en benadeelde}

Voorop staat dat tussen particuliere of sociale verzekeraars, overheidsinstanties of werkgevers, en anderzijds de benadeelde contractsvrijheid bestaat, ook ten aanzien van het regresrecht. ${ }^{1530}$ Voor sociale verzekeraars is een algemene uitsluiting van het regres naar geldend recht niet mogelijk. Volgens de voor hen gelden gedragscodes moet regres plaatsvinden, tenzij de kosten de opbrengsten zullen overtreffen. Bij de uitbreiding van het regres naar de volksverzekeringen is door het kabinet wederom benadrukt dat in alle gevallen waarvoor dat mogelijk is regres moet plaatsvinden. Aangesloten kan in dit verband worden bij het regres van gemeenten op onderhoudsplichtigen, in het kader van art. 93a van de Algemene bijstandswet. De ratio daarvan is, vergelijkbaar met het regres op de aansprakelijke, dat de onderhoudsplichtige wordt geconfronteerd met zijn verantwoordelijkheid. Voorkomen moet worden dat de wettelijke verplichting tot onderhoud op de gemeenschap wordt overgeheveld. ${ }^{1531}$ Dat neemt niet weg dat (ook) sociale verzekeraars een zekere mate van beoordelingsvrijheid toekomt bij de uitoefening van het regres. Zo ligt het, net als geldt voor de gemeenten in het kader van de Algemene bijstandswet, voor de hand dat uitkeringsinstanties de ruimte blijft voorbehouden hiervan af te wijken teneinde benadeling van de verzekerde in individuele gevallen te voorkomen, bijvoorbeeld terzake van regres op familieleden. ${ }^{1532}$

Schadeverzekeraars van de benadeelde kunnen wèl volledig in vrijheid afstand doen van hun recht om te worden gesubrogeerd. Ze kunnen bijvoorbeeld via polis-

1529 Koster (1971), p. 112.

1530 Koster (1971), p. 104

1531 Asser-De Boer (1998), p. 461

1592 Het lijkt onnodig beperkend om dit onderscheid, zoals Koster (1971), p. 112 doet. gelijk te stellen met het onderscheid tussen regres op basis van contractuele aansprakelijkheid (waarbij dan volgens hem personen met een bepaalde betrokkenheid tot het verzekerde object of tot de veraekeringnemer als 'verzekerde' mogen worden aangemerkt en darmee reges op hen uitgesloten is) en buitencontractuele aansprakelijkheid (waarbij het uitsluinen van deze denden, volkomen buitenstaanders, mocilijker is maar het wel mogelijk is om afstand te doen van de mogelijkheid van regres als zodanig, ongeacht op wie). 
bedingen van art. $284 \mathrm{WvK} / \mathrm{art}$. 7.17.2.25 $\mathrm{BW}$ afwijken. Zowel het uitsluiten van regres op bepaalde personen als van regres in het algemeen zijn in beginsel geoorloofd. ${ }^{1533} \mathrm{De}$ afstand of uitsluiting van regres kan niet ertoe leiden dat de benadeelde, naast de verzekeringsuitkering, zijn aanspraak op de schadeveroorzaker behoudt ( $\mathrm{en}$ daardoor dus ineens recht zou hebben op dubbele vergoeding). Het is een regel van schadevergoedingsrecht, voordeelstoerekening, dat de benadeelde die zijn aanspraak op schadevergoeding uit verzekering geldend maakt, ten belope van de verzekeringsuitkering zijn vordering op de schadeveroorzaker verliest.

Volgens Kōster volgt het verlies voor de benadeelde van zijn vordering op de aansprakelijke in dit verband uit het verzekeringsrechtelijke indemniteitsbeginsel. ${ }^{13.4} \mathrm{De}$ redenering is dan kennelijk dat door het bestaan van de vordering tot schadevergoeding geen aanspraak ontstaat uit schadeverzekering. Met evenveel overtuigingskracht kan men echter het omgekeerde beweren (de aanspraak uit aansprakelijkheid ontstaat niet wegens het ontbreken van schade), en het resultaat zou zijn dat de benadeelde met twee (of meer) potentiėle aanspraken op schadevergoeding uiteindelijk met lege handen staat.

Er zijn mijns inziens ook goede argumenten aan te voeren om de vrijheid tot renunciatie aan het regresrecht ook te laten gelden voor werkgevers ingevolge art. 6:107a $\mathrm{BW}$ (regres bij loondoorbetaling) en overheidsinstanties ingevolge de Verhaalswet ongevallen ambtenaren. Het aansprakelijkheidsrecht als instrument bij regres moet, zou ik menen, niet zo ver worden doorgedreven, dat particulieren gehouden zijn tot het instellen van een vordering omwille van het maatschappelijke belang daarvan (de handhavingsfunctie van aansprakelijkheid) en/of het belang van aansprakelijkheid voor de benadeelde (erkenningsfunctie). Mij lijkt wenselijk dat men bijvoorbeeld in staat is tot het doen van afstand of beperking, ook bij voorbaat, van regres op gezinsleden van de werknemer. Voorts zou ik me kunnen voorstellen dat het in een bepaalde branche gebruikelijk is dat werknemers voor meer dan één werkgever tegelijk werken en dat dit, opnieuw ter bescherming van de werknemer, een afstand bij voorbaat van regres op de andere werkgever wenselijk maakt. Ook bedrijfs-economische argumenten (de kosten verbonden aan de uitoefening van regres, de concurrentiepositie enzovoort) lijken afdoende voor uitsluiting van regres.

Voor afspraken met de benadeelde die strekken tot uitbreiding of versterking van het regresrecht zelve buiten de wettelijke grenzen bestaat voor sociale verzekeraars, overheidsinstanties en ABP en de werkgevers van art. 6:107a BW (kortom alle schadedragers met een zelfstandig regresrecht) in beginsel geen ruimte. Afwijking van de Tijdelijke regeling verhaalsrechten bijvoorbeeld is uitdrukkelijk uitgesloten.

1533 Zie o.m. Dorhout Mees (1935), p. 321; De Kok (1965), p. 91 nt. 3; Koster (1971), p. 104; anders Ledeboer (1927), p. 117 (zie daarop de kritick van Köster, a.w. p. 113)

1534 Koster (1971), p. 113. 


\subsection{Conclusie}

In dit hoofdstuk werd een aantal aandachtspunten behandeld met betrekking tot de uitvoering van het regres. Aangevangen werd met een bespreking van de mogelijkheden tot vereenvoudiging van het regres in de praktijk. De uitvoering $\tan$ het regres moet efficiënt zijn, maar niet met voorbijgaan aan haar functies. Inden voor individuele gevallen kan worden geprocedeerd zijn de uitvoeringskosten ran het regres (prohibitief) hoog. Het regres van sociale verzekeraars is daarom vrijvel volledig gestandaardiseerd, dat wil zeggen dat het vereenvoudigd wordt afgehand:ld op basis van afspraken met (aangesloten) WA-verzekeraars. Een uitstekend model daarvoor biedt het Convenant Verhaalsrecht 2001, het vroegere TICA-convenant voor het regres van sociale arbeidsongeschiktheidsuitkeringen. Daarin zijn belangijke afspraken gemaakt: er wordt niet meer geprocedeerd, en op lastige technische punten (het bruto-netto vraagstuk) wordt geen discussiemeer gevoerd. Wel gelden de normale verweren nog op het punt van aansprakelijkheid, voor kwesties zouls schuld, eigen schuld en ook verjaring. Ook de zogenaamde NORA-regeling werkt efficiënt. Kritisch was ik over de recente ontwikkeling, gesteund door het kabinet, om alle regresvorderingen in de vorm van één jaarlijkse afkoopsom (lump sun) af te wikkelen. Zoals ik in hoofdstuk 6 aangaf is de zin van het regres dat het een vorm van schadetoerekening biedt op basis van billijkheid: een sanctie op vormen van schadeveroorzaking die in individuele gevallen verwijtbaar zijn. Bij een gecollectiveerde afwikkeling gaat die meerwaarde verloren. Beter zou zijn de individuele schadeveroorzaker en benadeelde erbij te blijven betrekken, door ze over het regres te informeren en door premiesancties van de WA-verzekeraar. Gewezen werd op mogelijke verbeteringen van de uitvoering. Een ander punt dat op uitvoeringsniveau aandacht vraagt is het nadeel dat de benadeelde daarvan kan ondervinden. In dat verband werd onder meer verdedigd dat het werkgeversverweer afschaffing behoeft, en dat bij samenloop van de regresvordering met die van de benadeelde, de laatste voor gaat. Ten slotte werd ingegaan op de vraag in hoeverre naast de wettelijke regresregelingen alternatieve aansprakelijkheids-acties openstaan. Hiervoor lijkt in beginsel geen bezwaar. Wel werd gewezen op meer specifieke bezwaren van bepaalde onderlinge afspraken die moeilijk verenigbaar lijken met de grenzen van de wettelijke regresregelingen. 


\section{Samenvatting en conclusies}

\subsection{Inleiding}

\section{Hoofdstuk 1: Achtergrond}

Slachtoffers van ongevallen die met schade door letsel of overlijden worden geconfronteerd (daartoe reken ik ook nabestaanden van het primaire slachtoffer), staan naast het aansprakelijkheidsrecht veelal eigen ('first-party') voorzieningen ter beschikking, zoals aanspraken op hun particuliere ziektekosten- of uitvaartverzekeraar of het ziekenfonds. Voor schade die al langs deze andere weg werd vergoed, verliezen ze hun recht op schadevergoeding jegens de aansprakelijke (of diens WAverzekeraar. De gedachte is dat vergoeding van dezelfde schade moet worden voorkomen, en de benadeelde al door de 'first-party' betalingen werd vergoed. Met het vergoed zijn van de schade zijn de kosten van het ongeval uiteraard niet verdwenen; de schade wordt slechts door anderen gedragen dan door de benadeelde. Deze verschuiving van de schade naar 'first-party' betalers dient het belang van de benadeelde, maar biedt in termen van kostenallocatie niet het gewenste eindresultaat. Om die reden hebben zij, indien ze de schade van de benadeelde voor hun rekening nemen een wettelijk regresrecht jegens de schadeveroorzaker. Tot 1993 heerste de opvatting dat het regres van sociale fondsen op WA-verzekeraars leidde tot een vestzak-broekzak resultaat, aangezien ongeveer hetzelfde collectief van het regres profiteert (sociaal verzekerden) als het collectief dat daarvoor betaalt (WA-verzekerden). Gebukt onder zware sociale lasten, is het kabinet regres als een instrument gaan zien om sociale uitkeringen elders te verhalen. Op initiatief van het Ministerie van Sociale Zaken zijn de laatste jaren een groot aantal nieuwe regresrechten ingevoerd: voor de loondoorbetaling van werkgevers bij arbeidsongeschiktheid, uitkeringen uit volksverzekering (ANW en AWBZ) en uit werknemersverzekering (REA, WAJONG, WAZ). Het huldigt het beginsel dat 'de schadeveroorzaker betaalt'. Op die basisvoorziet het zelfs in stimuleringsmaatregelingen en subsidiesvoor ziekenfondsen, werkgevers, en ziektekostenverzekeraars die erin slagen regres te nemen op de schadeveroorzaker of WA-verzekeraar. Dè vraag die deze ontwikkeling oproept, is waar de grens ligt. Elke uitbreiding van het aansprakelijkheidsrecht zou immers kunnen worden onderbouwd door te wijzen op het genoemde credo: 'Heeft u vermogensnadeel of een hoge uitkeringslast? De veroorzaker betaalt!' 


\section{Hoofdstuk 2: Probleemstelling}

Met deze studie werd beoogd, de wijze waarop de regering voor haar rechtspolitieke doeleinden gebruik maakt van de wettelijke regresrechten door te lichten. In hoeverre is aanknoping bij het aansprakelijkheidsrecht op basis van het principe dat de schadeveroorzaker moet betalen los van de regresopbrengsten wenselijk en geoorloofd? Hier ligt de probleemstelling die voor de onderhavige studie centraal stond:

Welke gevolgen heeft de uitbreiding van het regres die het kabinet met het credo 'de schadeveroorzaker betaalt' propageert, voor de aansprakelijkheid van de schadeveroorzaker?

De studie was primair gericht op het positieve recht, en bestaat hoofdzakelijk uit rechtspraak- en literatuuronderzoek. Drie basisprincipes werden gekozen als theoretisch kader voor de normatieve analyse. De uitbreiding van het aansprakelijkheidsrecht ten behoeve van regresnemers moet in de eerste plaats dogmatisch onderbouwd kunnen worden, zij moet passen binnen het wettelijke kader van het aansprakelijkheidsrecht. Tevens moet zij overtuigend zijn en consequent voor wat betreft de daarmee beoogde functies. De legitimatie en functies moeten vervolgens op uitvoeringsniveau gewaarborgd blijven (uitvoerbaarheid).

\subsection{Wettelijk kader}

\section{De wettelijke systematiek}

In hoofdstuk 2, 3 en 4 volgt een bespreking van de contouren van dit wettelijke kader, mede in het licht van het genoemde principe. Uitgangspunt voor de wettelijke regresregelingen is dat de schadeveroorzaker als gevolg van de betalingen van de regresnemer in zijn verhouding tot de benadeelde is bevrijd. Daaraan ligt de opvatting ten grondslag dat de benadeelde niet uit meerdere bronnen vergoeding moet kunnen ontvangen voor dezelfde schade; schade kan slechts eenmaal worden vergoed. Wie al uit andere hoofde dan het aansprakelijkheidsrecht wordt vergoed, verliest daarmee zijn recht op schadevergoeding. De (bijkomende) consequentie daarvan is dat de schadeveroorzaker 'de dans ontspringt'. Door het regres komt de draagplicht met betrekking tot de schade alsnog bij hem te rusten. Het juridische kader waarvan de regresbepalingen deel uitmaken is dus in feite simpel: wat regresnemer en schadeveroorzaker verbindt is de gelijkenis, de samenloop, van de door ieder aan de benadeelde verschuldigde prestatie. Beiden moeten dezelfde schade vergoeden, waarbij de betaling die de eerste (regresnemer) deed aan de benadeelde, de laatste in diens eigen verhouding tot de benadeelde bevrijdt. 


\section{Hoofdstuk 3: Directe aanleiding voor het regres}

Het derde hoofdstuk vangt aan met een inventarisatie van de betalingen die de schadeveroorzaker van zijn vergoedingsplicht bevrijden. Op grond van die inventarisatie worden de regels die de schadeveroorzaker bij betalingen van derden bevrijd doen zijn, in een drietal regimes onderverdeeld: het regime voor betalingen van derden die voorkomen dat de benadeelde schade voelt in zijn eigen vermogen (zoals loondoorbetaling bij arbeidsongeschiktheid), het regime voor betalingen van derden die ertoe strekken om schade die wèl in zijn vermogen valt te vergoeden (vergoedingen, zoals particuliere en sociale verzekeringsuitkeringen) en het regime voor de betalingen die geen beide doen (voordeel zoals vrijblijvende giften). Voor de eerste twee categorieën van betalingen geldt dat die zonder meer, als regel, ertoe leiden dat de schadeveroorzaker voor het daarmee corresponderende schadedeel van zijn vergoedingsplicht is bevrijd (en de benadeelde dus zijn recht op schadevergoeding jegens hem verliest). Bij de derde categorie van betalingen van derden is van die samenloop geen sprake, en om die reden geen plaats voor regres: betalingen die de benadeelde ontvangt van derden en die geen schadevergoedingskarakter hebben zijn bezwaarlijk aan te merken als een alternatief voor de door de schadeveroorzaker verschuldigde schadevergoeding.

De belangrijkste conclusienaar aanleiding van deze inventarisatie is dat betalingen alleen zonder meer (ipso facto) bevrijdend werken, indien ze strekken tot het voorkomen of vergoeden van juist de schadesoort waarvoor ook de schadeveroorzaker aansprakelijk is. De wenselijkheid daarvan werd door mij onderschreven: om betalingen van derden zonder meer als alternatief te laten fungeren voor het recht op schadevergoeding, is nodig dat ze bedoeld zijn ter vergoeding van de betreffende schade(post). Het regresrecht van de betalende derde heeft vervolgens tot taak om de functies te herstellen die het geldend maken van het recht op schadevergoeding zou hebben gehad (zie hoofdstuk 6 en volgende).

Voor vorderingen tot vergoeding van de gederfde voorziening in het levensonderhoud (art. 6:108 lid $1 \mathrm{BW}$ ) is het samenloopregime terecht wat strenger: daar moet in beginsel de gehele vermogenspositie van de nabestaanden in aanmerking worden genomen bij het vaststellen van hun recht op schadevergoeding. Dat volgt uit de aard van de schade van art. 6:108 lid $1 \mathrm{BW}$ : alle activa die bedoeld is om bij te dragen aan het levensonderhoud heeft dan in feite een schadeverminderend effect. De schadeveroorzaker is in zoverre jegens hen bevrijd. Daartoe worden thans echter óók betalingen gerekend, die naar hun aard of strekking eigenlijk helemaal niet als voorziening zijn bedoeld voor juist het deel van de kosten van levensonderhoud waarvoor, zonder het overlijden, de gederfde onderhoudsvoorziening zou zijn aangewend (de uitkering uit hypothecaire levensverzekering van de nabestaanden beperkt hen dus in hun totale vordering, ongeacht of daarbij ook de post woonlasten als schade werd opgevoerd). Dat past niet bij het uitgangspunt dat het de schadeveroorzaker moet zijn die de schade draagt. 
Beter ware dan tot uitgangspunt te nemen dat er voor de (absolute) bevrijdend: werking van betalingen van derden sprake moet zijn van congruentie, samenloo, met de vergoedingsplicht van de schadeveroorzaker. Volgens dat beginsel zol beslissend moeten zijn of de betalingen van derden strekken tot voorziening in het levensonderhoud dan wel tot vergoeding van de gederfde onderhoudsvoorzie ning. Daarvoor zou, net als bij letselschade, de strekking van de betaling beslissenl moeten zijn. Alleen de betalingen van derden die als (gedeeltelijke) vervangin! van het levensonderhoud zijn aan te merken (uitkeringen uit gewone of hypothecai re levensverzekering, de Nabestaandenwet, onderhoudsvoorziening door de nieuw: partner enzovoort) zouden dan moeten worden verrekend, en dan uitsluitend voorzo ver ze daarop gelijkende kostenposten voor het levensonderhoud hebben opgevoerd Dat de Hoge Raad in de toekomst zijn koers in deze zin bijstelt is echter nie denkbeeldig; hij lijkt niet ongevoelig voor de kritiek op het onderscheid met letsel schade.

\section{Verhouding voordeelstoerekening - regres}

In het tweede deel van het hoofdstuk vragen nog enkele praktische punten me

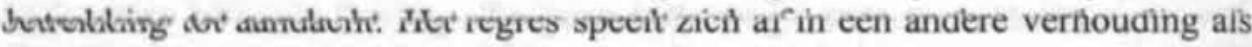
die waarin het zijn oorzaak vindt. De instantie waarbij over het al dan niet bevrijd zijn van de schadeveroorzaker wordt beslist oordeelt veelal immers onafhankelijk van de procedure waarin de regresvordering moet worden beoordeeld. Door een veelheid van factoren zoals ontwikkelingen in de gezondheidstoestand van de benadeelde, de wijze van procesvoering, en een informatiegebrek bij betrokkenen, is er een reële kans op een uiteenlopende beoordeling. Dit kan ertoe leiden dat voor een lager of hoger bedrag voordeelstoerekening plaatsvindt dan het bedrag van de verschuldigd regressom, waardoor de schadeveroorzaker uiteindelijk meer of minder verschuldigd is dan de totale schade. De belangrijkste conclusie op dit punt is dat een postenstelsel onmisbaar is voor een billijk eindresultaat in de samenhang met het regres. Niet alleen beperkt dat bij de zelfstandige regresrechten het risico van dubbele betaling, het houdt de zaak ook eenvoudiger: men hoeft uitsluitend rekening te houden met schadeposten die corresponderen met de te verrekenen first-party betaling. Maar het verband tussen de te verrekenen betaling en de schadepost is niet altijd eenvoudig vast te stellen. De betaling moet slechts worden verrekend voorzover deze naar haar aard en duur overeenstemt met schade waarvoor de schadeveroorzaker de schadevergoeding verschuldigd is. Als de schadeveroorzaker gehouden is tot vergoeding van inkomensschade van het tweede en derde ziektejaar, komt alleen dààrop de betreffende WAO-uitkering in mindering. Ten slotte vraagt meer recente jurisprudentie op het gebied van voordeelstoerekening aandacht, waarin de Hoge Raad enige ruimte laat om de aanspraak op firstparty uitkeringen ook aan de benadeelde toe te rekenen indien de uitkering uiteindelijk helemaal niet door hem wordt genoten. Hiervoor ontbreekt in mijn visie elke goede grond. Zelfs als de benadeelde de uitkering door zijn eigen schuld heeft 
moeten missen moet de schadeveroorzaker niet in staat zijn zich op die grond van zijn eigen vergoedingsplicht jegens de benadeelde te bevrijden. Veeleer behoort in de daarop volgende regreszaak, ervan uitgaande dat de aanspraken van de benadeelde niet tot betaling zullen komen, de regresvordering te worden afgewezen. Voor het geval dat het nog onzeker is of de betalingen door de benadeelde zullen worden genoten, opperde ik om de regresnemer een (voorlopig) toekenningsbesluit van de uitkering te laten overleggen of, als dat onder omstandigheden nog niet mogelijk is, zijn vordering voorwaardelijk toe te wijzen, analoog aan art. 6:105 BW.

\section{Hoofdstuk 4: grenzen van het wettelijke kader}

In hoofdstuk 4 wordt het 'pakket' regels besproken dat ervoor moet zorgen dat de schadeveroorzaker alsnog met de totale omvang van de schade wordt geconfronteerd. Aangevangen wordt met een bespreking van de relevante regresregelingen afzonderlijk, telkens gerelateerd aan specifieke schadeposten. Over de regresbepalingen heerst mede als gevolg van recente wijzigingen in het sociale zekerheidsrecht nog relatief veel onduidelijkheid. Getracht werd op die bijzondere punten helderheid te bieden; verwezen zij naar de betreffende besprekingen.

Daarnaast zijn er verstrekkers van bevrijdende betalingen die daarvoor naar geldend recht (vooralsnog) geen regresrecht hebben. Uitgaande van het principe dat de regering aanvoert voor het regres, althans de betekenis die daaraan moet worden toegekend, ligt uitbreiding van het regres naar zulke gevallen voor de hand (daargelaten de consequenties daarvan voor het regresvolume en de verzekerbaarheid van het extra WA-risico dat dit oplevert). Besproken wordt achtereenvolgens de wenselijkheid van het regres met betrekking tot de gemeentelijke uitkeringen en verstrekkingen in het kader van de Wet voorzieningen gehandicapten, aan (loon)compensatieregelingen gelieerde betalingen en onverplichte loondoorbetalingen van de werkgever en de (aanvullende) uitkeringen op grond van de Toeslagenwet. Op het gebied van overlijdensschade ontbreken met name regresrechten voor levensverzekeraars, pensioenfondsen, en de werkgever. Dat regresrechten voor de genoemde categorieën van betalingen ontbreken staat haaks op de principes van het gekozen beleid. Van het gemeentelijke regres lijkt op uitvoeringsniveau echter niet veel te verwachten. Voor werkgevers zou een uitbreiding van hun regresrecht naar alle - verplichte of onverplichte loondoorbetalingen die ze doen ingeval van letsel (èn naar de betalingen aan nabestaanden bij overlijden), het regresbeleid juist kunnen stimuleren (meer wellicht dan de WAO-maatregel die het kabinet daartoe introduceerde).

Vanuit wetenschap en praktijk klinkt intussen de roep om een duidelijke en meer consistente, geüniformeerde regresregeling. Anders dan voor het regres van medeschuldenaren ontbreekt voor de onderhavige regresrechten echter nog een algemeen theoretisch kader: wat zijn de kenmerken en systematiek van deze regresregelingen, en hoe verhouden zij zich tot andere (regres)rechten? Daaraan is het tweede deel 
van het hoofdstuk gewijd. De belangrijkste conclusie daarvan is dat de onderhavge regresrechten alle tezamen een zelfstandige categorie verhaalsrechten vorme, los van de algemene regresrechten of andere vorderingsrechten binnen het aanspakelijkheidsrecht. De regresbepalingen berusten op eenzijdige aansprakelijkhed van de schadeveroorzaker voor het ontstaan van de schade. Ze kunnen wordn omschreven als de wettelijke verbintenis tot terugbetaling tussen de aansprakelije (de schadeveroorzaker) en al degenen die anders dan op basis van aansprakelijkhid schade voor hun rekening hebben genomen. Daarop voortbouwend werd één uniform en algemeen regresrecht geformuleerd, dat zich tevens zou moeten uitstrekkn over de genoemde gevallen waarvoor (nog) geen regres geldt.

\subsection{Functies van het regres}

\section{Hoofdstuk 5: Wordingsgeschiedenis}

Het credo dat de schadeveroorzaker behoort te betalen is het dragende argument voor het hier geschetste kader, maar biedt weinig concrete aanknopingspuntn

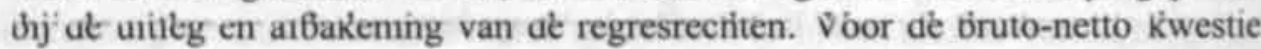
bijvoorbeeld, of de vraag in hoeverre het regres op de werkgever en op gezinsleden van de benadeelde geoorloofd is en wie prioriteit heeft als de regresvordering concurreert met de vordering van de benadeelde, zegt het helemaal niets. Om toch de rechtspolitieke doeleinden van het regres bij het antwoord op zulke vragen te kunnen betrekken, werd gezocht naar de functie van dat principe. Daartoe werd eerst in hoofdstuk 5 de achtergrond en ontwikkeling geschetst van de onderhavige regresrechten, vanaf de oude Ongevallenwet 1901 tot meer recente ontwikkelingen, zoals het genoemde pakket van stimuleringsmaatregelen dat de voorbije jaren door de regering werd ingevoerd. Een centrale rol komt daarbij toe aan het debat over de maatschappelijke betekenis van het regres van sociale verzekeraars. Daarbij heeft in het bijzonder het vestzak-broekzak bezwaar van Bloembergen bij een regresrecht voor de volksverzekeringen een belangrijke rol gespeeld. Naar zijn stellingzou het resultaat daarvan zijn dat bepaalde collectiviteiten premies opbrengen en vervolgens, tegen hoge uitvoeringskosten, weer regres op elkaar nemen. De groep die dan profiteert van lagere sociale premies zou grotendeels samenvallen met de groep die daarvan de lasten draagt door hogere WA-premies.

Dat het regres van sociale verzekeraars dit effect tot op zekere hoogte heeft is overtuigend. Maar dat wil nog niet zeggen dat het moet worden afgeschaft. Het belang van het vestzak-broekzak argument is eerder, dat het de discussieop scherp zet: waarom verzekeraars uitvoeringskosten laten maken voor transacties die elkaar per saldo opheffen? Het kabinet stelt zich intussen op het standpunt dat het vestzakbroekzak argument een algemeen argument is, dat voorbijgaat aan de allocerende werking van het regres (de functie dat het de kosten van schadeveroorzakend gedrag beter zichtbaar maakt). Daarnaast stelt het kabinet eraan te hechten dat de regresop- 
brengsten een bijdrage leveren aan de in het kader van de lastenverlichting wenselijke besparingen. Deze argumentatie kan echter niet sterk worden genoemd. Het regres zou budgettair aantrekkelijk zijn, maar dàt voordeel geldt alleen als men eenzijdig redeneert vanuit het perspectief van het Ministerie van Sociale Zaken; het geld zal toch ergens vandaan moeten komen. Daarnaast wijst de regering op het belang van het zichtbaar maken van de kosten van schadeveroorzakend gedrag, maar dit wordt nauwelijks onderbouwd. Wat wordt beoogd met het zichtbaar maken van de kosten, en: waarom blijft dit beperkt tot het zichtbaar maken van de kosten van verwijtbaar schadeveroorzakend gedrag (gedrag waarvoor aansprakelijkheid bestaat)?

\section{Hoofdstuk 6: Verwijtbaarheid als grond voor reallocatie}

Wat is dan wèl de doelstelling of functie van de wettelijke regresrechten? In hoofdstuk 6 wordt het beginsel dat de schadeveroorzaker moet betalen vanuit een aantal gezichtsvelden belicht. Vrij algemeen wordt het doel of de functie van het regres geassocieerd met rechtseconomische doeleinden. In die benadering staat het bevorderen van een optimale maatschappelijke welvaart voorop. Vanuit dat perspectief wordt regres in beginsel wenselijk geacht vanuit het oogpunt van preventie: het niveau van zorg dat van de (potentiële) schadeveroorzaker wordt verwacht, kan slechts optimaal worden gehandhaafd als de potentiële schadeveroorzaker wordt geconfronteerd met de totale kosten van zijn schadeveroorzakende activiteiten. Het veel gehoorde bezwaar dat de uitvoeringskosten te hoog zijn kan (inmiddels) voor een aantal gevallen worden gerelativeerd. Het regres van particuliere en sociale verzekeraars is echter hoofdzakelijk gericht op WA-verzekeraars. Ook dan heeft regres in beginsel een meerwaarde in de zin dat dit de WA-verzekeraar van de (potentiële) schadeveroorzaker confronteert met de totale kosten van diens gedrag en daardoor aanspoort tot het nemen van maatregelen die de kosten van het regres laten doorwerken in de premie (door verbeterde risicodifferentiatie). Of die maatregelen vanuit economisch perspectief toereikend zijn, is hoogst twijfelachtig.Een gecollectiveerde uitvoering van het regres zou de individuele premierespons negatief kunnen beïnvloeden (indien door die wijze van afdoening een minder uitvoerige administratie wordt gevoerd. Maar hoewel me moeilijk te ontkennen lijkt dat preventie (daarbuiten) een wenselijk gevolg kan zijn van de dreiging van het aansprakelijkheidsrecht bij regres, maakt dat het nog niet tot zelfstandig argument voor het (behoren te kunnen) inroepen van het aansprakelijkheidsrecht door regresnemers. Het is één iets, om een wenselijk neveneffect van het aansprakelijkheidsrecht te signaleren, maar het gaat een belangrijke stap verder dit tot het leidende argument te maken (het doel of de functie). Die laatste stap gaat mij te ver. De meerwaarde van de economische benadering is dat zij inzicht biedt in de positieve neveneffecten van het aansprakelijkheidsrecht en regres op preventievlak (en wijst op de kosten die daarmee gemoeid zijn). 
Regels voor contractuele en buitencontractuele aansprakelijkheid zijn naar hun aard immers specifiek gericht op het vinden van verwijtbaar gedrag en van de juiste maatstaf voor zorgvuldigheid die ten tijde van het schadevoorval van de schadeveroorzaker mocht worden verwacht. Het oordeel over de vraag bij wie van de partijen in het geding de schade behoort te rusten, hangt af van de verwijtbaarheid van ieders gedrag (en met het oog daarop de meest billijke afweging van de belangen). Het is in het kader van die beoordeling, dat ook de mate van gevaarzetting relevant kan zijn: hoe gevaarlijker, hoe eerder verwijtbaar. De allocatiebeslissing (het toeschrijven van de schade aan de aangesprokene) vindt uiteindelijk plaats op grond van 'shared notions of justice'. Bij het vaststellen van het doel of de functie van het aansprakelijkheidsrecht, en de betekenis daarvan voo: de regresrechten kan dan ook moeilijk voorbij worden gegaan aan de betekenis van de billijkheidsnormen die aan de bedoelde regels ten grondslag liggen. In de rechtsfilosofische doctrine wordt dit beginsel veelal zo uitgelegd, dat het aansprakelijkheidsrecht een vorm van correctieve rechtvaardigheid nastreeft. De intrinsieke functie ligt in mijn visie echter elders. Het aansprakelijkheidsrecht is - binner het gegeven wettelijke kader - een systeem van schadetoerekening (allocatie) op basis van billijkheid (faimess): het bevredigt een algemene (collectieve) behoefte om de feitelijke toedracht en de schending van concrete gedragsnormen die daarvoor gelden rechtens niet zonder gevolg te laten blijven. Het regres zet een prijs op verwijtbaar gedrag, en draagt daarmee bij aan een resultaat dat meer recht doet aan het rechtsgevoel (zij het op een algemeen niveau, en niet op het niveau van de individuele belangen van de benadeelde).

\subsection{Het aansprakelijkheidsregime bij regres}

\section{Hoofdstuk 7: Aansprakelijkheidsnormen}

Het regres moet bevorderen dat vanuit de rechtsorde een reactie plaatsvindt op verwijtbaar schadeveroorzakend gedrag; vanuit het oogpunt van gerechtigheid moet het de 'schuldige' zijn, die de schade draagt. Zo onderbouwd, kan het principe dat de schadeveroorzaker moet betalen dat de regering voorstaat worden gevolgd. Maar dat principe wordt in regressituaties op een aantal punten door het aansprakelijkheidsregime zelf gefrustreerd. Hierover gaan hoofdstuk 7, 8 en 9.

In hoofdstuk 7 wordt ingegaan op de toepasselijkheid van de regels van het aansprakelijkheidsrecht voor regresnemers, en de constructies die daarvoor gelden. De aansluiting bij de aard en omvang van aansprakelijkheid kan zowel bij subrogatie als bij de zelfstandige regresrechten (in het kader van het civiele plafond) tot moeilijkheden leiden. Achtereenvolgens wordt ingegaan op de knelpunten bij de vestiging en bij het vaststellen van de omvang van aansprakelijkheid. Voor de vestigingsfase geldt dat lang niet alle gronden voor aansprakelijkheid ook door regresnemers kunnen worden ingeroepen. De Tijdelijke regeling verhaalsrechten 
berust op gewijzigde inzichten, gepleit wordt terecht voor afschaffing van die regeling. Wel past voorzichtigheid bij de daarvoor aangevoerde gronden; met name het argument dat zij zou leiden tot rechtsongelijkheid is dunkt me onjuist. Een onoverkomelijk bezwaar is echter dat zij haaks staat op het beginsel dat de schadeveroorzaker betaalt. De zwaarte van dat argument varieert echter met de functie die aan dat beginsel worden toegeschreven. De omvang van aansprakelijkheid (afdeling 6.1.10 BW) moet by regres niet naar andere normen worden beoordeeld dan de normen die zouden zijn gehanteerd bij een actie van de benadeelde zelf. Maar er zijn bij het toepassen van de regels van afdeling 6.1.10 BW ook punten van verschil. Voor regresnemers gelden bijzondere regimes op het punt van eigen schuld, voordeelstoerekening (bij door de benadeelde genoten voordeel), matiging en smartengeld.

\section{Hoofdstuk 8: Rechtskarakter van regresvordering}

Het uitgangspunt voor het regres is dat de schadeveroorzaker er door het regres weliswaar, vergeleken met de vermogensrechtelijke positie waarin hij jegens de benadeelde zou hebben verkeerd niet op vooruit, maar evenmin op achteruit mag gaan. In hoofdstuk 8 komt een aantal kwesties aan de orde die illustreren hoe het bijzondere rechtskarakter van het regresrecht en de pluraliteit van schuldeisers die daarbij kan ontstaan dat uitgangspunt onder druk zetten. Als eerst volgt een bespreking van de zogenaamde bruto-netto problematiek. De jurisprudentie van de Hoge Raad inzake het civiele plafond lijkt in dit verband te strikt. Voorstellen worden gedaan voor een flexibeler regime, waarin regres op bruto basis niet al bij voorbaat uitgesloten is.

Een andere kwestie die het genoemde uitgangspunt onder druk zet, is de vraag naar de vergoeding van de buitengerechtelijke kosten van regresnemers. De Hoge Raad kiest het goed verdedigbare uitgangspunt dat zulke kosten niet verhaalbaar zijn. De raad oordeelt dat wèl de buitengerechtelijke kosten die worden gemaakt indien de regresvordering niet of niet tijdig door de schuldenaar wordt voldaan, op de voet van art. 6:96 lid 2 BW dienen te worden vergoed. Uitgaande van de functie van het regres moet dat worden onderschreven: om door de schuldeiser (regresnemer) effectief te kunnen worden uitgeoefend, zullen aan het regresrecht al de normale, daaraan toe te kennen rechtsgevolgen moeten toekomen die zouden toekomen aan het vorderingsrecht van de benadeelde. Voor regresnemers gelden in zoverre dezelfde rechten en bevoegdheden als voor de benadeelde zelf. Het gevolg daarvan is wèl, dat de schadeveroorzaker daardoor zeker bij ernstige letselschadezaken (waarbij veelal een aantal regresnemers betrokken is) 'slechter' af is dan hij zou zijn als de schade voor rekening zou zijn gebleven van de benadeelde. Dat lijkt gerechtvaardigd; het is een gevolg van het feit dat hij twee schuldeisers heeft, niet valt in te zien dat de positie van de schadeveroorzaker als schuldenaar beter zou moeten zijn dan die van andere schuldenaren met meer dan één crediteur. Het door de Hoge Raad gekozen regime lijkt, impliciet, wel enige bescherming 
daartegen te bieden: het regime moet dan zo worden verstaan, dat alleen de bijzondere buitengerechtelijke kosten van een herhaalde vordering moeten worden vergoed.

Onduidelijkheid heerst nog over de vraag welk verjaringsregime heerst bij regres. De Hoge Raad deed daarover meer recent een belangwekkende uitspraak. ${ }^{1535}$ Het argument dat de schuldenaar niet slechter mag worden van het regres trekt de raad door naar het toepasselijke verjaringsregime: in het kader van art. 3:310 $\mathrm{BW}$ geldt voor regresnemers in beginsel zonder onderbreking hetzelfde regime als voor de benadeelde. Dogmatisch gezien staat dat haaks op het genoemde uitgangspunt dat aan het regresrecht, om door de schuldeiser (regresnemer) effectief te kunnen worden uitgeoefend, al de normale, daaraan toe te kennen rechtsgevolgen moeten toekomen. In die zin is het verjaringsarrest ook moeilijk verenigbaar met, de genoemde benadering van de Hoge Raad bij de vergoeding van de buitengerechtelijke kosten. Voorgesteld wordt een algemeen regime, voor alle regresregelingen, dat tevens aansluit bij de beslissing van de Hoge Raad op dit punt. Ten slotte volgt een bespreking van de mogelijkheid tot het inroepen van eigen schuld van de regresnemer (en daaraan verwant verweren zoals rechtsverwerking).

\subsection{Uitvoering}

In hoofdstuk 9 wordt ingegaan op nog enkele bijzondere kwesties met betrekking tot de uitvoering van het regres en het regresbeleid. In de eerste plaats is dat de uitvoering van het regres: de uitvoering van het regres moet dus efficiënt zijn, maar niet met voorbijgaan aan haar functies. Omwille van het terugbrengen van de uitvoeringskosten van regresacties is daarom vrijwel volledig gestandaardiseerd, dat wil zeggen dat het vereenvoudigd wordt afgehandeld op basis van afspraken met (aangesloten) WA-verzekeraars. Een uitstekend model daarvoor biedt het Convenant Verhaalsrecht dat betrekking heeft op alle sociale arbeidsongeschiktheidsuitkeringen: er wordt niet meer geprocedeerd, en op lastige technische punten (het bruto-netto vraagstuk) wordt geen verweer meer gevoerd. Wel gelden de normale verweren voor het vaststellen van de aansprakelijkheid, voor kwesties zoals schuld, eigen schuld en ook verjaring. Ook de zogenaamde NORA-regeling werkt efficiënt: voor het regres van buitengerechtelijke kosten die rechtsbijstandsverzekeraars bij letsel of overlijden voor hun rekening nemen zijn vaste bedragen overeengekomen met WA-verzekeraars.

Kritischer zou ik willen zijn over de tendens om het regres in de vorm van één collectieve afkoopsom (lump sum) op jaarbasis af te doen. Ik meen dat de 'prijs' die daarvoor wordt betaald (geen vaststelling van aansprakelijkheid meer in individuele gevallen) te hoog is, in de zin dat dit het regres grotendeels 'uitkleedt', ontdoet van de meerwaarde die het in mijn visie heeft (en die zoals gezegd juist 
verband houdt met de toepassing van de aansprakelijkheidsnormen in concrete, individuele gevallen). Het kabinet bevordert dit door de invoering van speciaal daarop gerichte wetsbepalingen. De handhavingsfunctie betekent in mijn visie méér dan alleen maar handhaving van het systeem van het aansprakelijkheidsrecht als zodanig, het vraagt ook om concrete toepassing van de gedragsnormen en bekendheid daarvan bij de betrokkenen. Beter zou dan ook zijn de individuele afwikkeling te blijven handhaven. Besproken worden de methoden tot kostenbesparing door standaardisering die momenteel actueel zijn. Aandacht wordt echter gevraagd voor een viertal belangrijke punten daarbuiten die eveneens een efficiënte uitvoering van het regres kunnen bevorderen, en meer tegemoet komen aan de genoemde functies van het regres.

In paragraaf 9.2 en 9.3 wordt ingegaan op de vraag in hoeverre de benadeelde nadeel moet dulden van het regres. Aan de orde komt eerst de vraag of regres op gezinsleden en bedrijfsgenoten van de benadeelde geoorloofd (paragraaf 9.2). Daarbij wordt tot uitgangspunt genomen dat de benadeelde geen nadeel behoort te (kunnen) ondervinden van het regres. Het regres alleen tot handhaving van het aansprakelijkheidsrecht. Het mag niet leiden dat de benadeelde in zijn rechtspositie wordt benadeeld. Het belang dat verwijtbaar gedrag zijn prijs kent is ondergeschikt aan de belangen van degene die daarvan primair schade ondervond. De vraag is alleen in hoeverre in dit opzicht met de belangen van de benadeelde rekening dient te worden gehouden; de wettelijke regresrechten geven uiteenlopende regels. Voor het regres op gezinsleden moet beslissend zijn of de benadeelde economisch hinder vindt. Dat de regeling van afdeling 7.17.2 BW op dit punt (zoals laatstelijk gewijzigd op 24 april 2003) afwijkt is op zijn plaats; aanknoping bij die regeling voor het regres van sociale verzekeraars lijkt onwenselijk. Voor het regres op werkgevers en collega's van de benadeelde gelden andere argumenten. Gepleit wordt voor afschaffing van het werkgeversverweer (de beperking van het regres op werkgevers).

Het standpunt dat de benadeelde geen nadeel behoort te (kunnen) ondervinden van het regres wordt ook ingenomen in paragraaf 9.3, met betrekking tot de kwestie wiens vordering voor gaat, indien regresvordering en de vordering van de benadeelde voor het resterende (onverzekerde) deel van de schade samenlopen en het te verhalen bedrag ontoereikend is. Betoogd wordt dat dan de benadeelde voorrang behoort te hebben. Niet alleen sluit dat beter aan bij de meest gangbare praktijk van sociale verzekeraars en de regeling van afdeling 7.17.2 BW voor schadeverzekeraars. Dat past bij de functie van het regres, en ligt ook wetssystematisch meer voor de hand: de directe aanleiding van het regres ligt bij het regime dat dubbele vergoeding van de benadeelde moet tegengaan. Daarbij past niet, dat zijn verhaalspositie jegens de schadeveroorzaker uiteindelijk, door het systeem van voordeelstoerekening en regres, slechter is dan de positie van slachtoffers met onverzekerde schade. Omdat de voorrang van de benadeelde in de praktijk niet gegarandeerd is wordt een wettelijke regeling op dit punt voorgesteld. 



\section{Summary and conclusions}

\section{Introduction}

\section{Chapter 1: Background}

When a party is faced with high costs as a result of the wrongful conduct of another person, various legal and social schemes provide responses aimed at covering loss or injury suffered. Liability law may grant the wronged party, i.e. the injured party or its surviving dependants, a right to compensation. In addition, First-party private and social security insurers may provide compensation. Dutch liability law does not permit that wronged parties that have collected First-party insurance payments, also recover damages from the wrongdoer or that person's liability insurer. This would turn the wronged party's plight into a bonanza. The money received from First-party insurers compensates the wronged party for the damage sustained. This extinguishes that party's right to claim damages from the wrongdoer. It goes without saying that these First-party payments do not make the loss disappear; it merely has been shifted to the injured party's insurers.

However convenient this transfer of loss may be to the wronged party, it fails to definitively remedy the loss. This explains why Dutch insurance companies have been given statutory rights of recovery against the wrongdoer for virtually all compensation paid out by them to the wronged party. These statutory rights of recovery are mainly the result of numerous legislative bills introduced by the Ministry of Social Affairs and adopted by Parliament over the past ten years. Until 1993, the prevailing view in the Netherlands was that recovery action brought by social security insurers against Third-party insurers was not efficient, because it constituted robbing Peter to pay Paul. The government has changed its policy, however. As a result of having to shoulder heavy social burdens, it came to view recovery as an instrument for recouping social security benefits from persons liable under private law. Departing from the principle that 'he who causes damage, must pay for it', the government now even offers small subsidies and bonuses to those national health funds, private and public employers and other health insurers that successfully recover First-party payments. The principle underlying the new policy raises the question of the limits of civil liability. After all, making the wrongdoer pay could potentially lend support to any extension of civil liability law: 'Have you suffered economic loss or are you faced with high benefit or insurance 
pay-outs? The person who has caused the damage, must pay for it!' This cannot be the idea, of course. So, where then do we draw the line with regard to this new policy?

\section{Chapter 2: Thesis Question}

The study intends to research the way in which central government makes use of statutory recovery rights for legal-political reasons. Although a few years ago, abolition of statutory recovery rights seemed imminent, nowadays these rights form part of a new policy line intended to promote that the costs of compensation facing the social security funds, are ultimately borne by the wrongdoer himself. Employers, health insurers and national health funds are even promised a financial incentive, if they pursue an active recovery policy. However, this departure from traditional policy raises a number of questions. To what extent is connecting to civil liability law, premised on the principle that the wrongdoer must pay the damage caused by him or her, irrespective of the proceeds of recovery, desirable and permissible? Herein lies the central problem of this study:

'What consequences does extension of recovery to First-party payments, as propagated by the government through the principle 'He who causes the damage, must pay for it', have for the civil liability of the wrongdoer?'

The study is primarily concerned with positive law and consists mainly of an examination of decided cases and literature research. Three basic principles have been selected as the theoretical framework for a normative analysis. Firstly, extension of civil liability law to include parties seeking recovery requires dogmatic underpinning; such recovery must mesh with the statutory framework of civil liability law. Secondly, it must be convincing and consistent as to its purposes (functionality) and, thirdly, these purposes must be guaranteed at the level of execution (implementability).

\section{Statutory Framework}

\section{How the System Works}

In Chapters 2, 3, and 4, the outlines of this statutory framework are sketched in the light of the above principle. Statutory recovery regulations are based on the premise that First-party payments, such as those paid out to injured parties or their dependants by their own private and social security insurers and employers, releases the wrongdoer from his or her obligations towards these parties. This is founded on the view that the wronged party cannot be compensated for the same damage more than once; there can only be single compensation for the damage sustained. 
If a person has received compensation on grounds other than civil liability law, his or her right to compensation is extinguished. As a result, the wrongdoer would escape unscathed, were it not for First-party recovery action brought against him or her. This ensures that the burden of compensation will ultimately rest on the wrongdoer. The legal framework, of which the recovery provisions form a part, is, in effect, quite straightforward: what binds the wrongdoer and the party seeking recovery is that they owe the same debt to the wronged party. In his or her relation with the wronged party, the wrongdoer is liable for damage already compensated for by the party seeking recovery on the grounds of that party's relation with the wronged party. This is referred to as debt concurrence: First-party payments made to the wronged party by the party seeking recovery at the same time release the wrongdoer from his or her obligation towards the wronged party. Through recovery, the wrongdoer ultimately bears the financial burden in all cases, although he or she has been released from the obligation owed to the wronged party.

\section{Chapter 3: Immediate Reason for Seeking Recovery}

This chapter examines cases in which, as a result of First-party payments, the principle that the wrongdoer must pay for the damage caused by him is frustrated. It commences with an inventory of those First-party payments that release the wrongdoer from his or her compensation obligation. On the basis of the inventory, the rules effecting the release of the wrongdoer, are subdivided into three regimes: the regime for First-party payments that avoid that the wronged party will have to face the damage, such as continued wage payments in case of incapacity to work. Secondly, First-party payments which are intended to compensate for damage that does fall within the wronged party's estate (compensation, for instance private insurance payments and social security benefits). Thirdly, there is the regime for payments that have neither of the above effects, such as non-compensatory gifts, which constitute benefit. The effect of the first two types of payments is generally that the wrongdoer is discharged from his or her obligation to compensate the wronged party for the corresponding part of the damage and, as a result, the wronged party is no longer entitled to compensation (for that part) by the wrongdoer. With regard to the third category of First-party payments, there is no such concurrence and recovery is not an option: non-compensatory payments received by the wronged party from third parties cannot properly be regarded as an alternative for compensation owed by the wrongdoer. The most important conclusion that could be drawn from the inventory was that First-party payments only have a discharging effect where they are intended to prevent or compensate precisely that damage for which the wrongdoer is liable.

Claims for compensation of loss of support by dependants of a deceased, on the grounds of Article 6:108, par. 1, Dutch Civil Code (BW), fall within a somewhat stricter concurrence regime. The Netherlands Supreme Court has held that all First-party payments received by dependants will diminish their claim. The differen- 
ce with injury cases is that all First-party payments release the wrongdoer, in principle, and therefore also payments which, according to their nature or purpose, in actual fact do not redress loss of support. First-party payments under a mortgage-related life insurance for the benefit of surviving dependants are deducted from the total claim, irrespective of whether housing costs are claimed. This does not correspond with the principle that, in order for First-party payments to have full releasing effect, they must be concurrent and match the compensation obligation of the wrongdoer. At issue here is the question as to whether in the event of death First-party payments are intended to defray housing costs as such, or compensate for loss of support. In the author's view, the purpose of the First-party payment ought to determine the answer to this question, as in physical injury. Only those First-party payments that can be characterised as (part) compensation for costs of living, such as payments on the grounds of an ordinary or mortgage-related life insurance, the Surviving Dependants Act (Nabestaandenwet), maintenance provided by a new partner and so on, will exclusively have to be set off with claimed costs of living. Conceivably, the Netherlands Supreme Court may take this approach in the future. It does seem to take on board the criticism regarding the difference with physical injury.

\section{The Relation between Benefit Deduction and Recovery}

The second part of this chapter is dedicated to more practical matters. Recovery actions are often brought within a different relation from the one in which the recovery has its cause. The body which must (exclusively) decide whether or not the wrongdoer is discharged of his or her obligation owed to the wronged party, is, in principle, another than the body that assesses the merits of the recovery action. A range of factors, such as developments with regard to the injured party's health, the way in which proceedings are conducted, and lack of information on the part of the parties involved, make it very likely that the outcome of the two proceedings will be dissimilar. This may result in smaller or larger sums being deducted for any benefit enjoyed by the wronged party and in the wrongdoer ultimately having to pay too much or too little compared to the total amount of damages. The most important conclusion here is that itemisation of damage is really indispensable to achieve a fair outcome in recovery proceedings. This not only reduces the risk of dual payment in the event of independent recovery rights, it also keeps things simpler, leaving aside the requirement to assess the congruence between First-party payments and the head of compensation in question. First-party payments can only be set off, where these match the damage for which wrongdoer is liable, according to their nature and in relation to the period in which the damage was suffered. The First-party payment is then exclusively deducted from the amount of the specific head of compensation entered. If the wrongdoer is obliged to pay compensation for loss of income in the second and third year of illness, the relevant disability benefit payments is deducted from this debt and from this debt alone. 
Finally, the Netherlands Supreme Court has left some room for reducing a claim submitted by a wronged party, by taking off First-party insurance payments even where the wronged party does not receive these payments in the end through his or her own fault. The author does not see any convincing grounds for denying the wronged party his or her claim for damages against the wrongdoer. The defence, open to the wrongdoer in actions brought by the wronged party, that the wronged party missed out on social insurance benefits as a result of his or her own carelessness or malicious intent, ought not be accepted in recovery proceedings. Where it is still uncertain whether any advantage will be enjoyed by the wronged party, the author suggests that the First-part insurer seeking recovery submit to the court a (provisional) administrative decision by which such social security benefit was granted, or, if that is not yet possible under the circumstances, to award the claim for recovery conditionally, by analogy with Article 6:105 BW.

\section{Chapter 4: the Limits of the Statutory Framework}

In Chapter 4, the author examines the set of legal rules that ensure that the wrongdoer is confronted with the total extent of the damage caused by him or her. First, the regulations governing recovery of First-party payments are discussed, in relation to each head of compensation. In part as a result of recent amendments to social security law, there is much confusion in these special areas. The author attempts to provide clarity on these points: the reader is referred here to the dissertation itself. In addition to this, under current law some parties providing payments of a releasing nature are not (yet) entitled to recovery. From the principle put forward by the government in relation to recovery of First-party payments, or in any case from the way in which it is construed, broadening the right of recovery so as to include these parties follows logically, apart from the consequences for the volume of damages. The author discusses the desirability of a right of recovery in relation to municipal benefits and allowances under the Disability Allowances Act (Wet voorzieningen gehandicapten): payments tied to (wage) compensation rules; non-mandatory continued payment of wages by the employer; and supplementary benefits under the Allowances Act (Toeslagenwet). In the area of death-related loss, there are no rights of recovery for life insurers, pension funds and employers. Academics and practitioners alike call for a more transparent and more consistent and uniform set of mutual recovery rules. Unlike the mutual recovery rights of co-debtors, there is as yet no general theoretical framework for the recovery rights discussed here: what are their characteristics, how are they organised systemically and how do they relate to other rights (of recovery)? These points are discussed in the second part of this chapter. The most important conclusion is that, together, the recovery rights discussed here are a category in their own right, separate from recovery or other actions under civil liability law. According to the author, a prerequisite for the exercise of these rights is the unilateral civil liability of the wrongdoer. They may be defined as a statutory obligation owed by the person liable 
(the wrongdoer) to reimburse all those who have footed the bill of the damage other than on the grounds of their own liability. The author advocates the introduction of a single uniform and general law of recovery, of which this aspect should be a part.

\section{The Purposes of Recovery}

\section{Chapter 5: Historical Origins}

The principle that the wrongdoer must pay for the damage he or she has caused is the key argument supporting the framework outlined here. However, it offers few concrete indications for possiblequestions of interpretation. It fails to address, for instance, such questions as the limits of recovery action taken against employers or family members of the injured person and the problem of priority if the recovery claim concurs with the claim brought by the wronged party. In order to involve the legal-political aims of recovery actions in providing an answer to such questions, the role of the principle must be further investigated. Attention is therefore paid in Chapter 5 to the historical origins of recovery rights. First, the background and development of the statutory recovery rights under discussion are outlined, from the old Accidents Act (Ongevallenwet) to more recent developments, such as the earlier referred to set of incentives introduced by the government in the recent past. A pivotal role is allocated here to the debate on the social significance under private law. Departing from the principle that he who causes damage, mustof recovery rights for social security insurers. The 'Peter-Paul' argument put forward by Bloembergen against a right of recovery for national insurers has weighed in heavily. In his view, the result of such entitlement will be that certain groups of insured pay premiums and subsequently their respective insurers seek recovery from each other, incurring high administration costs in the process. In consequence, the group benefiting from lower social security premiums would in large part coincide with the group carrying the burden through higher statutory liability premiums.

That such an effect will occur as a result of mutual recovery action taken by social security insurers seems convincing to a degree. From this it does not follow, however, that such recovery rights must be abolished. According to the author, the importance of the 'Peter-Paul' argument is that it pinpoints the debate on the question of whether it makes sense to have insurers incur costs for transactions that cancel each other out. The government has taken the view that the 'Peter-Paul' argument overlooks the allocating role of recovery: it serves to render the costs of the damage-causing act more visible. In addition to this, the government asserts that it values the aspect that revenues derived from recovery contribute toward its policy of easing the tax and premium burden. This reasoning does not convince the author. Although recovery may have advantageous budgetary consequences, 
such advantages are only relevant to the Ministry of Social Affairs; the money, after all, has to come from somewhere. Furthermore, the government points at the importance of making visible the total extent of the damage caused by the wrongdoer (allocation). However, this is insufficiently supported by argument. What is more, it does not become clear why exposing the costs of damage-causing conduct is limited to making visible the costs of damage-causing wrongful conduct under civil liability law.

\section{Chapter 6: Observing Fairness in Reallocating Loss}

Chapter 6 deals with the purpose of recovery in the case of private and social security insurers, The principle that 'he who causes damage, must pay for it' is viewed from various angles. Recovery claims do not, either directly or indirectly through premium reduction, have an impact on the interests of the individual wronged party. However, reallocation of damage is also based on faimess. As regards the question as to who should bear the loss, the rules governing First-party recovery primarily aim at promoting fair assessment of the interests of the parties involved. They reflect a collective perception of what is fair, regardless of the quality of the parties invoking the rules.

A more common approach, however, is to examine the function or purpose of subrogatory and recovery actions from the perspective of wealth maximisation through a law-and-economic analysis of liability law. This approach seems to highlight the relevance of recovery for prevention: the level of care to be observed by a (potential) wrongdoer can only be maintained optimally, if that person is confronted with the overall costs accountable to him or her. An often-heard objection is that the costs of administering recovery actions are too high, but this can be called into question for a number of cases now. Recovery by private and social security insurers is mainly sought from Third-party insurers. In these cases, recovery has added value, in principle, in the sense that the potential wrongdoer's Third-party insurer is confronted with the overall costs of the wrongdoer's conduct, thus forming an incentive for the insurer to take measures which will reflect the costs of recovery in the premium, for instance, by charging risk-related premiums or premium adjustment. It is doubtful, however, whether these measures will suffice from an economic perspective. It is also possible that lump-sum collective settlements agreed between insurers negatively affect Third-party insurer's individual premium response. There is the danger that no or less accurate accounts are kept. Whereas prevention could clearly be an attractive effect of the establishment of liability through subrogatory or recovery actions, the author hesitates to view prevention as the key factor in broadening or, as the case may be, restricting liability. It is one thing to find an attractive effect, but another to promote such effect as the true goal of liability rules. Subrogatory and recovery rights should not be granted to First-party insurers for the sake of prevention alone. The added value of the law-and-economics approach is, however, that it provides an insight into 
the positive and negative side effects of recovery on prevention. The more intrinsic function of recovery is found elsewhere, according to the author. Within the relevant statutory framework, civil liability law is a system of loss allocation on the basis of faimess. This satisfies a collective need for ensuring that the actual events and the violation of the applicable concrete norms of conduct will have an effect in law. Recovery puts a price tag on wrongful conduct; it is the response of the legal order to such conduct, thus contributing to a result that better satisfies our sense of justice, although not primarily at the familiar level of the individual damage claim.

\section{The Liability Regime governing Recovery}

\section{Chapter 7: Norms of Civil Liability}

Recovery is intended to reallocate losses on the basis of a collective sense of fairness in attributing liability. Viewed from this perspective, the principle that the person who causes damage, must pay for it, can be appreciated. However, in the event of recovery the principle is frustrated by the civil liability regime on a number of points. Chapter 7 is about the extent to which parties seeking recovery may invoke rules of civil liability law and the relevant legal constructions: subrogation or independent recovery, limited by the extent of the wronged party's claim (maximum damages). The connection to the nature and extent of liability, as determined by the maximum damages rule, may cause problems in the event of either subrogation or independent recovery. The bottlenecks in establishing civil liability and determining its extent are discussed here. In the stage in which civil liability for wrongful conduct is determined, not all grounds for civil liability may be invoked by those seeking recovery. The Temporary Recovery Rights Regulation (Tijdelijke Regeling Verhaalsrechten) seems outdated and the author advocates that it be abolished. However, caution must be taken here in picking the arguments for such abolition: that this is to result in inequality under the law is not a valid argument, in the author's view. An overriding objection is that abolition is at odds with the principle that the person who causes the damage, must pay for it. The significance attached to this objection depends, however, on the aim or function ascribed to the principle. The same norms should apply for determining the extent of the liability in the case of recovery as apply in actions brought by the wronged party against the wrongdoer (Chapter 6.1.10 BW). However, different rules do apply to recovery actions. In the case of recovery, special regimes govern contributory negligence, benefit deduction, mitigation, and damages for mental distress. 


\section{Chapter 8: The Legal Character of the Right of Recovery}

Without exception, the premise is that the person who has caused the damage must not be brought in a more (dis)advantageous position as a result of recovery as he would have been placed in vis-à-vis the wronged party itself. In Chapter 8 , the author explains how the special legal character of the right of recovery and the potential plurality of creditors are putting this premise under pressure. If the parties seeking recovery were to enjoy the same rights and powers as the wronged party, the wrongdoer would certainly be put in a more disadvantageous position in the event of recovery.

The author discusses the gross/net issue in detail. The judgments rendered by the Netherlands Supreme Court in the matter seem rather rigid. This holds true in particular for cases of temporary incapacity to work, in that courts tend to award claims on a net basis. A more flexible regime with respect to capping the amount of damages to be awarded were to be preferred. The position of private employers and the State as employer, also in view of the changing status of public servants in social security law, is met with criticism.

There is confusion over the prescription regime governing recovery. The author proposes a general regime for all recovery regulations, which would remove the one remaining objection against the decision by the Supreme Court. Other points of discussion are the regime for compensation of out-of-court costs incurred by parties seeking recovery; contributory negligence on the part of parties seeking recovery; and the factoring in of financial advantage enjoyed by the party seeking recovery. The reader is referred here fo the relevant sections of the dissertation.

\section{Chapter 9: Exercise of the Right of Recovery}

Chapter 9 discusses a number of special issues that have raised questions in the light of the above. First, there is the actual exercise of the right of recovery. Recovery action must be efficient, without overlooking, however, the purposes for which recovery is intended. In order to reduce the administrative costs of bringing recovery claims incurred by First-party insurers, the applicable rules have been standardised and simplified. Recovery is now sought on the basis of agreements between social security insurers and Thirst-party insurers. A fine example is provided by the Recovery Law Agreement 2001 (Convenant Verhaalsrecht) and the less recent TICA agreement on recovery of social security benefits. Important arrangements have been made under these Agreements: claims for recovery will be settled out of court and tricky technical problems such as the gross/net issue have been resolved. The ordinary civil liability defences do apply here, in relation to, for instance, culpability, contributory negligence and prescription. The NORA arrangement also works well. The author is more critical about the tendency to settle claims through annual lump-sum deals. This is a recent development, which is backed by the government. In the author's view, the aim of submitting recovery claims 
is more than enforcement of civil liability rules as such. It also requires concrete application of norms of conduct and the parties' awareness of these norms.

A second point that requires attention in relation to the exercise of the right of recovery is the availability of alternative civil liability actions beyond the limits of statutory recovery regulations, such as separate actions in tort. The author does not object to these, in principle, although such actions may be without their problems. 


\section{Verkort aangehaalde literatuur}

Abraham, K.S. (1986), Distributing Risk. Insurance, Legal Theory, and Public Policy, New Haven/London (Yale University Press) 1986.

Van Achterberg, M.P. (1999), Overgang van vorderingen en schulden en afstand van vorderingen, Monografieën Nieuw BW-44, Deventer (Kluwer) 1999.

Akkermans, A.J. (1998), 'Verjaring bij letselschade en regres', TVP 1998, p. 33-37.

Algemene Rekenkamer (1996), Verhaalsrecht in de Ziekenfondswet, rapport, 's Gravenhage 1996 (ook gepubliceerd in kamerstukken TK 1996-97, 25025, nr. 2).

Arlen, J. (2001), 'Tort Damages', in: Volume II (Civil Law and Economics), Bouckaert, B. \& De Geest, G. (ed.), Encyclopedia of Law and Economics, Cheltenham/Northampton (Edward Elgar) 2001, p. 682-734.

Van Asch van Wijck, H.W. (1895), De Subrogatie van den Verzekeraar. Aantekeningen op Art. 284 W.v.K., dissertatie Utrecht 1895, Utrecht (Utrechtse Stoomdrukkerij) 1895.

Asser-Clausing-Wansink 5-VI (1998), Handleiding tot de beoefening van het Nederlandse Burgerlijk recht, Bijzondere overeenkomsten. De verzekeringsovereenkomst, bewerkt door P. Clausing en J.H. Wansink, Deventer (W.E.J. Tjeenk Willink) 1998.

Asser-Hartkamp 4-I (1998), Handleiding tot de beoefening van het Nederlandse Burgerlijk recht, Verbintenissenrecht, deel I: De verbintenis in het algemeen, 11e druk, bewerkt door A.S. Hartkamp, Zwolle (W.E.J. Tjeenk Willink) 1998.

Asser-Hartkamp 4-III (1998), Handleiding tot de beoefening van het Nederlandse Burgerlijk recht, Verbintenissenrecht, deel III: De verbintenis uit de wet, 10e druk, bewerkt door A.S. Hartkamp, Zwolle (W.E.J. Tjeenk Willink) 1998. 
Atiyah, P.S. (1996), 'Thinking the unthinkable', in: Wrongs and Remedies in the Twenty-First Century, Birks, P. (ed.), Oxford (Clarendon Press) 1996.

Atiyah, P.S. (1997), The Damages Lottery, Oxford (Hart Publishing) 1997.

Barendrecht, J.M. (1996), 'Vereenvoudigde afdoening van regresvorderingen', in: Regresrechten. Afschaffen, handhaven of uitbreiden, Van Boom, W.H., Hartlief, T. \& Spier, J. (red.), Deventer (W.E.J. Tjeenk Willink) 1996, p. 137-162.

Barendrecht, J.M (2002), 'Aansprakelijkheid en welzijn', NJB 2002, p. 605-617.

Barendrecht, J.M. \& Storm, H.M. (1995), Berekening van schadevergoeding, met D.D. Breukers e.a., Zwolle (W.E.J. Tjeenk Willink) 1995.

Barendrecht, J.M. \& Weterings, W.C.T. (2000), Efficiëntere afdoening van regresvorderingen, Tilburg (Centrum voor aansprakelijkheidsrecht) 2000.

Van Barneveld, H. (1984), Inleiding tot de algemene assurantiekennis, Deventer 1984

Van Bell, C. (1852), De subrogatie volgens het Nederlandsche recht, Leyden/Amsterdam (J.H. Gebhard) 1852.

Bell, P.A. \& O'Connell, J. (1997), Accidental Justice. The Dilemmas of Tort Law, New Haven, Connecticut/London (Yale University Press) 1997.

Beekman, D. (1995), 'Recente ontwikkelingen rond het regresrecht', PS 1995, p. 1224-1236.

De Beer, P. (1991), 'Het Schadefonds Geweldsmisdrijven: zijn toekomst en de dader', Proces 1991, p. 1-11.

Van den Bergh, R. \& Faure, M.G. (1990), 'Invloed van verzekering op de civiele aansprakelijkheid: een rechtseconomische analyse', in: De invloed van verzekeringen op de civiele aansprakelijkheid, Van den Bergh, R., Faure, M., Hartlief, T., Tjittes, R.P.J.L., Lelystad (Vermande) 1990, p. 9-53.

Bertels, J. \& Cocquyt, W. (1995), De sociale gezondheidszorgstelsels in de landen van de Europese Unie, deel 1, Antwerpen (MAKLU) 1995.

Bloembergen, A.R.(1965), Schadevergoeding bijonrechtmatige daad, dissertatie Utrecht 1965, Deventer (Kluwer) 1965. 
Bloembergen, A.R. (1966), 'Het verhaalsrecht van de risicodrager in de Algemene Wet Zware Geneeskundige Risico's', SMA 1966, p. 329-330.

Bloembergen, A.R. (1970), 'Aansprakelijkheidsrecht en sociale verzekering; nieuwe ontwikkelingen', SMA 1970, p. 74-80.

Bloembergen, A.R. (1978), 'Het rapport over het verkeersongevallenrecht', NJB 1978, p. 693-708 (met reacties en naschrift Bloembergen p. 994-1002).

Bloembergen, A.R. (1987), 'Het regresrecht van de sociale verzekeraar', in: Schadeverhaal, BW-krant Jaarboek 1987, p. 13-36.

Bloembergen, A.R. (1992), 'Verplaatsing van schade', in: Quod Licet (KleijnBundel), Deventer (Kluwer) 1992.

Bloembergen, A.R. (1994), 'Het Ser-rapport over regresrechten: een fout verhaal', NJB 1994, p. 117-123.

Bloembergen, A.R. (1996), in: Regresrechten. Afschaffen, handhaven of uitbreiden, Van Boom, W.H., Hartlief, T. \& Spier, J., Deventer (W.E.J. Tjeenk Willink) 1996, p. 73-79.

Bloembergen, A.R. \& Van Wersch, P.J.M. (1973), Verkeersslachtoffers en hun schade, mede P. Vinke en W.A. Hoynig, Deventer (Kluwer) 1973.

Bloembergen, A.R. \& Lindenbergh, S.D. (2001), Schadevergoeding: algemeen, deel I, Monografieën Nieuw BW-34, Deventer (Kluwer), 2001.

Van Boeschoten, C.D. (1950), 'Artikel 284 Wetboek van Koophandel en de ongevallenverzekeraar', WPNR 1950/4170, p. 614-616.

Bolt, A.T. (1989), Voordeelstoerekening bij de begroting van de schadevergoeding in geval van onrechtmatige daad en wanprestatie, Serie Recht en Praktijk, Deventer (Kluwer) 1989 (1989a).

Bolt, A. (1989), 'Subrogatie van de sommenverzekeraar?', Kwartaalbericht Nieuw BW 1989, p. 40-45 (1989b).

Bolt, A.T. (1992), Loterij of Rechtspraak?, Deventer (Kluwer) 1992.

Bolt, A.T. \& Spier, J. (1996), De uitdijende reikwijdte van de aansprakelijkheid uit onrechtmatige daad, NJV-preadvies, met medewerking van O.A. Haazen, Handelingen NJV 1996-I, Zwolle (W.E.J. Tjeenk Willink) 1996. 
Van Boom, W.H. (1994), 'Hoe geprivilegieerd is het voorrecht op de verzekeringspenningen?' WPNR 1994/6151, p. 635-640.

Van Boom, W.H. (1995), 'Het verhaalsrecht van de werkgever ex art. 6:107a BW', WPNR 1995/6206, p. 863-865.

Van Boom, W.H. (1996), 'Uniformiteit gewenst. Naar een eenvormig verhaalsrecht voor verzekeraars en risicodragers', in: Regresrechten. Afschaffen, handhaven of uitbreiden, Van Boom, W.H., Hartlief, T. \& Spier, J., Deventer (W.E.J. Tjeenk Willink) 1996, p. 95-118.

Van Boom, W.H. (1999), Hoofdelijke verbintenissen, dissertatie Tilburg 1999, Deventer (W.E.J. Tjeenk Willink) 1999.

Van Boom, W.H. (2000a), Verhaalsrechten van verzekeraars en risicodragers, Studiepockets privaatrecht, Deventer (W.E.J. Tjeenk Willink) 2000.

Van Boom, W.H. (2000b), 'Verjaring van mesothelioomclaims doorbroken', A\&V 2000 , p. $55-68$.

Van Boom, W.H. (2000), 'Wie profiteert van het voorrecht op de vordering uit de WA-polis? Opties voor de wetgever', WPNR 2000/6394, p. 195-197.

Van Boom, W.H. (2003), Structurele fouten in het aansprakelijkheidsrecht, oratie Tilburg, Den Haag (Boom) 2003.

Van Boom, W.H. \& Storm, H.M. (1995), 'Het verhaalsrecht van verzekeraars en risicodragers, aard, omvang en uitoefening', A\&V 1995, p. 149-161.

Boot, P.P.H. \& De Waal, D.P. (1991), 'Enige beschouwingen omtrent het verhaalsrecht van de Bedrijfsvereniging', De Beursbengel 1991, p. 174-175.

De Bosch Kemper, H.J.J.(1995), De WAM in werking. Dertig jaar jurisprudentie, Deventer (Kluwer) 1995.

De Bosch-Kemper, H.J.J. (2000), 'Wie draagt (nou eigenlijk) de schade?', VR 2000, p. 148.

Bouma, H.Th. (1992), 'De gevolgen van de Tijdelijke regeling verhaalsrechten', in: (Nieuw) BW en personenschade, LSA-reeks, 1992.

Bouman, H.A. \& Tilanus-Van Wassenaer, G.M. (1998), Schadevergoeding: personenschade, Monografieèn Nieuw BW, B-37, Deventer (Kluwer) 1998. 
Van Buchem-Spapens, A.M.J. (1992), Pluraliteit van schuldenaren en hoofdelijke verbondenheid, pluraliteit van schuldeisers en alternatieve en voorwaardelijke verbintenissen, Monografieën Nieuw BW, B-31, Deventer (Kluwer) 1982.

Van der Burg, V.A.M (1990), Schade- en sommenverzekeringsrecht, Serie Recht en Praktijk nr. 16, Deventer (Kluwer) 1990.

Calabresi, G. (1961), 'Some Reflections on Risk Distribution and the Law of Torts', 70 Yale Law Journal 1961, p. 499-553.

Calabresi, G. (1970), The Cost of Accidents. A Legal and Economic Analysis, New Haven (Yale University Press) 1970.

Cane, P. (1982), 'Justice and Justifications for Tort Liability', 2 Oxford Journal of Legal Studies 1982, p. 30-62.

Clausing, P. (1964), 'Aansprakelijkheid van werkgever en derden, in het bijzonder tegenover de ongevalsgetroffene, in de Ongevallenwet 1921 (en WAO)', SMA 1964 , p. $406-421$.

Clausing,P.(1970), 'Regresrecht krachtens de WAO', VR 1970, p. 208-210 (met naschrift Giltay Veth).

Coleman, J.L. (1983), 'Moral Theories of Torts: Their Scope and Limits: Part II', 2 Law and Philoshophy 1983, p. 5-36.

Commissie Moltzer (1960), Beperking van het verhaalsrecht. Persoonlijke verantwoordelijkheid en gemeenschapsplicht, rapport van de Wiarda Beckman Stichting, Amsterdam (N.V. De Arbeiderspers) 1960.

Van Dam, C.C. (1989), Zorgvuldigheidsnorm en aansprakelijkheid, een rechtsvergelijkend onderzoek naar plaats, inhoud en functie van de zorgvuldigheidsnorm bij de aansprakelijkheid voor letsel- en zaakschade, dissertatie Utrecht, Deventer (Kluwer) 1989.

Van Dam, C.C. (1991), 'De vererving van de smartengeldvordering', in: Liber Amicorum NBW (De Die-bundel), Arnhem (1991), p. 87-91.

Van Dam, C.C. (1993), 'Ieder draagt min of meer zijn eigen schade. Lagere en hogere drempels voor schadevergoeding in het herfsttij van de verzorgingsstaat', in: Beginselen van vermogensrecht, BW-krant Jaarboek 1993, p. 161-174. 
Van Dam, C.C. (1995), 'De schadeverzekering naar komend recht. Kanttekeningen bij Afdeling 2 van Titel 17 van het nieuwe Burgerlijk Wetboek', in: Verzekering naar komend recht, preadvies van de Vereeniging Handelsrecht en de Vereniging voor Verzekeringswetenschap, Zwolle (W.E.J. Tjeenk Willink) 1995.

Van Dam, M. (2001), Verkeersongevallen, dissertatie Maastricht, Den Haag (Boom Juridische Uitgevers) 2001.

Dennekamp, E.J. (2000), 'Het regres van de kruidenier', NJB 2000, p. 889-890.

Dommering-Van Rongen, L. (1993), 'Schadevergoeding en verzekering', in In volle verzekerdheid, Zwolle (W.E.J. Tjeenk Willink) 1993, p. 237-246.

Dorhout Mees, T.J. (1935), 'Artikel 284 Wetboek van Koophandel', in: Rechtskundige opstellen aangeboden aan E.M. Meijers, Zwolle (W.E.J. Tjeenk Willink) 1935 , p. $318-324$.

Dorhout Mees, T.J. (1972), 'Subrogatie van de verzekeraar', Tijdschrift voor Privaatrecht 1972 , p. 29-47.

Dorhout Mees, T.J. (1995), 'Buitengerechtelijke kosten en de verzekeraar', Vrb 1995, p. 23-26.

Van Dort, R.M.J.T., \& Rensema, J. (2002), Schadevergoeding, Deventer (Kluwer) 2002.

Drion, H. (1995), Verzekering en aansprakelijkheidsrecht, inaugurele rede Rotterdam, 's Gravenhage 1955.

Engelhard, E.F.D. (1999), 'Verkeersaansprakelijkheid. Vergoeding van personenschade in Europees perspectief', NTBR 1999, p. 180-185.

Engelhard, E.F.D. (2000), 'Behoeftigheid bij overlijden', NTBR 2000, p. 254-259.

Engelhard, E.F.D. (2001a), 'Moeten de bijzondere beperkingen van het regres van sociale verzekeraars worden afgeschaft?', in: Schade door arbeidsongevallen en nieuwe beroepsziekten, Faure, M. \& Hartlief, T. (red.), Den Haag (Boom) 2001, p. 47-76.

Engelhard, E.F.D.(2001b), 'Toerekening van een onrechtmatige daad', boekbespreking C.H. Sieburgh, NTBR 2001, p. 514-520. 
Engelhard, E.F.D. (2001c), 'Reflecties van de Hoge Raad over verdere ontwikkelingen van het verkeersaansprakelijkheidsregime. Reflexwerking' NTBR 2001, p. $478-483$.

Engelhard, E.F.D. (2001d), noot bij HR 10-11-2000, NJ 2000, 718 (Levob/Van den Bos), NTBR 2001, p. 107 e.v.

Engelhard, E.F.D. (2002), Shockschade en beroep op art. 8 EVRM en voordeelstoerekening, NTBR 2002, p. 162-166.

Engelhard,E.F.D.(2003), 'Aansprakelijkheidsregels, empathie en de positie van regresnemers', in: De rol van het aansprakelijkheidsrecht bij de verwerking van persoonlijk leed, Van Maanen, G.E. (red.), Den Haag (Boom) 2003, p. 225-247.

Engelhard, E.F.D. \& Van Maanen, G.E. (1998a), Aansprakelijkheid voor verkeersongevallen. Een rechtsvergelijkend perspectief op het Nederlandse verkeersongevallenrecht, Nijmegen (Ars Aequi Libri) 1998.

Engelhard,E.F.D. \& Van Maanen, G.E.(1998b), 'De vordering uit ongerechtvaardigde verrijking; géén billijkheidsactie! Het hek moet weer op de dam... ', NTBR 1998, p. 309-324.

Engelhard,E.F.D. \& Van Maanen, G.E.(1999a), 'Nieuw voorstel verkeersaansprakelijkheid in de maak', VR 1999, p. 353-357.

Engelhard, E.F.D. \& Van Maanen, G.E. (1999b), 'Naar een gedifferentieerd vergoedingsregime voor verkeersslachtoffers. Een nieuw wetsvoorstel', VR 1999, p. 135-139.

Epstein, R.A. (1979a), 'Nuisance Law: Corrective Justice and Its Utilitarian Constraints', 8 Journal of Legal Studies 1979, p. 49-102.

Epstein, R.A. (1979b), 'Causation and Corrective Justice: A Reply to Two Critics', 8 Journal of Legal Studies 1979, p. 477-504.

Faure, M.G. (1999), 'Milieuaansprakelijkheid: een inleidende economische analyse. Afscheid van schuld niet zonder risico', TBA 1999, p. 259-265.

Faure, M.G. (1996), 'Regres in rechtseconomisch perspectief', in: Regresrechten. Afschaffen, handhaven of uitbreiden?, Van Boom, W.H., Hartlief, T. \& Spier, J. (red.), Deventer (W.E.J. Tjeenk Willink) 1996, p. 45-71. 
Faure, M.G. \& Van den Bergh, R. (1989), Objectieve aansprakelijkheid, Verplichte verzekering en veiligheidsregulering, Antwerpen/Apeldoorn (MAKLU) 1989.

Faure, M.G. \& Van den Bergh, R. (2000), 'Aansprakelijkheidsverzekering, concurrentie en ongevallenpreventie', in: Verzekering en maatschappij, onder redactie van Hartlief, T. \& Mendel, M.M., Deventer (Kluwer) 2000, p. 315-342.

Faure, M.G. \& Hartlief, T. (2002), Nieuwe risico's en vragen van aansprakelijkheid en verzekering, Deventer (Kluwer), 2002.

Fleming, J.G. (1966), 'More Thoughts on Loss Distribution', 4 Osgoode Hall Law Journal 1966, p. 161-173 (1966a).

Fleming, J.G. (1966), 'The Collateral Source Rule and Loss Allocation in Torts', 54 California Law Review 1966, p. 1478-1549 (1966b).

Fleming, J. (1970), 'Collateral Benefits', Chapter 11 in Volume XI(Torts), Tunc, A. (ed.), International Encyclopedia of Comparative Law 1970.

Fleming, J.G. (1979), 'The Pearson Report: Its "Strategy"', 42 The Modern Law Review 1979, p. 249-265.

Fletcher, G.P. (1972), 'Fairness and Utility in Tort Theory', 85 Harvard Law Review 1972, p. 537-573.

Fletcher, G.P. (1983), 'The Search for Synthesis in Tort Theory', 2 Law and Philosophy 1983, p. 63-88.

Fluit, P.S. (2001), Verzekeringen van solidariteit, Deventer (Kluwer) 2001.

Fredericq, S. (1990), Moderne risico's en vergoeding van letselschade, Brussel (Bruylant) 1990.

Frenk, N. (1996), 'Regresrecht werkgever voor doorbetaald loon', A\&V 1996, p. 6-7.

Friedmann, D., \& Cohen, N. (1991), 'Payment of Another's Debt', in: X (Restitution - Unjust Enrichment and Negotionum Gestio), Schlechtriem, P. (red.), International Encyclopedia of Comparative Law, 1991 (1991a).

Friedmann, D., \& Cohen, N. (1991), 'Adjustment among Multiple Debtors', Chapter 11 in: X (Restitution - Unjust Enrichment and Negotiorum Gestio), 
Schlechtriem, P. (red.), Interational Encyclopedia of Comparative Law, 1991 (1991b).

Gilthay Veth, N.J.P. (1970), 'Nieuw regresrecht en oude rechtspraak', VR 1969, p. 209-213 en 233-239 (met nawoord VR 1970, p. 329-330).

Gregorius, F.K. (1994), 'De verzekeraar en de totale schadelast', in: Begroting van schade, verandering en verzekering, LSA-reeks nr. 5, Lelystad (Vermande) 1994.

Groutel, H. (1988), Le recours des organismes sociaux contre le responsable d'un accident, Paris (Litec) 1988.

Haardt, W.L. (1970), 'Sociale voorzieningen en de Verhaalswet Ongevallen Ambtenaren', VR 1970, p. 253-256.

De Haas, S.P. \& Hartlief, T. (1996), Collectivering en institutionalisering van regres: instrumenten voor kostenbeheersing, Den Haag (uitgave Verbond van Verzekeraars en Kluwer) 1996.

De Haas, S.P. \& Hartlief, T. (1998), Verkeersaansprakelijkheid. Vergoeding van personenschade in Europees perspectief, Den Haag (uitgave Verbond van Verzekeraars en Kluwer) 1998.

Hage, J.J. (1935), 'De sociale verzekering en het burgerlijk recht' in: Rechtskundige opstellen aangeboden aan E.M. Meijers, Zwolle (W.E.J. Tjeenk Willink) 1935, p. 122-146.

Hamer, M.J. (1989), 'Het verhaalsrecht van de bedrijfsvereniging ter zake van arbeidsongeschiktheidsuitkeringen en de fiscale aspecten van letselschade', WPNR $1989 / 5935$, p. 631-635.

Hammerstein, A. (1994), 'Gerechtigden tot schadevergoeding', in: Begroting van schade, verandering en verzekering, LSA-reeks nr. 5, Lelystad (Vermande) 1994, p. 1-11.

Hartlief, T. (1995), 'Letselschade en toerekening naar redelijkheid', VR 1995, p. 161-166.

Hartlief, T. (1996a), 'Subrogatie in zieligheid', NJB 1996, p. 1047-1050.

Hartlief, T. (1996b), 'De zwakke verkeersdeelnemer', preadvies, TvP 1996, p. 1271-1335. 
Hartlief, T. (1997), Ieder draagt zijn eigen schade, oratie Leiden, Deventer (Kluwer) 1997.

Hartlief, T. (1998), 'De positie van regresnemers: van art. 185 WVW naar art. IIB in het wetsvoorstel Verkeersongevallen', VR 1998, p. 257-261.

Hartlief, T. (2001), 'Verjaring, rechtszekerheid en billijkheid. Enkele beschouwingen naar aanleiding van HR 28 april 2000, NJ 2000, 430 en 431 (ARB)', NTBR 2001, p. 58-66 (2001a).

Hartlief, T. (2002/2001), Verkeersaansprakelijkheid. Noot bij HR 10 november 2000, RvdW 2000, 225 en HR 17 november 2000, RvdW 2000, 234, AV\&S 2001, p. $50-53$ (2001b).

Hartlief, T. (2001), 'De Hoge Raad en de reflexwerking van art. 185 WVW', AV\&S 2001, p. 73-80 (2001c).

Hartlief, T. \& Van Maanen, G.E. (1991), 'Bedrijfsvereniging, verhaal en Nieuw BW. Het einde van het verhaal!', SMA 1991, p. 292-303.

Hartlief, T. \& Van Maanen, G.E. (1994), 'Regres bij volksverzekeringen: de dader heeft het gedaan', NTBR 1994, p. 75-78.

Hartlief, T. \& Van Maanen, G.E. (1996), 'Regresrecht voor werkgever ter zake van loonbetalingen na letseltoebrenging door een derde', SR 1996, p. 125-129.

Hartlief, T. \& Tjittes, R.P.J.L. (1991), 'Regres in gezinsverband', WPNR $1991 / 6000$, p. $225-231$.

Hartlief, T. \& Tjittes, R.P.J.L. (1999), Verzekering en aansprakelijkheid, Deventer (Kluwer) 1999.

Van den Heuvel, H. (1960), Cumulatie van vorderingen en subrogatie van de ongevallenverzekeraar, overdruk uit WPNR nr. 1960/4614-4617 (met daarin geen gegevens over uitgave).

Honoré, T. (1997), 'The Morality of Tort Law', in: Philosophical Foundations of Tort Law, Owen, D.G. (ed.), Oxford (Clarendon Press) 1997, p. 73-95.

Hoogendijk, B. (1994), 'Arbeidsongeschiktheid en het verhaalsrecht van de werkgever', SR 1994, p. 8-12.

Jalink, D. (1989), 'Het Schadefonds Geweldsmisdrijven', AAe 1989, p. 110-119. 
Janssen, P.L.M. (1997), 'Verhaalsrechten in de sociale zekerheid', VerzekeringsArchief 1997 , p. $155-162$.

Janssen, P.L.M. (1999), 'Verbond van Verzekeraars en College voor Zorgverzekeringen sluiten convenant over collectieve afkoop van AWBZ-regres', TVP 1999, p. $80-81$.

Jaspers, A.Ph.C.M. \& Riphagen, J. (1991), Schets van het Sociaal zekerheidsrecht, Deventer (Kluwer) 1991.

Jaspers, A.Ph.C.M., Noordam, F.M., Van Oorschot, W.J.H. en Pennings, F.J.L. (red.) (2001), De gemeenschap is aansprakelijk... Honderd jaar sociale verzekering 1901-2001, Lelystad (Koninklijke Vermande) 2001.

Klosse, S. (2001), 'Schadevergoeding via sociale zekerheid en aansprakelijkheidsrecht: communicerende vaten?', in: Schade door arbeidsongevallen en nieuwe beroepsziekten, Faure, M. \& Hartlief, T. (red.), Den Haag (Boom) 2001, p. 1-18.

Klosse, S. (2003), 'Vergoeding als noodverband?', AV\&S 2003, p. 25-33.

De Kok, H.G.F.M. (1965), Het regres, dissertatie Nijmegen, Deventer (Kluwer) 1965.

Kohllhosser, H (1966), 'Lohnfortzahlung, Schadenersatz und Regressinteressen beim Unfall eines Angestellten', Archif für die civilistische Praxis 1966, p. 273 285.

Köster, H.K. (1971), 'Regresrecht van de verzekeraar?', preadvies voor de Vereniging voor vergelijkende studie van het recht in België en Nederland 1971, VA 1972, p. 73-148.

Kottenhagen-Edzes, P.A. (1993), 'Verzekeringsuitkering en voordeelstoerekening', in In volle verzekerdheid, Zwolle (W.E.J. Tjeenk Willink) 1993, p. 301-317.

Kremer, F.Th.(1998), Het indemniteitsprincipe, een juridische (her)waardering, Serie verzekeringsrecht, Zwolle (W.E.J. Tjeenk Willink) 1988.

Kremer, F.Th. (1991), 'Moeten alle buitengerechtelijke kosten vergoed worden; en zo ja, waarom niet?', in: Een Salomonsoordeel, Zwolle (W.E.J. Tjeenk Willink) 1991, p. 25-31.

Kremer, F.Th. (1994), 'Buitengerechtelijke kosten nader beschouwd', A\&V 1994, p. 59-64. 
Kremer, F.Th. (1996), 'Buitengerechtelijke kosten van regresnemers; ook hier een civiel plafond?', A\&V 1996, p. 93-96.

Kremer, F.Th. (1999), 'Administratiekosten en art. 6:96 BW', A\&V 1999, p. 14-20.

Kremer, F.Th.(2000), 'Regresconvenanten met aansprakelijkheidsverzekeraars: schaalvergroting in een notendop', in: Verzekering en maatschappij, onder redactie van Hartlief, T. \& Mendel, M.M., Deventer (Kluwer) 2000, p. 423-432.

Law Commission (1997), Damages for Personal Injury: Collateral Damages, Consultation Paper No. 147, London 1997.

Ledeboer,D.H. (1927), Het regt van den verzekeraar tegen derden; beschouwing van art. $284 \mathrm{~K}$, dissertatie Leiden, 1927.

De Leede, L.J.M. (1965), 'Verhaalswet Ongevallen Ambtenaren', TvO 1965, p. 19-20.

Van Leeuwen, A.W. \& Bouma, H.Th. (1993), 'VOA; een tussenbalans', VR 1993, p. 234-237.

Levelt-Overmars (1990), 'De afschaffing van het verhaalsrecht van de bedrijfsvereniging: vestzak-broekzak of zakkenrollen?', VR 1990, p. 322-324.

Lieverse, C.W.M. (1999), 'Het Bindend Besluit Regres; onzorgvuldigheid van de schadeveroorzaker', Vrb 1999, p. 37-39.

Lindenbergh, S.D. (1999a), 'Letselschade van kind. Noot bij HR 28 mei 1999, NJ 1999, 564 (m.nt. ARB) (Losser/De Vries)', NTBR 1999, p. 227-232.

Lindenbergh, S.D. (1999b), 'De overgang van het recht op schadevergoeding uit onrechtmatige daad', Groninger Opmerkingen en Mededelingen 1999, p. 58-68.

Lindenbergh, S.D. e.a. (2000) - Lindenbergh, S.D., Tromp, J.M., Van Haastert, M.F.H.M., Kremer, F.Th., De Vries, W.S., Buitengerechtelijke kosten. Vijf visies op de redelijkheid, Deventer (Kluwer) 2000.

Loeff, P.H. (1891), Hoofdelijke verbintenissen volgens het Nederlandsche recht, dissertatie Amsterdam, 1891. 
Luntz, H, 'The Collateral Source Rule Thirty Years On', in The Law of Obligations. Essays in Celebration of John Fleming, Cane, P. \& Stapleton, J. (ed.), Oxford (Clarendon Press), p. 377-408.

Van Maanen, G.E. (1984), 'Operatie 'stofkam', of stofkam-operette?', NJB 1984, p. 173.

Van Maanen, G.E. (1986), 'Doodslag en behoeftigheid', Kwartaalbericht NBW 1986, p. 121-124.

Van Maanen, G.E. (1991), Boekbespreking C.C. van Dam, Zorgvuldigheidsnorm en aansprakelijkheid, Kwartaalbericht Nieuw BW 1991, p. 21-24.

Van Maanen, G.E. (1994), 'Permanente beperking van de verhaalsmogelijkheden voor particuliere en sociale schadeverzekeraars', A\&V 1994, p. 94-97.

Van Maanen, G.E. (1998), 'Wetsvoorstel verkeersongevallen: dwaling of boerenbedrog? De ondergeschoven positie van regresnemers', NJB 1998, p. 116-122.

Van Maanen, G.E. (1999), 'Het systeem Van Maanen', RM Themis 1999, p. 54-56.

Van Maanen, G.E. (2003), 'Enkele gedachten naar aanleiding van het experiment in het Veterans Affairs Medical Centre in Lexington, USA' in: De rol van het aansprakelijkheidsrecht bij de verwerking van persoonlijk leed, Van Maanen, G.E. (red.), Den Haag (Boom), 2003, p. 1-24.

Van Maanen, G.E. \& Römers, P. (1994), De Tijdelijke regeling verhaalsrechten. Verhaalsmogelijkheden voor verzekeraars en uitkeringsinstanties, Ars Aequi Cahiers Privaatrecht deel 3, Nijmegen (Ars Aequi Libri) 1994.

Van Maanen, G.E. \& Nelissen, E.F.D. (1998), 'De positie van regresnemers in het wetsvoorstel verkeersongevallen. Enkele kritische opmerkingen mede in het licht van de ontwikkelingen in België en Frankrijk', in: Verkeersaansprakelijkheid in België en Nederland, Faure, M. \& Hartlief, T. (red.), Antwerpen/Groningen (Intersentia) 1998, p. 197 e.v.

Mac Lean, M.M. (1986), 'De Verhaalswet Ongevallen Ambtenaren (V.O.A.)', VR 1986, p. 281-291.

Markesinis, B.M. (1994), A Comparative Introduction to the German Law of Torts, Oxford (Clarendon Press) 1994. 
Mitchell, Charles (1994), The law of subrogation, Oxford (Clarendon Press) 1994.

Mok, L. (1997), 'De Verhaalswet Ongevallen Ambtenaren. Een verhaal met onverwachte wendingen', VA 1977 , p. 167-188.

Mok, L. (1998), Verzekeringsrecht. Civielrechtelijke hoofdstukken, Antwerpen/Groningen (Intersentia) 1998.

Möller, J.O. (1992), 'Erosie van het verhaalsrecht bij ziektekostenverzekeringen. Vraagtekens uit de praktijk', NJB 1992, p. 1109-1111.

Mijnssen, F.H.J. (1970), Regresrecht van de schadeverzekeraar, Studiekring Offerhaus reeks Handelsrecht no. 8, Amsterdam (Scheltema \& Holkema NV) 1970.

Mulder, S.J.A. (1998), Subrogatie, het verhaalsrecht van de verzekeraar, Serie Verzekeringsrecht, Zwolle (W.E.J. Tjeenk Willink) 1988.

Mulder-Rietra, A.G.J.M. (1993), 'Het verhaalsrecht in de sociale verzekeringen', SMA 1993, p. 715-722.

Noordam, F.M. (2000), Hoofdzaken socialezekerheidsrecht, Deventer (Kluwer) 2000.

Nubé (1961), 'Nogmaals: cessie op grond van het Ambtenarenreglement', WBGA 1961, p. 357-358.

Oosenbrug e.a. (1996), Schadeverzekering in Nederland, Oosenbrug, A., Bekouw, O., Gregorius, F.K., Dooren, F.T.E., De Vries, J. \& Remmerswaal, J.C.M., Finance \& Insurance, Oosenbrug, A. \& Van den Berghe, L.A.A. (red.), 's Gravenhage 1996.

Overeem, R(1997), 'Regresrecht en verkeersrisico-aansprakelijkheid', VA 1992, p. $67-75$.

Owen, D.G. (1997), 'Why Philosophy Matters to Tort Law', voorwoord in: Philosophical Foundations of Tort Law, Owen, D.G. (ed.), Oxford (Clarendon Press) 1997, p. 1-27.

Pardaan, I.F. (2001), Sociale verzekeringen voor de letselschaderegelaars, Monografiën Letselschade, Den Haag (Boom) 2001. 
Du Perron, C.E.(2003), 'Genoegdoening in het civiele aansprakelijkheidsrecht', NJV-preadvies, in: Het opstandige slachtoffer, Handelingen NJV 2003-1, Deventer (Kluwer), 2003.

Posner, R.A. (1979), 'Utilitarianism, Economics, and Legal Theory', 8 Journal of Legal Studies 1979, p. 103-140 (1979a).

Posner, R.A. (1979), 'Epstein's Tort Theory: A Critique', 8 Journal of Legal Studies 1979, p. 457-475 (1979b).

Posner, R.A. (1986), Economic Analysis of Law, Boston/Toronto (Little Brown) 1986.

Posner, R.A. (1996), The Economics of Justice, Cambridge/Massachusetts/London 1996.

Rinkes, J.G.J. (2000), 'Subrogatie verzekeraar bij onverplichte betaling (art. 284 WvK); de Hoge Raad gaat 'om", NTBR 2000, p. 205-207.

Robben, C.P. (1993), De action directe en de Wet aansprakelijkheidsverzekering motorrijtuigen, Apeldoorn (MAKLU), 1993.

Van Rossum du Chattel, L.A. (1964), 'Ontwerp Verhaalsongevallen Ambtenaren', TvO 1964, p. 494-496.

Schadevergoeding, losbladige editie onder redactie van Bloembergen, A.R., Deventer (Kluwer).

Schäfer, H.-B. \& Schönenberger, A. (2000), 'Strict Liability versus Negligence', in: B. Bouckaert \& G. de Geest, Encyclopedia of Law and Economics II, Cheltenham/Northampton (Edward Elgar) 2000, p. 597-624.

Scheltema, H.J. (1998), mr. M. Polak's Handboek voor het Nederlandse handelsen faillissementsrecht, deel 4, Algemeen deel van het schadeverzekeringsrecht, vijfde druk, bewerkt door F.H.J. Mijnssen, Alphen aan de Rijn (Kluwer) 1998.

Schoordijk, H.C.F. (1967), 'Eenige aantekeningen n.a.v. de aansprakelijkheid van ondernemer en arbeider voor bedrijfsongevallen na de inwerkingtreding van de WAO (...)', NJB 1967 , p. 341-350.

Schut, G.H.A. (1962), 'Ongeval en Cessie', WBGA 1962, p. 87-88. 
Schuurmans Stekhoven, W. (1938), De omschrijving van het risico en de regeling van de schade in het particuliere ongevallenverzekeringsrecht, dissertatie Utrecht, 's Gravenhage (G. Naeff) 1938.

Schwartz, G.T. (1990), 'The Ethics and the Economics of Tort Liability Insurance', 75 Cornell Law Review 1990, p. 313-365.

Schwartz, G.T (1994), 'Reality in the Economic Analysis of Tort Law', 42 UCLA Law Review 1994, p. 377-484.

Schwitters, R.J.S. (1991), De risico's van de arbeid. Het ontstaan van de Ongevallenwet 1901 in sociologisch perspectief, Rechtswetenschappelijke Reeks, Groningen 1991.

Selb, W.(1963), Schadensbegriff und Regressmethoden, Heidelberg (Carl Winter Universitätsverlag) 1963.

SER-rapport 93/14 (1993), Regresrechten in de sociale verzekeringen, Den Haag, 17 september 1993.

Shavell, S. (1984), 'Liability for Harm versus Regulation of Safety', 13 Journal of Legal Studies 1984, p. 357-374.

Shavell, S. (1987), Economic analysis of Accident Law, Cambridge (Harvard University Press) 1987.

Sheinman, H. (2003), 'Tort Law and Corrective Justice', 22 Law and Philosophy 2003, p. 21-73.

Sieburgh, C.H. (2000), Toerekening van een onrechtmatige daad, Deventer (Kluwer) 2000 .

Sinninghe Damsté, W.A. (1999), Regres bij onrechtmatige daad, Lelystad (Vermande) 1999.

Slagter, W.J. (1963), 'Het regresrecht van de risicodrager krachtens sociale verzekeringswetten volgens Nederlands recht', VR 1963, p. 1 e.v., 26 e.v., 147 e.v. en 195 e.v.

Smit, R.J.M. (1985), 'Het Bindend Besluit Regres', WPNR 1985/5725, p. 37-42. 
Smits, J.M. (2000), The Good Samaritan in European Private Law. On the Perils of Principles without a Programme and a Programme for the future, oratie Maastricht, Deventer (Kluwer) 2000.

Sociale Verzekeringsraad (1993), Regresrecht, advies A93/38, uitgave stafafdeling Bestuurszaken Zoetermeer november 1993.

Spier, J. (1992), Schadevergoeding, algemeen, deel 3, Monografieèn Nieuw BW36, Deventer (Kluwer) 1992.

Spier, J. (1995), 'De Grenzen der buitengerechtelijke kosten', A\&V 1995, p. 55-60.

Spier, J. (1996), 'De grenzen van subrogatie in zieligheid', in: Regresrechten. Afschaffen, handhaven of uitbreiden?, Van Boom, W.H., Hartlief, T. \& Spier, J. (red.), Deventer (W.E.J. Tjeenk Willink) 1996, p. 35-44.

Spier, J. (1999), Een nieuwe dageraad voor het aansprakelijkheidsrecht?, Deventer (W.E.J. Tjeenk Willink) 1999.

Spier, J. (2002), Rampscenario's. De prijs van de onzekerheid na de aanslagen in de Verenigde Staten op 11 september 2001, oratie Maastricht, Deventer (Kluwer) 2002.

Spier, e.a. (2000) - Spier, J., Hartlief,' T., Van Maanen, G.E., Vriesendorp, R.D., Verbintenissen uit de wet en schadevergoeding, Deventer (Kluwer) 2000.

Stapleton, J. (1986), Disease and the Compensation Debate, Oxford (Clarendon Press) 1986 (herziene handelsuitgave van dissertatie University of Oxford).

Stapleton, J. (1995), 'Tort, Insurance and Ideology', 58 The Modern Law Review 1995 , p. $820-845$.

Steendam, S.H. (1985), Het ontstaan van de brandregresregeling 1984, VA 1985, p. 243.

Stolker, C.J.J.M. (1994), 'Subrogatie en buitengerechtelijke kosten', Vrb. 1994, p. 1-2.

Storm, H.M. (1996), 'Een zelfstandig regresrecht voor de werkgever: de juiste keuze?', NTBR 1996, p. 94 e.v. 
Storm, H.M. (1996), 'Werkgeversregres', in: Regresrechten. Afschaffen, handhaven of uitbreiden?, Van Boom, W.H., Hartlief, T. \& Spier, J. (red.), Deventer (W.E.J. Tjeenk Willink) 1996, p. 119-130.

Studiegroep Verkeersaansprakelijkheid (1978), rapport, Deel I Vergoeding van schade door dood en letsel, Den Haag (Staatsuitgeverij) 1978.

Sugarman, S.D. (1985), 'Doing Away with Tort Law', 73 California law Review 1985 , p. 558-664.

Tollenaar, N.W.A. (2001), 'Subrogatie bij onverplichte betaling', VR 2001, p. 65-70.

Troostwijk, M. (1959), 'Cessie op grond van het Ambtenarenreglement', WBGA 1959, p. 503-506.

Troostwijk, M. (1966), 'Verhaalswet Ongevallen Ambtenaren', VR 1966, p. 194 196.

Ubbink, J.W. (1962), Ongevallen-, ziekengeld- en invaliditeitsverzekering, Amsterdam 1962.

Van der Veen, Th.L. (1961), 'Verhaalsrecht Sociale Verzekeringsbank in de praktijk', VVP 1961, p. 1-2.

Van der Veen, Th.L. (1961), 'Onbevredigend en onbillijk 'verhaalsrecht' van risicodraagster ex artikel 95 Ongevallenwet', NJB 1961, p. 931-932.

Van der Veen, Th.L. (1993), 'Evident groot manco in Boek 7A art. 1638c BW!', NJB 1993, p. 756-757.

Verheij, A.J. (2002), Vergoeding van immateriële schade wegens aantasting in de persoon, Nijmegen (Ars Aequi Libri) 2002.

Verwer, L.G.M. (1970), 'Het civielrechtelijke verhaalsrecht van de risicodrager in het sociaal verzekeringsrecht', SMA 1970, p. 81-95.

Viney, G. (1998), 'Le 'Wrongfulness' en Droit Français', in: Unification of Tort Law: Wrongfulness, Koziol, H. (red.), Den Haag (Kluwer) 1998, p. 57-64.

Voorlichtingsbrochure Regres Brand (1983) van de Vereniging van Brandassuradeuren in Nederland \& Nederlandse Vereniging van Algemene Aansprakelijkheidsverzekeraars AAV, Den Haag 1983. 
Van Vrijberghe de Coningh, A.W.J. (1943), Subrogatie, Zwolle(W.E.J. Tjeenk Willink) 1943.

Wachter, B. (1992), 'Aanrijdingen in familieverband', VR 1992, p. 136.

Weinrib, E.J. (1983), 'Towards a Moral Theory of Negligence Law', 2 Law \& Philosophy 1983, p. 37-62.

Van Wersch, P.J.M. (1971), 'Een vergelijking van de uitvoeringskosten van de particuliere motorrijtuigverzekering en enige sociale verzekeringen', VA 1971, p. 74-95.

Willems, H. (1996), 'Schadefonds Geweldsmisdrijven', APB 1996, p. 16-17.

De Winter, F. (1988), 'Het regresrecht van de risicodrager bij onrechtmatige daad in België en Nederland en de nederlandse risicodragers in Belgiê', VR 1988, p. 29 e.v.

Ziekenfondsraad (1993), Advies inzake invoering regresrecht in de AWBZ, Advies d.d. 28 oktober 1993, nr. 594, Amstelveen 1993.

Zwalve, W.J. (1993), 'Uit de geschiedenis van het Handelsrecht. Art. 284 K', Groninger Opmerkingen en Mededelingen 1993, X, p. 133-154. 


\section{Jurisprudentie}

\section{Rechtbank}

Rb. Almelo 21 oktober 1970, NJ 1971, 216 (Ziekenfonds/Oosterwijk) 277

Rb. Amsterdam 9 december 1960, NJ 1961, 221 (Koopman/Van Herreweghe)

Rb. Amsterdam 19 oktober 1965, NJ 1966, 300 (Centrale Werkgevers/Corbran)

363

Rb. Amsterdam 30 december 1998, VR 1999, 81 (S/Centraal Beheer)

Rb. Breda 9 november 1937, NJ 1938, 372 (BTO/Van Herwaarden) 268

Rb. Den Haag 3 oktober 1950, NJ 1952, 119 (Staatsbedrijf der Posterijen/Meeteren) 237

Rb. Den Haag 5 december 2001, NTBR 2002, p. 162 (H/Hannover International) 143,227, 382

Rb. Groningen 25 juni 1954, NJ 1955, 107 (Dikken/Hillebrink) 268

Rb. Groningen 7 augustus 1998, 222768/HA ZA 96-910 (niet gepubliceerd) 288

Rb. Roermond 25 juli 1991, NJ 1992, 738 (Krings/Lloyd's London) 181

Rb. Rotterdam 20 maart 1930, W 1930, 12180, p. 6 (Van Luijk/Banis) 160, 379

Rb. Rotterdam 15 mei 1931, NJ 1932, p. 202 (Centrale Werkgevers/Uleman)

Rb. Zutphen 26 maart 1936, NJ 1938, 443 (NBO e.a./Van den B) 150

Rb. Zwolle 30 december 1970, VR 1971, 82 (Bedrijfsvereniging/Visscher) 238

Rb. Zwolle 19 juni 1985, NJ 1988, 88 (Nieuwleusen/Hengeveld) 355

Rb. Zwolle 31 maart 1993, NJ 1993, 684 (ABP/SGHB) 311

\section{Gerechtshof}

Hof Amsterdam 8 december 1954, NJ 1955, 406 (Raad van Arbeid/Sprengler)

Hof Amsterdam 20 oktober 1966, NJ 1967, 26 (Centrale Werkgevers/Corbran)

Hof Amsterdam 29 december 1983, NJ 1985, 296 (Winterthur/Schuurman) 179

Hof Amsterdam 9 december 1993, rolnr. 254/92 (niet gepubliceerd) 274,296

Hof Amsterdam 23 december 1993, VR 1995, 23 (Eerste Algemene/Waterleiding Maatschappij)

Hof Amsterdam 14 november 1996, rolnr. $760 / 88$ (niet gepubliceerd) $288,312-313$

Hof Amsterdam 19 maart 1998, rolnr. 96/1028 (niet gepubliceerd) 296, 336

Hof Amsterdam 9 juli 1998, VR 1999, 64 (Turien/Van den Heuvel)

Hof Arnhem 28 oktober 1969, NJ 1970, 72 (Geerlings/Centrale WerkgeversB62

Hof Arnhem 16 november 1999, NJ 2000, 727 (Klaverblad/IZA) 264

Hof Den Bosch 3 februari 1953, NJ 1953, 735 (Van der Heijden/Jansen) 264

Hof Den Bosch 10 december 1974, NJ 1975, 141 (Mijnstreek/Vick) 355

Hof Den Bosch 24 december 1974, NJ 1977, 214 (Derkx/IBC) 68, 291

Hof Den Bosch 1 mei 1980, NJ 1981, 671 (Herber/Algemene Ziekenfonds) 277

Hof Den Bosch 26 september 1995, NJ 1997, 460 (Thijssen/ABP) 103, 236

Hof Den Bosch 26 juni 1996, NJ 1997, 252 (Bartels BV/Mammoet-Stoof BV)

Hof Den Bosch 17 juli 2001, NJ 2002, 399 (Joosten/Interpolis) 203

Hof Den Bosch 15 april 2003, rolnr. C0100972/HE (niet gepubliceerd)

Hof Den Haag 6 januari 1977, NJ 1977, 469 (Waarborgfonds/Ziekenzorg) 
Hof Den Haag 29 april 1998, rolnr. 95/1113 (niet gepubliceerd) 274, 296, 311

Hof Leeuwarden 7 mei 1997, NJ 1998, 292 (RZG/Stichting Savant) $\quad 250,253,254$

\section{Hoge Raad}

HR 27 februari 1925, NJ 1925, 566 (Spoorwegongeval te Weesp)

HR 30 oktober 1925, NJ 1926, 157 (Stoomvaartmaatschappij/rederij)

148

HR 5 december 1929, NJ 1930, 1055 nt. EMM (Ruhaak/Fatum) 65, 164, 233, 236

HR 24 januari 1930, NJ 1930, 299 nt. EMM (Brandstichting) 145, 154, 155, 377-378, 381, 382

HR 3 april 1930, NJ 1930, 1407 nt. EMM (Eerste Onderlinge/PGEM) 121

HR 2 januari 1931, NJ 1931, 348 nt. EMM (Vollaard/Van der Jacht) 144

HR 31 december 1931, NJ 1932, 419 nt. EMM (Spoorwegongeval De Vink)50, 107, 121, 128, 161

HR 19 januari 1933, NJ 1933, 1757 nt. EMM (Roodhuyzen/Hartogh) $\quad 148,150$

HR 15 februari 1935, NJ 1935, 417 nt. EMM (RVB/Tolenaars) 20, 65, 232, 236

HR 3 januari 1936, NJ 1936, 78 nt. EMM (Koopmans/Bedrijfsvereeniging) 44, 45, 85, 121, 128 148,161

HR 2 april 1936, NJ 1936, 752 nt. EMM (Crasborn/Liverpool) 167, 170

HR 18 november 1937, NJ 1938, 269 nt. EMM (Van Rompu/Cleeves) 128, 296

HR 5 mei 1938, NJ 1938, 707 nt. EMM (Vrachtrijders/Centrale Werkgevers)

HR 8 december 1938, NJ 1939, 545 nt. EMM (RVB/Schø̈nberger) 97, 284, 323

HR 10 januari 1941, NJ 1941, 824 nt. EMM (KPM/Liverpool) 86, 147, 162

HR 20 februari 1942, NJ 1942, $352 a$ (Gemeente Groningen/ATO) 237

HR 20 februari 1942, NJ 1942, $352 b$ (Centrale Werkgevers/Muskens) 237

HR 23 juli 1946, NJ 1946, 545 nt. DJV (Centrale Werkgevers/Ferwerda) $\quad 66,69,268,299,310$

HR 17 december 1954, NJ 1955, 68 nt. LEHR (Van G./X, Y en Z)

HR 4 november 1955, NJ 1956, 1 (London \& Lancashire Insurance/Huygen) 48

HR 10 januari 1958, NJ 1958, 79 nt. LEHR (Van Hoof/Van der Plas) 144, 167, 170

HR 17 januari 1958, NJ 1958, 80 (Sociale Verzekeringsbank/Snijders) 377

HR 30 januari 1959, NJ 1959, 548 nt. DJV (Quint/Te Poel)

HR 13 maart 1959, NJ 1962, 338 (Ziekenfonds/Hogestijn I) 85, 168, 208

HR 8 januari 1960, NJ 1960, 127 nt. LEHR (Daalder's Aannemers/Zandbergen) $\quad 164,268$

HR 8 april 1960, NJ 1960, 412 nt. HB (Haak/Meijering)

HR 9 december 1960, NJ 1962, 339 nt. HB (Hogestijn/Ziekenfonds II) $\quad 165,168$

HR 16 juni 1961, NJ 1961444 nt. LEHR (Telefoonkabel) $\quad 296$

HR 23 juni 1961, NJ 1961, 397 (Eerste Rotterdamsche/Visser) 96, 166, 285

HR 15 februari 1963, NJ 1964, 423 nt. DJV (Houtappel/Velthuyzen) 144

HR 8 maart 1963, NJ 1963, 317 nt. HB (Stad Rotterdam/Brunt) 385

HR

HR 24 januari 1964, NJ 1964, 465 nt. GJS (Bedrijfsvereniging/Hendriksen) 85, 86, 165

HR 5 oktober 1965, NJ 1966, 292 (J/Liverpool and London Globe)

320

HR 5 november 1966, NJ 1966, 136 nt. GJS (Kelderluik)243

HR 25 november 1966, NJ 1967, 259 (Rotterdamsche Droogdok/Oldermann) 64

HR 20 juni 1969, NJ 1969, 374 nt. GJS (Zitman/Nieuwe Eerste) 167

HR 28 november 1969, NJ 1970, 172 nt. GJS (IBC/Derkx) 49, 50, 51, 60, 128

HR 5 december 1969, NJ 1970, 140 (Gemeente Sneek/Oosterhof) 81, 103, 289

HR 3 april 1970, NJ 1970, 379 nt. GJS (Risicobank/Staat) 285

HR 19 juni 1970, NJ 1970, 380 nt. GJS (NBM/Eagle Star) $\quad 34,50,132,385$

HR 6 november 1970, NJ 1971, 76 nt. GJS (Geerlings/Centrale Werkgevers) 65

HR 3 maart 1972, NJ 1972, 339 nt. HB (La Confiance resp. L'Union/Maring) 
HR 16 juni 1972, NJ 1972, 375 (Van Wetten/Courtois) $144,379,380$

HR 12 januari 1973, NJ 1973, 177 nt. ARB (Nutsziekenfonds/Mahieu)

$233,237,276-277$

279

HR 2 februari 1973, NJ 1973, 225 nt. ARB (Centrale Werkgevers/Millenaar) 52, 353

HR 1 februari 1974, NJ 1974, 391 (Bedrijfsvereniging/Visscher) 289, 290, 299

HR 20 december 1974, NJ 1976, 318 nt. BW (Geenen/VGZ) 277-278

HR 11 april 1975, NJ 1975, 373 nt. GJS (Zopp/Mijnwerkersfonds) 350

HR 7 november 1975, NJ 1976, $332 \mathrm{nt}$. ARB (Ziekenfonds/Nationale Nederlanden) 165, 316, 360-361, 368

HR 2 april 1976, NJ 1976, 532 nt. ARB (Alliance Company/Staat)170, 286

HR 23 april 1976, NJ 1976, 451 nt. GJS (Fransiscaner pater) 21

HR 4 juni 1976, NJ 1977, 4 nt. ARB (Van Geffen/Staat) 80, 82, 103, 311, 312

HR 17 december 1976, NJ 1977, 351 nt. ARB (Van den Endt/Bongaerts) 66, 120

HR 4 maart 1977, NJ 1978, 144 nt. ARB (Providentia/ABP) $80,82,154,209,238,299$.

304-305

HR 30 juni 1978, NJ 1978, 685 nt. GJS (APF Ziekenfonds/De Boer) (Dillema I) 260, 263

HR 29 juni 1979, NJ 1980, 33 (Zwolsche Algemeene/Staat) 369

HR 16 april 1980, NJ 1981, 109 nt. FHJM (CLM/General Accident)

HR 5 juni 1981, NJ 1982, 221 nt. CJHB (Tijsterman/Hony) 35

HR 11 juni 1982, NJ 1983, 583 (Rijnstreek I) 351

HR 18 juni 1982, NJ 1983, 369 (Peters/Bedrijfsvereniging) 97, 285-286

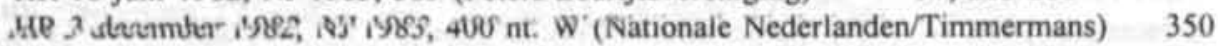

HR 25 maart 1983, NJ 1984, 681 (ABP/Delta Lloyd) 235

HR 8 april 1983, NJ 1984, 717 nt. CJHB (Van der Heijden/Holland)

$144,280,379$

HR 6 mei 1983, NJ 1983, 584 nt. FHJM (Rijnstreek II) 351, 355, 357

HR 20 mei 1983, NJ 1984, 649 nt. FHJM (Bedrijfsvereniging/Brok)

HR 25 november 1983, NJ 1984, 707 (Kappner/ABP) 80

HR 9 december 1983, NJ 1984, 708 (Zwolsche Algemeene/Staat) 286

HR 27 januari 1984, NJ 1984, 536 nt. G (Verstekeling) 143, 382

HR 15 februari 1985, NJ 1986, 687 nt. FHJM (Stad Rotterdam/ABP)

HR 19 april 1985, NJ 1986, 209 nt. FHJM (Rijnstreek III) 352

HR 24 mei 1985, NJ 1985, 732 (Zeven Provinciēn/Staat)236, 237

HR 13 december 1985, NJ 1986, 246 nt. G (ABP/Wink) 234, 235, 237, 290-291

HR 28 februari 1986, NJ 1987, 100 (Niks/Snippe) 35

HR 17 oktober 1986, NJ 1987, 317 nt. JBMV (Schotanus/Bedrijfsvereniging)

12,30899

HR 12 december 1986, NJ 1987, 958 nt. CJHB (Rockwool/Poly) 144, 145, 379, 380, 384

HR 6 februari 1987, NJ 1988, 57 nt. CJHB (GAFLIC/Mulder) 265

HR 13 februari 1987, NJ 1987, 602 nt. JBMV (Bedrijfsvereniging/Delta Loyd) $\quad 358,360$, 364,365

HR 3 april 1987, NJ 1988, 275 nt. CJHB (L\&L/Drenth) 297

HR 12 juni 1987, NJ 1988, 39 nt. G en EAAL (Holland/Beek) 350

HR 26 juni 1987, NJ 1988, 536 nt. JBMV (Nieuw Rotterdam/Bedrijfsvereniging) $\quad 350,352$, 353-354

HR 27 november 1987, NJ 1989, 48 nt. CJHB (Staat/Piers) 291-292

HR 18 december 1987, NJ 1988, 439 nt. G (Amro/Joy Coats) 378

HR 20 mei 1988, NJ 1988, 1032 nt. JBMV (Bedrijfsvereniging/Fireco) 361, 364

HR 4 november 1988, NJ 1989, 751 nt. CJHB (ABP/Van Stuyvenberg) 273

HR 28 april 1989, NJ 1990, 703 nt. JCS (Tollenaar/BVSA) 121, 161

HR 2 juni 1989, NJ 1990, 726 nt. MMM (Zwolsche Algemeene/Bedrijfsvereniging) 235

HR 3 november 1989, NJ 1990, 402 nt. JBMV (Ziekenfondsraad/Waarborgfonds) 249,287,

310 
HR 3 november 1989, NJ 1990, 699 nt. JBMV (Derksen/Scholten) 290 HR 8 december 1989, NJ 1990, 778 nt. CJHB (Vrieling/Ruröde) 263 HR 2 februari 1990, NJ 1991, 292 nt. CJHB (Vermaat/Staat en ABP) HR 23 februari 1990, NJ 1991, 574 nt. CJHB (Centraal Beheer/Bedrijfsvereniging) HR 1 juni 1990, NJ 1991, 720 nt. CJHB (Kolkman/Nationale Nederlanden) 260, 261 HR 22 juni 1990, NJ 1991, 760 nt. CJHB (ABP/Baauw) 102, 113, 271, 273 HR 7 december 1990, NJ 1991, 596 (Ziekenfonds/De Vries) $\quad 360,361,364$ HR 25 januari 1991, NJ 1992, 706 nt. CJHB (ABP/Elzenga) 352, 353-354 HR 31 mei 1991, NJ 1991, 721 nt. CJHB (De Backer/Van Uitregt)261 HR 22 mei 1992, NJ 1992, 527 (ABP/Winterthur) 262 HR 28 februari 1992, NJ 1993, 566 nt. CJHB (IZA/Vrerink) 261, 266 HR 10 december 1993, NJ 1995, 493 nt. CJHB (Gemeente Haarlem/ABP) 369 HR 24 december 1993, NJ 1995, 236 nt. CJHB (Sikes/Kellenaers) 261

HR 11 februari 1994, NJ 1995, 494 nt. CJHB (NOVO/RZG) 352, 354

HR 18 februari 1994, NJ 1995, 607 nt. CJHB (BMV/ABP) $269,287,299,323$

HR 25 februari 1994, NJ 1995, 608 nt. CJHB (Staat/Sterpolis) 235, 287, 293

HR 29 april 1994, NJ 1995, 609 nt. CJHB (NN/ABP) 33, 235, 299, 323

HR 10 augustus 1994, NJ 1995, 58 (General Accident/Staat en ABP) 82, 316

HR 16 september 1994, NJ 1996, 329 nt. CJHB (NN/Woudsend I) 44, 56, 62, 68, 71, 366

HR 9 december 1994, NJ 1995, 250 (Smit/De Moor) 302

HR 23 december 1994, NJ 1996, 349 (Douma/Bedrijfsvereniging) 9, 235, 236

HR 13 januari 1995, NJ 1997, 175 nt. CJHB (Korver/De Heel) 272, 274

HR 10 maart 1995, NJ 1997, 525 nt. MMM (TUS/lepenburg) 316, 343, 372

HR 2 juni 1995, NJ 1995, 700-702 nt. CJHB (Klaverblad/IZA enz.) 261

HR 16 februari 1996, NJ 1996, 393 (Staat, ABP, Plomp/Royal) 263

HR 20 september 1996, NJ 1997, 198 nt. PAS (Pollemans/Hoondert)

HR 19 april 1997, NJ 1997, 24 nt. MMM (Delta Lloyd/Interlloyd) 310

HR 4 oktober 1996, NJ 1997, 147 nt. CJHB (Dijksma/Klaverblad) 262

HR 21 februari 1997, NJ 1999, 145 nt. CJHB (Wrongful birth) $28,43,49,66,94,120,277$

HR 19 september 1997, NJ 1998, 689 (Verhagen qq/INB II) 383

HR 24 oktober 1997, NJ 1998, 693 nt. WMK (H/K) $\quad 110$

HR 7 november 1997, NJ 1998, 384 (Younis/Waarborgfonds Motorverkeer) 321, 323, 324

HR 5 december 1997, NJ 1998, 209 (Wijnings/Klaverblad) 262

HR 5 december 1997, NJ 1998, 400-402 nt. JH (Terminus/ZAO enz.) 262, 263, 266, 296, $300-302,303$

HR 16 oktober 1998, NJ 1999, 196 nt. ARB (Amev/Staat) 302

HR 15 januari 1999, NJ 1999, 242 (Mastum/Nationale Nederlanden) 349

HR 19 februari 1999, NJ 1999, 428 nt. ARB (Lahjaji/MMB) $\quad 164,167,362$

HR 28 mei 1999, NJ 1999, 564 nt. ARB (Gemeente Losser/De Vries) 8, 26, 30, 32, 142, $144,296,379$

HR 7 januari 2000, NJ 2000, 212 nt. MMM (NN/ Woudsend II) $39,48,85,86,122,149,157$, $162,205,207,310$

HR 4 februari 2000, NJ 2000, $600 \mathrm{nt}$. MMM (Kwidama/Raphael) Richardson) 33, 34, 35, 50, 51 , $52,54,124$

HR 28 april 2000, NJ 2000, 430-431 nt. ARB (Van Hese/De Schelde enz) 329-330

HR 12 mei 2000, NJ 2001, 300 nt. JH (Jansen/Jansen) 350

HR 8 september 2000 , NJ 2000, 734 nt. ARB (Baby Joost) 143,380

HR 22 september 2000, NJ 2000, 631 (N/ZLM) 20

HR 10 november 2000, NJ 2000, 718 (Levob/Van den Bos) 262, 263, 264

HR 17 november 2000, NJ 2001, 260 nt. CJHB (FBTO/Delta Lloyd) 262, 263

HR 4 mei 2001, NJ 2002, 214 nt. CJHB (Chan/Maalsté) 265 
HR 26 oktober 2001, NJ 2002, 216 nt. JBMV (R/Van de W) $8,144,280,380,383$

HR 1 februari 2002, NJ 2002, 122 (Van Straaten/Brandts) $46,56,58,63,71$

HR 22 februari 2002, NJ 2002, 240 nt. JBMV (Taxibus) 3, 7, 144, 146, 227, 380, 382 HR 31 mei 2002, C00/107HR (Bijlsma/Stichting Pensioenfonds ABP) $2 \mathrm{n}, 260,302,322323$

HR 20 september 2002, C00/328HR (Comapatiênt) 4, 109

HR 22 november 2002, NJ 2003, 32 (Leonardus/Linssen) 110

HR 6 juni 2003, C02/062HR (Krüter-Van de Pol/Holding BV)

$30,142,296$

HR 6 juni 2003, C01/356HR (Koning/Nationale Nederlanden)

125 


\section{Trefwoordenregister}

Abstracte schadebegroting

Affectieschade

$3,4,7,108,111,114,144,269,279,280,379$

Afgeleid karakter

$141,157,230,232,296$

Afkoopsom

$14,76-78,100,101,105,112,118,186,225,288,335$,

Algemeen rijksambtenarenreglement (ARAR) $339-341,388,398$

Algemene Arbeidsongeschiktheidswet (AAW)

80,102

Algemene bijstandswet

$175,180,185,190,313$

Algemene kinderbijslagwet

$5,103,117,119,137,174,386$

Algemene nabestaandenwet $\quad 33,34,44,61,111,112,133,165,185$,

120

Algemene ouderdomswet $187,191,215,235,247,289,339,340,341$

Algemene wet bijzondere ziektekosten

Ambtenaren

$61,79,80,89,94-96,101,102,112,113,133$, $134,140,166,169,170,174,179,187,192,194,236,247,286$, $287,289,292,299,311,322,353,354,369,371,372,387,419$,

$422-425,428$

Barema's

Bedrijfsongevallen $163,367,425$

Bedrijfsregeling Regres

$344,347-350$

Behoeftigheidsvereiste

Benadeling

Brandverzekeringen

Bruto-netto kwestie

Buitengerechtelijke kosten

$33-36,50,52-54,111,114,127$

$108,154,231,378,386$ 347,348

$287-296,336,337,394$ $29,93,234,270,272,274,283,284,287$. $296-303,323,332,337,347,397,398,416,421,422,427$

Cascoverzekeringen

Cessio legis

Civiel plafond $230,236,237,240,290,292-295,301,332,422$

Collectivering

Collegaverweer

$14,15,101,112,174,185,222,225,288,338-342,419$

College voor Zorgverzekeringen $184,330,360,364,365,367,369$

Compensatie

$38,43,53,59,85,93,99,104,159,200,201,211,228$, 
Concrete schadebegroting

Contante waarde

Convenant Verhaalsrecht (WAO)

Correctieve rechtvaardigheid

Coulance

Distributieve rechtvaardigheid

$67,68,107,114,153,165,225,226,229,232-234,239$, $14,82,95,97,100,101,105,112,285$ $14,96,97,234,248,313,336-337,388$ 202-206, 396 $47,48,149,312$ 207

Eigen schuld $258,260-265,267,270,272,274,275,281,284,304,306,309$, $314,333,337,342,370,372,374,376,377,388,392,397,398$ Formele rechtskracht

312,313

Gemeente $\quad 8,24,26,30,32,56,81,82,103,116-118,139,142,144,237$, $289,296,369,379,431,432,434$

Gliedertaxe

$53,70,131$

Hoofdelijke verbondenheid

Immateriële schade

Indemniteitsbeginsel

$149,150,415$

Inkomensschade

$3,4,10,11,26,28,43,66,67,73,107-111$, $200,229,269-272,277,279,380,383,384,428$

$22,58,160,162,242,387$ $2,10,29,31-33,36,43,45,51,66,67,69,70,73$. 75, off, 85, 95, 95, 95, 96-98, 100, 101, 103-108, 119, 130, 137, $139,193,235,238,240,248,268,269,271,273,292,295,296$,

$304,321,322,327,336,337,344,373,392$

Institutionalisering

Intern regres

$139,149,152,243$

kinderbijslag

$103,120,289$

Knock-for-knock

$171,346,347$

Kostenallocatie

$192,193,199,211,212,214,256,257,259,295,389$

Landelijk instituut sociale verzekeringen

Levensverzekeringen

Loondoorbetaling

$33,34,49,50,55,115,131-133$
$10,20,23,27,32,33,55,62,70,90,91,93,98$, $101,103-105,167,179,181,197,239,288,300,309,326,329$,

$358,359,387,389,391$

46,49

Matigingsrecht

Nabestaanden $4,7,14,33-37,44,45,53-55,108,111-114,132,138,142$, $159,163,168,169,170,176,193,285,298,375,389,391,393$

NORA-regeling

$234,297-298,347,388,398$

Omvangfase

$25,28-30,69,229,230,233,252,272$

Ongerechtvaardigde verrijking

$19,208,250,417$

Ongevallenverzekeringen

$51,53,84,103,104,124,130,131,159,161$

Ongevallenwet $\quad 65,96,163-165,167,168,233,237,239,250,268,269$, $284,285,310,317,352,361-363,371,394,406,415,426,428$

Onrechtmatige daad $13,51,58,117,133,135,143,144,154,160,161$, $171,208,248,253,265,377,378,381,382,385,412,413,416$,

$422,426,429$ 
Overlijdensschade

Pensioenen

Postenstelsel

Preventie

Rechtsbijstandverzekeraars

Rechtseconomische analyse

Rechtsverwerking

Redelijkheidstoets

Reflexwerking

Regresplafond

Relativiteit

Risicodrager

$1,16,180$,
hekeraars
he analyse

$4,9,29,31,36,52,73,110,112,138,250$,

291,393

$113,119,131,133,285,304$ $66-69,75,77,79,90,102,108,110,111,120$,

$268-272,374,392$
$220,222,223,228$

$256-259,368,395$ $272,297,298,347$

$221,259,412$ $308,310,398$

$297,301,302$

$13,253,263,265,275,281,417,420$

140,344

$144,146,205,227,384$

, 426, 428,429

Samenloop $\quad 16,21,22,24,33,38-41,43,44,46,48,60,67,69-71,73$, $108,110,115,116,118-120,124-126,131,132,135,137-139,148$,

$149,151,160,168,184,241,269,283,373,376,385,388$,

390-392

Schadebegrip

$28,29,42$

Schadebegroting

Schadefonds Geweldsmisdrijven

$88,106,108,109,113,114,134,138,140,176,230,246,249$,

$250,275,279,280,318,322,356,412,420,429$

Schadestaatprocedure 284

Schadeverzekeringen

$42,44,48,51,67,107,115,121,122,127,129,131$,

$132,155,162,347$

Shockschade

$25,144,417$

Sociale Verzekeringsbank

$4,6,14,44,112,120,163,164,166,168,188$, $206,239,339,340,361,362,375,377,428,432$

Sociale zekerheid $6,16,73,89,159,179,181,182,194,197,227$,

344,421

Sommenstelsel

$68,238,268-270,373$

Sommenverzekeringen $\quad 24,36,49,50,52,53,84,103,107,121-125,127$, $129,130,242$

Subrogatie

$11,28,39-45,48,50,53,56,59,60,64,67,70,72,83-87$, $104,105,109,110,115,121-124,126,127,130,132,140,141$, $148,151,154,160-162,164,165,173,208,222,229-235,240-243$, $249,266,269,272,274,277-281,284,288,297,306,307,317$, $318,321,322,324,325,328-331,347,355,356,366,374,376$, $381,383,385,396,411-413,416,419,420,424,425,427-429$

TICA

$94,288,336,388,409$ 
Tijdelijke regeling verhaalsrechten

$8,17,136,141,153,156$, $194,244,259,261,281,338,384,387,396,408,414,423$

Toeslagenwet

$118,393,405$

Toevallige samenloop

$39,40,43,44,46,60,67,69,108,124,125$,

$137-139,269$

Transactiekosten

59,173

Uniformiteit

355,414

UWV $\quad 6,10,13,92,93,95-102,105,106,116,118,119,193,225$, $248,249,287,297,299,309,336,337,340$

Verbond van Verzekeraars $10,14,78,79,92,94,112,134,186,191,192$, $205,288,336,337,339,340,341,344,348,419,421$

Verhaalsrecht

$5,14,80,81,88,91,92,94,96,97,102,117,124$, $142,153,155,157,161,164,170,174,180,181,183,187,188$, $192,195,225,226,232-234,242,248,250,262,269,271,273$, $274,287,288,313,323,330,336,337,338,342,343,345,352$,

$357,376,388,398,409,411,413-415,419,420,422,424,428$

Verhaalswet ongevallen ambtenaren

$61,79,102,112,133,134$,

$140,169,170,187,194,236,247,286,289,292,299,311,322$, $353,354,369,371,387,419,422-424,428$

Verjaring $226,231,232,320-331,337,388,398,411,414,420$

Verkeersaansprakelijkheid

$2,9,13,25,174,176-178,189,203,218$, $228,244,245,253,258,259,260,266,275,281,330,374,416$, $417,419,420,423,428$

Vestigingsfase $25,29,229,230,272,396$

Vestzak-broekzak argument $172,183,198,394$

Volksverzekeringen

$12,116,174,175,181-188,190,191,195,198$, $214,217,225,246,257,289,306,338,364,365,386,394,420$

Voordeelstoerekening

$22,27,28,30,31,33,34,37-57,59-72,74,75$, $77,84,91,93,95,116,120,123,124,128-131,139,162,168$, $236,241,271,275-279,281,304,314,316,333,358,387,392$, $397,399,413,417,421$

Voorschotconstructie

90

WAO $\quad 1,14,22,23,45,57,62,69,89,92,93,94-100,101,102,104$, $105,112,119,140,149,151,152,167-172,175,179,180,190$, $192,194,204,207,235,240,248,262,270,273,274,286-288$, $295,307,311-313,327,336-337,341,343,346,352-355,361-365$, $369,371,372,376,392,393$

WAO-Convenant: zie Convenant Verhaalsrecht

Werkgeversregres

Werkgeversverweer

Werknemersverzekeringen
$8,13,89,92,99,157,240,257,290,293,294$,

$299,355,367,428$ $63,156,359,360,362-366,368,388,399$

$6,10,14,62,63,79,93-96,98,100$, $101,105,106,167,168,174,175,354,364,369$ 
Wet voorzieningen gehandicapten

Zaakschade

Ziekenfondswet

$140,167,168,191,194,195,247,276,327,338,343,345,346$,

$351,354,359,364,411$

Ziektekostenverzekeringen

$82,84,85,89,355,424$

$12,14,22,44,45,61,89,93,94,96,97,102,121,164$, $165,167,168,170,178,186,187,192,194,204,207,247,285$,

$286,288,290,295,336,352,354,355,369$ 



\section{Curriculum Vitae}

Esther Engelhard werd geboren op 27 mei 1972 te Maastricht. Na de middelbare school studeerde zij rechten aan de Universiteit Maastricht, waar zij tevens als student-assistent werkzaam was bij de capaciteitsgroep Privaatrecht. Na het behalen van het doctoraal-examen Nederlands recht, afstudeerrichting privaatrecht was zij werkzaam als docent, assistent in opleiding en, thans, universitair docent. Binnen het onderzoek en onderwijs houdt zij zich hoofdzakelijk bezig met het verbintenissenrecht, in het bijzonder onrechtmatige daads- en schadevergoedingsrecht. Haar onderzoek maakt deel uit van de Ius Commune Onderzoeksschool. 
